UNIVERSIDADE DE SÃO PAULO

FACULDADE DE FILOSOFIA, LETRAS E CIÊNCIAS HUMANAS

Programa de Pós-Graduação em Sociologia

\title{
PAULISTANIDADE E RACIALIZAÇÃO \\ O Caso Nordestino
}

Marina Chaves de Macedo Rego 

UNIVERSIDADE DE SÃO PAULO

FACULDADE DE FILOSOFIA, LETRAS E CIÊNCIAS HUMANAS

Programa de Pós-Graduação em Sociologia

\section{PAULISTANIDADE E RACIALIZAÇÃO \\ O Caso Nordestino}

Marina Chaves de Macedo Rego

Dissertação de Mestrado apresentada ao Programa de PósGraduação em Sociologia da Universidade de São Paulo como parte dos requisitos para obtenção do título de Mestre em Sociologia.

Orientação: Prof. Dr. Antonio Sérgio Alfredo Guimarães

São Paulo

2018 
Autorizo a reprodução e divulgação total ou parcial deste trabalho, por qualquer meio convencional ou eletrônico, para fins de estudo e pesquisa, desde que citada a fonte.

Catalogação na Publicação

Serviço de Biblioteca e Documentação

Faculdade de Filosofia, Letras e Ciências Humanas da Universidade de São Paulo

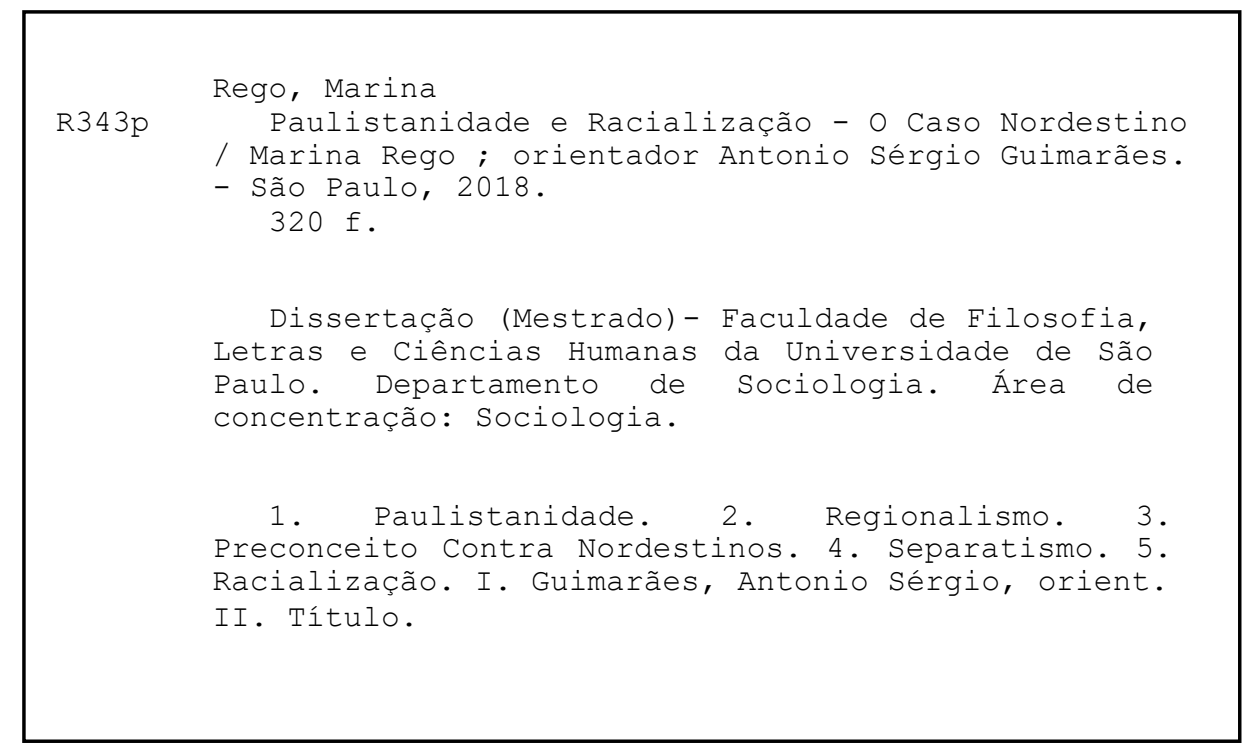


À Maria do Socorro, Renato e Frederico, fontes de inspiração, afeto e saudades. 



\section{Agradecimentos}

Ao Conselho Nacional de Desenvolvimento Científico e Tecnológico, pelo financiamento da bolsa.

Ao Professor Antonio Sérgio e ao grupo de orientandos, André, Benno, Bruno, Diego e Nico. Esta dissertação é fruto de seus comentários, conselhos e leituras.

À minha mãe, Maria do Socorro, por ser minha base e maior exemplo. Agradeço pelo amor, força e companheirismo. Dedico esta dissertação e tudo que sou à mulher admirável que você sempre foi, antes e depois de ser chamada de mãe.

Ao meu irmão, Renato, dedico minha ternura e admiração. Agradeço pela ajuda, pela alegria de ser Flamengo, pelo amor companheiro e por compartilhar a parte mais doce da vida comigo.

Ao meu pai, Frederico, agradeço, com o carinho da saudade, pela formação política, pelo gosto por estradas de terra, pelo afeto único e por ter insistido tanto em falar "isso é bairrismo." Sigo com a certeza de que em tudo que sou ou faço, há o amor que sinto por você.

À minha vó, Ilda, agradeço pelo amor que nunca hesitou em atravessar o país nos momentos precisos, pelo colo de vó e por ser parte de mim na Paraíba.

À Lu Cae, pela amizade, camaradagem e aprendizado en las montañas del sureste mexicano. À Maria, pela força que nos alerta, pela certeza da luta e pela profundidade no significado de amiga. À Dani, pela partilha das dores e alegrias e pela possibilidade de ter uma irmã. À Lau, pelo maior cuidado, empatia e carinho que encontrei em meu cotidiano. À Lu Cruz, por dividir vida, força e amor comigo. À Vibe, pelo empurrão de prestar o mestrado, pela risada marcante e pela certeza de uma amizade que não se perde com a distância. À Gabi, pelo retorno à minha vida e pelas lembranças carregadas de afeto e juventude: no Central às 18h? Ao Thales, pela companhia noturna e pelas confissões na madrugada. Ao Perds, pela certeza de que nossa ternura não ficou no tempo, presa na poeira. Ao Artur e Marcus, pelas cervejas no Vão e fins de tarde no Morrinho. Ao Merê, Grella, Fred, Gamero e Jussa, pela companhia e abrigo no 51 e 42. À Rob, pelos olhos de lince e conselhos certeiros. À Dessa, pelo nosso ano de 2009 e pela melhor seleção de trechos literários do Orkut. À Aline, pelos 3 mil quilômetros de carona na Patagônia e pelas aventuras em caminhões latinoamericanos. Ao Rafa Pacheco, Iza, Grazi, Mara, Pira, Fred, Rafa Tannus, Rica, Lu Girardi e à Bagaça e tantxs amigxs da faculdade: pela loucura necessária e pela falta que sinto. À Casa da Vila Nova Baixaria, pela morada que se mostrou mais que um espaço. Aos amigos de Valência, pelos dias em meios às laranjeiras de Benimaclet. À Casa das Minas, pelo Belchior na sala de estar, jantares, basquete, quedas de teto e possibilidade de um recomeço. Amo vocês, Lu, Lau, Fernandinho, Pedro e Lê. Aproveito para agradecê-los (e também nossas companhias felinas e caninas: Marighella, Pancho Villa e Sirius) pelo carinho durante o processo de escrita e por se tornarem, para além da Casa 752, pessoas em que encontrei o significado de lar.

Por fim, ao meu amor e companheiro, Pedro. Agradeço pelo olhar terno, pelo sonho do Monte Roraima, pela vontade de futuro, pelas manhãs te vendo escutar rap e pela segurança de, com você, estar sempre do lado certo da trincheira - te amo!

E, em especial, a todas e todos aqueles que me ensinaram o valor de caminhar abaixo e à esquerda principalmente às mães e pais de Ayotzinapa: seguiremos hasta encontrarlos!

Com a certeza, as vezes trôpega, mas ainda assim certa, de que outro mundo é possível,

Marina. 

REGO, Marina. Paulistanidade e Racialização: O Caso Nordestino. Dissertação de Mestrado. Programa de Pós-Graduação em Sociologia. Faculdade de Filosofia, Letras e Ciências Humanas da Universidade de São Paulo (USP). São Paulo, 2018. (320 p.).

\section{Resumo}

Apresento nesta dissertação a pesquisa que realizei sobre as relações entre a paulistanidade e o preconceito contra nordestinos. Exponho como o ideal de superioridade paulista foi historicamente acompanhado por uma narrativa racial, econômica e política que aponta a racionalidade, a branquidade e o mérito como virtudes diferenciais desta população. Apresento, da mesma maneira, a estigmatização dos nordestinos como um fenômeno social de grande alcance, associado à ideia de inaptidão econômica, política e racial imputada a este grupo regional, que aparece com frequência como contraponto da moralidade paulista. Analiso como noções de progresso e civilização, restritivas e racializadas, se adequam e se relacionam de formas distintas a identidades regionais variadas. Trato os regionalismos brasileiros de modo que seja possível investigar a ascensão da questão regional como um processo de racialização e demarcação econômica das populações brasileiras, notadamente simbolizadas por uma gama de marcadores sociais da diferença. Interessa-me entender tanto o caráter homogeneizador das narrativas regionalistas quanto as mobilizações em torno de raça e classe que estas possam abarcar. Focando no caso paulista, apresento o histórico da paulistanidade em torno de uma superioridade que frequentemente se apresentou como questão racial. Da mesma maneira, empreendo uma análise comprometida em averiguar as continuidades e descontinuidades deste regionalismo. A ascensão do discurso da democracia racial com seu consequente padrão de preconceito e discriminação que se estabelece de forma velada é, portanto, um marco importante para esta análise. Para destrinchar estas questões, focalizo a corrente crise política brasileira e os grupos separatistas paulistas que surgiram nesta década (2010). A tese que orienta esta pesquisa é de que a paulistanidade não somente recrudesce em momentos de disputa política, como aparece enquanto perpetradora de uma hierarquia nacional marcada por assimetrias raciais, regionais e de classe. Defendo, deste modo, que a contraposição histórica entre paulistas e nordestinos pode se apresentar como uma narrativa eficaz do conservadorismo nacional. Esta narrativa seria capaz de extrapolar o plano discursivo, possuindo materialidade política notável. Torna-se importante salientar que o regionalismo paulista é pensado de forma relacional aos outros regionalismos brasileiros.

Palavras-chave: Paulistanidade; Preconceito Contra Nordestinos; Racialização; Regionalismo; Separatismo. 

REGO, Marina. Paulistanidade e Racialização: O Caso Nordestino. Dissertação de Mestrado. Programa de Pós-Graduação em Sociologia. Faculdade de Filosofia, Letras e Ciências Humanas da Universidade de São Paulo (USP). São Paulo, 2018. (320 p.).

\section{Summary}

Here, I present a research on the relationship between the paulistanity (ideology which states the existence of a superiority of the people from the Brazilian State of São Paulo - i.e. Paulistas) and the discrimination against people from the Northeast region of Brazil. I show that the idea of a Paulista superiority was historically accompanied by a racial, economic, and political narrative that points the rationality, the whiteness, and merit as sources of this alleged superiority. In the same way, I present the Northeastern stigma as a pervasive social phenomenon, constantly associated with the imposed idea of an economic, political, and racial incapacity of this regional population which is often shown as an opposite to the Paulista morality. I analyze how narrow and racial-based notions of progress and civilization differently conform and relate to a variety of geographic regional identities. I analyze the Brazilian regionalisms in a way that allows me to investigate the rise of the regional matter as a process characterized by a wide racialization and an economic delimitation of Brazilian populations, notably characterized by a range of social markers of difference. I try to understand the racial and class aspects of regionalist narratives and I try to understand how regionalist narratives homogenize human groups. Regarding Paulistas' case, I present the history of the paulistanity and the associated sense of superiority that has been frequently presented as a racial matter. In the same way, I analyze the permanence and the discontinuity of this regionalism. Accordingly, an important issue for this analysis is the rise of the mythical racial democracy, accompanied by its pattern of prejudice and discrimination, which are stablished in a veiled way. In order to disentangle these questions, I incorporate to my analyses perspectives on the current Brazilian political crisis and perspectives on the Paulista separatists groups that were founded in the 2010s. This research is based on the thesis that the expression of paulistanity would not only enhance during instances of political dispute, but it would also promote a national hierarchy characterized by racial, regional, and class asymmetries. Therefore, I propose that the historical contrast between Paulistas and Northeastern Brazilians can be presented as an efficient narrative of national conservatism. This conservative narrative is not restricted to a speech level, but can also reach notable political materiality. Additionally, it is important to highlight that, in this study, I relate Paulista regionalism to other forms of regionalism found in Brazil. Finally,

Keywords: Prejudice against Northeastern Brazilians; Paulistanity; Racialization; Regionalism; Separatism. 



\section{Índice}

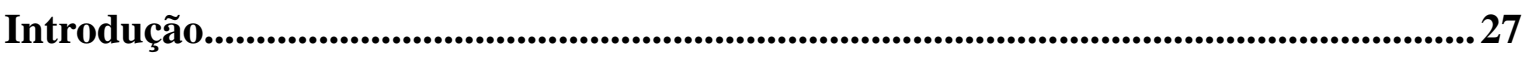

\section{Parte I}

\section{Capítulo I}

Enredos da Paulistanidade: Branquidade, Poder Econômico e Preconceito

1.1 - O Regionalismo Paulista Sob Uma Perspectiva Histórica........................................... 41

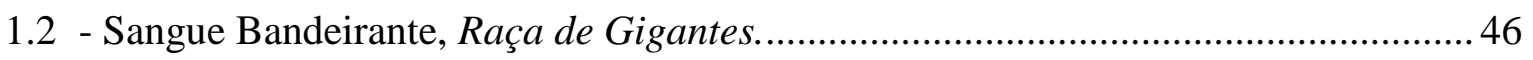

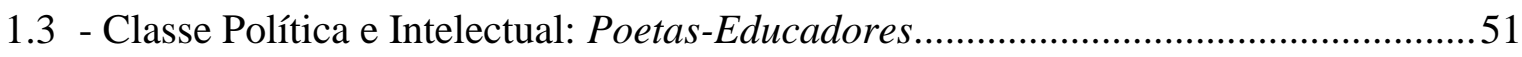

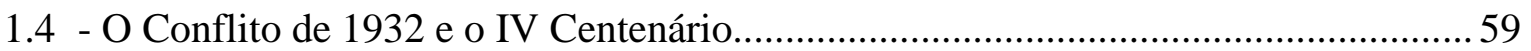

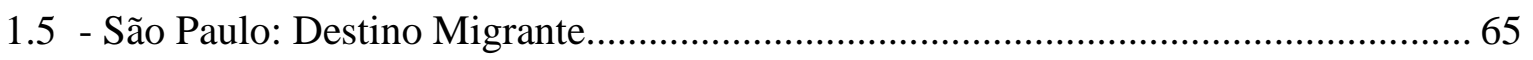

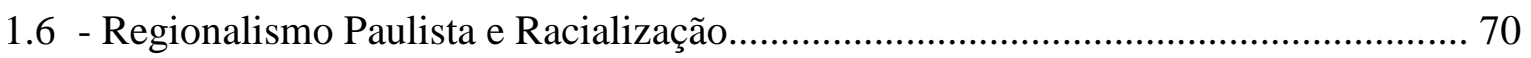

1.7 - O Regionalismo Paulista Como Mobilização Política de Exclusão............................ 73

\section{Capítulo II}

\section{Nordeste: Do Eu ao Outro Regional}

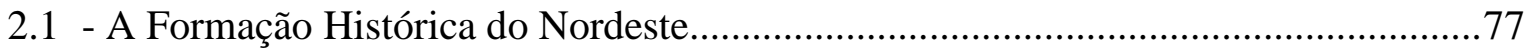

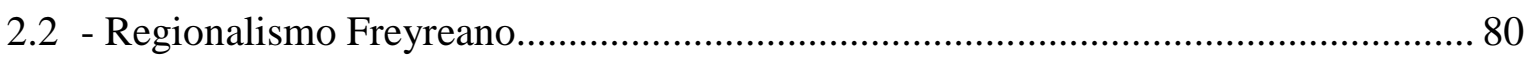

2.3 - Classe Artística e Intelectual Nordestina................................................................. 93

2.4 - O Preconceito Contra as Populações Nordestinas....................................................... 97

2.5 - O Nordeste como Bahia, o Nordestino enquanto Baiano......................................... 107

2.6 - Cangaceiros e Fanáticos: O Contraponto do Bandeirante......................................... 110

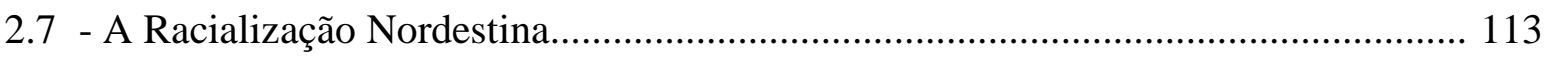

2.8 - Formas de Resistência.................................................................................... 120

\section{Capítulo III}

De uma Mítica Branquidade à Mítica Democracia Racial: Um Embate Entre Narrativas Regionalistas

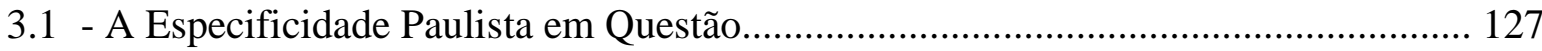

3.2 - Tensões Entre o Gauchismo e a Nação....................................................................... 129

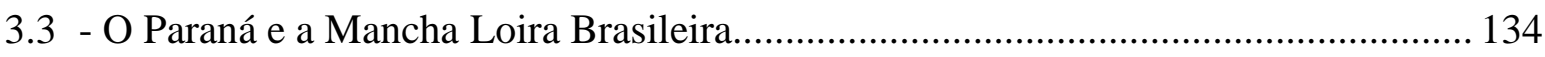

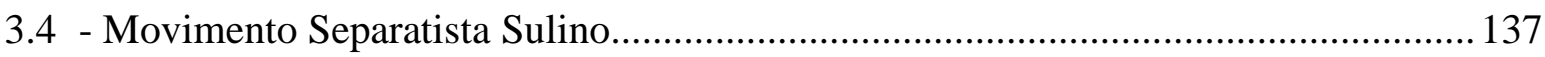

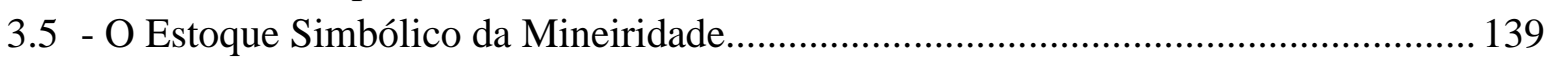

3.6 - O Ceará e o Mito das Duas Raças............................................................................... 142

3.7 - Bahia: Roma Negra............................................................................................ 144

3.8 - Pernambuco de Romero a Freyre............................................................................ 147

3.9 - A Criação do Mato Grosso do Sul............................................................................ 148

3.10- O Pará e a Porta de Entrada da Floresta................................................................... 150

3.11 - Dois Brasis Compactados no Eixo Rio-São Paulo..................................................... 153

3.12- Regionalizando Marcadores Sociais da Diferença................................................. 157 



\section{Parte II}

\section{Capítulo IV}

Crise Política, Legitimidade Eleitoral e Discriminação: Analisando o Gradiente da Paulistanidade

4.1 - Tinha que Ser Nordestino: Paulistanidade e Crise Política..................................... 173

4.2 - Mobilizações Políticas da Paulistanidade................................................................ 185

4.3 - Preconceito, Discriminação e Ódio: O Gradiente da Paulistanidade........................ 190

4.4 - Paulistanidade e Efervescência Política: Análise das Notícias Rastreadas............... 191

4.5 - Comentários Sobre Dois Casos Emblemáticos.......................................................... 200

4.6 - De Skinheads e Separatistas ao Senso Comum.......................................................... 201

4.7 - São Paulo Restrita............................................................................................. 222

\section{Capítulo V}

Ódio à Favela, ao Pobre e ao Nordestino: Analisando o Manifesto São Paulo Para Os Paulistas

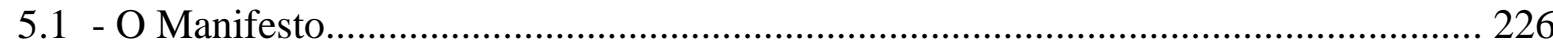

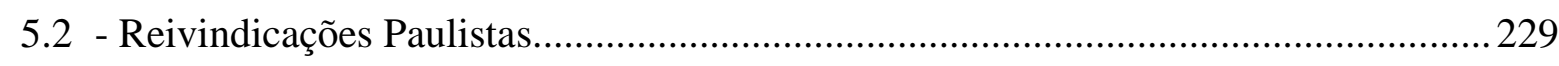

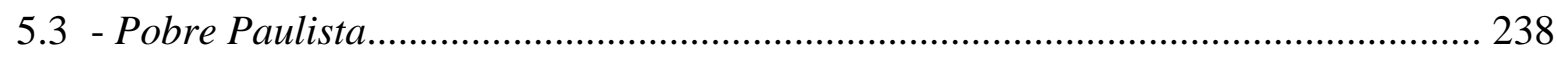

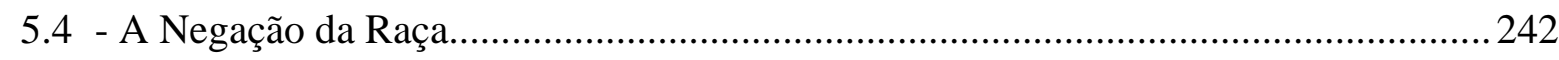

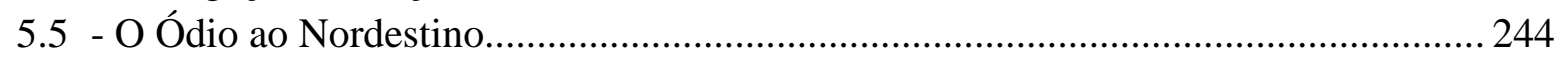

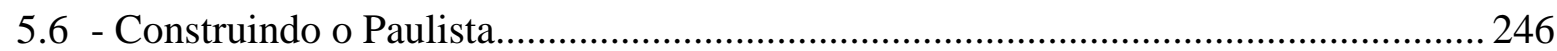

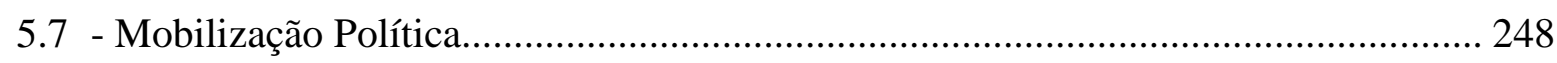

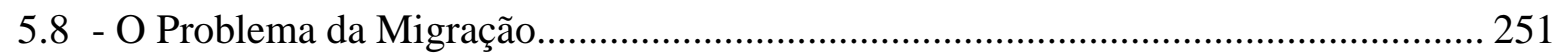

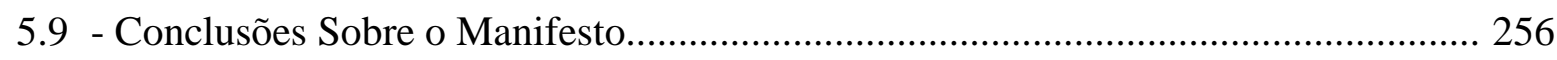

\section{Capítulo VI}

Livre-Mercado e Paulistanidade: O Conservadorismo do Movimento São Paulo Livre

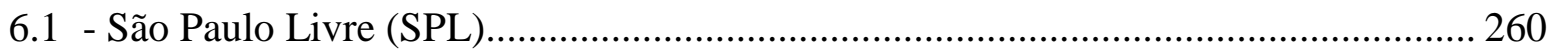

6.2 - A Paulistude do Movimento São Paulo Livre.............................................................. 266

6.3 - Argumentos Econômicos e Políticos............................................................................. 276

6.4 - A Apropriação das Pautas Contra Preconceito e Discriminação................................ 286

6.5 - Conclusões Sobre o Movimento São Paulo Livre..................................................... 301

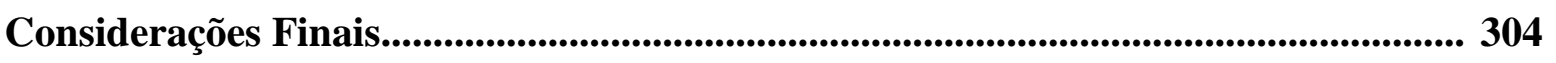

Referências Bibliográficas............................................................................................... 311 



\section{Lista de Imagens}

Imagem 1: Mensagem de Mayara Petruso (82)

Imagem 2: Charge Sobre Eleições (83)

Imagem 3: Mapa Eleitoral do Brasil (85)

Imagem 4: Campanha Contra o Preconceito (105)

Imagem 5: Mapa do Brasil Segundo os Paulistas (143)

Imagem 6: Mapa do Brasil Segundo os Paranaenses (143)

Imagem 7: Mapa do Brasil Segundo os Gaúchos (144)

Imagem 8: Mapa do Brasil na Visão de Dilma (144)

Imagem 9: Mapa do Brasil Segundo os Cariocas (147)

Imagem 10: Mapa do Brasil Segundo os Baianos (147)

Imagem 11: Mapa do Brasil Segundo os Pernambucanos (148)

Imagem 12: Lula e Bandeirante (158)

Imagem 13: Lula e Paulistas (159)

Imagem 14: Mensagem de Vanessa Brazil (165)

Imagem 15: Linha do Tempo (169)

Imagem 16: Apoio de MSPI a Deputados (190)

Imagem 17: Lula e Getúlio Vargas (191)

Imagem 18: MSPI na ALESP (191)

Imagem 19: MSPI e Polícia Militar (192)

Imagem 20: MSPI e Expressões Preconceituosas (192)

Imagem 21: MSPI no Monumento às Bandeiras (193)

Imagem 22: MSPI e Elitismo (193)

Imagem 23: MSPI e Ideologia do Trabalho Meritocrático (193)

Imagem 24: MSPI e a Ressignificação de Escravismo (194) 

Imagem 25: MSPI e o Rechaço à Pobreza (194)

Imagem 26: MSPI e Brasilidade (195)

Imagem 27: MRSP no Monumento às Bandeiras (197)

Imagem 28: MRSP e Polícia Militar (198)

Imagem 29: Relações Entre Brasilidade e MRSP (198)

Imagem 30: MRSP, Getúlio Vargas e 1932 (199)

Imagem 31: Conceito de Liberdade do MRSP (199)

Imagem 32: MRSP, 1932 e Monteiro Lobato (200)

Imagem 33: Tatuagem de Orgulho Paulista I (202)

Imagem 34: Tatuagem de Orgulho Paulista II (202)

Imagem 35: Campanha do Manifesto São Paulo Para os Paulistas I (219)

Imagem 36: Campanha do Manifesto São Paulo Para os Paulistas II (219)

Imagem 37: SPL e Empresariado (245)

Imagem 38: Militantes do SPL I (245)

Imagem 39: Militantes do SPL II (245)

Imagem 40: Outdoor do SPL (246)

Imagem 41: Charge de Vitimização do SPL (246)

Imagem 42: Análise do SPL Sobre 1932 (248)

Imagem 43: SPL e Colonialismo (248)

Imagem 44: Paulistude (249)

Imagem 45: SPL e Bandeirantes (249)

Imagem 46: SPL e Educação I (250)

Imagem 47: Ouro do SPL (252)

Imagem 48: SPL, Sexismo e Estigmatização (254)

Imagem 49: SPL e Educação II (254) 

Imagem 50: SPL e Energia Elétrica (255)

Imagem 51: SPL e Carnaval Racializado (255)

Imagem 52: SPL e Mérito (256)

Imagem 53: SPL e Economicismo (259)

Imagem 54: SPL e o Golpe de 2016 (260)

Imagem 55: SPL e Campanha Contra Dilma (261)

Imagem 56: SPL e Lula (261)

Imagem 57: SPL e José Dirceu (262)

Imagem 58: Enfrentamento ao SPL (264)

Imagem 59: SPL e Donald Trump (265)

Imagem 60: Partido Aliança Nacional (266)

Imagem 61: SPL e Propaganda com Nordestinos (269)

Imagem 62: A Representatividade do SPL (269)

Imagem 63: O Preconceito do SPL Contra Haitianos (272)

Imagem 64: O Elogio do SPL ao Sistema Escravocrata Paulista (273)

Imagem 65: SPL e Elitismo (275)

Imagem 66: SPL e Maria Rosa Sguassábia (280) 



\section{Lista de Tabelas}

Tabela 1: Comunidades Virtuais de Preconceito (85) - BATISTA, José

Tabela 2: Adjetivos Para Pessoas Negras e Nordestinas (86) - BATISTA, José

Tabela 3: Adjetivos Para Pessoas Nordestinas e Pessoal do Sul (87) - BATISTA, José

Tabela 4: Reivindicação Racial e Econômica dos Estados Brasileiros (141)

Tabela 5: Eventos de Preconceito, Ódio e Discriminação (180)

Tabela 6: Problemas da Migração Segundo São Paulo Para os Paulistas (235)

Tabela 7: Análise dos Comentários dos Signatários (236) 



\section{Lista de Gráficos}

Gráfico 1: Discriminação Contra Nordestinos (175)

Gráfico 2: Separatismo Paulista (175) 



\section{Introdução}

Há tempos que no Brasil ocorre o preconceito contra nordestinos e a afirmação da pretensa superioridade paulista. Objetivo, com esta dissertação, expor as relações entre estes fenômenos, bem como suas mobilizações em torno de noções de civilização, progresso, raça e classe. Isto porque acredito que o estigma nordestino, racializado e marcado pela pobreza, sirva à eficácia discursiva do regionalismo paulista que, a partir da contraposição, apresenta a população do estado como conectada à branquidade, ao poder econômico e à aptidão política. Do mesmo modo, creio que seja possível notar a relevância destas distinções atribuídas regionalmente na década de 2010, marcada pelo avanço institucional conservador.

Não é necessária uma reflexão muito demorada para ver as relações entre a paulistanidade, a racialização e a inferiorização econômica que atinge nordestinos. Já ao fim do século XIX estes fenômenos possuíam relevância: São Paulo firmou-se enquanto potência econômica após o boom do café, ao mesmo tempo que os propósitos do embranquecimento incentivaram a vinda de populações brancas, sobretudo europeias, para fixar-se no estado. Grupos privilegiados do estado paulista, anteriormente marcado pelo provincianismo, passaram a orgulhar-se do branqueamento e das possibilidades de crescimento econômico em um país com assimetrias salientes de poder regional, social, sexual e racial.

Enquanto São Paulo ascendia - sob o mote de locomotiva - um Norte difuso passava a ser considerado passado. Mais que isto: passado a ser esquecido, superado. Tal recorte espacial possuía o estigma que condensava atributos que as oligarquias de um país desigual queriam afastar: pobreza, negritude, indianidade e ruralidade. Entravam em cena noções arbitrárias e reformuladas de progresso, civilização, raça e classe. Neste processo, São Paulo passaria a ter sua imagem associada à branquidade e ao sucesso econômico através de uma narrativa oligárquica que negava a existência de parcela numerosa de sua população. Por outro lado, o Nordeste passaria a ser associado ao estereótipo sertanejo que as elites brasileiras buscaram continuamente dissociar da imagem nacional.

Esses fatos, apesar das descontinuidades que os marcam, ainda possuem relevância considerável. O que ficou evidente durante as eleições presidenciais de 2010, quando parcela significativa da população brasileira afirmou publicamente o estigma da inaptidão 
política e até mesmo humana dos naturais do Nordeste. ${ }^{1}$ A adesão massiva, em vista dos resultados eleitorais, aos dizeres "nordestino não é gente! Faça um favor a São Paulo: mate um nordestino afogado" ${ }^{2}$ não diz respeito apenas a um cenário político polarizado, mas à estrutura hierárquica de poder regional que marca o Brasil.

Baseando-me nestes fenômenos, busco expor a vigência de um traço do regionalismo paulista que se ancora em uma proposta hegemônica. Acredito que nos momentos em que a hegemonia de São Paulo é ameaçada, de forma material ou simbólica, entra em cena a narrativa cíclica e estrutural que defende a superioridade paulista e a manutenção do domínio das classes dominantes e da raça branca no Brasil. Na década de 2010, apresentou-se como principal incômodo a esta narrativa uma eleição presidencial dividida regional e ideologicamente, em que o candidato preferido pela maioria do eleitorado de São Paulo foi derrotado.

Nota-se, assim, que certos aspectos do regionalismo em questão se inserem em um processo amplo de racialização, demarcação econômica e política. Processo este capaz de contrapor, através de um viés regional, brancos e não-brancos, ricos e pobres e supostos aptos e inaptos politicamente. Vale ressaltar, com isto em vista, que tanto o estado paulista quanto a região nordestina são locais marcados por heterogenias humanas e geográficas. Por este motivo, focalizarei o nível representacional destas populações. Tratarei a região de forma similar à raça: sabendo que não há validade natural nestas conceituações, mas que seu histórico como atributos de estigma e desigualdade conferem materialidade a hierarquias sociais variadas. Atentando-me a estas questões, oriento esta pesquisa a partir do argumento de que a crise política brasileira da década de 2010 acentuou e reconfigurou o caráter preconceituoso abarcado pela paulistanidade.

Neste sentido, buscarei demonstrar que a ascensão cíclica de uma faceta do regionalismo paulista com relações estreitas com a estratificação social, foi característica do Golpe Institucional ocorrido em 2016, uma vez que este foi dotado de narrativas que engendraram, apesar das especificidades e descontinuidades, processos conservadores de períodos distintos. Exemplos disto seriam o Massacre de Canudos, o Conflito

\footnotetext{
${ }^{1}$ É válido salientar que as manifestações de preconceito contra nordestinos ocorridas após o resultado das eleições presidenciais de 2010 foram patentes em todo o país, inclusive no Nordeste. Notou-se, apesar disto, a centralidade de São Paulo no evento.

${ }^{2}$ Frase enunciada pela paulista Mayara Petruso, em vista do resultado das eleições presidenciais de 2010, com vitória petista. A revolta causada pelo resultado eleitoral, levou com que \#MateUmNordestinoAfogado fosse o tema mais comentado mundialmente na rede social Twitter nos dias 03 e 04/10/2010, uma vez que a vitória de Dilma Rousseff era creditada aos votos da região nordestina do país.
} 
Constitucionalista de 1932, o Golpe Militar de 1964 e outros tantos eventos que serão analisados ao longo desta dissertação.

Canudos, a título de exemplo, foi narrado na imprensa da época como um movimento de uma horda irracional e nordestina contraposta a um paulista republicano e moralizado. Do mesmo modo, 1932 foi, e frequentemente é, exposto como um conflito entre uma classe média branca paulista e uma jagunçada, sendo esta última colocada como responsável pelo domínio de Getúlio Vargas no Brasil. Em 1964 e 2016, da mesma maneira, viu-se grupos engajados na paulistanidade reivindicando a primazia em processos que, nesta lógica, redimiriam o mau exercício político de uma população nacional que é racializada e inferiorizada economicamente. No caso do Golpe Militar, a narrativa regionalista o teria afirmado como uma revolução benéfica conduzida pelos bandeirantes. Nota-se, nos diversos episódios históricos referidos, um discurso da paulistanidade que apresenta de forma recorrente e estruturada uma acepção de sociedade que é ao mesmo tempo conservadora e hierarquizante.

Deste modo, a estigmatização nordestina e a afirmação da superioridade paulista não apenas se relacionam, como são parte de um processo político empenhado na manutenção das desigualdades sociais e regionais. As elites paulistas, que historicamente almejaram aparentar riqueza e branquidade, foram salientes na tentativa de diferenciar São Paulo diante de um país marcado por sua posição periférica no capitalismo global e à margem da brancura europeia. Reside nestas demarcações imputadas sua reivindicação em torno da primazia da política conservadora, uma vez que o Brasil é marcado por assimetrias profundas entre classes sociais e grupos raciais e regionais.

A bibliografia especializada costuma apresentar que a paulistanidade recrudesce em momentos de disputa política pelo poder central. ${ }^{3}$ A partir dos dados já brevemente citados, mostro que tal recrudescimento acompanha com frequência o avanço de um ideal político conservador. Não quero com isto indicar que a paulistanidade alberga em si responsabilidades por eventos distintos ou que possua consonância somente com um discurso reacionário. Acredito, ao contrário, que sua eficácia esteja em sua generalidade. A afirmação de supremacia paulista e a estigmatização nordestina são capazes de abarcar as mais diversas camadas da população e aparecer em movimentos políticos diferentes, até mesmo contrapostos. Isto, todavia, não anula o fato de que frequentemente se cola à

\footnotetext{
${ }^{3}$ A análise de Jessita Moutinho (1991) é marcante neste sentido.
} 
narrativa paulista um ideal conservador de superioridade, sendo este ancorado na proposição de hierarquias raciais e econômicas.

Interessa-me, neste sentido, colocar em questão a especificidade deste regionalismo, uma vez que o preconceito regional, racial e de classe é patente em todo território brasileiro, bem como o engajamento de determinados setores no conservadorismo. Deste modo, torna-se essencial destrinchar os porquês de uma narrativa racista e elitista ter se colado historicamente a São Paulo a partir de uma manifestação de orgulho estadual, aparecendo de formas diferentes em outras manifestações regionalistas. Por tal motivo, apresentarei a relação entre as realidades e as mitologias que envolvem as formulações regionais.

Como aponta a bibliografia utilizada nesta pesquisa, ${ }^{4}$ nacionalismos e regionalismos aparecem como fenômenos dotados de empenho na mobilização e montagem de determinada História. Nações e regiões manipulam mitos, símbolos e fatos históricos para aparentarem sucesso, predestinação e até mesmo um caráter de eternidade. É necessário, portanto, destrinchar a materialidade que envolve estes discursos frequentemente orquestrados em prol das elites.

Creio que a eficácia da paulistanidade se dê justamente pela concentração de poder econômico em São Paulo, o que, ao fim do século XIX e início do século XX, contou com a companhia de um pretenso poder racial. Vale salientar novamente que em uma época em que imperava o racismo científico e o ideal de branqueamento, São Paulo aparecera, como outros estados ao Sul do país, como local que concentrava o influxo de imigrantes brancos; enquanto um Norte difuso, especialmente o que hoje se conhece por Nordeste, era majoritariamente negro. A eficácia discursiva do regionalismo paulista concentrou-se, deste modo, na narrativa da branquidade sustentada pelo ideal de supremacia econômica diante de um país com marcante racismo e desigualdade entre classes.

Desta maneira, o discurso paulistanista possuiu historicamente a possibilidade de afirmar seu suposto realismo enquanto estados outros, com elites também empenhadas em uma formulação regional, valeram-se com vigor de outra acepção mitológica. Era impossível a certos lugares reivindicar a branquidade e o poder econômico, uma vez que não possuíam a concentração econômica de um estado como São Paulo nem recebiam imigrantes estrangeiros. A Bahia, a título de exemplo, baseou-se na apresentação mítica de terra primogênita do Brasil para estabelecer seu diferencial regional.

\footnotetext{
${ }^{4}$ As obras de Benedict Anderson e Eric Hobsbawn são elucidativas neste sentido.
} 
A materialidade da riqueza econômica paulista, todavia, não anula o caráter imaginativo deste regionalismo. As narrativas da paulistanidade buscaram apresentar a população estadual de maneira exageradamente branca e rica, o que não possuía consonância com o que era e é visto no estado. Afirmando-se branco e enriquecido, este regionalismo negava a participação, e até mesmo existência social, de parcela ativa da população paulista. Neste sentido, nota-se o engendramento de uma ideologia que anulou as contribuições da classe trabalhadora pobre na ascensão econômica do estado, bem como invisibilizou grupos negros e indígenas.

Sendo assim, o enredo histórico apresentado pela paulistanidade valeu-se da apresentação romantizada do período colonial. Nesta, bandeirantes apareceriam como heróis e como patriarcas de uma linhagem moral que desde seu início indicava a superioridade e a conquista do Outro como características intrínsecas aos naturais de São Paulo. Curioso é o fato de que neste processo se sublimou tanto o genocídio do período quanto o fato de que as bandeiras foram expedições também realizadas por diversos outros grupos regionais.

Semelhante em termos de imaginação é a narrativa do apego dos paulistas ao mérito e a ao trabalho. Nesta, afirma-se que São Paulo seria o local com maior sucesso econômico (frequentemente colocado como sucesso moral) porque possuiria a população mais trabalhadora. Este discurso não é apenas eficaz em apontar uma especialidade paulista, mas também em interpretar o insucesso ${ }^{5}$ de outras populações como questão de vontade. Deste modo, o ideal meritocrático, além de não levar em consideração as assimetrias de oportunidade que marcam o contexto brasileiro, monopoliza para si o valor de esforço.

É possível ver nestas máximas da paulistanidade relações significativas com os estigmas que marcam o Nordeste. Os símbolos mitológicos nordestinos, frequentemente imputados externamente, seriam contrapontos do ideal bandeirante: o cangaceiro e o fanático. Do mesmo modo, a população deste recorte regional é estigmatizada a partir de categorizações atribuídas que buscam afirmar sua suposta falta de vontade e de aptidão ao trabalho - o que expõe distância do ideal paulista.

Contraposições regionais, todavia, não foram mobilizadas apenas pelos paulistas. Ao contrário: o Nordeste contou com uma série de esforços de construção regional própria. Longe da passividade e homogeneidade, as populações nordestinas foram ativas em

\footnotetext{
${ }^{5}$ Vale salientar a arbitrariedade que comporta as noções de sucesso e insucesso.
} 
formular sua identidade regional. Esta, em determinados períodos, foi notadamente avessa ao ideal modernista paulista. Neste sentido, grande parte do regionalismo da área setentrional do país ancorou-se em narrativas sobre mestiçagem, negros, indígenas e populações pobres. A partir da década de 1930, inclusive, viu-se parcela importante da classe intelectual nordestina esmerar-se neste sentido.

Esta imaginação regionalista distinta, todavia, não deve ser percebida como não excludente, uma vez que estes locais também são marcados pela assimetria de poder racial e econômico. Mobilizar a ideia de democracia racial serviu, deste modo, tanto à formação regional nordestina quanto à manutenção da desigualdade que vela os preconceitos e discriminações existentes nestes estados. Interessa-me, neste sentido, atentar novamente ao fato de que a narrativa excludente cola-se com maior frequência ao regionalismo paulista, apesar desta prática ser visível em todo país. Cabe a pergunta de como estas manifestações de exclusão apareceriam em outros locais que não São Paulo.

Deste modo, nota-se uma disputa entre as regiões brasileiras. Longe de constituir-se em diferencial supremo, o regionalismo paulista é rivalizado por outros regionalismos nacionais. A título de exemplo, Paraná, Rio Grande do Sul e Ceará também são estados que buscaram, em especial no início do século passado, apresentar a branquidade como qualidade diferencial. Como buscarei demonstrar nesta dissertação, as relações estreitas entre raça e classe no Brasil levam ao fato de que locais mais enriquecidos tenham maior facilidade neste tipo de proposição. Em outras palavras: o esforço da branquidade é mais viável em estados ricos.

Com isto em vista, faz-se necessário atentar as continuidades e descontinuidades que envolvem as manifestações regionalistas. Superioridades colocadas enquanto questão racial nos termos do racismo científico passaram por mudanças com os esforços brasileiros na tentativa de aparentar ser uma nação democrática e racialmente coesa. Neste sentido, as distinções regionais serviram primorosamente ao encobrimento da discriminação racial: notadamente baiano e cabeça chata, enquanto adjetivos pejorativos, servem à racialização e ao racismo.

Acredito que seja fundamental ao tratar destas questões a análise do gradiente das manifestações estaduais que se mostram preconceituosas ou discriminatórias: do mesmo modo que há muitos tipos de estigmatização, há diferentes, até mesmo conflitivas, manifestações de um mesmo regionalismo excludente. Com isto em vista, analiso como preconceito, discriminação e ódio podem ser percebidos em expressões diversas da 
paulistanidade. Busco mostrar, como já dito, que fenômenos dotados de maior agressividade se concentram nos momentos em que a hegemonia paulista é ameaçada.

Exponho também que nestes períodos ascendem propostas secessionistas em prol de um regionalismo exacerbado. Atentando-me a isto, argumentarei que a tradição separatista em São Paulo, consolidada durante o Conflito Constitucionalista de 1932, tende a ascender estruturalmente em defesa do domínio do estado. Por tal motivo, analiso os quatro movimentos independentistas paulistas que foram criados na década de 2010, marcada pela polarização política e eleitoral. São estes: Movimento São Paulo Livre, Movimento São Paulo Independente, Movimento República de São Paulo e São Paulo Para Paulistas.

A atenção dada nesta pesquisa às descontinuidades e reconfigurações abarcadas pela paulistanidade encontram possibilidade analítica valorosa no estudo destes grupos em prol da secessão, uma vez que estes apresentam uma linguagem mais suave quando comparados aos seus pares do início do século passado. Deste modo, vê-se um novo separatismo que busca afastar-se do histórico racista que acompanhou o regionalismo de São Paulo em diversos momentos. O preconceito de classe, todavia, ainda é uma premissa patente a estes grupos, bem como a racialização que, apesar da sutileza característica do racismo velado, possui coro notável.

Dito isto, é essencial pontuar o caráter marginal do separatismo que será analisado, uma vez que é diminuta a parcela da população que se engaja ativamente nesta proposta. Buscarei expor que esta, todavia, é capaz de tensionar as máximas do imaginário social. Deste modo, defendo que apesar de a proposta separatista ter continuamente falhado em resultado, suas mobilizações são essenciais a um discurso palatável e disseminado amplamente: o da superioridade paulista.

Outro fenômeno elucidativo na análise do caráter extremo com que a paulistanidade pode aparecer seria o de neonazistas separatistas de São Paulo, que não apenas possuem uma linguagem agressiva em relação a nordestinos, negros e LGBTQIA,$+{ }^{6}$ como também mobilizam a violência física para perpetrar sua ideologia. $\mathrm{O}$ fato de nordestinos serem alvo de grupos neonazistas em São Paulo é capaz de evidenciar que o ideal de superioridade regional ancorado na discriminação racial e econômica, gera resultados nefastos. Creio que

\footnotetext{
${ }^{6}$ Utilizo a sigla LGBTQIA+ pontuando as relevantes disputas e críticas que há em torno desta conceituação e nomenclatura.
} 
seja necessário pontuar, desta forma, que a recorrência de um ideal civilizatório branco e enriquecido dotaram a paulistanidade de agressividade.

Isto, todavia, é acompanhado do fato de que o regionalismo paulista não é um fenômeno unívoco. Expressões regionais em todo mundo podem abarcar lados diferentes do espectro político. É por tal motivo que nesta pesquisa apresento expressões da paulistanidade ancoradas na racialização e demarcação econômica, sendo estas frequentemente direcionadas aos nordestinos e acompanhadas de narrativas hierarquizantes com consequências materiais.

Na década de 2010 este fenômeno se recrudesce a partir do avanço conservador que não apenas se mostra reativo a uma decisão eleitoral marcada por votos nordestinos, como também propõe uma série de políticas caras à hierarquização social. Debates relevantes do contexto brasileiro recente, como o das políticas raciais afirmativas e o que envolve o Programa Bolsa Família, são essenciais a esta análise, uma vez que o discurso conservador não apenas reverberou preconceitos raciais e de classe em referência aos grupos abarcados por estas medidas, como também regionalizou sua atuação. A conexão que se faz em relação às populações nordestinas e o recebimento do Bolsa Família seria exemplo disto.

Deste modo, vê-se a perpetuação de uma regionalização que envolve marcadores sociais da diferença diversos. A ideia de que o Nordeste do Brasil é habitado por uma população inapta, frequentemente estigmatizada enquanto avessa ao trabalho, se converteu em um argumento político relevante na ilegitimidade que foi atribuída ao governo presidencial de Dilma Rousseff. Viu-se um discurso social que não focava na ineficácia da representatividade eleitoral, mas justamente nas parcas políticas petistas de redução da pobreza extrema. A atenção, ainda que diminuta, a uma região e populações constantemente estigmatizadas e alvos de preconceito, teria ferido não apenas a acepção política das elites brasileiras, como também um plano regional paulista que procura manter-se no topo da hierarquia nacional.

Por este motivo trato o recente impeachment brasileiro como um Golpe Institucional $^{7}$ com consequências relevantes aos fenômenos que analiso nesta pesquisa. Justifico a nomenclatura de Golpe por considerar o processo como medida aparentemente

\footnotetext{
${ }^{7}$ Vale lembrar que no meio acadêmico o termo está sendo constantemente mobilizado para se referir ao processo. Saliento, neste sentido, os cursos denominados de "O Golpe de 2016 e o futuro da democracia no Brasil" ministrados na Universidade de Brasília (UnB), Universidade Federal da Paraíba (UFPB), Universidade Federal da Bahia (UFBA), Universidade Estadual de Campinas (UNICAMP), Pontifícia Universidade Católica de São Paulo (PUC-SP), entre outras.
} 
legal e "supostamente dentro do Estado de Direito, mas com uma restrição cada vez maior de direitos" (LOWY, 2016:62) e por notar as assimetrias que o marcaram. Neste sentido, atento ao fato de que a expansão de políticas voltadas à cidadania que foi expressa pelos mandatos petistas não foi fruto da "agenda de um governo e sim uma agenda construída e demandada ao Estado brasileiro" (LIMA, 2010). Como já afirmado, creio que esteja justamente na ascensão destas demandas o incômodo de um conservadorismo nacional que foi capaz de fomentar e apoiar os meios institucionais que levaram à deposição. Deste modo, apesar de os mandatos petistas terem representado o avanço de um ideal conciliador, foi possível ver uma parcela dos setores conservadores que se mostraram avessos a sua representatividade em torno de elementos estigmatizados e discriminados da sociedade.

Assim, creio que seja possível afirmar que a recente crise política brasileira carregue em si noções restritas do que é considerado civilização e progresso. A imagem de Dois Brasis - um narrado como rural, negro, indígena e pobre e outro enquanto urbano, branco e rico - aparecem de forma saliente neste contexto. A efervescência da campanha Afogue um Nordestino após os resultados eleitorais de 2010, com suas mobilizações de ofensa racial e de classe, seria um exemplo evidente disto. Deste modo, empenho-me em apresentar uma dissertação capaz de destrinchar, a partir da análise regional, a materialidade política da desigualdade que marca o Brasil e suas manifestações regionalistas.

Este esforço é empreendido com atenção àquilo que Guerreiro Ramos afirmou sobre o estudo das relações raciais brasileiras: este continuamente aparece como um exercício de pesquisadores brancos que apresentam a "sociologia do negro brasileiro" (Ramos, 1995) e apartam-se do entendimento da branquidade e de seu papel central na estratificação social. Com isto em vista, busco afastar-me de uma abordagem que historicamente se debruçou neste viés analítico e político. Farei isto apresentando uma pesquisa concentrada em destrinchar as práticas e narrativas de grupos com concentração de poder, invertendo a análise que costumeiramente elencou populações estigmatizadas como objetos de estudo. Assim, o foco desta dissertação concentra-se em narrativas regionalistas esmeradas na formação racial branca e no domínio econômico, sendo a branquidade e a meritocracia fatores centrais de atenção. 
A presente dissertação é dividida em duas partes. Na primeira, analisarei aspectos regionalistas de estados brasileiros diferentes, em especial do Nordeste e São Paulo, a partir de uma revisão bibliográfica extensa. Na segunda, apresento estudos de caso que realizei tomando como dados eventos recentes, especialmente da década de 2010. A revisão bibliográfica das temáticas do regionalismo, do nacionalismo e da racialização valeu-se, em especial, da análise crítica das obras de Barbara Weinstein, Benedict Anderson, Eric Hobsbawn, Ruben Oliven, Antonio Sérgio Guimarães, Jessita Moutinho, Lilia Schwarcz e Abdias do Nascimento. Através do diálogo estabelecido com as proposições destas autoras e autores - e tantos outros que serão analisados - que a presente dissertação foi formulada.

No primeiro capítulo, intitulado de Enredos da Paulistanidade, apresento as máximas que envolvem a ideologia paulista: branquidade, poder econômico e preconceito. Com isto, quero mostrar que as narrativas que envolvem o discurso paulistanista não somente fogem, por diversas vezes, da realidade social, como também são responsáveis por criar um nível representativo em que o paulista aparece costumeiramente enquanto branco e de classe média. Também apresentarei neste capítulo a importância da figura do bandeirante na formulação da imagem identitária dos habitantes de São Paulo, bem como os empenhos das classes política e intelectual que, ao longo do século XIX e XX, foram capazes de determinar as bases narrativas do regionalismo do estado. Para tal, focalizo eventos históricos como o Conflito Constitucionalista de 1932 e o IV Centenário Paulistano, que foram eficazes tanto em aparentar São Paulo enquanto aproximação gloriosa da europidade e aptidão política quanto em pautar o Nordeste enquanto Outro Regional a ser rechaçado racial, cultural e economicamente.

Neste capítulo apresentarei as possibilidades que uma imigração branqueadora proporcionou a São Paulo. Tentarei expor o estado como mobilizador de um discurso de restrição, uma vez que até hoje impera a contraposição entre grupos migrantes, sendo uns considerados bem-vindos e outros rechaçados em seu tipo racial e econômico. Neste sentido, buscarei apresentar que as narrativas regionalistas paulistas envolvem um processo nacional de racialização, sendo que determinados locais e grupos humanos mobilizaram de formas distintas discursos sobre branquidade, democracia racial e o convívio entre grupos humanos. Procuro expor o discurso regionalista do estado de São Paulo em suas 
descontinuidades históricas, em que um projeto branqueador patente ao fim do século XIX e início do XX se tornou velado.

No segundo capítulo desta dissertação, intitulado de Nordeste, exibirei o caráter de disputa que envolve as regiões brasileiras. Pautando que não existe um povo nordestino unívoco, apresentarei as populações deste recorte espacial como agentes de sua formação social. Procuro, com isto, enfatizar que, longe da passividade que lhe é imposta, o Nordeste existe enquanto ambiente mobilizador de narrativas históricas que rivalizam com preceitos regionalistas de lugares distintos. Do mesmo modo, possui oligarquias empenhadas na criação de um discurso intelectual e político, frequentemente perpetrador de hierarquias sociais.

Para tal, apresento a obra de Gilberto Freyre como mobilização regionalista importante, em especial no que diz respeito à manipulação do discurso da democracia racial e do elogio à sociedade patriarcal açucareira. Mostrarei também expressões artísticas nordestinas que ao longo dos tempos contribuíram para a dizibilidade desta porção regional. Este empreendimento analítico será realizado em constante contraposição ao regionalismo paulista, apontando-se as diferenças entre suas acepções raciais e econômicas: o Nordeste articulando um discurso que envolve pobreza e mestiçagem e São Paulo afastando tais traços, focando na branquidade, na industrialização e na ascensão econômica.

Imersas em tal contraposição estão também as figuras míticas que são associadas ao Nordeste: o cangaceiro e o fanático. Estas serão apresentadas como contraponto do bandeirante. Neste sentido, buscarei expor que o preconceito contra as populações nordestinas vale-se de ideais em torno de raça e classe, sendo o nordestino constantemente racializado inferiormente e associado ou a uma elite considerada arcaica (coronel) ou a um povo tido como ineficaz (retirante). Parte deste preconceito será apresentado a partir da redução nordestina ao estereótipo que envolve o estado da Bahia. Finalizarei o capítulo expondo que há diversas formas de resistência frente a esta estigmatização regional.

No terceiro capítulo desta dissertação, Da Mítica Branquidade à Mítica Democracia Racial, colocarei em questão a especificidade paulista. Mobilizando uma série de narrativas regionais (Rio Grande do Sul, Paraná, Minas Gerais, Bahia, Pernambuco, Ceará, Pará, Mato Grosso do Sul e Rio de Janeiro) apresentarei as adequações variadas que estes estados possuem em relação à ideia imaginada de democracia racial e ao ideal de ascensão econômica. Pretendo, com isto, mostrar os graus diferentes de aceitação que 
narrativas regionais possuem em relação a um ideal civilizatório. Serão expostos locais em que o discurso regionalista esmerou-se em aparentar branquidade e sucesso econômico e outros que tomaram o caminho oposto. Interessa-me notar as possibilidades materiais e mitológicas e a eficácia discursiva de regionalismos distintos.

No quarto capítulo desta dissertação, intitulado de Crise Política, Legitimidade Eleitoral e Paulistanidade, apresentarei a continuidade de uma ideologia paulista conservadora a partir da mobilização de processos históricos variados. Para tal, mostrarei que narrativas que apareceram nos séculos XIX e XX engendraram um argumento paulistanista no Golpe de Estado ocorrido em 2016. Do mesmo modo, apresentarei grupos de orgulho paulista que propõem a separação do estado do restante da federação brasileira. Mobilizarei uma bibliografia capaz de expor que São Paulo, tanto pelo seu desenvolvimento econômico quanto por sua narrativa regional, aparece enquanto excludente em termos de espaço e acesso simbólico. Por este motivo, apresentarei neste capítulo o gradiente da paulistanidade. Interessa-me mostrar que as expressões do regionalismo paulista podem ser múltiplas e variadas, bem como a gradação entre discursos que envolvem preconceito, discriminação e ódio.

No quinto capítulo, intitulado de Ódio ao Pobre, à Favela e ao Nordestino, apresentarei o primeiro dos dois estudos de caso que serão apresentados nesta dissertação. Analisando discursivamente o Manifesto São Paulo Para Paulistas, com versões publicadas em 2010 e 2012, buscarei apresentar uma manifestação de paulistanidade atual que se mostra agressiva e avessa ao nordestino. Deste modo, será realizada a análise da referida proposta que, mobilizando especialmente restrições de classe e a sublimação da discriminação racial, almeja o fim da migração nordestina direcionada a São Paulo. Analiso como discursos que se mantém à margem do socialmente aceito podem causar tensão a um debate social mais amplo.

No sexto capítulo, intitulado de O Conservadorismo do Movimento São Paulo Livre, apresentarei um estudo de caso sobre este movimento separatista que surgiu após as eleições presidenciais de 2014. Sua validade concentra-se na possibilidade de analisar uma paulistanidade reconfigurada em diversos sentidos. Aparentemente defendendo a tolerância, a inclusão e a representatividade, o SPL aparece como grupo separatista que se afirma enquanto pós-racial e pós-sexista. Tentarei expor, todavia, que o grupo segue em um ideal restrito de superioridade que, apesar da sutileza, perpetua a racialização e estigmatização de variadas populações. 
PARTE I 



\section{CAPÍTULO I \\ Enredos da Paulistanidade \\ Branquidade, Poder Econômico e Preconceito}

\section{1 - O Regionalismo Paulista Sob Uma Perspectiva Histórica}

Inicio a discussão aqui proposta a partir do entendimento de que o regionalismo paulista se mobiliza em entornos políticos que não se mostram demarcados racial e economicamente em momentos históricos isolados, mas na afirmação recorrente de superioridade econômica, moral, regional e racial, ${ }^{8}$ sendo esta agravada em momentos políticos conturbados. ${ }^{9}$ Entendo, na esteira de pesquisadoras como Jessita Moutinho (1991) e Barbara Weinstein (2007, 2015), que fenômenos-chave nos estudos regionalistas, tais como os conflitos de 1932 e o IV Centenário de São Paulo, são elucidativos no entendimento de discursos e manifestações políticas hoje correntes. Da mesma maneira, defendo que tais episódios, exaustivamente analisados pela bibliografia especializada, não são os únicos a conter aspectos racializadores e economicamente preconceituosos em suas mobilizações. Sendo assim, proponho uma discussão preocupada com a análise do gradiente e das continuidades e descontinuidades da ideologia construída em torno do que é ser paulista e do orgulho regional daqueles que assim se identificam e são identificados.

De início vale dizer que o regionalismo paulista não é um fenômeno unívoco. Longe de querer demonstrar que tal regionalismo alberga em si apenas sentidos preconceituosos, acredito que na realidade este possua segmentos, expressões e modos de recepção diversos. Cabe a pergunta se seria mais eficaz falar de regionalismo paulista no plural, uma vez que suas expressões são múltiplas. Elejo, de todas as formas, a opção no singular. Isto porque acredito que no que tange ao mote dessa pesquisa - a racialização, a demarcação econômica e a mobilização regional política - existe certa unidade de

\footnotetext{
${ }^{8}$ Região e raça são pensadas nesta dissertação conjuntamente em muitos momentos, uma vez que o regionalismo paulista esbarra por diversas vezes em ideias que vão de encontro à eugenia (SOUZA, 2007) a partir da construção de um ideário responsável por expor os naturais do estado de São Paulo como uma "Raça de Gigantes"(ELLIS JR, 1926) em contraposição a um teórico, ridicularizado e racializado "Outro Regional" (WEINSTEIN, 2015). Para além disso, acredito que "quando falamos de lugares, falamos de etnias" (GUIMARÃES, 2003:96).

9 “A 'paulistanidade', conceito pelo qual procuramos caracterizar a ideologia afirmadora da superioridade étnica, econômica e política dos naturais do Estado de São Paulo relativamente ao restante dos brasileiros, surge em todas as épocas de crise e reformulação na forma do Poder Central" (MOUTINHO, 1991:2).
} 
discurso, apesar de haver variedade de expressões do mesmo. Busco, assim, apresentar expressões do regionalismo paulista que se pautam na paulistanidade.

O termo paulistanidade é utilizado tanto por estudiosos que buscam analisar o regionalismo paulista quanto por aqueles que advogam a superioridade de São Paulo, como é o caso de Alfredo Ellis Júnior. ${ }^{10}$ De maneira geral, o termo remete ao ideal que afirma a superioridade paulista em diversos aspectos. Alguns pesquisadores, como Luis Fernando Cerri (1998), defendem que a paulistanidade seria uma criação da oligarquia paulista para a construção de uma identidade regional que alberga determinadas características e valores como próprios dos paulistas, sacramentando tal ideologia com a figura do bandeirante que representaria o patriarca do povo de São Paulo.

Existe certo consenso entre os estudiosos da área de que tratar de tal fenômeno significa tratar de uma pretensa superioridade que, por diversas vezes, é exposta a partir de discursos preconceituosos. Algo fica nítido: a paulistanidade se constituiria em torno não só do ideal que estabelece São Paulo como superior, mas também no desprezo ao Outro Regional, sendo estas duas categorias - a de pertencente ou não-pertencente à identidade paulista - demarcadas em função de raça e classe.

Em História Regional e Identidade: O Caso de São Paulo, Ricardo Luiz de Souza faz um histórico breve da paulistanidade. O autor expõe como primeiro símbolo desta, a Proclamação de Amador Bueno como imperador dos paulistas em 1641, em negação à restauração do trono português. O episódio pôde ser mobilizado séculos depois como um símbolo da resistência paulista ou, como demonstra Weinstein (2015), da natureza paulista que se afirma enquanto sinônimo de liberdade, jamais sendo submissa.

Souza demonstra ainda que pode se identificar no século XVIII - a partir das obras $^{11}$ de Pedro Taques e Frei Gaspar da Madre de Deus - a origem da paulistanidade, tendo esta se ampliado nas últimas décadas do século XIX e atingido seu apogeu nos anos de 1930 do século XX. De todos os modos, como defende Joseph Love, a partir do fim do século XIX já havia o estereótipo paulista demarcado como uma "personalidade coletiva, séria, trabalhadora, materialista e empreendedora" (LOVE apud SOUZA, 2007:392).

No período que engloba a Abolição da Escravidão e a crise do Império, aspirações paulistas de separação em relação ao resto do país começam a compor um coro mais expressivo entre as elites do estado. Souza demonstra que os grandes latifundiários

\footnotetext{
${ }^{10}$ Que utiliza o termo em sua obra A Nossa Guerra.

${ }^{11}$ Frei Gaspar da Madre de Deus: Memória da História da Capitania de São Paulo, Lisboa, 1797. Pedro Taques: Nobiliarquia Paulistana, Genealogia das Principais Famílias de São Paulo.
} 
patrocinaram uma campanha separatista que teve como expoente principal Alberto Salles, autor de A pátria paulista. Nesta obra Salles estabelece em termos raciais a necessidade de separação ao defender que a colonização em São Paulo foi feita "por colonos brancos e compostos de gente limpa que não se confundiam com os naturais da terra" sendo que "o elemento africano por muito tempo aqui se conservou insignificante" (SALLES, 1887).

No decorrer do começo do século XX a paulistanidade seguiu com formulações excludentes, em especial nos meios intelectuais a partir de uma abordagem racista, atingindo, porém, seu nível máximo e generalizado nos anos de 1930, com a tomada de Getúlio Vargas do poder e o ressentimento das elites paulistas com tal fato. O conhecido Conflito de 1932 abarcou tanto grupos indiscretamente separatistas quanto conjuntos que acreditavam em São Paulo como responsável por civilizar o país, apesar de, nesta lógica, ser prejudicado pelo mesmo. O que mais suscita a necessidade de investigação no dado conflito é a comoção social gerada no período. Longe de serem restritos às elites, os conflitos de 1932 chegaram aos mais diversos grupos sociais, raciais e econômicos de todo o estado.

Com a derrota de São Paulo na chamada revolução, as elites paulistas - como defendido por Souza (2007) e Weinstein (2015) - se empenharam na reestruturação de uma paulistanidade que seria capaz de afirmar São Paulo como defensor da democracia e dos valores civilizados, ideia calcada no que era considerado uma premissa: “os paulistas não suportam a opressão" (SOUZA, 2007:398). Para Souza, o conflito foi responsável por uma idealização do passado paulista, como se nesta sociedade pretérita elites e povo tivessem irmanando-se em bases democráticas.

Findo os anos de 1930, São Paulo prosseguiu no que parecia uma marcha inexorável ao progresso. Maria Arminda do Nascimento Arruda em Metrópole e Cultura expõe que em meados do século XX São Paulo continuava a se estabelecer como o centro cultural mais moderno do Brasil. A autora caracteriza o período pós Segunda Guerra como um momento em que a vida moderna está se cristalizando na cidade de São Paulo, sendo isto visível em campos diversos de expressão cultural através de um empenho intelectual para a construção de um "futuro civilizado e internacionalmente articulado" (ARRUDA, 1997:1).

Os esforços para tal construção de civilização encontram como terreno fértil São Paulo e a elite intelectual consolidada na cidade. Os ecos desse fenômeno nas Ciências Sociais não são nítidos apenas em novas propostas metodológicas adotadas pela 
Sociologia, mas inclusive nas declarações de teóricos da área, como exemplificado pelas palavras de Florestan Fernandes: “os que pensam no Brasil como 'país do futuro' têm em vista, naturalmente, cidades como São Paulo, nas quais se está forjando, verdadeiramente, a sociedade brasileira da era científica e tecnológica” (FERNANDES, 1974:303).

Algo que buscava se firmar desde o fim do século XIX triunfou: a ideia de São Paulo como local do progresso. O que pode ser visto tanto na consagração do bandeirantismo na década de 1950 quanto na comemoração do IV Centenário e nas declarações de diversos intelectuais que, em meados do século passado, afirmavam que em São Paulo vicejava o espírito que selava a identidade de metrópole da cidade, sendo esta o lugar capaz de alçar o resto do país ao futuro. Neste sentido é válido lembrar que diversas vezes, em especial nos discursos da paulistanidade, cidade e estado de São Paulo se fundem. De todos os modos, frequentemente fala-se do cosmopolitismo e industrialização da capital paulista como algo que tocaria e elevaria todo o estado.

Posto isto, vê-se que há tempos ecoa no Brasil uma mesma certeza: São Paulo é o principal polo econômico e político brasileiro. A concepção hegemônica de progresso ainda se encontra mais estreitamente ligada ao estado paulista do que a qualquer outro. Grandes movimentos migratórios do Nordeste ao Centro-Sul, em especial em meados do século XX, são fatos históricos mobilizados diversas vezes para explicar o caráter preconceituoso do regionalismo paulista ou a pretensa superioridade de São Paulo. Como deixo nítido na presente pesquisa, a formação tanto da crença em tal superioridade quanto do desprezo ao Outro Regional são fatores anteriores a tal migração.

Atentando-me a isto, creio que para entender como determinados movimentos e contextos históricos voltam a mobilizar discursos que no fim do século XIX já mostravam força, é possível mobilizar o conceito de comunidade imaginada de Benedict Anderson (2008). Anderson, influenciado por Walter Benjamin, propõe uma ideia de tempo vazio e homogêneo como base da imaginação das comunidades. Estas, constituindo-se com mitos de fundação e montagem de enredos imaginados, estabelecem determinadas verdades e sentimentos de camaradagem capazes de fazer com que desconhecidos sintam-se conectados a um mesmo grupo. Empenhado em analisar os nacionalismos, Anderson demonstra que tais invenções possuem relevância considerável: é possível morrer em defesa de uma comunidade que em última instância é imaginada.

É essencial, deste modo, não somente entender a imaginação que envolve o discurso paulistanista, mas especialmente as premissas históricas que guiam este processo 
imaginativo. Acredito que a identidade paulista não se pautou apenas em uma ideia de superioridade que se baseia unicamente no enaltecimento de seus costumes, História e população. Para além disso, defendo que tal comunidade se calcou no ideal de aptidão ao modelo capitalista e na racialização de um Outro Regional. Tal racialização seria acompanhada da formação de uma narrativa descolada da realidade em que "no nível da representação o paulista é indubitavelmente branco e de classe média" (WEINSTEIN, 2007:291).

Acredito, como Weinstein, que essa racialização de um Eu e de um Outro Regional em muito pode se relacionar ao que Edward Said propôs em sua obra Orientalismo. Said expõe que os estudos orientalistas europeus foram responsáveis não apenas por rebaixar a categoria oriental como grupo desumanizado, mas também por criar tal categoria com o objetivo de se estabelecer enquanto grupo ocidental, grupo superior. Entendo que o rebaixamento e a racialização do Outro Regional, que em São Paulo é especialmente nordestino, é fator ativo na construção do eu-regional paulista enquanto superior, enquanto branco, enquanto imagem do sucesso econômico.

Apesar de discursos da paulistanidade estarem associados à fusão de períodos - da herança passada bandeirante ao progresso presente e à certeza de um futuro civilizado - há variações discursivas ao longo dos tempos. É neste sentido que uma indiscrição racista da paulistanidade aos fins do XIX e início do XX puderam ganhar um ar mais brando com o império do discurso da democracia racial. Deste modo, é válido analisar como máximas racializadoras podem aparecer com argumentos de cunho culturalista em um contexto que relega o racismo, antes escancarado, a esferas veladas.

Assim, defendo que seja válido pensar não apenas no regionalismo paulista como racializador, mas como parte de um processo nacional de racialização, no qual regionalismos formaram apenas um de tantos fatores e aspectos. Neste sentido é válido pensar no fato de que o tempo vazio e homogêneo pode, de fato, formar parte de um argumento paulistanista imaginado: apela-se a um patriarca fundador, tal qual o bandeirante, ao fato de a Independência brasileira ter se dado em terras paulistas e a uma série de episódios pretéritos para justificar São Paulo como a terra que sempre esteve fadada ao progresso e a um futuro brilhante. Este tempo vazio e homogêneo, todavia, está longe de constituir-se como algo constante e imutável: há, ao longo do tempo, mudanças estratégicas em torno da paulistanidade. 
Posto isto, pensar em uma imaginação das comunidades associada à racialização e demarcação econômica leva à investigação acerca de quais grupos foram imaginados como opostos à suposta branquidade e riqueza paulista. Por que São Paulo não se adequaria aos povos, mitos e bases nacionais? Por que teria que dizer-se tão superior? Quando desracializada, o que seria a identidade paulista? Como outros marcadores sociais da diferença se articulam nesta identidade? São estas algumas perguntas que nortearão o presente capítulo. Nele, apresentarei, em especial, manifestações paulistas do fim do século XIX e da primeira metade do século XX.

\section{2 - Sangue Bandeirante, Raça de Gigantes $^{12}$}

Se há algo que é explicitado em qualquer estudo acerca das expressões do regionalismo paulista, é o fato de o bandeirante aparecer como o patriarca do paulista (CERRI, 1998), como sinônimo do povo paulista (WEINSTEIN, 2007) ou até mesmo como aquele que mostraria o percurso da brasilidade, empós do povo paulista (VELLOSO, 1993). É, assim, nítido o aspecto central do regionalismo no dado estado, ao menos na primeira metade do século XX: $:^{13}$ a criação de uma identidade regional baseada na figura do bandeirante que formulou, em diversos contextos, uma narrativa em que é a "herança bandeirante que explica o progresso e a modernidade de São Paulo” (VELLOSO, 1993:19)

Maria Isaura Pereira de Queiroz em Ufanismo Paulista: Vicissitudes de um Imaginário demonstra que ser paulista é uma manifestação de coletividade geograficamente localizada que se torna aparente através da figura mítica do bandeirante, sendo esta mobilizada em seu passado imaginado: "quando conquistou para a Coroa Portuguesa o imenso interior brasileiro" (QUEIROZ, 1992:79). Neste sentido, acredito que o bandeirantismo demonstra o caráter da racialização de uma identidade que já em seu princípio baseia-se na conquista do outro.

Dizer que a figura do bandeirante foi reformulada significa notar uma mudança significativa, ocorrida no final do século XIX, no discurso acerca do que estes representavam. Queiroz expõe que em 1802 o termo "bandeirante" não aparecia no Diccionario de Lingua Portugueza. ${ }^{14} \mathrm{O}$ que seriam os bandeirantes aos poucos foi

\footnotetext{
${ }^{12}$ Alusão à obra Raça de Gigantes de Alfredo Ellis Jr.

${ }^{13}$ Apesar de o bandeirantismo continuar informando o debate regionalista no século XXI, como defendido por Weinstein.

${ }^{14}$ Publicado por Moraes e Silva.
} 
ganhando novo significado. Em 1913, no Novo Dicionário da Língua Portuguesa ${ }^{15}$ constava o termo como palavra que remetia a homens que exploravam os sertões brasileiros, caçando selvagens. Em 1928 no Novo Dicionário Nacional ${ }^{16}$, bandeirante seria ainda o sujeito que faz parte de uma expedição denominada bandeira. Finalmente, em 1938, no Grande e Novíssimo Dicionário da Língua Portuguesa, ${ }^{17}$ aparece um significado novo: bandeirante seria sinônimo de paulista. Tal visão se vê consagrada em 1960 no Pequeno Dicionário Brasileiro da Língua Portuguesa. ${ }^{18}$ Nele, bandeirante era o natural do estado de São Paulo.

Neste sentido é interessante pensar no porquê de os paulistas - dentre tantos outros grupos regionais que também participaram das bandeiras - reconhecerem-se e serem reconhecidos como conectados à figura bandeirante. Os historiadores já citados nessa pesquisa, Pedro Taques e Frei Gaspar da Madre de Deus, foram, segundo Kátia Maria Abud (1986), pioneiros ao conectar o símbolo bandeirante ao paulista; isto tendo ocorrido no século XVIII. Queiroz aponta que ambos, apesar de seus pontos analíticos diferentes, registravam que as qualidades bandeirantes "justificavam plenamente seu direito, e o direito de seus descendentes, de ocuparem posição de mando na capitania" (QUEIROZ, 1992:81).

Alberto Salles, já citado como responsável por advogar pelo separatismo de São Paulo, realizou uma mudança importante ao analisar o bandeirante no fim do século XIX não enquanto mito passado, mas como força que era atual. Para Salles não era pretérita a fibra moral paulista. Sua preocupação era expor, com intermédio de dados que almejavam o teor científico, o sangue pioneiro dos naturais de São Paulo: o paulista seria ainda um desbravador. Salles, com uma série de argumentos raciais e econômicos tentava, assim, expor a possibilidade de São Paulo ser independente; eram os supostos dados do presente que defendiam sua ideia.

É interessante pensar como a massa de imigrantes estrangeiros presente em São Paulo era vista em tal momento, uma vez que esta não trazia consigo o sangue bandeirante. Queiroz aponta que nos meios intelectuais houve preocupação com as influências forasteiras em terras paulistas. A autora, todavia, expõe que o bandeirante como "figura lendária reforçaria a coesão entre os naturais da região e os alienígenas,

\footnotetext{
${ }^{15}$ Publicado por Antonio Cândido de Figueiredo.

${ }^{16}$ De autoria de Carlos Teschauer.

${ }^{17}$ De autoria de Laudelino de Oliveira Freire.

${ }^{18}$ De autoria de Aurélio Buarque de Hollanda Ferreira.
} 
envolvendo a todos na mesma condição de pioneiros, cada qual a seu modo" (QUEIROZ, 1992:83).

Isto, todavia, não era o suficiente para aniquilar a discriminação interna: quem era tocado pelo poder de viver em uma região bandeirante ainda assim não era descendente desse símbolo. O Conflito de 1932 e a necessidade da elite paulista de obter apoio popular leva por terra tal separação: todos em São Paulo podiam ser paulistas legítimos, frutos da linhagem bandeirante. Como dito anteriormente, o dado conflito provocou uma comoção que não se restringiu somente ao meio intelectual ou de raízes aristocráticas.

Provavelmente a maior importância do estudo de Queiroz para a presente pesquisa resida na afirmação da autora de que o símbolo bandeirante é de essencial investigação não somente por possibilitar a coesão entre um grupo, mas sim por delimitar suas fronteiras. Nas palavras da autora "é devido a suas peculiaridades de elemento discriminador que o símbolo define seus predicados e constitui algo de vigoroso" (QUEIROZ, 1992:86). Desse modo, Queiroz explicita como a função mais profunda dos símbolos está em delinear para uma sociedade quem é o Outro e o $E u$.

Barbara Weinstein, também na defesa de que o estoque simbólico da paulistanidade é capaz de alçar-se identitariamente em contraposição a um Outro Regional, aponta que os bandeirantes foram publicizados ao longo do século XX como proto-capitalistas, sendo ignorado que estes eram também não-brancos, mamelucos (WEINSTEIN, 2015:37). Neste sentido, a presença negra nas bandeiras, que chegou a ser afirmada até mesmo por Taunay, ${ }^{19}$ foi sendo esquecida ao longo dos tempos.

Os supostos empreendedorismo e pragmatismo dos bandeirantes seriam características utilizadas por diversos expoentes do orgulho paulista para invocar uma ideia de supremacia econômica como traço nato, racial, dos paulistas. Assim, a simbologia bandeirologista não é relevante apenas por criar uma etnicidade imaginária bem sucedida, mas também por contrastar com "o decadente e tradicional plantador de açúcar do Nordeste colonial" (WEINSTEIN, 2007:288).

O desprezo a essa concepção de atraso do Outro Regional, representado especialmente pelo nordestino, é encontrado em diversas obras e discursos do começo do século passado. Ellis Jr., entusiasta da causa paulista, expunha indisfarçadamente sua crença na superioridade dos naturais brancos do estado. $\mathrm{O}$ autor posiciona tal argumento

\footnotetext{
19 TAUNAY, Afonso. Subsídios para a História do tráfico africano no Brasil. Rio de Janeiro, Imprensa Nacional.
} 
levando em conta, especialmente, fatores econômicos, mas fica nítido que em sua concepção os paulistas são uma Raça de Gigantes. Este sendo, inclusive, o título dado a sua obra publicada em 1926.

Nas ideias de Ellis Jr vê-se a etnicidade imaginária em seu máximo espectro: os paulistas estariam destinados à superioridade devido, justamente, à sua herança bandeirante. Defendo que, neste sentido, é necessário analisar o processo racializador imbricado nesta figura: o bandeirantismo indica uma formação racial a partir da etnicidade que branqueou os desbravadores das heróicas bandeiras ao mesmo tempo que estigmatizou por um viés racial outros tipos sociais e regionais.

Levando em conta a discussão aqui proposta, pontuo, em compasso com os argumentos de estudiosas como Queiroz e Weinstein, que o estoque simbólico referente ao bandeirantismo representa um mecanismo poderoso para a hierarquização de grupos e a afirmação de superioridade. Todavia, para além disso, objetivo expor como ultrapassando o simbólico, a figura do bandeirante também pode ser apreendida como uma forma de substrato ideológico. De tal forma, apesar de a paulistanidade reproduzir-se com generalidade, capaz de abarcar diversas classes e raças sociais, ${ }^{20}$ é nítido o fato de que o ideal do orgulho paulista serve às classes dominantes e a um propósito embranquecedor.

Como exposto na bibliografia que vem sendo discutida, o regionalismo paulista encontra sua base discursiva em máximas conservadoras acerca de pretensas superioridades econômicas e raciais. No entanto, nos últimos anos houve uma série de esforços no sentido de transformar o símbolo do herói bandeirante em uma figura que está conectada ao genocídio indígena. Um dos exemplos disso seria o Monumento às Bandeiras de Victor Brecheret - inaugurado no IV Centenário de São Paulo e localizado no Parque do Ibirapuera - ter sido alvo constante de intervenções políticas. Só nos últimos três anos o Monumento foi palco de manifestações indígenas pela demarcação de terras, ${ }^{21}$ de

\footnotetext{
${ }^{20}$ Antonio Sérgio Guimarães se refere a raças sociais, "o que retira toda referência biológica ou somática da noção de raça e chama a atenção para a realidade social do racismo." (MOSNMA, 2013:9).

${ }^{21} \mathrm{O}$ que pode ser visto em: FORUM. Monumento às Bandeiras homenageia aqueles que nos massacram. 2013. Disponível em: <http://www.revistaforum.com.br/2013/10/05/monumento-as-bandeirashomenageia-genocidas-que-dizimaram-nosso-povo-diz-lideranca-indigena/> Acesso em: 30/10/2016
} 
pichações pelo fim dos ataques às populações indígenas brasileiras ${ }^{22}$ e de protestos contra a ascensão de Michel Temer ao poder. ${ }^{23}$

O Monumento às Bandeiras amanhecer ocasionalmente ${ }^{24}$ coberto de tinta vermelha, representando o sangue derramado pelos bandeirantes, é sintomático em diversos sentidos. É possível ver uma parte da população que possui um ideal acerca do bandeirante frontalmente contrário aos ideais constituídos pelos discursos da paulistanidade. $\mathrm{O}$ movimento ${ }^{25}$ que busca modificar a nomenclatura de ruas com nomes de bandeirantes traz à luz um conflito que se mostra de grande relevância: é curioso o fato de que a paulistanidade foi eficaz ao alçar o bandeirante como seu símbolo máximo, este constando até no planejamento urbano, mas não abarcando todos os grupos sociais que configuram a população desse estado.

De tal modo, falar de ideologia faz-se necessário justamente por esses processos contíguos de construção da simbologia bandeirante e depreciação do Outro Regional. A lógica ideológica, como defendido por Chaú, "fabrica teorias a respeito da origem da sociedade e das diferenças sociais" (CHAUÍ, 2016:248). Ora, o que aqui se pode ver, é justamente o que Weinstein afirma quanto ao Outro Regional. A historiadora estadunidense defende que este não é alvo de preconceito com base em dados que levam em conta processos históricos que relevam a distribuição de poder, mas ao contrário, na naturalização racial e econômica de sua inferioridade, em contraposição à naturalização da superioridade paulista e branca, considerada descendente direta dos bandeirantes pioneiros.

Defendo, portanto, que tanto a ideologia bandeirologista quanto a busca pela modificação da mitologia que circunda a figura do bandeirante, exemplificada por uma série de movimentos sociais, deixam nítido o caráter político em torno da paulistanidade e suas acepções. Acredito que o discurso paulistanista é responsável por excluir e

\footnotetext{
${ }^{22}$ Como pode ser visto em: FOLHA DE SÃO PAULO. Estátua de Borba Gato e Monumento às Bandeiras são 'pichados' em São Paulo. São Paulo, 2016, Disponível em: <http://www1.folha.uol.com.br/cotidiano/2016/09/1818322-estatua-do-borba-gato-e-monumento-asbandeiras-sao-pichados-em-sp.shtml> Último acesso em: 30/10/2016

${ }^{23}$ Como pode em: ISTOE. Protesto Contra Temer Termina no Monumento às Bandeiras. São Paulom 2016. Disponível em: <http://istoe.com.br/protesto-contra-temer-termina-no-monumento-as-bandeiras-semgrandes-incidentes/ > Último acesso em: 30/10/2016

${ }^{24}$ Há uma recorrência em tal intervenção política. Desde os protestos ocorridos no Brasil em junho de 2013 até o corrente ano, em momentos de polarização ou decisões em torno das questões indígenas, o Monumento é posto em debate.

${ }^{25} \mathrm{O}$ movimento que não se constitui como um grupo fixo ou partidário, busca modificar os nomes de ruas, em especial daquelas que levam nomes de pessoas que fizeram parte do Regime Militar Brasileiro.
} 
estigmatizar certos segmentos sociais em função de raça e de classe. Nele, todos do estado podem ser paulistas e, assim, superiores em relação a um Outro Regional, mas quem representa este ideal é branco e de sucesso econômico o que, sem dúvidas, possui um caráter ideológico excludente. Caráter este que é contestado:

Bandeirantes, Anhanguera, Raposo, Castelo. São heróis ou algozes? Vai ver o que eles fizeram. Botar o nome desses caras nas estradas é cruel. É o mesmo que Rodovia Hitler em Israel. (Grupo Inquérito, 2015). ${ }^{26}$

\section{3 - Classe Política e Intelectual: Poetas-Educadores ${ }^{27}$}

O historiador João Miguel Teixeira de Godoy, em Identidade e Regionalismo Paulista: Trajetórias e Mutações, apresenta um resumo histórico de como os meios intelectuais trabalharam a paulistanidade ao longo dos tempos, seja para engendrá-la ou analisá-la. Como já apresentado nessa pesquisa, as obras de Frei Gaspar da Madre de Deus e Pedro Taques, da segunda metade do século XVIII, figuram com importância por, de maneira pioneira, defenderem certa excepcionalidade paulista, baseada na comparação com as outras regiões brasileiras, sendo São Paulo à época marginalizada em seus processos econômicos.

O boom do café ocorrido no século XIX e o início da ascensão paulista, bem como a implantação dos sistemas federalista e republicano, são marcados por outro tipo de intelectualidade. No discurso desta, a defesa da excepcionalidade paulista é demonstrada de forma explícita até o início dos anos 30. Os já citados Alberto Salles e Alfredo Ellis Jr. são parte ativa desse período. Porém, para enumerar alguns outros nomes, dentre tantos, é possível citar também Alcântara Machado, Olavo Bilac e Affonso Taunay.

Também fazia parte desse movimento regional Monteiro Lobato, autor questionado nos tempos atuais pelo teor de racismo em suas obras. É emblemática a frase do autor (1929) que, expressando apoio a Júlio Prestes e utilizando símbolos regionais de outros estados para uma provocação, afirma que "não é com queijo, nem carne seca que os graves problemas que defrontam o Brasil serão resolvidos. É com café, audácia, visão, iniciativa e as mais outras qualidades yankees que caracterizam o paulista." 28

\footnotetext{
${ }^{26}$ Trecho da música Eu só Peço a Deus, Grupo Inquérito, 2015.

${ }^{27} \mathrm{O}$ termo poeta-educador é de Mônica Pimenta Velloso.

${ }^{28}$ Carta de Monteiro Lobato a Júlio Prestes de Albuquerque, Nova York, 28 de agosto de 1929, citado em DEBES, Célio. Júlio Prestes e a primeira república. São Paulo: Imprensa Oficial, 1982, p. 96.
} 
Godoy aponta como importante a reformulação da paulistanidade após a derrota no Conflito de 1932, expondo como obras significativas do período Marcha Para o Oeste e $O$ Estado Novo e Seu Sentido Bandeirante, ambas de Cassiano Ricardo. Posteriormente a tal período, o historiador defende que a paulistanidade teria sido mercadorizada. Isto, tendo ocorrido nas décadas de 1950 e 1960, indicaria a instrumentalização propagandista em torno do ideal paulista.

A partir de então, o que se torna relevante seria a tomada da paulistanidade como questão acadêmica. Surgem os questionamentos acerca do que é de fato, em sentido metodológico, ser paulista. Em resumo o autor demonstra que:

\begin{abstract}
A preocupação dos autores ora voltam-se para os estudos da formação e significado da identidade regional (LOVE, 1982), suas conotações ideológicas e simbólicas (QUEIROZ 1992), suas manifestações literárias (VELLOSO, 1993), sua função política (ABUD,1986), condicionamentos institucionais (SCHWARCZ, 1993) e fundamentos simbólicos da construção do imaginário histórico (FERREIRA, 2002). O debate sobre seus significados divide os autores entre aqueles que enfatizam a função de coesão social e identitária da "paulistanidade", que se aprofunda nos momentos de crise (ABUD,1986; LOVE,1982) e aqueles que enfatizam sua função discriminatória, de exclusão e elitização dos grupos dominantes paulistas (QUEIROZ, 1992). (GODOY, 2011:6).
\end{abstract}

Godoy expõe, ainda, que o enraizamento da paulistanidade no sentido institucional (exemplificado pelo culto à memória em locais como o Instituto Histórico e Geográfico de São Paulo, Museu Paulista, Arquivo Público, entre outros) criou uma narrativa da hegemonia paulista que possibilitou desdobramentos posteriores. Desse modo, o autor afirma que a eficácia da narrativa paulista está longe de ter sido plena apenas em um conflito tão mobilizador como o de 1932 sendo, assim, recorrente.

Vejo como fundamental o entendimento de como os meios intelectuais trataram a paulistanidade não apenas pelas interpretações históricas que se encontra destrinchando o assunto, mas acima de tudo pela necessidade de analisar como tais meios engendraram o orgulho paulista. Em Brasilidade Verde-Amarela - Nacionalismo e Regionalismo, Mônica Pimenta Velloso expõe que os anos após a Primeira Guerra Mundial foram fundamentais para uma intelectualidade organicista, que via no Brasil, nas Américas, o novo em 
contraposição à Europa velha e decadente. ${ }^{29} \mathrm{~A}$ intelectualidade brasileira se vê então encarregada de buscar um tipo étnico que represente o Brasil. Curioso é o fato de que tais intelectuais "se auto-elegem a uma missão: encontrar a identidade nacional, rompendo com um passado de dependência cultural” (VELLOSO, 1993:1).

Frente a isto, a produção artística brasileira sofre uma guinada: o intimismo e a pessoalidade não são mais exaltados, importa falar sobre a nação, fazer o nacional. O que pode ser expresso tanto pelo nacionalismo literário de Olavo Bilac (VELLOSO, 1993) quanto pelas produções de nomes caros ao modernismo como Menotti Del Picchia, Oswald de Andrade e Mário de Andrade. Apesar das particularidades de cada um dos movimentos então existentes, o que a intelectualidade paulista da época possui em comum é o fato de ver São Paulo como o local febricitante do progresso, capaz de trazer a modernidade ao restante do Brasil.

Com esta imagem do país do futuro, São Paulo passa a ser enaltecida de todas as maneiras, seja nos jornais ou nas produções literárias. Suas formas arquitetônicas, sua população, sua cultura: tudo se torna motivo para enaltecer o caráter urbano e moderno paulista. Emblemático em tal momento seria a comparação dos dois polos urbanos do Brasil: Rio de Janeiro e São Paulo. No discurso que imprime o regionalismo paulista, o Rio de Janeiro aparece pautado enquanto um local de promiscuidade e displicência (VELLOSO, 1993:5).

Está nítida em tal comparação a delimitação de um Outro Regional que é capaz, através da contraposição, de reafirmar o estereótipo paulista, uma vez que "São Paulo aparece sempre como a terra do trabalho, do espírito pragmático, da responsabilidade e da seriedade" (VELLOSO, 1993:6). É possível afirmar mais uma vez, na esteira do pensamento de Weinstein, que a paulistanidade buscou estabelecer uma narrativa que expressa o desenvolvimento capitalista como próprio de um empreendedorismo natural da população do estado.

É importante ressaltar que ao se falar de um Outro Regional se pensa em regiões ativas em seus próprios processos de formação regional; não sendo estas, de maneira alguma, passivas. O Manifesto Regionalista ${ }^{30}$ de 1926 é um exemplo destacado disso. Da

\footnotetext{
${ }^{29}$ Tal fenômeno pode ser explicado justamente pelo contexto pós-Guerra. Os horrores da Primeira Guerra Mundial de certa forma afirmavam que os caminhos europeus não haviam funcionado.

30 "O Manifesto Regionalista do Nordeste registra o seu protesto contra a homogeneização, criticando o estilo citadino de vida, a cultura urbana ocidentalizada, enfim, a nova realidade do pós-guerra." (VELLOSO, 1993:8).
} 
mesma maneira, para Lima Barreto, São Paulo seria "a imagem da opressão do Brasil, por ser a capital do "espírito burguês"” (BARRETO apud VELLOSO, 1993:6). Tais considerações devem ser destacadas pela importância de explicitar o caráter de disputa que havia entre as regiões.

Tal disputa era tão cara à intelectualidade paulista que em 1907 é criado o Centro Paulista no Rio de Janeiro, contando com uma série de eventos que exaltam e expõem a cultura de São Paulo. Do mesmo modo, a Faculdade de Direito do Largo São Francisco passa a ser vista como "uma fábrica de bacharéis que deverão difundir a cultura brasileira" (VELLOSO, 1993:8).

O consenso entre a intelectualidade paulista residia na crença de um poeta-educador que aponta São Paulo como o modelo da nação, já que "pelo alto grau de desenvolvimento industrial e pela vanguarda de intelectuais que produziu, o estado deve necessariamente exercer o papel de líder" (VELLOSO, 1993:8). O momento-chave para entender a consagração da intelectualidade paulista está na ascensão do Modernismo, iniciada pela Semana de Arte Moderna de 1922. Weinstein aponta que as vanguardas paulistas do período proclamaram sua região como a apoteose da modernidade brasileira, como favorecida pelo destino, fato que levou a que nos anos de 1920 as elites por todo Brasil reconhecessem "rancorosamente que São Paulo detinha as economias industrial e agrária mais prósperas da nação, bem como suas tendências culturais mais inovadoras" (WEINSTEIN, 2007).

No pré-modernismo brasileiro já é possível elencar uma série de esforços intelectuais imbuídos na exaltação de São Paulo e dos paulistas. Talvez um dos exemplos mais emblemáticos seja o do projeto de Affonso Taunay para o Museu Paulista. Claudia Valladão de Mattos (2003) demonstra que o Museu, em 1922, com o novo plano decorativo de Taunay, não só centralizava a figura do bandeirante, inclusive em detrimento da de D. Pedro I, mas também buscava estabelecer uma relação entre o fato de a Independência do Brasil ter ocorrido em terras paulistas e a superioridade de São Paulo: “como sendo aquele o Estado que, desde o início de sua história continha já todas as forças reunidas para conquistar o conjunto do país e, graças a seu impulso e energia, arrastar esse país a seu destino de grande civilização" (MATTOS, 2003).

Nomes essenciais para o entendimento do modernismo brasileiro, como os de Oswald de Andrade e Mário de Andrade, são invocados, por diversas vezes, para o entendimento dessa relação entre o regional e o nacional. É por tal motivo que, apesar de 
ambos serem conhecidos pela defesa de uma cultura brasileira, há relação estreita entre os autores e o regionalismo paulista. É possível entender tal relação atentando-se à teoria da desgeografização de Mário de Andrade em que "o regional em si não tem sentido. $\mathrm{O}$ regionalismo aparece como uma mediação necessária para se atingir a Nacionalidade" (VELOSSO, 1993).

A mesma relação pode ser vista em declarações desses autores renomados. Oswald de Andrade afirmou que "a questão racial entre nós é uma questão paulista. O resto do país, se continuar conosco, mover-se-á como o corpo que obedece, empós do nosso caminho, da nossa ação, da nossa vontade" (VELLOSO, 1993:17). Do mesmo modo, Mário de Andrade, em carta a Paulo Duarte acerca do Conflito de 1932, esbravejou, também em bases raciais, uma diferença paulista:

\footnotetext{
Dêem um estatuto só para nós, pois que somos diferentes mesmo, e sobretudo não venham mais brigar na terra da gente, fazendo esse martirizado São Paulo de campo de suas guerrilhas, de roubo, de indivíduos e de merda. Vão brigar na terra deles, nesses brasis africanos onde a puta os pariu. (ANDRADE apud DUARTE, 1975:18).
}

Em tais declarações é possível ver com nitidez o argumento do progresso como sinônimo de São Paulo, o lema non ducor, duco (não sou conduzido, conduzo) em sua prática, a ideia de que São Paulo era o único lugar capaz de alçar o resto do Brasil ao futuro. Para além disso, torna-se importante salientar as impressões sobre a intelectualidade do período: esta seria exemplo das expressões agressivas de racialização e demarcação econômica que a paulistanidade pode comportar.

O grupo modernista Verde-Amarelo que possui como principal nome Menotti Del Picchia, possuía, por outro lado, o que Velloso chama de um senso extremado de localismo, rompendo assim, com outras correntes do modernismo. Faz parte dos esforços desse grupo uma apresentação do caipira para formar o típico brasileiro. No entanto, Mário de Andrade, com sua já citada desgeografização, trabalhava a questão do regionalismo pensando globalmente a nacionalidade. Velloso aponta que a diferença principal entre a concepção verde-amarela e a defendida por Mário de Andrade está no fato de a primeira relacionar a tradição com a esfera do espacial, enquanto a segunda foca no temporal.

Cassiano Ricardo figura como nome importante na concepção verde-amarela. Em sua obra, Martim Cererê, o autor cria os heróis geográficos que realizaram a epopeia bandeirante. O livro é emblemático em uma questão importante para o entendimento dos 
verde-amarelos: para eles São Paulo seria o cerne da nacionalidade devido a suas características geográficas. No estado, os rios do interior fizeram com que os bandeirantes desbravassem seus sertões, se afastassem do litoral e das influências externas - sendo, portanto, os mais legítimos brasileiros. Nesse caso, vê-se uma História montada em determinados enredos ${ }^{31}$ capaz de oferecer um mito explicativo que se estabelece como verdade ideológica.

A brasilidade defendida pelos verde-amarelos era contrária a ideias alienígenas, contrariando, assim, o estilo citadino de vida que abalaria as raízes brasileiras. A saída para tal problema seria a integração nacional, a qual era uma missão óbvia dos paulistas, uma vez que, nesta lógica, estes tinham a herança bandeirante. A grande questão acerca de tal retórica está no fato de São Paulo possuir, no dado período, uma presença marcante de imigrantes e, consequentemente, de ideias alienígenas. Frente a isto, os verde-amarelos defendiam que a brasilidade em São Paulo era tão forte que contagiaria os imigrantes, abrasileirando-os. Velloso expõe como, em tal sentido, a ideologia bandeirologista operou com eficácia: "o imigrante tornou-se trabalhador porque sofreu as influências benéficas do meio. Logo, é a herança bandeirante que explica o progresso e a modernidade de São Paulo" (VELLOSO, 1993:19).

É interessante notar que as duas vertentes, uma focada na dimensão espacial e a outra no contexto temporal, buscavam as raízes da cultura brasileira de uma forma que pode parecer contraditória. Ao mesmo tempo que pesquisavam o folclore e a população brasileira buscando exaltar o Brasil, estes intelectuais construíam uma narrativa imaginária sobre quem compunha essa nação. Tanto as já citadas afirmações de Oswald e Mário de Andrade, quanto o teor de discriminação indiscreta nas postulações de Mennotti del Picchia, expressam o que Alan Dundes (1985) demonstrou em Nationalism Inferiority: ao mesmo tempo que os intelectuais, em diversos países, envergonham-se do povo, considerando-o atrasado, o romantizam, uma vez que este seria remanescente do patrimônio cultural. Vai-se, portanto, da vergonha ao orgulho, de uma "inferioridade que gera a superioridade" (DUNDES, 1985:12) o que não somente expõe o elitismo patente, mas também a arbitrariedade do que é considerado cultura.

Esse misto de vergonha e orgulho pode ser esclarecedor ao analisar a paulistanidade dos grupos letrados em sua ideologia acerca do bandeirante. Dificilmente se pode crer que

\footnotetext{
${ }^{31}$ SCHWARCZ, Lilia. Prefácio. In: ANDERSON, Benedict. Comunidades imaginadas: reflexões sobre a origem e a difusão do nacionalismo; tradução Denise Bottman. Editora Companhia das Letras, 2008.
} 
os bandeirantes eram os homens retratados nas pinturas, esculturas, poesias e prosas feitas pelos que advogavam pelo orgulho paulista - especialmente no que diz respeito a sua cor, estatura e vestimenta. Sua romantização e estilo que fundaram a identidade paulista a partir de um mito expõem a seleção do que pode ser visto, afirmado e imaginado.

Para além da classe artística intelectual, é interessante analisar como a classe política se mobilizava com um discurso saliente na construção da paulistanidade. Como já dito, Alberto Salles com sua teoria racial sobre a superioridade paulista, possuía como projeto político a criação de uma pátria de São Paulo. Após esse período, já passadas as primeiras décadas do século XX, é interessante analisar Alfredo Ellis Jr e Paulo Duarte, militantes da causa paulista que se envolveram no Conflito de 1932. Sendo o primeiro do Partido Republicano Paulista (PRP) e o segundo do Partido Democrático (PD).

Em Confederação ou Separação, Ellis Jr. argumentava que somente a confederação poderia evitar uma separação total do Brasil. Para ele, as formas de governo de cada povo se deviam a circunstâncias geográficas, sociais, raciais e culturais. Sua obra consiste, basicamente, na tentativa de expor São Paulo como local explorado pelos outros estados, possuindo força para ser independente. $\mathrm{O}$ autor acredita que a distância geográfica e as diferenças culturais que, em sua lógica, perpassariam por aspectos raciais, não permitiriam que o Brasil fosse uma nação coesa. Desse modo, para ele, seria disparatado que todo o país possuísse a mesma forma de governo. Isto é expresso pela crença de Ellis Jr. em torno de uma noção de progresso arbitrária que teria atingido distintamente populações diferentes, sendo que umas "tomaram o voo rapidíssimo do avião" enquanto outras eram puxadas a cavalo ou até mesmo tinham “volvido para traz” (ELLIS JR, 1933:XV).

Disto, vale apreender as concepções de atraso e progresso como estabelecidas nos seguintes termos: São Paulo representa o progresso enquanto o Outro Regional, em especial o Nordeste brasileiro, representa o atraso. No livro com aspirações de manifesto, está evidente quem tomou o voo rapidíssimo de avião e quem volveu para trás. É neste sentido que na obra de Ellis Jr se percebe a defesa da legitimidade econômica enquanto força capaz de gerar a legitimação nacional. Segundo o autor "bastará acumular o que se paga para ser brasileiro" (ELLIS JR, 1933:XIX). Está nítida sua preocupação na suposta injustiça que passaria São Paulo, maior contribuinte do tesouro nacional. Para além do elitismo, no entanto, vê-se um projeto eugênico marcante: 
Não há quem não faça distincção entre um negro e um branco. Não há quem não faça a distincção perfeita de um nortista brachyplatycephalo, moreno, com um louro do Paraná, de Sta. Catharina ou do Rio Grande do Sul (...) as porcentagens de cada um desses elementos são diferentes, que tornam o ambiente racial completamente outro. S. Paulo, por exemplo, tem como Sta Catharina, $85 \%$ de brancos puros. A Bahia, só tem 33\%, a Parahyba só tem $32 \%$, o Amazonas $31 \%$ e o Pihauy apenas $24 \%$. (ELLIS JR, 1933:25).

Para além do caráter imaginado de tal afirmação, evidencia-se um discurso paulistanista que tende a ser repetido em diferentes períodos: o do desprezo à presença negra e sua importância na construção do estado. Da mesma maneira, Ellis Jr. apresenta o Outro Regional, em especial o nordestino, como inferior racial, cultural e economicamente. É evidente sua acepção liberal e racista de modelo de sociedade. Para o autor, são as aspirações econômicas os fatores principais que delimitam uma comunidade. São Paulo estaria à frente em tal sentido em relação a todos os outros estados brasileiros.

Neste sentido, a interpretação de Moutinho sobre a obra do autor é assertiva: Ellis Jr. estaria impossibilitado de advogar com transparência a separação de São Paulo, uma vez que isto era combatido no período, o que o leva a transmutar a ideia de separação na de Confederação (MOUTINHO, 1991:111). A afirmação da autora reforça uma ideia que a obra de Ellis Jr. não consegue mascarar: o autor preocupa-se com o destino de São Paulo que, superior, tanto no que diz respeito ao espaço quanto ao povo que o habita, não pode ser prejudicado pelo atrasado Outro Regional.

Outro nome importante para pensar no engendramento da paulistanidade seria o de Paulo Duarte, líder do Partido Democrático. Personagem relevante para os estudos acerca do racismo no Brasil, Duarte se destaca por sua indiscrição ao defender a supremacia paulista e branca, bem como pelo escancaramento nas ofensas que dirigia à população negra e de outras regiões brasileiras que não São Paulo. O misto de racismo e discriminação regional pode ser encontrado na colocação do intelectual que expressa os nordestinos como grupo que desempenha "o mesmo papel daqueles negros de Dakar, cartola à cabeça e os pés no chão, convictos duma alta posição de citoyen français, ${ }^{, 32}$ bem como em sua afirmação de que em 1932 a terra bandeirante fora invadida por selvagens herdeiros de Palmares.

Para além da análise de trajetória dos nomes políticos que produziram suas obras em torno da causa paulista, nota-se o apego da classe médica em um discurso paulistanista

\footnotetext{
${ }^{32}$ Que é que há?, Paulo Duarte.
} 
de superioridade. Santos e Mota (2010) apontam que a racialização do debate regionalista de São Paulo foi baseada nos discursos científicos das teorias eugênicas da primeira metade do século XX, engajados em produzir uma série de manuais didáticos sobre a eugenia e a viabilidade racial paulista enquanto o melhor do Brasil.

É importante, contudo, perceber a generalização do discurso da paulistanidade que não se restringia somente àqueles que esta defendiam abertamente. É em tal sentido e na crença de que as expressões de paulistanidade são múltiplas que se faz necessário pensar nos processos regionalistas posteriores ao Conflito de 1932, inclusive na fundação da Universidade de São Paulo e suas relações com a conexão do estado ao progresso. Para além do marco que a Universidade representa na produção científica do país, é interessante notar que esta resultou em uma série de estudos essenciais para a constituição do imaginário paulista. Irene Cardoso (1982) expõe que a criação da USP teria representado tanto um projeto político anticomunista e baseado em uma sociedade dividida em classes, quanto uma tentativa paulista de aparentar centralidade nos saberes brasileiros. Em concomitância a isto, membros da Universidade teriam concentrado esforços em desmistificar este ideal de superioridade e esta proposição social e política hierarquizante.

Apesar disto, é interessante notar que tanto personagens progressistas e anti-racistas do meio universitário, como Florestan Fernandes, quanto figuras conservadoras e abertamente racistas dos meios políticos e partidários, tinham discursos consonantes em um sentido: a ideia de São Paulo como local da era científica e tecnológica do país do futuro. Atenta a isto, Barbara Weinstein defende que mesmo quando proferido com objetivos e concepções políticas diferentes, o discurso acerca da modernidade paulista ajudou a constituir em meios e camadas sociais diferentes um ideal acerca de São Paulo como local do progresso inquestionável.

\section{4 - O Conflito de 1932 e o IV Centenário}

Hoje quase não é lembrado o fato de que baianos e pernambucanos apareciam como o ápice da civilidade no século XVIII. O estado de São Paulo seria, em tal época, considerada atrasado, provinciano, rural. Neste sentido, vale dizer que apesar do empenho dos propagandistas defensores da paulistanidade em afirmar São Paulo como triunfante desde seus primórdios, ${ }^{33}$ apenas no final do Império Brasileiro, período marcado pelo

\footnotetext{
${ }^{33}$ É válido apontar que tais primórdios seriam imaginados, uma vez que ignora-se a população que no local residia anteriormente à invasão colonial.
} 
boom das plantações de café, o local se tornou economicamente hegemônico no cenário nacional. $^{34}$

Barbara Weinstein defende que o dado período é de importância essencial para o entendimento da formulação do regionalismo paulista que, sob a preocupação das elites do estado, se configurou em busca da ordem social em um contexto pós-abolição. Preocupadas, simultaneamente, com a construção da identidade regional e o controle social, as oligarquias de São Paulo empenharam-se na criação do típico paulista. Este, entretanto, excluía certos segmentos ${ }^{35}$ raciais, de classe e de gênero, abarcando, assim, uma parte mínima da população (WEINSTEIN, 2015:20). Desse modo, o ideal paulista, se expressava pela imagem de um homem branco e bem sucedido economicamente.

Como já dito, o diferencial de eventos históricos como os ocorridos no Conflito de 1932 e no IV Centenário paulistano, está no fato de que uma parte grandiosa da população se engajou na construção da paulistanidade, esta deixando de ser preocupação exclusiva dos meios intelectuais e de elite. Como Weinstein, defendo que os dados períodos não podem ser analisados como fatos isolados. Ao contrário: não só ocorreram por uma base de discurso e política regionalista que já vinha sendo engendrada nos meios oligárquicos, como também continua a informar debates atuais. Como dito pela historiadora: o discurso sobre a grandiosidade paulista, criação de homens de letra e latifundiários, não é apenas reativo em contraposição a um projeto político, mas produtivo no que diz respeito a outro (WEINSTEIN, 2015:32).

O fim da República Velha no Brasil dá-se em 1930, quando o ex-governador de São Paulo, Júlio Prestes, teve sua posse de presidente impedida e o então presidente Washington Luís foi deposto. Invalidando a Constituição de 1891, a Revolução de 1930 levou Getúlio Vargas ao poder em um regime denominado Governo Provisório. É válido lembrar que o período é marcado pelas consequências da Crise de 1929. Preocupadas com a instabilidade do momento, as oligarquias paulistas romperam a política conhecida como café-com-leite ao indicar o paulista Júlio Prestes à presidência da República. Tal situação foi baseada em uma disputa que se acirrou aos poucos uma vez que, ao contrário do que afirmam muitas versões acerca do período, as elites de São Paulo não necessariamente se colocavam contrárias ao governo getulista em um primeiro momento. O Governo

\footnotetext{
${ }^{34}$ "A situação em que se encontrava a economia paulista, no início do século XIX, nada tinha de brilhante, de acordo com o testemunho dos contemporâneos, os viajantes principalmente." (FERNANDES \& BASTIDE, 2008:45).

${ }^{35}$ Sendo estes: mulheres, negros, indígenas e pobres.
} 
Provisório, sem uma Constituição, governava à base de decretos e contava com um ministério composto expressivamente por militares.

Já foi afirmado na presente pesquisa a premissa de Moutinho, de que o regionalismo paulista se mobiliza fortemente em momentos de disputa do Poder Central. A centralização política decorrente da ascensão de Getúlio Vargas ao poder ${ }^{36}$ bem como a adoção nacional do discurso da democracia racial típica desse período, seriam fatores para se pensar nas causas do Conflito de 1932. Este se constitui, inclusive, como o grande mito da história estadual (BORGES, 2004). Para além da centralização no que se refere à economia e política, o varguismo foi responsável por tentar homogeneizar a identidade nacional. O que, para as elites paulistas, detentoras de um poder considerável, não foi bem recebido.

Para além dos interesses econômicos, pode ser visto como fato relevante o estopim que levou ao acirramento de ânimos no dado período: Vargas nomeou um tenente nordestino, João Alberto Lins de Barros, como interventor do estado, e Miguel Costa como chefe da polícia de São Paulo. O primeiro era, segundo a propaganda paulista da época, partidário de ideias comunistas. É incontável o número de ofensas à população nordestina quando do ocorrido. $\mathrm{O}$ consenso entre os defensores da causa paulista era, basicamente, a sensação de ultraje por serem em alguma instância de governo representados por um nordestino. Vargas, ao tentar agradar as elites paulistas, nomeou Pedro de Toledo como interventor do estado, mas manteve Miguel Costa. Isto e a morte dos manifestantes que compõem a sigla M.M.D.C., ${ }^{37}$ em 23 de maio de 1932, culminaram na guerra iniciada em 9 de julho do mesmo ano.

Os meses que antecederam o conflito são marcados pela presença do discurso antitenentista que mostrava a impossibilidade de São Paulo não pegar em armas. Os partidos Democrático e Republicano se uniram em uma Frente Única, o que indica a unidade da oligarquia paulista no presente período. O combate foi marcado pelo escamoteamento do conflito de classes (MOTA, SANTOS, 2010) ou de qualquer outra clivagem social, uma vez que as elites estaduais propagaram ideais de luta que geraram mobilização, mas que mantinham inabaladas as hierarquias vigentes. É interessante, portanto, ver como a harmonia e união horizontal falaciosas, mas afirmadas pelos que engendravam a

\footnotetext{
${ }^{36}$ Tal centralização e busca pela homogeneização nacional é tão marcante que um mês depois da implantação do Estado Novo, Vargas realizou uma cerimônia de queima das bandeiras estaduais.

${ }^{37}$ Martins, Miragáia, Dráusio e Camargo.
} 
paulistanidade do período, foi eficaz ao construir uma identidade estadual em oposição à brasilidade (MOTA, SANTOS, 2010).

As versões sobre o conflito são díspares. A getulista foca no ressentimento das elites paulistas que, sedentas por retomar os mesmos privilégios que tinham antes de um governo imbuído na centralização nacional, instigaram o conflito. Os propagandistas da paulistanidade, de maneira geral, advogam que a guerra se deu pelo fato de a natureza paulista jamais se submeter à tirania. O conflito seria, a partir desse ponto de vista, uma luta contra a ditadura, uma missão de São Paulo que, inclusive, seria benéfica para o atrasado resto do Brasil que não tinha condições de saber o que era melhor para si.

Barbara Weinstein demonstra que diversos escritos produzidos na época expressam abertamente racismo em relação ao Outro Regional brasileiro. Como já dito, Mário de Andrade se referiu aos outros estados do país, em vista do conflito, como Brasis Africanos - o que se insere em um discurso que rebaixava o continente africano a partir dos preceitos do racismo científico. É também sintomático que o regime varguista tenha sido chamado à época de Ditanegra ${ }^{38}$ e que M.M.D.C. tenha, ao longo da guerra, se convertido em Mata Mineiro, Degola Carioca.

Longe da passividade, outras regiões brasileiras se mobilizaram em torno do conflito, tanto no que diz respeito à ação militar quanto na base discursiva. Raimundo Helio Lopes (2009) aponta que houve uma campanha jornalística intensa no Nordeste de mobilização em favor do Governo Provisório de Getúlio Vargas. A adesão massiva da população cearense para alistar-se, contudo, chama atenção. Lopes aponta que 1932 foi um ano de estiagem intensa no Ceará e os campos de concentração, ${ }^{39}$ que abrigavam flagelados atingidos pela seca, estavam com grande número de pessoas. Muitas destas alistaram-se em defesa do Governo Provisório. Todavia, é interessante notar que membros da classe média letrada também o fizeram: a chamada para a mobilização se imprimira nos meios intelectuais.

As outras regiões acusavam, majoritariamente, os paulistas de iniciarem uma luta separatista e fratricida. Lopes aponta que os jornais nordestinos foram eficazes em mostrar o discurso da paulistanidade em suas expressões racistas, em que os nordestinos eram identificados como "pigmeus de má compleição, sem inteligência e falhos de energia e iniciativa" (O POVO, 1932). Weinstein aponta que apesar de haver considerável fração

\footnotetext{
${ }^{38}$ Como visto em A Guerra de São Paulo, de Mário de Andrade.

${ }^{39}$ Política iniciada em 1915. Neles eram abrigadas pessoas que viviam nas ruas. Tal política era uma forma de fazer com que tal população estigmatizada não fosse vista nas cidades.
} 
separatista nos conflitos de 1932, a paulistanidade, de modo geral, se guiava por um norte que mesclava a infantilização e o ódio ao Outro Regional. Dessa maneira, os outros estados brasileiros eram vistos como povoados por pessoas incapazes de fazerem boas escolhas políticas; como se os paulistas fossem os únicos civilizados e aptos ao exercício político no território nacional. Como aponta a autora, abarcar o Brasil de tal maneira, "como um todo, com São Paulo" (WEINSTEIN, 2015) não era uma proposta política mais inclusiva do que o separatismo.

No que concerne a propostas separatistas concretas, Santos e Mota (2010) apontam o fato de que apesar destas terem sido engendradas por parte considerável dos que se engajaram na guerra, houve também propagandas paulistas contrárias à secessão. Como mostram os autores, é curioso que a historiografia sobre o conflito busque minimizar a tendência secessionista que contou com nomes caros à paulistanidade, como Mário de Andrade e Monteiro Lobato. O que unia as duas frentes, contrárias ou favoráveis à separação, seria a tentativa de rebaixamento do Outro Regional.

Apesar de Vargas ser do extremo sul do país, para os paulistas sua imagem era conectada à parte majoritariamente não-branca, pobre, e considerada inferior no Brasil: o Norte e o Nordeste brasileiros. ${ }^{40}$ Desta forma, quem lutou contra os soldados paulistas era, como exposto por Weinstein, constantemente retratado como jagunçada. ${ }^{41}$ É recorrente a leitura do período como um empenho das elites paulistas em orquestrar uma luta popular em torno de um poder que seria concentrado. Reconhecendo tal fato, Weinstein se interessa não tanto pela propaganda massiva realizada pelas elites no dado período, mas pela agência da população em geral ao engendrar a paulistanidade. Para a autora, é nítido que um conflito tão curto (cerca de três meses) foi explorado à exaustão pelos defensores da causa paulista justamente por ter fornecido os moldes à imagem, identidade, ideologia e simbologia da população desse estado.

O conflito, findo em 2 de outubro de 1932, teve uma propaganda que buscava associar São Paulo à liberdade. Nas palavras de Paulo Duarte, aquele era um embate entre homens que queriam ser livres e homens que queriam ser escravos. Weinstein aponta que a Guerra Paulista criou um sentimento de pertencimento tão forte que São Paulo se tornou praticamente uma mentalidade. Foi, inclusive, a chance de que precisavam os imigrantes

\footnotetext{
40 "Quando a gente fala nordestino já se entende são os nordestinos do Norte e os nordestinos do Sul" (ANDRADE aput SANTOS, MOTA, 2010:75).

${ }^{41} \mathrm{O}$ termo, exposto por Weinstein em The Color of Modernity, era amplamento utilizado pela imprensa da época.
} 
estrangeiros para demonstrar sua brasilidade. Nesta narrativa, quando estes pegaram em armas pelo estado foram contagiados pelo caráter paulista superior. Deste modo, de forma inédita, os meios de comunicação de massa foram utilizados em prol de uma propaganda política. A Causa Paulista estava em cartazes, poemas, programas de rádio, em praticamente tudo que era veiculado. Os argumentos que buscavam mostrar a injustiça sofrida por São Paulo tinham um teor de exagero econômico. Muitas eram as charges que buscavam retratar São Paulo como a preciosidade do tesouro nacional, abusada e sugada pelos outros estados brasileiros.

Até mesmo para o então cônsul dos Estados Unidos, São Paulo lutava "pela cultura do homem branco.” O conflito é apontado por Weinstein como um momento de expressão da classe média paulista não apenas por esta ter uma participação expressiva e ser aclamada por isto nos meios jornalísticos, mas especialmente pela experiência e memória de 1932 serem interpretadas em um esquema que se baseia em classe média branca $\mathrm{x}$ jagunçada. A imagem do paulista, mais que nunca, foi associada à política, à civilização. Dois Brasis entraram em jogo e as imagens formadas nesse momento ainda pairam em embates políticos. Um seria o Brasil de São Paulo, branco, moderno, de classe média, jamais submisso, sempre heroico. O outro era o imputado e arbitrário estigma da barbárie, do atraso, da escravidão, da inaptidão política pobre e não-branca.

Até mesmo a derrota de São Paulo na guerra pôde ser narrada pelos regionalistas paulistas como prova da superioridade do estado: o povo paulista havia lutado contra bárbaros histéricos e, apesar de não ter vencido o embate, venceu a causa - a Constituição fora garantida pelos herdeiros dos bandeirantes (WEINSTEIN, 2015). Os interesses da classe dominante são óbvios no Conflito de 1932. As elites paulistas construíram sua imagem de supremacia e foram capazes de mobilizar grande parte da população em torno de seus objetivos próprios. Todavia, a presença dos soldados da Legião Negra ${ }^{42}$ e de parte considerável da classe trabalhadora pobre não pode ser vista como fruto único de alienação. Agentes de seus objetivos, Weinstein defende que tais setores da população, tão marginalizados, seja em nível material ou ideal no discurso da paulistanidade, engendraram o orgulho paulista da época. Vale lembrar que a Legião Negra sofreu racismo saliente dos próprios companheiros de causa constitucionalista, sendo que alguns

\footnotetext{
${ }^{42}$ Batalhão formado por soldados negros. Participou ativamente da Guerra de 1932, caracterizava-se pelo protagonismo na linha de frente das batalhas.
} 
historiadores afirmam que tal batalhão teria sido dizimado pelo fogo amigo (SANTOS, MOTA, 2010).

Para Weinstein a categoria paulista é eficaz a tal ponto que, além de comportar interesses óbvios das elites, abarca também a identidade popular, uma vez que o discurso em torno do conflito pontuou que podem ser pobres e não-brancos, mas ainda assim são paulistas. Segundo a autora, longe de operar com base em uma proposição da igualdade racial e econômica, a paulistanidade nesse caso justificava as diferenças de poder social não em seu interior, mas tomando por referência o Outro Regional.

O Obelisco segue até hoje como símbolo dos mártires de 1932. Com o passar do tempo, o período foi trabalhado exaustivamente na mitologia paulista. É sintomático o fato de que em 2006 um grupo com trinta pessoas tenha caminhado $825 \mathrm{~km}$ para "divulgar os valores éticos e morais da Revolução" em uma travessia batizada de 9 de Julho (SANTOS, MOTA, 2010:7). Eventos como estes evidenciam que 1932 segue sendo um símbolo caro aos adeptos da paulistanidade. Como este, o IV Centenário da Cidade de São Paulo também é um ponto crucial para se pensar as narrativas do regionalismo paulista. Ocorrido em 1954, mais de duas décadas após o Conflito Constitucionalista, a comemoração contou com um empenho hercúleo para a exposição de uma São Paulo triunfante. ${ }^{43}$ As construções arquitetônicas buscavam trazer em si a grandiosidade do estado e de seu povo; São Paulo e sua modernidade apareceriam como dignas de celebração.

O planejamento urbano foi levado em consideração no IV Centenário. É, inclusive, em tal momento que se inaugura o Parque do Ibirapuera. Com acesso arquitetado para aqueles que possuíam carro, as largas ruas do entorno eram a expressão máxima da modernidade. As comemorações que duraram todo o ano foram divulgadas amplamente em vários meios. A superioridade paulista era, então, relacionada ao poder industrial da cidade. Interessante no contexto é conseguir notar como a História montada em determinados enredos possibilitou que o triunfo fosse óbvio em todas as mensagens propagandeadas.

\section{5 - São Paulo: Destino Migrante}

O triunfo paulista de que falo pôde se ancorar desde o século XIX na presença de imigrantes, em especial brancos e europeus, que vieram para o estado trabalhar, especialmente, nas lavouras de café. É válido pensar como esta imigração estrangeira

\footnotetext{
${ }^{43}$ A menção a triunfo é creditada a Weinstein (2015).
} 
elevou o status paulista em um período marcado pelo esforço embranquecedor: este seria o estado que teria a ferramenta branqueadora, constituidora de um melhor futuro, em suas mãos. O Nordeste, em contraposição, seria afirmado como um "velho caldeirão racial parado no tempo" (GUIMARÃES, 202:131).

A migração para São Paulo, todavia, não é um fenômeno restrito ao boom econômico do fim do século XIX. Para além da migração ocasionada pela invasão portuguesa com o sistema colonial e escravocrata, Fernandes e Bastide apontam que a decadência agrícola no Nordeste, já em meados do século XIX, ocasionou um tráfico interno de pessoas escravizadas que eram levadas até São Paulo (FERNANDES, BASTIDE, 2008:56). A proibição formal deste tipo de tráfico humano e a "fome por brancos" (FERNANDES, BASTIDE:2008:58) do projeto embranquecedor são fatores ativos na vinda europeia ao fim do século XIX. Os autores expõem que, especificamente em São Paulo, o tipo de desenvolvimento urbano favoreceu imigrantes brancos e europeus, em detrimento dos negros brasileiros libertos, diferentemente do que teria acontecido no Rio de Janeiro, ${ }^{44}$ por exemplo.

Com uma Abolição da Escravidão teórica, sem qualquer garantia de assistência aos recém-libertos ou atribuição de obrigações aos antigos escravocratas, "o elemento negro perde sua posição no sistema econômico de São Paulo" (FERNANDES, BASTIDE, 2008:68). Os autores expõem que esta nova forma de marginalização, levou à crença perversa de uma "incapacidade do negro de adaptar-se ao plano paulista" (FERNANDES, BASTIDE, 2008:75), sendo que se chegou a acreditar que estes deixariam de compor a população de São Paulo em cerca de meio século.

Neste contexto, com um racismo que ainda não era mascarado sob formas veladas, houve atrito entre grupos imigrantes brancos e grupos negros brasileiros. Fernandes e Bastide assinalam, todavia, que existia a ideia de que o imigrante chegaria ao Brasil sem preconceito, aprendendo-o aqui (FERNANDES, BASTIDE, 2008:159). Neste sentido, Jeffrey Lesser (2014) expõe que os grupos estrangeiros percebiam a distinção gritante de poder entre brancos e negros no Brasil, aceitando e utilizando tais categorias de modo que "tornar-se branco era tão importante para os recém-chegados quanto o era para a elite nacional" (LESSER, 2014:41).

\footnotetext{
44 "Onde os negros chegaram a monopolizar, em pleno regime servil, um grupo apreciável de atividades econômicas ligadas com a vida social urbana." (FERNANDES \& BASTIDE, 2008: 59).
} 
Objetivando expor que imigração, etnicidade e identidade podem se interligar a ponto de serem indistinguíveis, Lesser aponta a identidade e a etnicidade como construções históricas, sendo que a identidade nacional nunca seria única, estática. Neste sentido, o autor expõe que a imigração representou e representa a formação de um futuro melhor para o Brasil, tendo ajudado as elites brasileiras a imaginarem uma ascensão baseada na imagem “do 'país do futuro', no qual a branquidão iria eclipsar a negritude” (LESSER, 2014:29-34). Assim, já nos séculos XVII e XVIII a Coroa Portuguesa interessava-se em imigrantes de pele clara, "laboriosos e empreendedores" (LESSER, 2014:35).

O fato de a narrativa brasileira focar na imigração europeia explicita como a presença de certos grupos humanos era desejada e a de outros não. Ao mesmo tempo que havia o esforço para a atração de populações brancas, repelia-se, inclusive institucionalmente, ${ }^{45}$ os negros. A cidade do interior paulista, Americana, ter atraído, finda a Guerra Civil Norte-Americana, sulistas estadunidenses ansiosos em viver em um país com hierarquias raciais nítidas, torna este fato gritante (LESSER, 2014:82).

Do mesmo modo, a manutenção das categorias raciais brasileiras, demonstra como os racializados termos de aceitação podiam mudar ao longo do tempo. Lesser expõe que a presença de alguns imigrantes europeus, como os espanhóis, italianos e portugueses, levou com o passar do tempo ao receio das elites acerca das reivindicações trabalhistas que estes poderiam engendrar. Neste contexto, os imigrantes japoneses ascenderam como "modernos, laboriosos, dóceis" e até mesmo quase brancos (LESSER, 2014:45-46). Um dos principais episódios neste processo teria sido o Conflito de 1932, quando alguns imigrantes japoneses juntaram-se às forças armadas de São Paulo. Estes, após o ocorrido, apareceram não somente como brasileiros, mas como paulistas (LESSER, 2014:220).

A obra de Lesser aponta que os imigrantes tiveram papel ativo na constituição da brasilidade. É levando em consideração as proposições do autor que detenho-me na imigração nordestina com destino para o sudeste, especialmente São Paulo, ocorrida em meados do século XX. Dizer que São Paulo é a cidade mais nordestina do Brasil ou que São Paulo foi construída pelos nordestinos é comum em todo território brasileiro. A industrialização do estado paulista em concomitância com o agravamento de percalços sociais e ambientais ${ }^{46}$ no Nordeste, geraram um movimento migratório forte. Uma massa

\footnotetext{
${ }^{45}$ Enfatiza-se aqui as leis promulgadas em 1891 em que proibiu-se a entrada de imigrantes provenientes da África e da Ásia. (LESSER, 2014:101).

${ }^{46}$ Enfatiza-se a questão das secas e a estagnação das oportunidades econômicas na região.
} 
nordestina passou a viver em São Paulo e ser associada, a partir do preconceito de classe, com a pobreza, mendicância e vagabundagem (ROMERO, 2014).

Deste modo, ao mesmo tempo que trabalhadores nordestinos eram requisitados como mão-de-obra para a indústria paulista, eram rechaçados em seu tipo físico, estético, racial e econômico. Logo apelidos como pau-de-arara, baiano, paraíba e cabeça-chata tornaram-se, no sudeste, sinônimos de populações nordestinas diversas. Vital para entender tal fenômeno seria a política de embranquecimento tão enfatizada por Lesser, Fernandes e Bastide. A maioria dos migrantes nordestinos era composta por brasileiros que iam contra a racista imagem nacional que se almejava.

Como já afirmei, a discriminação contra nordestinos é anterior ao fluxo migratório em questão. É válido atentar-se, todavia, ao fato de que esta migração acirrou certas fronteiras e conflitos. Se o estereótipo nordestino já era incômodo à distância, sua presença só agravaria a situação. Neste agravamento, nordestinos foram historicamente responsabilizados pelas mazelas de São Paulo, da sujeira e poluição à falta de empregos e violência. Nesta lógica, um nordestino conseguiria, simultaneamente, ser associado à preguiça e à competição desleal no mercado de trabalho. Tal discurso ainda encontra coro atualmente.

Neste sentido, vale pensar na legitimidade imputada a certos imigrantes frente à ilegitimidade atribuída a outros. A título de exemplo, o Manifesto São Paulo Para Paulistas $^{47}$ - escrito em 2010 por grupos que visam a separação do estado do restante do país e rechaçam migrantes do Nordeste que residem em São Paulo - justifica-se em seu ódio contra os nordestinos afirmando que alguns imigrantes seriam bem-vindos em terras paulistas, tais quais os "respeitosos e trabalhadores" italianos e japoneses. O nordestino, em contrapartida, não seria bem-vindo por ser caracterizado como um violento adepto da "cultura cangaceira", sujo, desrespeitoso, aproveitador e preguiçoso. ${ }^{48}$ Todos estes atributos, fortemente racializados no contexto brasileiro, apontam para um preconceito que categoriza negativa e arbitrariamente duas características frequentemente entrelaçadas: não-branquidade e pobreza.

Feldman-Bianco (2009) ao estudar as vivências portuguesas e cabo-verdianas em duas cidades dos Estados Unidos, New Bedford e Fall River, aponta que portugueses

\footnotetext{
47 Manifesto (disponível em <http://www.petitiononline.com/estadosp/petition.html>) que contém atualmente quase duas mil assinaturas e que pleiteia uma São Paulo que não permita a migração nordestina. Acesso em: 15/08/2015

${ }^{48} \mathrm{O}$ que pode ser visto na leitura do Manifesto. Link acima.
} 
teriam sido discriminados nestes locais, sendo considerados não-brancos, até que um processo de mobilização, com apoio do Estado português, os levou, ao longo do tempo, a um status de população com patrimônio cultural desejado. Os cabo-verdianos, por outro lado, continuaram sendo discriminados e racializados. Estas assimetrias no tratamento de portugueses e cabo-verdianos evidenciam a necessidade de atentar-se aos graus distintos de aceitação de populações migrantes diversas. No contexto brasileiro, italianos, a título de exemplo, chegaram a ser rechaçados por porção da população brasileira em determinado período, no entanto, conseguiram ascender socialmente. O que, sem dúvidas, evidencia que europidade e branquidade são atributos acompanhados de maior poder social.

É interessante pensar, neste sentido, como São Paulo é considerada cosmopolita. Este status possui, inclusive, um apelo comercial: lojas, restaurantes, expressões culturais variadas conectam São Paulo ao ideal de local moderno e abrangente. Estes atributos, já em meados do século XX, eram mobilizados. Todavia, imigrantes desejáveis, patrimônio cultural, eram populações outras, mais brancas, civilizadas, que os nordestinos. Em relação a isto pode se pensar na relação fetichizada que há com a presença italiana em São Paulo. A pizza, os times de futebol italianos, o bairro do Bixiga e tantos outros atributos da italianidade não são mais exaltados que outras características regionais e nacionais por mera questão de gosto: a branquidade tem influência direta neste processo.

Defendo que hoje em dia pensar a presença nordestina em São Paulo segue passando por estas questões. Ao mesmo tempo que a cidade de São Paulo aparece como internacional - possuindo feiras bolivianas, casas do Norte especializadas em comidas nordestinas, restaurantes sírios, senegaleses, palestinos, peruanos - a restrição a alguns grupos ainda é nítida. Acredito que ao mesmo tempo que se constrói uma ideia de São Paulo como local tolerante, capaz de sempre abrigar mais um, se recrudesce a fronteira entre desejados e indesejados.

A presença crescente de refugiados estrangeiros nos últimos anos, em especial de países africanos e do Oriente Médio, engendra, simultaneamente, a ascensão de São Paulo como moderna e o preconceito contra não-brancos e vulneráveis economicamente. Este processo dúbio é o mesmo que levou, ao longo do tempo, ao fato de que migrantes nordestinos possam ser reconhecidos como portadores de características culturais ricas, já paulistanizadas, ao mesmo tempo que discursos outros defendem seu afogamento, morte e volta para a terra dos paus de arara. Assim, certas narrativas coexistem: os nordestinos 
construíram e destruíram São Paulo.

\section{6 - Regionalismo Paulista e Racialização}

$\mathrm{Na}$ presente pesquisa ficou nítido o uso de categorias raciais que compõe a base discursiva do regionalismo paulista. Como já visto neste capítulo, insiro para tratar esta questão o conceito de racialização. Segundo Antonio Sérgio Guimarães o termo se refere à transformação de "um conjunto de indivíduos em um grupo racial subalterno, ou simplesmente em raça, a partir de características" que são tomadas de forma arbitrária e justificadas ideologicamente (GUIMARÃES, 2016:164).

O sociólogo defende que se pode racializar uma pessoa, um grupo, um agrupamento regional ou residencial por intermédio da categoria de raça. Isto leva ao fato de que quando se racializa alguém, racializa-se a si mesmo. Importante nesta lógica é identificar quais grupos sociais possuem o poder de operar a classificação. Segundo Guimarães "quem tem o poder de classificar os outros busca para si a transcendência, a universalidade, um espaço simbólico e espiritual que ultrapasse o corpo, os limites biológicos ou o gueto - espaços de emparedamento, isolamento e segregação" (GUIMARÃES, 2016:166).

Defendo, levando em consideração o modo de conceber racialização do autor, que a paulistanidade se mostrou um discurso saliente ao longo da História no que diz respeito à racialização do Outro Regional, em especial o nordestino, e na afirmação de sua pretensa branquidade emparedada e segregada. Karl Monsma (2013) focando no fato de que o racismo se reproduz nas interações cotidianas, demonstra que conceber este unicamente como produto do colonialismo e imperialismo limita a análise de algumas formas de discriminação.

Nesse sentido, Monsma atenta para a necessidade de uma teoria que não se atenha somente às diferenças físicas, uma vez que estas funcionariam como marcadores sociais de supostas diferenças de disposições e capacidades. Desse modo, o pesquisador apresenta o racismo como a combinação de dois elementos: "a dominação étnica e uma ideologia que essencializa e categoriza negativamente o grupo subordinado, justificando sua subordinação" (MONSMA, 2013:6). Tal abordagem permite, segundo Monsma, agrupar semelhantes formas de dominação e essencialização negativa, evitando a proliferação de novos termos, como anti-imigrantismo (MONSMA, 2013:8). 
Levando em conta tais colocações, defendo que o discurso preconceituoso e discriminatório do regionalismo paulista apresenta em si grandes traços de racismo. $\mathrm{O}$ Outro Regional que encontra seu exemplo máximo no nordestino é o contraponto do paulista: este tido como branco e, assim, avançado, civilizado, bem sucedido economicamente; aquele considerado não-branco e por isto atrasado, inculto e pobre. Essa dualidade permitiu à paulistanidade não apenas imaginar seu ideal social, excluindo, assim, grupos sociais estigmatizados, mas também imaginar sociedades outras que comporiam o Outro Regional.

Da mesma maneira que Edward Said defende em Orientalismo que o Ocidente criou-se ao se contrapor a sua categoria inventada e reduzida de Oriente, defendo que a paulistanidade pautou-se na criação de um Outro Regional que era possível opor frontalmente às aspirações regionalistas paulistas. ${ }^{49}$ Said analisa a bibliografia europeia no que concerne aos estudos orientalistas. Nesta se vê tanto o processo de exotização quanto o reducionismo de grupos humanos diferentes à mesma categoria: oriental. Todo esse esforço era pautado em uma categorização preconceituosa.

Acredito que os esforços intelectuais imbuídos no regionalismo paulista que foram expostos nessa pesquisa, guardadas as devidas diferenças contextuais, possuíam o mesmo objetivo. Mário de Andrade falar em Brasis Africanos, Oswald de Andrade expor a pretensa locomotiva do Brasil como uma questão racial, Ellis Jr. contrapor uma raça de gigantes a outra de platycephalos, Paulo Duarte confrontar o paulista como livre e os outros brasileiros como escravos e Monteiro Lobato apontar o café paulista como guia para o progresso, são dados que - dentre tantos outros esforços intelectuais - expõem uma racialização do outro capaz de racializar o paulista. Assim, na mitologia em torno do Conflito de 1932 e nas narrativas expostas nas comemorações do IV Centenário, o objetivo era nítido: embranquecer São Paulo ao escurecer o Outro Regional em um contexto que sempre favoreceu o branco.

Weinstein defende que sem o discurso regionalista paulista que aponta a seca, o atraso, a pobreza e a não-branquidade como próprias do nordestino, a paulistanidade seria muito menos eficaz. Desse modo, tal contraposição alça o ideal de São Paulo a uma maior legitimidade argumentativa. A historiadora expõe tal fenômeno como uma forma de eugenia que busca, com argumentos baseados em estágios de civilização e mudanças culturais e geográficas, produzir categorias inatas que naturalizam as diferenças

\footnotetext{
${ }^{49}$ Weinstein realiza a mesma defesa em The Color Of Modernity.
} 
hierárquicas entre São Paulo e as outras regiões brasileiras (WEINSTEIN, 2015:91). Do mesmo modo, em um país que abraçou o discurso mítico da democracia racial, adjetivos pejorativos como cabeça chata, baiano e paraíba se tornam mais mascarados e fluídos para expressar o racismo.

A obra de Weinstein, The Color of Modernity, se mostra como central nos estudos acerca do regionalismo paulista por expor que foi crucial para o desenvolvimento das identidades nacional e regionais do país o engendramento das diferenças raciais com base na origem, na região. Isto foi feito através da mobilização de imagens associadas à modernidade, progresso econômico, tradição e atraso. A identidade paulista seria associada em todo Brasil ao embranquecimento e à marginalização das composições negras; tudo isto sendo feito em um contexto em que o debate racial explícito passou a esferas veladas (WEINSTEIN, 2007:282), em que era mais interessante usar o regional para seguir discriminando-se racialmente.

A historiadora ainda expõe que o desenvolvimento econômico desigual entre regiões e grupos humanos, típico do capitalismo, bem como o empenho da elite paulista na construção de um Eu Regional, foram responsáveis não só por excluir do discurso regionalista a contribuição do trabalho de pessoas escravizadas no enriquecimento do estado, mas também por anulá-las enquanto grupo humano. A imaginação da paulistanidade foi longe ao ponto de ignorar, em diversos momentos, a presença negra na população do estado.

O racismo muitas vezes foi exposto abertamente, como no trecho do Manifesto lançado após a derrota de São Paulo na guerra de 1932, em que se afirma que seria melhor ser uma nação pequena a ser "meros associados de uma terra inviável, dominada por mestiços que têm almas de escravos, e que estão a apenas um passo distantes dos seus ancestrais, cujos corpos foram escravizados aqui e na África” (Manifesto Paulista, 1932). Quando afirmado de modo mais discreto, todavia, eram noções arbitrárias de civilização e progresso que serviam à racialização.

Weinstein demonstra ainda que pode haver certa solidariedade entre paulistas e brasileiros brancos e de classe média de outros estados, sendo "a 'mosca na sopa' os nãobrancos nordestinos" tidos como atrasados e ignorantes (WEINSTEIN, 2007:296). Posso afirmar, portanto, que a paulistanidade alberga o objetivo não só de racializar o Outro para racializar superiormente a si, mas também a defesa de uma ideologia conservadora que, para além da meritocracia, impõe uma visão que dá os créditos de enriquecimento às elites, 
negando, assim, o trabalho realizado por aqueles que foram escravizados e/ou economicamente explorados. ${ }^{50}$

Neste sentido, é válido pensar que a pretensa superioridade de São Paulo - ancorada no bandeirante, na ciência, no progresso, na civilização, na indústria, no moderno racializa seus termos mais básicos. As terras paulistas serem o local do maior avanço científico, tecnológico e civilizador possui sem sombra de dúvidas relação com a imaginação da branquidade engendrada neste recorte espacial. Isto ocorre justamente porque as noções de modernidade, progresso e civilização caminham juntas não somente com o etnocentrismo, mas também com o preconceito racial.

Há relações salientes entre os pressupostos do evolucionismo social e a ideia de progresso e civilização como algo unívoco. Ora, o termo civilização desde seu início já busca enaltecer o civilizado diante de um suposto incivilizado. Parte-se do pressuposto da dicotomia entre rural e urbano, entre moderno e atrasado, entre brancos e não-brancos, como se o progresso fosse considerado de forma igual por todas as populações humanas, como se fosse relevante em seu molde restrito a todos os grupos sociais. As referências a progresso, civilização, incivilidade, atraso e modernidade constituem-se, portanto, na mobilização daqueles que tem o poder de racializar os outros estabelecendo a si mesmo como superiores.

\section{7 - O Regionalismo Paulista Como Mobilização Política de Exclusão}

Em A Parte e o Todo, Ruben Oliven, preocupado com o caráter imaginado das comunidades, atenta para o fato de que as reivindicações regionalistas procuram opor regiões entre si, como se estas fossem internamente homogêneas, sem clivagens sociais. Estas diferenças apontadas ao Outro permitiriam que a região construísse a si, mas, tal qual nos nacionalismos, isto pode abarcar facetas distintas, tendo caráter popular ou, como ocorre com frequência, reivindicações disfarçadas das classes dominantes (OLIVEN, 1992:16).

Atentando, portanto, ao fato de que a conotação política do regionalismo varia de acordo com o contexto social, Oliven indica que regionalismos podem expressar tanto discursos progressistas quanto conservadores. $\mathrm{O}$ autor trata as identidades produzidas em discursos regionalistas como traços que, apesar de abstratos, precisam ser entendidos em

\footnotetext{
50 "Todos reconhecem que o progresso de São Paulo é um produto da expansão agrícola do século XIX, e que ela mesma seria inconcebível sem o negro escravo." (FERNANDES \& BASTIDE, 2008:41).
} 
suas ocorrências cotidianas. Desse modo, é possível apreender que a imaginação, a invenção e os mitos de uma comunidade não podem ser vistos como opostos da realidade, uma vez que seus resultados são materiais: "identidades são construções sociais formuladas a partir de diferenças reais ou inventadas que operam como sinais diacríticos, isto é, sinais que conferem uma marca de distinção" (OLIVEN, 1992:26).

Neste sentido, creio que seja essencial salientar a questão de gênero como vital para esta análise. Gilroy (2001) aponta que as forças de uma biopolítica nacionalista - e, no caso desta pesquisa, regionalista - são capazes de interferir nos corpos das mulheres, uma vez que estas são tidas como encarregadas de assegurar a reprodução da diferença étnica e da continuação de determinadas linhagens: "a integridade da raça e da nação, portanto, emerge como a integridade da masculinidade" (GILROY, 2001:19). O autor atenta ao fato de que a nação só seria coesa se a hierarquia de gênero fosse constituída e reproduzida. Interessa-me, portanto, ver como esta racialização acompanhada da masculinidade e da premissa da hierarquia entre classes move a paulistanidade.

Para tal é essencial relembrar durante a leitura desta pesquisa que o caráter excludente da paulistanidade, no que diz respeito à raça, gênero e classe, em muito se relaciona ao que é considerado progresso e civilização em um país na periferia do capitalismo global e do ideal branco. Santos (2017) indica que ao fim do século XIX e início do século XX, apesar do esforço oligarca em aparentar riqueza, europidade e branquidade na imagem do estado paulista, nem tudo era italiano em São Paulo (sendo este o nome dado à obra do autor).

Apesar de este pensamento ser forte a ponto de Rui Barbosa afirmar que a capital paulista seria "a expressão do espírito yankee amenizado e perfumado pela graça do gosto italiano" (RUI BARBOSA apud RAFFARD, 1977), e do empenho em embranquecer a população paulista, pessoas pobres, negras e indígenas, em especial as mulheres destes grupos sociais, foram essenciais à resistência diante deste processo invisibilizador e civilizatório. Vale lembrar que isto é esquecido constantemente na bibliografia especializada, uma vez que anarquistas e socialistas estrangeiros aparecem com frequência como os únicos agentes a se insurgirem contra uma ordem social moralista, branca e baseada no trabalho explorado.

Santos ainda aponta que as práticas higienistas e policiais, que iam desde a remoção de pobres do centro urbano até a proibição dos batuques e festejos populares, existiam para estigmatizar moralmente a população que era atacada, silenciada e que se tentava apagar de 
São Paulo: "branco quando morre, foi a morte que o levou. Negro quando morre, foi cachaça que matou" (FERNADES apud SANTOS, 2017). É neste sentido que muitas das ofensas perpetradas hoje em relação a negros, indígenas, nordestinos, pobres e mulheres (que não são brancas ou das classes abastadas) ainda buscam estigmatizar moral, racial, social, econômica e higienicamente grupos sociais que não coadunam com um conceito de civilização arbitrário e racista.

Longe de manterem-se no plano discursivo, tais práticas levaram que estrangeiros brancos e europeus fossem contratados para trabalhar na indústria paulista ao invés dos nacionais despossuídos: buscava-se "a formação de um mercado de trabalho e uma sociedade que fosse apoiada numa cultura branca, 'moderna' e, ao mesmo tempo, conservadora da ordem, disciplinada e moralizada" (SANTOS, 2017:60). Neste sentido, a lógica higienista de tornar São Paulo branca e rica, pelo menos em sua aparência, foi saliente. Sobre a urbanização excludente que removia pessoas que contrastavam com o ideal branqueador e enriquecedor paulista chegou-se a afirmar: "não há lugar para hesitações porque a isso se opõem a beleza, o asseio, a higiene, a moral, a segurança, enfim, a civilização e o espírito de iniciativa em São Paulo" (TORRES apud SANTOS, 2017:92).

O trabalho de Santos se mostra essencial quando aponta, a partir das fotografias que expunham São Paulo no início do século passado, que grupos sociais invisibilizados não só existiam como resistiam a este projeto regional. Neste sentido, a contribuição do autor concentra-se na acepção de que não foi harmônica a tentativa de embranquecer São Paulo e torná-la apta a um modelo capitalista de trabalho controlado moralmente. Ao contrário: até hoje aqueles que se tentou apagar existem ativamente no estado, sendo parte essencial de sua cultura. As imediações da rua 25 de março, que tanto tentou-se tornar arquitetonicamente europeia no início do século XX, é atualmente uma das concentrações principais de populações que resistem a investidas que tornam seu trabalho ilegal.

Posto isto, torna-se essencial neste trabalho analisar o conflito contínuo que envolve a paulistanidade. O regionalismo paulista ainda possui conexões com um ideal de civilização socialmente invisibilizador. É curioso notar que as investidas das autoridades do fim do século XIX são similares as que ocorrem hoje em relação à população em situação de rua, à área da cidade chamada de Cracolândia e ao trabalho informal. Nota-se, simultaneamente, a continuidade de um projeto político, urbano e estadual que se concentra no afastamento da pobreza e a resistência diante disto. 
Acredito que a corrente crise política brasileira, marcada pela polarização nas últimas duas eleições presidenciais, bem como o golpe sofrido por Dilma Rousseff, são capazes de suscitar uma série de debates em torno deste tema. Os embates entre narrativas de orgulho regional demonstraram uma mobilização política de expressão considerável, enfatizada especialmente pela repercussão preconceituosa causada pelas vitórias de Dilma Rousseff no cargo de presidenta ${ }^{51}$ da República em 2010 e 2014. Fato que chegou a mobilizar jovens do sul e sudeste na rede social Twitter a constituírem uma campanha que proferia ataques à população do Nordeste brasileiro e aos pobres em geral.

Buscarei mostrar, a partir da análise das diversas expressões preconceituosas geradas a partir destes confrontos, que tanto a racialização do Outro Regional quanto a afirmação da inaptidão deste à política são fenômenos atuais no que diz respeito à paulistanidade. Da mesma forma, parte do ideal paulista segue em uma cruzada contra o que considera barbárie: a pobreza não-branca. Isto não é somente capaz de expressar o caráter conservador desta ideologia frequentemente conectada aos ideais das classes dominantes, como também a perpetuação de um projeto político que desde o fim do século XIX buscou afastar pobres, negros e indígenas de sua composição social imaginada.

\footnotetext{
${ }^{51}$ Vale salientar que me refiro à presidenta no feminino apesar de não haver tal designação formalizada na Língua Portuguesa.
} 


\section{CAPÍTULO II \\ Nordeste \\ Do $E u$ ao Outro Regional ${ }^{52}$}

\section{1 - A Formação Histórica do Nordeste}

Estudar a região denominada de Nordeste brasileiro torna necessário levar em consideração o que a inscreve e caracteriza enquanto local produtor de sentidos, identidades e máximas inseridas no senso comum. Para tal, afastar-se da naturalização de um espaço enquanto obviamente regional é imprescindível. Deste modo, empenho-me em compreender a partir de um contexto mais amplo, o do engendramento de uma identidade nacional, o que leva agrupamentos humanos e espaciais (com suas heterogenias internas e externas) a serem considerados de um estado e de um modo de ser legítimo ou marginal.

Margareth Rago em prefácio da obra de Durval Muniz de Albuquerque Jr., A Invenção do Nordeste e Outras Artes, enuncia que "até meados da década de 1910, o Nordeste não existia" (RAGO, 2011:13). A obra em questão apresenta o Nordeste brasileiro como fruto de uma invenção formulada por interesses políticos específicos. Esta invenção seria capaz de reverberar tanto em discursos externos e alheios à vida nordestina quanto em discursos internos, dos próprios nordestinos.

Deste modo, com o objetivo de expor as condições históricas que possibilitaram a emergência dos discursos produtores deste recorte espacial, Albuquerque Jr. critica a visão do Nordeste enquanto dado natural. Para tal, analisa linguística, geográfica e historicamente as linguagens e processos que permitiram a distribuição espacial dos sentidos capaz de tornar a dada região e seus habitantes em estereótipos periféricos do subdesenvolvimento (ALBUQUERQUE, JR, 2011:33).

Negando a preexistência do espaço a uma sociedade, o historiador preocupa-se em enfatizar o fato de que as regiões não formam o regionalismo, sendo, ao contrário, produtos deste discurso. Deste modo, toma o Nordeste enquanto invenção, analisando a

\footnotetext{
52 Outro Regional seria um termo utilizado por Weinstein (2015) para se referir a um discurso da paulistanidade que pauta o nordestino enquanto outro. Neste capítulo, com o intuito de mostrar as relações entre discursos nordestinos e paulistas acerca do Nordeste, insiro a ideia de Eu Regional. Como os regionalismos nordestinos pautariam sua própria identidade, portanto, aparece como relevante questão para esta pesquisa.
} 
regularidade com que certos enunciados se repetem, sendo tidos como definidores do local e de seus habitantes.

Longe de delimitar a região enquanto um dado estático, Albuquerque Jr. a expõe como centro de uma batalha. Batalha esta que se determina de maneira estratégica, podendo levar a outros processos de regionalização - de produção, trabalho, práticas culturais - no intento de operar a homogeneização de locais e grupos diversos. Assim, para o autor é preciso elencar os enunciados audiovisuais capazes de se cristalizarem enquanto representações de um espaço, buscando entender as redes de poder que sustentam e são sustentadas pelas identidades regionais. Estas identidades seriam uma repetição e uma semelhança superficial que na realidade concentram diferenças fundantes; por serem uma construção mental apresentam-se como conceitos sintéticos, até mesmo abstratos, que buscam generalizar grandiosa variedade de experiências humanas: "falar e ver a nação ou a região não é, a rigor, espelhar estas realidades, mas criá-las" (ALBUQUERQUE JR, 2011:38).

É por tal motivo que o autor critica a História Regional, acreditando que esta contribua para a dizibilidade da invenção do Nordeste, especialmente enquanto local atrasado e periférico. Assim, o regionalismo em suas formas múltiplas, seria para o historiador algo que vai além da ideologia das classes dominantes, impregnando-se no discurso de camadas diversas da população. Afirmar isto, todavia, não leva Albuquerque Jr. a ignorar a influência das elites nordestinas na produção dos estereótipos que rondam o Nordeste. Para o autor, foi justamente a perda de privilégios desta camada social, no início do século XX, o que levou ao seu engajamento na criação do discurso do que é a região.

De tal modo, Albuquerque Jr. pontua a década de 1920 como momento chave para se pensar identidade, raça e caráter nacionais, conceitos que em tal período, febricitante na busca da formação da nação, levam a uma forma nova de conceber as regiões do país. A obra do autor explicita que junto com o desenvolvimento da imprensa, há a preocupação de se conhecer profundamente os diferentes lugares do Brasil. A divisão entre Norte e Sul, neste caso, aprofunda-se. Seguindo a mesma abordagem de Barbara Weinstein, o historiador expõe uma série de reportagens engajadas em expor o Sul como moderno e avançado e o Norte enquanto atrasado e arcaico. É o que se pode apreender do trecho a seguir, retirado do jornal O Estado de S. Paulo e publicado em setembro de 1920:

Incontestavelmente o Sul do Brasil, isto é a região que vai da Bahia até o Rio Grande do Sul, apresenta um tal aspecto de progresso em sua vida material que forma um contraste doloroso com o 
abandono em que se encontra o Norte, com seus desertos, sua ignorância, sua falta de higiene, sua pobreza, seu servilismo (OESP, 1920:4).

De tal trecho apreende-se não somente a dicotomia entre Norte e Sul, atraso e progresso, mas especialmente o caráter transitório e disputado do que é uma região. Em tal época, não se falava em Nordeste, era um Norte difuso que estava em questão; a Bahia, posteriormente considerada por muitos paulistas como símbolo nordestino, ${ }^{53}$ era então considerada Sul, sendo apenas ocasionalmente associada ao Norte. ${ }^{54}$

Levar em consideração que as regiões são locais historicamente concebidos e disputados, leva Albuquerque Jr. a aprofundar-se na importância da Abolição da Escravidão e migração internacional para o Brasil, em especial para a região conhecida à época como Sul. O historiador conclui que havia, no início do século XX, um desprezo em São Paulo pelos agrupamentos negros e indígenas em sua composição histórica: o estado paulista e seus habitantes apareceriam como um grupo impregnado pelo progresso civilizador e embranquecedor europeu. Tal fato, por óbvio, é conectado a já citada racialização regional do Brasil.

Posto isso, torna-se importante frisar que o regionalismo alterou-se ao longo do tempo. Albuquerque Jr. aponta que a formação da nação e o ideal de pátria forma, em meados do século XIX, uma série de regionalismos. Caráter muito diferente possui, todavia, os novos regionalismos da década de 1920: "a emergência da formação discursiva nacional-popular provoca o surgimento de uma consciência regional generalizada, difusa no espaço, que consegue ir se ligando às várias existências individuais, mas principalmente à própria vida coletiva" (ALBUQUERQUE JR, 2011:63).

Pensar neste regionalismo ligado tanto às várias experiências individuais quanto à vida coletiva, torna necessário aprofundar o porquê de relacionar, nesta pesquisa, expressões da paulistanidade e do preconceito contra a população do Nordeste. De que

\footnotetext{
${ }^{53}$ Insere-se aqui o fato de que em São Paulo coloquialmente se reduz os grupos nordestinos à categoria única de baiano.

${ }^{54}$ Vale lembrar que a configuração do mapa do Brasil alterou-se significativamente ao longo dos anos. Só no século XX houve mais de cinco mudanças oficiais: em 1913 a divisão era em regiões Setentrional, Norte Oriental, Oriental e Meridional, sendo que se inseria a Bahia no Oriente e parte dos outros estados hoje nordestinos no Norte Oriental; em 1940 Bahia, Sergipe e Espírito Santo passaram a formar a região denominada leste; em 1945 grande parte do que hoje é Nordeste dividia-se em Leste Setentrional, Nordeste Ocidental e Nordeste Oriental; em 1950, Maranhão e Piauí passaram a integrar o Nordeste; em 1970, com a divisão que temos hoje, o Sudeste foi criado e à região nordestina foi anexada a Bahia e o Sergipe.
} 
paulistas e de que nordestinos que falo? Concebo ambos os grupos de maneira heterogênea. Clivagens sociais diversas permeiam tanto o estado de São Paulo quanto a região nordestina. Levar em consideração, porém, a heterogeneidade do Nordeste e de São Paulo, não descarta o fato de que tais locais são reduzidos a uma representação discursiva que deve ser pesquisada.

Posto isto, torna-se válido relembrar que utilizo as categorias de paulistas e nordestinos pensando em um nível representativo. Defendo que, apesar de tais identidades regionais abarcarem hierarquias e segmentos sociais múltiplos, há, em torno de ambas, uma imagem associativa. Imagens estas com consequências à realidade social: a ideia recorrente em torno da inaptidão política nordestina já pôde, inclusive, ser justificativa para a defesa do assassinato coletivo dos nordestinos residentes em São Paulo. ${ }^{55}$

Focar nestes estereótipos, todavia, não reduz a atenção dada às hierarquias internas a estas regiões. O Nordeste contém uma série de regionalismos e rivalidades históricas. Do mesmo modo, dentro de qualquer agrupamento humano, dispositivos de poder marcam as relações sociais. Notadamente, um nordestino rico é imaginado e vive diferentemente de um pobre, tal qual um negro de um branco, um cearense de um baiano, um homem de uma mulher. Heterogenias internas a uma região são gritantes. A saliência destas, todavia, não anula o fato de que ao paulista cola-se, frequentemente, a ideia imaginativa do avanço branco, enquanto ao nordestino, o ideal perverso da decadência mestiça.

Deste modo, no presente capítulo buscarei apresentar a relação dicotômica entre o ideal de paulistas e de nordestinos, bem como de São Paulo e do Nordeste brasileiro. Farei isto explicitando a possibilidade de encaixes diferentes no que diz respeito à imaginação, invenção e fechamento social dessas comunidades. Interessa-me analisar discursos históricos produzidos em relação ao Nordeste, bem como estratégias e símbolos criados na formação da dizibilidade deste recorte espacial e humano.

\section{2 - Regionalismo Freyreano}

O capítulo anterior explicitou o protagonismo da classe política e intelectual de São Paulo na formação da paulistanidade. Agora, busco apresentar a relevância de análise da classe política e intelectual nordestina, de modo a aprofundar o entendimento do regionalismo deste local. Entre outros aspectos, tal exposição possibilita confrontar a

\footnotetext{
${ }^{55}$ Novamente a menção se dá em torno do episódio protagonizado por Mayara Petruso após as eleições presidenciais de 2010.
} 
postulação já clássica que apresenta os nordestinos enquanto passivos, negando-lhes qualquer forma de agência. Como será exposto, houve e ainda há um embate regional de grande espectro. De tal maneira, apresento o presente escrito em comparação ao tópico Classe Política e Intelectual: Poetas-Educadores, integrante do capítulo anterior, de modo a colocar em contraposição certos aspectos dos regionalismos paulista e nordestino.

Tratar deste embate passa necessariamente pelo entendimento da produção de Gilberto Freyre como essencial ao regionalismo e à defesa das tradições nordestinas na primeira metade do século XX. É o que se pode apreender em muitas obras do autor: de Casa-Grande e Senzala a Nordeste e ao Manifesto Regionalista encontra-se nítida preocupação em, não somente enaltecer certos costumes do Nordeste açucareiro, como também em defender-se contra a perda dos mesmos.

Publicado em 1937, Nordeste: Aspectos da Influência da Cana sobre a Vida e a Paisagem do Nordeste do Brasil, apresenta preocupação em diferenciar esta região, separando-a do que até então era conhecido como Norte. Do mesmo modo, dentro deste Nordeste, Gilberto Freyre postula a existência de duas, dentre várias, regiões distintas: uma agrária e outra pastoril. Entre estas duas, Freyre analisa a agrária, a da cana de açúcar. Segundo o autor, este Nordeste seria mais antigo que aquele outro, o do sertão, apesar deste último estar à época ofuscando a região açucareira tendo em vista a repercussão de suas secas. Terra gorda, ar oleoso, gente vagorosa, manchas d'água sempre presentes são alguns dos atributos que Freyre utiliza para descrever esse "Nordeste que vai do Recôncavo ao Maranhão, tendo o seu centro em Pernambuco" em que "a doçura das terras de massapê contrasta com o ranger da raiva terrível das areias secas do sertão" (FREYRE, 2010:46-47).

O sociólogo endereça ao Nordeste de que fala a importância de ter albergado toda a nacionalidade brasileira, tendo sido, em especial, o primeiro lugar em que o português havia se fixado. Tal fato, na visão do autor, teria permitido a formação da "fisionomia brasileira, os traços, os valores, as tradições portuguesas que junto com as africanas e as indígenas constituiriam aquele Brasil profundo, que hoje se sente o ser mais brasileiro" (FREYRE, 2010:50). Torna-se evidente, deste modo, um forte traço regionalista que, como já visto anteriormente acerca da paulistanidade, reivindica para si a brasilidade, a melhor e verdadeira composição nacional.

Em tal reivindicação encontra-se a elevação do tipo regional do local: o cabra. Vale lembrar que Abdias do Nascimento, contrário aos dizeres apaziguadores e racistas de 
Freyre, indica que cabra, tal qual mulato, pardo e mestiço são termos que buscam eufemizar a categoria de negro em um país que apela ao embranquecimento (NASCIMENTO, 2017:48). Segundo Freyre, este cabra teria "possibilidades eugênicas" magníficas (FREYRE, 2010:50) devido à mestiçagem entre índios, portugueses e negros. É nítida a diferença do enaltecimento da mestiçagem entre o discurso freyreano e a maior parte dos discursos regionalistas paulistas vistos no capítulo anterior, uma vez que, como já afirmado, no discurso regional de São Paulo os paulistas apareceriam enquanto unicamente brancos. $^{56}$

O aspecto temporal é outra diferença a se levar em consideração: Freyre enfatiza a todo o momento o receio da perda de poder do grupo nordestino, da mesma forma que o expõe como "hoje em decadência" (FREYRE, 2010:50), dissertando sobre aspectos morais e sociais não vistos com bons olhos pelas lentes do progresso. Para além de nos discursos regionalistas paulistas anteriormente analisados, haver o poder no tempo presente, não se encontra aspectos de decadência: a riqueza, a modernidade e a branquidade mascaram quaisquer traços considerados negativos.

No embate para categorizar o Nordeste como local em posse da brasilidade, Freyre contrapõe o símbolo do bandeirante ao caráter sedentário imputado ao povo do Nordeste açucareiro. Sem diminuir o valor das bandeiras, e atribuindo ao bandeirante a característica de mameluco ${ }^{57}$, o autor afirma que o esforço destas teria sido praticamente em vão se desde o século XVI não se concentrassem as "energias criadoras" das figuras nordestinas dos engenhos de açúcar (FREYRE, 2010:51).

Há em tal afirmação uma disputa nítida: o bandeirante, símbolo tão caro à paulistanidade, é colocado em interdependência com os tipos sociais do Nordeste. ${ }^{58}$ Freyre, ao afirmar que os esforços das bandeiras seriam quase inúteis sem a contribuição dos nordestinos na formação da nação, reivindica um aspecto regionalista para a brasilidade.

O mesmo pode ser visto em relação à narrativa empreendida pelo sociólogo no que concerne à Independência do Brasil, tendo esta se realizado "firmando-se principalmente sobre uma aristocracia quase feudal de senhores de terras de massapê" (FREYRE,

\footnotetext{
56 Repete-se aqui a postulação de Weinstein de que "no nível da representação o paulista é indubitavelmente branco e de classe média." (WEINSTEIN, 2007:291).

${ }^{57}$ Tal qual Weinstein $(2007,2015)$.

${ }^{58}$ Freyre realiza tal movimento, todavia, sem diminuir certa superioridade bandeirante em termos bélicos: "a superioridade militar do bandeirante sobre o senhor de engenho parece, em grande parte, consequência disto: da alimentação do bandeirante ter se tornado rapidamente quase a mesma alimentação do indígena." (FREYRE, 2010:114).
} 
2010:51). O capítulo anterior elencou uma série de exemplos que demonstravam enredos do regionalismo paulista capazes de responsabilizar o estado tanto pela conquista do interior do país quanto pela Independência do Brasil. Vê-se como tais enredos, apesar de suas especificidades, encontravam coro também em outros regionalismos. É o que se pode apreender da defesa de Freyre em apontar o Nordeste como superior em termos de construção da nação.

O tom de afeto que Freyre toma para falar do Nordeste açucareiro estende-se à paisagem: rios, o triângulo rural (engenho, casa, capela), a canoa, a jangada, o cavalo e o boi ganham um aspecto sentimental conectado ao humano e à particularização daquela região. Sua defesa de que a água representa quase tudo para o Nordeste da cana-de-açúcar (FREYRE, 2010:58) e de que os rios seriam "às vezes feios e barrentos, mas quase sempre bons e serviçais" (FREYRE, 2010:59) ajuda a contrapor a divisão entre a região das terras de massapê e a do sertão. Do mesmo modo, dá ao rio um caráter quase mítico ${ }^{59}$ na construção daquele recorte espacial: estes rios teriam contribuído com o sedentarismo e a agricultura, o que permitiu que se moldasse o verdadeiro brasileiro.

É interessante relacionar este aspecto com um atributo do discurso regionalista paulista que defende que os rios em São Paulo levaram os bandeirantes à conquista do território brasileiro. ${ }^{60}$ Vê-se nestas duas formações de enredos regionalistas distintos, a tomada de características geográficas como argumentos que naturalizam a História e, por conseguinte, a superioridade da região. Freyre põe em seu favor até o fato de os rios do Nordeste açucareiro serem pequenos, possibilitando uma constância e equilíbrio de grande “importância na formação rural do Brasil” (FREYRE, 2010:61).

A exaltação que Freyre faz à paisagem, geografia e grupos nordestinos é, todavia, acompanhada por uma angústia do que está se perdendo: os rios, tão importantes para a nação, se poluíram; o solo, tão rico para a agricultura, fora massacrado pela monocultura da cana de açúcar; e o povo, miscigenado pelas três raças, perdia no Nordeste seu elemento caboclo (FREYRE, 2010:69). É em tal sentido que se encontra na obra de Freyre grande crítica aos fabricantes de açúcar e à monocultura estimulada pela "coroa na sua fase já parasitária" (FREYRE, 2010:80), bem como à importação de elementos europeus, exemplificada pelas árvores que não oferecem sombras (FREYRE, 2010:84) e pela culinária pré-fabricada, que perdera seu aspecto caseiro.

\footnotetext{
${ }^{59}$ Nas palavras do autor "Pouca gente acredita que o passado dos rios do Nordeste tenha sido tão bonito e tão ligado à nossa vida sentimental. Mas foi." (FREYRE, 2010:72).

${ }^{60}$ Uma grande defesa desta ideia encontra-se na obra de Cassiano Ricardo, Martim Cererê
} 
Toda esta intrusão alterava, segundo o autor, a sociedade que lá era formada, acentuando a diferença entre os grupos humanos, os que trabalhavam no fabrico de açúcar e os que dele viviam, afastando-os dos aspectos naturais daquela terra. Assim, a escravidão que se deu em torno dos engenhos era vista enquanto produto da monocultura exclusivista e brutal de um "açúcar com A maiúsculo (...) ao serviço de uma minoria insignificante" (FREYRE, 2010:87).

É com esta crítica do que foi feito da região açucareira nordestina que Freyre afirma a aristocratização do branco, a degradação do índio e a escravidão do negro com suas consequentes divisões entre pessoas, habitações e paisagens. Em tal sentido, Freyre relaciona o senhor de engenho, em sua dignidade, ao cavalo ${ }^{61}$ e o escravo, em sua opressão, ao boi. ${ }^{62}$ Tal relação torna possível elucidar uma série de questões raciais e de gênero na sociedade patriarcal pelo autor descrita e, até certo ponto, exaltada. As descrições dos cavalos bons enquanto mulheres boas (gordas e bonitas) e até certo ponto em símbolo afeminado, maricas (FREYRE, 2010:103) em contraposição ao boi enquanto um equivalente do negro (que carrega o trabalho açucareiro em suas costas) deixa nítido o alicerce racista e sexista do contexto em questão. É curioso, inclusive, apontar o fato de que o cavalo aparece enquanto figura complementar ao senhor de engenho, este estando acima daquele, enquanto os grupos femininos e negros são animalizados, aparecendo em equivalência animal e não em complementação.

É com este caráter conciliador que se inscreve a questão racial e de gênero na produção freyreana. As necessárias críticas, acadêmicas ou não, dos movimentos negros e feministas chamam atenção ao fato de que ideias como a da doçura suavizam a crueldade do regime escravocrata e patriarcal, engendrando a mítica democracia racial como pilar da sociedade brasileira. Levando-se isso em consideração, posso afirmar - acerca da questão racial ao longo de toda a obra Nordeste - que há um movimento de vai-e-vem nas posições freyreanas. Tal movimento vai da afirmação de horror diante do modo com que as pessoas escravizadas eram tratadas à exaltação desta sociedade e seu esquema social desigual enquanto o melhor do Brasil, levando o autor à defesa deste contra a sua progressiva decadência.

\footnotetext{
61 "O animal, mais que qualquer outro, a serviço do domínio dos defensores da Ordem sobre a massa (...) O senhor de engenho do Nordeste foi quase uma figura de centauro: metade homem, metade cavalo." (FREYRE, 2010:98),

${ }^{62}$ Que, dominado e serviçal, seria um dos pilares de trabalho do Nordeste açucareiro.
} 
No que diz respeito a tal sociedade, Freyre atribui a formação do "tipo mais puro de aristocrata brasileiro: o senhor de engenho" (FREYRE, 2010:121). É neste sistema agrário patriarcal que teriam surgido as seguintes figuras nordestinas:

O cabra de engenho, o moleque da bagaceira, o capanga (de ordinário, caboclo ou mulato), o mulato vadio caçador de passarinho, o malungo, o pajem, o branco pobre, o "amarelo" livre, a mãe-preta, a mucama, o negro velho, o curandeiro, o caboclo conhecedor da mata e dos seus bichos, a ama-de-leite tapuia ou negra, a 'cabra-mulher' (FREYRE, 2010:121).

É assim, pontuando a miscigenação, como se vê nos tipos sociais expostos, que Freyre argumenta o início da civilização nordestina como consequente da junção portuguesa, indígena e negra. A consideração do autor de que todos estes grupos humanos formam a civilização nordestina, apesar de aparentar maior inclusão que o regionalismo paulista, ainda assim indica um caráter excludente. Isto porque Freyre suaviza a escravidão e o estrutural racismo brasileiro a ponto de dizer que no Nordeste, do contrário do que teria acontecido em São Paulo, a pessoa escravizada seria "fiel, capaz de dar sua vida pelo branco (...) quase pessoa de casa (...) quase membro da família” (FREYRE, 2010:131).

Por este motivo que, apesar de o sociólogo afirmar o potencial de luta do negro, defende que não havia no Nordeste açucareiro um ambiente favorável para o ódio da pessoa escravizada contra o senhor: novamente a doçura "do português com relação à gente de cor" (FREYRE, 2010:136), enganosa e problemática por princípio, sustentava o argumento freyreano.

Não foi apenas essa doçura, todavia, que Freyre apontou na relação entre portugueses e afrodescendentes. As revoluções nas Antilhas ${ }^{63}$ ao gerarem medo de insurreição no Brasil, levou a coroa a permitir certa ascensão negra na tentativa de acalmar os ânimos. Desse modo, o sociólogo expõe que alguns negros nordestinos (por ele chamados de mulatos) se tornaram, pelo timbre e inflexão da voz, mais educados e portugueses que muitos senhores de engenho (FREYRE, 2010:140).

É com base nisto que Freyre preza pela superioridade lusitana: defendendo a falaciosa doçura portuguesa em relação à colonização inglesa e sua melhor adaptação ao meio tropical. Em tal sentido o autor, ao apresentar a miscigenação do povo do Nordeste açucareiro com o elemento português, negro e indígena, aponta um perfil psicológico com

\footnotetext{
${ }^{63}$ Uma série de insurreição anti-escravistas que se concentraram no fim do século XVIII e começo do XIX.
} 
"maiores pontos de semelhança com o de certo tipo antigo de paulista andejo, empreendedor, bandeirante do que o homem do Nordeste agrário" (FREYRE, 2010:153). É curioso notar que até mesmo em um embate regional como o de Freyre há necessidade de aproximar-se de algum modo do paulista e afastar-se do estigma sertanejo.

Novamente pode-se notar na obra de Freyre o vai-e-vem já mencionado: os tipos nordestinos são apresentados enquanto povo mais brasileiro, muitas qualidades são exaltadas, suas tradições não podem ser perdidas, ao mesmo tempo que se diz que a atração causada pelo esplendor do açúcar no Nordeste gerou "uniões ou cruzamentos de tais indivíduos" que "teriam transmitido à prole tão infeliz o peso da inferioridade biológica, e não apenas social" (FREYRE, 2010:153).

É neste movimento de reconhecimento do que considera inferioridade seguido pela exaltação de elementos atenuantes que Freyre conclui que a colonização do extremo Nordeste não foi tão fina quanto na Bahia, em termos estéticos, morais e sociais, mas mesmo assim havia chance para a população dessa região. A necessidade freyreana de expor a população do Nordeste açucareiro enquanto geneticamente apta $^{64}$ diz respeito a um contexto em que o racismo científico vigorava em grande parte das teorias, bem como o receio em relação ao futuro de um país tão miscigenado. Freyre, ao contrário, considerava tal miscigenação importante para a nação brasileira.

Desse modo, Freyre defende que se as pessoas do Nordeste supostamente se degeneraram mais que em outras regiões do país, isto se deu devido à "exclusão das culturas de subsistência; pelo latifúndio; pela escravidão; pelo patriarcalismo monossexual, ao mesmo tempo que monocultor" (FREYRE, 2010:171). Assim, exaltando a miscigenação, o sociólogo defende que foi o esforço do cabra, deste tipo social, que sustentou esta sociedade em específico.

Esta defesa que aponta para as condições de vida como responsáveis pela decadência atribuída ao cabra, ao invés de sua genética, leva Freyre a criticar Morais Barros, Carneiro Leão, Nina Rodrigues, Oliveira Vianna, Sílvio Romero e José Veríssimo (nomes caros ao racismo científico) em seus argumentos que imputam "o feio, o bisonho, o franzino da população mestiça do Nordeste" (FREYRE, 2010:174). O sociólogo explica que tais observadores não levaram em consideração as questões de classe que subjugam a

\footnotetext{
${ }^{64}$ Nas palavras do autor: "Se a raça, como lembram os antropólogos modernos, conta menos do que a composição genética das populações, o extremo Nordeste pode apresentar-se como uma região particularmente bem dotada, do ponto de vista dos elementos que the serviam de base à colonização branca e negra de suas terras de cana." (FREYRE, 2010:158).
} 
população não-branca. Deste modo, Freyre pontua que a Abolição da Escravidão com sua subsequente industrialização contribuíram para a degradação do povo de que fala: o fim das relações - que devo lembrar: nunca foram existentes - de proximidade, de doçura, prejudicou o cabra, a culinária, a paisagem e as mais arraigadas tradições nordestinas.

É este receio frente à modernidade da industrialização que leva o sociólogo a lamentar a perda de certos costumes. Freyre aponta uma série de poetas, médicos, acadêmicos, bem como elenca construções e fatos que apontam a dignidade que vinha se perdendo naquela região. Se apreende da obra, como já falado, o movimento de vai-e-vem constante: o sociólogo conclui que nunca uma sociedade foi tão patológica e opressora quanto a nordestina, mas pelo fato de que justamente os "doentes que dão as pérolas (...) nenhuma foi mais criadora do que ela, de valores políticos, estéticos e intelectuais" (FREYRE, 2010:195), saindo, assim, vitoriosa.

É com esse mesmo tom que Gilberto Freyre anuncia o Manifesto Regionalista de 1926. Com uma lista extensa de nomes estrangeiros que endossavam as características nordestinas, o Manifesto defende não ater-se em bairrismos, mas pura e simplesmente na necessidade, mais social que política, de defender os costumes e as tradições deste recorte espacial.

Encarando a iniciativa como um novo tipo de regionalismo, o texto clama pela emergência de outros movimentos que pudessem conter as influências estrangeiras que assolavam o país. Fica nítido um apelo, inclusive às autoridades: a ação inter-regional na defesa da cultura brasileira verdadeira. O Nordeste é exposto como local marcado pela fome, cangaço, malária e pobreza, mas novamente em um vai-e-vem de crítica e enaltecimento, se expõe a região como possivelmente sendo a mais rica em tradições e caráter.

Os recursos em defesa de tal argumento são as descrições detalhadas dos mucambos enquanto símbolo de arquitetura, das ruas estreitas com nomes brasileiros que levam a uma maior familiaridade com as cidades e dos quitutes e doces feitos, especialmente, por mão de obra negra. Tudo aparece como um marco afetuoso que deve ser preservado contra a burguesia estrangeira. A culinária nordestina, tão minuciosamente descrita, aparece como a melhor justamente por equilibrar os traços brancos, indígenas e negros. O texto chega a afirmar que uma cozinha em crise significa uma civilização inteira em perigo. Tais argumentos expõem uma sociedade nordestina extremamente miscigenada, afirmando isto como o melhor e mais característico traço do Brasil. Vale lembrar que 
Nascimento (2017) atenta ao fato de que culturas negras serem salientes na brasilidade, aparece constantemente como justificativa da democracia racial: como se a existência de certa culinária, da capoeira e tantos atributos não fossem fruto de constante resistência de movimentos negros ou apropriação cultural das classes dominantes brancas, mas sim da teórica tolerância racial do país.

Posto isto, torna-se importante salientar que os traços do regionalismo nordestino que expus na presente dissertação são distintos dos que demonstrei no capítulo anterior em relação ao regionalismo paulista. Pela perda de poder do Nordeste com o progressivo deslocamento político e econômico para o eixo Centro-Sul, é possível ver na obra de Freyre um saudosismo patente. O regionalismo paulista que expus fala de seu tempo, narra um passado, em grande parte imaginado, enaltecedor, o presente e o futuro são brilhantes: nada, nenhum período, possui qualquer traço do que é considerado decadente.

Antes de aprofundar-me nas diferentes questões de raça, gênero e classe, todavia, vale salientar a variação entre um regionalismo como o de São Paulo, que trata como centro a capital do estado, e um regionalismo que abarca toda a região, como o freyreano, tratando como centro a capital de Pernambuco, um dos tantos estados de que diz respeito. Tal variação permite apreender melhor a ideia de região enquanto um local de disputa, em constante transição. É interessante notar também que o Nordeste é reconhecido como um todo para além de seus meios regionalistas: o senso comum paulista muitas vezes reconhece todo nordestino como baiano. É possível afirmar que o próprio reducionismo com que é tratado uma região e um regionalismo indica uma assimetria de poder.

Dito isto, são nítidas as diferenças de abordagem em torno da questão racial quando compara-se o regionalismo nordestino freyreano aos tantos discursos paulistas anteriormente apresentados, como os de Ellis Jr., Cassiano Ricardo, Mário de Andrade, Alberto Salles, Affonso Taunay, entre outros. Já foi afirmado nesta dissertação que no nível da representação o paulista aparece como branco (WEINSTEIN, 2007), tendo, inclusive, seu símbolo, o bandeirante, embranquecido ao longo de sua emergência enquanto categoria mítica de São Paulo (WEINSTEIN, 2015; QUEIROZ, 1992). No regionalismo freyreano é a miscigenação racial que é tida como característica diferencial.

O cabra, de que Freyre fala, é defendido com sua influência negra e indígena. A retórica da maior parte dos discursos do orgulho paulista se dá justamente no afastamento da composição de não-brancos como grupo social marcante em São Paulo. Há, portanto, como afirmar, sem sombra de dúvidas, que as representações sociais de ambos os grupos 
regionais $^{65}$ diverge, assim como os recursos utilizados para defender a superioridade destes. Analogamente, defendo que o preconceito racial, marcante em qualquer região brasileira, possui peculiaridades e distinções em cada um dos contextos regionais. ${ }^{66}$

O mesmo pode ser dito no que diz respeito à questão de classe: as narrativas paulistas mostradas no capítulo anterior evidenciam a tentativa de pautar São Paulo enquanto capitalista, empreendedora, industrializada - o local do progresso - enquanto que a narrativa freyreana pauta em nível de interdependência as diversas camadas econômicas da sociedade patriarcal do Nordeste açucareiro. Não há qualquer tentativa por parte de Freyre de anular a importância das camadas pobres, sendo estas em alguns momentos até mesmo exaltadas pelo autor por terem sido a mão de obra da região. É curioso notar como viu-se nos discursos paulistas culpabilização dos migrantes nordestinos pela pobreza em São Paulo, enquanto o discurso freyreano não só assume, como salienta a presença deste fenômeno no Nordeste de seu tempo.

Para além de se pensar as diferenças entre os recursos utilizados em ambos os regionalismos, vale apontar para uma assimetria aos moldes do que afirma Norbert Elias: os grupos outsiders não possuem recursos de poder suficientes para ofender os grupos estabelecidos (ELIAS, 2000). Neste caso, do mesmo modo que paulista não é reconhecido enquanto adjetivo pejorativo à maneira que são baiano e paraíba, não há condições para os discursos regionalistas nordestinos, do qual o freyreano é um exemplo, conterem ofensas elitistas ou racistas direcionadas aos agrupamentos paulistas: resta a defesa das tradições. Nesta linha argumentativa, rios, paisagem, cidades e grupos humanos do Nordeste podem ser assumidos como feios, decadentes, patológicos, mas nessa sua inferioridade reside a primazia na formação da nação brasileira.

No que diz respeito às questões de gênero, Weinstein (2015) defende que, em especial no Conflito de 1932, a mulher paulista aparece como exemplo de orgulho cívico e auto-sacrifício, bem como enquanto figura arquetípica que indicaria as qualidades necessárias para ser uma mulher de São Paulo (WEINSTEIN, 2015:164). Tal narrativa encontra na categoria mítica do bandeirante uma explicação: a mulher paulista esperava em casa seu homem que ia conquistar o interior brasileiro, o que a fortaleceu (WEINSTEIN, 2015:165). Destrinchando uma série de recursos de propaganda utilizados no Conflito de

\footnotetext{
${ }^{65}$ Considerando suas imensas heterogenias internas e lembrando que grupos não são naturalmente constituídos.

${ }^{66}$ Tal afirmação não deve levar à ideia de que se considera nesta dissertação uma expressão de racismo como menos danosa ou mais superficial que outras.
} 
1932, a historiadora aponta o fato de que a mulher paulista então representada, e que se tornou um ícone, é branca e da alta sociedade.

Novamente é possível visualizar uma série de diferenças no trato de duas narrativas regionalistas em torno de um marcador social: o discurso freyreano apresentado foca na participação das mulheres negras - estas restritas, em especial, ao cuidado do lar, das pessoas e da culinária. Em contrapartida, em grande parte do regionalismo paulista, as mulheres de São Paulo aparecem - em nível de representação - enquanto brancas e ricas. Sua participação no Conflito de 1932 - apesar de mais moral do que política (WEINSTEIN, 2015:164) - é utilizada como um diferencial em relação às mulheres de outros estados, na tentativa de defender uma pretensa superioridade destas em relação às outras.

Vale dizer que é necessário observar que no regionalismo paulista a mulher raramente aparece enquanto centro da narrativa do orgulho estadual e quando isto ocorre, vê-se que se baseia o feminino em um ideal masculino: a mulher existe à sombra do bandeirante. É interessante, portanto, que na produção freyreana e no regionalismo nordestino em geral, mulheres, apesar de serem marcadas pela opressão de gênero e raça, sejam figuras tão aparentes: da mulher que foi escravizada, reduzida à noção cruel de mãe preta das crianças brancas, à atual baiana. Dito isto, é importante salientar que tais mulheres, em especial as não-brancas, raramente podem enunciar este discurso sobre si: o regionalismo, como a maior parte das ideologias, é com frequência um produto dos dizeres masculinos.

No que se refere aos marcadores sociais da diferença tratados, raça, classe e gênero, é interessante realizar o exercício proposto por Wimmer (2013): desracializar grupos para enxergar a validade de tratar com categorias raciais o fenômeno estudado. Para o autor uma pesquisa apurada deveria explicar os motivos da etnicidade importar em graus diferentes e de formas variadas em sociedades, situações e períodos distintos (WIMMER, 2013:3).

Fica nítido em tal caso que, mesmo quando analisado pelo viés do gênero, ambos os grupos são racializados: a mulher paulista aparece enquanto branca nos discursos regionalistas enquanto a mulher nordestina aparece enquanto negra não apenas em uma série de discursos regionais, mas também no que se diz externamente ao Nordeste. Do mesmo modo, defendo que para além do fato de não haver possibilidade de tratar classe 
sem tratar do privilégio branco, há na narrativa paulista preconceituosa em relação ao nordestino pobre um estereótipo racial.

Albuquerque Jr. enxerga nos regionalismos nordestinos, inclusive o de Freyre, a memória como principal traço característico. Memória esta que, romantizada, se coloca contra um ideal de progresso, mascarando quaisquer interesses das classes dominadas: estas aparecem como avessas ao moderno e não às hierarquias sociais que as oprimem. Neste contexto, nomes caros ao regionalismo nordestino como os de José Lins do Rego e Gilberto Freyre, defendem o regionalismo tradicionalista, criticando fortemente um regionalismo modernista como o paulista. Suas críticas se davam ao excesso de centralização e falta de busca das tradições deste último.

Albuquerque Jr. identifica uma estratégia freyreana em que, frente a um discurso dominante embranquecedor, enfatizava não só a mestiçagem, mas também a mescla entre culturas. Assim, o autor justifica o porquê de Freyre, como já visto, não focar no ódio do negro escravizado contra o senhor branco: mais do que uma luta de raças e classes, Freyre interessava-se por uma luta de mentalidades e culturas (ALBUQUERQUE JR, 2011:111). Deste modo, para além de defender o Nordeste enquanto berço da cultura brasileira miscigenada, apontava São Paulo como local mais conflituoso nas relações raciais, justamente devido à sua modernidade mercantil. Seria para Freyre, portanto, a sociedade patriarcal a constante do Brasil, a que permitia certo equilíbrio da sociabilidade.

Defender esta constante da família patriarcal leva Freyre, inclusive, a negar a raiz aristocrata paulista. Albuquerque Jr. nota, neste sentido, um embate entre os regionalismos que - para além de opor o nomadismo do bandeirante à sedentariedade do senhor de engenho ou à pobreza de um à riqueza atual de outro - opunha o Nordeste enquanto memória e natureza e São Paulo enquanto história e cultura (ALBUQUERQUE JR, 2011:121).

Fica nítido, deste modo, que Freyre foi essencial ao estabelecer um tipo de regionalismo nordestino com contraposições significativas à paulistanidade. É evidente que o regionalismo nordestino amparado pelas teorias freyreanas não nega a existência e a importância pobre, negra e indígena na formação brasileira. Cabe a pergunta, todavia, de até que ponto isto seria mais inclusivo do que um discurso mais abertamente excludente como o do regionalismo paulista. Creio que seja possível afirmar que as propostas regionalistas freyreanas, apesar de conterem maior inclusão aparente, fomentam uma ideia 
restrita de harmonia que, por caracterizar-se pelo apaziguamento, é mais difícil de ser percebida e combatida frontalmente.

Como já dito, dentro e fora do ambiente acadêmico contesta-se a perspectiva freyreana, uma vez que esta ajuda a endossar e suavizar a desigualdade racial e de gênero no Brasil. Acredito que para além disso, o regionalismo de Freyre tenha perpetuado uma lógica em que - apesar de o Nordeste aparecer como evidentemente miscigenado mantém-se o lugar das hierarquias sociais presentes nesta região. Isto sendo feito com um agravante: como se por serem representados como grupos salientes da região, os oprimidos não tivessem tanto motivo para contestação quanto teriam em locais com discurso mais acirrado.

Enquanto a lógica da paulistanidade foi e é marcada por marginalizar material e discursivamente pessoas não-brancas e pobres, o Nordeste é reconhecido, interna e externamente, como local de convívio, dotado de uma sociabilidade que, por ser tida como pré-capitalista, é romantizada enquanto mais próxima e horizontal. Este reconhecimento do convívio, todavia, não deve ser visto como proximidade da igualdade. Ao contrário: como São Paulo, os estados nordestinos são marcados por desigualdades raciais, econômicas e de gênero o que, contrariando o afirmado por Freyre, nada traz de doce à realidade humana do local.

Se a imaginação paulistanista é capaz de ir longe ao imaginar uma sociedade branca e enriquecida enquanto proposta nacional, o regionalismo nordestino não fica para trás: as elites do Nordeste que fomentaram o regionalismo deste recorte espacial, impossibilitadas por anularem uma composição social tão marcante, foram tão longe quanto ao imaginar uma convivência racial e econômica harmônica. É por tal motivo que é possível ver que há limites aos debates regionais. Acredito que as elites que engendram estes tipos de discurso, atentam-se às composições sociais locais e ao contexto socioeconômico em que se inserem. $\mathrm{O}$ nordestinismo filiou-se à defesa das tradições e do mito pacificador das três raças justamente porque os propósitos embranquecedores serviam à região que na época recebia imigrantes brancos e tinha mais sucesso econômico: o sudeste. Frente a isto, não havia muito que se fazer: restava manipular mitos regionais e seguir mantendo internamente as hierarquias de classe, raça e gênero. 


\section{3 - Classe Artística e Intelectual Nordestina}

É importante seguir adiante na análise das formulações intelectuais e políticas do regionalismo nordestino, uma vez que estas vão além de Freyre. Farei isto atenta às similaridades e diferenças em relação ao debate freyreano e às máximas paulistas apresentadas no capítulo anterior. Albuquerque Jr. realiza, em sua obra, uma pesquisa extensa sobre o assunto. O diferencial do autor concentra-se, especialmente, na afirmação de que não só a narrativa preconceituosa de outros locais insere o Nordeste e o nordestino como ligados ao fracasso, sendo isto também fruto dos discursos regionalistas da própria região.

Também reconhecendo o Nordeste enquanto o Outro ${ }^{67}$ oposto a São Paulo, Albuquerque Jr. defende o deslumbramento urbano do modernismo da década de XX no estado paulista enquanto um movimento que pautava o Nordeste como medieval. Isto teria se dado concomitantemente às produções regionais nordestinas que apontavam em si uma região assolada por calamidades.

O autor conceitua tais discursos nordestinos como um regionalismo de inferioridade, apontando o fato de que a busca da identidade nacional quando posta na ordem do dia, levou à necessidade de distinções regionais. Deste modo, o cangaço, o messianismo e o coronelismo aparecerem como temas definidores do Nordeste diz respeito a uma multiplicidade de interesses capazes de iluminar uns dentre tantos outros aspectos regionais.

Posto isto, Albuquerque $\mathrm{Jr}$ aponta o fato de que a literatura é capaz de reproduzir uma série de estereótipos. A clássica obra Os Sertões, de Euclides da Cunha, seria exemplo da narrativa que apresenta como par de opostos o paulista e o sertanejo, o litoral e o sertão. Sendo este sertão e este sertanejo sempre colocados enquanto exóticos, distantes.

O autor aponta como marco da formação do sertão enquanto ícone de sofrido e pedinte o ano de 1877, com sua seca intensa. Com a Abolição da Escravidão na década seguinte, este período seria reconhecido por muitos, inclusive por Gilberto Freyre, como o início da decadência nordestina frente à ascensão do Sul. Tudo isto contribuiu para um cenário em que nos discursos da impressa e da intelectualidade, debruçados sobre os

\footnotetext{
67 "A instituição sociológica e histórica do Nordeste não é feita apenas por seus intelectuais, não nasce apenas de um discurso sobre si, mas se elabora a partir de um discurso sobre e de seu Outro, o Sul. O Nordeste é uma invenção não apenas nortista, mas, em grande parte, uma invenção do Sul, de seus intelectuais que disputam com os intelectuais nortistas a hegemonia no interior do discurso histórico e sociológico." (ALBUQUERQUE JR, 2011:117).
} 
paradigmas naturalistas, este Norte difuso aparecesse como inferior devido a suas próprias condições naturais e raciais:

A certeza de que o rápido desenvolvimento do Sul, notadamente São Paulo, se explicava por sua superioridade de clima e de raça, por ser um estado de clima temperado e raça branca, levava a que não tivesse dúvidas do destino desta área: 'puxar o trem descarrilhado de uma nação tropical e mestiça' (ALBUQUERQUE JR, 2011:75).

Deste modo, para Albuquerque Jr, o que faz surgir a região chamada Nordeste, fundada na tradição e na saudade, seria a perda de poder das oligarquias nordestinas. $\mathrm{O}$ nome da região teria sido usado incialmente para se referir à área de atuação da Inspetoria Federal de Obras Contra as Secas (IFOCS) em 1919. Assim, na década de 1920 ainda se confunde muito em nível de discurso e reconhecimento o que seria Norte e Nordeste: estas regiões foram aos poucos se consolidando. Em um contexto em que este Nordeste confuso aparecia enquanto pobre e flagelado, acentua-se tanto o medo que leva ao acirramento das fronteiras estaduais quanto a ideia do nordestino enquanto pedinte em relação ao Poder Central (o que, inclusive, era utilizado estrategicamente pelas classes dominantes nordestinas).

Estas disputas regionais fortaleceram um regionalismo literário que no Nordeste encontra expressão nos romances de 1930, sendo que estes, apesar da variedade de estilos dos autores, aparecem majoritariamente enquanto "áridos, secos, pontiagudos, lembram o deserto, o cacto" (ALBUQUERQUE JR, 2011:124). Do mesmo modo, os próprios romancistas de 30 preocuparam-se em definir tipos humanos de sua região: nordestinizam o Nordeste, possuindo como tema a decadência da sociedade patriarcal, "o Nordeste aparece como mundo primitivo, em oposição à degenerescência do mundo civilizado" (ALBUQUERQUE JR, 2011:132).

São exemplos importantes destes romances de 1930 as obras de José Lins do Rego, repercutindo a confusão interna e externa pela perda dos códigos morais tradicionais, de José Américo de Almeida, que expõe a transição entre a ordem patriarcal e burguesa, e de Rachel de Queiroz, trabalhando a imagem do sertanejo e a reação deste frente à modernização. Apesar das diferenças estilísticas e, sobretudo, políticas, dos autores, os romances de 1930 de modo geral expressam a figura do coronel com seu poder que decai frente ao Estado, o cangaceiro como possuinte de um "instinto quase animalesco" (ALBUQUERQUE JR, 2011:143), o beato enquanto fanático de um movimento 
messiânico e os retirantes como eternos aflitos da seca. Tais atributos possuem ainda hoje ligação ao estereótipo nordestino.

Para além dos romances de 1930, Albuquerque Jr. defende que a pintura, a música e a televisão tiveram papel fundamental na formação da maquinaria discursiva que institui o Nordeste enquanto região. Deste modo, aponta as pinturas de Cícero Dias e Lula Cardoso Ayres, com sinhazinhas, mães-pretas e ioiôs, como exemplos da dizibilidade de um espaço de saudade da tradição patriarcal escravocrata.

Esta maquinaria discursiva, especialmente aparatada pelas oligarquias nordestinas, foi direcionada às camadas populares. A música de Luiz Gonzaga, como exemplo disso, aparece enquanto representante da identidade regional frente à migração crescente. Assim, com uma imagem já consagrada do nordestino, especialmente pelos romances de 1930, a produção de Luiz Gonzaga e Humberto Teixeira emerge como novo espaço da saudade, do sotaque e do engendramento de uma identidade. Neste sentido o autor aponta o fato de que tal produção musical se dá em um cenário de busca da música regional e nacional que permite a realimentação da memória, a invenção de tradições e costumes de um Nordeste que "parece sempre estar no passado" (ALBUQUERQUE JR, 2011:182). No que diz respeito a esta dizibilidade do Nordeste, o mesmo pode ser visto em $O$ Auto da Compadecida, de Ariano Suassuna.

Neste regionalismo expresso até agora, os interesses estavam conectados majoritariamente a uma visão conservadora de sociedade, tendo, inclusive, o apoio de figuras importantes no Golpe de 1964, como é o caso de Rachel de Queiroz e Ariano Suassuna. A década de 1930, todavia, inicia concomitantemente um regionalismo fundado na revolta, sem qualquer saudade das tradições da casa grande. Neste sentido, o Nordeste aparece como território do amanhã, do "fazer história" (ALBUQUERQUE JR, 2011:207). Pode-se apontar como exemplos deste movimento as obras de Graciliano Ramos, Jorge Amado, João Cabral de Melo Neto e do Cinema Novo. Albuquerque Jr. chama atenção, todavia, que apesar de propostas políticas diferentes, o recorte espacial nordestino segue sendo tratado sob os temas da fome e miséria, evidenciando que "o Nordeste não existe sem a seca e esta é atributo particular deste espaço. O Nordeste não é verossímil sem coronéis, sem cangaceiros, sem jagunços ou santos. O Nordeste é uma criação imagéticodiscursiva cristalizada" (ALBUQUERQUE JR, 2011:217).

$\mathrm{O}$ autor expõe que, apesar de ter propostas progressistas, muitas das obras que tratam o Nordeste como território de revolta, o colocam como contraponto do Sul, em 
especial São Paulo. Neste caso, o estado paulista apareceria como local dotado de uma modernidade capaz de tirar da alienação os sertanejos nordestinos. Deste modo, mesmo quando valorizados, os tipos sociais nordestinos ainda aparecem, ocasionalmente, como inferiores.

Por esta maquinaria discursiva impregnar até mesmo opostos políticos, Albuquerque Jr. classifica o Nordeste enquanto invenção recente, sendo a "elaboração regional mais sofisticada do país" (ALBUQUERQUE JR, 2011:342). Preocupado com reducionismos e naturalizações, o autor considera tal regionalismo reacionário, fruto da camada dominante que, temerosa frente a sua perda de poder, foi capaz de conclamar uma série de aparatos que fazem com que o Nordeste se reproduza hoje no imaginário de camadas sociais diversas.

A interpretação histórica das expressões regionalistas nordestinas, em especial da primeira metade do século XX, permite o entendimento de que, mesmo quando se trata de enaltecer a região, há a sombra de uma inferioridade. O passado é objeto da narrativa, justamente pela não adequação do presente e da expectativa do futuro em relação aos ideais de progresso. Como já dito, insere-se nestes discursos categorias racializadas e demarcadas economicamente que, em contraposição à maioria das narrativas da paulistanidade, pautam o Nordeste enquanto não-branco e pobre.

Do que foi apreendido, é interessante salientar que muitas vezes a defesa do Nordeste se dá pelo ataque às imagens que geralmente são associadas a este. É possível argumentar que a pobreza e não branquidade enquanto símbolos da região incomodam mais que os ideais preconceituosos de progresso, modernidade, riqueza e embranquecimento. Deste modo, é comum não se atacar padrões restritivos, mas justamente figuras discriminadas e estigmatizadas.

É interessante pensar, neste sentido, em relação ao que Wimmer expôs em sua obra acerca dos imigrantes chineses que viviam em Mississipi, EUA. Parte considerável deste grupo, considerado como não-branco e por isto discriminado, tornou-se através do tempo um grupo étnico mais aceito, o que os levou, em parte, a reproduzirem a segregação racial vigente nos EUA e serem rigorosos em legitimar quem poderia ultrapassar determinadas fronteiras (WIMMER, 2013:30). Como já dito, o mesmo foi identificado por Jeffrey Lesser em A Invenção da Brasilidade, demonstrando o racismo de grupos estrangeiros em São Paulo no início dos anos de 1920. Racismo este que, para além de os afastar dos negros 
brasileiros, permitia a elevação de status e aproximação das normas sociais do país que então viviam.

É possível apreender destes padrões o já conhecido afastamento da negritude e da pobreza na formação de grupos. Percebe-se incômodo, especialmente das elites brancas nordestinas, em serem estereotipadas de uma maneira racializada e economicamente estigmatizada. Incômodo este que se mostra maior do que o incômodo com as discriminações e preconceitos raciais e econômicos em si, uma vez que estes são também perpetuados pelas elites do Nordeste. Disto se apreende a assimetria de poder, bem como a heterogenia interna dos grupos regionais. Como se sabe, há nordestinos de todas as raças e classes sociais. A culpabilização da existência de preconceito é atribuída, contudo, tanto interna quanto externamente, àqueles mais estigmatizados. Os estereótipos se reproduzem com base neles e a culpabilização da existência de tais estereótipos recai sobre os mesmos. E discursos racistas e elitistas servem, deste modo, às hierarquias internas.

\section{4 - O Preconceito Contra as Populações Nordestinas}

A centralização do poder no Sul do país ao longo do século XX gerou a ideia de dois Brasis, como exposto por uma série de estudiosos apresentados na presente dissertação. Esta ideia - capaz de contrapor em níveis representativos um local negro, empobrecido, arcaico e considerado inferior em relação a outro branco, enriquecido, moderno e tido como superior - gerou expressões de preconceito que são agravadas, especialmente, em momentos de acirramento político. Elenquei no primeiro capítulo discursos paulistas de ódio e/ou desprezo aos nordestinos. Por tal motivo, exponho agora estudos variados que tratam do preconceito e da discriminação nordestina, especialmente em São Paulo.

Albuquerque Jr. expõe o estereótipo nordestino na fala de um careca do $\mathrm{ABC}^{68}$ que, na tentativa de explicar seu ódio contra os naturais do Nordeste, afirmou "você já viu um nordestino com 1,80 de altura e inteligente?” (ALBUQUERQUE JR, 2011:29). Neste sentido, é possível ver que a cristalização da imagem regional ressoa nos argumentos regionalistas. $\mathrm{O}$ mesmo pode-se perceber ao analisar a narrativa de Barbara Weinstein que aponta o embaraço de um soldado branco paulista ao encontrar um soldado da Legião

\footnotetext{
${ }^{68}$ Grupo neonazista que possui como lema Deus, Pátria e Família. Tendo surgido no ABC paulista e se espalhado pela capital paulista, hoje possui adeptos em diversas cidades do país.
} 
Negra durante o Conflito de 1932. Este não podia crer que um homem negro não fosse nordestino, não fosse das tropas inimigas (WEINSTEIN, 2015:122).

Tanto a fala do careca do ABC quanto a do soldado de 1932 enfatizam a já mencionada representação dos dois Brasis. Como argumentei, tal representação sugere não apenas a assimetria de poder entre os diferentes grupos, como também uma disputa com continuidades e descontinuidades ideológicas ao longo do tempo. Por tal motivo, torna-se válido investigar como a percepção regionalista paulista engendra historicamente suas formulações: desde Canudos - com uma horda mestiça de fanáticos - de 1932 - com uma população mestiça inapta politicamente e indigna de respeito - a 2010 - com a campanha Mate um Nordestino Afogado ${ }^{69}$ após as eleições presidenciais.

Como já exposto, o preconceito contra os nordestinos é anterior aos grandes deslocamentos migratórios ocorridos no Brasil ao longo do século XX. Guimarães (2002) aponta que já na virada do século XIX para o XX o Nordeste, em especial a Bahia, era considerado um local decadente, racialmente inferior. Do mesmo modo, viu-se como o Conflito de 1932 teve repercussão de ódio contra nordestinos.

Fenômeno também ocorrido na década do IV Centenário de São Paulo. A estudiosa Mariza Romero (2014) expõe que na imprensa paulista dos anos de 1950, em especial através do Diário da Noite, culpabilizava-se o nordestino pela situação de rua encontrada no centro da capital do estado. Com manchetes sensacionalistas - "Milhares de Pedintes Nordestinos na Rua" (ROMERO, 2014:8) - a imprensa acostumou-se a expor o nordestino como falso pedinte, ilegítimo mendicante e malandro violento que não hesitava em usar a peixeira. A ideia que se passava era praticamente a de uma infecção: os nordestinos, como grupo anômico, ameaçavam a dignidade da sociedade paulista.

O documentário de 1993 Tem que Ser Baiano, dirigido por Henri Gervaiseau, mostra o acirramento regional na cidade de São Paulo, ocorrido após a gestão como prefeita de uma nordestina: Luiza Erundina. As pichações que incitavam a violência contra os baianos - neste caso considerados como todos os nordestinos - e a vigência de um discurso popular contra estes, levou o diretor a realizar um documentário que conta com a participação de paulistas incomodados:

\footnotetext{
${ }^{69}$ Como já dito, as palavras foram proferidas pela jovem paulista, Mayara Petruso, e logo gerou grande apoio e revolta nos meios virtuais.
} 
Nós aqui entramos num metrô é só a presença dos nordestinos, debaixo dos viadutos é só a presença deles, em todos os lugares hoje é $90 \%$. Acho que eles tão vindo, tá tudo aqui porque onde você olha tem nordestino, tá infestado mesmo. (Mulher paulista, nome não divulgado).

Tá inchado, não tem condições de suportar maiores correntes migratórias. Hoje até embaixo de ponte serve de moradia, debaixo de ponte! Se a gente percorrer a longínqua periferia vai observar isso. É uma Bangladesh, é uma Etiópia. Enfim, é um lugar muito difícil, a qualidade de vida em São Paulo está muito difícil. São Paulo até para quem tem melhores condições econômicas, que é o meu caso (...) eu tenho que pagar guardas na minha casa porque já fui assaltado duas vezes, quer dizer eu vivo num verdadeiro bunker na minha casa porque os assaltos se sucedem. É sombria a perspectiva. Aqui deveria fazer algo como acontece na Europa. O cidadão para mudar tem que provar que tem contrato, casa para morar, aqui qualquer cidadão pode se movimentar de Seca a Meca, do Oiapoque ao Chuí. Enfim, pode caminhar tranquilamente. Eles embarcam em qualquer canto do Brasil, embarcam num pau de arara qualquer e vem para São Paulo, fica embaixo da ponte, vão pedir esmola, as meninas se prostituem. (Brasil Vita, Vereador de São Paulo em 1993).

Muitas das cadeias na sua totalidade está recheada de irmãos nossos nortistas e nordestinos. Por que isto? Alguma discriminação? Não. Porque hoje eles são maioria em São Paulo. (Afanasio Jazadji, Deputado Estadual de São Paulo em 1993).

Pierucci (1994) ao estudar as disputas eleitorais em São Paulo nas décadas de 1980 e 1990 explicita o fato de que as tendências de ódio aos nordestinos embasavam-se em argumentos que afirmavam a degradação moral de São Paulo causada pela migração, bem como uma degeneração racial e cultural que gerava um sentimento paulista de perda. Caldeira (2000) ao estudar discursos sobre o crime, identificou o mesmo sentimento de perda, sendo que criminosos eram descritos normalmente como nordestinos e pobres.

Esta repulsa e este sentimento são nítidos nos três depoimentos colhidos no documentário Tem que ser Baiano. Pela argumentação encontrada, vê-se uma formulação que postula São Paulo enquanto local de qualidade máxima antes da chegada dos nordestinos. Estes estariam infestando a cidade, prejudicando-a. Tal ofensa possui grande demarcação econômica e racial: são pessoas que vivem embaixo da ponte, lembram o povo de Bangladesh, da Etiópia, se prostituem. A ofensa se concentra, basicamente, em afirmálos como não-brancos, como pobres. 
É curioso pensar como há certa continuidade nos argumentos da paulistanidade em relação a este preconceito. É o que se pode ver na trajetória e ascensão política de Luiz Inácio Lula da Silva. Uma série de atributos é relacionada ao ex-presidente na tentativa de depreciá-lo: era um nordestino de origem pobre que não dominava outros idiomas, envergonhava o país. As vitórias de Dilma Rousseff como presidenta do Brasil, todavia, foram o auge da repercussão deste preconceito. Tanto em 2010 quanto em 2014, uma série de eleitores paulistas atribuiu a responsabilidade da vitória de Dilma ao eleitorado do Nordeste. Integrantes da banda musical Bixiga 70 chegaram a ser fisicamente atacados ao tocarem a música Asa Branca $^{70}$ em um concerto público que ocorreu na capital paulista próximo às eleições, mas que não era partidário. ${ }^{71}$ Os exemplos a seguir, de imagens e frases da época, são parte da mobilização virtual em torno do assunto.

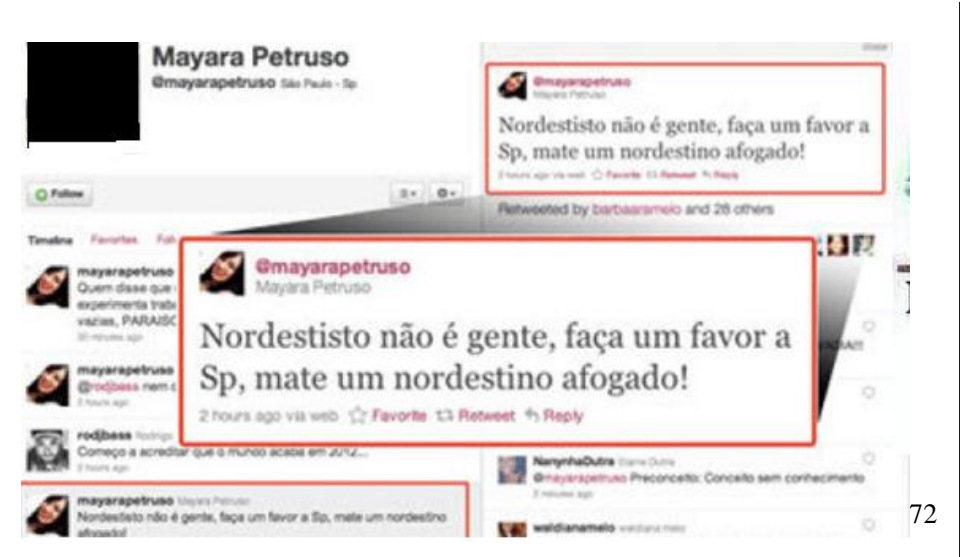

Imagem 1

Frase de Mayara Petruso em vista dos resultados eleitorais de 2010. A estudante foi condenada em 2012 por crime de racismo. "Mate um Nordestino Afogado" foi uma campanha virtual de ampla abrangência entre os dias 03 e $04 / 10 / 2010$.

\footnotetext{
${ }^{70}$ Canção de Humberto Teixeira e Luiz Gonzaga, de 1947, que é ainda considerada um símbolo nordestino.

${ }^{71}$ Carta de esclarecimento do grupo Bixiga 70: SPRESSOSP. Em show, músicos do Bixiga 70 são agredidos por ativistas antipt. Disponível em: < http://spressosp.com.br/2014/11/06/em-show-musicos-bixiga-70-saoagredidos-por-ativistas-anti-pt/> Acesso em: 12/05/2017.

${ }^{72}$ Imagem retirada em: HUFFPOST. Xenofobia não! Você pode denunciar autores de mensagens contra nordestinos. 2014. Disponível em: <http://www.huffpostbrasil.com/2014/10/07/xenofobia-contranordestinos_n_5949284.html> Acesso em: 25/03/2017.
} 


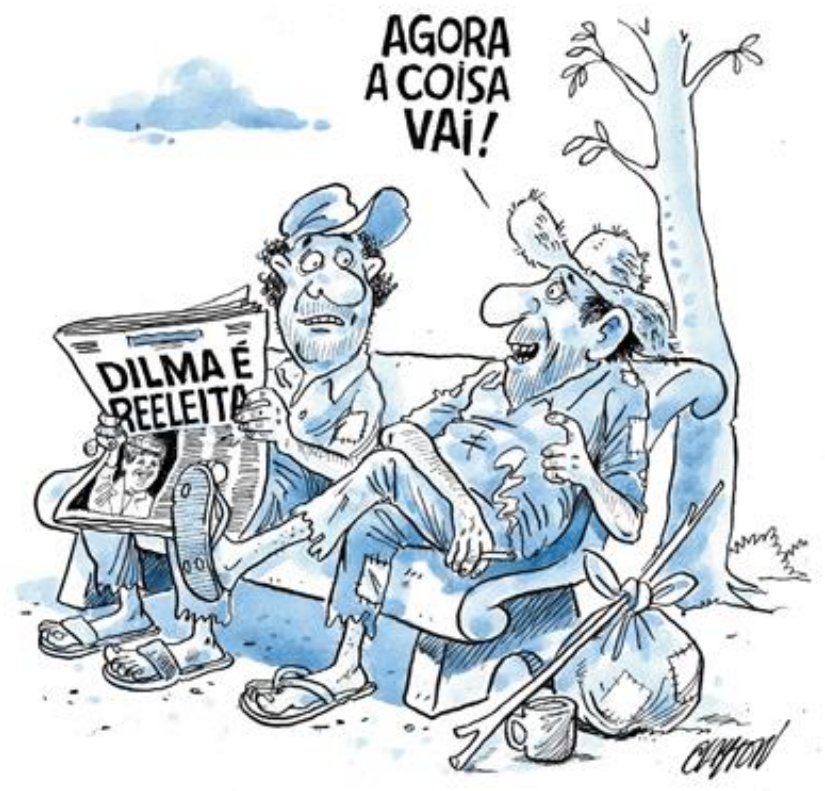

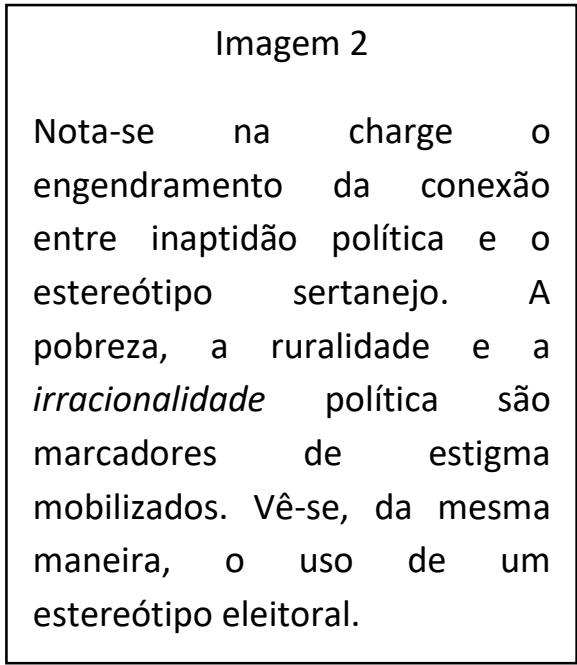

73

Nordeste reelegeu Dilma, povo burro, vagabundo, merece mesmo passar fome e sede. Votar em presidente por causa de bolsa família para ficar em casa vagabundando. ${ }^{74}$

Esses nordestinos pardos, bugres, índios, acham que tem moral, cambada de feios. Não é a toa que não gosto desse tipo de raça. ${ }^{75}$

Desculpem nordestinos, mas essa região do Brasil merecia uma bomba como em Nagasaki, pra nunca mais nascer uma flor sequer por 70 anos. Voto censitário já. ${ }^{76}$

Muro já! ${ }^{77}$

Vagabundo, bandido, bolsa família ... tem em todo lugar. Quanto mais pra cima do mapa, o número vai multiplicando ainda mais. ${ }^{78}$

73 Imagem retirada em: JORNAL DO BESTA FUBANA. Disponível em: < http://www.luizberto.com/coluna/fuleiragem/page/313>. 2014. Acesso em: 12/04/2017.

74 Frase retirada em HUFFPOST. Xenofobia não! Você pode denunciar autores de mensagens contra nordestinos. 2014. Disponível em: <http://www.huffpostbrasil.com/2014/10/07/xenofobia-contranordestinos_n_5949284.html> Acesso em: 25/03/2017.

${ }^{75}$ Frase retirada em: O GLOBO. OAB recebe 90 denúncias em $24 \mathrm{~h}$ por ataques a nordestinos. 2014 Disponível em: <http://g1.globo.com/bahia/noticia/2014/10/oab-recebe-90-denuncias-em-24h-porataques-contra-nordestinos-na-web.html> Acesso em: 25/03/2017

${ }^{76}$ Frase retirada em: CIDADE VERDE. Revoltados, eleitores disparam contra nordestinos no Twitter. 2014. Disponível em: <http://cidadeverde.com/noticias/175263/revoltados-eleitores-disparam-contranordestinos-no-twitter> Acesso em: 25/03/2017.

${ }^{77}$ Frase retirada em: O GLOBO. Ataques nas redes sociais continuam após divulgação dos resultados. 2014. Disponível em: <http://oglobo.globo.com/brasil/ataques-nas-redes-sociais-continuam-apos-divulgacao-dosresultados-14374414> Acesso em: 25/03/2017.

${ }^{78}$ Frase retirada em REDE BRASIL ATUAL. Crescente desde 2010, discurso de ódio contra o PT expõe racismo contra

nordestinos.

2014.

Disponível

em: 
Nordestino adora PT, adora Lula. Eu sou Paulista, filha de europeu. Não consigo viver nesse cabresto. ${ }^{79}$

Nordestinos pretos, dinheiristas, dependente de bolsa. ${ }^{80}$

A campanha - Mate um Nordestino Afogado - iniciada pela estudante de Direito, Mayara Petruso, foi o tópico mais comentado mundialmente na rede social Twitter. A estudante, processada pela OAB-PE, foi condenada por crime de racismo. Todavia, mesmo após sua condenação, manifestações de ódio contra os nordestinos dominam ocasionalmente as redes sociais.

Posto isto, considero que no ano de 2010 tenha havido um diferencial tanto em relação à repercussão gerada pela manifestação preconceituosa quanto na ascensão de tal fenômeno ao status de preconceito. Uma rivalidade não poderia mais ser alegada: o crime - com repercussão internacional, inclusive - fora punido como racismo. Em tal sentido, ocorreu uma disputa que teve como instrumento as redes sociais virtuais. A imagem apresentada na próxima página é exemplo disso.

Nas semanas que seguiram a primeira vitória de Dilma Rousseff na presidência, houve divulgação ampla do primeiro mapa que compõe a imagem. Alegava-se, inclusive, a necessidade de separar o Brasil, uma vez que os estados de um Norte difuso haviam votado majoritariamente na proposta petista. A ideia dos dois Brasis - que permeia tão fortemente o imaginário social - havia ganhado um desenho muito nítido. O segundo mapa, todavia, foi divulgado em resposta a este reducionismo: o vermelho e o azul representando a polarização política não eram totais, havia uma série de nuances.

$<$ http://www.redebrasilatual.com.br/cidadania/2014/10/discursos-de-odio-contra-nordestinos-e-eleitoresdo-pt-se-espalham-na-internet-4303.html> Acesso em: 12/04/2017

${ }^{79}$ Frase retirada em: PAVALOG. Nordestino adora PT, eu sou paulista e não consigo viver neste cabresto. 2013. Disponível em: <http://www.pavablog.com/2013/06/25/princesa-de-cristo-nordestino-adora-pt-soupaulista-filha-de-europeu-nao-consigo-viver-neste-cabresto/> Acesso em: 12/04/2017

${ }^{80}$ Frase retirada em REDE BRASIL ATUAL. Crescente desde 2010, discurso de ódio contra o PT expõe racismo contra nordestinos. 2014.2 Disponível em: $<$ http://www.redebrasilatual.com.br/cidadania/2014/10/discursos-de-odio-contra-nordestinos-e-eleitoresdo-pt-se-espalham-na-internet-4303.html> Acesso em: 12/04/2017. 


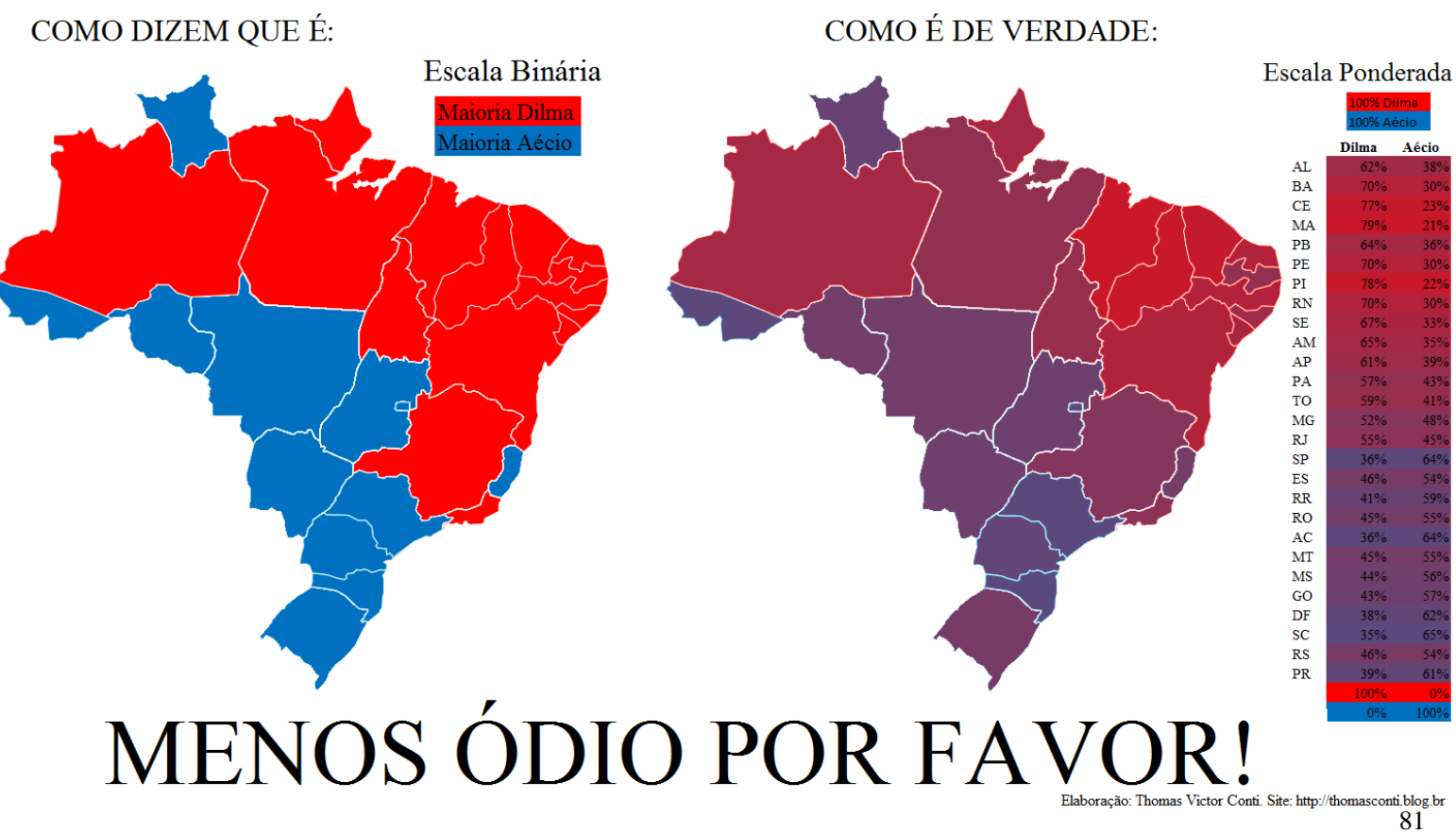

Imagem 3

Os mapas tornam possível observar tanto a distribuição eleitoral brasileira, quanto sua mobilização para uma proposta secessionista, uma vez que a parte em azul da primeira imagem foi largamente veiculada como um necessário novo país. É possível observar com nitidez a narrativa de Dois Brasis, bem como suas históricas adequações a noções de progresso, civilização e urbanização.

Para além do embate gerado nas redes sociais entre narrativas regionalistas, houve uma série de estudos empreendidos de modo a investigar o ódio contra nordestinos nas redes sociais virtuais. O Grupo de Pesquisa em Comportamento Político disponibilizou dados sobre comunidades da rede social Orkut que podem ser vistos a seguir

Tabela 1

\begin{tabular}{l|c|c|c}
\hline \multicolumn{1}{c}{ Nome da comunidade } & $08 / 11 / 10$ & $14 / 11 / 10$ & $23 / 11 / 10$ \\
\hline Não queremos nordestinos em SP & 485 & 501 & 512 \\
Eu odeio nordestino & 444 & 486 & 502 \\
Odeio sotaque/povo nordestino! & 226 & 238 & 240 \\
Nós amamos Mayara Petruso & 82 & 111 & 120 \\
Nós Apoiamos Mayara Petruso & 328 & 373 & 386 \\
Devolvam o Nordeste pra Africa & 599 & 600 & 607 \\
Lugar de nordestino é no nordeste & - & 158 & 170 \\
Odeio vizinho Paraiba/baiano & - & 576 & 580 \\
\hline Total & 2164 & 2843 & 3117 \\
\hline
\end{tabular}

${ }^{81}$ Retirado em: THOMAS V. CONTI. Contra o preconceito! O Resultado Ponderado das Eleições. 2014. Disponível em: <http://thomasvconti.com.br/2014/contra-o-preconceito-o-resultado-ponderado-daseleicoes-por-estado/> Acesso em: 25/03/2017. 
Novamente se vê a ideia que aponta o nordestino como uma infestação em São Paulo. Infestação esta que, nesta lógica, deve ser eliminada. É relevante também a associação do Nordeste ao continente africano tendo em vista a comunidade "Devolvam o Nordeste Para a África." Evidentemente racista, a declaração aponta também para a indicação da África enquanto local subdesenvolvido, inferior. Como defende Barbara Weinstein acerca do orgulho paulista no que tange ao preconceito contra os nordestinos, há nas expressões racistas uma série de mecanismos regionalizantes.

Em Os estereótipos e o efeito do contato virtual no preconceito contra negros e nordestinos, José Batista investiga relações entre o preconceito racial e o preconceito contra os naturais do Nordeste. O autor pesquisou entre cem estudantes de uma universidade nordestina a frequência de adjetivos que os entrevistados julgavam ter relação com os negros e com os nordestinos. O resultado, que pode ser visto a seguir, aponta para a aproximação na estigmatização dos dois grupos.

Tabela 2

\begin{tabular}{|c|c|c|c|}
\hline \multicolumn{4}{|c|}{ Adjetivos para as pessoas negras $(n=50)$} \\
\hline \multicolumn{2}{|l|}{ Positivos } & \multicolumn{2}{|l|}{ Negativos } \\
\hline Trabalhador & 20 & Desonesto & 19 \\
\hline Alegre & 12 & Agressivo & 18 \\
\hline Simpático & 4 & Preguiçoso & 8 \\
\hline Batalhador & 19 & Burro & 16 \\
\hline \multicolumn{4}{|c|}{ Adjetivos para os nordestinos $(\mathrm{n}=50)$} \\
\hline \multicolumn{2}{|c|}{ Positivos } & \multicolumn{2}{|l|}{ Negativos } \\
\hline Generoso & 10 & Burro & 30 \\
\hline Alegre & 12 & Desajeitado & 19 \\
\hline Batalhador & 9 & Acomodado & 9 \\
\hline trabalhador & 20 & Preguiçoso & 11 \\
\hline
\end{tabular}

Batista demonstra ainda que os resultados apontam para um modelo ${ }^{83}$ em que grupos considerados subdesenvolvidos frequentemente são tidos como menos competentes, mas também mais sociáveis. Em consonância com isto, quando o autor pesquisa, em outra universidade pública nordestina, as diferenças entre o que os entrevistados e a sociedade pensam sobre pessoas do sul e nordestinos, vê-se enfaticamente a noção de dois Brasis.

\footnotetext{
${ }^{82}$ Esta tabela e as três próximas foram retiradas da Tese de Doutoramento de José Batista: Os estereótipos e o efeito do contato virtual no preconceito contra negros e nordestinos, (BATISTA, José. 2014:27).

${ }^{83}$ Fiske, S T., Cuddy, A. J. C., Glick, P., Xu, J. (2002). A Model of (Often Mixed) Stereotype Content: Competence and Warmth Respectively Follow From Perceived Status and Competition. Journal of Personality and Social, 82(6), 878-902.
} 
Tabela 3

\begin{tabular}{l|c|c|c|c}
\hline \multirow{2}{*}{ Adjetivos } & \multicolumn{2}{|c|}{ Eu penso } & \multicolumn{2}{c}{ A sociedade pensa } \\
\cline { 2 - 5 } & nordestinos & $\begin{array}{c}\text { pessoas do } \\
\text { sul }\end{array}$ & nordestinos & $\begin{array}{c}\text { pessoas do } \\
\text { sul }\end{array}$ \\
\hline Negativos & 2 & 2 & 29 & 4 \\
\hline Burro & 6 & 6 & 23 & 7 \\
Desajeitado & 6 & 4 & 23 & 6 \\
Acomodado & 2 & 2 & 23 & 3 \\
Preguiçoso & \multicolumn{4}{|c}{} \\
\hline Positivos & 38 & 31 & 16 & 24 \\
\hline Alegre & 22 & 29 & 14 & 23 \\
Trabalhador & 39 & 9 & 12 & 13 \\
Batalhador & 24 & 24 & 11 & 5 \\
Generoso & \multicolumn{4}{|c}{} \\
\hline
\end{tabular}

Esta contraposição que eleva o Sul, notadamente São Paulo, ao rebaixar o Nordeste, também foi pesquisada por Sueli Damergian em Migração e Referenciais Identificatórios. A autora, ao pesquisar o ambiente escolar em um colégio da periferia do ABC paulista, notou forte preconceito contra nordestinos. O que acontecia tanto por parte da instituição de ensino quanto por parte dos alunos paulistas. É o que se pode apreender dos relatos a seguir.

As crianças nordestinas apresentam um rendimento muito fraco. Elas são lentas. São mais fracas que as crianças paulistas. Têm mais problemas em linguagem, mais problemas para conversar. Elas não têm coordenação motora, não sabem nem usar a borracha. Os daqui são normais, a gente nota a diferença. (Profa. M. G., entrevista $\left.n^{\circ} 14\right)$.

A origem influencia em todo o rendimento escolar. As crianças daqui apesar do bairro ser pobre, encontram apoio em casa. As nordestinas não, os pais não sabem ler nem escrever... O problema não é eles serem pobres, porque pobre também tem aqui. $\mathrm{O}$ problema é eles terem vindo do nordeste. (Profa. A., entrevista $n^{\circ}$ $7)$.

O problema é que os paulistas começam a falar como os nordestinos. Então a gente tem que isolar essas crianças para a recuperação, senão não tem jeito. Além disso, têm o problema de casa, de costumes enraizados, não corrigem os pais. O maior problema acaba sendo o ambiente (Profa. D., entrevista $\mathrm{n}^{\circ} 2$ ).

Têm vários problemas ligados ao seu meio, problemas de pobreza, de carência afetiva e têm um temperamento mais agressivo, são geniosos, briguentos, comigo e com os colegas. É o temperamento nordestino mesmo. (Profa. M. G., entrevista $n^{\circ} 14$ ). 
Eunice de Alencar (1985) ao estudar em um colégio de Brasília a atribuição de estereótipos regionais por parte de crianças, também concluiu que o nordestino era considerado, dentre outros grupos regionais, como mais feio e menos inteligente. Vê-se, assim, certa unidade de discurso, uma imagem cristalizada. Novamente ao nordestino, mesmo quando criança, é atribuído o perigo da infestação. Nestes discursos, sua presença prejudica os alunos de São Paulo. Sua inteligência é menor. Sua agressividade atrapalha. Seu futuro não tem salvação: "o problema é eles terem vindo do Nordeste" (DAMERGIAN, 2009:225).

Não é somente no ódio ou na discriminação explícita que se encontra conteúdos de desprezo aos nordestinos. O pesquisador Alan Lobo indica que nas piadas regionalistas há "alusão à ignorância, à esperteza (tirar proveito de alguém ou de alguma situação" em que o nordestino aparece "como um objeto do riso (ignorante, pobre, marginal)" (LOBO, 2012:2). Da mesma maneira, o pesquisador Ricardo Nóbrega afirma que "a modalidade exercida por meio da pilhéria alcança os efeitos de depreciação da identidade e da cultura por meios mais brandos e eufemizados, mais dificilmente perceptíveis e combatíveis e, por isso mesmo, mais facilmente compartilháveis" (NÓBREGA, 2007:2). Deste modo, apreende-se que tais expressões preconceituosas permeiam esferas sociais diversas, podendo se dar de maneira jocosa, agressiva, velada, acirrando-se, sobretudo, em momentos de disputa.

Posto isto, pode-se identificar, certa constante em relação à discriminação e preconceito sofridos pelos nordestinos. Argumentos que se baseiam na degeneração moral e racial, apesar das mudanças contextuais, continuam sendo mobilizados. Do final do século XIX às primeiras décadas do século XXI, o nordestino é representado pejorativamente como não-branco (como se isto fosse um defeito), anômico e perigoso para a sociedade paulista: ora esquentado, ora lesado; ora competidor na disputa por empregos, ora preguiçoso; ora engraçado, ora repulsivo.

Ofensas sobre as atribuídas (falta de) beleza, incapacidade intectual, inaptidão política e mendicância podem ser encontradas tanto nas reações aos eventos de Canudos e 1932 quanto nos contextos da década de 1990 - com uma prefeita nordestina em São Paulo - e 2010 - com uma presidenta eleita por votos majoritariamente nordestinos. Disto apreende-se a continuidade ideológica da paulistanidade excludente que se expressa, através do tempo, na afirmação de sua pretensa superioridade racial, econômica, moral, geográfica, política e humana. 


\section{5 - O Nordeste enquanto Bahia; o Nordestino como Baiano}

Durante as três últimas décadas, uma série de estudos, especialmente etnográficos, foram realizados com o objetivo de pesquisar a presença de migrantes nordestinos no Sudeste do Brasil (a título de exemplo; Morales, 1993; Caldeira, 2001; Rigamonte, 2001; Rezende, 2001; Fontes, 2008). Nestes trabalhos, aponta-se o fato de que em São Paulo baiano significa nordestino pejorativamente, enquanto no Rio de Janeiro é paraíba que possui tal sentido. Nóbrega (2010) considera estas categorizações reducionistas como uma das primeiras formas de discriminação que os migrantes nordestinos enfrentam no Sudeste.

Manoel Correia de Andrade em prefácio da obra Nordeste, aponta que baiano é reconhecido vulgarmente no estado paulista como todo migrante vindo da porção setentrional do país, sendo que os mineiros seriam chamados ocasionalmente de baianos cansados por não terem conseguido chegar até São Paulo (ANDRADE, 2010:13). Gilberto Freyre, por outro lado, afirmava que baiano chegou a ser equivalente de francês: "excessivamente flexuosos e até falsos, homens sem palavra" (FREYRE, 2010:52), bem como a Bahia - com seu grande poderio no século XVIII - teria seus homens reconhecidos como "excessivamente civilizados: quase efeminados" (FREYRE, 1936:369).

Vê-se, assim, uma mudança em torno do termo que se deu ao longo de diferentes períodos. De excessivamente civilizado a "imigrante pobre, ignorante, servil, preguiçoso, beócio, sem espírito empreendedor" (GUIMARÃES, 2002:125) e ainda ridicularizado como ocupante de profissões de baixo prestígio: um tipo considerado pouco civilizado, feio e de mau gosto (NÓBREGA, 2007:3-4). Apesar destas mudanças, Guimarães aponta que "baiano enquanto metonímia de gente do Norte, ou Nordeste, como passou a ser conhecida a região a partir dos 60 do século XX, era já uma criação do século XVIII" (GUIMARÃES, 2002:126).

$\mathrm{O}$ autor demonstra ainda que a perda de reconhecimento em torno da civilidade ocorreu na Bahia na virada para o século XX. A Bahia seria, então, o local em que predominava o catolicismo barroco em contraposição à modernidade, era tida como um "velho caldeirão racial parado no tempo, a receber o influxo demográfico dos negros" em um país que aspirava ao embranquecimento (GUIMARÃES, 2002:131). Caldeirão racial este expresso por termos como mulato pachola que, como aponta Thales de Azevedo, era designado para se referir pejorativamente a intelectuais baianos como preguiçosos, vaidosos e exibicionistas (AZEVEDO, 1996:58). 
Foi somente com buscas tradicionalistas como as de Gilberto Freyre ou até mesmo modernistas - objetivando encontrar as raízes nacionais - que a Bahia retornou ao cenário intelectual como uma fonte de referência, em especial a partir de 1930. A então ideia de berço do Brasil e Terra Boa, no entanto, já não possuía conexão ao estereótipo excessivamente civilizado do século XVIII. O que havia era a "imagem do pré-industrial e do pré-moderno em termos de costumes e de tempo: a malemolência, o atraso, a preguiça, a lentidão" (GUIMARÃES, 2002:132). A mudança foi tão brusca que no Dicionário Houaiss os significados de "tolo, negro, mulato, ignorante e fanfarrão" (MARQUES, 2004:85) eram atribuídos a um conceito racista de baiano.

Sobre este estereótipo ainda frequente, Elisete Zanlorenzi disserta em $O$ Mito da Preguiça Baiana. A autora demonstra que tal mito tem conexão com o racismo, tendo sido engendrado pelas elites baianas. A Ladeira da Preguiça, localizada no centro de Salvador, seria um recorte espacial capaz de expor esta ideia: "nos tempos da escravidão, e também depois dela, quem reclamava da íngreme travessia, carregando nas costas as mercadorias desembarcadas no porto, eram os negros - 'preguiçosos' na visão desdenhosa dos brancos que, das janelas de seus sobrados, gritavam: 'Sobe, preguiça!’” (MARQUES, 2004:85).

Zanlorenzi buscou desmistificar o baiano enquanto preguiçoso através de uma série de dados que comparavam as horas de trabalho e faltas ao serviço em regiões diferentes, comprovando, assim, que - mesmo em uma lógica capitalista - o baiano não teria motivo para ser considerado como avesso ao trabalho. Para a antropóloga, mais uma prova de que o mito possui relações com o racismo seria o fato de o candomblé - religião de grande parte dos moradores do estado - ser estigmatizado e mal entendido no que diz respeito a sua ideia de tempo, uma vez que, segundo suas premissas religiosas, trabalho e lazer não seriam categorias necessariamente contrapostas.

Posto isto, torna-se importante diferenciar a preguiça e malemolência de que falam certos ícones baianos - como Gilberto Gil, Jorge Amado e Dorival Caymmi ${ }^{84}$ - da preguiça acusatória dita no sudeste ou pelas elites baianas em sua própria região. Zanlorenzi aponta que a preguiça de Gil e Caymmi, por exemplo, seria a recusa ao mundo urbano e não a repulsa ao trabalho. Tal formulação em torno da ideia de preguiça contrapõe-se aos ideais empreendedores e pragmáticos da paulistanidade: mais que um embate em torno do

\footnotetext{
${ }^{84}$ Sobre eles, Albuquerque Jr. aponta que "a obra de Amado, como a de Caymmi instituirão o ser baiano, pensarão a baianidade, a identidade baiana e da sua cultura como algo à parte no Brasil" (ALBUQUERQUE $J R, 2011: 246)$.
} 
trabalho ou não-trabalho, parece ser, de fato, um confronto sobre como encarar o mundo, como portar-se política, econômica e culturalmente.

É em tal sentido que se torna importante entender os motivos de a Bahia ser disputada em termos simbólicos. Antônio Risério (1993) defende a existência de um mito baiano. Do mesmo modo, a Bahia está conectada à ideia de ancestralidade enquanto primogênita do Brasil (NOVA \& MIGUEZ, 2008:3). Os pesquisadores Nova e Miguez expõem que tanto acadêmica quanto coloquialmente se confunde a ideia de Salvador e Bahia; fala-se do estado querendo se falar da cidade e vice-versa. Da mesma maneira, os autores expõem que conceber estes locais enquanto ancestrais, se expressa em um mito que mescla tempos áureos e decadentes. Mito este também observado por Pinho (1998) que, ao classificar a Bahia como uma comunidade imaginada, a aponta como um discurso articulado sobre a mestiçagem.

É levando em consideração tais ambivalências que Miguez e Nova pesquisam a tentativa da classe política baiana de, nas últimas décadas, se fazer ser reconhecida como apta a um padrão capitalista avesso à preguiça. Neste processo, a baianidade foca em festas do estado, em especial o carnaval, ora aproveitando-se da preguiça, sendo esta contagiante - "suas férias terão preguiça de acabar" (DANTAS, 2013:117) - ora utilizando-se de estatísticas que comprovam a aptidão dos baianos em termos capitalistas, isto sendo feito através da mercantilização de uma “cidade feliz” (NOVA \& MIGUEZ, 2008:14).

É tomando como base o ideal em torno do local da felicidade que diversos autores (Zanlorenzi, 1998; Dantas; 2013, Nova \& Miguez, 2008; Albuquerque Jr, 2011; Diniz, 2009) identificam o papel da imprensa como engendradora do estereótipo baiano. Diniz (2011) expõe que a ideia da baianidade veiculada em termos de mestiçagem levou - no contexto em que impera a ideia mítica de democracia racial - ao estereótipo ofensivo da mulata baiana de sexualidade lasciva; do negro baiano como bem dotado sexualmente; de uma docilidade e alegria passivas, bem como de uma musicalidade intrínseca (DINIZ, 2011:9). Do mesmo modo, Dantas (2013) expõe uma propaganda turística que, focada nestes atributos racistas, é capaz de inserir a Bahia como um dos destinos mundiais mais buscados no que concerne à prostituição, inclusive infantil.

Posto isto, é possível enxergar uma série de ambivalências no movimento que foi de tachar os baianos como pessoas de características excessivamente civilizadas até à ridicularização nordestina desde o fim do século XIX, em especial destinada aos imigrantes da região. É válido salientar novamente a interseccionalidade presente neste 
fenômeno: marcadores como os de raça, gênero e classe em muito influenciam nestas atribuições. Como diz Nóbrega (2007), este preconceito não atinge indistintamente todos os migrantes ou nordestinos, uma vez que pertencer a uma classe social mais elevada pode amenizar a discriminação, apesar de não eliminá-la. Imerso neste dado estaria o fato de que nordestinos ricos seriam associados com frequência à figura de um coronel arcaico, de valores culturais atrasados. $\mathrm{O}$ autor atenta ao fato de que apesar de nordestinos abastados não serem associados à imagem de migrantes pobres estigmatizados nos termos paraíba e baiano, estes ainda assim seriam conectados ao ideal de incivilidade.

$\mathrm{O}$ mesmo pode ser visto no que concerne às questões de raça e gênero. $\mathrm{O}$ estereótipo desrespeitoso em torno da mulata baiana é um exemplo disto. Do mesmo modo, Guimarães demonstra que categorizar enquanto baiano ou paraíba os imigrantes nordestinos teve relação com os tipos sociais que vieram em maioria para o sudeste: "era o tipo de gente que o brasileiro do sul não gostaria que fosse brasileiro: mestiço, imigrante, pobre" (GUIMARÃES, 2002:133). Assim, do termo baiano, o sociólogo apreende o preconceito contra o que era considerado antigo, incivilizado, ultrapassado.

Posto isto, verifica-se que ao mesmo tempo que baiano pode ser qualquer um vindo do Nordeste, não se trata de qualquer um. Defendo que há neste estereótipo uma demarcação sócio-racial. Demarcação esta permeada de ambivalências que vão além da contradição primeira em reduzir nove estados a uma única categoria estadual. Tais ambiguidades, todavia, são certeiras no que diz respeito ao tipo social atacado. É o que pode ser visto ao reformular-se a frase do careca do $\mathrm{ABC}$ que, nesta dissertação, já foi mencionada - "você já viu um nordestino com 1,80 de altura e inteligente?": você já viu um branco, alto e tido como culto ser tratado pejorativamente como baiano? Você já viu paulista ser utilizado como qualidade racial e cultural negativa? Novamente a assimetria de poder - entre classes, raças e regiões - é sintomática.

\section{6 - Cangaceiros e Fanáticos: o Contraponto do Bandeirante}

“Os alunos são esquentados e respondem mal, brigam, são valentões, tipo Lampião" (DAMERGIAN, 2009:258). Foi com esta frase que uma professora, entrevistada por Sueli Damergian, explicou o porquê de considerar os alunos nordestinos inferiores em relação aos paulistas. Do mesmo modo, quando questionados sobre o porquê de não quererem nordestinos em São Paulo, grupos do Manifesto São Paulo Para Os Paulistas 
responderam ${ }^{85}$ que a cultura nordestina era violenta, tendo como símbolo o cangaceiro Lampião. ${ }^{86}$

Em contrapartida, o cangaço figura em outros meios como símbolo de resistência. Exemplos no cenário musical vão desde a banda Nação Zumbi defendendo um "banditismo por uma questão de classe" ${ }^{87}$ até a banda El Efecto que, ao tematizar sobre um encontro temporalmente impossível entre Lampião e o empresário Eike Batista, descreve o milionário sendo expulso por um Lampião enfurecido com a especulação de suas terras: "hay que, Eike, hay que resistir!" 88

Posto isto, é nítido que a concepção acerca do cangaço varia de um extremo ao outro do espectro político. Como já dito na presente dissertação, Albuquerque Jr. aponta que a esquerda por diversas vezes institui o Nordeste como território de revolta, sendo símbolo máximo destas revoltas o cangaço e os movimentos messiânicos. Da mesma maneira, discursos conservadores utilizam estes símbolos para expressar o que consideram primitivo no nordestino: as atribuídas violência, irracionalidade e barbárie. Neste sentido, uma série de autores (a título de exemplo, Weinstein, 2015; Romero, 2014; Lopes, 2009) apontaram que a figura do cangaceiro foi mobilizada em discursos da paulistanidade, em especial na imprensa, para deslegitimar o nordestino, apontando-o como um saqueador anômico tal qual seria, nesta lógica, Lampião.

Deste modo, em um pensamento conservador, restaria aos naturais do Nordeste dois estereótipos: ou o de fanático ou o de cangaceiro. Albuquerque Jr. aponta que ambos os estereótipos se pautam na imputada irracionalidade nordestina, vigorando até hoje em diversas representações - estas exemplificadas, em especial, pelas telenovelas. Estabelecida na primeira metade do século XX a concepção do meio como definidor social, uma série de explicações apontava para o Nordeste como território por excelência do fanatismo ou cangacismo. $\mathrm{O}$ fanatismo sendo representado pelo beatismo através das ideias de que em Canudos dominava uma horda de religiosos alienados, de que no Nordeste todos são fervorosos devotos e de que procissões irracionais são cotidiano de todos os habitantes da região. Enquanto o cangaço seria representado pela ideia de todo nordestino como saqueador, irritado, destemperado, anômico, ladrão. É interessante,

\footnotetext{
${ }^{85} \mathrm{O}$ que pode ser visto no Manifesto em questão.

${ }^{86} \mathrm{O}$ que possui estreita relação com o fato, analisado por Albuquerque Jr, de que havia em São Paulo especialmente durante o tempo da Abolicação - um receio sobre um negro mau vindo do Nordeste, um violento (ALBUQUERQUE JR, 2011:74).

${ }^{87}$ Composição de Chico Science e Nação Zumbi.

${ }^{88} \mathrm{O}$ encontro de Lampião com Eike Batista, El Efecto.
} 
pontuar, neste sentido a restrição que há na ilegitimidade atribuída a determinadas expressões culturais e religiosas.

Josué Castro disserta sobre o cangaço e o messianismo em Geografia da Fome, defendendo que a fome afetaria não somente o corpo, mas também o espírito, a estrutura mental e intelectual dos sertanejos nordestinos. Para o autor, o tipo predominante no sertão seria o de "esquizotímico, com sua curva de temperamento instável" com "cangaceiros sanguinários e beatos fanáticos" (CASTRO, 2001:231). Estes problemas mentais seriam causados pela fome. Castro é firme em apontar a "férrea honestidade" do sertanejo nordestino em condições normais, afirmando, porém, que as eras de calamidades são capazes de gerar bandidos e santos, sendo que a periodização destes fenômenos naturais cristalizou certos tipos humanos (CASTRO, 2001:232). Também endossou tal relação entre as secas periódicas e os tipos sociais, o estudioso Roger Bastide.

Rui Facó (1976) - também acreditando que os cangaceiros proliferavam em tempos de seca - aponta os movimentos messiânicos e o cangaço como a tomada de consciência da classe explorada contra a classe dominante. Para o pesquisador, havia um discurso majoritário que tentava expor a irracionalidade destes movimentos, mas que, do contrário, estes seriam contestadores conscientes da ordem social. Deste modo, para além do meio como definidor humano, o que estaria em questão para Facó seria a luta de classes; esta sim geraria estes tipos sociais.

Torna-se nítida, assim, uma disputa em torno dos símbolos do cangaceiro e do fanático. Violento, repulsivo e irracional para uns; resistente, assolado pela miséria e racionalmente batalhador para outros. Como visto no subtópico do capítulo anterior, Sangue Bandeirante; Raça de Gigantes, há similar disputa política em torno da figura mítica do bandeirante. Herói, desbravador e forte para uns; genocida, explorador e sanguinário para outros.

Tal relação me leva a defender que estes regionalismos se mobilizam de maneiras políticas distintas. O estoque simbólico nordestino permeado de Lampiões, sertanejos e beatos - nitidamente situado no polo mais vulnerável de uma relação de poder assimétrica é conectado de maneira mais valorosa a um discurso das classes populares, bem como da esquerda, ${ }^{89}$ sendo considerado repulsivo no discurso político direitista. O estoque simbólico paulista, em contrapartida, permeado por bandeirantes, civilizadores, brancos e

\footnotetext{
${ }^{89}$ Por mais que diversas vezes este movimento se dê expressando o Sul como vanguarda que guiará a região atrasada que é considerada o Nordeste, como exposto por Albuquerque Jr (2011).
} 
ricos, heróis de 1932, conecta-se nestes termos a um discurso conservador e especialmente oligárquico, enquanto é criticado por um discurso progressista.

Posto isto, defendo que cangaceiros e fanáticos aparecem como contraponto à ideia do bandeirante. Novamente entra em questão a noção dos dois Brasis. O cangaço e o fanatismo se inserem na esfera do que é considerado pré-moderno, do emocional, da fome. O bandeirante se insere na esfera do que é tido como racional, do sucesso: foram eles que permitiram, na lógica paulistanista, a ascensão de São Paulo à modernidade. Ambas as simbologias são interpretadas e mobilizadas diferentemente de acordo com o propósito político. De tudo isto fica claro que ambas deixam nítida a ideia de civilização $x$ incivilidade que, como de praxe, relega o conceito arbitrário de atraso ao lado nordestino.

\section{7 - A Racialização Nordestina}

Busquei expor no presente capítulo que o regionalismo nordestino é pautado, interna e externamente, de maneira racializada. Seus principais nomes falavam de uma região mestiça. Do mesmo modo, empenhei-me em demonstrar tanto que o preconceito e discriminação contra as populações nordestinas mobiliza argumentos de cunho racial quanto que baiano enquanto ofensa se designa a um determinado tipo social: quando se fala baianada não se pensa em brancos e ricos, isto é uma certeza.

Da mesma maneira, cangaceiros e fanáticos, enquanto símbolo de uma região, não possuem nenhuma brancura: são Lampiões, Conselheiros e devotos de Padre Cícero. Todos estes atributos que expõem um nível de representação do nordestino enquanto nãobranco, me levam a defender que há um processo contínuo de racialização dos grupos humanos do Nordeste brasileiro; processo este que acompanha o estrutural racismo do país.

Posto isto, empenho-me em destrinchar os diferentes contextos que explicitam tal racialização. Lilia Schwarcz em Nem preto nem branco, muito pelo contrário, expõe que a raça teve importância central para se pensar o Brasil que, desde seu início enquanto colônia, já era pensado enquanto outro exótico. Uma vez que a ideia de raça data do século XVI e as ideias do determinismo racial começam a ganhar coro em meados do século XVIII, torna-se importante pensar como o Nordeste foi racializado nestes termos e períodos.

Nina Rodrigues, pesquisador maranhense ativo na Escola Baiana de Medicina, é um dos nomes mais mobilizados para se pensar no darwinismo social. O estudioso 
advogava pela ideia de que a miscigenação levaria, sem quaisquer dúvidas, à degeneração social e que nem todos os grupos raciais, mesmo quando separados, poderiam chegar ao mesmo estágio de progresso. Assim, diferentemente de Tobias Barreto e Sílvio Romero que eram filiados ao racismo científico pela crença de que cada raça, separadamente, poderia alcançar sua perfectibilidade - Nina Rodrigues via na mestiçagem o fracasso inevitável (SCHWARCZ, 2012:21). Gilberto Freyre em Nordeste, aponta que estes três estudiosos, bem como Morais Barros, A. Carneiro Leão, José Veríssimo e Oliveira Vianna, acreditavam na "inferioridade do mestiço brasileiro" (FREYRE, 2010:175).

Neste sentido, é válido salientar que Oliveira Vianna figura como nome importante na ofensa do nordestino como exemplo da degeneração racial. Albuquerque Jr. expõe que tanto Oliveira Vianna quanto Dionísio Cerqueira atribuíam a superioridade de São Paulo a sua maior eugenia, sendo que ambos ficaram encantados com os migrantes brancos europeus no estado paulista (ALBUQUERQUE JR, 2011:56). Deste modo, a pretensa superioridade de São Paulo era tida como natural, biológica.

Neste contexto, a ideia da criminalidade mestiça vigorou fortemente. Nina Rodrigues defendia que os crimes eram involuntários para certas raças: determinados grupos estavam fadados a ser criminosos. É em tal sentido que é possível entender certas atribuições do nordestino - enquanto mestiço - a um criminoso nato. Atribuições estas que permeavam as reportagens sensacionalistas nos anos de 1950 e que ainda vicejavam no fim do século XX - como exposto por Pierucci (1994) e Caldeira (2000) - e início do XXI, tendo em vista a culpabilização atual dos nordestinos pelos índices de violência no estado paulista. $^{90}$

Freyre, como já exposto, contrapunha-se à ideia de mestiçagem como fracasso, uma vez que sua defesa de uma harmonia irreal entre grupos humanos guiava-se justamente pelo ideal de convívio e junção humana que, ainda assim, manteria hierarquias nítidas. Em vista disto, o autor chega a afirmar que os pensadores que defendiam tal ideia desconsideravam "os elementos sociais de inferiorização de uma classe ou de um proletariado que, pela persistência dos efeitos da escravidão, é, na sua quase totalidade, de gente de cor” (FREYRE, 2010:175). Posicionando-se contrariamente à inferioridade biológica mestiça, Freyre buscava outras explicações para a então decadência que era atribuída ao cabra. É válido salientar que este argumento evidencia como o ideal restrito de

\footnotetext{
90 Salienta-se novamente a culpabilização neste sentido que é apreendida na análise do Manifesto São Paulo Para Paulistas de 2010.
} 
inferioridade vinculou-se ao determinismo social e econômico quando de seu desvencilhamento à proposta estritamente racial.

O mesmo pode se dizer sobre Josué de Castro. O autor - também distinguindo o Nordeste em uma área açucareira e outra sertaneja - defende que qualquer desvio destas populações teria relação com os desequilíbrios pelos quais passaram seus meios, em especial devido à colonização. Nota-se, portanto, um determinismo espacial que perpassa pela temática da condição social. No que diz respeito ao Nordeste açucareiro, Castro afirma que apesar da resistência dos índios, negros e brancos pobres, o latifúndio venceu com consequências catastróficas. Com estas consequências catastróficas que se explicaria a suposta inaptidão ao trabalho que caracteriza, nesta lógica, o habitante da região:

\footnotetext{
Desta alimentação precária, resultam graves consequências para as populações nordestinas (...) As primeiras manifestações diretas da deficiência alimentar são as que resultam de sua insuficiência calórica, de sua pobreza energética. Por sua conta decorre, em grande parte, a reduzida capacidade de trabalho dessa gente que se cansa ao menor esforço, que não é capaz de acompanhar o ritmo do trabalhador das regiões de melhor alimentação do sul do país. Ou mesmo dos habitantes da zona do sertão. O sertanejo sempre se sentiu superior ao brejeiro, tachando-o de preguiçoso, pela pequena capacidade de trabalho que ele demonstra (CASTRO, 2001:127).
}

Denunciando Freyre no que diz respeito à má alimentação que o escravo recebia considerada abundante na perspectiva freyreana de uma doçura inexistente - Castro atribui que não havia um mal de raça no Nordeste açucareiro, mas sim um mal de fome (CASTRO, 2001:129). Assim, expõe a assimetria de poder da região, demonstrando que tabus alimentares, que faziam com que os mais pobres não consumissem certas frutas, por exemplo, teriam sido criados pelas oligarquias proprietárias e brancas na defesa de seus bens.

Castro ainda defende a população do Nordeste açucareiro no que diz respeito à fama de seu mau gênio - de "olhos vermelhos e injetados" - argumentando que seriam as deficiências nutritivas que causariam seu descontrole e irritabilidade (CASTRO, 2001:143). Assim, o autor considera a contribuição deste grupo humano quase nula para o país em geral, porém assinala que isto só se dá por sua alimentação ser deficiente.

Em relação ao Nordeste sertanejo, Castro considera a alimentação do local uma das mais fortes e racionais do país (CASTRO, 2001:158). O problema que acometeria o tipo social que lá habita seria, então, os surtos epidêmicos de fome causados pelas secas 
esporádicas. $\mathrm{O}$ autor chega a comparar a população sertaneja e a árabe, considerando que ambos os grupos teriam semelhanças por suas características de semi-nômades em locais desérticos (CASTRO, 2001:174). ${ }^{91}$

Assim, pautando o sertanejo nordestino enquanto forte, um ser ativo, Castro defende que apenas nas extraordinárias situações de fome intensa causada pela seca que este teria o organismo e a mente deteriorados. Por serem cíclicas, tais situações o animalizariam, o tornariam cangaceiro ou fanático. Castro defende enfaticamente que a luta que se deve travar frente a esta situação não seria contra a seca, o clima, mas sim contra o arcabouço social que permite a exploração e proletarização abusiva. $\mathrm{O}$ autor conclui, enfim que, em seu tempo, o Nordeste finaliza sua tentativa de estender a mão lamuriosa para o Sul, buscando, assim, mudanças econômicas e políticas concretas (CASTRO, 2001:246).

Vê-se nas afirmações de Castro e Freyre - apesar destas serem divergentes em diversos sentidos - a tentativa de colocar em aspectos sociais, ao invés de raciais, o que seria considerado a decadência mestiça e, logo, nordestina. Esta tentativa é capaz de evidenciar que, apesar do desvio no foco de análise, tais populações eram ainda concebidas como inferiores. Do mesmo modo, Euclides da Cunha, muito antes de ambos os autores, oscilava em ser contrário ou favorável à mestiçagem, ora desprezando-a, ora aceitando-a e, por fim, tachando o sertanejo de forte, afirmando que no Brasil estaríamos "condenados ao progresso" (CUNHA, 1973).

Neste contexto mostrado - de fins do século XIX até a primeira metade do século $\mathrm{XX}$ - os embates se davam, portanto, com a preocupação acerca do futuro da nação: havia os que, como Nina Rodrigues e Oliveira Vianna, consideravam que a miscigenação comprometeria tal futuro e outros, como Freyre e Castro, que apostavam nesta mestiçagem, apontando que os problemas brasileiros seriam de cunho social, não biológico. Os que tomaram o primeiro rumo, como João Batista Lacerda e Roquete Pinto, apostavam em uma eugenia indiscreta que levaria com o passar dos tempos à aniquilação do mestiço, negro e indígena da sociedade brasileira. Alguns, como Renato Khel, chegaram a advogar pela esterilização de tais populações.

Schwarcz demonstra que a década de 1930 foi de importância vital neste embate: por fim a mestiçagem alçava seu status de símbolo nacional, passava a ser vista, em termos

\footnotetext{
91 "O cearense, exemplar típico de nômade brasileiro, sempre cheio de fé e de iniciativa, de energia e de inquietação criadora, é, como o árabe, o saariano, enfim, como todo habitante do deserto tropica, um hipermetabólico, um gastador de energia." (CASTRO, 2001:186).
} 
de discurso, como sorte ${ }^{92}$ (SCHWARCZ, 2012:28). Neste contexto, o racismo foi relegado à esfera da intimidade: apesar do reconhecimento de que há racismo, este jamais é admitido pelos indivíduos brancos. A mítica democracia racial tomara como símbolo uma nação mestiça, mas que, veladamente, valoriza a branquidade, discriminando o não-branco: "quanto mais branco melhor, quanto mais claro mais superior, eis uma máxima difundida, que vê no branco não só uma cor mas também uma qualidade social” (SCHWARCZ, 2012:44).

É neste contexto que institui o mestiço como ícone nacional que a autora aponta para uma série de esforços privados, oligárquicos, em constituir a ideia de povo tal qual uma nacionalidade imaginada (SCHWARCZ, 2012:48). Assim, uma comida afrodescendente como a feijoada torna-se prato nacional, a capoeira antes reprimida, é oficializada, o samba passa a ser música brasileira, Nossa Senhora da Aparecida é escolhida como padroeira e a mulata como ícone da nação. É neste mesmo sentido e contexto que a autora aponta a ascensão do bandeirante que de mero aventureiro, caçador de indígena, foi a heróico símbolo de São Paulo. No que concerne à questão da categoria atribuída de mulata, uma série de autoras feministas indica que nesta categorização está a perpetuação da hipersexualização dessas mulheres, como se estas fossem prova de uma convivência harmônica irreal.

Posto isto, vê-se que tal movimento foi capaz de romantizar a escravidão, sendo Gilberto Freyre grande exemplo disso ao destacar a intimidade do lar, omitindo a vida dura do escravo no campo; romantizando relações violentas, inclusive de abuso sexual e, por fim, contrapondo a escravidão brasileira - de "bons proprietários e escravos dadivosos" - à norte-americana (a primeira aparecendo como melhor, quase como um mal necessário) (SCHWARCZ, 2012:51).

Nesta nacionalização da mestiçagem, o que abria discurso para o preconceito, como demonstra Schwarcz, passou a ser a diferença cultural, não mais a biológica. Neste sentido, os estudos de Costa Pinto no Rio de Janeiro e de Roger Bastide e Florestan Fernandes em São Paulo, foram essenciais para desmascarar as falácias do mito da democracia racial (SCHWARCZ, 2012:69). Em contrapartida, apesar de tais estudos apontarem para distinções regionais em torno da questão racial - mostrando maior quantidade de negros no

\footnotetext{
92 "O mestiço transformou-se em ícone nacional, em um símbolo de nossa identidade cruzada no sangue, sincrética na cultura, isto é, no samba, na capoeira, no candomblé, na comida e no futebol." (SCHWARCZ,2012:28).
} 
Norte e no Nordeste - circunscreveu-se a ideia de racismo como conectada estritamente à classe.

Schwarcz aponta que não seria mera coincidência o fato de a maior concentração de não-brancos estar nas regiões de economia menos desenvolvida do país, bem como o fato de que a endogamia entre raças aumenta quanto mais ao Sul do Brasil se vai. Do mesmo modo, a autora - expondo a marcada assimetria que há entre negros e brancos no acesso ao ensino, à saúde, à moradia e ao emprego - aponta para a negociação brasileira que há em torno da cor: nestes termos, condição social seria capaz de escurecer ou clarear alguém. É esta indefinição em relação à raça que levou que, no Censo de 1976, 136 cores diferentes fossem ditas pelos entrevistados em resposta à pergunta "qual a sua cor?".

É de vital importância para a presente pesquisa notar que apenas quatro ${ }^{93}$ das 136 cores apontadas se referem à origem, sendo que destas, somente duas se referem a origens nacionais brasileiras: baiano e paraíba. O que seriam estas cores? Defendo que tal dado é explícito na comprovação de uma racialização nordestina. Para além de pautar a subjetividade de respostas que explicitam como cor no Brasil é um assunto complexo, torna-se necessário pensar no que leva a ter uma composição regional nesta aquarela do Brasil.

Como categorias atribuídas no sudeste aos migrantes nordestinos - tais como baiano e paraíba - foram incorporadas pelos mesmos? Se os pesquisadores se perguntam se tais categorias possuem alguma relação com a representação mestiça do nordestino, com um preconceito em relação a sua cor, a resposta não deixa dúvidas: quem respondeu baiano e paraíba a esta pergunta considera tal característica - majoritariamente imputada - como racial.

Schwarcz aponta o fato de que do engendramento do mito de uma sociedade racialmente igualitária - de Freyre - à desconstrução do mesmo - com os tantos movimentos negros em luta - ocorreu no Brasil a permanência das duas máximas: tanto de que não somos racistas, vivemos em harmonia quanto de que a democracia racial é um mito a ser desmascarado. Assim, o mito se altera sem se extenuar (SCHWARCZ, 2012:113). O mito é destrinchado com o passar dos tempos, mas persiste a ideia de que o racismo à brasileira seja melhor, menos maléfico. E mesmo em tal sentido, racistas são sempre os outros, nunca quem fala.

\footnotetext{
${ }^{93}$ Baiano, paraíba, russo, polaco.
} 
É deste modo que se pode pensar na racialização nordestina. Longe de ser um fenômeno que se verifica somente em São Paulo, a representação racial nordestina se dá no cenário nacional de maneira estereotipada, com atributos estigmatizados e apresentados como inferiores. Marcadores sociais da diferença que envolvem raça, classe e gênero se entrelaçam para formar uma imagem ridicularizada dos naturais do Nordeste. É em tal sentido que Weinstein aponta - como já mencionado no capítulo anterior - que em um cenário de engendramento da mítica democracia racial e da mestiçagem, certos racismos explícitos reconfiguraram-se, tornando-se, assim, velados. Seguindo essa fórmula do racismo que se dá na intimidade, que se mascara, de preto como adjetivo pejorativo podese ir facilmente a baiano.

Posto isto, como não relacionar o racismo à discriminação e preconceito sofridos por nordestinos? Albuquerque Jr fala sobre um contexto em que, no período pós-abolição, havia um receio racista em relação à ideia de um negro mau vindo do Nordeste (ALBUQUERQUE JR, 2011:74). Guimarães (2002) também expõe uma ideia que já no século XIX era recorrente: as elites nordestinas não sabem lidar com seus negros. Romero (2014), da mesma forma, mostrou que em meados do século XX havia medo da massa mestiça nordestina que imigrava com destino a São Paulo. E, como já visto, em 2010 a internet foi tomada por um ideal do sudeste enquanto branco e do nordeste enquanto preto, como se ser negro fosse pior. Levando-se em consideração que em todas regiões brasileiras, sem exceção, o racismo é uma máxima cotidiana, é fácil perceber um discurso das elites brancas, nordestinas e paulistas, que pautam o outro indesejado enquanto negro. No discurso paulistanista, todavia, há um agravante imaginado: os negros vieram de lá, não são daqui. De um Nordeste racista a uma São Paulo racista, às populações negras é imputada a estigmatização histórica que reverbera no maior número de mortos pela Polícia Militar $^{94}$ e no menor acesso a qualquer direito básico. ${ }^{95}$

Por tais motivos que é possível ver uma definição de dicionário que conceitua baiano enquanto "tolo, negro, mulato, ignorante e fanfarrão"; milhares de mensagens no twitter incitando o afogamento de nordestinos e classificando-os como "pretos dinheiristas dependentes de bolsas." Se esta já não é uma racialização explícita cotidianamente, vê-se

\footnotetext{
${ }^{94}$ Como demonstra o estudo - Desigualdade Racial e Segurança Pública (2014) - do Grupos de Estudos de Violência e Administração de Conflitos da Universidade Federal de São Carlos, ao apontar que negros são três vezes mais mortos pela Polícia Militar do Estado de São Paulo.

${ }^{95}$ Schwarcz expõe como, no cenário atual, negros possuem menos acesso à educação, saúde e emprego, quando relacionados aos brancos.
} 
que escapa - em situações de acirramento - o que o preconceito do dia a dia deixa sob panos quentes: o desprezo ao nordestino se dá, entre outros fatores, por este ser pensado como um não-branco em um país estruturalmente racista em que quanto mais claro se é, melhor.

\section{8 - Formas de Resistência}

O 8 de outubro é tido, desde 2009, como o Dia do Nordestino. A data foi escolhida por marcar o nascimento do poeta e compositor cearense Antônio Gonçalves da Silva, mais conhecido como Patativa do Assaré. O Projeto de Lei 14.952/2009, responsável por instituir este dia de enaltecimento, foi formulado em São Paulo pelo vereador potiguar Francisco Chagas.

Como já colocado nesta dissertação, diz-se frequentemente que São Paulo seria a cidade mais nordestina do país e que teria sido construída pelos imigrantes oriundos do Nordeste. Deste modo, torna-se importante refletir sobre o que faz imigrantes advindos de tantos estados do Nordeste serem pensados em São Paulo não somente como baianos, mas como povo nordestino.

Enfrentar tal questão requer refletir sobre como imbricam-se identidades regionais e estaduais. Se é baiano, sergipano, alagoano, pernambucano, paraibano, potiguar, cearense, maranhense, piauiense antes de ser nordestino? Como a situação migrante poderia alterar a formulação destas identidades?

É possível observar que em disputas internas ao Nordeste engendram-se narrativas rivais que afirmam que pernambucanos seriam metidos a intelectuais ou que baianos se sentiriam o suprassumo da região. Da mesma maneira, João Pessoa ${ }^{96}$ e Campina Grande rivalizam na disputa por ser o polo econômico e cultural da Paraíba, bem como Caruaru e Campina Grande por ter o maior São João do mundo. Cearenses podem sofrer preconceito quando em situação migrante na Bahia e diferenciações de sotaques e estilos de vida são apontadas e percebidas entre nordestinos de estados diferentes.

Longe de serem a massa homogênea que se é frequentemente pensada no sudeste, as populações nordestinas perpassam, como qualquer grupo humano, por diversas diferenças que englobam classe, raça, gênero e, especialmente notável para esta pesquisa, região. Posto isto, suponho que identidades estaduais podem confluir para uma formação

\footnotetext{
${ }^{96}$ É interessante pensar que recentemente João Pessoa passou a ser tratada, sob forma de gíria, como Jampa (em analogia à Sampa, de São Paulo).
} 
de identidade regional em situações de ataques discriminatórios e preconceituosos ou de vivência migrante. Desta maneira, pensar em formas de resistência à racialização nordestina permite abordar com mais qualidade o imbricamento de identidades regionais e estaduais.

Expor a presença de nordestinos na cena cultural brasileira é uma estratégia costumeiramente utilizada para rebater argumentos que rebaixam a importância da região. Deste modo, frequentemente se ouvem variantes de como imaginar um Brasil sem festas de São João, sem Jorge Amado e Suassuna, sem Caetano Veloso, Gil, Bethania, Gal, Belchior, João Ramalho e Luiz Gonzaga? Evidenciando-se a presença de intelectuais, músicos e costumes nordestinos na formação cultural brasileira rebate-se a ideia de que tal região em nada contribuiria para o Brasil. No próprio Manifesto Regionalista de 1926 a estratégia, ainda corrente, foi adotada.

De todos os modos, a classe artística e intelectual do Nordeste, não apenas é mobilizada enquanto afirmativa regional, como também mobiliza-se frequentemente contra a estigmatização nordestina. Belchior já era ativo neste sentido na década de 1970, afirmando em relação à situação migrante do nordestino no sudeste que "o sol não é tão bonito pra quem vem do Norte e vai viver na rua. ${ }^{.97}$ Do mesmo modo, em meados da década de 1980, a canção Nordeste Independente, composta por Bráulio Tavares e Ivanildo Vilanova, fez sucesso na voz da cantora paraibana Elba Ramalho. Os compositores afirmaram que a música seria uma resposta ao preconceito lá do Sul (Rio e São Paulo). ${ }^{98}$ Fica evidente na composição, não só o enaltecimento da região, mas também a afirmativa de que caso acontecesse a separação do Brasil, os nordestinos não seriam mais prejudicados que os sulistas. É o que se pode apreender dos trechos a seguir:

Já que existe no sul esse conceito / Que o nordeste é ruim, seco e ingrato /Já que existe a separação de fato / É preciso torná-la de direito / Quando um dia qualquer isso for feito / Todos dois vão lucrar imensamente / Começando uma vida diferente / De que a gente até hoje tem vivido / Imagina o Brasil ser dividido / E o nordeste ficar independente. ${ }^{99}$

\footnotetext{
${ }^{97}$ Fotografia $3 \times 4$. Belchior, 1976.

98 O que pode ser visto em: DRZEM. Entrevista <http://www.drzem.com.br/2009/12/o-nordesteindependente-de.html> 2009. Data da última visita: 11/05/2017.

${ }^{99}$ Nordeste Independente. Bráulio Tavares, Ivanildo Vilanova. 1984.
} 
Este tipo de mobilização artística está longe de restringir-se somente ao século XX. A repercussão da discriminação e preconceito contra nordestinos desde a campanha Afogue um Nordestino em 2010, bem como o recrudescimento de certas lutas sociais, geraram um movimento neste sentido. O ano de 2016 foi marcado por uma batalha regional entre rappers. Sulicídio ${ }^{100}$ é o nome da composição que mais gerou polêmica. Reclamando o domínio dos artistas do Sudeste na cena do rap, a letra teve repercussão não apenas pelo tom de ameaça em relação aos rappers do sul, mas especialmente por ser ofensiva em relação às mulheres e LGBTQIA+. ${ }^{101}$ Entre tudo isto, todavia, ficou evidente uma demanda: "respeitem o Nordeste!"102

Em um entrelaçamento denso de diversos marcadores sociais da diferença, as respostas a Sulicídio foram variadas. Rappers nordestinas responderam contra a opressão que sofrem, seja pelo domínio masculino ou pelo domínio cultural paulista e carioca. No sudeste, afirmou-se que os sotaques nordestinos seriam incompatíveis com o rap. Em diversos estados nordestinos, rappers se juntaram contra o preconceito do Sul.

A polêmica de 2016, todavia, advém de um cenário em que se recrudescia há pelo menos cinco anos a luta contra o rebaixamento nordestino no rap brasileiro. Em 2010, após a campanha Afogue um Nordestino, rappers dos nove estados do Nordeste se juntaram para realizar uma canção-manifesto, Yoxente:

Quem construiu o Estádio do Morumbi / Também fez o Planalto Central, a USP, Jockey Club / A injustiça qual é? (...) Nordestinos do bom, somos bravos combatentes / Sinta no peso do refrão o poder dessa gente. (...) A pele branca e a conta bancária é imunidade contra moradia carcerária ${ }^{103} /$ Me deixa revoltado, me deixa infeliz ver quem tá se tornando advogado e juiz ${ }^{104}$ / Que se tivessem um pouco de inteligência saberiam / Que São Paulo existe da competência de imigrantes nordestinos / Fugitivos da miséria que levantam seu país enquanto você passa férias / Quando li o comentário dos seus amigos no Twitter / Lembrei dos idiotas que gritavam Heil Hitler. ${ }^{105}$

\footnotetext{
${ }^{100}$ De Baco Exu do Blues e Diomedes Chinaski.

${ }^{101}$ Saliento novamente que utilizo a sigla LGBTQIA+ pontuando as disputa e críticas que há em torno desta conceituação.

102 Trecho de Sulicídio.

${ }^{103}$ Referência ao fato de que ninguém foi detido pelas mensagens de ódio proferidas nas redes sociais à época da campanha Afogue um Nordestino.

${ }^{104}$ Referência à estudante de Direito, Mayara Petruso, que iniciou a campanha Afogue um Nordestino.

${ }^{105}$ Yoxente. Jorge Hilton, Preto Nando, Kalyne Lima, Preto Du, Zé Brown. 2011.
} 
Do mesmo modo, o rapper Rapadura defende em suas canções um rap nordestino que não tenha vergonha de expor suas tradições e costumes. Preocupado com a perda de símbolos nordestinos, o artista rimou em 2011:

Não vejo cabra da peste, só carioca e paulista / Só
frestyleiro em nordeste, não querem ser repentistas /
Rejeitam xilogravura o cordel que é literatura / Quem não
tem cultura jamais vai saber o que é rapadura / Foram
nossas mãos que levantaram os concretos os prédios / Os
tetos os manifestos, não quero mais intermédios / Eu quero
acesso direto às rádios, palcos abertos / Inovar em projetos
protestos / Escuta! A cidade só existe por que viemos antes
/ Na dor desses retirantes com suor e sangue imigrante /
Rapadura, eu venho do engenho rasgo os canaviais / Meto
o norte nordeste o povo no topo dos festivais, toma! / Ei!
Nortista agarra essa causa que trouxeste / Nordestino
agarra a cultura que te veste.

A mobilização da classe artística, todavia, foi apenas um de tantos aspectos do movimento social de resistência à estigmatização nordestina. As redes sociais virtuais geraram muito conteúdo sobre o assunto. Páginas e grupos online de resistência surgiram e tiveram grande repercussão. São exemplos os portais do Facebook Orgulho Nordestino e Nação Nordestina.

Indo neste sentido, em outubro de 2016, a agência de publicidade Base Propaganda, realizou uma campanha aclamada nas redes sociais virtuais. Nela, nordestinos eram fotografados segurando cartazes com frases ofensivas que ouviram no Sul e Sudeste brasileiros. Exemplos como "te acho bonito, nem parece nordestino" ou "o Nordeste é ótimo, só praia né?” geraram comoção na internet. A foto a seguir é um exemplar da campanha.

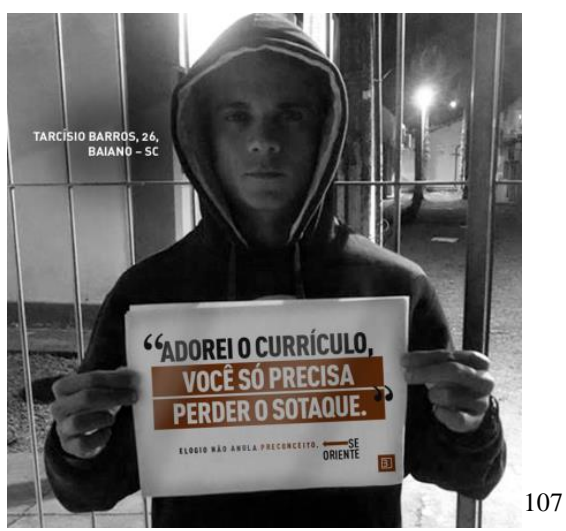

\section{Imagem 4}

A frase enunciada no cartaz indica

o estigma que pode ser imputado ao sotaque, em especial no que se refere a determinadas áreas do mercado de trabalho.

\footnotetext{
${ }^{106}$ Norte e Nordeste Me Veste. Rapadura. 2011.

107 Imagem retirada em: AGENDA. Campanha com participação de alagona viraliza ao expor preconceito contra nordestinos. 2016. Disponível em: <http://www.agendaa.com.br/negocios/midia-e-
} 
Posto isto, creio que seja possível afirmar que frente a situações de estigmatização, diversas populações estaduais do Nordeste se mesclem em certo orgulho e defesa regionais, se formem enquanto povo nordestino. $\mathrm{O}$ mesmo pode se supor acerca de uma parte vulnerabilizada da população migrante nordestina que vive em São Paulo. O preconceito atinge, por óbvio, de formas diferentes um imigrante enriquecido e branco e um estereotipado enquanto retirante. É válido, portanto, pensar como esta população, estigmatizada que migrou para São Paulo em busca de emprego, opera em uma formação regional.

Em seu trabalho etnográfico, Rigamonte (2001) expõe que o Centro de Tradições Nordestinas (CTN), localizado em São Paulo, representa um local em que migrantes sentem maior liberdade para exercer seus costumes e estabelecerem laços entre iguais. Discriminados em uma cidade restrita, estes migrantes encontram no CTN um espaço em que sua cultura regional é exaltada. A antropóloga chega a conceituar o local como uma mancha nordestina da cidade de São Paulo. O CTN, portanto, não é reconhecido unicamente como baiano ou sergipano, alagoano, pernambucano, paraibano, potiguar, cearense, maranhense, piauiense. É nordestino.

Desta maneira, é de se supor que entre uma experiência migrante e outra nativa, identidades estaduais e regionais relacionem-se de forma diferente: enfatiza-se povo nordestino ao invés de povo piauiense ou cearense, a título de exemplo, em uma situação e local em que imigrantes do Nordeste são, de modo geral, discriminados e alvos de preconceito. O mesmo pode se dizer sobre nordestinos em contextos de acirramento discriminatório ou preconceituoso, vivendo ou não em seus locais de origem: frequentemente há certa união em defesa da região que ultrapassa uma lealdade estadual.

Este padrão pôde ser percebido nas formas de resistência expostas neste subcapítulo. A canção Nordeste Independente enumera uma série de atributos dos nove estados nordestinos que buscam pautar enquanto legítima a região de que falam; até mesmo enquanto possível país. Do mesmo modo, Yoxente reúne nordestinos de diversas regiões que respondem, conjuntamente, à campanha Afogue um Nordestino.

É interessante a frequência com que se pauta a importância da mão de obra nordestina na construção de São Paulo. Se um discurso paulistanista excludente afirma o estado como detentor único do progresso, rebate-se que tal progresso só existe por conta 
da mão de obra nordestina. As mesmas estratégias podem ser pensadas quando da revolta em relação às vitórias de Dilma Rousseff como presidenta da República, bem como com a subsequente responsabilização do Nordeste por tal resultado político. Aos que afirmaram o Nordeste como culpado pela eleição da presidenta deposta, houve respostas estatísticas que apontavam outras regiões e estados em que a maioria dos votos também havia sido para o PT.

Neste sentido, chama atenção uma movimentação nordestina conservadora em que se culpa as camadas historicamente discriminadas da região pelo estigma da inaptidão política que, nesta lógica, prejudicaria a imagem dos nordestinos mais civilizados. Neste viés, defende-se o Nordeste verdadeiro enquanto rico e branco, não enquanto pobre, nãobranco. Esta defesa de cunho elitista e racista que chega, inclusive, a responsabilizar outras regiões ou estados nordestinos pelo estereótipo que engloba a região como um todo, evidencia a heterogeneidade das populações nordestinas.

Da mesma maneira, remete a um fenômeno nacional: a tão recorrente vergonha de ser brasileiro, de ser terceiro mundo, ancorada em um ideal de branquidade e progresso, encontra uma variante nas elites nordestinas - estereotipadas na figura de um coronel mítico - que se traduz em vergonha de ser nordestino. Neste caso opera a mesma repulsa paulistanista em relação ao estereótipo do Nordeste; a racialização e demarcação de classe são nítidas.

É em tal sentido que se dá constantemente um discurso que defende o Nordeste não só como terra de pobre, de seca, de beneficiários do bolsa família. Nesta lógica, o incômodo direciona-se ao estigmatizado, não às práticas ou grupos que operam a estigmatização. Pobreza, não-branquidade e seca continuam sendo fatores atacados; atributos vistos como vergonha em um argumento preconceituoso econômica e racialmente. Deste modo, fica nítido como o embate de Dois Brasis, perpassa por uma série de outros embates que não permitem generalização.

De todos os modos, há uma série de outros movimentos empenhados na resistência frente à estrutura racista, elitista e regionalmente discriminadora e preconceituosa. Nestes, há a percepção da estigmatização nordestina como fenômeno marcado pela racialização e demarcação econômica pejorativa. Se resiste a um padrão preconceituoso levando em consideração que um discurso de dois Brasis ancora-se no racismo e preconceito de classe. Yoxente rimar - em menção aos ataques cybernéticos direcionados aos nordestinos "Quando li o comentário dos seus amigos no Twitter, lembrei dos idiotas que gritavam 
Heil Hitler" - evidencia uma luta que se direciona contra uma estigmatização histórica que engloba opressões variadas. Da mesma maneira, reivindicar o trabalho realizado em São Paulo daqueles imigrantes chamados de retirantes, expõe uma afirmativa da contribuição nordestina ao progresso industrial paulista.

De tudo isto apreende-se que as formas de resistência à racialização dos nordestinos são múltiplas e partem de interesses e posicionamentos sociais distintos. Longe de qualquer passividade ou vitimização, as populações nordestinas responderam, ao longo dos tempos, de diversos modos à estigmatização que lhes é imposta. Isto evidencia não somente a disputa em torno da assimetria de poder regional e econômico no Brasil, como também a contestação de diversas formas de preconceito cultural, racial e de classe. 


\section{CAPÍTULO III \\ Da Mítica Branquidade à Mítica Democracia Racial Um Embate Entre Narrativas Regionalistas}

\section{1 - A Especificidade Paulista em Questão}

A paulistanidade reivindicar certa excepcionalidade em torno do ser paulista é um fato que analisei extensivamente ao longo da presente dissertação. Da mesma maneira, salientei que a raça e a classe são elementos focalizados na tentativa de endossar esta pretensa superioridade. Interessa-me agora destrinchar o que há de excepcional nesta linha argumentativa: o que diferencia o orgulho paulista de outras manifestações regionalistas vigentes no contexto brasileiro?

Acredito que tal busca permita o afastamento de uma armadilha tradicional nos estudos regionais: foco exaustivo na manifestação regionalista da qual trata a pesquisa. Deste modo, empenho-me em analisar narrativas identitárias de estados brasileiros diferentes, bem como seus imbricamentos na ideia de formação racial e econômica do país.

Tal esforço concentra-se no fato de que em um Estado Nacional com apelo à aptidão capitalista e à mítica democracia racial, bem como ao racismo velado e generalizado, distinções regionais servem a discursos discriminatórios que fogem da nitidez e do confronto aberto. Da cordialidade dita por Sérgio Buarque de Holanda à generalização da expressão não sou racista, mas conheço quem seja, um vocábulo simples e usual - tal qual baiano - permite expressar com destreza a mensagem que se preferiu deixar nas entrelinhas: a referência a populações não-brancas e pobres.

É o que possibilita no presente contexto nacional que paulista e gaúcho - a título de exemplo - sejam pensados majoritariamente enquanto um tipo social branco e com sucesso econômico, enquanto grupos outros são associados à pobreza e afastamento da branquidade, que me leva a pensar em como narrativas regionais distintas mobilizam identidades raciais e econômicas. O que faz com que certos locais e populações sejam considerados arautos da branquidade e do progresso? O que leva, em contrapartida, que outras regiões e grupos humanos reivindiquem ativamente sua negritude ou indianidade frente a uma nação que, mesmo veladamente, exprime de forma acentuada seu racismo? São estas algumas perguntas que nortearão o presente capítulo. 
Para respondê-las, busquei analisar a discursiva regionalista, em especial das classes dominantes, ${ }^{108}$ de variados locais. Aparecerão neste capítulo, com foco maior, os estados do Rio Grande do Sul, Paraná, Minas Gerais, Ceará, Bahia, Pernambuco, Mato Grosso do Sul, Pará e Rio de Janeiro. A escolha destes estados se deu pela preocupação de distribuir social e geograficamente manifestações estaduais diversas. Isto levando em consideração a macrodivisão oficial das cinco regiões formadoras do Brasil. Do mesmo modo, busquei apresentar narrativas regionalistas significativas em relação a um tema caro a esta pesquisa: branquidade e miscigenação, progresso e decadência.

Vale dizer que as fontes que serviram a este capítulo são variadas e devem ser especificadas, tanto em seus propósitos quanto em seus contextos. Mobilizei narrativas diferentes em torno do tema desta pesquisa. Há análises sociológicas, mas há também escritos de intelectuais engajados em defenderem suas respectivas regiões como imprescindíveis para o modelo de nação. Neste último caso, vê-se apego à narrativa regionalista militante e não a preceitos analíticos. ${ }^{109}$ Do mesmo modo, expus entendimentos que permeiam o senso comum e atribuem determinadas características como intrínsecas a um recorte espacial e humano.

Disto apreende-se que os regionalismos estão longe de serem abordados unicamente nos Institutos Históricos e Geográficos do país ou pela agenda das elites letradas. Interessa-me ver como os regionalismos brasileiros - para além do fato de constituírem frequentemente discursos em prol das classes dominantes - mobilizaram ideais que imprimiram estereótipos capazes de abarcar discursivamente camadas diversas da população. Deste modo, o debate regional será analisado em fontes plurais, seja como objeto de estudo científico, como militância, como forma de discriminação e preconceito ou como formação étnica de grupos.

\footnotetext{
${ }^{108}$ Este estudo se deterá, mais frequentemente, nos discursos regionalistas das classes dominantes, especialmente de grupos intelectuais do fim do século XIX e início do século XX. Creio que tal recorte facilite o entendimento acerca das possíveis funções políticas em torno das narrativas analisadas. Tendo isto em vista, torna-se importante salientar a generalização destes regionalismos que - indo além de suas elites engendradoras - são reproduzidos por variados grupos societários.

${ }^{109} \mathrm{O}$ que não significa que o ato de analisar possua neutralidade.
} 


\section{2 - Tensões Entre o Gauchismo e a Nação}

A tensão entre integração e autonomia, marcante na relação entre o Rio Grande do Sul e o Brasil (OLIVEN, 1992:9), é recorrente não apenas nas análises da bibliografia especializada, como também no imaginário nacional. Do senso comum que pauta a região como muito europeia para ser brasileira até uma reverência à suposta branquidade do Sul enquanto força civilizatória do país, coexistem discursos acerca do estado que esbarram ora em estranhamento, ${ }^{110}$ ora em admiração.

Do mesmo modo, as narrativas empreendidas por grupos de orgulho gaúcho costumeiramente vão de encontro à dubiedade expressa neste atrito. É interessante pensar como este vai-e-vem em muito se relaciona à formação nacional e regional brasileira que, como expressa Oliven, pode ir da desvalorização do país (tomando-se culturas europeias e estadunidenses como modelo) à exaltação de símbolos nacionais imaginados (OLIVEN, 1992:32).

Estas descontinuidades permitem analisar que dentre as contraposições em torno de nação e separação, progresso e atraso, branquidade e mestiçagem, o orgulho gaúcho enquanto realidade histórica aparelhou de diferentes formas seus discursos ao longo do tempo. Interessa, portanto, analisar a persistência de padrões que tanto externa quanto internamente pautam o estado do extremo sul brasileiro como um contraste branco frente a um país mestiço.

De início vale dizer que a questão da geografia fronteiriça e da "integração tardia ao resto do país" (OLIVEN, 1992:47) é vital para pensar o estado. Em suas narrativas regionalistas, é constantemente citada tanto a posição estratégica que a região tinha para a proteção da Coroa Portuguesa quanto sua suposta aptidão para a defesa do território nacional.

A colonização de fronteiras agrícolas com a retirada forçosa de populações indígenas das terras rio-grandenses foi, como exposto por Kaiser (1998), narrada como a façanha de "homens audaciosos que transformaram terras outrora improdutivas no celeiro do Brasil." Fato que torna nítido "o uso político do ser gaúcho como argumento de acesso a um patrimônio simbólico articulado com a ocupação de territórios" (KAISER, 1998:31$32)$.

\footnotetext{
110 “Ele é frequentemente contraposto como um todo ao resto do país, com o qual manteria uma relação especial, a ponto de ser as vezes chamado jocosamente por outros brasileiros de 'esse país vizinho e irmão do Sul'"' (OLIVEN, 1992:47).
} 
Do mesmo modo, forjou-se um enredo histórico em que se afirma que o Rio Grande do Sul teria escolhido fazer parte do Brasil, pagando por tal escolha um preço alto devido às guerras diversas ${ }^{111}$ pelas quais passou o estado. Nesta lógica, estas teriam contribuído para formar um "tipo social específico marcado pela bravura que é exigida do homem ao lidar com as forças da natureza e da árdua vida campeira" (OLIVEN, 1992:49).

Ruben Oliven chama atenção ao fato de que apesar de o Rio Grande do Sul estar longe de ser um estado homogêneo geográfica, econômica e socialmente, segue sendo representado através deste único tipo social: o gaúcho. Este, embora brasileiro "é muito distinto de outros tipos sociais do país" sendo sua identidade construída constantemente em referência a um passado glorioso de virilidade, bravura, lealdade e honra (OLIVEN, 1992:50).

Do mesmo modo que o bandeirante serve à fixação arbitrária de um glorioso e heroico passado paulista, o gaúcho é mobilizado para endossar a construção de um imaginário que se pauta na suposta excepcionalidade dos naturais de seu estado. Assim como o termo bandeirante alterou-se ${ }^{112}$ no decorrer da formulação da narrativa regional de São Paulo, gaúcho ${ }^{113}$ - que chegou a ser sinônimo de desviante e marginal - foi ressemantizado em uma identidade regional positiva (OLIVEN, 1992:50). Mudanças drásticas como estas permitem observar o caráter histórico da formação das identidades: distantes de quaisquer naturalizações, manifestações regionalistas incipientes ganharam força a partir da alçada da construção da nação enquanto mote brasileiro, característica marcante do século XIX.

Conferiram legitimidade à naturalização destas distinções regionais, intelectuais como Oliveira Vianna (1920) que, para além de seu receio frente à mestiçagem brasileira (apontada, especialmente, no Nordeste), defende a superioridade política gaúcha. Oliven aponta que o mesmo autor dedica ao estado o conceito de democracia sulina, sendo este, posteriormente, somado à ideia de democracia racial.

\footnotetext{
111 “As peculiaridades da relação entre o Rio Grande do Sul e o Brasil ficam evidenciadas de forma simbólica na bandeira do estado, que é formada por três faixas coloridas: uma verde, a outra amarela, ambas evocando as cores da bandeira nacional, separadas por uma faixa vermelha denotando o sangue que foi derramado na história do estado." (OLIVEN, 1992:58).

${ }^{112}$ O que é exposto por Queiroz (1992) em Ufanismo Paulista: Vicissitudes de um Imaginário e já foi tratado na presente dissertação.

113 "Segundo Love (1975), a palavra "gaúcho", o homem livre dos campos, foi aplicada inicialmente para definir um tipo humano arredio, o nômade do pampa, muitas vezes um desertor desobediente da lei e da ordem, que cavalgava sem rumo em uma área vastíssima sempre atrás de gado amansado ou chucro e de cavalos. Gente de laço e de doma, sua cultura derivou de um amálgama entre os hábitos indígenas e europeus, resultando em um caldeamento étnico muito próprio." (LOVE apud LUVIZOTTO, 2009:25).
} 
A citação famosa de Saint-Hilaire (1839) de que "não há, creio, em todo o Brasil, um lugar onde os escravos sejam mais felizes que nesta capitania", bem como a suposta primazia pró-abolição ${ }^{114}$ do Conflito Farroupilha viriam, posteriormente, a endossar esta proposição mítica. Vale lembrar que estudiosos como Leitman (1979) defendem a tese de que os chefes farroupilhas jamais pretenderam de fato abolir o sistema escravocrata.

A ideia falaciosa de que as pessoas escravizadas no Rio Grande do Sul eram tratadas com maior humanidade em comparação ao resto do território nacional, acompanha a concepção de que os negros não possuem contribuição relevante para o estado. $\mathrm{Na}$ construção social desta identidade, tanto indígenas quanto negros são afastados com recorrência. Mesmo a partir da década de 1930, em que grande parte do Brasil engaja-se em pautar-se enquanto miscigenado e racialmente democrático, a historiografia riograndense seguia subestimando a presença do negro e afastando o índio de sua formação identitária (OLIVEN, 1992:54).

Não é de causar espanto que na mesma época, em meio à Revolução de 30, o propagandeamento deste cenário político alicerçava-se na "pretensa superioridade física e moral do gaúcho", povo destinado ao "papel de regenerador da Nação corrompida" (LEITE apud OLIVEN, 1992:60). Do mesmo modo, o fato de três dos cinco generais que governaram o Brasil após o Golpe de 1964 serem gaúchos, exprime a perpetuação da ideia do Rio Grande do Sul como interventor da política nacional, como restaurador.

Concomitantemente a esta autoproclamação de regenerador político, o discurso do estado tende a repetir que o Rio Grande do Sul deve muito menos ao Brasil, que o Brasil a ele, reivindicando em diversos períodos maior atenção, destaque e lucro na política e economia brasileiras. É neste sentido que o dia 20 de setembro aparece como Dia do Gaúcho. A data escolhida ser a mesma do início da Revolução Farroupilha explicita tanto a recorrência de uma reivindicação econômica quanto o fato de que esta identidade regional pauta-se em certa contraposição ao nacional.

Torna-se interessante analisar que a figura imaginada do gaúcho - ligada ao campo, ao trabalho e à bravura - não apenas serviu para impulsionar a coletividade estadual em busca da ascensão de seu poderio regional, como também permitiu contrapor

\footnotetext{
${ }^{114}$ É comum a bibliografia sobre o tema expor que os dirigentes da Revolução Farroupilha mobilizaram a causa abolicionista por interesses próprios, inclusive "Bento Gonçalves, ao mesmo tempo em que solicita como condição de paz ao governo imperial a liberdade de escravos que estão a serviço da República, deixa, como herança, ao morrer em 1847, 53 escravos em sua fazenda de Camaquã. Outros integrantes do movimento revolucionário também possuíam escravos vários anos após o término da luta armada." (BAKOS, 1985:79;94).
} 
ao restante do Brasil um tipo social que abarcou ao longo do tempo diferentes grupos étnicos de imigrantes europeus. Este passou a ser tão exaltado com o passar do tempo, que os Centros de Tradições Gaúchas - iniciados em 1948 na capital Porto Alegre - são hoje uma das maiores manifestações culturais do mundo (OLIVEIN, 1992).

Os Centros passaram por mudanças ao longo dos anos, mas seguem constituindo uma tradição forte tanto no estado quanto fora dele. ${ }^{115} \mathrm{O}$ segundo CTG ter sido fundado na cidade de Taquara, especialmente por alemães e seus descendentes, indica que o gauchismo foi eficaz para que colonos europeus reivindicassem sua brasilidade (OLIVEN, 1992:80).

Torna-se necessário salientar que a identidade gaúcha chegou a defender em dado momento superioridade em relação ao italiano e ao alemão. Esta exclusão, todavia, se torna mais branda ao longo do tempo (especialmente após o fim da II Guerra Mundial) passando a herança europeia no Rio Grande do Sul a ser vista como trunfo branqueador. Em concomitância, acentuou-se e perpetuou-se o afastamento de negros e indígenas na construção da identidade regional. Thales de Azevedo demonstra que além de identificarse branca, a gauchidade se sente mais próxima aos "vizinhos platenses do que aos brasileiros mulatos e pretos do norte do país e aos caboclos da Amazônia e do Nordeste" (AZEVEDO, 1984).

Um termo como gaúcho que de início significava marginal e um tradicionalismo que era indicado pelas elites como coisa de grosso passou, ao logo do tempo, a compor uma série de bens simbólicos e operar nas mais diversas camadas da sociedade gaúcha, especialmente nas dominantes. $\mathrm{O}$ uso da bombacha e o chimarrão se tornou rotina em centros urbanos como se sempre estivesse estado presente. É válido lembrar que esta imagem do gaúcho, tão cultuada, é, acima de tudo, masculina. ${ }^{116}$

Para além da identidade do gaúcho dizer respeito a um gênero específico, Luvizotto (2009:35) aponta que a etnicidade acentuaria a diferença dos naturais do Rio Grande do Sul em relação a outros brasileiros. Deste modo, a autora detém-se na análise de como o gauchismo atrelado ao separatismo ganhou coro expressivo nas últimas décadas.

\footnotetext{
115 “A expansão do tradicionalismo também se dá fora do Rio Grande do Sul, que é um dos estados de maior emigração do Brasil” (OLIVEN, 1992:91).

116 "Ao vestirem peças da indumentária dos homens, as mulheres estão se apropriando de símbolos de prestígio restritos à figura masculina do gaúcho, que é o tipo social representativo de uma sociedade onde a mulher tem lugar secundário" (OLIVEN, 1992:115).
} 
Kaiser (1998), da mesma maneira, indica que a formação de Centros de Tradição Gaúcha fora do estado sulista, em especial na região central do Brasil, é baseada no discurso de que o gaúcho está presente em outros locais para colonizar a terra, melhorá-la, uma vez que, nesta lógica, o povo brasileiro não estaria apto a esta tarefa. Nas palavras do autor, opera neste sentido um marketing social em paralelo à domesticação do outro, o que faz coro a argumentos conservadores e preconceituosos em relação à higiene, preguiça, lentidão e falta de vontade que são atribuídas ao brasileiro:

O pessoal daqui é preguiçoso, tudo baiano e mineiro de cabeça pequena. O gaúcho é um povo trabalhador, está na maioria dos projetos agrícolas. Eles são selecionados pela competência, tem 'know-how' (...) A baianada vive em volta para conseguir trabalho. E é assim mesmo que tem que ser; eles têm que ser mandados. Ai desta bosta aqui se não fossem os gaúchos. Ainda bem que, Brasil afora, tem mais gaúcho que gente (in KAISER, 1998:71-72).

É esta ideia de que o gaúcho "não pode sentir cheiro de terra molhada que tem que plantar, enfrenta todas as dificuldades e não desiste" (KAISER, 1998:81) que torna nítido o padrão meritocrático desta ideologia que, frequentemente, associa-se à proposição de superioridade racial. As torcidas de futebol do Rio Grande do Sul estarem, tão constantemente, entoando o canto “Ah, eu sou gaúcho!” e a conexão em discursos regionalistas deste estado à branquidade, herança europeia e sucesso econômico não são mera coincidência: o que opera, neste local, com certa semelhança a São Paulo, é o afastamento de estigmas raciais e econômicos a partir da estigmatização do outro. É sintomático que esta "ideologia étnica" exacerba sua "identidade e seus diacríticos em relação ao outro sertanejo e nordestino" (KAISER, 1998:101). Novamente a ideia de dois Brasis - e suas estereotipias em torno da raça e da classe - entram em questão.

Deste modo, coexiste no Rio Grande do Sul tanto a lógica de que o local é parte ativa na economia e na formação do Brasil e, por tal motivo, mereceria mais reconhecimento, quanto a indicação de que a separação seria necessária já que o estado daria mais do que receberia. Kaiser expõe que ao mesmo tempo que ser gaúcho reforça a identidade nacional - através da ideia de consolidação, expansão das fronteiras e sucesso colonizador - também repele esta identidade a partir da exacerbação de sua ideologia étnica.

É interessante notar certas semelhanças entre o tradicionalismo gaúcho e o regionalismo paulista: ambos pautados na autoreverência e no trabalho enquanto lema, 
bem como na aposta no embranquecimento. Da mesma maneira, a formulação de um enredo que se baseia em um passado de glória que justificaria o poder de mando frente ao país deixa nítido o afastamento arbitrário de populações não-brancas. Isto, todavia, cai por terra com um olhar mais atento: a título de exemplo, o Grêmio, time de futebol ligado constantemente a uma identidade branca, teve seu hino composto pelo músico negro Lupicínio Rodrigues (OLIVEN, 1992:105).

\section{3 - O Paraná e a Mancha Loira Brasileira}

O estado do Paraná no início do século passado, especialmente em meados da década de $1920,{ }^{117}$ passou por um hercúleo esforço intelectual, artístico e político para gestar sua identidade regional. A ascensão econômica do estado sulista levou à necessidade de uma campanha veloz e assertiva de construção do tipo paranaense.

Romário Martins seria um dos nomes principais envolvidos nos esforços desta construção regional. Salturi (2009) demonstra que o intelectual foi responsável pela fundação do Instituto Histórico e Geográfico do Paraná e pelo Centro Paranista, bem como pela ampla divulgação da história e do folclore paranaense e até mesmo pela criação de leis, como a referente à bandeira do estado.

Romário Martins via o paranismo como uma identidade forte a ponto de constituirse em estado sentimental. Para ele paranista seria "todo aquêle que tem pelo Paraná uma afeição sincera, e que notavelmente a demonstra em qualquer manifestação de atividade digna, útil à coletividade paranaense" (MARTINS, 1948:38).

Apreende-se de proposições como esta que o movimento paranista na primeira metade do século XX foi responsável por esboçar uma série de símbolos que formariam a identidade estadual. No início deste movimento, a fauna e a flora local eram exaltados, bem como a formação de certa mitologia indígena. ${ }^{118} \mathrm{O}$ esforço das elites paranaenses na tentativa de aparentar civilidade e modernidade é fator que terá crescimento exponencial no período.

Algumas décadas após Romário Martins, outro destacado intelectual buscou afirmar a existência de uma identidade paranaense coesa. Trata-se de Bento Munhoz da

\footnotetext{
117 “O paranismo, em meados da década de 1920, se constituiu como um movimento integrado em que políticos, intelectuais e artistas envolveram-se com a questão da definição de uma identidade local" (SALTURI, 2009:2).

118 "A década de 1930 tem como marca o cultivo de tudo aquilo que faz referência ao Paraná, através do paranismo de Romário Martins, que valorizava as lendas indígenas." (RODERJAN apud SALTURI, 1969).
} 
Rocha Netto, conhecido por apresentar a região enquanto uma mancha loira no Brasil. Cordova (2012) demonstra que o autor objetivava pautar nacionalmente um diferencial racial paranaense. Bento Munhoz chegou a contrapor a figura da mãe preta a de uma mãe loira não muito conhecida, indicando uma branquidade do estado sulista.

A afirmação do autor - "é claro que compreendemos Casa Grande \& Senzala como sabemos que não estamos incluídos na obra" (ROCHA NETTO,1969:50) - expõe as características do imaginário paranaense. O que incomodava na obra de Gilberto Freyre não era a mestiçagem em si - uma vez que, segundo o próprio Bento Munhoz, esta também teria acontecido no Sul, com elementos europeus - mas sim o fato de o Brasil de mestiçagem não-branca excluir a imagem que se queria demonstrar do Paraná: “o sul é branco" (ROCHA NETTO, 1960:73).

Desta maneira, Bento Munhoz defendia que os paranaenses honravam ${ }^{119}$ a herança europeia e não poderiam ser entendidos da mesma forma que outros grupos brasileiros possuidores de expressiva herança africana e indígena. Cordova aponta que o orgulho regional do autor explicitaria incômodo frente ao espaço amplo que o regionalismo nordestino ocupava no Brasil, uma vez que isto indicaria a marginalização do Paraná em seus diferenciais.

Emblemático no argumento de Bento Munhoz é a reivindicação da brasilidade que estranhamente para grande parte do território nacional - não esbarrava na miscigenação das três raças: para ele a branquidade e o ser loiro representariam, também, uma marca brasileira. Vital para o entendimento desta pesquisa é a localização de São Paulo entre estes Dois Brasis miscigenados distintamente:

Ser paulista, paranaense, catarinense ou gaúcho, sentir-se prêso ao seu meio, onde se situa o centro de todos os seus interêsses, preocupações e aspirações, é, para a gente de poucas gerações de Brasil, o grande e verdadeiro caminho de inteira assimilação pela cultura nacional (ROCHA NETTO, 1960, p. 61).

É por este sentido branqueador que estudos como os de Oliveira (2001) indicam a "produção de silêncio" como parte da identidade paranaense. Para além da continuidade de poder de suas classes dominantes (OLIVEIRA, 2001:166), as elites paranaenses esforçaram-se em aparentar um caráter europeu que anularia suas populações não-brancas.

\footnotetext{
119 "Honramos a herança europeia [...] Devemos continuar as funções do continente europeu, conservando a altura de sua missão. Temos o poder de nos desvencilhar de tôdas as deformações do espírito europeu. De todos os seus ismos que cometem devastações" (ROCHA NETTO, 1962. p. 86-87).
} 
Cordova aponta que o paranismo pôde se reconfigurar levando em conta contextos históricos diferentes: se em seu início conectava-se a símbolos especialmente rurais, a partir da década de 1930 busca apresentar-se como um movimento urbano dotado do requisito de modernidade que marcava a época. É o que Alves (2017) expõe ao tratar da formação identitária paranaense em meados dos anos de 1950:

Desafiada pelo rápido desenvolvimento econômico e ao buscar importar uma modernidade concebida nos centros da vida cultural nacional, a elite paranaense viu-se em dificuldades para fazer prevalecer sua própria visão regional da modernidade, que tinha a branquidade como valor fundamental (ALVES, 2017:1).

Esta dificuldade pode ser observada na preocupação em torno do centenário estadual: mesmo sendo uma potência agroexportadora, o estado não passava a impressão moderna que se almejava. Isto se daria especialmente pela mediocridade ${ }^{120}$ de sua capital (ALVES, 2017:4). As comemorações do Centenário seriam planejadas de modo a contornar esta imagem.

O período, sob o governo de Bento Munhoz, causou tensão na identidade paranaense. O paranismo, que reivindicara o bandeirante enquanto um formador identitário e, da mesma forma que São Paulo, buscava se pautar como uma potência do café - uma locomotiva do país - viu-se em apuros ao "imaginar a nação a partir da sua região", especialmente através de um símbolo pretérito tal qual as bandeiras (ALVES, 2017:13-16). Interessava o futuro do estado, bem como a herança europeia.

Alves expõe que a escultura do Homem $N u$, entregue em 1955 e feita por vanguardistas da escola carioca por conta das comemorações de 1953, causou choque nas elites paranaenses. A nudez, o formato do corpo, do rosto, da estatura e da fisionomia entraram em confronto direto com a branquidão que as classes dominantes gostariam de refletir. $\mathrm{O}$ autor demonstra que esta brasilidade mestiça, que possuía certo espaço na capital fluminense, "tinha potencial para ferir todo o espectro ideológico" do estado (ALVES, 2017:19).

Uma narrativa paranaense branqueadora teria encontrado seu trunfo diferencial neste período: investiu-se na brasilidade a partir da miscigenação branca. É marcante que com o passar do tempo, a etnicidade no Paraná tenha tido inserção na cultura nacional ao

\footnotetext{
120 "Apesar de um surto de verticalização dos edifícios da área central, que transmitia a sensação de progresso econômico, a cidade permanecia com ar medíocre em comparação com as grandes cidades brasileiras." (ALVES, 2017:4).
} 
ser associada aos colonos europeus, em detrimento dos grupos negros e indígenas. Estabeleceu-se, portanto, uma narrativa sobre a modernidade que tinha "como pedra de toque a branquidão" (ALVES, 2017:24).

\section{4 - Movimento Separatista Sulino}

O Movimento Separatista Sulino Contemporâneo, ${ }^{121}$ iniciado em meados da década de 1980, visa a criação de um novo país: a República Federal do Pampa. A base argumentativa de seus participantes em muito se assemelha aos discursos do separatismo paulista: uma afirmação de diferenciação - que indica superioridade - cultural e econômica, bem como a acusação de que o Sul seria prejudicado por regiões menos desenvolvidas. A pretensa superioridade sulista alicerçou-se tanto no suposto estreitamento com as culturas europeias, quanto na negação negra e indígena (LUVIZOTTO, 2009:41).

Do mesmo modo que em diversas manifestações regionalistas, este movimento pretende indicar um caráter de "eternidade" (LUVIZOTTO, 2009:44) em suas fundamentações históricas: como se o Sul desde sempre estivesse destinado à grandeza e a uma população excepcional. Desta maneira, episódios como os dos Farrapos buscam dar embasamento histórico para uma separação que há muito se faz necessária.

O Movimento, com duas frentes amplas de atuação (Movimento Pela Independência do Pampa e O Sul é Meu País) teve Irton Marx - que em 1993 foi preso por propaganda nazista ${ }^{122}$ - como uma de suas lideranças. Associar as regiões do Norte e Nordeste do país ao coronelismo, paternalismo e inaptidão política é constante na organização. O excerto abaixo expressa que apesar de se reivindicar o Sul enquanto país, o

\footnotetext{
121 “É justamente pelo caráter histórico do Movimento Separatista Sulino que adota-se o termo "contemporâneo" como maneira de diferenciá-lo dos movimentos de autonomia do passado (Revolução Farroupilha (1835-1845) e Federalista (1893-1895)) e, principalmente, porque isso demonstra que a ideia de separação e independência não é uma novidade do século $X X$, fazendo parte da própria história do povo gaúcho, apesar de que, no passado, a ideia de emancipação esteja ligada a outro contexto e outras motivações." (LUVIZOTTO, 2009:41).

122 "Em 21 de fevereiro de 1993, o principal líder do movimento, Irton Marx, anunciou que a República Federal do Pampa, uma vez concretizada, fechará suas fronteiras à mão de obra não qualificada, e, em pouco tempo, o novo país se tornará o primeiro país desenvolvido da América Latina, contando com o apoio de empresários do Canadá e da África do Sul "diante da ameaça do domínio dos negros". Segundo Irton Marx, como o Rio Grande do Sul está inserido em uma Federação, seu destino é ser comandado por "pessoas mais atrasadas", fazendo referência à representatividade no Congresso Nacional. Para ele, o ideal é o Rio Grande do Sul se unir a seus semelhantes, Paraná e Santa Catarina, e constituir uma nova pátria. Quando perguntado se sabe falar alemão, por ser um descendente, de forma descontraída Marx respondeu: "Dá para dizer heil Hitler". Irton Marx foi preso nesse mesmo ano portando material nazista e acusado de propagar a ideia nazista durante as assembleias separatistas." (LUVIZOTTO, 2009:48).
} 
Sudeste pode ser mencionado em consonância com a região sulina. Fica evidente que o Brasil parasitário de que falam não remete ao ideal sudestino enriquecido.

A proporcionalidade do voto, criminosamente desigual na representatividade do sufrágio universal, tem sido um dos álibis para desviar fortunas, de regiões extremamente produtivas, em favor de regiões servidas pelo cartelismo clientelista do Palácio do Planalto, aliciadas pela carriola de políticos investidos dos piores vícios (...) Cada Deputado do Sul/Sudeste representa 341.870 habitantes. No Norte, Nordeste e Centro-Oeste, cada Deputado equivale a 240.078 habitantes. No Senado a desproporção na representatividade é maior ainda. No Sul e Sudeste a relação é um senador para cada 4.004.762 habitantes. No Norte/Nordeste/Centro-Oeste é de um senador para cada 1.028.833 habitantes. ("Autodeterminação motivos históricos" in http://www.pampa.cjb.net)

$\mathrm{O}$ argumento econômico e eleitoral possui como acompanhamento uma base racial. Torna-se válido apontar, neste sentido, que "é possível configurar a influência do nazismogermanismo no movimento" (LUVIZOTTO, 2009:49). Não é de se espantar, portanto, que Irton Marx, quando entrevistado, tenha afirmado existir um perigo negro no país. Da mesma forma, o militante sulista sempre foi claro na referência a quem representa o Brasil que, segundo ele, envergonharia ${ }^{123}$ e prejudicaria o Sul:

Se torna necessária a nossa separação do Brasil, pois sob sua guarda jamais conseguiremos colocar um plano de recuperação econômica em prática, continuaremos eternamente em decadência, deixando de ser gaúchos para nos tornar sertanejos. (MARX, 1985).

É o Brasil representado pelo sertanejo que causa o incômodo de Irton Marx. Não o Brasil associado ao progresso e à branquidade. Curiosamente, o militante que porta material nazista e diz em entrevistas Heil Hitler, nega qualquer tipo de racismo institucional em sua proposta de país sulino, afirmando que negros gaúchos teriam direitos garantidos e possibilidade de orgulhar-se de sua raça na República do Pampa. Infelizmente para Irton Marx, seu esforço de afastar-se de uma cultura brasileira, ocasionalmente fracassa: o mascaramento da discriminação racial na proposta separatista que defende em

\footnotetext{
123 "Nós, gaúchos, passamos vergonha ao encararmos os estrangeiros nas nossas ruas, que nos olham com desprezo, como sendo velhacos, incompetentes e ignorantes, sem o poder de ação, quando na verdade eles não sabem que o povo gaúcho nada tem a ver com os erros técnicos e a discrepâncias do governo do Brasil. Os estrangeiros não sabem que somos um povo diferente, que só não somos ainda independentes porque deixamos passar dezenas de anos na esperança que tudo pudesse se modificar de uma hora para outra." (MARX, 1985:54)
} 
muito se assemelha ao racismo velado à brasileira e à aposta nacional no embranquecimento.

Atualmente o movimento - que passa por momento de maior efervescência política, valendo-se de uma interpretação conservadora da luta catalã e da crise política brasileira possui argumentos mais sofisticados em sua tentativa de adequação ao discurso da tolerância. Uma pesquisa breve pelo website "O Sul é meu País" permite que se veja o foco na questão econômica em detrimento da racial. Se fala de um tipo étnico específico diferente em relação ao resto do país - que chega a incluir raízes africanas, ${ }^{124}$ mas o foco é no diferencial cultural e econômico desta população. No dia 7 de outubro de 2017, todavia, o plebiscito informal que contou com cerca de 500 mil eleitores - $96 \%$ destes aprovando a separação - tornou nítido que, apesar de ter uma carta de princípios branda em relação a preconceitos, um ideal de superioridade segue intacto. A declaração a seguir é exemplo disto:

Eu sou do Sul é Meu País e do São Paulo Livre. Se acontecer as separações, eu quero dupla cidadania. Sou dos dois porque perdemos para Norte e Nordeste em representatividade e também porque mandamos para lá tudo o que arrecadamos. ${ }^{125}$

\section{5 - O Estoque Simbólico da Mineiridade}

Maria Arminda do Nascimento Arruda (1990) aponta que a mitologia da mineiridade se gestaria na ideia de conciliação, de modo que o estado apareceria com importância nos momentos de transição da política nacional. Desta maneira, características como bom senso, austeridade, introspecção, moderação e equilíbrio estariam postas como parte da identidade mineira. A autora aponta que a figura de Tancredo Neves foi, inclusive, mobilizada para justificar a presença de Minas na transição política brasileira após o Regime Militar (ARRUDA, 1990:14).

\footnotetext{
124 “A população Sulina hoje é de cerca de 25 milhões de pessoas, de origem europeia, miscigenada ao africano, ao americano nativo e ao asiático. Esta miscigenação que absorveu cultura, costumes e tradições de quatro continentes, associada aos fatores climáticos e geográficos inerentes à Região Sul, moldou o perfil que é peculiar do sulino, diferenciando-o das demais regiões brasileiras. O povo Sulino tornou-se assim detentor de uma diversificadíssima cultura, que se expressa através dos costumes e das tradições que a região cultiva, de onde se projetaram expressões artísticas para o mundo inteiro." Carta de Princípios: 0 Sul é meu País. Retirado em: SUL LIVRE. Carta de Princípios. Disponível em: <https://www.sullivre.org/cartade-principios/> Data da última visita: 13/11/2017.

125 Joca Palhanos, 55 anos. Retirado em: GAZETA DO POVO. Adesão ao Sul é meu país. Disponível em: <http://www.gazetadopovo.com.br/politica/parana/adesao-ao-o-sul-e-meu-pais-perde-forca-na-regiaomas-aumenta-em-curitiba-1q0n48t4wte0d6e41sziwa8ln> Data da última visita: 13/11/2017.
} 
Do mineiro relatado pelos viajantes europeus do século XVIII até o sertanejo de Guimarães Rosa, aponta-se um estoque simbólico conectado à terra, à montanha, ao local de difícil acesso. Curioso é que em concomitância estigmatizou-se o mineiro enquanto fraco, demasiado supersticioso e preguiçoso ${ }^{126}$ e se conectou Minas ao ouro e a uma importância central para o país: "o coração a emitir fluxos vitais para o corpo" (ARRUDA, 1990:55).

É neste sentido que opera a ideia de que Minas irradiaria a liberdade ${ }^{127}$ para todo o Brasil. ${ }^{128}$ Eventos históricos - em especial o da Inconfidência Mineira - foram mobilizados constantemente nos discursos da intelectualidade do estado para indicar que por conta da opressão sofrida pela região, a liberdade seria intrínseca a ela (ARRUDA, 1990:65). Tiradentes ascende, portanto, como a figura que mineiramente mostraria os caminhos patrióticos que o Brasil deveria seguir.

Fica clara a função que tal postulado cumpriu para as elites mineiras: a ideia do estado enquanto central para a política nacional precisava ser naturalizada. A enunciação de Tancredo Neves - a partir da junção de eventos ressignificados - é elucidativa acerca do caráter que pode atingir esta narrativa: "todas as grandes revoluções ${ }^{129}$ do Brasil partiram de Minas. Desde Tiradentes até 1964."

Outro fato com serventia para as classes dominantes do estado seria o ideal meritocrático dotado de potencial para endossar a mítica democracia racial: já no período colonial acreditava-se que as populações negras mineiras possuiriam mais oportunidades, uma vez que bastaria encontrar minérios valiosos para conseguir riqueza e alforria. ${ }^{130}$ Neste mesmo sentido, Antônio Francisco Lisboa - conhecido como Aleijadinho - seria mobilizado séculos mais tarde enquanto artista que representaria a miscigenação, a independência, uma nova imagem do Brasil (ARRUDA, 1990:78).

Diferentemente de locais como São Paulo, Rio Grande do Sul e Paraná que acima de tudo reivindicam a branquidade, em Minas a mescla racial entre europeus, africanos e

\footnotetext{
126 “O acalanto do ouro provocava a paralisia do todo social, transformando as minas no pólo irradiador da preguiça nacional” (ARRUDA, 1990:57).

127 "Não por acaso a bandeira do estado de Minas Gerais é um libelo a favor da liberdade, com a inscrição Libertas quae será tamen." (LYZARDO-DIAS)

128 "Enquanto síntese, Minas emerge ligada a um destino inelutável, qual seja o de garantir a ordem e a liberdade, a tradição e a esperança" (ARRUDA, 1990:70).

${ }^{129}$ Grifo meu. Saliento que, nesta pesquisa, o processo de 1964 recebe o nome de Golpe.

130 "Se um negro encontrava um diamante de dezessete quilates e meio, era coroado de flores, conduzido em procissão até o prédio da administração do Distrito e ali lhe concediam a liberdade" (PINHEIRO, 1966 apud ARRUDA, 1990:77).
} 
indígenas é utilizada discursivamente para tentar explicar um suposto caráter harmônico do mineiro. Isto se dá a partir da sugestão de um "entrecruzamento étnico equilibrado" (ARRUDA, 1990:105). A mineiridade chega a apontar - através da acepção clássica que trata grupos estigmatizados sob um viés festivo - que imigrantes nordestinos de modo geral e negros do estado teriam compensado a rigidez mineira, trazendo maior entusiasmo a esta identidade. $^{131}$

Arruda aponta, desta maneira, que o mineiro aparece como resumo do brasileiro: ao invés da particularização, este se distingue a partir da fusão com o todo (ARRUDA, 1990:108). É interessante notar que ao invés de pautar-se enquanto moderna, em consonância com tantas outras formulações identitárias, a mineiridade atrelou-se ao rural, ao tradicional. É inclusive neste sentido que a rivalidade com o paulista foi expressa: o matuto mineiro estaria à frente do moderno paulista por conta de suas artimanhas, Minas seria mais brasileira por levar em consideração o todo nacional, enquanto São Paulo relevaria apenas a si mesma (ARRUDA, 1990:111-119).

Minas já teria uma tarefa gigantesca se buscasse homogeneizar somente a si mesma. Todavia buscava, para além disso, resumir o todo nacional, misturando em seu enredo - que busca passar a continuidade como característica intrínseca - momentos e grupos plurais. Neste sentido, tanto bandeirante quanto sertanejo se tornam figuras evocadas para basear esta formulação identitária. Minas pode ser sertão, o esplendor do ouro no período colonial e a temperança necessária em momentos de conturbação da política nacional.

Rocha (2001) expõe que em fins do século XIX, a formulação desta identidade foi vital, tendo em vista o momento de fragmentação econômica e política do estado. Negando a homogeneidade imposta pela mineiridade, a autora entrevista mineiros de quatro ${ }^{132}$ diferentes regiões do estado, tendo como objetivo investigar as impressões destes em torno dos estereótipos locais retratados pelos meios televisivos. Rocha conclui que grande parte dos entrevistados acaba por naturalizar o tipo social identitário como próprio de si e da

\footnotetext{
131 "Os baianos, pernambucanos e mais nortistas vieram trazer um pouco de sol, de entusiasmo, de poesia e de gosto pela dança e pelo bate-papo para alegrar a tristeza dos montanheses caladões e levantá-los da apatia herdada do aborígene e aumentada pelo isolamento e pela melancolia da paisagem que os conduz a intensa vida interior. Os negros, de temperamento cicloide, concorreriam com a sua afetividade, sua doçura, sua fantasia, sua fidelidade e sua vocação para a música e para as festividades e folguedos, além da resistência ao trabalho duro das lavras e das roças, ao sol e à chuva, sem olvidar sua resignação diante do inevitável e sua paciência nas privações" (CARVALHO apud ARRUDA, 1990:107).

132 1) Região Central; 2)Norte e Nordeste Mineiros; 3) Triângulo Mineiro e Alto do Parnaíba; 4) Sul de Minas (ROCHA, 2001:5).
} 
população de seu estado. Há, contudo, certa resistência, em especial por parte dos naturais do Triângulo Mineiro: “essa história de montanhas de Minas, isto nem serve para nós, nós nem temos montanhas" (ROCHA, 2001:10). É interessante que em tal local se fala de separatismo, de um estado triangulino.

O que ocorre em Minas Gerais seria exemplo de como a homogeneização da narrativa regionalista acaba por esbarrar em certos obstáculos. Seja por seu ideal de democracia racial - certamente negado por grupos negros em território mineiro - seja pela associação única da população do estado ao rural, à temperança. Interessante neste contexto é a articulação eficaz de momentos históricos que apresentaram o estado enquanto irradiador da liberdade: a Inconfidência Mineira é, sem dúvidas, um dos movimentos mais reconhecidos no território brasileiro.

\section{6 - O Ceará e o Mito das Duas Raças}

A estigmatização nordestina no Sudeste brasileiro, em especial no Rio de Janeiro e em São Paulo, não hesita em pautar os cearenses enquanto não-brancos. Do preconceituoso termo cabeça chata enquanto sinônimo de cearense à conexão do grupo estadual à excludente concepção de atraso, imagina-se o Ceará como um local com inquestionável mestiçagem. A historiografia cearense, contudo, bem como a mitologia deste estado, empenhou-se - a partir do século XIX - a afastar a negritude de sua composição social. Segundo os intelectuais que formaram a identidade cearense, esta conformaria um tipo social com heranças indígenas e portuguesas. É sintomática a invisibilização ${ }^{133}$ do negro neste processo.

Uma série de autores (a título de exemplo Sousa, 2006; Schwarcz, 1993) demonstra a persistência do ideal que apresenta os cearenses como avessos à escravidão. Isto se daria devido à primazia do estado na abolição teórica e formal do sistema escravocrata, ocorrida em 1884, quatro anos antes da nacional. Tal marco serviu tanto à consonância estadual com a ideia falaciosa de democracia racial quanto à invisibilização dos grupos negros do estado.

133 "O preconceito étnico caracteriza-se fundamentalmente pela "ideologia da invisibilidade" (não há negros no Ceará). Isto precisa ser superado através da apresentação e resgate das Comunidades Negras existentes em todo o território cearense. A ideologia quer negar ao Povo Negro a possibilidade e o direito natural de ser negro nesta terra, a participação deste povo na construção desse estado em toda a sua história" (SOUSA, 1993). 
Sousa (2006) expõe os riscos de associar o racismo diretamente à escravidão, uma vez que a persistência da discriminação racial à cearense ocorre apesar de o estado ter possuído reduzido número de trabalhadores escravizados. Salienta-se, no mesmo sentido, a lógica perversa exposta por Funes (2001) de associar única e recorrentemente o negro à escravidão. Vale lembrar que antes mesmo da Abolição, já havia no Ceará um número considerável de pessoas negras livres com ativa importância social. ${ }^{134}$

É uma tarefa árdua entender como uma população estadual, que já no século XIX era majoritariamente negra, foi discursivamente embranquecida pelas elites do estado. Vale ressaltar que o Ceará em meados do século passado, antes vinculado a Pernambuco ${ }^{135}$ e com pouco destaque ${ }^{136}$ nas produções da Colônia, dá um salto econômico a partir da pecuária. As elites beneficiárias da civilização do couro, no entanto, tiveram felicidade curta: de 1877 a 1880 o estado passa por secas calamitosas que causam declínio econômico na região, deixando hordas de flagelados. ${ }^{137}$

Para além da necessidade de construir a identidade regional - que assolava todos estados da nação - as classes dominantes cearenses se incumbiram de outra tarefa: positivar a imagem regional em uma época de flagelo e disputa territorial com o Piauí (MENDES, 2017). O discurso da primazia na abolição seria, portanto, muito mais estratégico do que humanitário: buscava-se aparentar uma imagem de progresso e civilização frente ao restante da nação. $\mathrm{O}$ afastamento da composição negra na formação social do estado acompanharia esta tentativa de pautar o Ceará enquanto branco, progressista e com potencial civilizador.

Era a Terra da Luz que tentava entrar em cena, demonstrando-se nova, racional e moderna (OLIVEIRA, 2001). Para cumprir tal esforço, foi necessária a ascensão dos homens de sciencia (SCHWARCZ, 1993). A intelectualidade cearense passou a falar do genocídio indígena de maneira romantizada - até harmônica - apresentando o encontro entre índios e portugueses como o mito fundador do estado. Nesta lógica, a ancestralidade

\footnotetext{
134 “A presença afrodescendente no Ceará não ocorreu somente pela importação de pessoas para o escravismo criminoso. A ocupação negra acontece com a chegada de grandes populações, compostas em grande parte de ex escravizados em fuga, vindas de Pernambuco e Bahia, entrando pela região sul do Ceará conhecida como Cariri" (MENDES, 2017).

${ }^{135}$ Tendo sido parte desta capitania até 1799 .

136 "É fato que as condições físicas cearenses excluíram esse território de todos os grandes ciclos econômicos nacionais implicados com o uso da mão de obra escravizada: ciclo do açúcar, ciclo do ouro e ciclo do café. No território cearense o uso da mão de obra escrava, em comparação com outros lugares do Brasil, foi débil." (MENDES, 2017)

${ }^{137}$ Termo utilizado na época para se referir aos grupos que ficaram em situação de rua e vulnerabilidade extrema.
} 
indígena unida à potência civilizadora europeia teriam formado o cearense. Para além da exclusão do negro nesta narrativa, o indígena era embranquecido, uma vez que a raça branca teria, nesta lógica, o poder de moldá-lo através da mestiçagem. ${ }^{138}$

Fundamental neste processo foi o Instituto Histórico e Geográfico do Ceará que, ao invisibilizar o grupo negro, negou seu poder de ação no período abolicionista. As dubiedades desta narrativa são óbvias, uma vez que a incorporação de Francisco José do Nascimento - o combatente negro conhecido como Dragão do Mar - foi essencial para o estado forjar sua primazia em uma teórica libertação. Gomes e Oliveira (2010) mostram, todavia, que o uso da figura do Dragão do Mar foi estratégico, uma vez que se restringiu a presença negra no local a uma única figura. A ideia era falar da abolição como um negócio de brancos (GOMES, OLIVEIRA; 2010:46).

Nesta construção da identidade regional, as classes artísticas e intelectuais do estado perpetuaram uma ideia que ainda hoje se faz corrente: não existe negro no Ceará. Até o clássico Iracema foi mobilizado nesta narrativa, uma vez que o encontro da indígena com o elemento branco teria criado o primeiro cearense: Moacir (SOUSA, 2006). Resta indagar as diferenças entre o sucesso interno e externo desta criação intelectual esmerada no embranquecimento. Creio que seja possível afirmar que, por uma óbvia assimetria de poder regional e econômico, o Ceará não conseguiu, da mesma forma que São Paulo, Paraná e Rio Grande do Sul, apresentar-se nacionalmente enquanto branco.

\section{7 - Bahia: Roma Negra}

A Bahia, enquanto estereótipo e discurso de autorepresentação, já foi tratada ao longo desta dissertação. Mostrou-se, a partir dos estudos de Guimarães (2002), que baiano seria metonímia de gente do Nordeste já no século XVIII e que o fluxo de europeus no Sudeste brasileiro, ao fim do XIX, endossou a ideia do estado enquanto um "caldeirão racial parado no tempo" (GUIMARÃES, 2002:131). O local que fora centro econômico e intelectual brasileiro passou a ser associado ao atraso, sendo sua grandiosa concentração negra vista como obstáculo frente aos propósitos cruéis do embranquecimento.

Vale lembrar o que já foi dito no segundo capítulo desta pesquisa: a existência de um mito baiano (RISÉRIO, 1993; PINHO, 1998; NOVA \& MIGUEZ, 2008) que é conectado ao ideal de ancestralidade. A Bahia aparece - em uma narrativa imaginada que

\footnotetext{
138 "Nas palavras de Joaquim Catunda, outro historiador do Instituto, 'seguiam o curso das raças inferiores e retardatárias; emigravam uns, morriam os outros'” (Oliveira, 2001 apud MENDES).
} 
mescla tempos áureos e decadentes - enquanto primogênita do Brasil. Do mesmo modo, Salvador e Bahia confundem-se: fala-se do estado querendo se falar da capital e vice-versa (NOVA \& MIGUEZ, 2008).

Interessante neste contexto é indagar acerca do que fez as próprias classes dominantes baianas - com um racismo capaz de pautar a preguiça enquanto própria dos grupos negros do estado ${ }^{139}$ - a aceitar desde meados do século XX a Bahia enquanto inquestionavelmente negra. Schwarcz (1993) demonstra que este caminho esteve longe de ser contínuo. A Gazeta Médica baiana, primeiro periódico médico brasileiro (1866), esforçou-se em colocar as populações negras enquanto questão científica, apresentando diversas doenças, de modo descaradamente preconceituoso, enquanto sinal de degenerescência mestiça (SCHWARCZ, 1993:272).

Como já dito, ao fim do século XIX a ideia de fazer a nação imperava. Os intelectuais baianos incumbiram-se desta tarefa através de um projeto eugênico que bebia nas fontes do darwinismo social. Preocupados em encontrar uma especificidade na ciência brasileira, os peritos baianos da tradicional Escola de Medicina tiveram na teoria do enfraquecimento da raça uma "sinistra originalidade" (SCHWARCZ, 1993:277). O famoso Nina Rodrigues se destaca nesta cruzada embranquecedora: para ele a mestiçagem deveria ser condenada ao máximo.

Alguns intelectuais brasileiros do período acreditavam no mal da raça enquanto definitivo, outros enquanto reparável. De modo geral, no entanto, a Gazeta Médica da Bahia expressava em suas páginas pessimismo em relação ao futuro de uma nação inquestionavelmente mestiça. Fato que começa a ser mudado a partir da década de 1930, em que - de forma ainda hierarquizante - foca-se em um mal cultural e não mais estritamente racial.

Emblemático de tal processo seria o fato de a sociedade ser encarada como um imenso hospital (SCHWARCZ, 1993:300). Tentava-se das formas mais discriminatórias possíveis tornar o Brasil mais branco. O mito freyreano da mistura harmônica das três raças, bem como a ascensão do Estado Novo e sua narrativa em torno da democracia

\footnotetext{
${ }^{139}$ Sobre este estereótipo ainda tão frequente, Elisete Zanlorenzi disserta em O Mito da Preguiça Baiana. A autora demonstra que tal mito tem uma forte conexão com o racismo, tendo sido engendrado pelas elites baianas. A Ladeira da Preguiça, localizada no centro de Salvador, seria um recorte espacial capaz de expor esta ideia: "nos tempos da escravidão, e também depois dela, quem reclamava da íngreme travessia, carregando nas costas as mercadorias desembarcadas no porto, eram os negros - "preguiçosos" na visão desdenhosa dos brancos que, das janelas de seus sobrados, gritavam: 'Sobe, preguiça!" (MARQUES, 2004:85).
} 
racial, aos poucos vão mudando este discurso. A mestiçagem passa a ser vista enquanto diferencial brasileiro e um racismo mais escancarado passa à esfera velada.

É neste período que as elites baianas passam a exaltar a negritude enquanto característica do estado. A ideia de terra boa, terra da felicidade e de Salvador como uma cidade feliz tentam apresentar a região como portadora de um turismo que é vocação popular. A Bahia passa a ser mercantilizada em sua mestiçagem e o carnaval se torna palco-síntese deste processo (NOVA \& MIGUEZ, 2008). Como já dito nesta pesquisa, passa-se a ideia de uma musicalidade e alegria intrínsecas aos baianos, bem como de uma mestiçagem dócil e hospitaleira (DINIZ, 2009), mascarando, desta maneira, os conflitos e as desigualdades do local.

Vê-se nas últimas décadas que as elites baianas buscaram tanto demonstrar a aptidão estadual ao modelo capitalista de trabalho quanto exaltar uma estereotipada preguiça. A mestiçagem seria mercantilizada a ponto de, como expõem Nova e Miguez, a própria prefeitura soteropolitana anunciar em 2001 que o potencial turístico baiano se daria devido à presença de uma "raça única no país." ${ }^{140}$ Este processo mascara, sem dúvidas, não apenas a desigualdade racial do estado, como também os aspectos perversos de uma propaganda turística baseada na ultrassexualização das mulheres negras (DANTAS, 2013).

Percebe-se, deste modo, que o diferencial das elites baianas estaria - passada a obsessão pelo embranquecimento - na mercantilização de sua mestiçagem. A Bahia reconhece-se e é reconhecida enquanto preta. Vale lembrar que isto se dá, não só em um viés mercantil, como também de resistência. ${ }^{141}$ As diversas músicas que fazem menção ao estado como um território africano, uma Roma Negra e um país africano do Brasil ${ }^{142}$ mostram que esta imagem está pautada no imaginário social e é recebida em núcleos diferentes de maneiras variadas.

\footnotetext{
140 "Salvador é a mais bela cidade do Atlântico Sul. Tem uma posição privilegiada no mapa geográfico do Brasil, possui uma gente maravilhosa, hospitaleira e que tem uma enorme tradição de receber com todo carinho os visitantes. Salvador é a capital do Estado da Bahia. O berço da Nação brasileira, o local que originalmente sediou o Governo geral do Brasil colônia de Portugal e forjou uma rica cultura, onde há uma miscigenação de credos e raça única no país"(Prefeitura 2001) (apud NOVA \&MIGUEZ, 2008:12).

${ }^{141}$ Este viés de resistência não será tratado no presente capítulo justamente pelo foco nas narrativas dos grupos dominantes e pelo objetivo da pesquisa em geral de focar no viés opressor.

${ }_{142}$ Território africano estaria na composição Raiz de Todo Bem de Saulo Fernandes (2013). Roma Negra e Meca da Negritude são epítetos constantemente associados à cidade de Salvador; a primeira expressão é, inclusive, utilizada por Caetano Veloso na canção Reconvexo (1989). País africano do Brasil seria o modo pelo qual Tom Zé se referiria em 2008 ao estado na música Solvador Bahia.
} 


\section{8 - Pernambuco de Romero a Freyre}

É emblemático que o Instituto Archeologico e Geográfico de Pernambuco tenha sido fundado em 1862, quadragésimo primeiro aniversário da restauração brasileira frente ao domínio holandês. Com a tarefa de pautar o orgulho de ser pernambucano em tempos de declínio econômico e regional, o Instituto apresentava a expulsão holandesa como mérito maior do estado.

O evento histórico - que ganha ares de mito - passa a ser justificativa para um diferencial pernambucano: "foi uma luta desigual, mas nunca se viu tanta virtude, tanto heroísmo, tanta abnegação" (RIAGP, 1886:460-1). Junto com ele, a Revolução de 1817, bem como o ideal religioso e patriótico, apresentariam Pernambuco como defensor máximo da liberdade nacional, um Leão do Norte (SCHWARCZ, 1993:159).

Schwarcz aponta que o Instituto de Pernambuco talvez tenha sido a instituição brasileira que apostou mais explicitamente no branqueamento. Os estudos antropológicos tentariam atestar a existência de uma raça pernambucana, mais avançada em termos civilizatórios (SCHWARCZ, 1993:159).

Do mesmo modo, a Escola de Direto pernambucana buscava formar pensadores que mostrassem a independência do país na prática, que formassem a nação. Vale lembrar que as duas primeiras escolas de Direito do país foram fundadas em São Paulo e em Olinda (sede posteriormente transferida para Recife). Enquanto a Escola de Direito paulista associava-se a um viés de análise liberal, a Escola pernambucana focava na raça: era o Direito associado à biologia evolutiva, ao determinismo racial, a Spencer e Haeckel. Os estudos jurídicos acabavam por criar uma influente classe intelectual e política brasileira: "o Brasil depende exclusivamente de nós e está em nossas mãos. O futuro nos pertence" (in SCHWARCZ, 1993:197).

O mal estar frente a um país mestiço era óbvio. Como apostar em um futuro positivo se as teorias seguidas iam de encontro à condenação da mestiçagem? Foi Silvio Romero, nome mais destacado da Escola de Recife, que encontrou a solução capaz de manter intacta a discriminação e branqueamento almejados. Apontando a mestiçagem como saída, Romero defendia a viabilidade nacional a partir do branqueamento (SCHWARCZ, 1993:202). A junção de raças permitiria, nesta lógica, "a condição de vitória do branco no país", uma vez que sua pretensa superioridade aos poucos branquearia os elementos genéticos de negros e indígenas. 
A perspectiva freyreana sobre raça modificou esta aposta embranquecedora da intelectualidade do estado, especialmente no que diz respeito à zona açucareira pernambucana e nordestina de modo geral. Freyre não deixa quaisquer dúvidas sobre qual o tipo social daquela região: um mestiço. Este - chamado de cabra - segundo a perspectiva freyreana teria "possibilidades eugênicas magníficas" (FREYRE, 2010:50).

Já foi dito nesta dissertação que o autor endereça ao Nordeste, que para ele teria como centro Pernambuco, a importância de ter albergado toda a nacionalidade brasileira (FREYRE, 2010). Para Freyre seria tal fato que permitira a formação da fisionomia brasileira. A contribuição freyreana ${ }^{143}$ para a ideia enganosa de democracia racial teve coro pelo estado. O Manifesto Regionalista de 1926 foi um marco neste sentido: intelectuais pernambucanos juntaram-se para exaltar a tradição patriarcal açucareira e, de certa forma, os tipos sociais nela imersos. Características geográficas, arquitetônicas e culinárias eram exaltadas em contraposição ao estrangeirismo e ao modernismo que despontava especialmente em São Paulo. Os romances de 1930 viriam, em todo o Nordeste, endossar este choque frente à perda de tradições.

Vê-se, assim, que em Pernambuco a radical aposta no branqueamento foi contornada pela - também hierarquizante - lógica freyreana de elogio à mestiçagem. O mito estadual em torno da expulsão holandesa passou a narrar três heróis que comporiam a mistura racial brasileira: Camarão, um índio, Henrique Dias, um negro, e Vieira, um branco (SCHWARCZ, 1995). O estado é hoje considerado um dos centros intelectuais nordestinos e rivaliza com outras capitais brasileiras na produção artística, pautando-se enquanto centro de efervescência cultural. Neste processo, nota-se que a racialização de sua população, bem como sua demarcação econômica, adequa-se a um sistema nacional que tende a mascarar desigualdades.

\section{9 - A Criação do Mato Grosso do Sul}

A questão da identidade sul mato-grossense é marcada pela criação tardia do estado, ocorrida em 1977 quando da separação do Mato Grosso. ${ }^{144}$ Galetti (2000) aponta que no início do século XX as elites mato-grossenses engajaram-se para afastar a ideia de

\footnotetext{
${ }^{143}$ Vale repetir que as necessárias críticas a Freyre, acadêmicas ou não, dos movimentos negros e feministas chamam atenção ao fato de que ideias como a da doçura, suavizam a crueldade do regime escravocrata e patriarcal, engendrando a mítica democracia racial como pilar da sociedade brasileira.

${ }^{144}$ Que na época compreendia os estados de Rondônia e Mato Grosso do Sul.
} 
que a população do estado seria formada por bárbaros. Através deste esforço, criou-se o que Zorzato (1998, 2000) definiu como memória de consenso.

Queiroz (2006) indica que o estado sofria com o estigma de atraso, incivilidade, barbárie, preguiça e violência. Frente a isto, as classes intelectuais do local buscaram aproximar - tal qual os paulistas, mineiros e paranaenses - sua imagem ao bandeirante, o que permitiria o afastamento do estereótipo de selvagem. Do mesmo modo, se enfatizou a herança europeia, o patriotismo, um caráter forte, determinado e destemido (ZORZATO, 1998).

Como de praxe o Instituto Histórico e Geográfico do local possuiu papel ativo nesta empreitada identitária: buscou-se valorizar as características naturais da região, bem como apresentar um estado que seria defensor fronteiriço (QUEIROZ, 2006:153). O matogrossense apareceria enquanto um bravo homem ${ }^{145}$ que defende e doma o interior brasileiro. Nesta narrativa, a população do local é embranquecida através do afastamento do elemento indígena.

A ascensão econômica da porção sul do velho Mato Grosso causou desarmonia entre as elites sulistas e nortistas do estado. Campo Grande começava a, econômica e culturalmente, ascender demasiado rápido em relação a Cuiabá. Cuiabá passaria a ser chamada de burgo podre (GALETTI, 2000) e ser vista como menos civilizada e moderna.

Neste processo, a porção sul do estado, representada pela cidade de Campo Grande, passa a reivindicar um estreitamento com as tendências culturais e econômicas do eixo Rio-São Paulo. A racialização da população nortista ocorreria através da acusação de que esta estaria condenada pelo amarelão, enquanto o sul do estado, com a vinda de gaúchos, estaria pronto para a ascensão modernizante (GALETTI, 2000).

Essencial para esta pesquisa é resgatar o fato de que as elites sul mato-grossenses utilizaram o Conflito Constitucionalista de 1932 para pensar a divisão do estado, tendo este, durante o período, instaurado dois governos. As classes dominantes sulistas apoiaram São Paulo, enquanto as do norte seguiram com Getúlio Vargas. Esta divisão causou tal efervescência na relação regional que no fim do mesmo ano foi criada a Liga Sul Matogrossense (QUEIROZ, 2006:160). Queiroz defende que é neste período que começa a se gestar uma identidade local. Creio que seja importante pensar como para além da ideia de dois estados, estava a ideia de Dois Brasis: modernidade $\mathrm{x}$ atraso, sul x norte.

${ }^{145}$ De fato no gênero masculino. 
Neste sentido, a formação identitária do Mato Grosso do Sul se pautou em contraposição ao seu vizinho do norte, atribuindo a este decadência e atraso. Enfatizou-se a presença de imigrantes, como os gaúchos, e indicou-se, através da reivindicação econômica, ${ }^{146}$ que o Sul nada deveria ao Norte, sendo este muito menos bem sucedido economicamente do que aquele. Do mesmo modo, narrou-se a Guerra do Paraguai como o momento em que a região sulista teria defendido heroicamente o território brasileiro. $\mathrm{Na}$ questão racial, mencionava-se com orgulho uma eugênica mocidade sulista (QUEIROZ, 2006:166).

É interessante notar que as classes dominantes sulistas embalaram-se em uma narrativa semelhante a de São Paulo: não apenas na demarcação econômica e racial de seu imaginado grupo humano através da estigmatização de outro, como também valendo-se ocasionalmente de proximidade com a natureza paulista. Queiroz expõe, inclusive, que após a derrota de São Paulo na dita revolução, as elites sul-matogrossenses tornaram o discurso separatista mais brando, sendo que, posteriormente, este se intensificaria em determinados períodos.

Torna-se necessário salientar a verticalidade na separação destes dois estados: sem participação popular, o regime militar em 1977 teve motivos para formar uma nova base política estadual em momento de decadência do governo ditatorial (QUEIROZ, 2006:178). Neste período, retoma com velocidade o discurso em contraposição ao Mato Grosso: "sulista é paulista enquanto que o nortista é amazônico" (SALDANHA apud BITTAR, 1997:234). O Mato Grosso do Sul encarou tardiamente, portanto, a tarefa que foi comum a todas regiões ao fim do XIX e início do XX: manipular bens simbólicos que constituíssem um tipo social característico. O fato de ser recente este movimento permite desnaturalizar certas narrativas e explicitar seu caráter histórico, imaginado e político.

\subsection{0 - O Pará e a Porta de Entrada da Floresta ${ }^{147}$}

Na última década do século XIX foi fundado o Museu Paraense Emilio Goeldi (1891). No período, não só o boom da borracha trazia atenção ao estado: ao longo do século a região recebera uma série de pesquisadores estrangeiros. Estes, em seus estudos, exotizavam a fauna, flora e população local. A criação do Museu viria, deste modo, tanto

\footnotetext{
146 "Uma população desamparada sua, trabalha, amontoa riquezas, para gozo de outra, que se supõe com mais direitos!" (A divisão..., 1934:16 apud QUEIROZ, 2006).

${ }^{147}$ Expressão retirada da obra O Espetáculo das Raças (SCHWARCZ, 1993).
} 
como uma tentativa de tornar Belém uma Paris do Sol - modernizá-la - quanto como uma porta de entrada a estudiosos da exótica Amazônia (SCHWARCZ, 1993).

A boa localização do Museu se dava pela ideia de que o local seria o paraíso dos naturalistas (SCHWARCZ, 1993). Em uma época que vigorava o racismo científico, o estudo sobre populações originárias era visto como essencial para o entendimento hierarquizante acerca das diferenças humanas. Schwarcz expõe que se partia da flora e da fauna para chegar ao humano.

Neste sentido, a intelectualidade paraense utilizou como trunfo a não branquidade do estado:

Nessa região, raças cuja origem se ignora e a filiação se desconhece, cuja história não se sabe, existiram, viveram, lutaram, deixaram vestígios... Quem sabe senhores, se aqui não está a chave de um dos enigmas mais excitantes da curiosidade scientífica desses tempos: a origem do homem americano (BMPEG, 1894:67).

Deste modo, se as classes dominantes paraenses não invisibilizaram os grupos nãobrancos do estado, isto não se deu por um ideal igualitário. Ao contrário: seu uso poderia ser científico. Longe de pautarem-se enquanto indígenas ou mestiços, estes intelectuais portavam-se enquanto humano único, enquanto superior, enquanto estudiosos frente a um objeto de estudo. Vale lembrar que o diretor do museu era um evolucionista social convicto.

Esta identidade paraense conectada ao exotismo e à floresta amazônica pode ser analisada em tempo corrente. Gomes e Silva (2013) demonstram que o governo do estado empenhou-se, no final do século XX e início do XXI, a reafirmar um paraenismo:

Em nenhum outro lugar da vida cotidiana paraense a diversidade de elementos é tão marcante quanto a cultural. As influências indígenas, europeias e africanas formam a pluralidade do paraensismo, característica humana e sócio-cultural que o governo Almir Gabriel procurou resgatar desde 1995, deslanchando em todo o Estado um processo contínuo da afirmação da auto-estima paraense e das potencialidades regionais, que haviam se perdendo ao longo da história. (in GOMES, SILVA, 2013).

Neste sentido, ao longo do século passado, intelectuais, políticos e artistas se uniram frente ao domínio cultural do eixo Rio-São Paulo em uma cruzada de definição em torno da cultura paraense. A temática típica do século XIX acerca do caboclo e do ribeirinho, bem como da flora e da fauna local, ganham um aspecto de diferencial cultural. 
Episódios históricos como a Cabanagem foram mobilizados em manifestações políticas para denunciar a falta de investimento no local e o predomínio do sudeste na política brasileira. Gomes e Silva demonstram, inclusive, que a revolta foi apropriada conservadoramente durante a ditadura militar e o governo estadual de Jader Barbalho (GOMES, SILVA, 2013:178). Vale lembrar que a bibliografia especializada aponta na Cabanagem - que finalizou com a morte de 40 mil pessoas - um viés de resistência de índios e negros contra a opressão branca (NOGUEIRA, 2016:71).

No início do corrente século o empenho governamental voltou-se à expansão desta identidade sob o lema de a Amazônia é Brasil. Vê-se, assim, que a apreensão externa da identidade paraense esbarra frequentemente no espaço exótico, quase mítico, que o local preenche no imaginário nacional. Da mesma maneira, a história desta formação identitária segue, desde o século XIX, baseada na figura do indígena; apresentado constantemente enquanto outro.

Nogueira (2016), contudo, expõe que a reivindicação deste tipo social pôde ser problemática para esta formação regional idealizada, uma vez que é generalizada a ideia de que o índio está morto. Assim, a discriminação indígena - que há séculos já se constituiria na ideia falaciosa de repulsa ao trabalho - se reconfigura tanto na acusação de responsável pela própria pobreza quanto na negação de sua existência. Vaz (1996) indica os problemas em torno da conceituação de caboclo presente neste regionalismo, uma vez que caboclo é sempre uma categoria atribuída.

Neste sentido, Nogueira aponta que a constante do regionalismo amazônico, não só paraense, se concentraria na ideia de que o local é mais conectado à natureza do que à sociedade. Isto teria relação com o fato de que o regionalismo no Brasil constituiu-se em torno de elites agropecuárias, tendo vital importância a propriedade de terra, o poder local e central. Devido a seu diferencial no período colonial, de cunho especialmente extrativista, a região não possuía uma elite intelectual como outras regiões e, quando passou a ter, esta não seria natural da região (NOGUEIRA, 1999:73). Tais fatos levam que hoje, com uma classe dominante mais consolidada, o discurso amazônico se baseie na valorização, integração, segurança e desenvolvimento: o modo de fazer a área ser valorizada se concentra em apresentá-la enquanto patrimônio brasileiro. 


\subsection{1 - Dois Brasis Compactados no Eixo Rio - São Paulo}

A chegada da família real ao Brasil causou mudanças significativas na formação histórica do país. De início vale dizer que em tal período começou a surgir a preocupação em torno de uma História brasileira oficial, institucional. O Rio de Janeiro, como capital da nação, foi o local mais marcado por este empenho. Marco disto seria a fundação do Museu Nacional em 1818 com influência de D. João VI. Do mesmo modo, o primeiro local de pesquisa do país seria fundado na capital fluminense em 1839: o Instituto Histórico e Geográfico Brasileiro tentaria sacralizar-se enquanto guardião da História oficial através de uma produção unificadora que, embrionariamente, pensava e fazia a nação.

Ao longo do século XIX, outras instituições de saber foram fundadas em partes diversas do país. É interessante, contudo, que à instituição carioca era dado o papel de pensar o Brasil, enquanto as de outros locais focavam em suas especificidades regionais (SCHWARCZ, 1993). Vale lembrar da relação entre o Instituto do Rio de Janeiro e o imperador D. Pedro II.

Como já tratado no primeiro capítulo desta dissertação, o Museu Paulista é fundado (1895) em torno do ideal da glória paulista, indicando a ascensão de uma nova região como centro de poder. Os atritos entre este Museu e o Museu Nacional revelariam, em fase gestacional, um fenômeno ainda corrente: o embate regional entre Rio de Janeiro e São Paulo em torno da narrativa e poder de mando nacionais.

O saber institucional de ambos os estados engajou-se no propósito embranquecedor. No início da década de 1930 o Museu Nacional, todavia, passa a superar o racismo científico. O I Congresso Brasileiro de Eugenia, ocorrido em 1929, teve Roquete Pinto como expoente: este afirmaria o problema brasileiro enquanto uma questão de higiene e não de raça. Um caráter higienista que já havia tomado a então capital brasileira se torna mais patente. Vale lembrar que o sanitarista Oswaldo Cruz despontava há tempos enquanto nome importante na cruzada para limpar a nação. A Revolta da Vacina, ocorrida em 1904, foi um marco frente a esta higienização vertical e autoritária.

Em São Paulo, outro nome de destaque no discurso racial e medicalizante seria o de Monteiro Lobato. O autor, com o objetivo de limpar e modernizar o homem rural - este visto enquanto obstáculo à civilização - lançou o famoso Jeca Tatu no Almanaque Biotônico Fontoura. O escritor paulista condenaria o caboclo enquanto o pior do Brasil, tomando o estigma deste como inspiração para a construção do personagem. 
Moraes (1997) indica que a criação de Monteiro Lobato se daria justamente na época em que sua fazenda - herdada pelo avô no interior paulista - fracassara, sobrando a culpa ao trabalhador da terra. Este, personificado por Jeca Caboclo, é descrito enquanto piolho da terra, indolente, lento, sem vontade, beleza ou aptidão política. $\mathrm{O}$ escritor de Taubaté o compara ao italiano, sendo o estrangeiro tido como trabalhador e esforçado e o brasileiro acomodado: "do lado delle morava um italiano que já estava ficando rico. O homem trabalhava o dia inteiro e seu sítio era uma belleza. Por que não fazia Jéca o mesmo?"

Muito além do viés meritocrático, a personagem exprimia a preocupação racial de seu autor, adepto inquestionável das teorias do darwinismo social. Carola (2004) indica que o Jeca foi um marco divisório entre o mundo urbano e o rural, a modernidade e o atraso, o progresso e o mal racial: era o passado que precisava ser superado. Sucesso no Brasil inteiro este personagem apresentaria mudanças significativas em pouco mais de três décadas.

Park (1999) apresenta o diferencial do Jeca Tatu em três momentos. O primeiro (1912-14) seria representado pelo Jeca Caboclo que aparece tanto em A Velha Praga e Urupês, palavra que não por acaso significa fungo. O segundo (1920), Jeca Tatu e a Ressureição, apresentaria o personagem enquanto passível de cura mediante formas autoritárias de instrução e medicalização. O terceiro (1947), Zé Brasil - em uma inesperada guinada - mostra o problema do Brasil como a concentração de terra.

Neste período os paulistas - que até 1870 eram considerados demasiado provincianos para os cariocas - começam a rivalizar com os guanabarinos nas instâncias mais variadas. No discurso regionalista paulista, o Rio passaria a ser racializado. O seguinte dizer racista de Monteiro Lobato é elucidativo neste sentido:

Que contra-Grécia é o Rio! O mulatismo dizem que traz dessoramento do caráter. Dizem que a mestiçagem liqüefaz essa cristalização racial que é o caráter e dá uns produtos instáveis. Isso no moral - e no físico, que feiúra! (...) Os negros da África, caçados a tiro e trazidos à força para a escravidão, vingaram-se do português da maneira mais terrível — amualatando-o e liquefazendo-o (...) metade daquela gente não tem braço ou não tem uma perna, ou falta-lhes um dedo, ou mostram uma terrível cicatriz na cara. Como consertar essa gente? (...) Talvez a salvação venha de São Paulo e outras zonas que intensamente se injetam de sangue europeu. Os americanos salvaram-se da mestiçagem com a barreira do preconceito racial. Temos também aqui essa barreira, 
mas só em certas classes e certas zonas. No Rio não existe. (LOBATO, 1944: 133).

Machado (2016) demonstra que o meio futebolístico é também frutífero no estudo desta rixa estadual com viés racial. O futebol que chega ao Brasil como um sport fidalgo e civilizador mobiliza as duas capitais. Na imprensa de ambos os estados, se tenta privilegiar o futebol de um à revelia do outro. O regionalismo paulista que - já se pautava enquanto locomotiva do Brasil - justificaria vitórias brasileiras devido a jogadores do estado e acusaria derrotas pelos erros fluminenses.

A partir da década de 1930 os times brasileiros, especialmente cariocas, passariam a ter forte presença negra entre seus jogadores. Aos poucos, com a ascensão do mito da democracia racial, se começa a atribuir a negritude ao futebol brasileiro. Futebol Mulato seria, inclusive, o modo freyreano de se referir ao esporte. Machado expõe que este elogio à mestiçagem privilegiaria, em especial, as narrativas regionais carioca e nordestina. São Paulo, frente a isto, se posicionaria com um futebol bandeirante. No imaginário social, o Rio passava a aparecer como o drible, a ginga e a malandragem, enquanto São Paulo era a disciplina, a técnica e o pragmatismo.

Esta dicotomia entre futebol bandeirante e mulato seria mobilizada em momentos diversos. Em 1938 quando os jogadores cariocas Leônidas e Domingos da Guia se meteram em apuros com a polícia de Salvador, a imprensa bandeirante não tardou em anunciar que o que faltava ao futebol carioca seria a disciplina paulista. Enquanto este antagonismo esportivo - com forte viés racial - calcava-se em São Paulo através do ideal de racionalidade e supremacia, no Rio seria a democracia racial que, colocada como verdade nacional, introduziria o carioca enquanto malandro, um resumo bem humorado do jeitinho brasileiro.

Este apego ao ideal da malandragem fica claro em 1942, quando Zé Carioca, personagem de Walt Disney, chega às telas com Alô Amigos. Schwarcz (1995) defende que no período a mestiçagem moral e nacional se ressignificaria na malandragem, sendo que o próprio olhar estrangeiro apresentaria o malandro enquanto síntese nacional. A imagem do personagem - bem como o estereótipo do carioca em geral - teria caráter dúbio. Schwarcz indica que esta imagem ora estaria associada à atribuída vagabundagem, inaptidão ao trabalho, criminalidade e ora ao bom humor e alegria.

No cenário político da época, em que o Estado Novo buscava fortalecer uma coesa identidade nacional, uma série de elementos negros é apropriada para endossar a existência 
harmônica entre raças. Como já dito nesta dissertação, samba e capoeira, antes criminalizados, passam a ser exaltados enquanto cultura brasileira, a feijoada se torna prato típico e a padroeira brasileira, Nossa Senhora Aparecida, é instituída enquanto negra. Longe de indicar uma real democracia racial, Schwarcz expõe que este mestiço malandro enquanto síntese nacional apareceria, com o passar do tempo, cada vez mais embranquecido.

Nestas últimas duas décadas o estereótipo em torno dos tipos sociais paulista e carioca ainda possui relação estreita com o que foi pensado no século XX. O Rio de Janeiro, de algum modo, mobiliza-se simbolicamente enquanto local de convívio, junção. Há até um determinismo geográfico em tal imaginário: as praias da capital fluminense e os morros entre os bairros ricos permitiriam que o povo e a elite convivessem de forma democrática. O tema da violência urbana carioca, contudo, é usado de forma estigmatizadora para se referir ao local a partir de estigmas raciais e econômicos. De uma maneira ou de outra, o discurso oficial ainda procura apresentar o estado e - mais especificamente sua capital - enquanto exemplo de democracia racial.

São Paulo, por outro lado, que seguiu uma tônica muito mais embranquecedora que o Rio de Janeiro, oferece uma análise mais dúbia. Do mesmo modo que é colocada oficialmente enquanto a cidade mais cosmopolita do Brasil, seu regionalismo ainda se pauta - como mostrado recorrentemente nesta dissertação - em termos raciais e econômicos ligados à brancura. Isto se dá, na maioria das vezes, através de um discurso brando, assumindo o racismo à brasileira que, desde meados do século passado, procura esconder-se em uma pretensa cordialidade. Há, todavia, explicitação do mesmo em momentos políticos conturbados.

Essencial para esta pesquisa é o fato de que a ideia de dois Brasis distintos - um branco, civilizado, bem sucedido economicamente e outro atrasado, não-branco e pobre se ligam pela Rodovia Dutra. O discurso oficial paulista foi eficaz ao colocar o tipo social deste estado enquanto máximo da civilidade. Parafraseando novamente a frase de Weinstein (2007), no nível de representação o paulista aparece, indubitavelmente, como branco e de classe média.

O carioca, contudo, pode tanto aparecer enquanto um rico e branco morador do Leblon - como o horário nobre da Rede Globo de Televisão indica - quanto como um malandro estigmatizado racial e economicamente. O poder econômico do estado fluminense, bem como sua desigualdade geograficamente explícita, permite que se pense 
no Rio de Janeiro tanto pela exotização imputada às suas favelas quanto pela fetichização da Zona Sul de sua capital. Ora pobre e malandro, ora rico e bossa nova, o estereótipo do Rio de Janeiro cumpre a função de fundir realidades díspares.

A concentração de poder nacional, em diversos âmbitos, que marca estes dois estados, deixa nítido um embate entre narrativas raciais brasileiras. Mais velada em uns lugares e mais escancarada em outros, a prática racista segue, inquestionavelmente, uma realidade social da nação. Como já exposto, o fato de as polícias militares de ambos os estados causarem número alarmante de vítimas fatais através de seu racismo institucional é só mais uma prova disso.

\subsection{2 - Regionalizando Marcadores Sociais da Diferença}

O curioso ao estudar narrativas variadas em torno da questão identitária concentrase na facilidade, sobretudo das classes dominantes, em fechar os olhos frente à realidade social. Há uma negação do visível nos dizeres não tem negro no sul e no Ceará ou na aposta em afirmar-se uma democracia racial. Hobsbawm (2004) chamou atenção a este aspecto dos nacionalismos, uma vez que nações mobilizariam tradições inventadas para apresentarem-se enquanto superiores e antigas, até mesmo eternas. Para o historiador, caberia aos pesquisadores distinguir entre fatos históricos e ficções orquestradas em prol das elites.

Bourdieu (1989) defendeu que estes discursos regionalistas estariam em embate pelo poder de classificação. Neste caso a região deveria ser vista enquanto realidade, já que se apresenta como representação do real. Elias (1990), no entanto, atentou para a assimetria de poder entre nações. A questão da identidade - tão cara a alguns países - seria quase irrelevante para outros. Neste segundo caso estariam, por exemplo, França e Inglaterra que não precisariam engajar-se em questionar sua própria identidade: ela é um fato e basta (SCHWARCZ, 1995:3).

É refletindo sobre isto que me detenho a analisar a questão identitária do Brasil e de seus estados. Não hesito em afirmar a função política e econômica que tais narrativas nacionais e regionalistas cumpriram para as elites de um país na periferia do capitalismo global. Preocupa-me, para além disso, analisar os mecanismos com que estas tradições inventadas projetaram-se.

Narrativas regionalistas que apostaram na distante branquidade brasileira, jamais invisibilizaram por completo a majoritária população negra e indígena do país, engajada 
frequentemente em movimentos resistentes. De algum modo, porém, estereótipos regionais foram fortes o suficiente para pautar, típica e representativamente, certas populações enquanto brancas.

Sahlins afirma que "se a cultura é pública, seu significado sempre está em risco" (SAHLINS, 1990:3 apud SCHWARCZ, 1993). Entendo, neste sentido, que não se deu por falta de descontinuidades a eficácia relativa do discurso da elite paulista empenhada, nos últimos dois séculos, a apresentar o estado enquanto branco e bem sucedido economicamente. Da ponte pra $c a^{148}$ a uma rápida olhada por São Paulo vê-se que esta idealização foge da realidade. De alguma maneira, porém, este é um estereótipo que persiste.

Para destrinchar o porquê destas persistências é necessário analisar as descontinuidades do centralismo político brasileiro. A tensão entre o regional e o nacional teve como período marcante a Proclamação da República, dada a ocorrência da descentralização econômica e administrativa. Isto se mostraria um terreno fértil para o assentamento de regionalismos. Veio, porém, a República Nova que - com a emblemática queima de bandeiras estaduais comandada por Vargas - buscaria centralizar a nação, causando reação potente dos grupos dominantes de diferentes estados.

Como salientado no presente capítulo, a intelectualidade brasileira, em especial a geração de 1870, estreitou laços com propostas do darwinismo social. Torna-se importante destacar que estes pesquisadores não teriam sido meros recebedores das teorias europeias: um viés político esteve na eleição do racismo científico enquanto mote nacional. Como diz Cruz Costa, as teorias de Hegel e Kant poderiam ter sido escolhidas. Elegeu-se, de todas as formas, o conservador germanismo (CRUZ COSTA,1967:284). Um país que já era marcado por séculos de escravidão, passara a ser visto como laboratório racial. É por isso que a raça - que não tem validade biológica - opera como categoria relevante na análise brasileira. Ou melhor dizendo: o "racismo é um fato que confere à raça sua realidade política e social" (MUNANGA, 2009:15).

A mestiçagem enquanto diferencial brasileiro viria na tentativa de mascarar este racismo patente e de unificar a identidade nacional. Como já dito, o Estado Novo empenhou-se para instituir o ainda corrente mito da democracia racial através da apropriação de uma série de símbolos negros e indígenas. Vale lembrar que "a conversão

\footnotetext{
${ }^{148}$ Menção à música dos Racionais Mc's.
} 
de símbolos étnicos em símbolos nacionais não apenas oculta uma situação de dominação racial, mas torna muito mais difícil a tarefa de denunciá-la" (FRY, 1982:52).

Entre tais práticas de momentos históricos distintos - a saber, racismo explícito e racismo velado - algumas identidades regionais se assentariam. A seguinte tabela diz respeito a isto. Rio Grande do Sul, Paraná, Ceará, Mato Grosso do Sul e São Paulo seriam exemplos de estados que se constituíram identitariamente através de uma pretensa branquidade. É interessante notar, todavia, que apesar destes esforços, Ceará e Mato Grosso do Sul não alçaram nacionalmente sua imagem em estreitas relações com o ideal de civilização. Neste sentido que o desenvolvimento econômico regional se mostra conectado à narrativa da branquidade.

Tabela 4

\begin{tabular}{|c|c|c|c|}
\hline Estado & $\begin{array}{c}\text { Reivindicação } \\
\text { Racial }\end{array}$ & $\begin{array}{c}\text { Reivindicação } \\
\text { Econômica } \\
\text { Recorrente }\end{array}$ & $\begin{array}{l}\text { Atribuições } \\
\text { Externas }\end{array}$ \\
\hline RS & Branquidade & $x$ & Civilidade \\
\hline PR & Branquidade & $x$ & Civilidade \\
\hline MG & Miscigenação & & Atraso \\
\hline CE & Branquidade & & Atraso \\
\hline BA & $\begin{array}{c}\text { Mestiçagem e } \\
\text { Negritude }\end{array}$ & & Atraso \\
\hline PE & Miscigenação & & Atraso \\
\hline MS & Branquidade & & Incivilidade ${ }^{149}$ \\
\hline PA & Indianidade & & Incivilidade \\
\hline RJ & Miscigenação & & Malandragem \\
\hline SP & Branquidade & $x$ & Civilidade \\
\hline
\end{tabular}

\footnotetext{
${ }^{149}$ Como será mostrado nas próximas páginas, a ideia de incivilidade relacionada aos estados do Mato Grosso do Sul e Pará concentra-se na negação da existência de seus grupos humanos.
} 
Angela Davis indica que da mesma maneira que a classe informa a raça, o gênero e a raça informariam a classe (2016:12). A análise da autora é vital por nos permitir compreender o insucesso das elites cearenses e sul mato-grossenses em apresentarem-se enquanto brancas. Acredito que o pouco destaque econômico que estas regiões têm frente à concentração de poder no Sul brasileiro, não coaduna com o que é pensado de branco.

Com isto em mente, é preciso lembrar da desigualdade econômica com viés racial no Brasil. O estigma nordestino de classe não permitiria - qualquer que fosse o esforço da narrativa embranquecedora cearense - a eficácia do discurso das duas raças. Do mesmo modo, o Mato Grosso do Sul se vê embranquecido somente quando da inserção de seus migrantes gaúchos. Os naturais do local ainda sofrem o estigma de inaptidão ao trabalho, barbárie e periferia.

A relativa eficácia que Rio Grande do Sul, Paraná e São Paulo tiveram em pautar-se enquanto brancos e economicamente poderosos pode ser relacionada à eficiência que Bahia e Rio de Janeiro tiveram em apresentarem-se enquanto mestiçamente harmônicas. Do estereótipo do malandro carioca à baiana típica, se tem figuras evidentemente negras. Fenômeno que, como já visto, pode assumir tanto feições preconceituosas quanto resistentes. Creio que, de modo geral, seja interessante pontuar que estaria nesta ligação com a negritude a falta de uma reivindicação econômica destes estados. Mesmo o Rio de Janeiro, destacado centro comercial, não possui uma agressiva demonstração de supremacia econômica aos moldes do separatismo sulista ou do ideal de locomotiva brasileira típico de São Paulo. Acredito que a idealização em torno do capitalismo brasileiro em progresso, pouco se adequa às imagens não-brancas.

Os mapas a seguir são elucidativos no entendimento desta relação entre a classe, a raça e a atribuição de estigmas. Vale dizer que por terem sido retirados de websites humorísticos, sua fonte não é conhecida. Deste modo, não necessariamente quem os tenha feito, seja do estado mencionado em autoria. Creio, de todas as maneiras, que tais divisões regionais em muito se relacionam a um imaginário expressivo no senso comum brasileiro, concentrando-se aí a validade de sua análise. 

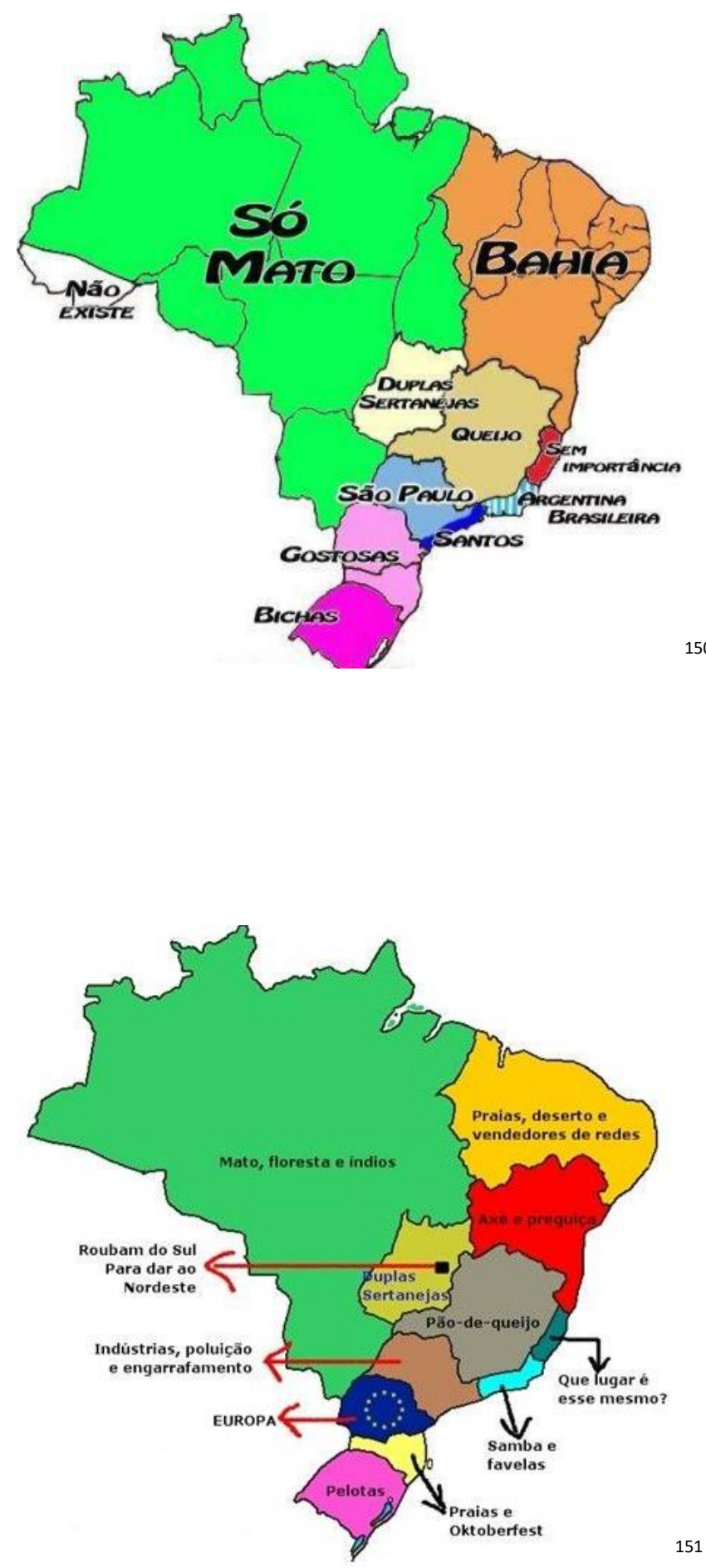

Imagem 5

"Mapa do Brasil Segundo as Paulistas"

Nota-se a continuidade de um estigma nordestino reduzido ao estereótipo da Bahia. Vê-se a desumanização que é imputada às populações do Norte e Centro-Oeste brasileiros.

Imagem 6
"Mapa do Brasil Segundo os
Paranaenses"
Vê-se novamente a desumanização
das populações do Norte e Centro-
Oeste. O Nordeste é dividido sob o
estigma da inaptidão ao trabalho
(preguiça) e pelo estereótipo de
suas paisagens. O Rio de Janeiro é
narrado como local estigmatizado
economicamente, enquanto São
Paulo aparece como símbolo de
urbanização.

150 Retirado em: IMAgINAÇÃo ATIVA. Mapa do Brasil Segundo os Paulistas. 2009. Disponível em: $<$ https://imaginacaoativa.files.wordpress.com/2009/06/1-mapa-brasil-paulista-oow.jpg> Acesso em: 10/11/2017.

${ }^{151}$ Retirado em: SE LOCALIZE. Mapa do Brasil Segundo os Paranaenses. 2012. Disponível em: <http://selocalize.blogspot.com.br/2012/09/mapas-do-brasil-segundo.html> Acesso em: 10/11/2017. 


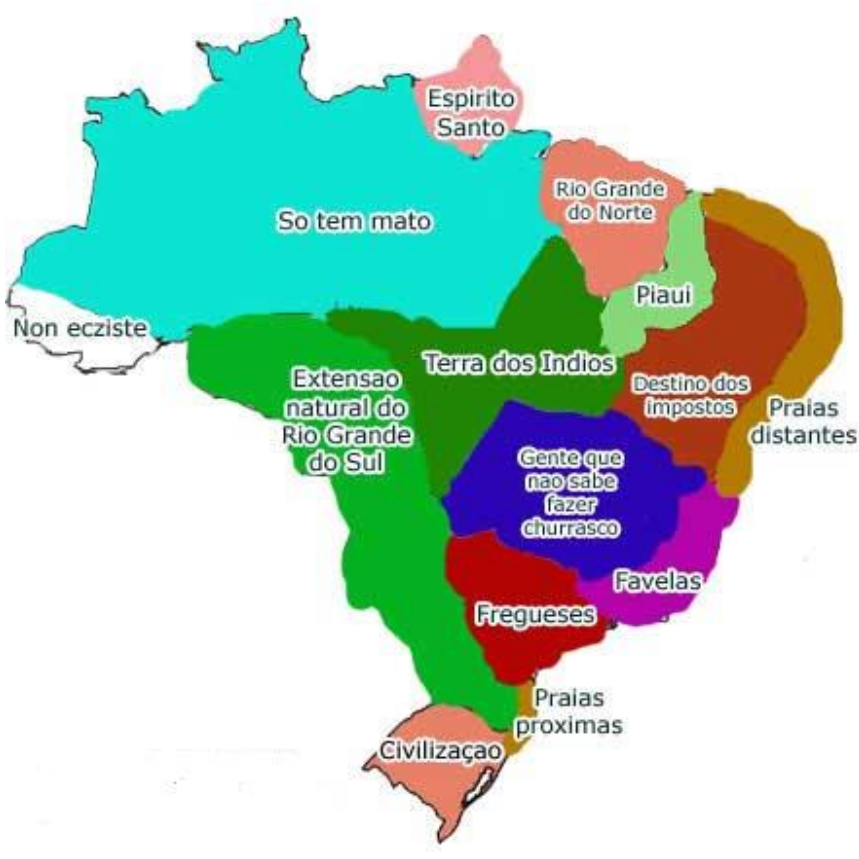

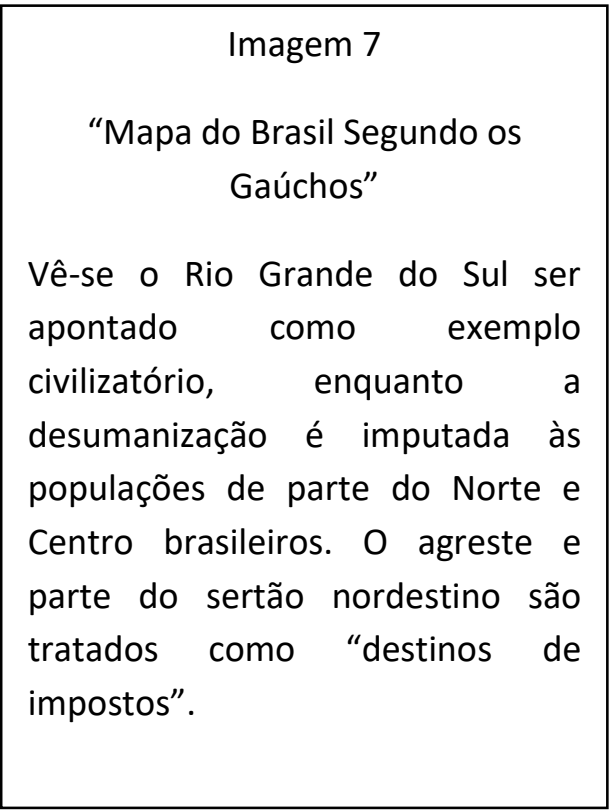

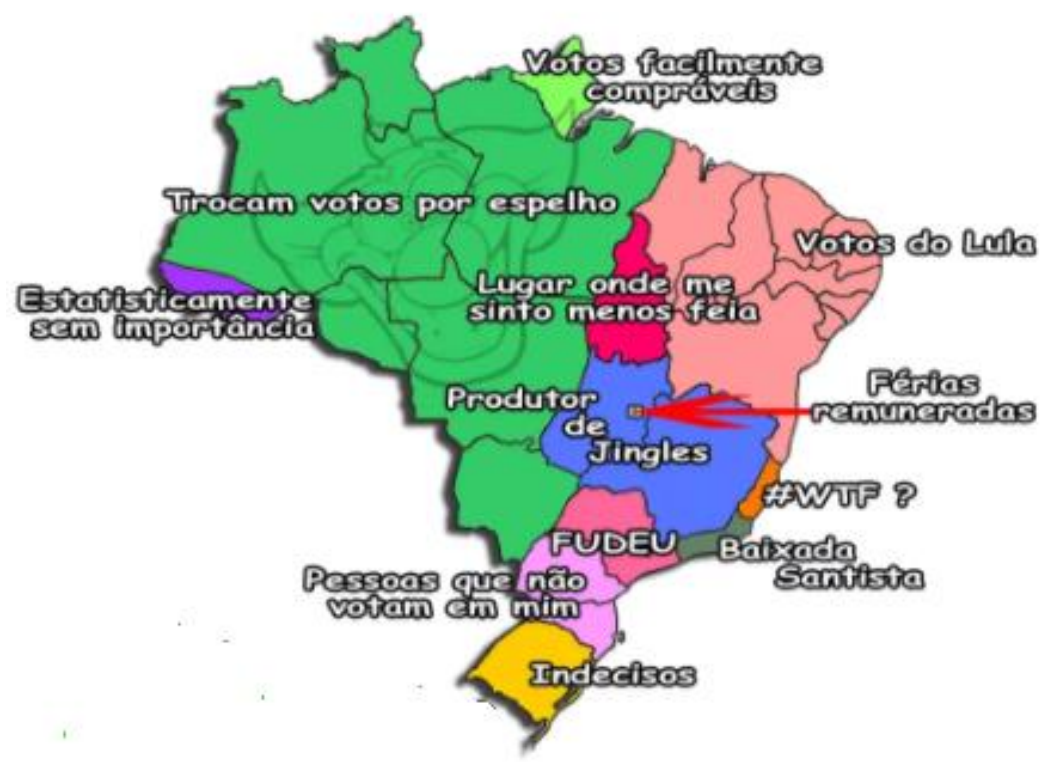

\begin{tabular}{|c|}
\hline $\begin{array}{c}\text { Imagem } 8 \\
\text { “Mapa do Brasil na Visão } \\
\text { de Dilma" }\end{array}$ \\
\hline $\begin{array}{l}\text { A imagem evidencia a } \\
\text { noção de Dois Brasis. } \\
\text { Enquanto a humanidade, } \\
\text { progresso e suposta } \\
\text { racionalidade política é } \\
\text { direcionada a um Sul } \\
\text { difuso, vê-se a } \\
\text { desumanização } \\
\text { preconceito contra } \\
\text { populações de um Norte } \\
\text { brasileiro abrangente. }\end{array}$ \\
\hline
\end{tabular}

152 Retirado em: ALAGOAS 24 HORAS. Mapa do Brasil Segundo os Gaúchos. (Ano não especificado). Disponível em: <https://www.alagoas24horas.com.br/683830/mapa-do-brasil-segundo-os-gauchos/> Acesso em: 10/11/2017.

${ }^{153}$ Retirado em: OS QUERIDÕES. Mapa do Brasil Segundo Dilma. 2010. Disponível em: <https://osqueridoes.wordpress.com/2010/08/18/mapa-do-brasil-na-visao-da-dilma/> Acesso em: 10/11/2017. 
Tais mapas indicam a reivindicação regionalista dos estados brasileiros que se afirmam, racial e economicamente, como o Brasil que deu certo. As ofensas neles contidas, indicam que gênero, sexualidade, raça e classe são elementos mobilizados para além de uma autoafirmação, tendo significativo poder para constituir o outro. Este outro, quando colocado em contraposição, é capaz de salientar uma visão de si. Novamente valho-me das ideias do Orientalismo de Said e da formação do Ocidente a partir da estigmatização oriental. Não estariam as narrativas defendidas nestes mapas tentando contrapor noções de civilização e atraso? De branquidade e miscigenação?

O mapa paulista possui, em síntese, atributos regionalistas típicos deste estado: a rivalidade com os cariocas, a redução do Nordeste ao estereótipo negativo da Bahia e restringimento considerável do Norte e Centro-Oeste brasileiros ao natural, aparecendo como irrelevantes seus grupos humanos. É curioso que o Rio de Janeiro aparecer enquanto Argentina brasileira, em nada teria a ver com o tipo racial representativo do país vizinho. Ao contrário: o foco está na rivalidade para com estes. Do mesmo modo, Paraná e Santa Catarina aparecem, em um viés sexista, a partir da sexualização de suas mulheres, frequentemente associadas à branquidade, à mancha loira brasileira. $\mathrm{O}$ uso de bichas como ofensa homofóbica direcionada aos gaúchos advém da associação deste tipo social masculino à falta feminina.

O típico gaúcho do pampa, desbravando a natureza sem companhia de mulheres, foi comumente associado, de forma jocosa e preconceituosa, à homossexualidade (MAESTRI, 2006). Da homofobia externa à interna, as populações LGBTQIA+ foram afastadas recorrentemente de reivindicações regionalistas oficiais: em 2002, um militante empunhando a bandeira do orgulho gay na Comemoração Farroupilha de Porto Alegre foi linchado por membros do Movimento Tradicionalista Gaúcho; em 2005 um professor foi expulso do Centro de Tradições Gaúchas de Passo Fundo por usar um brinco como acessório (MAESTRI, 2006:1). Creio que tal situação indique o que uma extensa bibliografia vem mostrando nos estudos raciais das últimas décadas: aos homens negros é recorrentemente atribuído um estigma de ultrassexualização viril. A branquidade regionalista reivindicar um gaúcho macho, "mas tão totalmente macho" (MAESTRI, ibdem) poderia apresentar uma resposta branca a esta visão.

Voltando aos mapas expostos, vê-se que as narrativas paranaenses e rio grandenses, seguem a lógica, também paulista, da contraposição entre progresso e atraso. O Rio de Janeiro aparece conectado a um estereótipo racial que é exotizado pelo samba ou pela 
favela. O Nordeste e o Norte são expostos a partir do lazer, da pobreza e da desvalorização de seus grupos humanos: ou estes não existem ou são apresentados como inferiores.

Neste sentido, é interessante que Brasília apareça no mapa paranaense como o local que roubaria o dinheiro do estado para deslocá-lo ao Nordeste, sendo esta região, portanto, culpada de males variados mesmo quando não está em foco. Tão clássico quanto isto são os gaúchos, articulando seu argumento em torno da ocupação territorial e naturalizando uma porção central e sul do país como sua. Vale salientar que nestes mapas é possível discernir entre rivalidades brandas e racializadas: nitidamente "axé e preguiça" (Bahia) têm, tanto em nível quanto em essência, uma crítica diferente de "indústrias, poluição e engarrafamento" (São Paulo).

Dentro desta mesma reflexão se pode analisar o mapa do Brasil segundo a presidenta ${ }^{154}$ deposta Dilma Rousseff. Uma acepção conservadora em torno da inaptidão política brasileira - exacerbada no regionalismo paulista tanto em 1932 e 1964 quanto em 2010 e $2016^{155}$ - procura apresentar o espetro político do país sob uma contraposição arbitrária entre barbárie e vocação política. Para além da preconceituosa conexão entre a indianidade do Norte e Centro brasileiros e um escambo eleitoral imaginado, o Nordeste é, majoritariamente, pensando enquanto eleitor do ex-presidente Lula. Grupo eleitoral que, como será exposto no próximo capítulo, é estigmatizado no contexto atual em uma narrativa conservadora acerca do Programa Bolsa Família. Não à toa o país que se narra branco e de sucesso econômico - Paraná, Santa Catarina e São Paulo - aparece como avesso à política de Dilma. Emblemático é o caso do Rio Grande do Sul - até 2015 sob o governo do petista Tarso Genro - aparecer como indeciso. Até quando criticado, o estado sulista não sofre ofensas por um viés racializado ou economicista.

\footnotetext{
${ }^{154}$ Como já dito anteriormente, opta-se pelo uso de tal vocábulo no feminino apesar de sua inexistência formal.

${ }^{155}$ Em 1932, os discursos majoritários da paulistanidade bradavam por um estereótipo do nordestino - ser arcaico de inaptidão política - como responsável pelo domínio de Getúlio Vargas. O Golpe de 1964 e suas devastadoras consequências também possuem forte conexão com um discurso paulistanista que alberga em si tanto a afirmação dos paulistas como detentores do saber político legítimo quanto a acusação dos nordestinos como grupo caracterizado por uma ignorância e má fé política. Em 2010, sob a alcunha de Mate um Nordestino Afogado e em 2016, quando do golpe de Estado, o discurso da paulistanidade responsabilizou eleitores nordestinos pelo governo petista. Este tema é tratado com maior profundidade no quarto capítulo desta dissertação.
} 


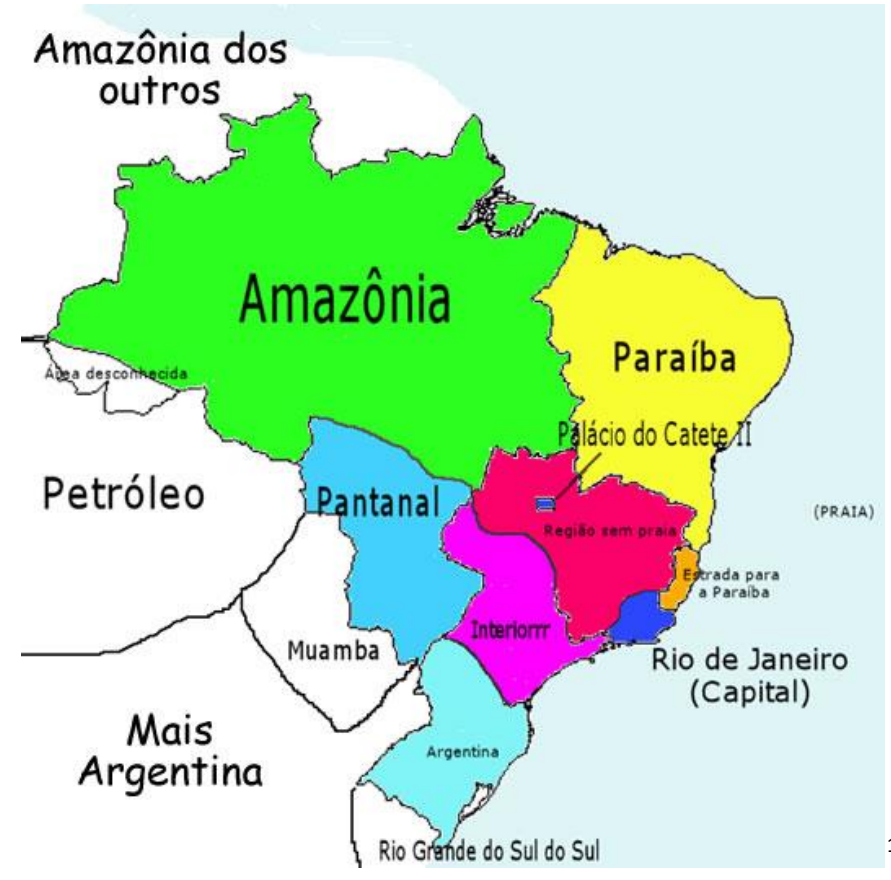

"Mapa do Brasil Segundo os
Cariocas"
"â-se a associação do Norte ao
natural e do Nordeste a um
estereótipo negativo de paraíba. O
Sul brasileiro é associado à
Argentina, país simbolizado por
uma aproximação à europidade. O
Rio de Janeiro se apresenta como
central aos destinos brasileiros e
rivaliza com São Paulo e parte de
Minas Gerais indicando o
provincianismo dos estados.

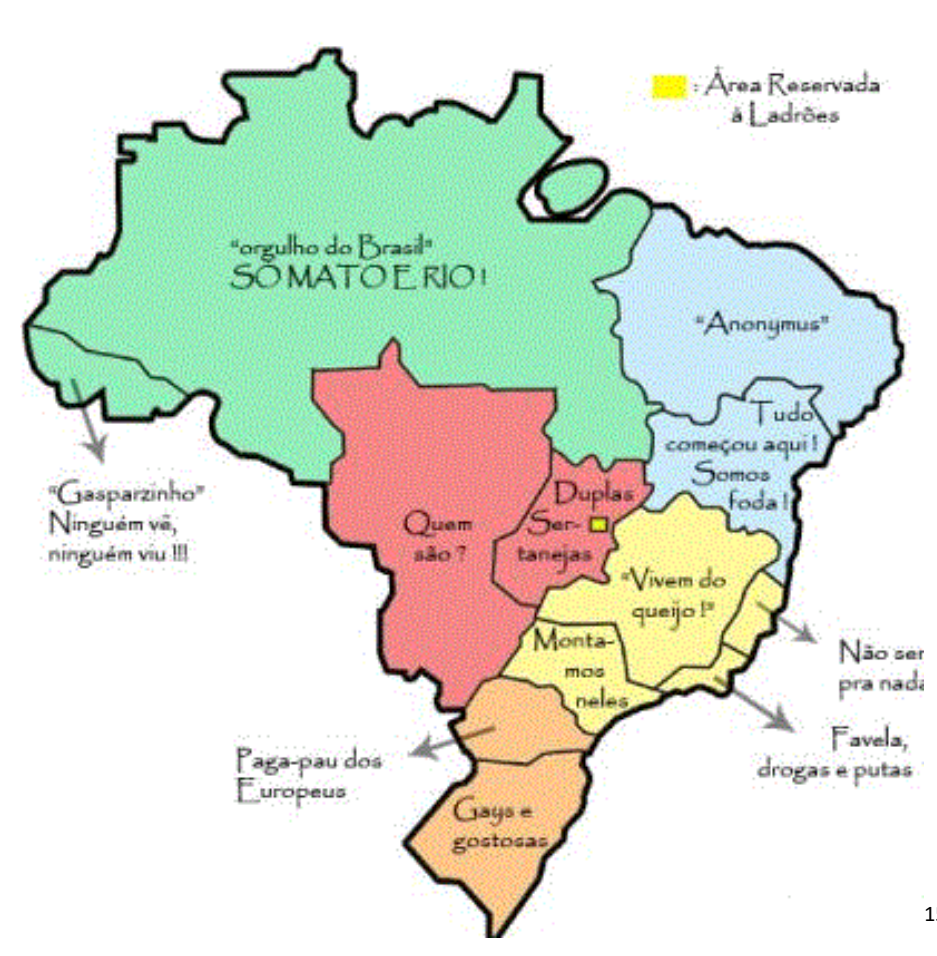

\section{Imagem 10}

"Mapa do Brasil Segundo os Baianos"

Vê-se a desumanização imputada ao Norte brasileiro e a mobilização de atribuições homofóbicas e sexistas para se referir à parte do Sul, que também é visto como aproximado à Europa. O Rio de Janeiro é estigmatizado por uma demarcação econômica e pelo estereótipo direcionado às mulheres. A Bahia mobiliza a narrativa de pioneira do Brasil e a área mais setentrional do Nordeste é tachada como irrelevante.

\footnotetext{
156 Retirado em: SE LOCALIZE. Mapa do Brasil segundo os Cariocas. 2012. Disponível em: <http://selocalize.blogspot.com.br/2012/09/mapas-do-brasil-segundo.html> Acesso em: 29/04/2018.

157 Retirado em: REAL TRADER. Mapa do Brasil Segundo os Baianos. 2012. Disponível em: <http://www.realtrader.com.br/forum/view.php?bn=realtrader_forumbrsm\&key=1341455059\&v=t> Acesso em: 13/11/2017.
} 


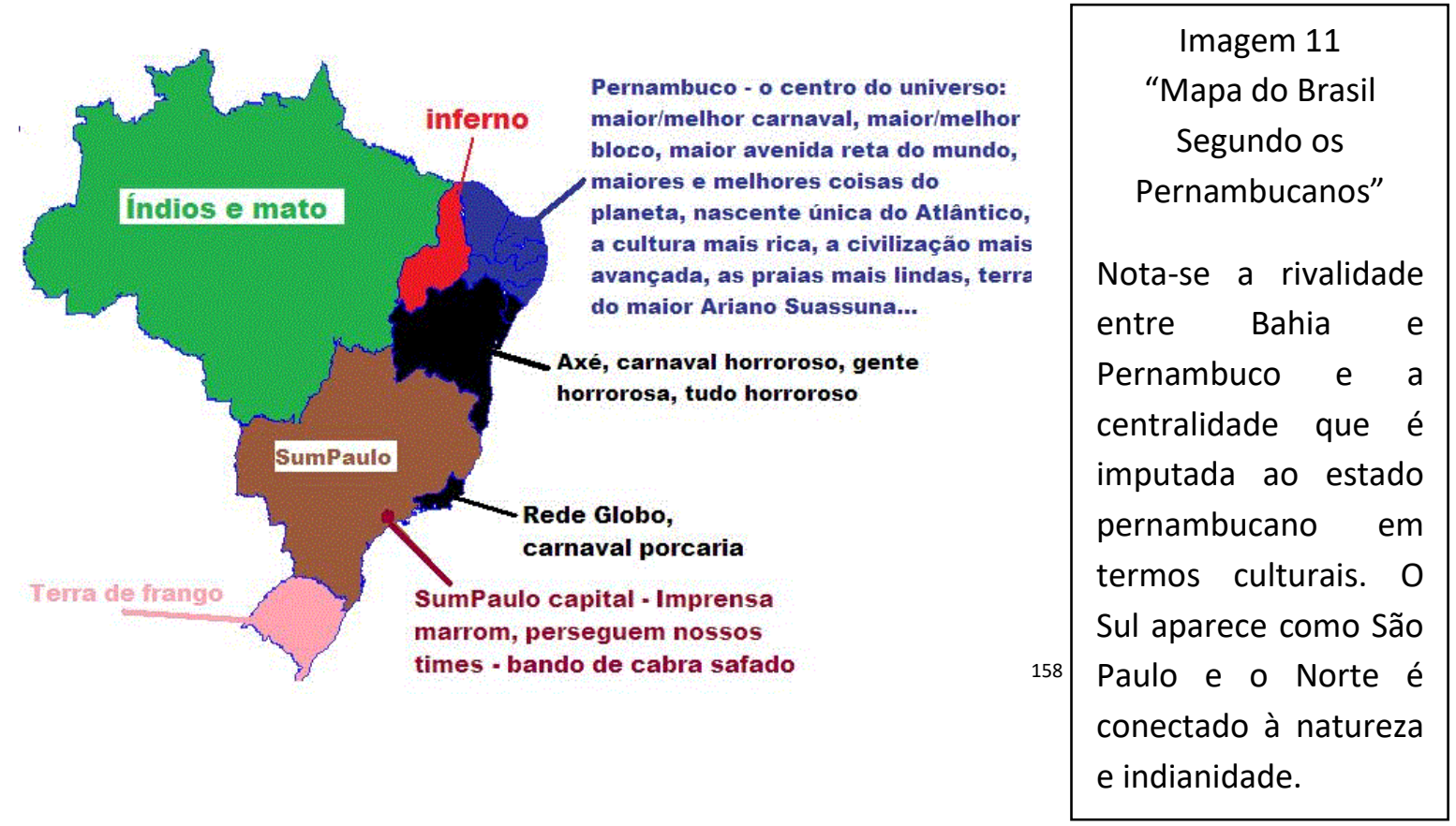

Estes mapas dos estados do Rio de Janeiro, Bahia e Pernambuco permitem expor uma racialização persistente em locais que, regional e historicamente, pautaram-se no mito da harmonia das três raças. O mapa do Rio de Janeiro é tachativo ao reduzir o Nordeste a um negativo estereótipo da Paraíba. Do mesmo modo, conecta o Norte ao natural, o Sul à exclusão nacional e São Paulo e parte de Minas a um interior difuso, em uma já antiga menção ao suposto provincianismo, caipirismo, destes locais. Apresenta-se, deste modo, como central para o Brasil, querendo enfatizar um poder de mando que não teria se perdido com o deslocamento da capital: o Palácio do Catete seguiria em Brasília.

Os mapas baianos e pernambucanos indicam como a estigmatização nordestina pode ser direcionada a outras partes do Nordeste. O mapa da Bahia concentra este estigma na área setentrional da região, enquanto o mapa pernambucano endossa esta ideia atacando o território baiano. Ambos os mapas expõem a associação do Rio Grande do Sul à homossexualidade e de um abrangente Norte à inexistência humana.

Interessante no mapa de Pernambuco seria a associação do Sul também à europidade e à ultrassexualização de suas mulheres, constantemente imaginadas enquanto brancas. A ancestralidade está, no ponto de vista baiano, da mesma forma que a centralidade/originalidade no pernambucano. O diferencial destas narrativas estaria no passadismo e apego à cultura que buscam pautar os estados. Diferentemente dos mapas do

158 Retirado em: REAL TRADER. Mapa do Brasil Segundo os Pernambucanos. 2012. Disponível em: <http://www.realtrader.com.br/forum/view.php?bn=realtrader_forumbrsm\&key=1341455059\&v=t> Acesso em: 13/11/2017. 
Paraná, Rio Grande do Sul e São Paulo não se vê uma aposta no ideal de progresso, mas sim de tradição.

Todas as formulações estaduais expostas neste capítulo apresentaram a reivindicação de certos tipos sociais, econômicos e raciais, bem como de eventos históricos capazes de gerar heroísmo e um diferencial frente ao todo nacional. Em suma, buscaram explicitar uma contribuição regional específica à nação. Esta tanto pode ser forjada pela Guerra do Paraguai, por Farrapos, pela Inconfidência ou pelo ideal de ancestralidade, quanto pela miscigenação das três raças ou branquidade. Acredito, todavia, que devido à disparidade brasileira de poderio regional, algumas narrativas regionalistas tiveram eficácia mais ampla na temática do progresso.

Rio Grande do Sul, Paraná e São Paulo afirmarem tão recorrentemente serem dotados de uma potência econômica - carregar o Brasil nas costas, em bom e preconceituoso português - possui relação com as migrações europeias ocorridas nestes locais ao fim do século XIX e início do XX. Passada a Segunda Guerra e com ela a associação de grupos europeus e japoneses ao fascismo, se pôde, de maneira mais livre, reivindicar uma brasilidade baseada na mescla embranquecedora.

Do mesmo modo, o assentamento do eixo econômico no sul e sudeste brasileiros deixava um Norte abrangente no passado. Quem pôde se exibir enquanto futuro branco e bem sucedido economicamente tinha tanto a migração branqueadora quanto a ascensão econômica em mãos. Apesar da consagração nacional de um discurso da democracia racial, afirmar-se branco continuava - mesmo que veladamente - melhor no pensamento racista das classes dominantes destes estados.

É neste sentido que tantos grupos estaduais reivindicaram aproximação com a paulistanidade a partir do século XX. O discurso paulistanista despontara no Brasil como a mais eficaz afirmação de supremacia regional (WEINSTEIN, 2015). Não à toa Mato Grosso do Sul e Paraná buscaram em determinados momentos se associar a este caráter bandeirante que - antes reivindicado por tantos - se tornou a consagração de São Paulo. Era melhor ser ligado ao tipo paulista que era pensado em termos de progresso e branquidade do que ao sertanejo estigmatizado. $\mathrm{O}$ mineiro ser frequentemente chamado de baiano cansado porque não teria conseguido chegar ao estado de São Paulo (ANDRADE apud FREYRE, 2010:13), indica que estes supostos dois Brasis tinham como contraposição marcante no espectro de poder os imaginados progresso paulista e atraso nordestino e nortista. 
Por óbvio, há descontinuidades e contradições nestes discursos. Os reducionismos com que são tratados estados e regiões não permitem abarcar especificidades: um Rio de Janeiro pensado enquanto Leblon é diferente do Rio de Janeiro do Complexo do Alemão; a Minas Gerais de Belo Horizonte é oposta ao sertanejo norte mineiro; a São Paulo dos manos é vista com diferença em relação à Avenida Paulista. É pensando nisto que saliento a generalização dos discursos analisados: para além de suas narrativas irem, frequentemente, em direção oposta à composição social, estas não dizem respeito a um todo regional.

Tendo isto em vista, defendo que alguns estados terem narrado historicamente uma pretensa harmonia e igualdade raciais, não aboliu o racismo cotidiano nestes locais. Do mesmo modo que o carioca - racializado como malandro e vagabundo - se vale do estigma paraíba para indicar uma pretensa superioridade, cearenses - tão conectados a baiano no imaginário paulista - podem relegar a estigmatização nordestina à Bahia, assim como baianos constantemente o fazem em relação ao Ceará. Isto torna possível ver que atributos de estigma são constantemente afastados em narrativas regionalistas.

Do mesmo modo, o tipo social regional ser constantemente pensado enquanto masculino, endossa o caráter patriarcal da sociedade brasileira. Weinstein (2015) e Oliven (1992) expuseram que as mulheres gaúchas e paulistas foram, frequentemente, diferenciadas das outras brasileiras. Nestas narrativas regionalistas, sua superioridade seria justificada por uma imaginada cor branca e pelo fato de que esperavam seus desbravadores homens bandeirantes e gaúchos em casa. ${ }^{159}$ As figuras femininas no argumento freyreano também seriam constantemente evocadas para descrever os tipos sociais nordestinos. A suposição fantasiosa de Freyre acerca de uma doçura na relação entre mulheres negras e indígenas com os homens brancos, chega a atribuir certo destaque ao feminino nos estudos do autor.

Em todas estas distintas argumentações regionais, contudo, a mulher aparece como complementar, inferior em relação ao tipo masculino que é oficial e externalizado. Vale lembrar de rivalidades regionais que utilizam categorias sexistas em um embate argumentativo em torno da mulher típica: acusa-se uma beleza ou feiúra, bom ou mau comportamento. De um ou de outro modo, a mulher aparece sem vez ou voz, passível de análise e crítica, constantemente associada à estética e a um comportamento sexual

\footnotetext{
159 Insere-se aqui a racialização deste estereótipo que, para além de restringir o feminino ao espaço privado, nega a existência de mulheres negras e indígenas que - ativa e historicamente - ocuparam o espaço público.
} 
regulado. Neste sentido, nota-se o que expressou Gilroy (2001) acerca da formação da nação, da raça ou da região: estas ideologias se sustentam no ideal hierárquico que beneficia a masculinidade.

O gênero, a orientação sexual, a classe e a raça estarem entrelaçados nas mais distintas formulações regionalistas torna possível explicitar a hierarquia contida nas relações regionais, uma vez que tais elementos estão conectados organicamente à estratificação da sociedade. São Paulo, tão empenhada em uma especificidade, teria um regionalismo com características semelhantes a tantas outras manifestações brasileiras: apego a eventos históricos imaginados, tipificação racial e reivindicação de supremacia econômica. Se é possível falar de excepcionalidade, esta estaria na concentração de poder do estado paulista e em como isto engendraria a eficácia de seu discurso.

Do mesmo modo, apresentei que certos estados, mesmo imersos em um cenário brasileiro de insistência no discurso da democracia racial, recorrem, frequentemente, a um ideal de branquidade. Creio que com isto seja possível pensar na mítica democracia racial em corrente contraposição à branquidade e não apenas em um plano sequencialmente histórico de abordagens distintas em torno da raça. Do racismo científico e do darwinismo social não se chegou total e continuamente no mestiço enquanto tipo nacional. Sem dúvidas é inquestionável a generalização do discurso da miscigenação das três raças no território brasileiro. Defendo, contudo, que a adequação de algumas regiões a ele seria mais incômoda e parcial, tendo em vista o apego ao ideal branqueador.

Alves (2017) indica um deslocamento na fronteira racial brasileira que iria, com o passar do tempo, representar uma branquidade cada vez mais sulina. Neste sentido, creio que seja possível perceber na paulistanidade uma reviravolta em sua discursiva racialista. Exemplo disso seria o fato de que os últimos anos mostraram uma inusual retomada do carnaval de rua na capital do estado. Com um viés elitista - como de praxe em diversas regiões do país - priorizou-se os foliões dos bairros nobres. Assim mesmo, um carnaval domesticado recorrentemente, ganhou espaço nas ruas. É interessante, contudo, que uma cidade que já foi chamada de túmulo do samba ${ }^{160}$ tenha tido neste período uma parcela da classe dominante reivindicando, rivalizando - e também embranquecendo - um símbolo tão conectado ao Brasil mestiço, à Bahia, Recife, Olinda e Rio de Janeiro.

${ }^{160}$ Expressão atribuída ao poeta Vinícius de Moraes. 
Coexiste neste fenômeno tanto uma parcela branca que ocasionalmente reivindica e apropria atributos negros - "Seu filho quer ser preto? Rá, que ironia!",161 - quanto o recrudescimento de discursos resistentes que não deixaram ícones de uma cultura constantemente folclorizada ou apropriada serem invisibilizados. Se como Sahlins diz, a cultura é pública e está sempre em risco, concluo que uma cultura da branquidade e sucesso econômico em São Paulo é frequentemente - e em concomitância - articulada e combatida.

${ }^{161}$ Trecho da música Negro Drama dos Racionais MC's. 
PARTE II 



\section{CAPÍTULO IV}

\section{Crise Política, Legitimidade Eleitoral e Discriminação Analisando o Gradiente da Paulistanidade}

\section{1 - Tinha que ser Nordestino: Paulistanidade e Crise Política}

Apresentarei neste capítulo uma análise sobre o gradiente da paulistanidade. Isto será feito a partir da investigação de eventos históricos marcados pela efervescência política, de notícias sobre discriminação ou preconceito regional que foram veiculadas nos últimos anos e de grupos adeptos ao regionalismo de São Paulo. Objetivo, a partir desta análise, mostrar a recorrência conservadora de parcela significativa dos movimentos mobilizados em prol do orgulho paulista.

Do mesmo modo, me empenharei em realizar um exercício caro aos estudos regionais: buscar entender quando um ideal de superioridade e preconceito latente pode se converter em ódio e discriminação, em mobilização política. Com o objetivo de responder estas perguntas, apresentarei contextos variados em que é possível refletir sobre o assunto.

Inicio esta discussão a partir do estudo de eventos históricos que engendraram narrativas da paulistanidade, uma vez que esta frequentemente aparece como propositora política. Tal aspecto foi expressivo durante o Conflito Constitucionalista. Como já dito nos capítulos anteriores, não há dúvidas de que em 1932 os discursos majoritários da paulistanidade afirmavam um estereótipo do nordestino - enquanto ser arcaico de inaptidão política - como responsável pelo domínio de Getúlio Vargas no Brasil. Afirmava-se que a culpa de o país não ter uma Constituição seria desta população, considerada tão atrasada, que nem mesmo percebia o que estava acontecendo. A ideia era de que a alienação era tanta que ao nordestino restava apoiar, ou por interesses indignos ou por ignorância, um poder maléfico para o país, para São Paulo. A narrativa engendrada, portanto, caracterizava os paulistas como grupo dotado da sabedoria política que constitucionalizaria o país.

O Golpe de 1964 também possui conexão com o discurso paulistanista que alberga em si tanto a afirmação dos paulistas como detentores do saber político legítimo quanto a acusação dos nordestinos como grupo caracterizado pela ignorância e má fé política, aparecendo estas até mesmo como perigosas para o país. À luz disso, Barbara Weinstein (2015) atenta a dois editorais do jornal O Estado de S. Paulo acerca do golpe militar 
brasileiro. Estes documentos evidenciam a relação entre o dado regionalismo e as mobilizações políticas do contexto. O primeiro, Os Paulistas e a Nação em Perigo ${ }^{162}$ de 21/03/1964, e o segundo, São Paulo Repete $32,{ }^{163}$ de 01/04/1964, publicado na manhã do Golpe.

No editorial anterior ao Golpe Militar se vê o enaltecimento dos paulistas. Os mesmos paulistas que haviam lutado contra "a soldadesca de Getúlio Vargas" (OESP, 1964:4), marchavam sóbria e racionalmente pelo bem do país inteiro contra quaisquer ares perigosos que pudessem vir de Moscou: era da reacionária Marcha com Deus Pela Família e Liberdade de que se falava. Afirmava-se, ainda, que se em 1932, com apenas 5 milhões de habitantes, São Paulo havia sido capaz de empreender uma guerra em defesa de seu "território sagrado", em 1964, portanto, não haveria força capaz de deter esta "raça" (OESP, 2964:4) na missão de proteger todo o Brasil frente ao perigoso governo de João Goulart.

O outro editorial, publicado na manhã do Golpe de 1964, é claro em seu título: São Paulo havia repetido os feitos de 32. E, neste caso, repetir seria mostrar e supervalorizar o domínio do estado: a raça paulista - que jamais se submete - não admitiria conluios sindicalizantes do então presidente João Goulart; seria o "governo bandeirante" que se levantaria contra os perigos comunistas. Foi com este tom que grande parte da imprensa de São Paulo comemorou o golpe militar brasileiro. Os editoriais expostos não apenas o defendem como o creditam a um povo paulista teórico e valoroso, como se este estivesse sempre à frente do resto do país.

Outro episódio emblemático no que concerne ao regionalismo paulista enquanto mobilização política conservadora seria a repercussão contra a vitória de Luiza Erundina, política nordestina filiada na época ao Partido dos Trabalhadores, como prefeita de São Paulo nas eleições de 1988. O Centro de Tradições Nordestinas, inaugurado pela prefeita em 1991, chegou a ser baleado e pichado ${ }^{164}$ em 1992 com ofensas e ameaças às populações oriundas do Nordeste. Nesta lógica, seria a presença destes na capital paulista que explicaria os resultados eleitorais. É curioso pensar no espectro político da dada eleição:

\footnotetext{
162 Retirado em <http://acervo.estadao.com.br/pagina/\#!/19640321-27274-nac-0003-999-3-not> Data da última visita: 29/03/2017.

${ }^{163}$ Retirado em <http://acervo.estadao.com.br/pagina/\#!/19640401-27282-nac-0003-999-3-not> Data da última visita: 29/03/2017.

${ }^{164}$ Como pode ser visto em NAÇÃO NORDESTINA. Facebook. Disponível em: <https://ptbr.facebook.com/nacaonordestina/photos/a.306157526084157.82461.306125182754058/5536 27238003850> Acesso em: 29/03/2017.
} 
Paulo Maluf disputara contra a então prefeita. Novamente em um discurso de direita, o nordestino, enquanto atrasado, prejudica São Paulo.

Como tantas vezes comentado nesta dissertação, o mesmo se deu quando das vitórias de Dilma Rousseff, em 2010 e 2014, como presidenta do Brasil. O argumento, que chegou ao ponto de incitar o afogamento de nordestinos, baseava-se na ideia de que o Nordeste seria responsável pela vitória da candidata. Discursos como "temos que proibir o povo de porteiros e empregadas de votar" e "são parasitários dependentes de Bolsa Família" indicavam revolta com o resultado eleitoral, bem como a mobilização de preconceitos raciais e econômicos para expressar o descontentamento. ${ }^{165}$ Muitos afirmaram uma impossibilidade de continuar vivendo no Brasil em vista do resultado do pleito: como se o país fosse atrasado e incivilizado demais para os paulistas. Os nordestinos apareceriam, assim, como pedintes: mortos de fome ${ }^{166}$ que trocariam votos por bolsas e viveriam em uma relação cíclica de clientelismo. É essencial pautar que nesta lógica os auxílios governamentais são vistos como favor, como vergonha. Da mesma forma, ofendese os nordestinos em relação a suas supostas raça e classe como se estas fossem, por si só, ofensivas.

E quanto a 2016? São Paulo teria repetido $32^{167}$ no processo de golpe ${ }^{168}$ que depôs Dilma Rousseff como presidenta da República em 31/08/2016? Teriam os paulistas que incitaram o afogamento de nordestinos devido à vitória da ex-presidenta finalmente remediado o erro dos eleitores do Nordeste? Foi com esse discurso paulistanista que grupos regionalistas paulistas ${ }^{169}$ se mobilizaram diante da questão. Um exemplo disso seriam as imagens expostas nas próximas páginas que, compactando uma série de símbolos, mostram os bandeirantes retirando Lula - ícone nordestino do Partido dos Trabalhadores - do poder. Nesta narrativa, novamente os paulistas - jamais submetidos a ditaduras - salvaram a pátria. Torna-se essencial notar que o estigma da inaptidão política é forte a ponto de ser chamado de ditadura um governo eleito pela maioria da população. Longe de o argumento concentrar-se na ineficácia da representação democrática, vê-se a diminuição do valor do voto de determinados grupos humanos e políticos.

\footnotetext{
${ }^{165}$ As frases entre aspas são paráfrases de discursos de fato enunciados na rede social Twitter.

${ }^{166}$ Expressão constantemente mobilizada para se referir ao eleitorado nordestino.

${ }^{167}$ Em analogia ao Editorial já citado - São Paulo Repete 32 - do jornal O Estado de São Paulo quando do golpe de 1964.

${ }_{168}$ Há, atualmente, um caloroso debate político em torno da nomeação do processo. Tido como impeachment majoritariamente por seus defensores e como golpe para a maioria dos que se posicionaram contrariamente.

${ }^{169}$ Cita-se aqui os grupos Orgulho Paulista e São Paulo Livre.
} 
É sabido que o processo conservador que levou à deposição da ex-presidenta Dilma Rousseff contou com mobilizações em todo território nacional, inclusive em cidades nordestinas. Os nordestinos, longe da passividade e homogeneidade que lhes é imputada, mobilizaram-se tanto favorável quanto contrariamente ao processo. $\mathrm{O}$ cenário político em que isto ocorreu estava visivelmente polarizado. Apesar de o governo petista ter se caracterizado, desde a sua alçada ao poder em 2002, por medidas conciliadoras de classe (BRAGA, 2012; MARTINS, 2016) que iam contra pautas históricas esperadas por seu eleitorado, uma relevante porção do discurso direitista afirmava que o partido representava um perigo comunista.

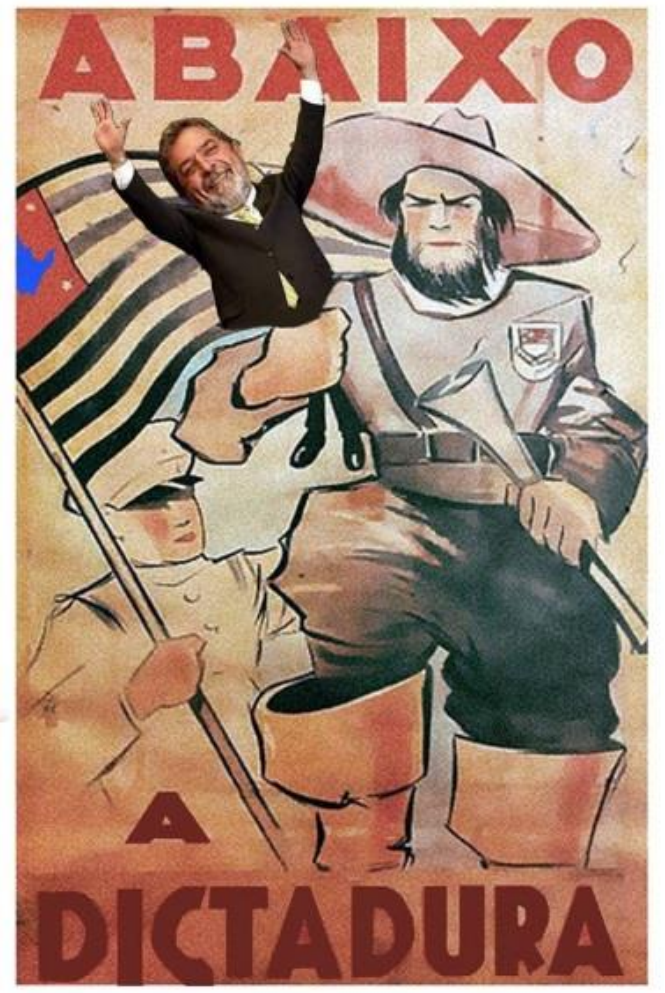

Imagem 12

É possível elencar na imagem diversos fragmentos de enredos típicos da paulistanidade: o bandeirante é mobilizado enquanto ícone paulista em um cartaz que foi veiculado durante o Conflito Constitucionalista de 1932. Este, na imagem, seria readequado aos tempos atuais, na tentativa de que o paulista apareça como central na retirada de Lula do poder. 


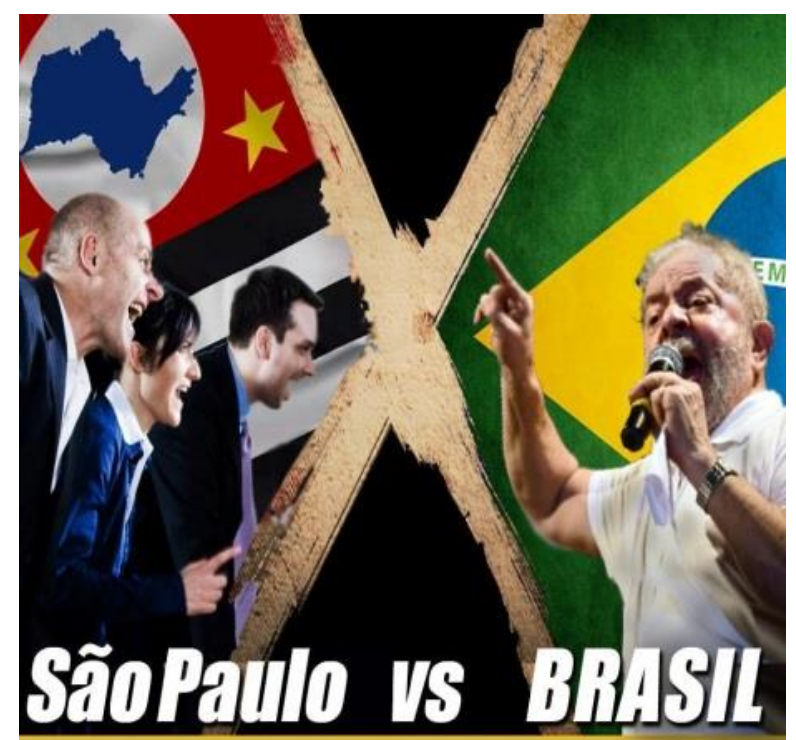

Pense bem, é o seu futuro em jogo aqui...

E aí, que lado você vai apoiar em 2017?

Imagem 13
Vê-se a conexão do estigma
brasileiro ao ex-presidente Lula,
enquanto paulistas são retratados
como pessoas brancas, com
aspecto empresarial. Nota-se a
tentativa de pautar São Paulo
enquanto central à política
brasileira e a mobilização de uma
polaridade política e eleitoral que
distinguiria São Paulo.

São Paulo LIVRE.org

Foi em tal contexto que uma série de mobilizações favoráveis ao golpe aconteceram. Os panelaços ${ }^{171}$ durante os discursos da então presidenta Dilma foram só o começo. Diversas passeatas tomaram as ruas do país. Houve, nestas ocasiões, grupos que clamavam por uma Intervenção Militar. ${ }^{172}$ A grande maioria, todavia, expressava revolta com o tema da corrupção, sem exibir propostas concretas para além da deposição da presidenta. Lula e Dilma se tornaram, neste imaginário, chefes de quadrilha ${ }^{173}$ a serem perseguidos; mais do que uma reivindicação estrutural, via-se um empenho de sentido moralizante.

\footnotetext{
${ }^{170}$ Imagens retiradas em: SÃO PAULO LIVRE (SPL). Facebook. 03/02/2017. Disponível em: <https://www.facebook.com/movimentoSPL/photos/a.1732684196957716.1073741827.173265863029360 6/2255809004645230/?type=3\&theater> Acesso em: 29/04/2018. ORGULHO PAULISTA. Facebook. $16 / 03 / 2016$. Disponível em: <https://www.facebook.com/OrgulhoSP/photos/a.552055881481232.1073741828.552035274816626/106 3227747030707/?type=3\&theater> Acesso em: 29/03/2017.

${ }^{171}$ Assim ficou conhecido o protesto que consistia em bater panelas durante os discursos televisionados da então presidenta.

172 O que pode ser visto em PORTAL TERRA. Grupo pede intervenção militar e causa tensão em Brasília. 2015. Disponível em: <https://noticias.terra.com.br/brasil/politica/grupo-pede-intervencao-militar-e-causatensao-em-brasilia,f649b9a211f1c410VgnVCM20000099cceb0aRCRD.html> Acesso em: 30/03/2017.

${ }^{173} \mathrm{O}$ que pode ser visto em JUNTOS PELO BRASIL. Quadrilha de Dilma e Lula recebeu 50 milhões em Propina. 2015. Disponível em:<http://juntospelobrasil.com/quadrilha-de-dilma-e-lula-recebeu-r-50milhoes-em-propinas-para-campanha/> Acesso em: 30/03/2017.
} 
As ofensas dirigidas a Lula e Dilma, bem como aos eleitores petistas, extrapolaram a esfera política e se concentraram em torno de diversos marcadores sociais da diferença. Dilma foi representada, por exemplo, como uma mulher que merecia a violação sexual, ${ }^{174}$ masculinizada, ${ }^{175}$ ladra. ${ }^{176}$ É essencial notar que este tipo de ofensa é contrário a qualquer ideal em tornos dos Direitos Humanos. Para além disso, é curioso que Dilma, nascida na capital mineira, tenha sido associada pejorativamente às populações nordestinas. Este tipo de associação não seria recente nos discursos da paulistanidade: até mesmo o gaúcho Getúlio Vargas, quando do Conflito de 1932, teve sua identidade regional conectada de forma crítica ao Nordeste. Vê-se, deste modo, mobilizações de identidade regional que se convertem em uma ideia moral, estereotipada, da região.

Da mesma maneira, o que recaiu sobre Lula foi o preconceito de classe através de uma narrativa em que ele seria representado como um nordestino ignorante, de origem pobre, analfabeto, cangaceiro, ${ }^{177}$ ladrão que envergonhava o país. Aos eleitores petistas, novamente, foi imputada a imagem de nordestinos, dependentes de bolsa, pobres e ignorantes; como se quaisquer destes atributos indicasse menor valor moral. Uma comunidade virtual médica chegou a defender a castração química dos mesmos. ${ }^{178}$

Como já dito, as mobilizações pró-golpe não se restringiram aos paulistas e ao estado de São Paulo, apesar de diversos grupos adeptos ao orgulho paulista reivindicarem a linha de frente de tal processo político. É interessante, contudo, pautar a importância de um governo eleito por uma (i)responsabilidade nordestina - como afirmado pelas reações de ódio nas eleições de 2010 e 2014 - ter sido deposto. Acredito que a eficácia do processo concentre-se justamente na ideia de inaptidão política como algo racializado e demarcado regional e economicamente: as mobilizações favoráveis ao golpe conseguiram afirmar o governo como ilegítimo devido, em considerável parte, ao fato deste ter sido eleito majoritariamente por grupos sociais estigmatizados.

\footnotetext{
${ }^{174}$ O que pode ser visto em: REVISTA FÓRUM. Adesivos misóginos são nova moda contra Dilma. 2015. Disponível em: <http://www.revistaforum.com.br/questaodegenero/2015/07/01/adesivos-misoginos-saonova-moda-contra-dilma/> Acesso em: 30/03/2017.

${ }^{175} \mathrm{O}$ que pode ser visto em: <http://g1.globo.com/politica/noticia/2011/11/bolsonaro-pede-dilma-paraassumir-se-gosta-de-homossexual.html> Data da última visita:30/03/2017

${ }^{176}$ O que pode ser visto em: FOLHA NOBRE. Dilma Rousseff: Assaltante de Banco que virou Presidente do Brasil. 2016. Disponível em: <http://folhanobre.com.br/2016/03/28/dilma-rousseff-assaltante-de-bancoque-virou-presidente-do-brasil/26065> Acesso em: 30/03/2017.

177 O que pode ser visto em: O ESTADO DE S. PAULO. O PT e o Cangaço. 2016. Disponível em: <http://cultura.estadao.com.br/blogs/estado-da-arte/o-pt-e-o-cangaco/> Acesso em: 30/03/2017.

${ }^{178}$ Retirado em: ÚLTIMO SEGUNDO IG. Comunidade Médica prega holocausto no Nordeste em campanha contra Dilma na Web. 2014. <http://ultimosegundo.ig.com.br/politica/2014-10-07/comunidade-medicaprega-holocausto-no-nordeste-em-campanha-contra-dilma-na-web.html> Acesso em: 30/03/2017.
} 
O argumento político contra o golpe de 2016 concentrou-se em escancarar as facetas elitistas, machistas, reacionárias e racistas do processo. Desse modo, $\operatorname{parte}^{179}$ da esquerda se concentrou na defesa institucional do Governo Dilma, engendrando a pauta dos Diretos Humanos e de grupos sociais oprimidos. Em contrapartida, o discurso entoado pelos defensores do golpe era, em grande parte, contrário a quaisquer destas pautas. Cartazes, palavras de ordem e discursos das manifestações favoráveis à deposição frequentemente continham ataques a pobres e nordestinos. Estes discursos eram entoados por uma multidão vestida de verde e amarelo que afirmava estar defendendo a nação. Neste sentido, o preconceito ao nordestino que ocorria naquele momento era pautado novamente em sua suposta inaptidão política, em sua pobreza, em sua responsabilidade na eleição daquele governo.

Vê-se neste processo que o discurso paulistanista foi capaz de se reconfigurar e colocar em pauta suas máximas, apesar de não ter sido o único a engendrar a deposição. As imagens mostradas anteriormente reforçam esta ideia. É válido salientar, todavia, que os próprios discursos da paulistanidade fogem à homogenia. No contexto político de que falo, há tanto a ideia do paulista como salvador do Brasil frente a um governo maléfico quanto o argumento de que há a necessidade de São Paulo tornar-se uma pátria independente, já que o restante do Brasil, para além de aproveitar-se dos recursos paulistas, não saberia nem ao menos eleger uma presidenta.

A primeira linha de pensamento pode ser expressa nas afirmações de que São Paulo foi o local em que mais houve mobilizações contra o governo petista, ${ }^{180}$ tendo finalmente conseguido, após 110 anos, um presidente natural do estado de São Paulo. Já a segunda ganhou força, em especial, com movimentos que almejam a separação de São Paulo do resto do país. É o que pode ser visto, por exemplo, nos discursos do Movimento São Paulo Independente que afirmam o PT como um partido engajado na desconstrução da identidade

\footnotetext{
179 É importante pautar que uma considerável parte dos grupos de esquerda se posicionava contrariamente ao governo petista. Isto se dava, todavia, por motivos contrapostos aos dos movimentos de direita. Esta fração da esquerda, justamente pelo caráter conciliador do governo petista (BRAGA, 2012; MARTINS, 2016) não considerava o partido como representante dos interesses populares. A Lei Antiterrorismo, sancionada por Dilma, e o gritante genocídio indígena nos seus últimos dois mandatos, endossam esta crítica.

${ }^{180}$ O que pode ser visto em: O ESTADO DE S. PAULO. Manifestações em todos os estados superam as de março do ano passado. 2016. Disponível em: <http://politica.estadao.com.br/noticias/geral,manifestacoesem-todos-os-estados-superam-as-de-marco-do-ano-passado,1000002104> Acesso em: 30/03/2017
} 
paulista. Deste modo, o grupo defende que não seria o verde e amarelo que deveria representar a luta contra este partido, mas sim as cores da bandeira do estado. ${ }^{181}$

Esta mescla de discursos da paulistanidade foi também visível em 1932. Barbara Weinstein (2015) expõe que no conflito da primeira metade do século XX em uma mesma fala podia-se apreender tanto a ideia do Brasil como país impossível de se viver, sendo necessária a separação, quanto a de São Paulo como local que se auto-sacrifica na missão de civilizar o restante do país.

No que concerne à imagem do Nordeste diante deste processo, vale lembrar que a estereotipização nordestina como local racializado e demarcado economicamente de maneira estigmatizada não ocorre apenas em São Paulo, sendo este fenômeno visível em todo o território nacional, inclusive na região em questão. Chama atenção, detendo-se em uma reflexão neste sentido, o fato de uma das operações da Lava Jato ${ }^{182}$ ter sido batizada de Acarajé. A operação que visava investigar a suposta ocorrência de desvio de dinheiro em campanhas publicitárias eleitorais, tendo como principal alvo o publicitário baiano João Santana, foi criticada por movimentos negros no que concerne ao nome escolhido. ${ }^{183}$ Estes expunham o desrespeito ao candomblé, uma vez que o alimento em questão é sagrado nesta religião. Para além disto, é válido pensar que novamente um símbolo da baianidade foi mobilizado pejorativamente: a terra do pau de arara, do acarajé, da seca, da dependência de auxílio governamental - todo este Nordeste reduzido ao estereótipo da Bahia - é imaginada em enredos políticos nítidos.

Posto isto, torna-se válido pensar como o PT encarou o ódio aos nordestinos repercutido após suas vitoriosas eleições nos últimos anos. Luiz Inácio Lula da Silva publicou um comunicado, a convite da $B B C$, sobre a onda preconceituosa ocorrida no Twitter quando da apuração dos resultados da eleição de 2014:

É um absurdo que o nordeste e os nordestinos sejam caracterizados como ignorantes ou desinformados por seus votos. Quem faz afirmações deste tipo, imagina o nordeste da década de 90 ou de antes, onde reinavam a fome, o desemprego e a falta de oportunidade. Por isso, muitos, como eu, tiveram que abandonar sua terra natal e migrar para outras regiões em busca de melhores

\footnotetext{
${ }^{181} \mathrm{O}$ que pode ser visto em: SÃO PAULO INDEPENDENTE. A elite branca contra os nordestinos: apenas uma arma política. 2014. Disponível em: <http://www.saopauloindependente.org/blog/a-elite-branca-paulistacontra-os-nordestinas-apenas-uma-arma-politica> Acesso em: 30/03/2017.

182 Lava jato foi o nome dado às operações que visam a investigação da corrupção que envolveu a estatal Petrobras.

${ }^{183}$ Retirado em: UOL NOTÍCIAS. Movimento Negro repudia uso de nome Acarajé pela PF na Operação Lava Jato. 2016. Disponível em: <https://noticias.uol.com.br/politica/ultimas-noticias/2016/02/22/movimentonegro-repudia-uso-de-nome-acaraje-pela-pf-na-operacao-lava-jato.htm> Acesso em: 30/03/2017.
} 
condições de vida. Hoje, o nordestino anda de cabeça erguida porque não é mais tratado pelo governo como cidadão de segunda categoria. (DA SILVA in BBC, 2014) ${ }^{184}$

O ex-presidente Fernando Henrique Cardoso participou da discussão afirmando que “o PT está fincado nos menos informados, que coincide de ser os mais pobres. Não é porque são pobres que apoiam o PT, é porque são menos informados" (BBC, 2014) ${ }^{185} \mathrm{Da}$ mesma maneira, acusou - em um vídeo ${ }^{186}$ - o PT de fazer demagogia na tentativa de colocar seu partido, PSDB, contra o povo, afirmando que o preconceito contra nordestinos não possuiria consonância com a política tucana. A indicação patente de preconceito na afirmação do ex-presidente foi respondida pelas unidades nordestinas da Central Única dos Trabalhadores (CUT) em nota de repúdio. ${ }^{187}$

Fica evidente, assim, embates e similaridades entre os discursos dos ex-presidentes. Lula aposta na mudança do Nordeste, atribuindo esta ao governo petista que teria focado mais na região. Curioso neste sentido é o fato de que não se ataca a discriminação ou preconceito em si: como se antes, quando reinavam a fome e o desemprego, o voto nordestino tivesse de fato menor valor. FHC, por outro lado, nega qualquer preconceito contra o nordestino e o pobre, ao mesmo tempo que atribui a estes uma maior ignorância política. É curioso pensar, sobretudo, que ambos os partidos esforçaram-se em agradar os eleitores do Sudeste e do Nordeste. FHC afirmou ${ }^{188}$ que seu governo e a política do PSDB sempre fora guiada para todos, sem qualquer discriminação, apesar de ser sabido que o

\footnotetext{
184 Retirado em: BBC. Lula critica internautas que atacaram nordestinos. 2014. Disponível em: <http://www.bbc.com/portuguese/noticias/2014/10/141006_salasocial_eleicoes2014_lula_rs> Acesso em: 30/03/2017.

185 Retirado em: BBC. Lula critica internautas que atacaram nordestinos. 2014. Disponível em: <http://www.bbc.com/portuguese/noticias/2014/10/141006_salasocial_eleicoes2014_lula_rs> Acesso em: 30/03/2017.

${ }^{186} \mathrm{O}$ vídeo pode ser visto em: VEJA. Em vídeo, FHC desfaz mentira de Lila sobre ódio contra nordestinos. 2014. Disponível em: < http://veja.abril.com.br/blog/felipe-moura-brasil/em-video-fhc-desfaz-mentira-delula-sobre-8220-odio-contra-nordestinos-8221-8220-o-povo-sabe-que-quem-fez-o-plano-real-fomos-nosque-melhorou-a-vida-de-todo-mundo-8221-fato/> Acesso em: 30/03/2017.

187 “Em um momento histórico da luta pela superação dos preconceitos, sejam de credo, cor, gênero ou quaisquer outras, é lamentável que se acentue o preconceito por uma região mediante manifestações expressas sem qualquer constrangimento e ratificadas por alguém que já presidiu o país. Essa posição de FHC somente reafirma o descaso com que a população nordestina foi tratada durante os oito anos em que o PSDB governou o Brasil." BRASIL 247: CUTs do Nordeste repudiam preconceito e declaram repúdio a FHC. 2014. Disponível em: <https://www.brasil247.com/pt/247/brasil/156605/CUTs-do-Nordeste-repudiampreconceito-e-declara\%C3\%A7\%C3\%B5es-de-FHC.htm> Acesso em: 29/04/2018.

${ }^{188} \mathrm{O}$ que pode ser visto no vídeo já mencionado.
} 
partido é ancorado em bases estaduais paulistas ${ }^{189}$ e que a derrota de Aécio Neves teria sido o estopim para parte de seu eleitorado reagir contra os nordestinos.

A estratégia petista, por outro lado, chama mais atenção. Nas eleições de 2014, ainda marcadas pela campanha Afogue um Nordestino de 2010, o jingle de Alexandre Padilha, candidato do PT ao governo do estado de São Paulo, entoava "meu estado de São Paulo, sempre foi a mais de mil, a grande locomotiva que dá força pro Brasil.” Indo no mesmo sentido, a imagem de campanha do candidato era ilustrada com diversos mapas do estado paulista. Dilma, da mesma forma, buscou em seu primeiro discurso após a reeleição o caminho da conciliação contra a divisão ideológica e, como visto nesta dissertação, regional do país:

Não acredito, sinceramente, do fundo do meu coração, não acredito que essas eleições tenham dividido o país ao meio. Entendo, entendo, sim, que elas mobilizaram ideias e emoções às vezes contraditórias, mas movidas por um sentimento comum: a busca de um futuro melhor para o País. (OESP, 2014). ${ }^{190}$

Vê-se que novamente o PT tomou um caminho conciliador buscando, inclusive, evidenciar que São Paulo ainda seria a locomotiva do país, como visto no caso do jingle e das imagens da campanha de Alexandre Padilha. São Paulo e seu lema - não sou conduzido, conduzo - se mantiveram intactos nesta opção de marketing. Deste modo, a conciliação de classes empreendida pelo PT passa também por conciliações que dizem respeito a outras pautas: se falou de forma dúbia sobre discriminação racial ${ }^{191}$ e pouco foi dito sobre discriminação regional, a legalização do aborto ${ }^{192}$ continuou sendo um tabu não discutido e medidas anti-protesto ${ }^{193}$ marcaram a gestão petista.

\footnotetext{
189 “Durante o governo FH alguém inventou o termo 'paulistério', porque seu ministério tinha paulistas demais e ministros do resto do Brasil de menos" in O ESTADO DE S. PAULO. PSDB paulista ou nacional? 2018. Disponível em: <https://oglobo.globo.com/opiniao/psdb-paulista-ou-nacional 22360369\#ixzz5DVQHt6EY> Acesso em: 29/04/2018.

190 Retirado em: O ESTADO DE S. PAULO. Leia o Primeiro Discurso de Dilma Rousseff. 2014. <http://politica.estadao.com.br/noticias/eleicoes,leia-o-primeiro-discurso-de-dilma-rousseff-comopresidente-reeleita,1583452> Acesso em: 30/03/2017.

${ }^{191}$ Assinala-se aqui o fato de que, apesar dos avanços proporcionados pela Reforma Universitária e pela inserção da disciplina História da África na educação básica, o genocídio negro causado pela polícia militar brasileira e a "veracidade da cor" - exigida em certos contextos de cotas - foram discutidos de forma superficial.

192 O que pode ser visto em ÚLTIMO SEGUNDO IG. Na contramão de países desenvolvidos, Dilma e Aécio negam legalização do aborto. 2014. Disponível em: <http://ultimosegundo.ig.com.br/politica/2014-1010/na-contramao-de-paises-desenvolvidos-dilma-e-aecio-negam-legalizacao-do-aborto.html> Acesso em: 31/03/2017.

${ }^{193}$ Ressalta-se aqui - para além da aprovação da Lei Anti-terrorismo (13.260) - a forte repressão ocorrida durante os protestos contrários ao Mundial de Futebol e a ocupação feita pelo exército na Favela da Maré no Rio de Janeiro.
} 
Os episódios tratados até então (tanto os de 1932 e 1964 quanto os de 1992 e 201014-16) evidenciam a constante ideológica da paulistanidade ao atribuir ao nordestino o estigma da incapacidade política - chegando a defender que o mesmo perca o direito ao voto. ${ }^{194}$ Incapacidade esta que, nesta lógica, seria causada ora por ignorância e pobreza, ora pela malandragem e pela troca de direitos políticos por favores. É sintomático que um episódio como o Golpe de 1964, com todas as violações aos Direitos Humanos que o caracteriza, tenha sido atribuído aos paulistas no sentido de uma revolução benéfica. Nesta narrativa, estes constituiriam, naturalmente, o povo mais apto a civilizar o país, apesar das investidas e retrocessos causados por aqueles habitantes exóticos e incompreensíveis do Brasil arcaizado e estereotipado enquanto Nordeste.

Também é sintomático o fato de que tachar a região nordestina enquanto local dotado de uma população inapta politicamente seja algo comum em todo Brasil. A imagem a seguir é elucidativa neste sentido e permite trazer a esta análise a complexidade do fenômeno. Nota-se a cristalização de um estigma capaz de fazer com este preconceito seja eficaz em pautar distinções internas à região. Este tipo de diferenciação entre nordestinos não seria reduzida à questão eleitoral: no segundo capítulo já foi afirmado que a racialização e a demarcação econômica do Nordeste poderia servir à hierarquização entre grupos humanos da região, em especial entre brancos e não-brancos e ricos e pobres. Isto se traduziria na narrativa de determinadas composições sociais que afirmariam a vergonha de ser nordestino.

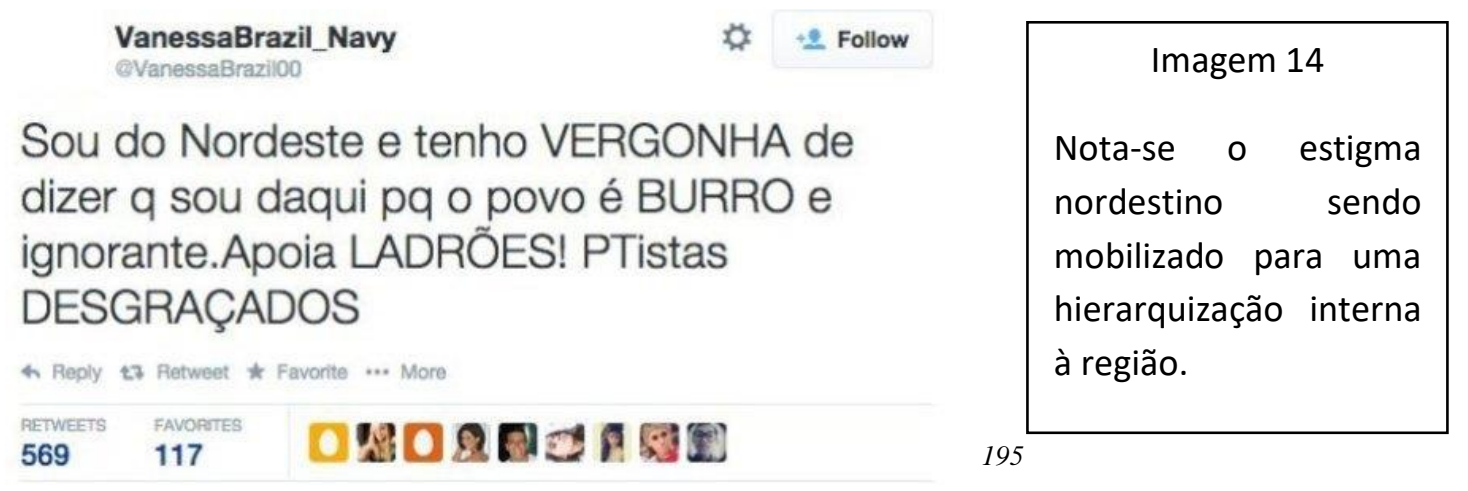

\footnotetext{
194 O que pode ser visto em: CARTA CAPITAL. As eleições e o preconceito contra o Nordeste. 2010. Disponível em: <https://www.cartacapital.com.br/politica/as-eleicoes-e-o-preconceito-contra-o-nordeste> Acesso em: 30/03/2017.

${ }^{195}$ Imagem retirada em: HUFFPOST. Xenofobia não! Você pode denunciar autores de mensagens contra nordestinos. 2014. Disponivel em: <http://www.huffpostbrasil.com/2014/10/07/xenofobia-contranordestinos_n_5949284.html> Acesso em: 25/03/2017.
} 
Interessa-me, nesta reflexão, a análise da serventia que este estigma pode possuir para grupos regionais e sociais distintos. Acredito que a racialização e preconceito de classe, que acompanham a estigmatização nordestina, dote as elites do Nordeste de mais um argumento hierarquizante em relação às classes populares de sua região. Do mesmo modo, serve à paulistanidade o estigma que historicamente contrapôs o paulista ao nordestino e permitiu situar qualquer mácula como exógena. Em resumo: o regionalismo de um local como São Paulo é capaz de forjar seu ideal de supremacia baseando-se nesta contraposição regional, enquanto grupos privilegiados do Nordeste o fazem internamente, valendo-se do próprio estigma da região.

Isto indica a assimetria de poder regional que existe no Brasil. Grupos nordestinos, incapacitados de se ancorarem na ideia de superioridade civilizatória, utilizam como mecanismo de hierarquização e defesa seu afastamento de compostos humanos estigmatizados. Apesar deste esforço, as oligarquias do Nordeste são concebidas de forma arcaizada a partir da figura do coronel. Nota-se, desta maneira, que - apesar de o fenômeno do afastamento de grupos estigmatizados não ser restrito à paulistanidade - há eficácia paulista ao valer-se desta narrativa em frentes diferentes: as culpas são sempre externas. Os problemas de São Paulo são narrados como consequência da presença nordestina no estado enquanto os problemas do Brasil aparecem como consequência da existência do Nordeste.

É nesta mesma lógica que se Getúlio Vargas domina o país, tinha que ser nordestino para apoiar tal governo. Se Erundina ganha uma eleição, tinha que ser nordestino para permitir que isto acontecesse. Se o PT esteve no poder presidencial por catorze anos, tinha que ser nordestino o responsável. Em contrapartida, se governos são depostos $^{196}$ em 1964 e 2016, os paulistas estiveram à frente na defesa e melhora do Brasil.

Esta máxima - tinha que ser nordestino - é repetida em diversas ocasiões alheias a qualquer debate eleitoral. Tendo em vista o caráter racializador e economicamente estigmatizador deste fenômeno, pode-se concluir que a ilegitimidade eleitoral atribuída ao Nordeste perpassa pelas problemáticas de raça e classe. $\mathrm{O}$ voto nordestino é considerado irracional, desonesto e irresponsável justamente porque aos habitantes desta região é imputada uma imagem contrária a qualquer ideal de branquidade, progresso, civilização e sucesso econômico. Tinha que ser nordestino é uma expressão recorrente - tal qual tinha que ser preto - não apenas pela democracia racial ser inquestionavelmente mítica, mas,

\footnotetext{
${ }^{196}$ É válido afirmar a distinta natureza - contextual e causal - no que concerne a ambos os processos (1964 e 2016).
} 
sobretudo, pela permanência de um ideal de nação que almeja ser branca, rica e civilizada: alguns teriam que ser os culpados por isso estar longe de ser realidade.

\section{2 - Mobilizações Políticas da Paulistanidade}

Com o objetivo de relacionar momentos históricos em que houve recrudescimento da paulistanidade e do estigma nordestino, apresentarei nas próximas páginas uma linha do tempo. Nela pontuarei eventos que foram tratados nesta dissertação e que permitem analisar em simultaneidade o ideal da racionalidade econômica, política e racial paulista em contraposição à ideia do Nordeste enquanto local povoado por uma população inapta e irracional no que concerne a estes atributos.

Não é minha intenção com a apresentação destes eventos indicar a univocidade do regionalismo paulista e da estigmatização nordestina. Ao contrário: acredito que cada momento é marcado por peculiaridades contextuais e por composições distintas, tanto no que tange ao engendramento das narrativas regionais quanto na natureza dos processos políticos. Da mesma forma, acredito que uma série de outros momentos que escapam a esta linha do tempo poderiam ser mobilizados para a compreensão da dicotomia que há entre a imagem paulista e a nordestina. Isto não anula, todavia, a possibilidade de análise da continuidade paulista em defesa de determinada ordem social e busca pelo poder de mando nacional.

Posto isto, é importante analisar a recorrência com que emergem certas expressões da paulistanidade como fenômeno mantenedor de hierarquias. Nota-se na linha do tempo que será apresentada a perpetuação de uma filiação política conservadora capaz de garantir a ordem social com as clivagens econômicas, raciais e de gênero que marcam o contexto brasileiro. Interessa, neste sentido, analisar a eficácia de um discurso paulista que aparece de forma estrutural em defesa de sua hegemonia e de assimetrias de poder entre grupos humanos. Vale lembrar que os limites desta análise concentram-se na impossibilidade de investigar como outros regionalismos lidaram com os mesmos eventos históricos. 


\section{Linha do Tempo}

\section{1) Boom do Café (Últimas Décadas do Século XIX)}

São Paulo ascende enquanto potência econômica e como local que recebia o influxo de imigrantes brancos em uma sociedade nacional influenciada pelas teorias do racismo científico e do embranquecimento. Enquanto isto, o Nordeste é atribuído como local de decadência tanto pelo deslocamento do eixo político e econômico do Norte ao Sul quanto pela sua composição social, majoritariamente não-branca.

2) Abolição da Escravidão (1888)

São Paulo passa a prosperar ainda mais com a mão-de-obra imigrante. Do mesmo modo, as elites do estado engendram o afastamento dos grupos negros, em nível de representação e materialidade. A imigração de pessoas negras do Norte ao Sul do país, em especial do Nordeste a São Paulo, engendra uma narrativa das elites paulistas baseada no estigma perverso do "negro mau vindo do Nordeste" (ALBUQUERQUE JR, 2011:74) ao mesmo tempo que se firma a ideia desta região, em especial a Bahia, como um "velho caldeirão racial parado no tempo" (GUIMARÃES, 202:131).

3) Massacre de Canudos (1902)

A imprensa do Sul de modo geral, e de São Paulo em particular, apresenta o movimento de Canudos como irracional e estigmatiza sua composição pobre e não-branca. Enquanto isto, o paulista ascende enquanto exemplo de eficácia moral, racial, econômica e política. Do mesmo modo, "eliminar os canudenses passou a ser uma questão crucial para a sobrevivência política do projeto civil, e àquela altura paulista, de consolidação da República no Brasil”" (HERMANN, 1996:16).

4) Semana da Arte Moderna (1922)

Sacraliza o deslocamento de poderio cultural do Norte ao Sul. As elites nacionais reconhecem a primazia paulista em manifestações culturais inovadoras (WEINSTEIN, 2007) e o Nordeste passa a ser tachado enquanto culturalmente medieval (ALBUQUERQUE JR., 2011). Destacados nomes do modernismo paulista engajaram-se na Guerra de 1932 e atribuíram ao Nordeste o estigma racial e político. Longe da passividade, a região nordestina conta com uma série de manifestações culturais avessas ao modernismo.

5) Conflito Constitucionalista (1932)

Discursos da paulistanidade engendram uma narrativa que frequentemente esbarraria no separatismo ou na defesa de um Brasil com São Paulo no topo. O Regime de Vargas é chamado na imprensa paulista de Ditanegra e estabelecese com vigor o Outro Regional como nordestino arcaizado e não-branco. $\mathrm{O}$ Conflito seria narrado como uma luta entre membros da classe média branca paulista e uma jagunçada. 
Imagem 15: Linha do Tempo

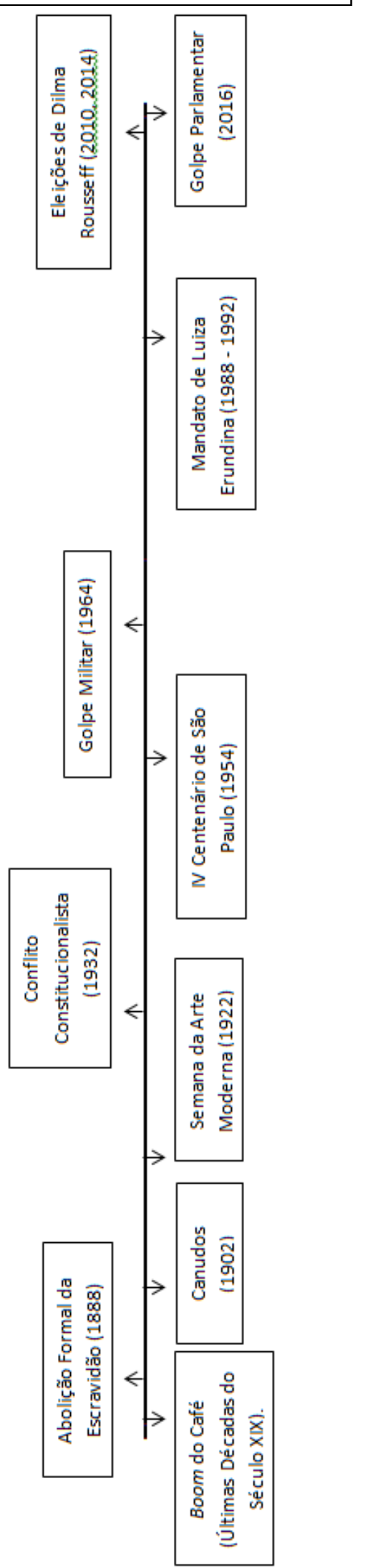


6) IV Centenário de São Paulo (1954)

Exacerba-se a ideia já estabelecida de São Paulo enquanto local da modernidade brasileira. As narrativas em torno do bandeirantismo e do Conflito de 1932 ganham forma mais saliente nas comemorações.

7) Golpe Militar (1964)

Parte da imprensa paulista reivindica primazia no processo e busca pautar São Paulo como local essencial ao encaminhamento político. Fala-se em um governo bandeirante que seria capaz de garantir a ordem social contra perigos comunistas.

8) Eleição e Mandato de Luiza Erundina (1988 - 1992)

A revolta com os resultados da eleição municipal entre Erundina e Maluf ocasionam diversos crimes de ódio. Com número expressivo, pichações em São Paulo pediam morte aos baianos e o Centro de Tradições Nordestinas, fundado pela então prefeita, é invadido, baleado e pichado com os dizeres fora nordestinos.

9) Eleições de Dilma Rousseff (2010 - 2014)

A revolta com o resultado das eleições gera grande conteúdo de ódio cibernético. "Mate um Nordestino Afogado", campanha da paulista Mayara Petruso, é a frase mais mencionada na Rede Social Twitter nos dias 03 e 04/10/2010. Houve quem afirmasse, após os dois pleitos, o estigma da inaptidão política nordestina e a necessidade de dividir o país.

10) Golpe Parlamentar (2016)

Grupos engajados no Orgulho Paulista reivindicam a primazia paulista no processo. A figura do ex-presidente Luis Inácio Lula da Silva é associada a um estereótipo nordestino e pobre em porção relevante dos argumentos defensores da deposição. O Nordeste segue sendo responsabilizado pelas duas eleições anteriores a partir do estigma da inaptidão política.

O que estes eventos possuem em comum, guardadas suas devidas diferenças contextuais, é o recrudescimento da paulistanidade enquanto ideologia engajada na racialização e demarcação econômica e política de elementos considerados exógenos (os nordestinos). A memória formada em torno destes fatos históricos traz à tona a dicotomia entre noções de progresso/civilização e atraso/incivilidade e como estas se adequam às imagens de São Paulo e do Nordeste.

Do mesmo modo, nota-se que as descontinuidades e reconfigurações nos discursos paulistanistas analisados não abalam uma forma estrutural e contínua de pautar o estado e sua população enquanto superior concomitantemente à estigmatização do Outro Regional. É patente e estruturante deste fenômeno, portanto, a continuidade de uma manifestação 
regionalista que aparece como mantenedora tanto da ordem social quanto da hegemonia paulista na hierarquia brasileira.

A importância de analisar estes dados em um estudo sobre paulistanidade detém-se justamente no fato de que há no Brasil uma assimetria de poder regional. Como exposto, Norte e Sul aparecem de modos diferentes em narrativas que envolvem progresso, civilização, raça e classe. Do mesmo modo, a concentração de poder econômico, industrial e político é materialmente visível no Sudeste brasileiro, em especial na capital de São Paulo.

Posto isto, é interessante destrinchar o que há de paulista nas crises políticas e econômicas brasileiras. Acredito que há um discurso relevante da paulistanidade empenhado em garantir a hegemonia de São Paulo na composição nacional, sendo que faz parte desta proposta hegemônica a continuidade de clivagens raciais e econômicas. Deste modo, a paulistanidade aparece, estruturalmente e em diferentes contextos políticos, como reservatório simbólico do conservadorismo nacional. Este garantiria a defesa de um modelo social capitalista, com oportunidades restritas àqueles discriminados racial e economicamente.

Este fenômeno não possuiria relevância apenas na esfera simbólica, a partir do regionalismo paulista que aparece como politicamente propositivo. Ao contrário: geraria consequências em todo território nacional, uma vez que a imagem de São Paulo como habitada por seres dotados de racionalidade econômica, racial e política serviu ao engendramento de processos sociais hierarquizantes distintos.

Até mesmo o governo de Getúlio Vargas, ao qual a paulistanidade foi tão avessa, valeu-se da narrativa do estado paulista para apresentar, concomitantemente, o Brasil enquanto democracia racial e São Paulo enquanto potência embranquecida, capaz de redimir uma nação pobre e não-branca: "foi de toda uma base eugenista paulista que seus apoiadores buscaram configurar uma "raça sadia"” (SANTOS E MOTA, 2010:151). ${ }^{197}$ Do mesmo modo, foi São Paulo o estado que mais profundamente se conectou, no último e no presente século, ao ideal de aptidão capitalista, tão almejado pelas elites do Brasil enquanto nação subdesenvolvida. Estas narrativas revelam serventia a um projeto caro à ordem social, regional e nacional. Apresenta-se, assim, como um projeto de nação que é baseado e fundado na desigualdade.

197 “O governo getulista não perdeu a oportunidade de incorporar São Paulo aos desígnios federais, confiando-Ihe a tarefa médica e sanitária de colaborar na formatação de um homem novo e restringir os grupos que poderiam ameaçar a construção do 'novo Brasil'." (SANTOS E MOTA, 2010:151). 


\section{3 - Preconceito, Discriminação e Ódio: O Gradiente da Paulistanidade}

Como já dito diversas vezes nesta dissertação, o regionalismo paulista não é um fenômeno unívoco e está longe de abarcar em si apenas traços de autovalorização e estigmatização de determinados grupos humanos. É por tal motivo que é preciso salientar novamente que apresento expressões de regionalismo que se pautem na paulistanidade: o ideal da superioridade paulista que, ancorando-se em imagens restritas de raça e classe, costuma racializar populações nordestinas como seu contraponto. No tópico anterior demonstrei que nas práticas e discursos que formam este conceito concentra-se uma narrativa do conservadorismo brasileiro, este aparecendo estruturalmente em nome da perpetuação de clivagens sociais essenciais à hierarquização racial, nacional e econômica.

Há, todavia, que destrinchar o gradiente desta paulistanidade. Como o racismo, por exemplo, se estabelece nas convicções regionais? Seria um regionalismo que se vale do racismo para estabelecer distinções ou seria o estrutural racismo brasileiro envelopado em bases regionalistas? Como analisar nestes fenômenos as noções de etnocentrismo, discriminação, preconceito e ódio? Em que contexto as discriminações, veladas em períodos de maior estabilidade, ou os preconceitos íntimos, surgiriam como rechaço? O que faz com que um ideal latente em torno da superioridade paulista e inferioridade nordestina se converta em ódio escancarado?

Para responder estas perguntas, é essencial notar como variados graus e tipos de expressões da paulistanidade aparecem no mundo social. Antonio Sérgio Guimarães (2004) possibilita a análise desta gradação ao apresentar o que se convencionou chamar de preconceito e de discriminação. Segundo o sociólogo, seria frequente nesta conceituação a evocação a preconceito como algo que trataria de "propósitos e disposições interiores" enquanto discriminação apareceria a partir de "comportamentos e ações concretas" (GUIMARÃES, 2004:18).

Do mesmo modo, Valle Silva (2004) indica que nos estudos sociológicos brasileiros aparece com frequência a atitude discriminatória como consequência do preconceito. Pensando nos resultados materiais da discriminação de grupos humanos, o autor apresenta um propósito discriminador de grande relevância para as práticas excludentes: a manutenção das hierarquias sociais.

Valendo-me disso, creio que seja possível pensar que grupos estigmatizados sofrem discriminação devido, em considerável parte, à perpetuação ativa de assimétricas disposições de poder. Deste modo, é essencial pontuar que se tais grupos atingissem a 
igualdade, grupos com maior poder social não acessariam os privilégios de que dispõem normalmente. Como já afirmei, é por tal motivo que as práticas discriminatórias expostas nesta pesquisa devem ser vistas também como mantenedoras de hierarquias diversas.

O subtópico anterior foi eficaz ao pontuar os momentos históricos em que uma paulistanidade agressiva foi mobilizada, por grupos distintos e de formas diferentes, para defender a supremacia do estado e de sua população. Interessa agora, todavia, pontuar as distinções destes processos e dos grupos que os engendraram. Como seriam suas expressões?

Para realizar este empreendimento analítico, apresentarei nas próximas páginas grupos separatistas de São Paulo e notícias sobre temas regionais. Buscarei expor diferenças nestes fenômenos ao analisar narrativas que ora aproximam-se da discriminação e do ódio e ora se valem do preconceito. Para tal, é imprescindível analisar a variedade na mobilização de estigmas de classe, raça e gênero. Apesar destes marcadores sociais serem conectados com frequência em um embaralhamento de hierarquias, aparecem como independentes em diversas narrativas.

Detendo-me nisto, buscarei mostrar que um preconceito de classe que aparece com frequência na paulistanidade, torna-se ódio em determinadas circunstâncias. Da mesma maneira que nem sempre acompanha, especialmente de modo explícito, um discurso racista e sexista. É com isto em mente que analiso as distinções e similaridades entre discursos e práticas que envolvem a paulistanidade.

\section{4 - Paulistanidade e Efervescência Política: Análise das Notícias Rastreadas}

Neste tópico destrincharei o gradiente da paulistanidade a partir da análise de um banco de dados que iniciei em 2012. A coleta deste banco de dados foi possibilitada pelo rastreamento de notícias virtuais da ferramenta Google Alerts, sendo feito a partir de duas palavras-chave: 1) Mayara Petruso e 2) Discriminação Contra Nordestinos. O Google Alerts é uma ferramenta que permite a detecção de conteúdo online referente a determinadas palavras. Assim, se um usuário criar um alerta guiado para discriminação contra nordestinos, o sistema Google detecta notícias que provavelmente tenham referência com o tema, enviando um e-mail para o solicitante em que consta o conteúdo rastreado.

Formulei a primeira palavra-chave, Mayara Petruso, com o intuito de acompanhar ao longo dos anos, em especial nos momentos de acirramento eleitoral, a memória formada 
em torno da campanha criada pela estudante paulista: "Mate um Nordestino Afogado". Acredito que a repercussão gerada pelo discurso desta jovem se configurou como um relevante e emblemático marco na temática discriminatória e de crimes de ódio cibernéticos. Criei a segunda palavra-chave, Discriminação Contra Nordestinos, objetivando acompanhar expressões, virtuais ou não, em torno do dado fenômeno, bem como a repercussão na imprensa ocasionada por estas.

$\mathrm{O}$ rastreamento destas palavras-chave permitiu que por cerca de seis anos eu alimentasse um banco de dados extenso. Diversas notícias relacionadas ao tema chegam diariamente ao meu e-mail, o que de 2012 até a presente data representou um montante de mais de três mil links considerados pelo sistema Google Alerts como relevantes para o assunto.

Apenas uma parte das notícias, todavia, foi relevante para esta pesquisa. Isto porque a filtragem proporcionada pelo Google Alerts frequentemente não estabelece uma relação satisfatória com o tema investigado. As notícias que foram mapeadas não formam todo o conteúdo online gerado sobre o assunto nos últimos anos. Para além disso, diversos estudos (a título de exemplo: WU et al, 2015) expõem o fato de que a empresa Google manipula dados de pesquisa. Assim, certos veículos de informação aparecem com maior destaque do que outros.

Tal rastreamento permitiu, apesar de sua parcialidade, analisar padrões e entrar em contato com notícias interessantes para esta dissertação. Em anos eleitorais, 2012 e 2016 com eleições municipais e 2014 com a eleição presidencial, notei certa acentuação nas discussões sobre discriminação contra nordestinos e orgulho paulista. Vale dizer, todavia, que opto nesta pesquisa por não realizar uma análise estatística destes dados devido à superficialidade da ferramenta de pesquisa utilizada. O que não impede o estudo de estatísticas que, apesar do pouco rigor do Google, atestam o recrudescimento em momentos eleitorais da discriminação nordestina na esfera pública. Neste sentido, apresento gráficos da ferramenta Google Trends. Esta técnica permite que se observe a frequência de buscas online sobre determinados temas.

De início, pesquisei a frequência de buscas relacionadas à discriminação contra nordestinos. Para tal, delimitei o período de análise entre janeiro de 2010 e abril de 2018 (data em que escrevo), de modo que momentos como os das eleições presidenciais (2010 e 2014) pudessem ser abarcados, assim como os pleitos municipais (2012 e 2016). Vale lembrar que a ferramenta Google Trends expõe a popularidade de um tema, sendo 100 sua 
escala máxima e 0 a irrelevância no que concerne a determinado tipo de investigação temática (no sentindo de que poucas foram as buscas de internautas sobre o assunto).

Gráfico 1: Discriminação Contra Nordestinos - Jan/2010 a Abr/2018 198

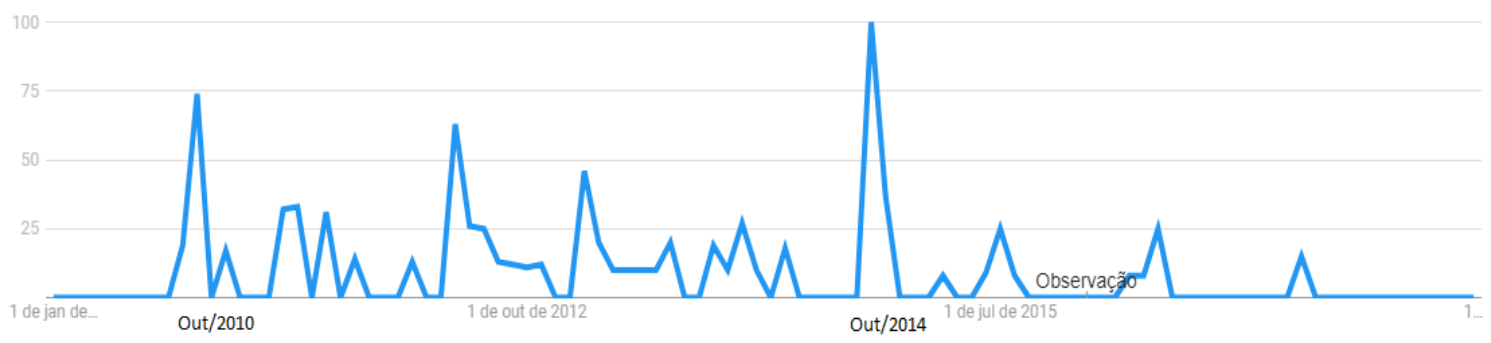

Vê-se que há maior frequência de busca sobre esta discriminação nos períodos exatos que corresponderam aos últimos dois turnos das eleições presidenciais: outubro de 2010 e outubro de 2014. O pico em maio de 2012 refere-se à condenação de Mayara Petruso, ocorrida em 18/05/2012, o que evidencia como a jovem foi conectada à demonstração pública desta discriminação.

Objetivando investigar se haveria relações entre a discriminação nordestina e o recrudescimento do orgulho paulista, utilizei como variável de análise o fenômeno separatista em São Paulo. Deste modo, criei a partir do Google Trends um gráfico que abarcasse o mesmo período que o Gráfico 1 (janeiro de 2010 a abril de 2018), utilizando como palavra-chave Separatismo Paulista. Os resultados podem ser vistos a seguir.

Gráfico 2: Separatismo Paulista - Jan/2010 a Abr/2018 199

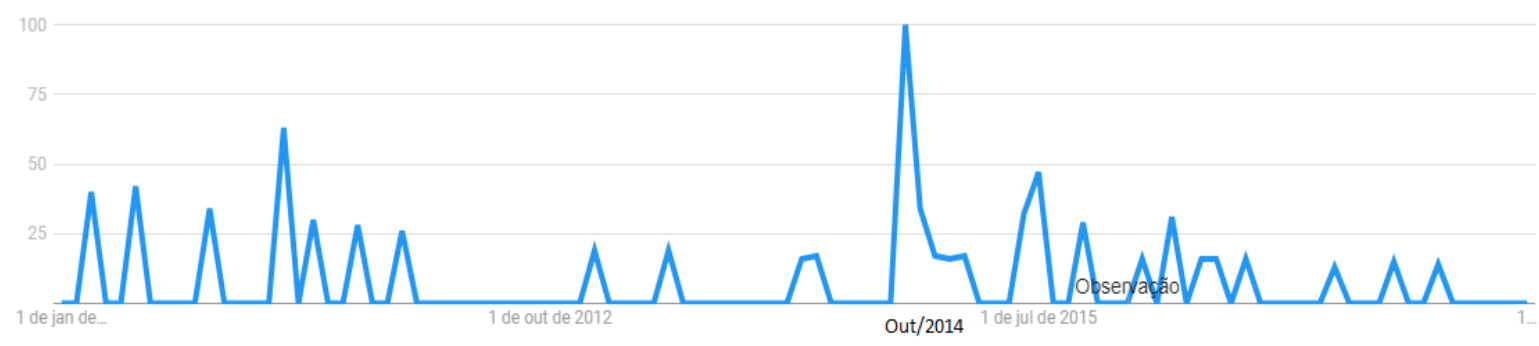

198 GOOGLE TRENDS. Discriminação contra nordestinos de janeiro de 2010 a abril de 2018. 01/04/2018.

${ }^{199}$ GOOGLE TRENDS. Separatismo Paulista de 2010 a abril de 2018. 01/04/2018. 
Acredito que seja expressivo o fato de que o maior pico de busca online sobre o dado separatismo se dê em 2014, uma vez que a maior frequência relacionada à discriminação nordestina tenha ocorrido no mesmo momento, sendo este marcado pela segunda vitória presidencial de Dilma Rousseff. O segundo maior pico do Gráfico 2 estaria também relacionado à segunda maior frequência do Gráfico 1: outubro de 2010, o mês em que Dilma pela primeira vez ascendeu ao poder.

As relações entre estes fenômenos permitem que eu traga a esta discussão uma série de questões. Seria nestes momentos de acirramento eleitoral que a esfera do preconceito contra o nordestino - muitas vezes baseada na pretensa superioridade paulista - passaria à prática discriminatória? Entraria em cena, nestas circunstâncias conturbadas, o ódio? Acredito que seja possível afirmar não apenas o argumento de Moutinho (1991) de que a paulistanidade recrudesce em momentos de disputa política pelo poder central, mas também o fato de que preconceitos e ideais latentes aparecem de forma mais explícita em momentos acirrados.

Do mesmo modo, aparece o histórico da paulistanidade em filiar-se à ideia da separação do estado em contextos específicos. Creio que seja possível dizer que uma narrativa eficaz - a da superioridade de São Paulo - estavelmente ancorada em um preconceito contra o nordestino enquanto contraponto paulista, aparece em momentos conturbados a partir do extremo da defesa separatista. Desta maneira, não apenas um preconceito velado pode passar à esfera discriminatória visível, como uma superioridade sutil ascende a propostas de secessão.

Como já dito, isto não apenas diz respeito a uma discriminação que se funda no preconceito, mas que busca garantir, material e simbolicamente, a hegemonia do estado. Os pleitos dos anos de 2010 e 2014 teriam ferido tal proposta hegemônica pelo fato de a eleição presidencial ter sido majoritariamente decidida por votos nordestinos, sendo que a maioria paulista optou pelo candidato derrotado. É possível aventar a possibilidade, portanto, de que o separatismo apareça quando a hierarquia nacional, com um poder de mando que se quer paulista, é ameaçada. Interessante neste fenômeno é o fato de que se vê a ideia de superioridade quase sempre intacta. A proposta de separação fracassa em resultado e em mobilização, inclusive pelo fato de serem reduzidos os grupos que a engendram, mas é estabelecido continuamente o estado e sua população enquanto superiores. 
Posto isto, é válido analisar como as notícias armazenadas no banco de dados se relacionam a estes picos de frequência temática. Também buscarei expor momentos de natureza distinta em que apareceram com visibilidade a discriminação nordestina e a conexão que esta pode estabelecer com a narrativa da paulistanidade.

No ano de 2012, as notícias que coletei relacionavam-se principalmente à repercussão em torno da condenação da estudante paulista Mayara Petruso. O conteúdo gerado dizia respeito ao acirramento eleitoral causado pelas eleições municipais, ${ }^{200}$ à onda virtual de chacota contra nordestinos causada pela falta de luz em estados do Norte e Nordeste $^{201} \mathrm{e}$, especialmente, à relação deste fenômeno com a condenação de Mayara Petruso.

Em 2013 a maior parte das notícias coletadas dizia respeito aos encaminhamentos judiciais dos crimes de ódio contra nordestinos ocorridos nas eleições municipais. De modo que 2013 apareceu no presente banco de dados como um ano em que a repercussão sobre a paulistanidade e a discriminação contra nordestinos estava conectada aos acontecimentos do ano eleitoral de 2012.

No ano de 2014, em contrapartida, acontecimentos diversos geraram volume considerável de notícias: o episódio emblemático da torcedora do Grêmio que foi filmada gritando macaco para o goleiro Aranha durante um jogo de futebol ${ }^{202}$ (tal crime foi relacionado ao de Mayara Petruso e também enquadrado como racismo); a declaração pública de um piloto da Companhia Aérea Avianca sobre o que considerava a inferioridade nordestina; ${ }^{203} \mathrm{e}$, majoritariamente, a segunda vitória de Dilma como presidenta da República com novo montante de expressões discriminatórias e preconceituosas em consequência do resultado eleitoral.

Em 2015 poucas novas notícias foram rastreadas. Como ocorrido em 2013, as notícias possuíam relação com a discriminação eleitoral do ano anterior, sem o

\footnotetext{
${ }^{200}$ O que pode ser visto em: UOL. Nordestinos são vítimas de preconceito antes das eleições em São Paulo. 2012. Disponível em: <https://www.bol.uol.com.br/eleicoes/2012/noticias/redacao/2012/10/08/nordestinos-sao-vitimas-depreconceito-antes-das-eleicoes-em-sao-paulo.htm> Acesso em: 03/04/2017.

${ }^{201}$ O que pode ser visto em: DIÁRIO DO NORDESTE. Com apagão, preconceito contra nordestino volta a surgir. 2012. Disponível em: <http://diariodonordeste.verdesmares.com.br/cadernos/cidade/online/comapagao-preconceito-contra-nordestino-volta-a-surgir-na-web-1.855023> Acesso em: 03/01/2017.

202 O que pode ser visto em: PRAGMATISMO POLÍTICO. Torcedora do Grêmio é racista com goleiro Aranha. 2014. Disponível em: <http://www.pragmatismopolitico.com.br/2014/08/torcedora-do-gremio-racistagoleiro-aranha.html> Acesso em: 03/04/2016.

${ }^{203} \mathrm{O}$ que pode ser visto em: O GLOBO. Vereador repudia piloto da Avianca após comentário contra paraibanos. 2014. Disponível em: <http://g1.globo.com/pb/paraiba/noticia/2014/03/vereador-repudiapiloto-da-vianca-apos-comentario-contra-paraibanos.html> Acesso em: 30/03/2017
} 
levantamento de novos episódios com relevância destacada. Em 2016, em contrapartida, grande conteúdo foi gerado a partir de novos acontecimentos: a publicação de pesquisa do DECRADI (Delegacia de Crimes Raciais e Delitos de Intolerância) informando que negros e nordestinos seriam o grupo que mais sofreria discriminação em São Paulo, ${ }^{204}$ o processo de golpe parlamentar ao mandato da ex-presidenta Dilma Rousseff com conteúdo de discriminação aos nordestinos; os acirramentos gerados pelas eleições municipais; os comentários públicos do cantor Roger que, revoltado com as pesquisas eleitorais indicando Lula na dianteira, afirmou que nordestinos seriam ignorantes; ${ }^{205}$ e a ofensa da atriz Alexia Dechamps que, em reunião no Congresso Nacional, afirmou para parlamentares nordestinos: "calem a boca porque eu pago o Bolsa Família do Nordeste."206

Em 2017, ano sem pleitos eleitorais, as notícias diziam respeito a manifestações discriminatórias e/ou preconceituosas pontuais, sendo que as que obtiveram maior repercussão foram: as afirmações de que nordestinos seriam bois e o Nordeste curral publicadas no website de Diogo Mainardi e Mário Sabino; ${ }^{207}$ os dizeres de uma mulher, Nelma Baldassi, que em referência ao atentado ocorrido em Manchester, Reino Unido, afirmou publicamente: "só lamento que tenha sido em Manchester e não na Bahia, seria lindo ver aquele gente nojenta e escurinha da Bahia explodindo"; 208 a decisão da Justiça de Pernambuco de processar Diogo Mainardi pela afirmação quando da eleição de 2014: “o Nordeste sempre foi retrógrado, sempre foi governista, sempre foi bovino"; 209 e as críticas

\footnotetext{
${ }^{204} \mathrm{O}$ que pode ser visto em: UOL. Negros e nordestinos são principais vítimas de discriminação em São Paulo. 2016. Disponível em: <https://noticias.uol.com.br/cotidiano/ultimas-noticias/2016/02/24/negros-enordestinos-sao-principais-vitimas-de-discriminacao-em-sp.htm> Acesso em: 03/04/2017.

${ }^{205} \mathrm{O}$ que pode ser visto em: NOSSA POLÍTICA. Roger ataca nordestinos. 2016. Disponível em <http://nossapolitica.net/2016/07/roger-ataca-nordestinos/> Acesso em: 29/04/2018.

${ }^{206}$ O que pode ser visto em: YOUTUBE. Atriz Alexia Dechamps ofende nordestinos na Câmara. 2016. Disponível em: <https://www.youtube.com/watch?v=cXPXEclzNCk> Acesso em: 29/04/2018.

${ }^{207} \mathrm{O}$ que pode ser visto em: Antagonista chama nordeste de curral e nordestinos de bois. 2017. Disponível em:<https://www.brasil247.com/pt/colunistas/eduardoguimaraes/280883/\%E2\%80\%9CAntagonista\%E2\%8 0\%9D-chama-nordestinos-de-\%E2\%80\%9Cbois\%E2\%80\%9D-e-Nordeste-de \%E2\%80\%9Ccurral\%E2\%80\%9D.htm> Acesso em: 29/04/2018.

${ }^{208}$ O que pode ser visto em: SRZD. Racismo e discriminação contra nordestinos chocam pela agressividade. 2017. Disponível em: <http://www.srzd.com/brasil/racismo-discriminacao-nordestinos/> Acesso em: 29/04/2018.

${ }^{209} \mathrm{O}$ que pode ser visto em: JC. Justiça Federal em PE julgará jornalista da Globonews por discriminação a nordestinos. 2017 Disponível em: <http://jconline.ne10.uol.com.br/canal/mundo/brasil/noticia/2017/05/26/justica-federal-em-pe-julgarajornalista-da-globonews-por-discriminacao-a-nordestinos-286123.php> Acesso em: 29/04/2018.
} 
de governadores dos estados do Nordeste feitas no Tribunal de Contas da União, afirmando que o Governo Federal estaria discriminando nordestinos. ${ }^{210}$

Analisarei as principais notícias de 2018 até meados do mês de abril, uma vez que escrevo este tópico neste período. Por tal motivo, há número reduzido de notícias neste ano, sendo que as principais foram: a ofensa virtual a um repórter nordestino da Globo, Rogério Gallindo, que pejorativamente foi tratado como paraíba; ${ }^{211}$ e a afirmação do governador baiano, Rui Costa, de que neste ano eleitoral exige respeito à Bahia e espera que não haja discriminações como consequência das eleições. ${ }^{212}$

A partir destes dados é possível estabelecer que notícias de práticas discriminatórias com maior impacto se condensem em anos eleitorais. Em outras palavras: nos anos de eleição houve grande mobilização social, intenso conteúdo gerado, não se tratando de movimentos diminutos ou individuais. É sintomático que nos anos sem pleitos eleitorais as notícias se concentrem, especialmente, em declarações pessoais ou em decisões jurídicas sobre crimes ocorridos em outros momentos, especialmente na fase de eleições.

É importante salientar que tal rastreamento possibilita a análise de uma estigmatização nordestina na esfera pública, em especial virtual. Não há dúvidas de que práticas da esfera privada necessitem de outros métodos de análise, uma vez que raramente chegam ao conhecimento público. Ainda assim, é emblemático os contextos que tenham desencadeado estas expressões de preconceito e/ou discriminação. Buscando entendê-los, analisarei alguns casos ocorridos nos últimos anos. Para ilustrar melhor os eventos, valhome da tabela a seguir.

\footnotetext{
${ }^{210} \mathrm{O}$ que pode ser visto em: JC. Governadores do Nordeste fazem crítica ao governo federal em reunião da TCU. $2017 . \quad$ Disponivel em: <http://jconline.ne10.uol.com.br/canal/politica/nacional/noticia/2017/12/06/governadores-do-nordestefazem-criticas-ao-governo-federal-em-evento-do-tcu-318757.php> Acesso em: 29/04/2018.

${ }^{211}$ O que pode ser visto em: VEJA. Repórter da globo desabafa após ofensa: 'nordestino com orgulho'. 2018. Disponível em: <https://vejasp.abril.com.br/blog/pop/reporter-da-globo-desabafa-apos-ofensa-nordestinocom-orgulho/> Acesso em: 29/04/2018.

${ }^{212} \mathrm{O}$ que pode ser visto em: BAHIA. Em ano eleitoral Rui dá recado a Temer: 'exigimos respeito a Bahia'. 2018. Disponível em: <http://bahia.ba/politica/em-ano-eleitoral-rui-da-recado-a-temer-exigimos-respeitoa-bahia/> Acesso em: 29/04/2018.
} 
Tabela 5

\begin{tabular}{|c|c|c|c|}
\hline \multicolumn{4}{|c|}{ ANÁLISE DAS NOTÍCIAS RASTREADAS } \\
\hline ANO & EVENTO & CONTEXTO & ATRIBUTOS DA OFENSA \\
\hline 2012 & $\begin{array}{c}\text { Ampla } \\
\text { Discriminação } \\
\text { Virtual }\end{array}$ & $\begin{array}{l}\text { Falta de Luz em } \\
\text { Estados do NE }\end{array}$ & $\begin{array}{c}\text { Atraso, } \\
\text { Subdesenvolvimento }\end{array}$ \\
\hline 2014 & $\begin{array}{l}\text { Comentário de } \\
\text { Eduardo Pfiffer }\end{array}$ & $\begin{array}{l}\text { Insatisfação com o } \\
\text { Serviço Recebido }\end{array}$ & $\begin{array}{c}\text { Sujeira, Inaptidão ao } \\
\text { Trabalho }\end{array}$ \\
\hline 2016 & $\begin{array}{c}\text { Ofensa de Alexia } \\
\text { Dechamps }\end{array}$ & $\begin{array}{c}\text { Discussão no } \\
\text { Congresso Nacional }\end{array}$ & Pobreza \\
\hline 2017 & $\begin{array}{c}\text { Ofensa de Nelma } \\
\text { Baldassi }\end{array}$ & $\begin{array}{l}\text { Atentado em } \\
\text { Manchester }\end{array}$ & Raça \\
\hline
\end{tabular}

O primeiro evento, ocorrido em outubro de 2012 (mês de eleições municipais) em referência à falta de luz em estados nordestinos, seria o único nesta tabela que envolveu grande número de pessoas. O universo online foi tomado por conteúdo preconceituoso quando do ocorrido. Diferentemente das outras manifestações massivas analisadas nesta dissertação, o teor não se aproximava de ódio explícito. Ao contrário: era chacota. Tal ridicularização era baseada na ideia de que o apagão no Nordeste teria surpreendido os moradores de outras regiões, já que estes nem mesmo saberiam que a região nordestina possuiria energia elétrica. Desta maneira, manipulou-se um ideal restrito de civilização (a energia elétrica como sinal de progresso) para estigmatizar a região. $\mathrm{O}$ evento, que gerou grande mobilização do Ministério Público em busca dos autores das ofensas, indica a continuidade do estigma do atraso nordestino.

O comentário de Eduardo Pfiffer, feito em 2014 em sua página pessoal no facebook, mobiliza outros atributos na constituição da ofensa. 
Para manter o padrão porco, nojento, relaxado, medíocre, escroto de tudo no Nordeste como sempre... Depois de 1 h10 esperando um file de peixe simples sem nada diferente eles conseguem errar e fazer outra coisa completamente diferente do cardápio que já não tem opção nenhuma... Povo escroto do caralho! Lugar nojento! (PFIFFER, 2014).

Nota-se no discurso do piloto da Avianca o asco direcionado às populações nordestinas. Estas aparecem como inaptas a realizar trabalhos de qualidade, como relaxadas, porcas. Neste sentido, vê-se novamente a continuidade de estigmas costumeiramente conectados ao nordestino: sujeira, vagabundagem. Vale dizer que após a repercussão na imprensa sobre os comentários de Eduardo, a Avianca o demitiu.

O terceiro evento mobilizado na tabela refere-se a uma discussão política. A ofensa feita por Alexia Dechamps - "calem a boca porque eu pago o Bolsa Família do Nordeste" - ocorreu durante um debate na Câmara dos Deputados sobre a regulação das vaquejadas. Inflamada pela discussão, a atriz proferiu publicamente estas palavras a uma série de parlamentares nordestinos. Nota-se, portanto, que foi mobilizado o estigma da pobreza nordestina, esta colocada frequentemente como solicitante de auxílio que, nesta lógica, é oferecido pelas regiões desenvolvidas. Deste modo, inferioriza-se a região por sua suposta dependência econômica.

O episódio envolvendo Nelma Baldassi, por outro lado, apresenta conteúdo de ódio racial. Nelma, ao comentar sobre o atentado ocorrido em Manchester, no Reino Unido, publicou em sua página pessoal no facebook: "só lamento que tenha sido em Manchester e não na Bahia. Seria lindo ver aquela gente nojenta e escurinha explodindo" (BALDASSI, 2016). Fica nítido não apenas o processo contínuo de racialização que envolvem as populações baianas, mas o ódio para com estas: a vontade é de que sejam eliminadas.

A análise destas notícias permite observar continuidades históricas na discriminação e preconceito com nordestinos: racialização, demarcação econômica e o estigma da inaptidão política. É interessante pontuar mais uma vez que esta discriminação e preconceito não estão restritos a São Paulo. Do contrário: número considerável das notícias aqui mobilizadas teriam protagonistas de outros estados, em especial do sudeste e do sul brasileiro.

Estes dados permitem a observação de como funciona o gradiente da estigmatização nordestina. As práticas discriminatórias e os discursos de ódio são 
evidenciados em momentos de revolta, seja com resultados eleitorais, qualidade de serviços oferecidos ou em uma discussão inflamada na Câmara dos Deputados. O preconceito, todavia, aparece com ligação à chacota: o evento relacionado à falta de luz que acometeu a região nordestina no ano de 2012 seria um exemplo disto. Deste modo, elementos do preconceito racial e de classe podem passar à esfera da discriminação e do ódio em determinadas situações de acirramento. Este fato se relacionaria à paulistanidade justamente por sua efervescência, historicamente acompanhada desta estigmatização, se dar nestes momentos.

\section{5 - Comentários Sobre Dois Casos Emblemáticos}

O caso de maior repercussão durante a revolta com os resultados eleitorais de 2010 foi o de Mayara Petruso, uma jovem estudante de Direito do interior paulista que virtualmente afirmou: "nordestino não é gente! Faça um favor a SP: mate um nordestino afogado." Em 18/05/2012, Mayara Petruso foi condenada por crime de racismo ${ }^{213}$ a um ano, cinco meses e quinze dias de prisão. A pena foi convertida em prestação de serviços comunitários e pagamento de multa e indenização no valor de $\mathrm{R} \$ 500,00$.

Posto isto, é válido refletir sobre a caracterização atribuída aos indivíduos que protagonizam atitudes preconceituosas e ganham repercussão na imprensa. O caso emblemático de uma jovem gremista, Patrícia Moreira, que foi filmada em pleno estádio gritando macaco para o jogador de futebol Aranha, gerou uma série de discussões neste sentido. Analiso este evento a partir da relação - mobilizada em especial pelos meios jornalísticos - entre Patrícia Moreira e Mayara Petruso.

É de vital importância para esta análise o fato de que a atitude racista da jovem gremista foi respondida por alguns internautas ${ }^{214}$ com ameaças de estupro. Vê-se que os marcadores sociais da diferença se entrelaçam em modos de estigmatização diferentes. Diversos movimentos de mulheres negras se posicionaram contrariamente a tal resposta, uma vez que seria irracional combater uma opressão munindo-se de outra.

Neste sentido, é interessante pensar que Mayara Petruso foi combatida em um sentido estereotipado. Grande parte das notícias relacionadas a ela tinha como temática sua nudez com comentários de internautas afirmando que ela precisaria ser violada para aprender. Apreende-se, para além de um machismo saliente, uma discriminação situada na

\footnotetext{
${ }^{213}$ Enquadrado na Lei n.o 7.716/89 que prevê punição para discriminação motivada pela procedência regional das vítimas.

${ }^{214}$ Muitos deles brancos.
} 
intimidade: todos se revoltam com Mayara Petruso, com a jovem racista que ofendeu o goleiro Aranha; poucos atribuem tais preconceitos a si. Racista é sempre o outro. Ataca-se as preconceituosas não tomando como base seu preconceito, mas o fato destas serem mulheres e, logo - em uma sociedade sexista - inferiores, estupráveis.

As atitudes das duas jovens permitem, simultaneamente, a atribuição de inaceitável a um ato preconceituoso e a absolvição do discurso social que personaliza agressões racistas: ainda somos uma democracia racial, alguns indivíduos desviantes que não entendem isto. É a banalidade do mal (ARENDT, 1963) em seu sentido mais simples: racistas, discriminadores, são alguns, não a sociedade branca. Neste sentido, diversos movimentos negros e feministas se engajam na tentativa de expor o aspecto estrutural e amplamente difundido da desigualdade.

O fato de Mayara Petruso ter sido associada pela imprensa à torcedora gremista, apesar de passados quatro anos de seu discurso que incitava o afogamento de nordestinos, prova que o caso da estudante paulista tornou-se emblemático e, portanto, relevante a esta investigação. Acredito que para além de o episódio ter fortalecido grupos que lutam contra estes tipos de discurso excludente, ${ }^{215}$ houve uma formalização da atitude: não foi uma mera rivalidade regional, o crime se enquadrou como racismo. Neste sentido, minha defesa de que a paulistanidade e suas propostas de hierarquia são racializadas, encontra mais um suporte.

Do mesmo modo, é interessante analisar os esforços jurídicos em torno da estigmatização nordestina. Como exposto pelos dados tratados neste tópico, houve número considerável de condenações a autores de comentários virtuais com tom preconceituoso ou discriminatório. Nos estudos regionalistas, todavia, há um desafio frequente: a falta de conceituação judicial da discriminação e preconceito regional brasileiro. Por ser tratado de forma ocasional como racismo, nota-se a ineficácia estatal no entendimento deste tema. É importante, contudo, pontuar que a ideia da racialização nordestina está imersa até mesmo neste meio: o crime de Mayara Petruso foi enquadrado como racismo justamente porque se sabe que ao nordestino cola-se uma imagem não-branca.

\section{6 - De Skinheads e Separatistas ao Senso Comum}

São Paulo possui uma série de movimentos sociais mobilizados em torno do

\footnotetext{
${ }^{215}$ O surgimento e recrudescimento de vários grupos online como Orgulho Nordestino e Nação Nordestina são exemplos disso.
} 
orgulho paulista. Detendo-me na análise destes grupos posso analisar o gradiente da paulistanidade, uma vez que estes possuem o regionalismo como pano de fundo, mas aparentam diferenças estratégicas e ideológicas. Neste sentido, chamam atenção grupos neonazistas que defendem as pretensas superioridades paulista e branca, expressando sua ideologia não somente a partir de discursos agressivos, mas também com a violência física. Em um local diferente do espectro político, há os grupos separatistas que almejam a independência de São Paulo e defendem uma cultura paulista unívoca e emparedada.

As diferenças que há entre skinheads regionalistas e grupos separatistas - no que concerne a práticas, propósitos e composição social - ainda assim apontam para uma similitude: o extremismo e a marginalidade. Estes atributos são concebidos e aparecem de forma distinta, bem como separam estes grupos da maioria populacional: poucos são os que se engajam ativamente nestas frentes ou as defendem abertamente.

Apesar do impacto reduzido destes grupos em mobilização macrossocial, é importante ao analisar expressões extremas da paulistanidade o fato destas basearem-se na ideia generalizada de que o paulista é superior. Isto muitas vezes é acompanhado do argumento de que seu contraponto idealizado, o nordestino, é inferior. Defendo, deste modo, que não se deva analisar grupos de agressividade patente como aberrações surgidas sem amparo social. Ao contrário: existem devido à naturalização difundida de um ideal de supremacia paulista que esbarra com frequência na branquidade e na ideia de aptidão econômica e política. ${ }^{216}$

Há casos emblemáticos da agressividade de que falo. Um deles teria ocorrido em setembro de 1992, nove dias antes de ocorrer as eleições municipais da cidade de São Paulo (no período sob o mandato da nordestina Luiza Erundina que seria sucedida no cargo por Paulo Maluf). Na ocasião, seis jovens skinheads invadiram o Centro de Tradições Nordestinas disparando tiros e pichando símbolos nazistas. No ano seguinte um jovem, também skinhead, assassinou a chutes uma pessoa em situação de rua em Ribeirão Preto. Ao ser detido, afirmou que estaria limpando a cidade de negros e nordestinos. Em 2011, dezoito anos depois, a mídia veiculou com intensidade a notícia de que neonazistas espancaram quatro pessoas em São Paulo, na estação de metrô Paraíso, gritando "negros, nordestinos, filhos da p., somos skinheads e vamos matar vocês, seus zumbis" (FOLHA DE SP, 2011).

\footnotetext{
216 “O racista numa cultura com racismo é por esta razão normal. Ele atingiu a perfeita harmonia entre relações econômicas e ideologia" (FRANTZ FANON, 1967).
} 
Oliveira (2014) expõe que estaria na formação destes grupos extremistas a necessidade de formar uma identidade a partir da contraposição. Nas palavras do historiador Peter Gay: "seja nação, província ou cidade, seja região, classe ou cultura quanto maior o amor por si mesmo, maior o direito de odiar o Outro" (GAY, 1995). Neste caminho que vai de intitular-se supremo à desumanização do outro apresenta-se como central nos novos fascismos brasileiros a questão migratória e a estigmatização nordestina. Oliveira (2014) indica que o afirmado por Mayara Petruso não possui tanta distância do proposto por estes jovens neonazistas: vê-se justamente a vontade de apagamento social do nordestino em São Paulo, sendo isto tanto uma prática discursiva quanto base para crimes de ódio.

Para pensar em tal questão, é essencial saber que nacionalismos e regionalismos encontraram coro na extrema direita ao longo do século XX e no início do século XXI. ${ }^{217}$ Bracht (2005) aponta que skinheads - presentes em parte do continente europeu desde a década de 1960 e no Brasil de 1980 - seriam voluntários da direita radical, apesar de serem, como apontado por Silva (1996), considerados escória pela organização formal de movimentos chauvinistas.

Dentre os skins brasileiros, há aqueles que permitem negros e nordestinos em sua formação e outros que são explicitamente adeptos ao orgulho branco. As semelhanças entre estes, todavia, estaria no apego ao nacionalismo e, no caso das regiões Sul e Sudeste, ao regionalismo. Isaiah Berlin (1993) aponta que engajamentos nacionalistas e regionalistas provêm, frequentemente, de uma espécie de humilhação coletiva. Deste modo, pode-se pensar nos skins brasileiros como grupos engajados a eliminar aquilo que consideram vergonha nacional o que, em São Paulo, é associado perversamente ao nordestino, às populações não-brancas e homossexuais.

Perguntando-se se este ódio skin ao nordestino pode ser encarado como questão racial, Bracht aponta que para além da raça são adicionados fatores que fogem a um racismo simples, mas que "ajudam a conformá-lo como tal" (BRACHT, 2005:102). O autor ainda atenta ao fato de que o ódio estaria presente tanto em grupos skins adeptos do whitepower quanto naqueles que se afirmam contra o racismo. Vê-se até mesmo skins de São Paulo com origem nordestina explicando o porquê do ódio aos naturais do Nordeste: o

\footnotetext{
217 "Após a dissolução do socialismo soviético, readquiriu forças e passou a ser usado como ferramenta essencial da extrema-direita européia ocidental, hábil em capitanear questões como o desemprego e as supostas desagregações cultural e racial causadas pela migração excessiva de terceiro-mundistas" (BRACHT, 2005:95).
} 
roubo de emprego seria então o argumento mobilizado (BRACHT, 2005:104). No caso dos skins adeptos à supremacia branca seria não somente a questão econômica que moveria o grupo, mas também a racial e cultural. O trecho a seguir - da música Migração, do grupo neonazista Brigada NS - é efetivo ao expor isto.

Dia após dia/ Migram do nordeste/ Centenas de imundos/ Que são uma grande peste/ Nossa histórica cultura/ Está sendo esquecida/ Nosso povo se mistura/ Com essa espécie apodrecida/ Não, migração, não/ São Paulo está/ Ficando pequeno demais/ Amo São Paulo/ Quero viver em paz/ Migração diária polui o nosso estado/ Tenho de lutar/ Não vou ficar parado. (BRIGADA NS).

Os grupos skins de orgulho branco de São Paulo e da região Sul são adeptos da independência de suas regiões ou estados. Há, contudo, certa divisão entre os movimentos: quem acredita que São Paulo deveria ser um país à parte e os que acham que deveria se juntar ao Sul. Bracht (2005) aponta, inclusive, que muitos skins da região sulina não querem juntar-se a São Paulo, já que para eles o paulista seria menos branco que o sulista.

A contradição destes movimentos não se dá somente com base em uma raça pura imaginada, mas também pelo fato de a maior parte de seus membros serem pobres e, alguns, não-brancos e nordestinos. É desafiador refletir sobre esta questão pensando que a discriminação perpetrada pelos skins é - em nível de discurso - direcionada à parte deles próprios. Vê-se um estigma - racial, de origem, econômico e sexual - forte a ponto de fazer com que indivíduos também estigmatizados passem a tratar seus iguais como externos, como passíveis de eliminação.

É sintomático o fato de que movimentos formais que não utilizam as mesmas técnicas ou bases discursivas que os skins, mas que frequentemente endossam ideia similar de superioridade, busquem afastar sua imagem a destes grupos. É o que se pode perceber nos movimentos separatistas de São Paulo. O estado possui hoje quatro movimentos sociais formalizados que tratam do tema da migração e independência. Seriam estes: Movimento São Paulo Independente, Movimento República de São Paulo, São Paulo Livre e São Paulo Para Paulistas.

O mais antigo deles é o Movimento São Paulo Independente (MSPI), fundado em 1992 pelo advogado João Nascimento Franco, que foi vice-presidente da seção paulista da Ordem dos Advogados do Brasil (OAB). Após a morte de João Franco, o movimento passou por um período de inatividade, tendo sido refundado em 2013 e formalizado em 2014 na sede paulista do Partido Progressista (PP). Declarando-se apartidário, o 
movimento expressou-se nas eleições de 2016 a partir de uma "frente bandeirante", com candidatos separatistas concorrendo em partidos diferentes nas cidades de São Paulo, Itaquaquecetuba, Jundiaí, Mogi das Cruzes e Itapetininga.

Apesar de pautar um rígido controle da migração, o MSPI afirma que não defende a expulsão de quaisquer moradores atuais de São Paulo em caso de ocorrência da separação. Do mesmo modo, coloca-se como protetor da cultura paulista frente à suposta imposição cultural sofrida por São Paulo. Para os membros do grupo, migrantes bem-vindos seriam os trabalhadores, honestos, que não impõem sua cultura e adequam-se à ideologia da livre iniciativa (MSPI, 2014). Em uma narrativa do embranquecimento, o grupo afirma que povos que souberam respeitar São Paulo seriam exemplificados pela migração europeia e japonesa.

O movimento, que possui cerca de 45,000 seguidores em sua página no facebook, engaja-se em afastar-se do perfil discriminador e preconceituoso, afirmando que o grupo é contrário a qualquer forma de discriminação e que possui valores humanos, especialmente guiados para a família tradicional. Toda esta defesa, no entanto, não anula a demarcação econômica e moral de seu discurso. Afirma-se que enquanto o brasileiro sente vergonha de si, o paulista possui orgulho e que seu único defeito seria estar atrelado a um país como o Brasil que traz a São Paulo drogas, violência, atraso e subdesenvolvimento (MSPI, 2017). Do mesmo modo, afirma-se que a alcunha de elitista, frequentemente recebida pelo grupo, não seria ofensa, mas sim motivo de orgulho, uma vez que São Paulo estaria destinado a ser parte do primeiro-mundo.

No que concerne à questão racial, observa-se apego à anulação de sua existência histórica. Afirma-se que em São Paulo não há cores, mas sim paulistas, sublimando-se a discriminação e preconceito existentes no estado. Do mesmo modo, remonta-se a ideia de democracia racial com a afirmação de que São Paulo possui uma tradição cultural que "prova que sempre fomos uma sociedade tolerante e acolhedora" (MSPI, 2017).

Apesar da tentativa de afastar-se do histórico racista que acompanhou diversas vezes a paulistanidade, vê-se relação com a historicidade embranquecedora, focada na imigração europeia e no bandeirantismo. Mais marcante ainda é o fato de autores racistas como Alberto Salles, Alfredo Ellis Jr. e Monteiro Lobato - serem mobilizados e homenageados pelo grupo tanto em seu website quanto em suas redes sociais virtuais. Neste sentido, nota-se uma estratégia comum a movimentos formalizados: afirma-se 
constantemente a não filiação a ideologias discriminatórias e preconceituosas, apesar das fontes mobilizadas serem notadamente discriminadoras.

O movimento, que também busca afastar-se do histórico da estigmatização nordestina, defendeu Mayara Petruso nas repercussões sobre sua campanha - "nordestino não é gente! Faça um favor a São Paulo: mate um nordestino afogado" - e a chamou de “jovem paulistinha” que teve a vida destruída (MSPI, 2014).

Para apresentar sua proposta de independência, o MSPI possui acepções clássicas da paulistanidade, especialmente em torno da ideia de que São Paulo seria saqueada econômica e culturalmente pelo resto do Brasil. Do mesmo modo, o grupo perpetua um ideal de aptidão política paulista frente à inaptidão brasileira, em especial nordestina. $\mathrm{O}$ trecho a seguir é elucidativo neste sentido.

As pessoas do norte e nordeste, e também de Minas que foram fundamentais para eleger a senhora Dilma Rousseff tem todo o direito de assim procederem. Se eles querem viver sob o governo do partido político mais sujo e corrupto da longa história de imundície desse país, ora, que vivam, mas não nos obriguem a viver sobre esse mesmo regime. (MSPI, 2014).

Afirmando que São Paulo deve lutar contra o "grande câncer que é o Brasil” (2014) o MSPI possui uma linguagem própria, montada a partir da seleção de eventos históricos: inimigos são chamados de emboabas, São Paulo de um dos países que compõem a América Portuguesa e o povo do estado de valoroso herdeiro de 1932. Do mesmo modo, o grupo apresenta apego à Polícia Militar paulista, estando ela presente com frequência em fotos e discursos divulgados pelo movimento. Neste sentido, o grupo defende a ação policial na área da cidade estigmatizada sob o nome de Cracolândia e nos protestos variados que ocorrem no estado. Não causa estranhamento, portanto, que o movimento apoie um político que compõe a bancada da bala: “o Coronel Telhada é um político que admiramos" (FOLHA DE SP, 2015).

Desta forma, as propostas do MSPI para São Paulo enquanto país envolvem um Estado forte, a defesa da propriedade privada "como princípio inegociável” (2014), a formação de forças armadas vigorosas, controle rígido sobre o crime, salvaguarda da família em seu modelo tradicional, ${ }^{218}$ a ética do trabalho e responsabilidade individual, o fim do teórico paternalismo governamental e a defesa da cultura paulista. Vê-se, portanto,

${ }^{218} \mathrm{O}$ que apresenta um caráter profundamente heteronormativo. 
apego a uma economia de cunho liberal ancorada no mérito e em composições culturais e políticas conservadoras.

É interessante que o grupo possua relações com outros movimentos separatistas, não só brasileiros, mas também norte-americanos. Há contato a partir de congressos interestaduais com os militantes d'O Sul é Meu País desde a década de 1990. Da mesma forma, travou-se relações com o movimento separatista texano: Texas Nationalist Movement. O grupo estadunidense declarou apoio ao MSPI em 2015.

O MSPI engendrou e apoiou o processo de Golpe ocorrido em 2016, expressando o ódio ao PT e aos seus eleitores que marcou o período. Chama atenção, para além disso, o fato de o grupo criticar - sob a alcunha de alienado - os que se manifestavam com a bandeira do Brasil em prol da deposição. Na lógica do MSPI, seria a bandeira de São Paulo a representante desta luta. Do mesmo modo, defende-se que o tema da independência deveria ser mais amplamente discutido e não o do impeachment.

O movimento evoca, além da admiração ao militarismo, armamento e às ações da polícia militar, figuras conservadoras como as de Olavo de Carvalho e Diogo Mainardi. Vale dizer que os membros do grupo independentista realizam manifestações na rua, em especial no 9 de julho (que marca o início do Conflito Constitucionalista) e no 14 de novembro (dia do bandeirante). Os locais escolhidos coadunam ao plano histórico e arquitetônico que engendrou a paulistanidade: o Monumento às Bandeiras (feito para a comemoração do IV Centenário) e a Avenida Paulista (símbolo de urbanização) são os locais mais frequentes de manifestações deste grupo.

Compilei dez, dentre as quase duas mil fotos que o grupo já publicou em sua página de facebook, para expor parte da ideologia do MSPI. Vê-se nas imagens (20, 22, 23, 25) tanto um ideal meritocrático, capaz de naturalizar a desigualdade de uma sociedade de classes, quanto o apego aos pretensos diferenciais em torno do trabalho e pragmatismo paulista. Do mesmo modo, nota-se o apego a figuras políticas conservadoras (imagem 16), bem como o reconhecido ódio (imagem 17) direcionado a Lula e a Getúlio Vargas em prol de um discurso paulistanista.

O rechaço à pobreza (imagem 25) também pode ser observado, bem como a tentativa de endossar a mítica democracia racial (imagem 20) ao tratar do tema das cotas como um "prejuízo para os que estudam". Vale dizer que o MSPI é reconhecido por frequentar a Assembleia Legislativa de São Paulo (imagem 18), em especial no mês de julho, marcado pela memória do Conflito de 1932. O nome 9 de julho ser dado ao palácio 
da ALESP e a uma avenida da cidade endossam o fato de que o extremismo de um grupo como o MSPI baseia-se na legitimidade generalizada da paulistanidade.

Para além disso, as imagens pontuam a já citada filiação do grupo ao militarismo (imagem 19), à ideia de que São Paulo seria economicamente prejudicado pelo Brasil (imagem 24) e às manifestações públicas do orgulho paulista (imagem 21). É importante analisar na figura 26 a racialização e demarcação econômica das manifestações culturais postas como avessas ao ideal paulista.

\section{gles leVARAM A baNdeira paUlista AO CONGRESSO}
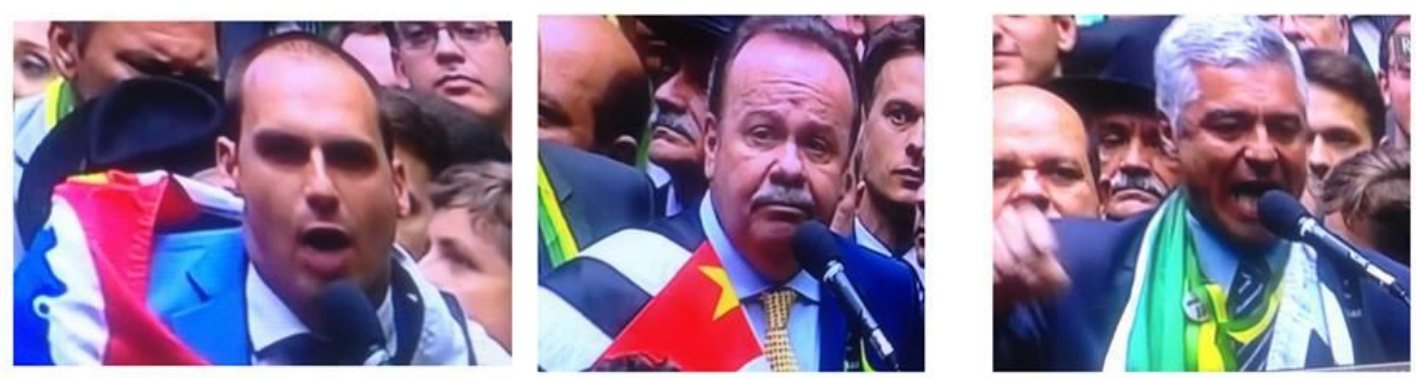

PARABÉNS AOS DEPUTADOS EDUARDO BOLSONARO, GOULART E MAJOR OLIMPIO POR HONRAREM A VERDADEIRA PÁTRIA PAULISTA. MUITO OBRIGADO, DEPUTADOS!

MOVIMENTO SÃO PAULO INDEPENDENTE

DIVULGUE APOIE COMPARTILHE

www.saopauloindependente.org

Imagem 16

Nota-se a filiação do MSPI a figuras conservadoras do plano político, conhecidas pelo pertencimento à chamada Bancada da Bala.

\footnotetext{
${ }^{219}$ Imagem retirada em: MOVIMENTO SÃO PAULO INDEPENDENTE. Facebook. 17/04/2016. Disponível em: < https://www.facebook.com/MSPIreal/photos/a.138763312986243.1073741828.137976879731553/491597 127702858/?type=3\&theater $>$ Acesso em: 29/04/2018.
} 

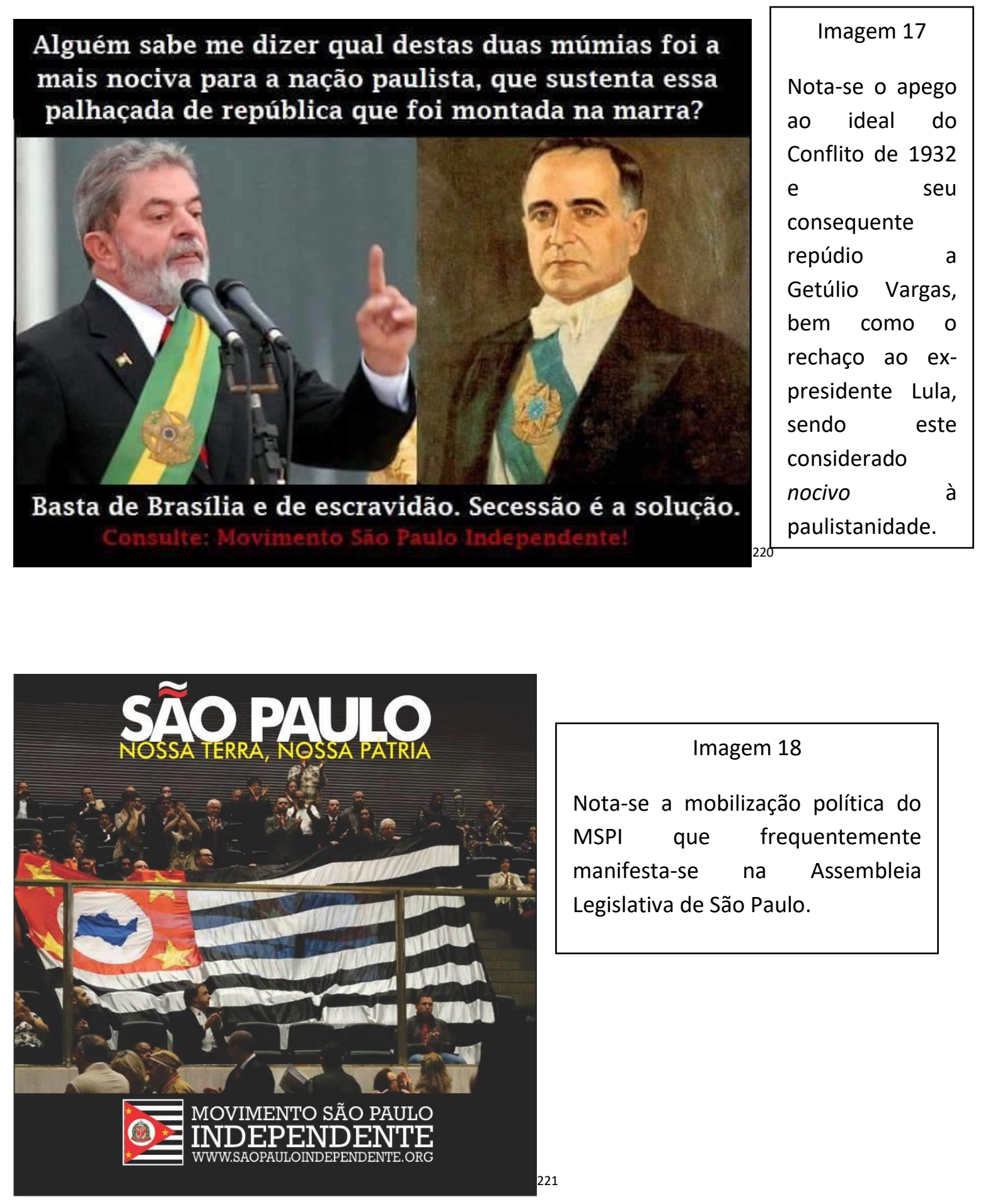

\section{Imagem 18}

Nota-se a mobilização política do MSPI que frequentemente manifesta-se na Assembleia Legislativa de São Paulo.

\footnotetext{
${ }^{220}$ Imagem retirada em: MOVIMENTO SÃO PAULO INDEPENDENTE. Facebook. 30/01/2016. Disponível em: < https://www.facebook.com/MSPIreal/photos/a.138763312986243.1073741828.137976879731553/462382 567290981/?type=3\&theater $>$ Acesso em: 29/04/18.

${ }^{221}$ Imagem retirada em: MOVIMENTO SÃO PAULO INDEPENDENTE. Facebook. 25/09/2017. Disponível em: < https://www.facebook.com/MSPIreal/photos/a.138763312986243.1073741828.137976879731553/722225 261306709/?type=3\&theater $>$ Acesso em: 29/04/2018.
} 


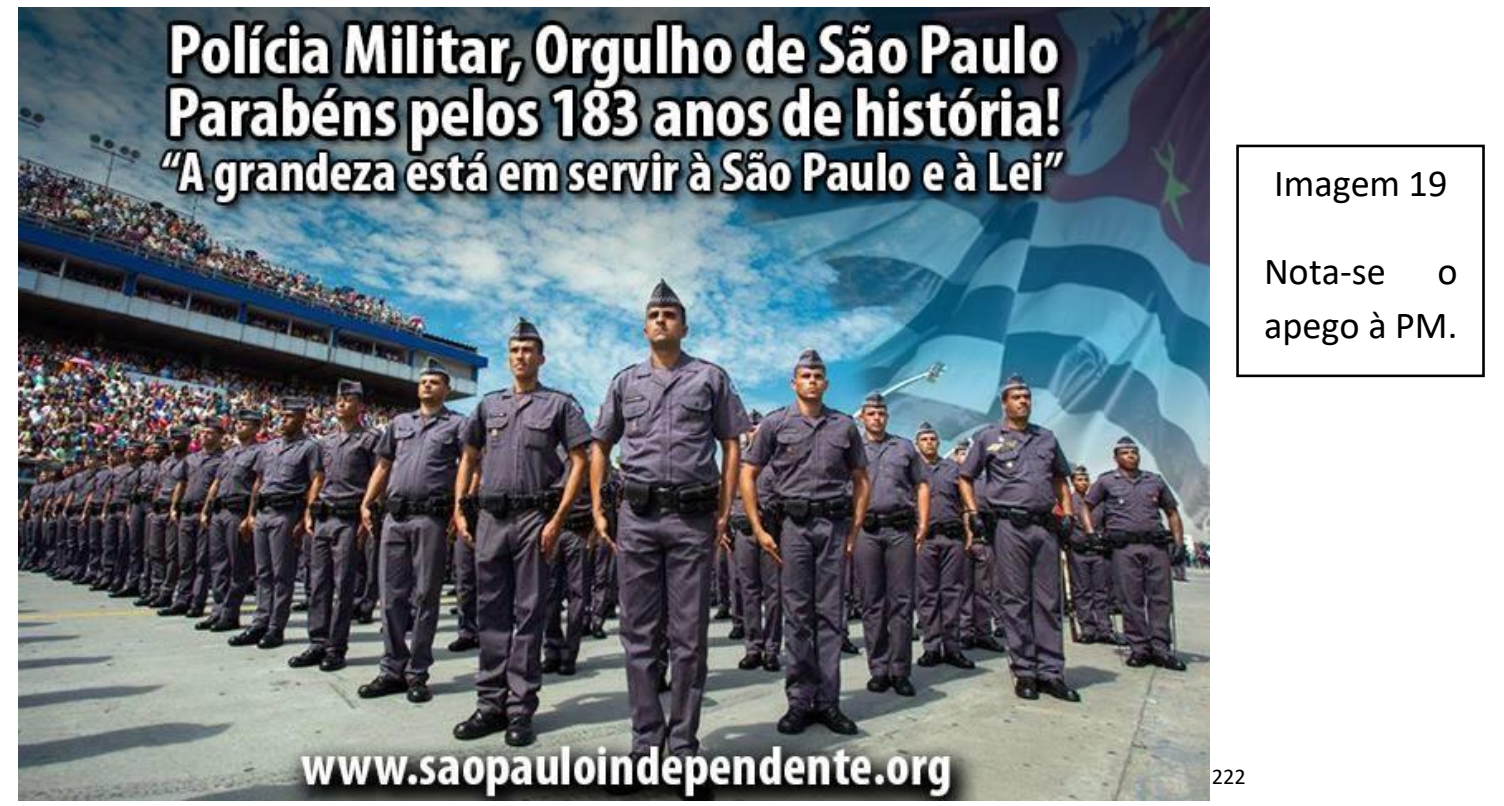

A maioria dos brasileiros se diz contra a violência, mas elogia Getúlio Vargas, Zumbi, Lampião e os cabras-machos que espancaram a mulherada e os homens fracos por não levarem desaforo pra casa;

A maioria dos brasileiros se diz contra a corrupção e desigualdade, mas elogia a cota racial universitária e a cota racial de emprego público em fävor de quem não quer estudar em prejuízo aos que estudam, bem como paga e/ou recebe propina e obtém vantagens em detrimento de quem é honesto;

A maioria dos brasileiros se diz contra os ladrões, mas elogia o Lula e a Dilma em desfavor ao povo do Estado de São Paulo;

A maioria dos brasileiros se diz contra o Movimento São Paulo Independente, mas elogiam efusivamente a Inconfidência Mineira.

Qual é a lógica nisso tudo?

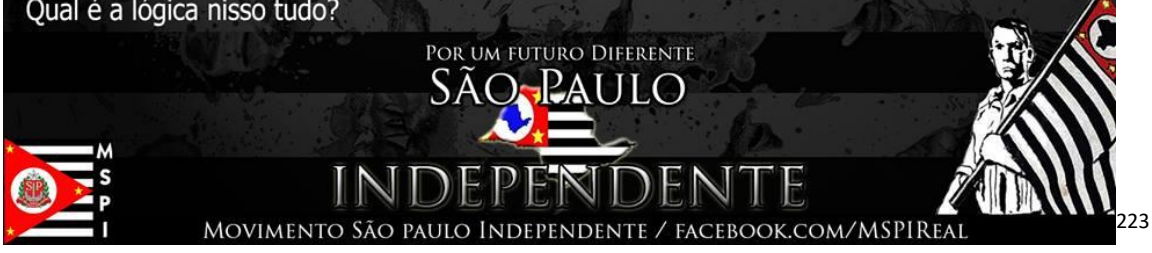

Imagem 20

Símbolos negros e nordestinos, como Zumbi e Lampião, são descritos como violentos covardes. e políticas raciais afirmativas são afirmadas exemplos de desigualdade, até mesmo corrupção. $\quad$ As eleições de Lula e Dilma são colocadas como "desfavor a São Paulo" e o brasileiro aparece como irracional.

${ }^{222}$ Imagem retirada em: MOVIMENTO SÃO PAULO INDEPENDENTE. Facebook. 15/12/2014. Disponível em: < https://www.facebook.com/MSPIreal/photos/a.138763312986243.1073741828.137976879731553/326452 587550647/?type=3\&theater> Acesso em: 29/04/18.

${ }^{223}$ Imagem retirada em: MOVIMENTO SÃO PAULO INDEPENDENTE. Facebook. 05/04/2014. Disponível em: < https://www.facebook.com/MSPIreal/photos/a.138763312986243.1073741828.137976879731553/226069 534255620/?type=3\&theater> Acesso em: 29/04/18. 


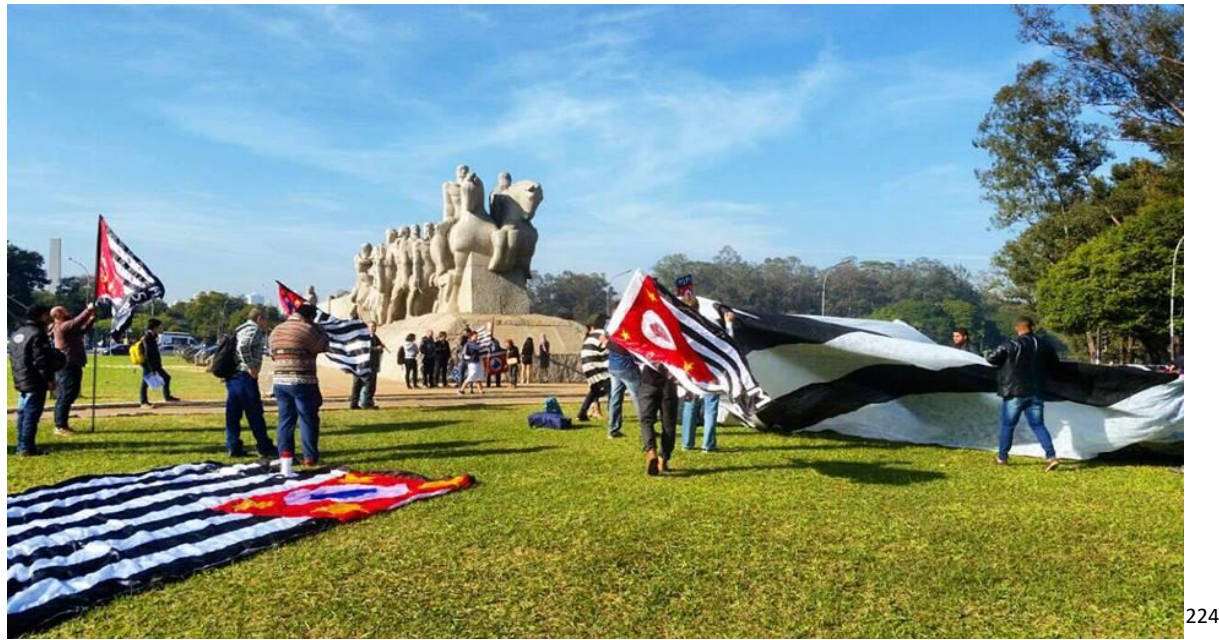

Imagem 21

Exemplo de manifestação pública feita pelo grupo.

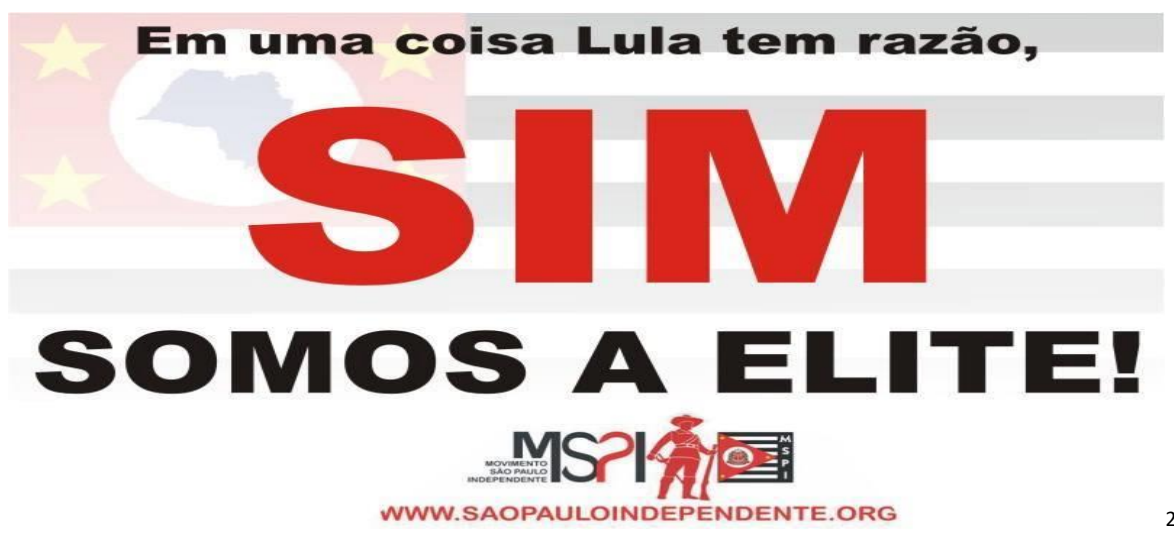

225

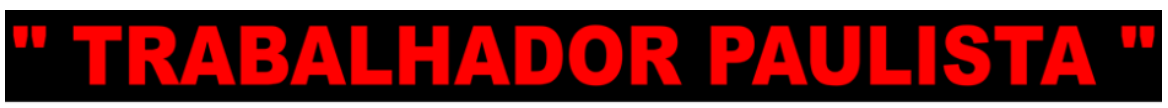

\section{Este é um exemplo de expressão redundante, pois as palavras "trabalhador" e "paulista" significam exatamente a mesma coisa.}

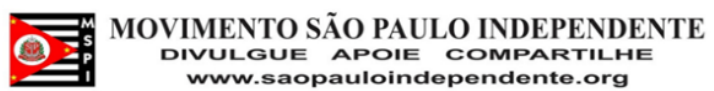

Imagem 23

Nota-se os ideais de trabalho, pragmatismo, mérito empreendedorismo como características intrínsecas ao paulista.

\footnotetext{
${ }^{224}$ Imagem retirada em: MOVIMENTO SÃO PAULO INDEPENDENTE. Facebook. 09/07/2016. Disponível em: < https://www.facebook.com/MSPIreal/photos/a.138763312986243.1073741828.137976879731553/520038 281525409/?type=3\&theater $>$ Acesso em: 29/04/2018.

${ }^{225}$ Imagem retirada em: MOVIMENTO SÃO PAULO INDEPENDENTE. Facebook. 07/11/2017. Disponível em: < https://www.facebook.com/MSPIreal/photos/a.138763312986243.1073741828.137976879731553/739007 756295126/?type=3\&theater> Acesso em: 29/04/2018.

${ }^{226}$ Imagem retirada em: MOVIMENTO SÃO PAULO INDEPENDENTE. Facebook. 01/05/2017. Disponível em: < https://www.facebook.com/MSPIreal/photos/a.138763312986243.1073741828.137976879731553/655948 694601033/?type=3\&theater> Acesso em: 29/04/2018.
} 

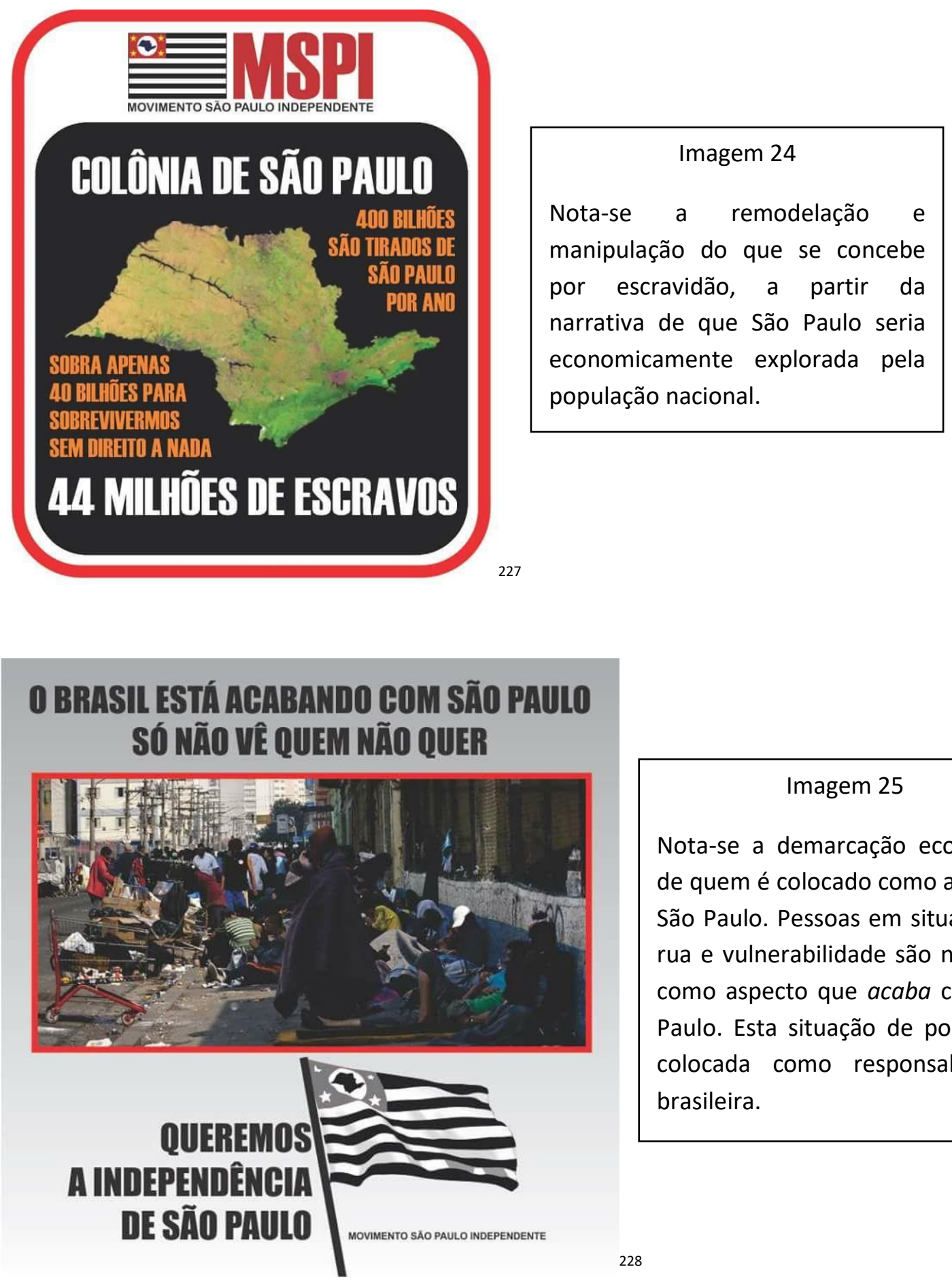

Imagem 25

Nota-se a demarcação econômica de quem é colocado como avesso a São Paulo. Pessoas em situação de rua e vulnerabilidade são narradas como aspecto que acaba com São Paulo. Esta situação de pobreza é colocada como responsabilidade brasileira.

${ }^{227}$ Imagem retirada em: MOVIMENTO SÃO PAULO INDEPENDENTE. Facebook. 20/09/2017. Disponível em: < https://www.facebook.com/MSPIreal/photos/a.138763312986243.1073741828.137976879731553/720187 904843778/?type=3\&theater $>$ Acesso em: 29/04/2018.

${ }^{228}$ Imagem retirada em: MOVIMENTO SÃO PAULO INDEPENDENTE. Facebook. 10/03/2017. Disponível em: < https://www.facebook.com/MSPIreal/photos/a.138763312986243.1073741828.137976879731553/628547 634007806/?type=3\&theater $>$ Acesso em: 29/04/18. 


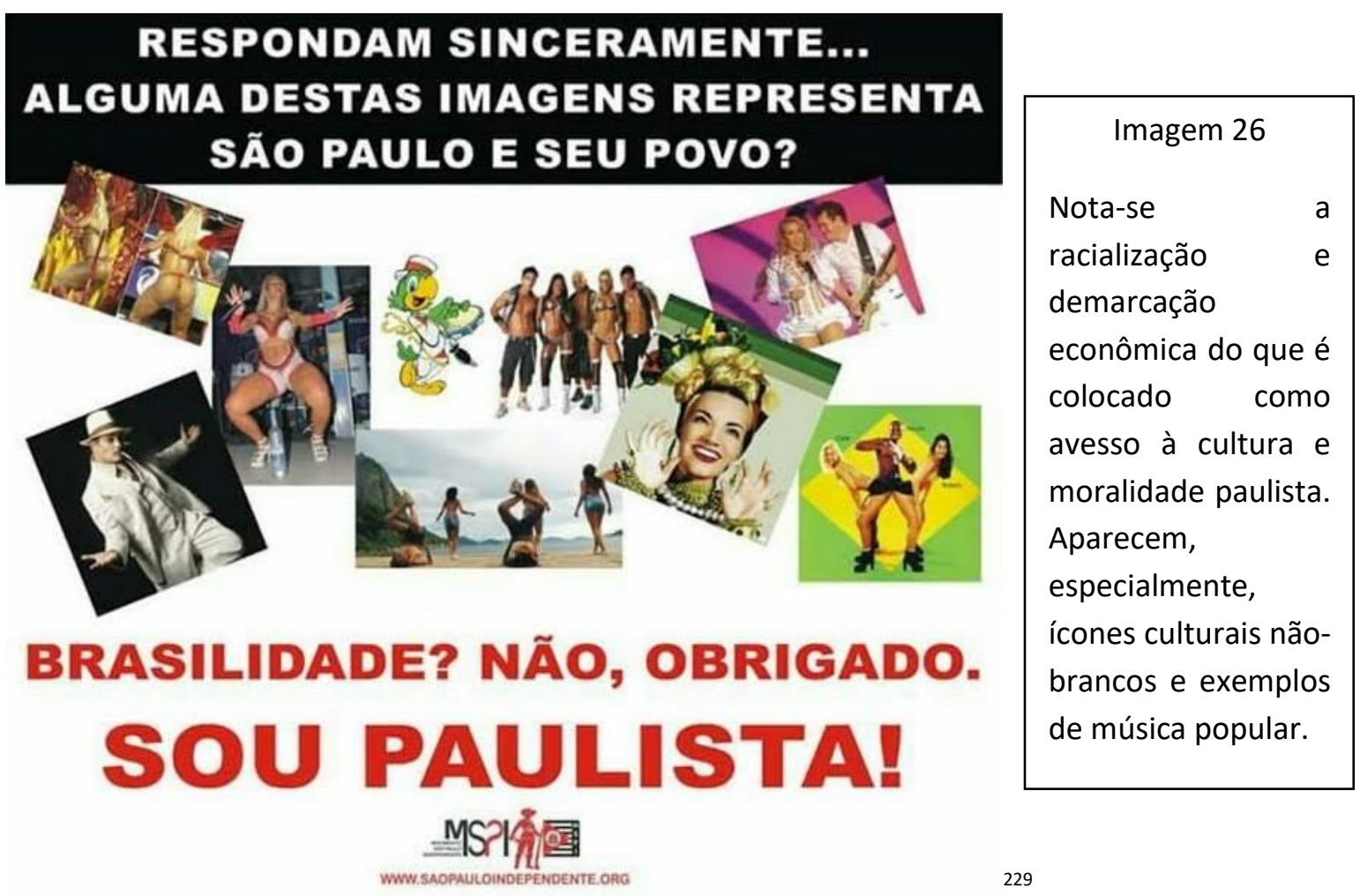

Outro movimento paulista engajado na independência do estado seria o MRSP: Movimento República de São Paulo. O grupo, formado em 09 de julho de 2011, possui quase 1.100 membros - segundo exposto em seu website - e é acompanhado por cerca de 22.000 pessoas em sua página no facebook. Um dos maiores diferenciais do MRSP em relação ao MSPI seria o rechaço à Polícia Militar do estado. Afirma-se que esta seria auxiliar da ocupação brasileira que ocorre desde outubro de 1932. Inclusive, a cada comunicado escrito, o grupo finaliza afirmando que a república paulista estaria, em 2018, no seu $128^{\circ}$ ano de fundação, $87^{\circ}$ ano de revolução e $87^{\circ}$ ano de ocupação militar e política do Brasil.

Apesar de afirmar-se pacífico em seu estatuto (2014), ${ }^{230}$ o MRSP defende com certa recorrência a necessidade de armamento da população, bem como o direito sagrado à propriedade privada que, se violado, poderia ser defendido à bala. ${ }^{231}$ Esta é uma dentre

\footnotetext{
${ }^{229}$ Imagem retirada em: MOVIMENTO SÃO PAULO INDEPENDENTE. Facebook. 05/08/2016. Disponível em: < https://www.facebook.com/MSPIreal/photos/a.138763312986243.1073741828.137976879731553/530408 693821701/?type=3\&theater $>$ Acesso em: 29/04/2018.

230 "O Movimento República de São Paulo, estatutariamente e dentro do espírito democrático de suas lideranças e de seus membros, refuta veementemente qualquer uso bélico para a libertação de São Paulo, que parta de suas fileiras ou de seus membros." (MRSP, 2014).

${ }^{231}$ "Quando reerguermos a República de S. Paulo, cada paulista terá os seu sagrado direito a propriedade privada preservada em absoluto e o sagrado direito de defender a bala o produto do seu trabalho da agressão criminosa daqueles que ousarem tentar violar este direito. Um sociedade armada, é uma sociedade livre com propriedade privada assegurada." (MRSP, 2017).
} 
muitas pautas propostas pelo movimento. Como observado em outros grupos em torno da paulistanidade, defende-se a cultura paulista frente à suposta imposição cultural sofrida pelo estado, o livre mercado e o mérito. Do mesmo modo, ampara-se em uma narrativa com apego ao bandeirantismo, a 1932 e à imigração europeia. Nesta lógica, São Paulo aparece como estado que possui uma cultura única, ninguém poderia se comparar ao paulista e, quando é possível a comparação, seria devido à presença de linhagem direta de habitantes de São Paulo em outras regiões. ${ }^{232}$

Para basear estes argumentos, o MRSP mobiliza argumentos clássicos da paulistanidade: o Brasil só possui o tamanho atual devido a um paulista-bandeirante difuso; São Paulo sustenta econômica e moralmente o restante do Brasil; a grandeza do estado existe por uma questão de merecimento. Do mesmo modo, apresenta preocupação similar a de seus pares ao afastar-se da mácula de discriminador ou preconceituoso. Afirma-se que o movimento não seria adepto a nenhum princípio excludente, o que, como no caso do MSPI, é contrariado pela filiação a uma historicidade baseada em figuras racistas como Monteiro Lobato e Ellis Jr.

Para afirmar a pretensa superioridade de São Paulo e seus habitantes, indica-se que não se pode levar em consideração somente a mescla, comum a todo Brasil, entre indígenas, brancos e negros, mas sim o caráter distintivo acerca de quais seriam estes indígenas, estes brancos e estes negros. Esta etnicidade imaginária ainda é evocada em São Paulo com um diferencial: deve-se levar em consideração as correntes migratórias dos séculos XIX e XX.

Vê-se nitidamente nesta narrativa um apego a migração europeia como sorte e a tentativa de enaltecimento distinto das populações negras e indígenas que fazem parte de São Paulo: como se todos grupos humanos que compuseram o estado fossem distintos, tivessem criado a especialidade paulista. ${ }^{233}$ Deste modo, não se vê o apagamento de

\footnotetext{
232 “Há ainda que registrar que São Paulo, culturalmente falando é ímpar. Embora guarde traços de assemelhação com outras populações latino americanas (em especial as populações do Sul do Brasil, de Mato Grosso, Mato Grosso do Sul, Minas Gerais e Goiás, neste caso, pelo fato dessas populações serem descendentes diretas, filhas da cultura paulista), isso se deve aos fatores étnicos da formação desses povos" (MRSP, 2014).

233 “Há ainda que registrar que São Paulo, culturalmente falando é ímpar (...) Há sempre a combinação de europeus+indígenas+africanos, entretanto temos que colocar em questão quais indígenas, quais europeus e quais africanos povoaram cada uma dessas regiões e que vieram a dar nessas populações modernas. Há ainda que deixar registrada a grande influência das correntes imigratórias dos Séculos XIX e XX. Para esse estudo não há regra fixa, há a observação dos fatos e só” (MRSP, 2014).
} 
composições negras e indígenas que costumou acompanhar a paulistanidade. A afirmação de existência destes grupos sociais, todavia, leva à asserção destes como superiores em relação aos seus pares externos a São Paulo. Neste caso, nota-se a continuidade de uma paulistanidade que coloca a questão da desigualdade como exógena ao estado e seus habitantes.

As imagens, por mim compiladas da página de facebook do MRSP, são capazes de resumir um pouco da narrativa empreendida pelo grupo. Assim como o MSPI, o movimento caracteriza-se por realizar manifestações em locais de São Paulo caros à paulistanidade (imagem 27). Do mesmo modo, vê-se a mobilização do termo liberdade como natural de sua causa (imagem 31). Nota-se o rechaço à polícia militar do estado (imagem 28) e aos paulistas conectados ao ideal de brasilidade (imagem 29) a partir da mobilização de termos sexistas. Também é possível apreender o apego ao Conflito de 1932 com seu consequente repúdio a Getúlio Vargas (imagem 30). A imagem 32 permite que se perceba tanto a importância do evento constitucionalista para o grupo quanto a mobilização de fontes que se esmeravam em pautar a desigualdade racial brasileira, como Monteiro Lobato (que fez parte da associação eugênica do Brasil).

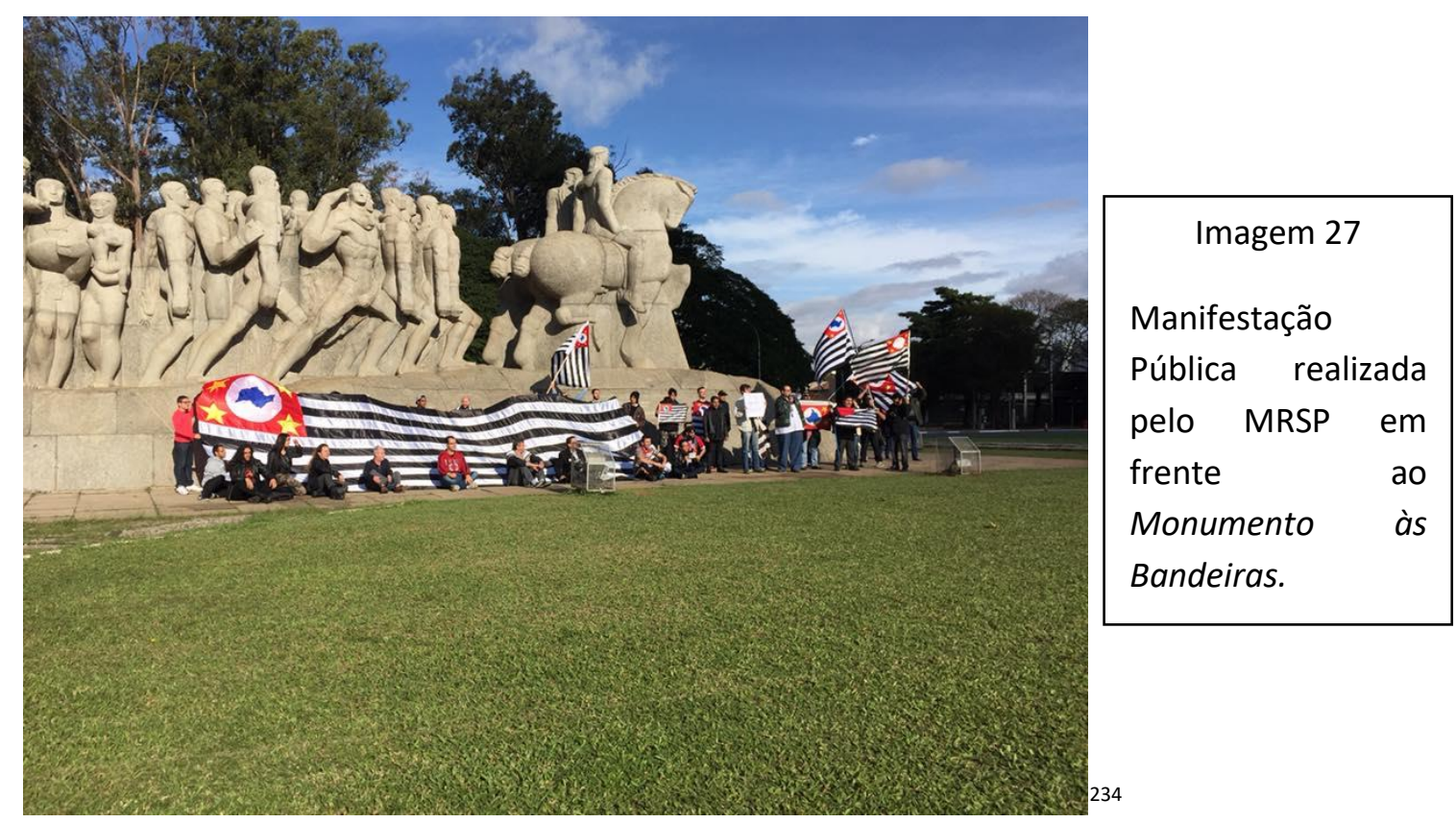

\footnotetext{
${ }^{234}$ Imagem retirada em: MOVIMENTO REPÚBLICA DE SÃO PAULO. Facebook. 09/07/2015. Disponível em: https://www.facebook.com/MrspOficial/photos/a.657584087620752.1073741827.348521371860360/9193 13728114452/?type=3\&theater $>$ Acesso em: 29/04/18.
} 


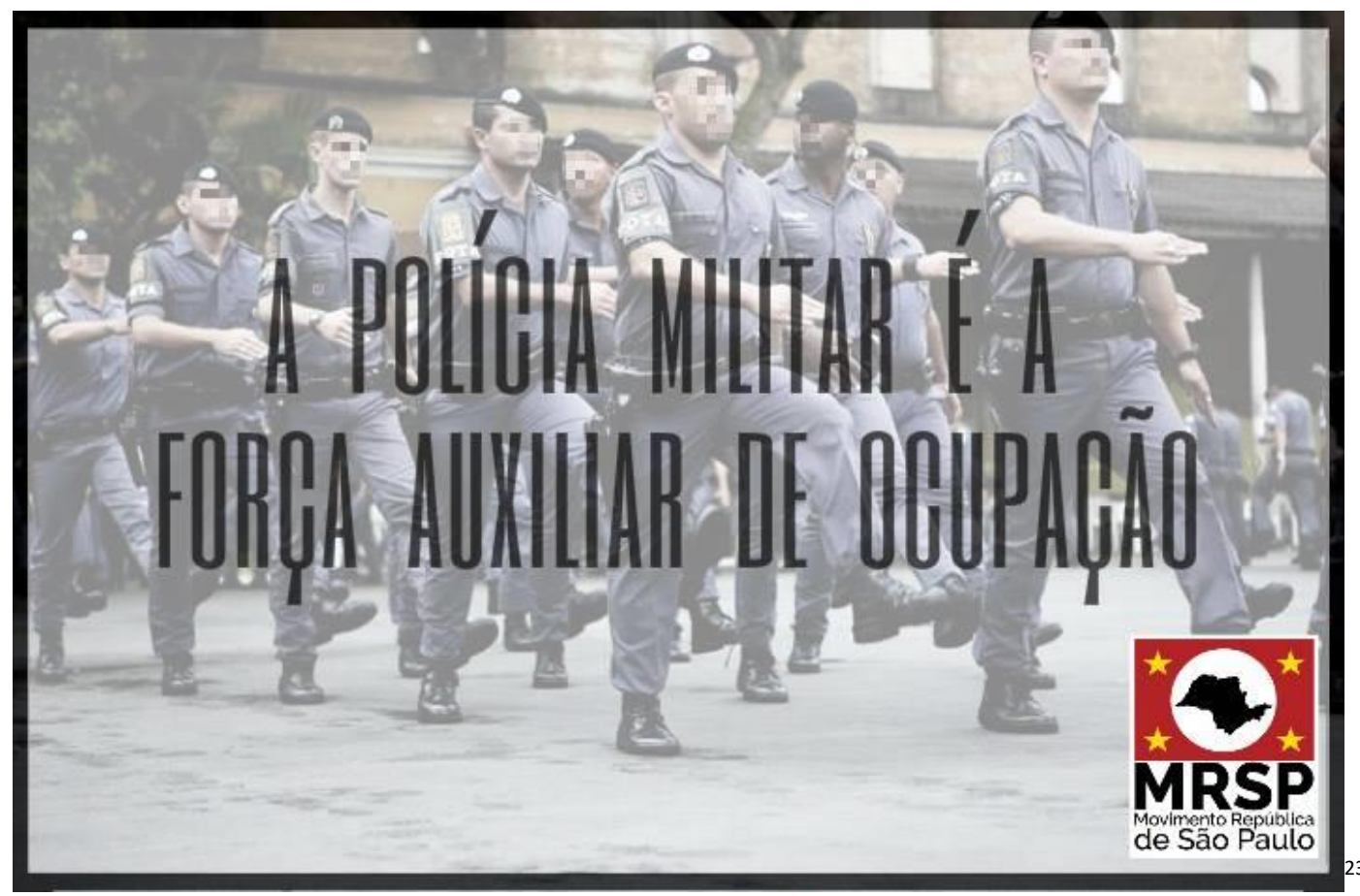

Imagem 28

Nota-se o repúdio do MRSP à Polícia Militar.

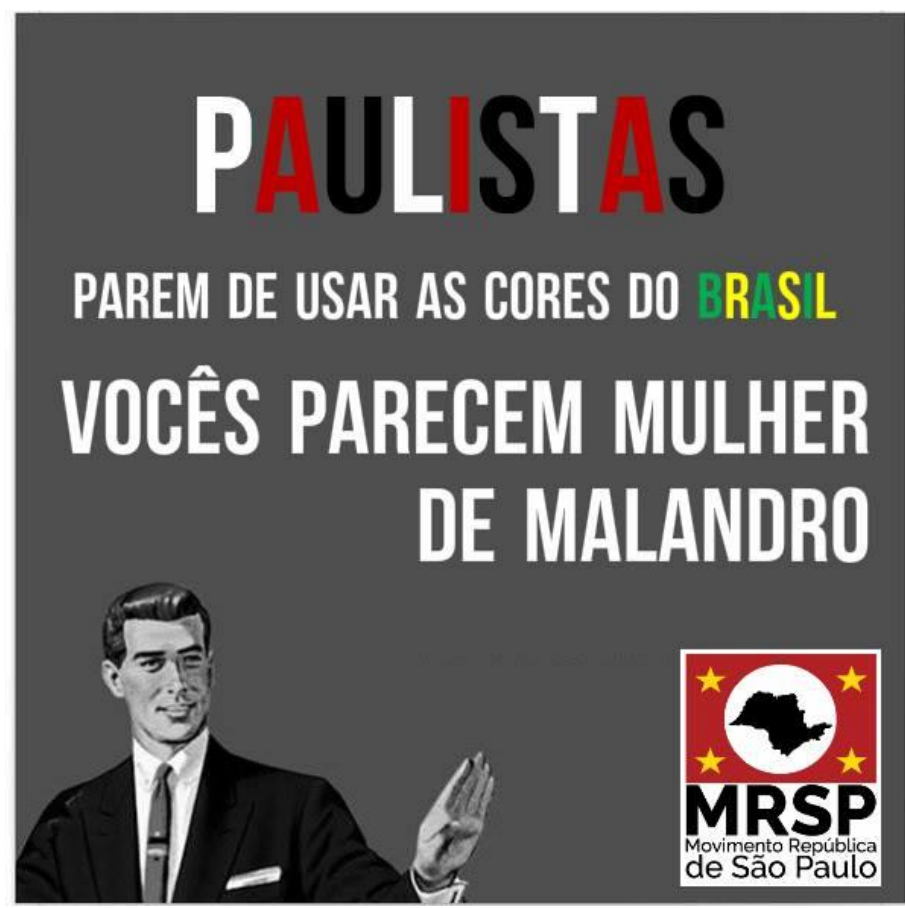

Imagem 29

Uma categoria sexista, mulher de malandro, é mobilizada tanto para expor São Paulo como estado prejudicado pelo Brasil, quanto para endossar o argumento em prol da separação.

\footnotetext{
${ }^{235}$ Imagem retirada em: MOVIMENTO REPÚBLICA DE SÃO PAULO. Facebook. 10/02/2017. Disponível em: < https://www.facebook.com/MrspOficial/photos/a.348970691815428.81048.348521371860360/130876475
} 9169345/?type=3\&theater $>$ Acesso em: 29/04/18. 


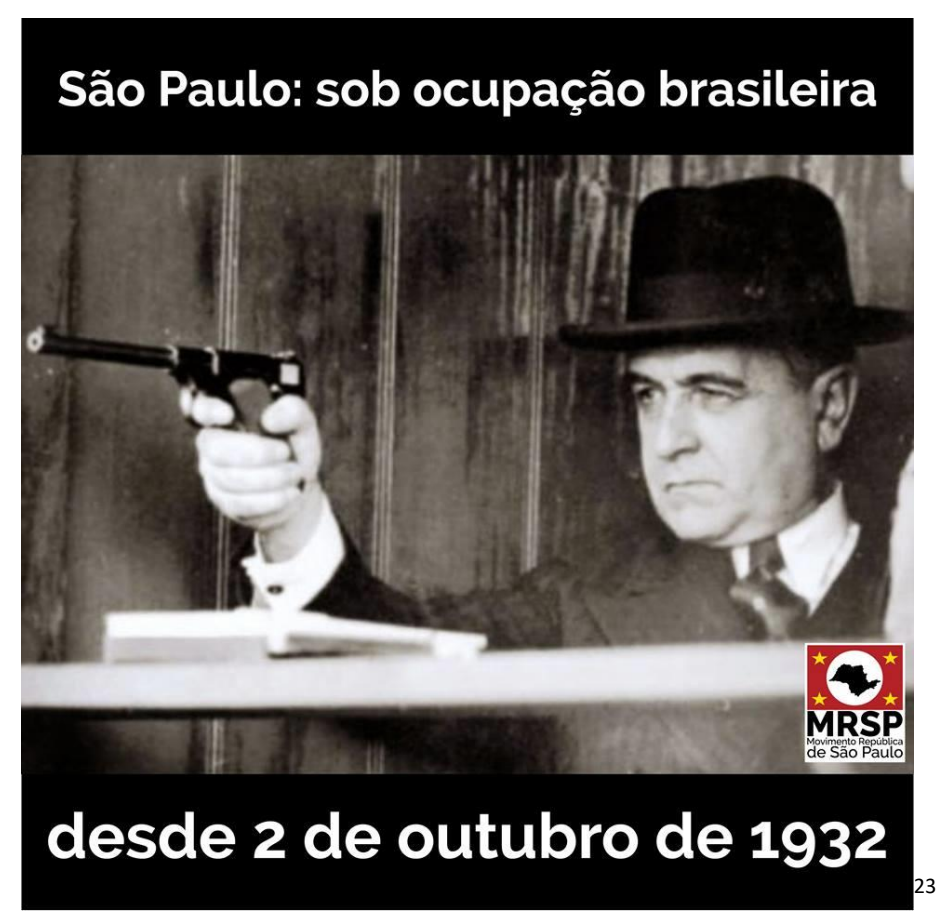

\begin{tabular}{|l|}
\hline \multicolumn{1}{|c|}{ Imagem 30} \\
Vê-se o apego do grupo ao Conflito \\
de 1932 e a crença de que desde \\
então São Paulo estaria sob jugo \\
brasileiro.
\end{tabular}

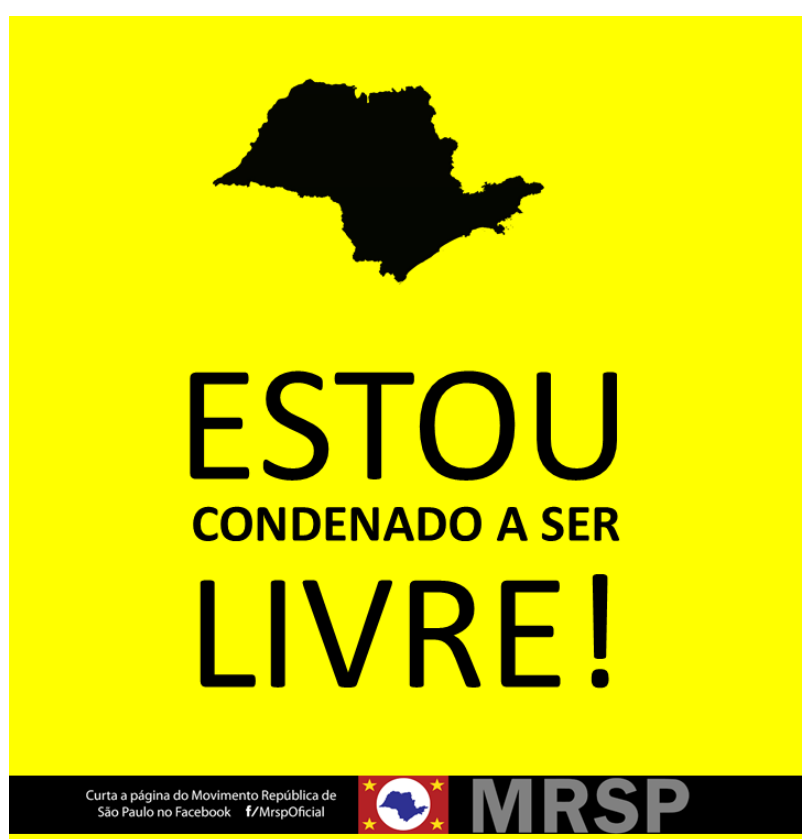

Imagem 31

Pauta-se a liberdade paulista como algo que surgiria com a República de São Paulo.

${ }^{236}$ Imagem retirada em: MOVIMENTO REPÚBLICA DE SÃO PAULO. Facebook. 06/10/2016. Disponível em: $<$ https://www.facebook.com/MrspOficial/photos/a.348970691815428.81048.348521371860360/11807899 75300158/?type=3\&theater $>$ Acesso em: 29/04/18.

${ }^{237}$ Imagem retirada em: MOVIMENTO REPÚBLICA DE SÃO PAULO. Facebook. 18/04/2016. Disponível em: <https://www.facebook.com/MrspOficial/photos/a.348970691815428.81048.348521371860360/10586469 40847796/?type=3\&theater> Acesso em: 29/04/2018. 


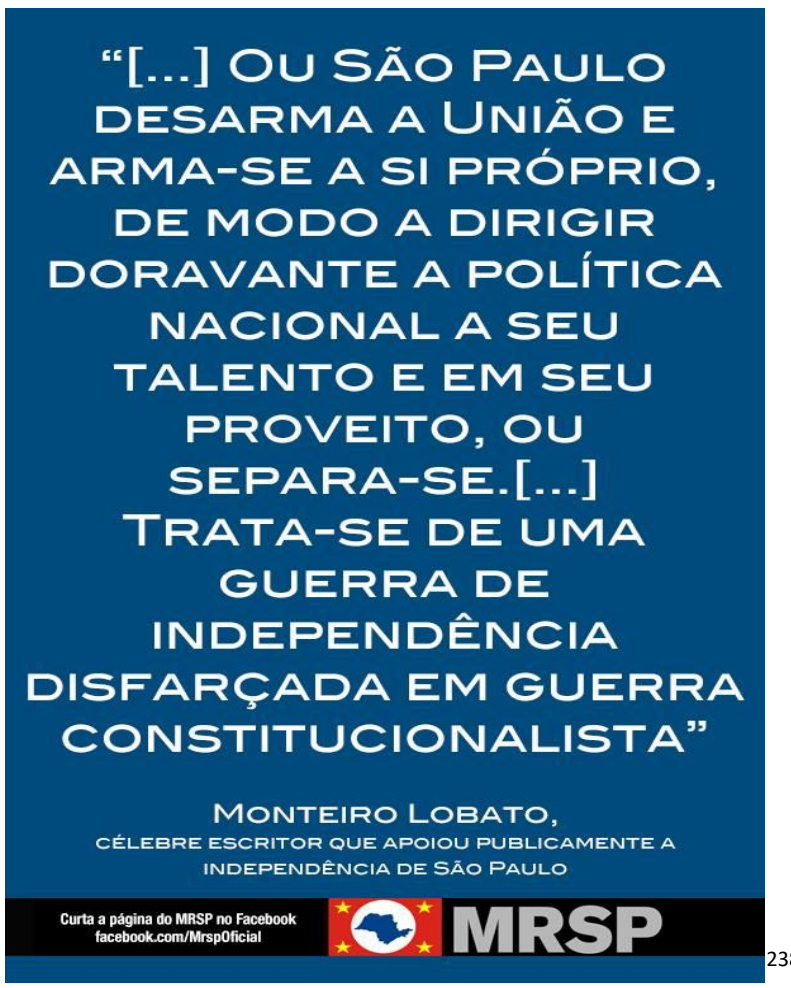

Imagem 32

Novamente vê-se o apego ao Conflito Constitucionalista e a figuras que se imbuíram na discriminação racial, como é o caso de Monteiro Lobato.

Outros dois movimentos formalizados em torno do orgulho paulista são o São Paulo Livre, criado em 2014, e o São Paulo Para Paulistas, criado em 2010. Os dois próximos capítulos desta dissertação tratarão especificamente destes grupos, uma vez que suas narrativas permitem analisar caminhos diferentes tomados em torno da paulistanidade.

São Paulo Para Paulistas, como já dito nesta dissertação, trata-se de um manifesto contra a presença migrante em São Paulo, o que faz com que o grupo tenha atividades menos contínuas. Os documentos criados pelo movimento apresentam linguagem notadamente agressiva. Deste modo, dentre o gradiente da paulistanidade, nota-se o grupo mobilizando pautas discriminatórias que em determinados momentos configuram prática de ódio. O São Paulo Livre, por outro lado, busca conectar-se com o empresariado paulista e, a partir de uma linguagem que aparenta suavidade, realiza plebiscitos para ampliar o ideal separatista.

Todos estes quatro movimentos apresentados possuem como premissa básica a pretensa superioridade econômica, política e moral dos paulistas, bem como a defesa de que sua militância seria amparada pelo direito à liberdade de expressão. É interessante pensar o que os difere. São Paulo Para Paulistas, MSPI e SPL se caracterizam por uma admiração à polícia militar do estado, enquanto o MRSP a repudia enquanto força da

\footnotetext{
${ }^{238}$ Imagem retirada em: MOVIMENTO REPÚBLICA DE SÃO PAULO. Facebook. 06/04/2014. Disponível em: < https://www.facebook.com/MrspOficial/photos/a.348970691815428.81048.348521371860360/690370331 008794/?type=3\&theater> Acesso em: 29/04/2018.
} 
ocupação brasileira. O MRSP e o São Paulo Para Paulistas não se engajam politicamente na defesa de qualquer candidato eleitoral, enquanto o SPL acaba de criar um partido e o MSPI tem candidatos concorrendo em diferentes setores partidários. O SPL busca estreitar relações com o empresariado de São Paulo e aparentar uma imagem mercantil e moderna, enquanto o MSPI mostra-se mais conectado a uma tradição separatista, amparada pela relação com outros movimentos secessionistas do país e com estudos históricos paulistas. Comparados com estes dois grupos, o MRSP e o São Paulo Para Paulistas possuem uma aparência menos profissional e também menos enriquecida.

É comum a todos a busca de afastar-se do estigma do preconceito, apesar de apresentarem o paulista como superior, o ideal do mérito e a filiação a fontes históricas que se aproximaram do racismo científico. Como já dito, as figuras de Monteiro Lobato são reivindicadas pelo MRSP, SPL e MSPI, enquanto Alfredo Ellis Jr. e uma série de bandeirantes são mencionados positivamente pelos quatro movimentos. Aparece como contraditório, portanto, que os grupos busquem afastar suas premissas do racismo e, simultaneamente, optem por estas fontes históricas.

Nota-se em todos indignação frente à situação econômica e política do país: São Paulo aparece enquanto um estado provedor que é prejudicado pela inaptidão brasileira e pela falta de representatividade política. Para além disso, vê-se que a paulistanidade engendrada ao longo dos séculos XIX e XX possui valor para estes movimentos: bandeirantismo, período do Café, imigração europeia, modernismo e 1932 são elementos evocados por todos os grupos analisados.

Neste sentido é possível notar que a construção de uma identidade regional, característica tão marcante do fim do século XIX e início do XX, foi bem sucedida em apresentar uma história de sucesso para São Paulo. Estes quatro movimentos mobilizam justamente os períodos e contextos históricos capazes de basear seus argumentos em torno da ideia de supremacia. É interessante, do mesmo modo, que estes grupos busquem formalizar-se, seja através de estatutos ou projetos de lei enviados a instâncias governamentais.

É sintomático ver nestes movimentos - que juntos são seguidos, de forma online, por quase cem mil pessoas - a defesa de que São Paulo, o local com maior concentração econômica do país, seja extorquido e desrespeitado sob jugo brasileiro. Apesar de suas diferenças, portanto, nota-se um pano de fundo comum: o engendramento de um regionalismo que apresenta São Paulo como local destinado à grandeza, à superioridade, 
em especial econômica, mas frequentemente moral, racial e política. Esta idealização seria forte a ponto de centenas de pessoas enviarem com frequência a estes grupos imagens de tatuagens com a temática do orgulho paulista. Centenas de ilustrações de locomotivas, soldados constitucionalistas e bandeiras do estado aparecem diariamente nas páginas virtuais destes movimentos expondo uma paulistanidade à flor da pele.

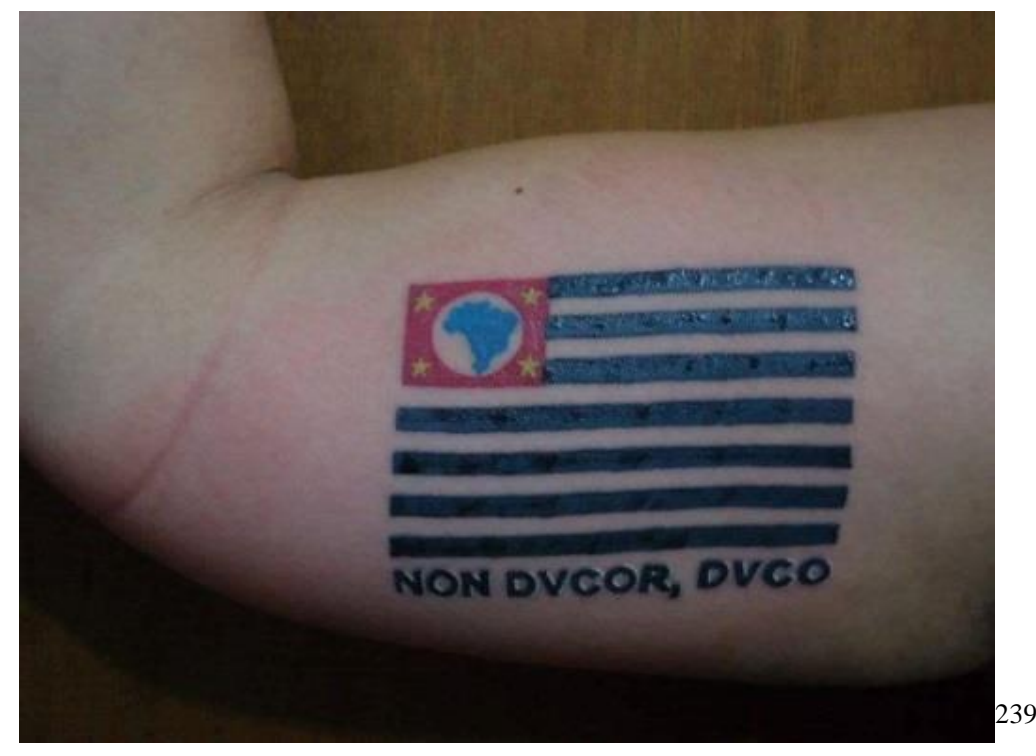

\begin{tabular}{l}
\hline \multicolumn{2}{|c|}{ Imagem 33} \\
Tatuagem com a \\
bandeira do estado \\
paulista e o lema não \\
sou conduzido, \\
conduzo. \\
\hline
\end{tabular}

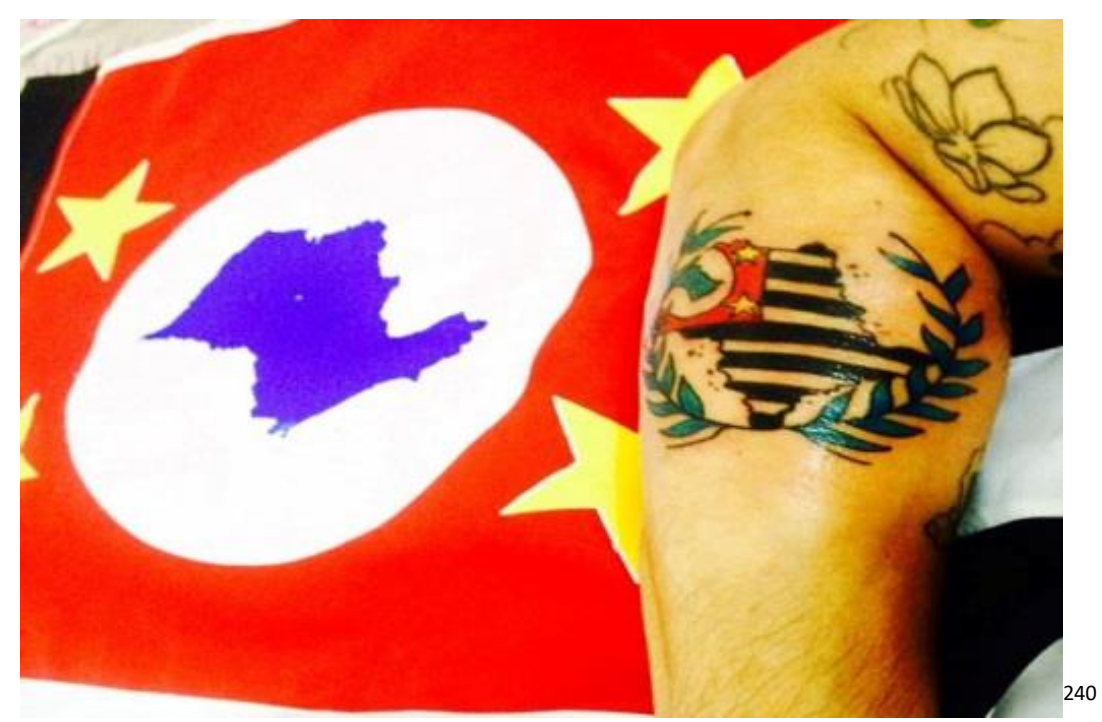

\section{Imagem 34}

Braço tatuado com o mapa paulista e as cores da bandeira do estado.

\footnotetext{
${ }^{239}$ Imagem retirada em: MOVIMENTO SÃO PAULO INDEPENDENTE. Facebook. 05/11/2017. Disponível em: <https://www.facebook.com/MSPIreal/photos/a.138763312986243.1073741828.137976879731553/73814 7249714510/?type=3\&theater> Acesso em: 29/04/2018.

240 Imagem retirada em: SÃO PAULO INDEPENDENTE. Facebook. 17/05/2018. Disponível em: <https://www.facebook.com/MSPIreal/photos/a.138763312986243.1073741828.137976879731553/66017 3004178602/?type=3\&theater $>$ Acesso em: 30/04/2018.
} 
A análise dos distintos movimentos apresentados neste capítulo permite ver que um pano de fundo regionalista está longe do reducionismo analítico, possuindo a mescla de ideologias diferentes. Nota-se, nos casos dos skinheads adeptos à supremacia branca, o racismo e o regionalismo que se baseia em um ideal falacioso de superioridade. $\mathrm{O}$ regionalismo apareceria, deste modo, como um mecanismo de perpetração da desigualdade racial. É válido salientar que a marginalidade inerente a estes grupos os dota de menor poder social em um plano macro: está justamente na radicalidade discriminatória sua amplitude reduzida. Isto, todavia, não anula o impacto que estas margens produzam ao conjunto social. Creio que se concentra justamente nestas práticas extremas a condensação de projetos discriminatórios mais brandos e amplos em técnica e discurso.

No que concerne aos movimentos separatistas analisados, nota-se a ideia de superioridade regional que pode aparecer em conexão com outros ideais de supremacia. A filiação dos movimentos à historicidade racista, apesar destes possuírem um discurso que se afirma constantemente contra a discriminação racial, torna a análise dos grupos bastante complexa. É nítido que discursos que engendraram a separação de São Paulo basearam-se, em outros momentos históricos, na discriminação contra negros e indígenas. Estes grupos separatistas adequam-se ao tempo atual ao não trazerem a discriminação e o preconceito de forma visível ao seu discurso.

Deste modo, nota-se a prática de um regionalismo que se afirma pós-racial, mas que estabelece conexões a um ideal que historicamente foi racializado. De todas as maneiras, vê-se uma proposta que possui como objetivo principal o orgulho regional. Se em outras circunstâncias a separação de São Paulo foi posta enquanto questão de raça, vêse estes grupos utilizando uma diferenciação localizada: seu foco seria o regionalismo. Isto não só possuiria relação com o caráter velado da discriminação e preconceito racial, mas também com as táticas de grupos desta natureza, uma vez que estes buscam atrair às suas fileiras a maior quantidade de adeptos que for possível.

A análise de grupos que endossam a superioridade paulista de maneira tão ativa é interessante para pensar em como este ideal possui consonância com o exercício político do estado. A política estadual institucional, tão distante destes movimentos diminutos e marginalizados, traz em si conexões com a defesa da hegemonia de São Paulo. Um exemplo disto seria o discurso do atual governador de São Paulo, Mário França, quando de sua posse em abril deste ano. O político que tomou o cargo em substituição de Geraldo Alckmin afirmou o seguinte: 
Um estado forte, um estado soberano, um estado que é exemplo para o Brasil (...) São Paulo é forte e tem uma longa trajetória de ajudar e de poder proporcionar ao Brasil saídas inteligentes e saídas importantes nos momentos mais difíceis. Foi de São Paulo que saiu o berço da nossa democracia (...) Foi também a partir de São Paulo que nós forjamos todo esse mapa, que a gente hoje chama de Brasil. Essa linda nação, grande nação, conquistada através de bandeiras e bandeirantes, de entradas, de pessoas que tiveram a coragem de subir a serra e enfrentar todos os problemas para poder fazer esse mapa bonito e grande, que tornou o Brasil tão grande como nação. São Paulo deu exemplo em diversos momentos e voltou a dar exemplo na independência, quando nós resolvemos e decidimos aqui, a partir de D. Pedro, que faríamos o grito para poder nos separarmos de Portugal e nos transformarmos de colônia em terra e país. Depois, mais uma vez, foi de São Paulo que saiu a grande revolução Paulista de 1932 para defender legitimamente a posse de Julio Prestes presidente da república eleito - o último paulista eleito - e que não tomou posse porque a União não deixou (...) Portanto, o Brasil nunca pôde falar que de São Paulo não partiram as soluções para os seus problemas.

Não tenho a intenção de colocar em relação direta discursos tão díspares. Aparece, porém, neste discurso, relações patentes com o ideal de superioridade paulista. Ideal este que aparece com recorrência em um gradiente complexo de expressões da paulistanidade. As similaridades entre estas expressões concentram-se na defesa da hegemonia paulista. Mário França afirma, de forma explícita, um poder de mando, um diferencial que vem de São Paulo. Interessa pontuar, portanto, a forma estrutural de afirmação suprema como método político do estado. Variam técnicas, crenças e composições sociais. Mantém-se intacta, todavia, a ideia de superioridade.

\section{7 - São Paulo Restrita}

Neste capítulo, a partir de abordagens diversas e com a apresentação de eventos distintos, busquei expor a recorrência de parcela significativa da paulistanidade na mobilização de discursos conservadores. O risco desta análise poderia concentrar-se, portanto, na aparência de um regionalismo paulista unívoco. Buscando contornar isto, apresentei graus e tipos de mobilização diferentes que há em torno do ideal da superioridade paulista. Longe da univocidade, vê-se uma ideologia que, em sua face excludente, pode abarcar diferentes modos de expressão, entendimento e posições políticas. Os fenômenos do preconceito, discriminação e ódio, em vista disto, devem ser analisados com rigor. 
Neste sentido vale salientar que as expressões e formulações da paulistanidade são variadas e permeiam os extremos do espectro político. São Paulo aparece como superior tanto na narrativa que apresenta o estado como formador de uma vanguarda de luta em um local de contradições capitalistas nítidas quanto ao ser representada como branca, rica e aliada ao progresso. Há, da mesma forma, expressões discriminatórias escancaradas e outras um tanto veladas.

Ainda assim há em proporção saliente um preconceito contra o nordestino associado à paulistanidade que é ligado a ideologias conservadoras. Os eventos históricos apresentados neste capítulo através da linha do tempo, as notícias compiladas no banco de dados e a análise dos movimentos separatistas evidenciam justamente isto. Apesar das diferenças contextuais e de composição grupal, parcela relevante da paulistanidade engendra discursos mantenedores tanto da ordem social quanto de sua hegemonia regional. Acredito que estes discursos e práticas apareçam em defesa do domínio de classes na sociedade brasileira, bem como de suas assimetrias de poder em função de raça e região.

Atenta a isto, creio que seja necessário analisar a paulistanidade em seu extremo, através dos grupos (já apresentados) que defendem a separação do estado paulista da federação brasileira. Buscarei expor que a demarcação econômica e a racialização podem ser base argumentativa destes grupos e formulam expressões de orgulho paulista mais brandas.

A investigação de tal tema requer uma análise atenta à urbanização e fluxos migratórios que ocorreram no Brasil. Uma série de etnografias (Rao, 2010; Telles e Hirata, 2007; Sassen, 2012; Schiller e Çaglar, 2010; Felman-Bianco, 2009) demonstraram na última década que a urbanização é perpetradora de restrições: o avanço neoliberal de uma urbanização concentrada, como a de São Paulo, torna o usufruto urbano restrito aos privilegiados (HARVEY, 2012) sendo que neste processo medidas higienistas são tomadas não para minar desigualdades, mas para invisibilizá-las (RAO, 2010).

Em $O$ Direito à Cidade, David Harvey expõe que a destruição cíclica apontada por Engels (1935) ainda tem espaço na lógica da urbanização neoliberal, sendo esta destruição a expulsão e o desalojamento frequentes que afastam, cada vez mais, os pobres dos centros urbanos. Acredito que longe de tais restrições restringirem-se somente ao fator econômico, é possível afirmar que

Conexões e contiguidade - de modo mais geral, a representação de território - variam consideravelmente graças a fatores como classe, gênero, raça e sexualidade, e estão disponíveis de forma 
diferenciada aos que se encontram em locais diferentes do campo de poder. (FERGUNSON, GUPTA, 2000:47).

Neste mesmo sentido é que se pode entender que tanto a aceitação urbana de uns quanto a negação de outros, são partes de um mesmo processo: "a informalidade se torna uma função da legalidade" (RAO, 2010:415) ou, como dizem Telles e Hirata ao pensar na informalidade do trabalhador urbano, trata-se de deter-se sobre "um mundo social feito de um especial embaralhamento entre o formal e o informal, o legal e ilegal, e o lícito." (HIRATA; TELLES, 2007:179).

Posto isto e detendo-me na confusão discursiva entre cidade e estado paulistas (WEISTEIN, 2015) que é válido pensar que São Paulo - inquestionavelmente o local mais urbanizado do país - mobiliza um caráter de restrição. Creio que quando grupos separatistas paulistas advogam pela restrição migratória, mais uma das ferramentas de destruição cíclica está sendo acionada: migrante/nordestino é, em nível de representação e na maioria das vezes, pobre e não são os pobres que se deseja ver em uma cidade (HARVEY, 2012; RAO, 2010).

Da mesma maneira, creio que o embaralhamento exposto por Telles e Hirata, constitui uma peça chave para se pensar no preconceito contra o nordestino que reside em São Paulo. O nordestino, representado tantas vezes como anômico e informal, é embaralhado em um processo que, apesar de contrapor certas máximas como se estas tivessem natureza distintas, as produz concomitantemente: se a informalidade, ilegalidade e ilegitimidade é conectada ao nordestino, é porque ao paulista é ligada a formalidade, legalidade e legitimidade. Neste sentido, quando Rao argumenta que "a informalidade se torna uma função da legalidade" (RAO, 2010:415), creio que seja possível pensar como o atraso se torna uma função da modernidade, como o estigma da anomia nordestina se torna uma função da pretensa racionalidade paulista.

A urbanização se concentrar no sudeste e, em especial, em São Paulo, não apenas endossa discursos que defendem certas regiões como legítimas e outras como ilegítimas, mas também reforça o argumento meritocrático: não atentando-se à decadência de um local como parte de um mesmo processo que é capaz, inclusive, de $\operatorname{urbanizar}^{241}$ outro, falase do avanço, desenvolvimento e progresso paulistas como uma questão de mérito. $\mathrm{O}$ embaralhamento entre formal, informal, progresso, atraso, avanço e decadência é mascarado: não se conecta o alto P.I.B. paulista aos menores P.I.B.s dos estados

${ }^{241}$ Vale salientar como, nesta lógica, o urbano é considerado inquestionavelmente melhor que o rural. 
nordestinos. Na lógica separatista paulista o argumento é de que se há uma diferença entre P.I.B.s, acesso a recursos e qualidade de vida, esta residiria no mérito de cada local, sendo que os processos formadores destas diferenças seriam separados, distintos.

Há ainda que se atentar ao fato de que ideais em torno de progresso e civilização são referenciados por um evolucionismo social capaz de reduzir a mesma noção conceitual às mais diversas experiências humanas: como se todas as populações do mundo tivessem apenas uma concepção em torno destes termos. Nota-se, neste caso, o etnocentrismo: como se determinados padrões culturais, e aqueles por estes representados, pudessem ser distribuídos em estágios de progresso distintos.

Posto isto, continuarei a analisar o gradiente da paulistanidade apresentando estudos de caso. Nos dois primeiros capítulos, expus um histórico breve dos regionalismos paulista e nordestino, bem como as racializações e demarcações econômicas típicas destes. Unindo tal análise ao estudo das desigualdades típicas da urbanização, realizarei um estudo no próximo capítulo que se detém na análise do Manifesto São Paulo Para Paulistas. No sexto capítulo analisarei o Movimento São Paulo Livre.

A realização destes estudos de caso levou a uma análise virtual, uma vez que as reuniões presenciais destes grupos costumam ser fechadas para membros. Vale dizer que o conteúdo virtual gerado pelos mesmos é extenso e constante o que me levou semanalmente a coletar suas atualizações via websites, facebook e twitter. José Santos (2001) disserta sobre a necessidade de a sociologia abarcar os meios virtuais não somente para uso no método sociológico, como também para a mobilização do material gerado no ciberespaço enquanto objeto de pesquisa. Do mesmo modo, Pieniz (2009) atenta para a necessidade de aprimoramento dos métodos de investigação virtual, uma vez que o ciberespaço seria um espaço de sociabilidade humana fundamental às ciências sociais contemporâneas.

Como venho salientando nos últimos capítulos, acredito que a paulistanidade concentra máximas racializadoras e demarcadoras economicamente, do mesmo modo que não só estabelece o paulista como contraposto do nordestino, como também acirra tal contraposição em momentos de disputa pelo poder. Com isto em mente, buscarei analisar se estes fenômenos encontram espaço em novos grupos regionalistas que atuam de forma ativa na internet: São Paulo Para Paulistas e São Paulo Livre. 


\title{
CAPÍTULO V \\ Ódio à Favela, ao Pobre e ao Nordestino \\ Analisando o Manifesto São Paulo Para os Paulistas
}

\section{1 - O Manifesto}

\begin{abstract}
Nenhuma discriminação é mais brutal do que a discriminação contra si mesmo. O paulista olha ao seu redor e se vê um estrangeiro em sua própria terra. Presencia desrespeito e hábitos impostos. Alta criminalidade, hospitais superlotados. Isto tudo relacionado à migração nordestina que a nossa terra sofreu nos últimos tempos. (2010:1).
\end{abstract}

Apresento este capítulo com o objetivo de analisar o conteúdo do Manifesto São Paulo Para Os Paulistas. Empreenderei esta análise focando em determinadas representações identitárias enunciadas neste documento, com atenção às mobilizações em torno de raça, classe e origem, bem como a um conceito restrito de cultura.

Vale dizer que iniciei este estudo de caso na segunda metade do ano de 2010. Após a repercussão da campanha de Mayara Petruso em vista dos resultados das eleições presidenciais, tive acesso ao documento do qual trata este capítulo. Do mesmo modo, passei a acompanhar websites e fóruns cibernéticos de discussão que contribuíam ou endossavam os dizeres do Manifesto.

Como em toda pesquisa de longo prazo que se debruça no universo virtual, dificuldades metodológicas - que se mostram um desafio à Sociologia Contemporânea surgiram. Websites foram retirados do ar, grupos investigados mudaram de nome e endereço online, até mesmo de métodos ou objetivos, e o cenário político que efervescia aquela discussão sofreu alterações.

Imerso nestas mudanças está o Manifesto virtual São Paulo Para Os Paulistas, publicado inicialmente em 23 de maio de 2010 - não por acaso o dia que marca a morte daqueles que compõem a sigla M.M.D.C. ${ }^{242}$ - na plataforma virtual Petition Online. O Manifesto passou por mudanças ao longo dos anos e a página em que continha sua versão original foi encerrada. Neste capítulo, analisarei a primeira versão do documento (2010) e

\footnotetext{
242 Vale repetir que a sigla se refere aos jovens Martins, Miragaia, Dráusio e Camargo, considerados mártires que causaram o estopim do Movimento Constitucionalista de 1932.
} 
a segunda (2012), que além de ser encontrada no mundo virtual, foi entregue em julho de 2012 à Assembleia Legislativa do Estado de São Paulo.

O primeiro documento se apresenta como um caminho para "encarar o problema da migração" (2010:1). Contendo quinze artigos e cento e dezesseis reivindicações direcionadas às Autoridades, Instituições e Sociedades Paulistas, o Manifesto dispõe o que considera solução frente a supostos problemas $^{243}$ causados pela migração e pelos desrespeitos sofridos por um povo paulista não muito bem delimitado. É importante salientar que uma linguagem agressiva é evidente no documento em concomitância à negação a qualquer forma de preconceito ou discriminação.

Publicado na plataforma internacional Petition Online, o Manifesto recebeu assinaturas de adeptos das suas reivindicações e propostas. $\mathrm{O}$ fim da coleta de assinaturas se deu no dia 24/11/2011, data em que contava com 1954 signatários. ${ }^{244}$ Para validar a veracidade das assinaturas, o website, que não existe atualmente, requeria dados pessoais, como nome, sobrenome e local de origem do assinante. Todavia, a partir da análise do material, pode-se perceber que não necessariamente o Manifesto contou com tantos apoiadores: diversas assinaturas foram rejeitadas pelo website e nomes com pouca credibilidade, como Paulo Paulista, aparecem na lista de signatários.

O segundo documento (2012) possui dezessete solicitações referentes às defesa do povo paulista e regulação da questão migratória. Diferentemente do primeiro, não foram registradas as assinaturas de adeptos deste texto. No entanto, na página do website Tudo Por São Paulo ${ }^{245}$ narra-se que os esforços para sua formulação contaram com a protocolação do mesmo através do envio de cartas ao Ministério Público de São Paulo em 18/11/2010 e à Delegacia de Polícia Civil em 09/07/2011. Salienta-se, em especial, que sua divulgação ocorreu no dia 03/07/2012 com o envio do Manifesto a cinco deputados estaduais de São Paulo, não especificados pelo grupo formador do movimento em questão.

Fica claro que frente a uma manifestação deste tipo, há cuidados analíticos a serem tomados. Em especial no que se refere à identidade daqueles que compõem o Manifesto. Como saber a composição exata deste grupo é um desafio em que ainda não obtive

\footnotetext{
${ }^{243}$ Neste capítulo uma série de termos nativos (como "problemas", "livre", "imposição cultural") serão apresentados em itálico. Isto será feito para salientar que para além de uma categoria nativa, trata-se da opinião do movimento analisado.

${ }^{244}$ Tanto a versão original do Manifesto quanto a lista de signatários pode ser encontrada no link a seguir: <http://tudoporsaopaulo2010.blogspot.com.br/p/andamento.html> Acessado em: 27/02/2018.

${ }^{245}$ Com o presente endereço virtual: <http://tudoporsaopaulo2010.blogspot.com.br/> Acessado em: $27 / 02 / 2018$.
} 
resultados salientes. Com uma atividade online que esbarra diversas vezes na criminalidade, pouco se pode saber factualmente acerca de quem enuncia estes discursos. Em entrevistas, todavia, um nome aparece com certa recorrência: seria o de Fabiana Pereira, escritora da versão do Manifesto publicada em 2010. A militante paulista, após publicar seus escritos, teria entrado em contato com outras pessoas que aprovaram suas ideias e se esforçaram na formulação de um novo documento. Ao Portal Terra, em agosto de 2010, uma destas pessoas - William Godoy Navarro - concedeu uma entrevista como porta voz do movimento. ${ }^{246}$ Vale lembrar que isto se deu dois meses antes do debate regionalista causado pelas eleições presidenciais do mesmo ano.

$\mathrm{Na}$ entrevista, William não deixou claro quantas pessoas fazem parte do grupo, afirmando apenas que seriam dezenas de jovens entre 18 e 25 anos e que o texto - por possuir "palavras muito fortes" (TERRA, 2010) - seria modificado, oficializado de outras formas. Ainda segundo William, Fabiana escreveu o Manifesto como resposta às discussões que estavam ocorrendo na Assembleia Legislativa acerca da possibilidade de o ensino público paulista abarcar temas da cultura nordestina em sua grade curricular. Afirmando que há valorização da cultura nordestina em São Paulo, em detrimento da paulista, o Manifesto teria sido criado para pensar em diferentes resoluções para os temas da migração em São Paulo e representatividade e acessibilidade da população natural deste estado.

Neste sentido, cabe a pergunta acerca de como analisar - à distância e com o rigor necessário - um Manifesto com composição não apenas incerta, mas de certa forma anônima. Qual seria a validade de deter-me na análise do discurso de uma jovem paulista que obteve pouco menos de duas mil assinaturas (de veracidade questionável) em seu Manifesto? Como buscarei expor nas próximas páginas, o discurso estudado permite trazer à luz questões que englobam a crise política brasileira da década de 2010, bem como a recorrente formação discursiva e regional de São Paulo baseada em um ideal delimitado de raça e classe.

Para além disso, acredito que trabalhar o anonimato com que se apresenta o grupo seja de essencial importância, uma vez que a possibilidade anônima é fundadora deste tipo de dado. $\mathrm{O}$ rechaço às camadas pobres e nordestinas que há no documento evidencia que não seria uma tarefa fácil a realização deste projeto de forma pública. Isto também seria

\footnotetext{
${ }^{246}$ Disponível em: TERRA. Em Manifesto na Web Paulistas Criticam Migração. 2010. Disponível em: <http://terramagazine.terra.com.br/interna/0,,Ol4605938-El6594,00Em+manifesto+na+web+jovens+ paulistas+criticam+migracao.html> Acesso em: 27/02/2018.
} 
indicado pelo fato de a repercussão em torno do Manifesto ter sido majoritariamente contrária a seu conteúdo de ódio. Deste modo, creio que apesar de o anonimato permitir a formação de dados com maior agressividade, há alcance reduzido em propostas do tipo: permite, sem dúvidas, certo tipo de mobilização, mas não nos mesmos termos obtidos por movimentos engajados em imagens públicas personalistas.

Neste sentido, ao deterem-se na análise de grupos virtuais estadunidenses e antiimigrantes, Gemignani e Hernandez-Albujar atentam ao fato de que estudos sobre discursos extremistas - minoritários em seu modo mais escancarado - aparecem como essenciais a uma pesquisa apurada, uma vez que as margens são capazes de determinar o centro (GEMIGNANI, HERNANDEZ-ALBUJAR, 2015:2757). Entendo que o Manifesto São Paulo Para Os Paulistas possa endossar a tese apresentada nesta dissertação em relação à exacerbação regional, econômica e racial típica do estado de São Paulo. É, pois, com a generalidade da paulistanidade em mente que analiso o Manifesto.

\section{2 - Reivindicações Paulistas}

A migração de milhões na terra alheia, aliada à mordaça ao anfitrião, representa Imposição cultural. Nenhuma Cultura, forte que seja, resiste a investidas contínuas. Favelas e camelôs não estão relacionados meramente à pobreza, e sim a valores (2010:5).

O Manifesto publicado em 23/05/2010 inicia sua discussão apresentando o paulista enquanto vítima da imposição cultural migrante, em especial nordestina. Defende a narrativa de que paulistas que lutam por um estado livre seriam criminalizados, que o tema da regulação migratória seria proibido, censurado. O primeiro artigo do documento recebe o nome de Autenticidade e tenta validar a reivindicação virtual como um meio legal para se atingir o objetivo de que São Paulo seja dos paulistas. O segundo, intitulado de Liberdade de Expressão, apresenta o Brasil como uma ditadura camuflada, orientada por uma mídia tendenciosa.

Curiosamente, uma afirmação como esta, que encontra coro em movimentos à esquerda, é utilizada para afirmar o suposto autoritarismo sofrido por este movimento conservador, que seria vítima de intolerância - sendo este o nome dado ao terceiro artigo do Manifesto. Esta suposta intolerância seria calcada em uma ferramenta utilizada por grupos contrários ao movimento paulistanista: a acusação de racismo. Uma seção inteira do documento - o quarto artigo - é direcionada a uma nova conceituação de discriminação 
racial. Concomitante a isto, acontece a defesa do Manifesto em relação a qualquer acusação de preconceito.

Reivindica-se a Legião Negra na Guerra de 1932 e os primeiros africanos do Brasil - "do Congo e Angola" (2010:2) - como grupos que fariam parte da cultura do povo paulista. Como mostrarei neste capítulo, a presença de composições negras só é reivindicada quando da defesa contra as acusações de racismo e quando da chamada de apoiadores. Quando o tema é diverso, vê-se foco em populações brancas e em imigrantes europeus, em especial italianos.

O racismo é tratado no texto como "método de intimidação" (2010:2) de grupos contrários ao Manifesto. Para além disso, sublima-se sua realidade histórica em prol de um regionalismo exacerbado: "nossa cor não é branca, não é morena, não é negra. Nossa cor é São Paulo" (2010:20). Afirma-se que racistas seriam os migrantes que - ao escutarem músicas altas, ocuparem terrenos irregulares e realizarem o que chamam de migração predatória - estariam exterminando a cultura de São Paulo.

Os conceitos de multiculturalismo e pluralismo também são apresentados de maneira diferente da usual, esta aparecendo no quinto artigo do documento: para a autora seriam palavras utilizadas para suprimir culturas, seriam um modo de intolerância. Percebe-se, em tal sentido, um ideal hierarquizante acerca do significado de cultura: "se valores culturais são diferentes e convivem, aquele de mais exigentes padrões morais, será prejudicado pelo outro" (2010:2). Do mesmo modo, xenofobia, nome dado ao sexto artigo do Manifesto, aparece como as práticas que os migrantes possuem em São Paulo em relação aos naturais do estado.

Com um sétimo artigo intitulado de Pobres e Segregação, o Manifesto busca afirmar que seus objetivos não consistiriam em uma cruzada contra a pobreza. Afirma-se que tratar pobres e migrantes como sinônimos seria uma tática de vitimização e que não seriam "níveis sociais" que determinariam índoles e modos de agir, mas sim "valores culturais" (2010:2). Do mesmo modo, o artigo seguinte, intitulado de Preconceito, apresenta um conceito novo do termo, afirmando-se que se há "veracidade das afirmações feitas", não se trataria de um conceito prévio (2010:2).

A ideologia da meritocracia permeia todo o discurso do Manifesto. O que fica claro no nono artigo - Igualdade, Justiça, Cidadania, Solidariedade - em que se afirma que só pode haver igualdade quando respeitado os princípios do mérito. Do mesmo modo, defende-se que a justiça só seria eficaz livre de "ideologias do fascismo politicamente 
correto" (2010:2) o que, de certa forma, evidencia a presença de um discurso conservador, marcante da presente década, frente à ascensão de movimentos sociais que põem em questão expressões discriminatórias ou preconceituosas.

No décimo artigo do documento, intitulado de Discriminação, nota-se novamente a readequação de um conceito. Neste caso, afirma-se que os paulistas sofreriam historicamente discriminação por parte do resto do Brasil. Isto é exposto com certo ressentimento histórico: afirma-se que São Paulo foi relegado ao esquecimento durante os ciclos do Ouro, do Cacau e da Cana. Desta desvantagem, todavia, teria vindo um diferencial: defende-se que o paulista, sozinho, com seu próprio suor, teria elevado São Paulo a uma grande potência. Disto depreende-se o argumento da reivindicação econômica: São Paulo sempre deu mais ao Brasil do que recebeu. Deste ponto se vai à elaboração de uma nova ideia de discriminação: "a discriminação contra o possuidor por mérito, é uma violência mais agressiva do que as discriminações gratuítas (sic) por origem" (2010:3).

Sustentando-se neste conceito de discriminação, o Manifesto segue em seu décimo primeiro artigo - Somos todos brasileiros? - afirmando que São Paulo seria brasileiro para com seus irmãos, mas estes não seriam com São Paulo, o que leva a uma conclusão emotiva: "é hora do Povo Paulista ser menos altruísta, e pensar mais em si mesmo e em seus próprios filhos" (2010:3).

O décimo segundo artigo do texto busca explicar quem teria construído São Paulo, defendendo a tese de que teria sido o espírito bandeirante. Reivindica-se, inclusive, que o estado teria sido pioneiro em buscar mão-de-obra livre, que o italiano seria a língua mais falada no local entre a virada do século XIX e que estes migrantes teriam sido parte crucial da ascensão paulista. Enfatiza-se a importância da vinda de mais de cem mil migrantes europeus e japoneses no período entreguerras, salientando-se que seria na década de 1950 que o estado teria construído seus pontos culturais, econômicos e turísticos mais importantes. Um problema, no entanto, estava por vir:

A partir da década de 60 , com a chegada dos migrantes brasileiros sobretudo nordestinos e mineiros começa a degradação, com a construção de favelas, bairros irregulares e uma estrutura caótica de cidade (...) invasão devastadora que desde então causou a descaracterização e agressão à Cultura Paulista (2010:4). 
$\mathrm{O}$ artigo segue em uma linguagem que atinge seu ápice agressivo: afirma-se que deve ser desmentido que migrantes construíram São Paulo, que isto seria um ultraje, que São Paulo não teria optado por este tipo de mão-de-obra, afinal teria escolhido "povos mais respeitadores" (2010:4). O migrante é tido como alguém que "paga o bem com ingratidão" através da criminalidade, deterioração cultural e sujeira. O paulista aparece como vítima em um estado invadido por tipos anômicos, perigosos e avessos a qualquer tipo de zelo.

Este paulista difuso de que se fala nas primeiras páginas do Manifesto, ganha corpo com o décimo terceiro artigo: São Paulo é de todos? Quem são os Paulistas? Afirma-se que anteriormente à migração imposta, São Paulo já teria formado sua população. Para basear este argumento, diferencia-se o que é chamado de colonizador de povoamento e migrante de exploração. O primeiro deixaria sua terra natal sem intento de retornar, depositando amor e respeito na terra que o acolheu, enquanto o segundo "mantém vínculos com sua origem, pretende extrair tudo que puder, despredá-la (sic), e retornar. Impositivo, exige dádivas, faz-se de vítima" (2010:4).

Para explicar o que seria um paulista, mobiliza-se, como de costume, o Conflito de 1932. Segundo o documento, paulistas seriam aqueles cujos pais e avós teriam industrializado São Paulo e vivenciado a luta pela Constituição, que se lamentam ao ver a deterioração causada após as correntes migratórias dos anos 60, que viveram no interior e cultivaram a cultura paulista. Neste sentido, apela-se ao suposto perigo de apagamento cultural: afirma-se que apesar de um passado heroico, exemplificado por 1932, há tentativas, inclusive por parte da mídia, de tomar a terra dos paulistas, de apagar sua cultura e História.

Os dois últimos artigos tratam de choques culturais e daquilo que no texto é chamado de migração predatória. Afirma-se que culturas são formadas por valores, regras morais e costumes. Do mesmo modo, diz-se que não há culturas superiores e inferiores. Duas linhas após essa afirmação, no entanto, apresenta-se o migrante como ser de violência inata:

A Cultura migrante caracteriza-se por ser agressiva, violenta, simbolizada no fato de ter como seu herói a figura de um cangaceiro - cuja história representa os valores culturais de sua região. Daí a alta taxa de criminalidade cometida por migrantes no estado de SP (2010:5).

Em concomitância a esta apresentação do migrante (demarcada regionalmente) apresenta-se a cultura paulista como não adepta a solicitar gratuidades ou benefícios 
governamentais, uma vez que histórica, e supostamente, sustentou a si própria e aos demais. Isto seria mais um motivo de choque cultural dentre muitos outros que são atribuídos: vitimismo, imposição, inadimplência, fraude, agressividade, relações familiares de diferente natureza, assédio e danificação ao patrimônio. É neste sentido que esta migração é descrita como predatória: estes migrantes pelo Manifesto imaginados "não amam São Paulo" (2010:5), ao contrário: insultam, desrespeitam, estão no estado por benefícios.

Estes quinze artigos do Manifesto são seguidos por cento e dezesseis reivindicações que se iniciam pela chamada de que o povo paulista de todas as raças, níveis sociais e setores de atividade assine o abaixo-assinado. As reivindicações são variadas e buscam apresentar uma série de dados que tentam indicar que o paulista seria reprimido e saqueado diariamente por aquilo que é chamado de cultura migrante. Chega a se usar o Plano Marshall como vetor de análise, afirmando-se que o que São Paulo daria ao Brasil é superior aos esforços pela reconstrução da Europa pós-guerra.

O teor apresentado pelo Manifesto debruça-se no uso de termos ressignificados e exacerbados. A título de exemplo, se fala que o Nordeste recebe $\mathrm{R} \$ 45,000,000,000,00$ por ano do Governo Federal, o que levaria São Paulo a uma situação de discriminação e escravismo. Da mesma maneira, alega-se que São Paulo viva uma situação opressora de colonização, até mesmo extermínio. Toda esta suposta opressão, todavia, não anularia o fato de que "o paulista é um caridoso incansável” (2010:7).

É costumeiro no texto o paulista ser vitimizado para, em seguida, ser glorificado. Para utilizar termos de Norbert Elias (2000) trata-se dos paulistas munindo-se da fofoca elogiosa, enquanto o migrante é ofendido pela fofoca depreciativa. O que é exemplificado pela afirmação de que em São Paulo se paga menos a policiais e professores por conta do saque sofrido por outros estados, mas que, mesmo assim, a população paulista seria a que mais realizaria transplantes de órgãos no país, a com maior abnegação.

Como de praxe, esta reivindicação vem acompanhada de uma solicitação eleitoral. Defende-se que o paulista é subrepresentado politicamente, que o voto de um sergipano, a título de exemplo, vale o de vinte paulistas. Neste sentido, salienta-se a ideia de que São Paulo daria $41 \%$ do sustento do país, mas não teria sequer possibilidade de eleger seu governo.

É interessante pensar nesta conexão do paulista à imagem de provedor que aparece em todo o documento. Há insistência na ideia de que São Paulo forneceria recursos 
econômicos, humanos e científicos para o resto do Brasil, sendo isto, especialmente, explicitado pelo uso de seus serviços públicos por migrantes: hospitais, escolas, transporte público, entre outros. Nota-se, neste caso, a restrição do conceito de público e da extensão de Direitos Humanos. Uma justificativa para isto é dada na defesa de que as outras regiões e povos mostram a São Paulo ingratidão e rancor frente a tanta benevolência. Fator que leva o documento a reivindicar que não sejam expandidos os serviços públicos de São Paulo, mas sim que sejam de uso restrito do grupo paulista, uma vez que - nesta lógica quanto mais houver expansão de serviços, mais migrantes se direcionarão ao estado. Neste caso, fica evidente qual tipo de migrante é considerado incômodo: o pobre. Estigmatiza-se cortadores de cana, moradores de favela e pessoas em situação de rua: na narrativa empreendida todo e qualquer problema social enfrentado no estado paulista se deu devido a esta migração.

Ao expor uma lista de repúdios, o documento responsabiliza o migrante pela criminalidade no estado paulista, bem como pelo roubo de empregos, especialmente dos pobres naturais do estado de São Paulo, que são afirmados como o grupo mais afetado pela migração. O ódio escancara-se ao falar sobre costumes de populações migrantes. Narra-se horror diante de situações em que se ouve músicas nordestinas, em especial o forró, e até mesmo certos sotaques:

Repudiamos a descaracterização causada pelo excesso migratório. Repugnamos o R gutural, vogais abertas, as expressões ôxe, etc (2010:9).

Da mesma maneira, afirma-se que a expressão "São Paulo é a cidade mais nordestina" seria "racista e odiosa" (2010:9). Nota-se que o ódio que se tenta generalizar na palavra migrante concentra-se com vigor no nordestino. A este nordestino de que se fala é imputado todo tipo de culpa: violência urbana, sexual, imoralidade e até mesmo desrespeito ao idoso.

O Manifesto publicado em 2012 - dois anos após esta versão que acabo de apresentar - é mais sucinto e tenta expor grau maior de formalidade. Forma-se pela divisão de certas solicitações e justificativas extensas para cada uma delas. São estas solicitações:

1) Definição da Música oficial do Hino Estadual Paulista (Hino dos Bandeirantes);

2) Inclusão da Disciplina "História do Estado de São Paulo" como obrigatória no currículo escolar, desde o ensino fundamental;

3) Execução do Hino Estadual Paulista nas escolas e em todos os eventos cívicos e esportivos no estado; 
4) Valorização aos Heróis Paulistas. Conclusão das reformas no Obelisco do Ibirapuera. Divulgação intensa na Midia (sic) para o Desfile da Revolução Constitucionalista, no Ibirapuera;

5) Exclusão do nome "Getúlio Vargas" de todos os logradouros do estado;

6) Alteração do nome de estação do Metrô para "MMDC-Butantã" ou "MMDCRepública", em homenagem aos mártires de 32;

7) Maior atuação dos nossos Representantes na Defesa de São Paulo;

8) Popularização de informações referentes à Exploração econômica e Discriminação política, sofridos pelo Estado de São Paulo;

9) Direcionamento prioritário dos Serviços Públicos ao Contribuinte de São Paulo;

10) Criação de Disque-Denúncia para Invasão de Terreno;

11) Lei que estabeleça transferência dos presidiários a seus Estados de origem para cumprir pena. Censo sobre a criminalidade, referente à origem do praticante de crime;

12) Defesa da Manifestação do Pensamento;

13) Referente a insultos e depreciações ao Povo Paulista;

14) Referente à Imposição Cultural;

15) Sobre a proliferação de festas e eventos relativos a outras regiões no Estado de SP com Verbas Públicas;

16) Revogação de datas comemorativas "Dia do Nordestino" e similares ATÉ QUE - em RECIPROCIDADE e reconhecimento mútuo - todos estes respectivos estados criem o "Dia do Paulista"; 17) Discussão sobre possível alteração na Bandeira do Estado de São Paulo, sendo esta a substituição do mapa do Brasil para o mapa da América do Sul.

O Manifesto falha no intento de apresentar um conteúdo sem agressividade, permitindo ao leitor ver a continuidade do ódio ao nordestino, bem como da hierarquização de culturas e preconceito de classe. Sintomático neste sentido está a defesa de que o escritor e político do início do século XX, Ellis Jr. - tão discutido nesta dissertação - seja de leitura obrigatória nas escolas paulistas. Nota-se que apesar de presente a técnica brasileira de velar preconceitos, a um leitor atento fica claro o que a defesa da leitura de Ellis Jr. significa: o ensino da superioridade racial, econômica e cultural do paulista, afirmada veementemente na primeira metade do século passado sob a tutela do racismo científico.

No que concerne à questão de classe, vê-se um entendimento liberal e meritocrático acerca das desigualdades sociais. Salienta-se que São Paulo seria uma potência devido à iniciativa privada e não devido aos trabalhadores, em especial migrantes, que são precarizados na construção civil. Torna-se nítida a anulação da contribuição da classe trabalhadora pobre como componente paulista. Interessante neste sentido é o fato de tal ideologia esmerar-se em aparentar-se trabalhadora, pragmática e suprema. A ode neste 
sentido é aos empresários e não a grupos estigmatizados em sua profissão. Nesta mesma via, o Manifesto prossegue com a preocupação que já possuía em 2010: criminalidade e existência de favelas.

Migrantes ocupam espaços que pertencem ao paulista. Arruaças em transportes públicos. Burlas de catraca. Heliópolis e Paraisópolis. Migram, saciam a fome, depois permanecem em SP impondo seus costumes (2010:14); (Grifo Meu).

Para além disso, vê-se no documento a defesa em relação às acusações de racismo que a versão de 2010 recebeu. Para tal, apresenta-se casos em que ficaria evidente que racismo seria utilizado como ferramenta de falsa acusação. Um destes casos se refere à denúncia de racismo da Escola de Samba Acadêmicos do Tucuruvi que - ao desfilar com o samba-enredo São Paulo, capital do Nordeste - sofreu uma série de ameaças. Outro caso apresentado se refere à estudante de Direito Mayara Petruso que enunciou: "Nordestito (sic) não é gente! Faça um favor a São Paulo, mate um nordestino afogado.”

É sintomático que estes casos sejam mobilizados pelo Manifesto como falsa acusação de racismo. Vale lembrar que os tons de ameaça à Escola Acadêmicos do Tucuruvi causou repercussão na imprensa e levou a uma investigação do Ministério Público que identificou três jovens envolvidos no ataque. Sobre o episódio, o Manifesto afirma: “o agressor tornou-se vítima! Jovens foram acusados pelo 'crime' de defender seu estado" (2012:6). No que concerne ao caso de Mayara Petruso, a conclusão do Manifesto expõe consonância indiscreta com o que foi por ela afirmado:

A jovem foi condenada. A consequência foi que as pessoas não critiquem o sistema eleitoreiro, temendo ser processadas (2012:6).

Creio que esta tipificação - falsa acusação de racismo - permite não apenas analisar a manipulação do conceito de ofensa, discriminação e preconceito racial, como também os métodos adotados por movimentos de ódio para afastarem-se do estigma de discriminador ou preconceituoso. Concomitante a isto, os documentos de 2010 e 2012 revelam a tentativa de formação regional a partir do preconceito de origem e exacerbação da paulistanidade. As imagens a seguir, direcionadas pelo grupo às 1954 pessoas que assinaram o Manifesto, indicam um apelo de formação grupal que busca afirmar os paulistas enquanto conjunto humano moralmente superior e coeso. 

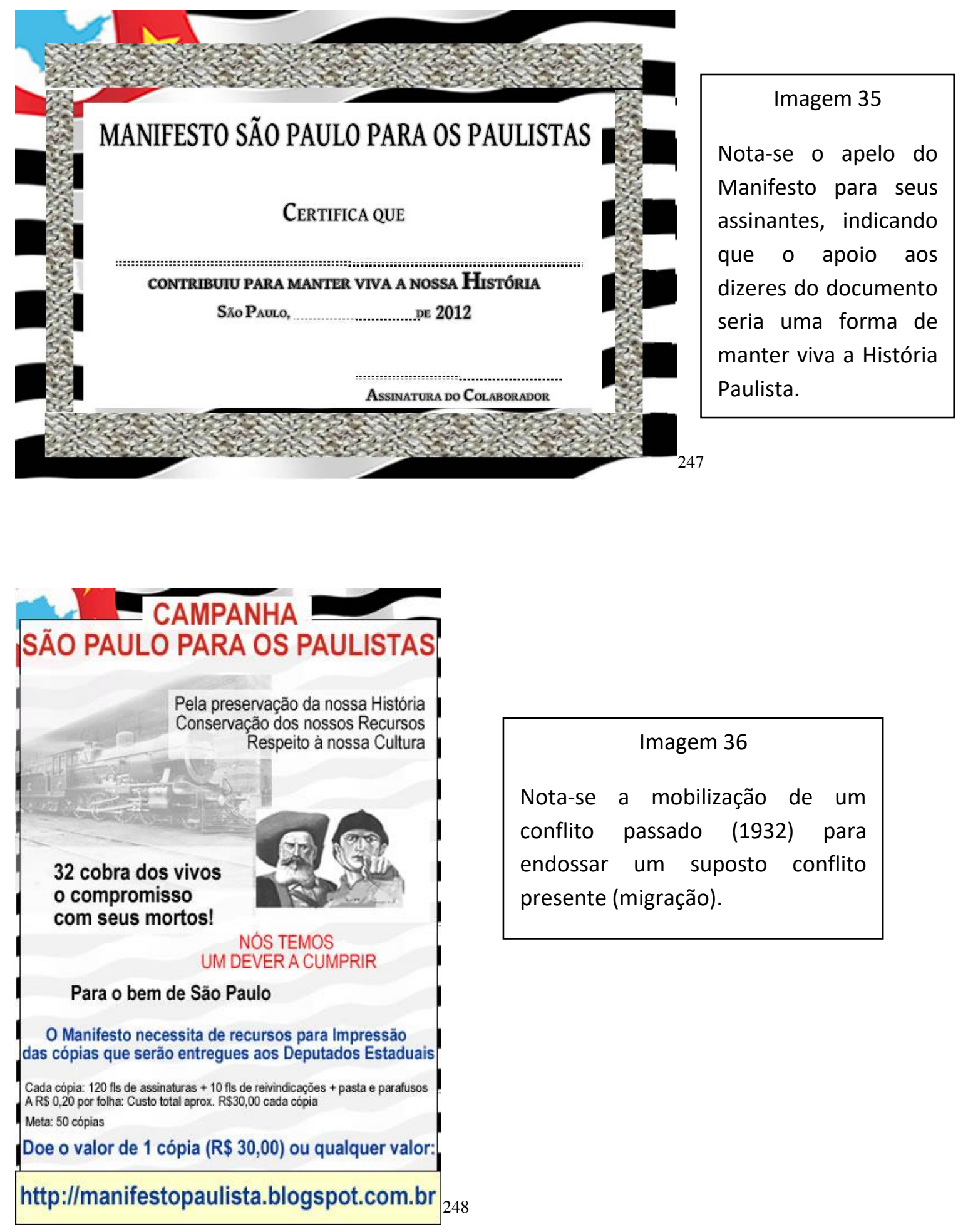

\footnotetext{
247 Imagem retirada em: TUDOPORSAOPAULO. 2010. Disponível em: <http://tudoporsaopaulo2010.blogspot.com.br/> Acesso em: 06/03/2018. 248 Imagem retirada em: TUDOPORSAOPAULO. 2010. Disponível em: <http://tudoporsaopaulo2010.blogspot.com.br/> Acesso em: 06/03/2018.
} 


\section{3 - Pobre Paulista ${ }^{249}$}

São Paulo é um estado grandioso porque nossos antepassados trabalharam muito para isso. Então, os benefícios são dos paulistas por direito. Não se deve permitir que pessoas de outros lugares se apoderem do que é nosso. Se querem também, construam o seu. Cada um na sua terra. S Paulo deve cuidar dos seus pobres. E não dos pobres dos outros. (2010:18).

No documento analisado afirma-se de forma recorrente que não se engendra o ódio ao pobre, mas sim a defesa do pobre paulista. Este seria prejudicado pela cultura migrante que teria invadido São Paulo com favelas, ocupações irregulares de terrenos, falta de decoro em ambientes públicos e situações outras que indicam vulnerabilidade e/ou estigmatização.

Neste sentido se reforça o argumento de que São Paulo teria ascendido como potência sem qualquer ajuda externa. Como já dito, o Manifesto reivindica como fato que uma cultura paulista teórica seria, de forma inata, avessa a qualquer tipo de auxílio, em especial governamental, diferentemente da teórica - e com definição confusa - cultura migrante. Deste modo, aos escritores do Manifesto aparece como óbvia a conexão da riqueza paulista a um padrão idealizado de trabalho, pragmatismo e pioneirismo. Desta acepção, depreende-se que o usufruto deste esforço, considerado diferenciado em qualidade, deva ser direcionado somente àqueles que o realizaram, o que, nesta visão, aparece como os verdadeiros paulistas.

Deste modo, segue-se a acusação clássica de que migrantes, em especial nordestinos, roubariam empregos paulistas, possuindo até mesmo melhores salários. A revolta que se vê acerca do tema é tanta que o documento chega a defender que empresas sejam punidas em caso de contratação nordestina e falta de devolução do migrante para sua terra natal. Enfatiza-se, acerca desta questão, a categoria dos cortadores de cana.

A menção à Produto Interno Bruto é constante no Manifesto. Busca-se demonstrar um panorama em que São Paulo aparece como vítima de um saque brasileiro contínuo. A divisão social e econômica em dois Brasis seria a base que sustentaria esse argumento: um

\footnotetext{
${ }^{249}$ Pobre Paulista faz menção a uma expressão utilizada no Manifesto. É também nome de uma canção do grupo musical Ira: "Não quero ver mais essa gente feia / Não quero ver mais os ignorantes / Eu quero ver gente da minha terra / Eu quero ver gente do meu sangue / Pobre São Paulo / Pobre paulista, Oh, Oh." ${ }_{8}$ "Sendo fruto de nosso espírito e nossa cultura, o nosso Progresso, Faculdades, novos trens do Metrô sejam para usufruto do nosso povo verdadeiramente paulista" (2010:21).
} 
Sul difuso, representado idealmente por São Paulo, sustentaria o Norte e o Nordeste brasileiros. Fala-se, inclusive, que São Paulo seria como um país que sustentaria outro território nacional, de natureza humana e econômica totalmente distinta.

Apesar de apresentar como problema a população que vive em favelas e o trabalho de ambulantes conhecidos como camelôs, o documento busca continuamente dizer-se contrário a qualquer forma de ataque à pobreza. Para tal, afirma que os paulistas pobres seriam o grupo mais vulnerável frente a esta categoria de migrantes predatórios. Da mesma maneira, os escritores apresentam-se como vítimas de um sistema que não permite a exposição de sua revolta contra os migrantes, já que poderiam ser acusados de preconceituosos.

Como já dito em diversos momentos desta dissertação, a paulistanidade buscou historicamente afastar grupos negros, indígenas e pobres de sua composição social imaginada. É interessante notar que frente a esta questão, o Manifesto passa a idealizar o que chama de pobre paulista, pobre honesto. ${ }^{250}$ Este, apesar de não ser bem sucedido economicamente, seria pobre devido aos problemas causados pela migração. Enquanto aos grupos migrantes se imputa a simultânea culpa de roubo de empregos e repulsa ao trabalho, se apresenta um pobre paulista romantizado que seria saqueado por indivíduos externos a sua cultura. Apesar de pobre, todavia, segue tendo um valor diferencial:

\footnotetext{
Nossa cultura gerou o nosso Progresso. Porém, conforme citado no tópico XIV, mais recatada, não solicita gratuidades. Nossos pobres paulistas - quando até mais necessitados - raramente requisitam benefícios. Assim, na prática, a QUASE TOTALIDADE dos serviços públicos fornecidos por $\mathrm{S}$ Paulo, são para usufruto de outras culturas. (2010:10)
}

Esta culpabilização meritocrática nega a estrutura desigual de uma sociedade de classes ao mesmo tempo que afasta de São Paulo qualquer conexão ao estigma da pobreza. O excerto a seguir é elucidativo neste sentido:

O Est de S Paulo e seus governos são responsabilizados por desabamentos de terra e outras tragédias. Porém S Paulo não foi buscá-los em sua origem. Não concedeu permissão para invasão e construção em áreas de risco (2010:13).

\footnotetext{
250 "Não é correto que pessoas pobres esforcem-se para adquirir um imóvel dignamente, enquanto outras invadem e apropriam-se de terrenos. Isto é uma punição ao pobre honesto." (2012:4).
} 
Torna-se nítido que qualquer problema estrutural da sociedade é - na visão do documento - causado por fatores e populações tidas como externas à cultura paulista. $\mathrm{O}$ ódio ao cidadão que habita áreas irregulares do estado - que aparece em quantidade saliente nos referidos textos - existe porque à sua pobreza soma-se a característica migrante, em especial nordestina. Vale dizer que, sob qualquer olhar atento, sabe-se que dentre as populações residentes de áreas irregulares há também pessoas naturais do estado de São Paulo. O higienismo do Manifesto, todavia, ignora este dado. Apesar da menção a um pobre paulista romantizado, o documento evidencia o afastamento da pobreza típico da paulistanidade.

Sua lógica excludente se apresenta com mais nitidez na defesa de que não deve haver qualquer ampliação de direitos em São Paulo. Defende-se que quanto mais direitos forem estendidos, mais imigrantes se estabelecerão no estado. Tal defesa torna nítido o teor deste discurso: apresenta-se a proposta de que benefícios como o Programa Mãe Paulistana, a residência em conjuntos habitacionais, a assistência em hospitais e a admissão em concursos públicos sejam direcionados prioritariamente a paulistas. Para além do fato de que grande parte dos serviços citados é direcionada a populações pobres, percebe-se um erro argumentativo do documento: defende-se, em teoria, que o problema da migração seja causado pelo esgotamento dos recursos utilizados pelos migrantes, todavia, não se quer a ampliação dos mesmos. O problema não está na falta de direitos, mas sim na presença de grupos sociais indesejados.

Posto isto, torna-se mais compreensível a reivindicação do documento de 2010 “Total proibição de camelôs e todo tipo de comércio ilegal" (2010:21) - que persiste na versão de 2012: “Criação de Disque-Denúncia para Invasão de Terreno (...) amplo levantamento nas favelas paulistas." (2012:4-5). Há em tais demandas demarcação nítida da classe do migrante. Torna-se óbvio que o ódio a este não é genérico - do contrário: tem classe e origem.

Um discurso capaz de deixar ainda mais visível as conexões discursivas entre o manifesto e uma ideologia política conservadora seria o de William Godoy, porta voz do Movimento:

Quem constrói São Paulo não são os pedreiros. São os empresários, os aplicados na cidade, feitos por paulistas. Falar que outras pessoas construíram a cidade é absurdo. Eles trabalharam, usaram sua força de trabalho. Não significa que construíram São Paulo. Esse prédio que você trabalha, por exemplo, não foi construído por 
migrantes... por pedreiros. Foi construído pela empresa que investiu, que financiou o projeto. (PORTAL TERRA, 2010)

O discurso enunciado apresenta não apenas a negação da contribuição da classe trabalhadora na construção de São Paulo, mas também um explícito viés político desacostumado a levar em conta questões como precarização, exploração e mais-valia. Uma vez que a paulistanidade é caracterizada por apresentar um ideal conectado ao progresso e ao sucesso econômico, não causa espanto que as classes dominantes sejam enaltecidas no Manifesto em detrimento das camadas pobres e estigmatizadas da sociedade.

Cabe a questão, todavia, se haveria possibilidade de tratar o documento como repulsa entre economicamente iguais. Vê-se o engajamento no ódio à pobreza e quem a representa baseado, como típico nos meios paulistanistas, na origem nordestina. Desconhecer, todavia, a composição de quem o escreve, não permite a assunção de que se trata de um discurso proferido por membros privilegiados da sociedade.

Apesar do desconhecimento em torno desta composição, vê-se a negação de desigualdades internas em uma comunidade imaginada como puramente paulista. Os marcadores de estigma típicos da sociedade brasileira são tratados como externos ao estado e quem o compõe. Neste sentido é possível perceber que quando Benedict Anderson (2008) explicita o fato de que "as comunidades se distinguem não por sua falsidade/autenticidade, mas pelo estilo em que são imaginadas" (ANDERSON, 2008:33), é possível estabelecer em termos mais concretos muitas das características do regionalismo paulista. Nada mais próximo à camaradagem horizontal de que fala Anderson - que expõe como as comunidades imaginadas lidam com seus segmentos sociais com uma ideia de igualdade, ignorando diversas clivagens sociais - do que o mito paulista que faz com que todos os naturais de São Paulo reúnam as características superiores quando relacionados ao restante dos brasileiros.

Torna-se necessário salientar que esta camaradagem horizontal, todavia, não anula a discriminação sofrida por grupos paulistas pobres. Se no nível do discurso, São Paulo possui o que é chamado de pobre honesto, pobreza causada pelo problema da migração, na prática as populações desfavorecidas do estado são estigmatizadas, apesar do suposto diferencial de sua origem. O mito do trabalho paulista, do pragmatismo e da iniciativa incansável não alcançam os membros da sociedade que são historicamente invisibilizados. 
Seu diferencial existe quando da comparação externa. Internamente continuam sendo tudo aquilo que uma paulistanidade inflamada sempre procurou afastar: o estigma da pobreza.

\section{4 - A Negação da Raça}

Rejeitamos calúnias de 'racismo'. Nossa cor não é branca, não é morena, não é negra. Nossa cor é São Paulo. (2010:21).

A rejeição às denúncias de incitação ou prática de racismo, aparente em todo Manifesto, torna nítido que as ideias da superioridade paulista são recebidas costumeiramente enquanto discriminação ou preconceito racial por grupos contrários ao paulistanismo. É interessante como está até mesmo em um imaginário difuso o fato de que o ódio ao nordestino vem acompanhado da racialização do mesmo. Em negação a isto, o documento analisado possui como técnica discursiva a ressignificação de racismo. Racismo, neste caso, seria dizer que São Paulo foi construída por nordestinos; discriminação seria o desrespeito de um migrante a um anfitrião, sendo este desrespeito a existência social do migrante.

Novamente neste estudo de caso, defronto-me com a impossibilidade de saber a composição social daqueles que o escreveram e o assinaram. Será que, como acredito, seria uma maioria de pessoas brancas? Apesar do desconhecimento deste dado, defendo que seja possível afirmar que, mesmo veladamente, o discurso apresentado possui conexões com um histórico paulista ancorado na ideia de superioridade racial.

Tal fato pode ser visto na supervalorização da população europeia (italiana em geral) e japonesa que emigrou para São Paulo no final do século XIX até meados do século XX. Sobre a composição do paulista ideal afirma-se:

Tivemos os Bandeirantes, o Café, os Imigrantes, a Industrialização, a Revolução Constitucionalista, o IV Centenário. Todos os povos que integraram São Paulo são importantes. (2012:7).

É sintomática a negação de populações indígenas, a ode ao bandeirantismo e a rejeição de grupos chegados após esta idealizada primeira metade do século XX. Afirma-se que em tal momento - considerado como o mais glorioso do estado - a "presença de migrantes brasileiros era irrisória" e que a degradação teria início com a chegada dos mesmos, especialmente nordestinos, na década de 1960. 
A bibliografia especializada que foi exposta nesta dissertação é saliente ao afirmar que o horror frente à chegada nordestina em São Paulo possui relação com a cor e a condição econômica dos imigrantes do Nordeste brasileiro. Torna-se interessante, deste modo, analisar o fato de que isto não é dito abertamente em trecho algum dos documentos em questão. Defende-se, todavia, que se ensine nas escolas a obra de um autor como Alfredo Ellis Jr., tachativo ao classificar o nordestino - de forma estigmatizada - como um brachyplatycephalo moreno e o paulista - de forma valorativa - enquanto branco. ${ }^{251}$

André Mota e Marco Cabral dos Santos (2010) demonstram que o referido autor anulava a presença negra na composição do estado. A defesa da mestiçagem empreendida por Ellis Jr. residia na crença de um projeto eugênico paulista que unia portugueses e invisibilizados - tidos como pretéritos - indígenas. Vale lembrar que Ellis Jr. defendia que o Brasil se tornasse uma Confederação e um dos motivos para tal seria a existência de ambientes raciais distintos no território nacional.

A reivindicação em torno da obra de Ellis Jr. já seria suficiente para expor a racialização que traz o Manifesto analisado. Para além disso, todavia, há a negação da hierarquização racial da sociedade. Afirmar que "nossa cor não é branca, não é morena, não é negra. Nossa cor é São Paulo" (2010:21) demonstra a sublimação de uma discriminação e preconceito históricos. Além da ressignificação de um racismo confuso a partir da defesa de que racistas são os migrantes, mobiliza-se a ideia mítica de democracia racial. Como se em São Paulo não houvesse cor e discriminações, mas simplesmente o ser paulista.

Torna-se necessário salientar, neste caso, que a negação racial aparece costumeiramente como técnica de embranquecimento: longe de indicar a rejeição ao conceito de raça - que de fato não possui qualquer validade biológica - anula-se a carga histórica de uma opressão social recorrente; adequa-a a uma nova - e embranquecida identidade regional imaginada. Há, todavia, que se demarcar as diferenças contextuais que indicam a variação do discurso paulistanista. $\mathrm{O}$ receio de identificar-se como racista indica o recrudescimento das pautas dos movimentos negros contra os avanços da discriminação. Longe de manter um discurso homogêneo ao longo dos tempos, vê-se neste Manifesto uma

\footnotetext{
251 “Não há quem não faça distincção entre um negro e um branco. Não há quem não faça a distincção perfeita de um nortista brachyplatycephalo, moreno, com um louro do Paraná, de Sta. Catharina ou do Rio Grande do Sul (...) as porcentagens de cada um desses elementos são diferentes, que tornam o ambiente racial completamente outro. S. Paulo, por exemplo, tem como Sta Catharina, $85 \%$ de brancos puros. A Bahia, só tem 33\%, a Parahyba só tem 32\%, o Amazonas 31\% e o Pihauy apenas 24\%." (ELLIS JR, 1933:25).
} 
paulistanidade reconfigurada em um momento político em que o escancaramento racista não é bem visto.

\section{5 - O Ódio ao Nordestino}

A grande maioria das confusões diárias, agressões, atendimentos hospitalares, emergências, ocorrências, brigas, deslocamentos policiais, está relacionada a pessoas de origem nordestina. (2010:14).

Na tentativa de suavizar o conteúdo do Manifesto - frente à revolta ocorrida após a sua publicação - o porta voz do movimento, William Godoy, afirma ${ }^{252}$ que o documento não seria contrário a um tipo de migrante específico, mas sim a qualquer forma de migração. É curioso, no entanto, que na primeira edição do abaixo-assinado tenham sido citadas vinte e uma vezes as palavras Nordeste e nordestinos. Do mesmo modo, na segunda edição do Manifesto, cita-se Nordeste e nordestinos trinta e cinco vezes. Vale dizer que nenhuma destas cinquenta e seis menções foi positiva. A única outra origem brasileira citada pelo documento é a mineira, sendo duas vezes mencionada em cada uma das duas edições.

Em relação às origens estrangeiras menciona-se um europeu difuso - com foco no italiano - e também japoneses, australianos e franceses. Os japoneses são lembrados para indicar que é possível cultivar tradições e ser símbolo de progresso. ${ }^{253}$ Por outro lado, franceses e australianos são mobilizados na defesa do acirramento fronteiriço: cita-se o exprimeiro-ministro australiano, John Howard, e o ex-presidente da França, Nicolas Sarkozy, em discursos conservadores acerca da ida de imigrantes a seus respectivos países. ${ }^{254}$ Vale lembrar que se mobilizou, nestes últimos dois casos, populações nacionais com estereótipo branco.

Posto isto, é possível afirmar categoricamente que o Manifesto não deixa dúvida acerca de quais seriam os migrantes indesejados, o alvo de repulsa do documento: as populações nordestinas. Como já visto no capítulo II desta dissertação, o fenômeno do

\footnotetext{
252 “Não existe essa preocupação particular. Mineiros, nordestinos, mato-grossenses, paulistas que vieram do interior para a capital. Todos" (PORTAL TERRA, 2010)

253 "A preservação cultural não é sinônimo de atraso ou estagnação. O Japão por exemplo cultiva suas tradições e é símbolo de progresso. As Culturas locais devem ser respeitadas" (2010:2).

254 "Citamos as palavras do 10 Ministro da Austrália, aos imigrantes naquele país. "A Austrália não tem que se adaptar a você. É você quem tem que se adaptar à Austrália". Sarkozy, estadista global, reivindicou o direito de falar de imigração sem ser tachado de racista. Afirmou: "a imigração de hoje é a França daqui a 30 anos". Preservar sua Identidade é direito de todo Povo" (2010:17).
} 
cangaço é constantemente mobilizado em um argumento preconceituoso acerca da atribuída anomia nordestina. Neste sentido, qualquer tentativa de o Manifesto mostrar-se neutro quanto ao preconceito regional cai por terra ao conceituar quem seriam os migrantes considerados causadores de problema: justifica-se que a cultura migrante seria violenta por ser baseada na imagem de um cangaceiro.

Deste modo, o documento aparenta, em diversos momentos, a tática de generalização da palavra migrante. Apesar de classificar a diferenciação entre migrantes de povoamento e de exploração fica evidente no texto que migrante problemático seria sinônimo de nordestino. Afirmar a contribuição italiana e japonesa como benéfica a São Paulo e, simultaneamente, classificar a presença nordestina no estado como predatória, segue em consonância com a brasileira - e paulista - narrativa de embranquecimento. Para além disso, reafirma o que foi exposto nesta dissertação: a paulistanidade reforça a sua coesão regional identitária em contraposição ao estigma atribuído ao nordestino.

Não é curioso, portanto, que esta sociedade marcada pelas relações assimétricas entre Norte e Sul brasileiros mostre-se avessa a qualquer fator que seja considerado um orgulho regional do Nordeste. É assim que se pode entender as reivindicações analisadas: fechamento de Centros de Tradições Nordestinas; fim de festas tradicionais do Nordeste (festa junina e carnaval); ${ }^{255}$ encerramento $^{256}$ das atividades do COPANE (Conselho Estadual da Comunidade Nordestina, vinculado à Secretaria Estadual da Justiça e Defesa da Cidadania); entre outras. São apresentados também como fatores de repúdio o sotaque, a existência de Casas do Norte e de músicas que são escutadas em locais públicos.

Apesar de afirmar-se que estes costumes e ambientes seriam focos de violência, percebe-se que o ódio ao nordestino não se trata somente da imputação a este da culpa por problemas de cunho social, mas também da repulsa a sua presença, voz, maneira: sua origem e o estigma que ela traz. Qualquer menção ao Nordeste é rechaçada com vigor:

\footnotetext{
255 "Ainda no contexto da IMPOSIÇÃo CULTURAL, tem ocorrido a proliferação de festas no estado como: "Sampa Sertão", "Cubatão Danado de bom", "Festa nordestina em Atibaia", similares em Americana, Taubaté, e em muitas de nossas cidades. Além de eventos e homenagens diversos. Com verbas públicas, que são oriundas de todos os contribuintes (...)Nossas tradicionais festas juninas, com temática caipira, há tempos vêm sendo descaracterizadas e substituídas por temática nordestina. Isto é um desrespeito e preconceito" (2012:8)

256 "Exigimos a EXTINÇÃO IMEDIATA deste grupo agressor de nome COPANE. Se os migrantes desejam a presença de sua cultura no currículo escolar, cultivá-la, governar, QUE NÃO HESITEM EM RETORNAR ÀS SUAS TERRAS DE ORIGEM. A imposição cultural viola a Diversidade. Que vão pleitear inserção na politica de suas terras, que também têm muitas necessidades e carências" (2010:16).
} 
Repudiamos qualquer tipo de evento à cultura migrante com verbas públicas. Como a 'Homenagem à Luís Gonzaga no Anhangabaú (...) Reivindicamos a demolição do absurdo 'Monumento ao Migrante Nordestino' (...) bem como a extinção completa do comércio ilegal no local (2010:15).

Não é necessário muito para compreender que este Manifesto se trata de um discurso ancorado em hierarquizações sociais: odeia-se o forró; não a música clássica; repudia-se o oxe, não o tchê; revolta-se com a festa junina, não com a achiropita. Reafirma-se, neste sentido, a ideia que nesta dissertação tanto insisto em expor: o afastamento do nordestino é parte ativa na construção de um paulista idealizado, que não possuiria em si qualquer traço do Nordeste e da estereotipização e racialização que esta região carrega. Repulsa que fica nítida no excerto a seguir.

\begin{abstract}
Respeitamos a cultura nordestina como uma OUTRA cultura, com suas qualidades. Porém NÃO a reconhecemos e rejeitamos como contribuinte ou integrante na formação Cultural Paulista. Não faz parte da nossa História. Não se funde com a nossa de maneira alguma. Visto que foi uma imposição a partir da década de 60, e jamais uma aceitação espontânea. (2010:16).
\end{abstract}

\title{
5.6 - Construindo o Paulista
}

O paulista não mudou! Buscamos ouro pelos sertões. Demos ouro para o bem de São Paulo. Hoje a riqueza que buscamos é a preservação da nossa Identidade e nossa Cultura. (2010:21)

Com desprezo à contribuição da classe pobre e dos grupos não-brancos na formação de São Paulo e sua identidade regional, não é de se estranhar que a paulistanidade enunciada no Manifesto possua um enredo imaginário acerca de quem são os verdadeiros paulistas. Neste discurso, o espírito bandeirante aparece como o maior diferencial dos naturais de São Paulo. De um tempo imaginado após a invasão portuguesa - com óbvia anulação das composições indígenas - romantiza-se um bandeirante capaz de alargar fronteiras nacionais e dá-se um salto à época da migração europeia nas lavouras de café. Após isto, salienta-se a industrialização, a chegada de mais migrantes europeus e japoneses, o Conflito de 1932 e o IV Centenário com sua marca de São Paulo triunfante. ${ }^{257}$ Neste discurso, início e fim da formação populacional paulista são estritamente limitados.

Nota-se, desta maneira, manipulação de eventos históricos e compostos sociais na tentativa de aparentar conexões entre o estado de São Paulo, sucesso econômico,

${ }^{257}$ Expressão utilizada por Barbara Weinstein (2015). 
branquidade e glória. Este seria o motivo de a expressão nordestinos construíram São Paulo causar tanto incômodo: uma ideologia que preza por um modelo de trabalho, pragmatismo e pioneirismo não poderia ser abafada por uma população estigmatizada justamente em tais atributos.

Desta maneira, é possível perceber o porquê de em todo Manifesto escrever-se em maiúsculo povo e cultura paulista. A mensagem que se objetiva passar é nítida: superioridade. E para isto, não se poupa o uso indiscriminado de uma categoria regionalmente identitária: paulista/paulistas e São Paulo são palavras utilizadas trezentas e noventa e quatro vezes nas cerca de trinta páginas que compõem as duas edições do documento. Da mesma forma, glorioso estado, dignidade, grandeza e sagrado interior são atributos mobilizados para referenciar o estado e seus habitantes. Trata-se, sem dúvidas, de uma formação regional mobilizada na construção de um grupo identitário.

Para isto, utiliza-se com recorrência o Conflito de 1932. Relembra-se, para angariar fundos para o movimento, a campanha do Conflito Constitucionalista - dar ouro a São Paulo - em que houve engajamento econômico de diversos setores da população. Cita-se, em variados momentos, a frase de Alcântara Machado - "São Paulo não esquece, não transige, não perdoa." Fala-se dos heróis do conflito e de como estes deveriam ser enaltecidos. Defende-se que estações de metrô recebam o nome de M.M.D.C. e que logradouros com nome de Getúlio Vargas sejam retirados do estado. Exige-se placas e homenagens na cidade referentes aos mortos no Conflito e referências ao 23 de maio e 9 de julho. Isto é feito para demonstrar que assim como na época da guerra, São Paulo se une atualmente em uma missão que, neste caso, se daria contra a migração e o suposto saque brasileiro dos cofres estaduais:

Havia o sentimento de "Povo Paulista". Nosso povo se uniu em 32. Empunhavam as bandeiras das 13 listras. Diziam "São Paulo dominado por gente estranha". Os obreiros da tirania, em sua insensatez, esforçavam-se em apregoar "elites querendo recuperar poder". Mas não se sustentava diante do que se via. Negros, brancos, mulheres, velhos, crianças, todos juntos. Um forte sentimento regionalista (...) Nossos soldados tombaram. Pagaram um alto preço em amor a São Paulo. Para que hoje, o Brasil tente destruir nossa identidade. (2010:5).

Esta tentativa de alicerçar-se em um conflito pretérito para basear um suposto atrito presente indica a ideia de Benjamin - acerca do tempo vazio e homogêneo - da qual Anderson trata ao analisar as comunidades imaginadas. Torna-se evidente que a mobilização de períodos é determinada: elege-se aquilo que se quer enaltecer, anula-se o 
que se quer apagar e manipula-se o que não se pode reescrever. Desta maneira, se São Paulo um dia foi considerada provinciana, a narrativa é a de que esta situação gerou a qualidade do paulista para seu autosustento e seriedade. Se o Conflito de 1932 foi derrotado, houve vitória na união de seu povo valoroso, povo este que ainda estaria disposto a defender o que é seu.

Esta formação regional analisada no discurso do Manifesto tem saliência nas reivindicações apresentadas. No documento de 2012, sete, dentre as dezessete solicitações, possuem como tema direto o orgulho paulista. Tratam sobre hinos, heróis, nomes de logradouros, um diferente ensino da História Estadual e tantos outros atributos historicamente construídos. Diz-se que o mapa do Brasil presente na bandeira estadual deve ser trocado pelo da América do Sul, uma vez que o pioneirismo de São Paulo

ultrapassaria fronteiras. ${ }^{258}$ Fala-se que o paulista deve retomar sua auto-estima e o apontam como símbolo de grandeza, bondade e força de trabalho. Reivindica-se o potencial científico, econômico e, especialmente, moral do estado. É curioso que nesta tentativa de construção grupal de um movimento tão extremado, vê-se um esforço similar aos esforços intelectuais dos idos séculos XIX e XX. Lê-se uma formação regional que ainda possui como base a demonstração agressiva de sua pretensa superioridade nos mais variados sentidos, em especial econômicos e morais.

\section{7 - Mobilização Política}

Reivindicamos as seguintes medidas:

a) Torne-se crime no Estado de São Paulo, a invasão e loteamento de terrenos ou prédios - públicos ou privados. São Paulo não foi buscá-los em sua origem. Portanto, não tem obrigação de sofrer suas práticas. b) Cobrança de água, luz e IPTU nas favelas, sem taxas diferenciadas. Sem tolerância a roubos de serviços e ligações irregulares, sendo também encarado como crimes. c) Suspensão de TODO e QUALQUER benefício e gratuidades a migrantes. d) O uso dos serviços públicos (hospitais, postos, escolas, creches, assistência social, etc.) sejam limitados e) Total proibição de camelôs e todo tipo de comércio ilegal (...) Ambulantes têm o total direito de fazer suas atividades. Em suas terras de origem.

\footnotetext{
258 “O Estado de São Paulo representa um pioneiro não apenas no Brasil, sua área de influência atinge o continente latino-americano. Seus hospitais, universidades, destacam-se para além das fronteiras do Brasil, em toda a América latina. Como símbolo que representa, esta mudança refletiria a ampliação de relações e integração com os países vizinhos, os povos-irmãos, e sua posição de grandeza, destaque e fraternidade no continente" (2012:10).
} 
f) Tolerãncia (sic) zero com todo tipo de crimes; g) Não tolerar transgressão a leis contra ruído, desordens, veículos de som e forrós ilegais, fraudes, burlas de catraca, pixações, desrespeitos. (2010:21).

Como já dito neste capítulo, o Manifesto analisado possui mobilização política em prol de maior representatividade eleitoral. ${ }^{259}$ Neste sentido, o documento defende que políticos nordestinos eleitos em São Paulo possuem o objetivo de beneficiar seus conterrâneos. ${ }^{260}$ De tal maneira, reivindica-se a existência de uma campanha: "paulista vota em paulista." ${ }^{261}$ É interessante notar, todavia, que a mobilização política engendrada por este discurso vai além da questão eleitoral.

No cerne disto está a ênfase no direcionamento prioritário (e ocasionalmente restrito) de serviços públicos a paulistas: atendimento em creches, hospitais, escolas, transportes, empregos e vagas em concursos públicos. Afirma-se que sem esta prioridade, há discriminação. Para além disto, apresenta-se como preocupação política o engajamento contra a criminalização do debate exposto e sua conexão à prática preconceituosa. Enfatiza-se que o Brasil estaria perpetuando autoritarismo, intolerância e padrões ditatoriais ao classificar como discurso de ódio esta paulistanidade exacerbada. Acredita-se que a mídia possua um conluio antipaulista e que grupos migrantes estariam engajados no combate a este conceito restrito de cultura de São Paulo. Assinantes do Manifesto chegam a falar em Ditadura Nordestina.

Ainda em um imaginário acerca da representação dos naturais do Nordeste, o documento mobiliza-se com agressividade em torno do que chama de assistencialismo. $\mathrm{O}$ debate acerca de bolsas governamentais - e o discurso conservador que este pode engendrar - estão presentes sob a seguinte fórmula: o paulista, de modo geral, não necessita de quaisquer auxílios - quando necessita, valoroso que é, não os aceita - o

\footnotetext{
259 "S Paulo fornece $41 \%$ do sustento do país, e é governado por presidentes eleitos por outras regiões; submetido a governos que não escolheu" (2010:9).

${ }^{260}$ "Na Câmara dos Deputados, o voto de um acreano vale o de 7 paulistas. No Senado, que representa os estados, o voto de um sergipano vale o de 20 paulistas. Além disso, as regiões votam em bloco. Para assim, vencerem como maioria, e decidirem como dizimarem o dinheiro tomado de SP. Além da inferior representação, muitos dos representantes de S Paulo NÃO são paulistas. Logo, pensam no benefício de suas terras natais. É uma situação degradante de semi-Colonialismo" (2010:9).

261 “Grande parte dos políticos na Região Metropolitana são nordestinos. O número se elegendo aumenta a cada eleição. Isto é seríssimo. Curiosamente, não é encarado como preconceito anti-paulista. A fim de frear esta usurpação, reivindicamos que - independente das opções partidárias e eleitorais, sem desrespeito à legislação - seja promovida a Campanha "Paulista vota em Paulista", para nossas prefeituras, vereadores, deputados. Para conscientização da população. Bem como a escolha para Secretarias do governo, sejam paulistas" (2010:11).
} 
nordestino (apresentado como parasitário) manipula sua situação para garantir estes auxílios para si.

Estas máximas são acompanhadas da defesa partidária conservadora. Isto fica evidente quando diz-se que seria calunioso responsabilizar o governo paulista pelas enchentes anuais em áreas vulneráveis do estado, uma vez que, nesta lógica, seriam os migrantes que "inundam de lixo nossos bueiros" (2010:15). Da mesma maneira, defendese o ex-prefeito de São Paulo, Gilberto Kassab, contra os insultos sofridos por moradores da área Jardim Pantanal - que vaiaram o político após mais um episódio de alagamento. Como de praxe, apresenta-se repúdio à figura do ex-presidente Lula: reivindica-se que este seja considerado persona non grata no estado. Apesar de não apresentar qualquer menção partidária, fica nítido em que lado do espectro eleitoral se situa o movimento.

Posto isto, é possível dizer que o atual discurso conservador brasileiro é identificado com saliência no Manifesto. A disputa em torno dos temas da Educação é emblemática neste sentido, uma vez que se repudia as teóricas "práticas gramcistas" (2010:180) e doutrinações ideológicas que ocorreriam no ambiente escolar. Vê-se, deste modo, um discurso similar ao do atual movimento Escola Sem Partido. ${ }^{262}$

Desta maneira, o documento posiciona-se contra uma série de fatores em torno da legislação e Constituição do país. Exige a extinção de diversas leis ${ }^{263}$ que fazem referência ao Nordeste e o encerramento de atividades variadas, até mesmo recreativas, relacionadas à região. O documento não aparece, porém, somente como reativo. Suas proposições indicam a defesa do sistema confederacional em que cada estado teria gestão total de seus recursos e autonomia cultural e política. Da mesma maneira, reivindica a implementação de leis como a do Projeto De Volta Para Minha Terra (P.L. 550/2004) e o levantamento de favelas e "terrenos usurpados" (2010:20). Creio que estas asserções políticas em muito se relacionam à maneira que Weinstein (2015) analisou o Conflito de 1932, uma vez que tal

\footnotetext{
${ }^{262}$ Escola Sem Partido é um movimento conservador que une estudantes, pais e responsáveis de alunos especialmente da educação básica, mas em alguns casos também da superior - e luta contra o que chama de doutrinação ideológica nas escolas. Uma de suas tantas reivindicações é a exigência de que o Exame Nacional do Ensino Médio retire de suas regras a atribuição da nota zero a quem faça redações com conteúdo que fira os Direitos Humanos.

263 "Exigimos a revogação imediata das seguintes leis e projetos similares: Lei 8.441 (23/11/1993), Lei 12.061 (26/9/2005), Lei 50.587 (13/3/2006), Lei no 11.755 (01/07/2004), todas referentes a homenagens a migrantes. Bem como a Lei Municipal 2.819 (30/06/2005) de Cosmópolis, Lei 2.468 (14/07/1999) de Itanhaém, Lei 4.345 (05/05/2010) de Taubaté. Casos semelhantes em todas as nossas cidades. Festas nos Calendários oficiais. Basta de agredir o povo paulista e entregar nosso estado para migrantes" (2010:15).
} 
exacerbação de superioridade não seria uma proposta mais inclusiva que um separatismo declarado.

\title{
5.8 - O Problema da Migração
}

\author{
Migrantes representaram processo de deterioração, alta \\ criminalidade por fatores culturais, lixo para todos os lados. Seu \\ sustento, grande peso para S Paulo. (2010:4). \\ Migrantes e descendentes devem respeitar a Lei, a Cultura Paulista, \\ limpeza, hábitos, portar-se com discrição. (2010:18).
}

Com o objetivo de analisar a agressividade deste Manifesto, criei categorias que englobam os problemas da migração. Seriam estes as alegadas: 1) Imposição Cultural; 2) Tomada de Recursos; 3) Criminalidade do Migrante; 4) Anomia do Migrante; 5) Vitimização do Migrante; 6) Ataque à Liberdade Paulista; 7) Domínio Eleitoral do Migrante. Vale dizer que tais categorias - com exceção da 4: Anomia do Migrante - foram nomeadas a partir de uma linguagem presente no próprio documento. Imposição cultural, tomada de recursos, criminalidade, vitimização, domínio eleitoral e ataque ao paulista são termos utilizados recorrentemente no Manifesto. Para realizar esta categorização, me debrucei somente na primeira edição (2010), uma vez que possui linguagem mais agressiva em relação à segunda que, escrita após grande volume de críticas, suavizou o discurso.

A primeira categoria, referente à teórica Imposição Cultural sofrida pelos paulistas, aparece com saliência considerável. Neste sentido, praticamente qualquer prática migrante é considerada imposta violentamente. Para contabilizar as referências a isto, coletei menções diretas que englobam a ideia de descaracterização regional causada pela migração. Estas, muitas vezes, se constituem como rechaço a figuras nordestinas, nomes de logradouros públicos e até mesmo o ato de escutar forró. Desta maneira, tanto uma enunciação como esta - "Pretender modificá-los, moldá-los a si, impôr (sic) os próprios, forçar os anfitriões a aceitar a descaracterização" (2010:2) - quanto como esta "Repudiamos qualquer tipo de evento à cultura migrante com verbas públicas. Como a Homenagem à Luís Gonzaga no Anhangabaú" (2010:15) - são contabilizadas como Imposição Cultural.

Com a categoria Tomada de Recursos busco contabilizar menções diretas de rechaço à utilização de serviços por parte de migrantes, bem como as afirmações que indicam a saturação - teoricamente causada pela migração - do estado de São Paulo. As 
terceira e quarta categorias - Criminalidade e Anomia do Migrante, respectivamente - são mobilizadas para contabilizar as menções com teor do que Elias (2000) chamou de fofoca depreciativa em relação ao grupo outsider. Neste sentido, contabilizarei menções às alegadas sujeira, maldade, violência, malandragem, alto índice de natalidade, extorsão e fraude que são imputadas aos nordestinos ao longo de todo Manifesto. Por tipificarem um ser profundamente anômico, nomeei a quarta categoria de Anomia do Migrante. Vale salientar que Criminalidade poderia fazer parte desta mesma temática. Creio, no entanto, que é válido enfatizar a recorrência com que o documento classifica o nordestino como criminoso inato, com profunda consonância ao que Pierucci (2013) expôs em pesquisa sobre o discurso conservador em São Paulo nas últimas décadas do século XX. O excerto retirado do Manifesto e apresentado a seguir é elucidativo neste sentido:

Assistimos nos noticiários: Estuprador de Ferraz foge para o Maranhão. Ex-jogador que asassinou (sic) esposa foge para a Bahia. Pedófilo de Catanduva era foragido de Pernambuco. Prefeito de Taboão da Serra suspeito de corrupção mora na Paraíba. De todos os crimes dos noticiários, freqüentemente há migrantes envolvidos (2010:14); (Grifo Meu).

Tabela 6

\begin{tabular}{|c|c|}
\hline \multicolumn{2}{|c|}{ ANÁLISE DO MANIFESTO SÃO PAULO PARA OS PAULISTAS } \\
\hline PROBLEMA ALEGADO & 34 \\
\hline Impósição Cultural & 42 \\
\hline Tomada de Recursos & 14 \\
\hline Criminalidade do Migrante & 26 \\
\hline Anomia do Migrante & 10 \\
\hline Vitimização do Migrante & 16 \\
\hline Ataque à Liberdade Paulista & 9 \\
\hline Domínio Eleitoral Migrante & \\
\hline
\end{tabular}


Com as quinta e sexta categorias, Vitimização do Migrante e Ataque à Liberdade Paulista, busco expor as menções de repúdio à criminalização do debate proposto por este Manifesto. Isto pode ser visto pelas afirmações de que migrantes praticariam vitimismo - o que será contabilizado na quinta categoria - e de que paulistas seriam criminalizados sob falsas acusações de racismo ao exporem sua paulistanidade - o que será contabilizado na sexta categoria. Com a sétima categoria, Domínio Eleitoral do Migrante, contabilizarei menções de culpabilização dos migrantes por resultados eleitorais ou que indiquem um conluio político nordestino.

Todas as categorias indicam argumentos que pautam a migração enquanto um problema. Vê-se que a tomada de recursos, um argumento de cunho econômico, é o mais mobilizado na tentativa de convencer o público leitor. O que não seria uma novidade à paulistanidade: como já exposto nesta dissertação, é constante a mobilização da teórica racionalidade econômica paulista, bem como do ideal de que São Paulo sustentaria a todos os outros estados do país. Do mesmo modo que o é a estigmatização do Outro Regional, sendo este o segundo argumento mais mobilizado no Manifesto. Uma vez que tanto Anomia quanto Criminalidade do Migrante indicam o uso da fofoca depreciativa como mecanismo para estigmatizar a população atacada, é possível unir estes dois vetores de análise para pensar na agressão direta como justificativa mobilizadora. Estas agressões, que juntas formam 40 menções, indicam a carga preconceituosa deste discurso de ódio. Da mesma maneira, o terceiro argumento mais recorrente indica a exaltação da identidade paulista e o receio frente a uma suposta imposição cultural. Da mesma forma que esta ideia de imposição serviria à agressão do grupo atacado - este aparecendo como impositivo nota-se a ideia de que os paulistas seriam especiais demais para conviver com culturas consideradas inferiores.

Creio que seja possível dizer que o quarto e quinto argumentos mais recorrentes no texto - ataque à liberdade paulista e vitimização do nordestino, respectivamente - indicam a presença de um discurso conservador que no debate brasileiro atual baseia-se nas contraposições entre discriminação e liberdade de expressão. Percebe-se que ao mobilizar estes argumentos, o Manifesto busca tanto defender seu direito ao preconceito (sem ser considerado preconceituoso) quanto atacar os discursos contrários a ele (que focam no viés racializador e elitista do documento) sob a alcunha de vitimização. Da mesma maneira, o nono argumento mais utilizado - Domínio Eleitoral do Migrante - evidencia a associação histórica da população nordestina ao ideal de inaptidão política. Vale lembrar que o 
Manifesto foi publicado cerca de cinco meses antes da primeira vitória de Dilma Rousseff como presidenta da República.

Da mesma forma que analisei o conteúdo do Manifesto, me debrucei nos comentários realizados por seus signatários. Das 1954 pessoas que assinaram este documento, 612 comentaram em breves textos sua assinatura. Oito categorias foram por mim elencadas na tarefa de destrinchar estes pareceres: 1) Agressão; 2) Separatismo; 3) Apoio; 4) Argumento Econômico; 5) Indignação com a Atual Situação de São Paulo; 6) Exacerbação da Paulistanidade; 7) Menção a Nordestinos ou ao Nordeste; 8) Outros.

A primeira categoria, Agressão, foi mobilizada quando os comentários possuíam agressão direta a migrantes. Vale dizer que, neste caso, observou-se um discurso empenhado na desumanização do Outro Regional: alegava-se violência, malandragem, sujeira, inaptidão eleitoral e ao trabalho como características intrínsecas desta população. A segunda categoria, Separatismo, mapeou os comentários que demonstravam a exigência de que São Paulo se torne um país independente. A terceira, Apoio, mobilizou comentários simples, normalmente de menor tamanho, que demonstravam acordo com o proposto pelo documento. A quarta categoria, Argumento Econômico, indica o discurso economicista na fala dos signatários. Deste modo, foram contabilizadas tanto narrativas de que São Paulo sustentaria o Brasil, quanto acusações de que o migrante usufrua parasitariamente da economia paulista.

A quinta categoria, Indignação, busca mapear comentários que expressem revolta com a situação de São Paulo: "chega de migração" ou "eu não aguento mais" foram falas frequentes neste mapeamento. A sexta categoria, Exacerbação da Paulistanidade, refere-se aos numerosos non ducor, duco e hinos paulistas que foram citados, bem como argumentos do discurso paulistanista como, por exemplo, o da locomotiva do Brasil. A sétima, Menção a Nordestinos, mobilizou todos os comentários que utilizassem as palavras Nordeste ou nordestino/a/os/as. A oitava categoria diz respeito a comentários que fugiam ao proposto pela situação: propagandas de websites ou a escrita do nome do signatário foram exemplos disto. Vale dizer que em minha análise percebi que certos comentários englobavam mais de uma categoria. 
Tabela 7

\begin{tabular}{|c|c|}
\hline \multicolumn{2}{|c|}{ ANÁLISE DE COMENTÁRIOS DOS SIGNATÁRIOS } \\
\hline CATEGORIA OBSERVADA & NÚMERO DE MENÇÕES \\
\hline Agressão & 96 \\
\hline Separatismo & 59 \\
\hline Apoio & 151 \\
\hline Argumento Econômico & 56 \\
\hline Indignação com a Atual Situação de SP & 127 \\
\hline Exacerbação da Paulistanidade & 190 \\
\hline Menção a Nordestinos & 57 \\
\hline Outros & 9 \\
\hline
\end{tabular}

As duas categorias mais recorrentes - exacerbação da paulistanidade e apoio aos dizeres do Manifesto - podem indicar a eficácia da construção mitológica de São Paulo enquanto uma comunidade imaginada. Não sou conduzido, conduzo, menções a 1932, ao Café, à pretensa locomotiva do Brasil apontam para mecanismos clássicos mobilizados na tentativa de pautar a superioridade paulista. Da mesma maneira, o terceiro argumento mais recorrente - Indignação com a Atual Situação de São Paulo - evidencia como responsabiliza-se o externo, o não-paulista, pelos problemas estruturais do estado. O que leva com que o Separatismo enquanto solução esteja mencionado diretamente em 59 dos 612 comentários analisados.

Creio que seja possível afirmar que tal indignação e desejo de separação apontam para um caráter ideológico da paulistanidade que naturaliza um grupo humano enquanto generalizadamente culpado. Isto explicaria o número alto de agressões que foram vistas nestes comentários, sendo a quinta menção mais recorrente na tentativa de justificar o porquê da assinatura do Manifesto. Uma vez que o Nordeste aparece historicamente enquanto contraponto do ideal paulista, é possível entender o porquê de os nordestinos serem a única população - nacional e internacional - mencionada nos comentários enquanto um problema a ser resolvido. Seguido a isto, vê-se o argumento econômico endossando o proposto pelo documento. 


\section{9 - Conclusões Sobre o Manifesto}

A análise empreendida neste estudo de caso - levando-se em consideração todas as críticas que o Manifesto recebeu e sua repercussão na imprensa - permitiu que eu analisasse continuidades e descontinuidades da paulistanidade. Percebi que certas bases históricas e imaginadas continuam sendo mobilizadas em prol do orgulho paulista. Seriam estas: 1) a ideia de uma pretensa, e posta como inquestionável, superioridade do estado e de seus habitantes em sentidos morais, raciais, culturais e econômicos; 2) a narrativa em torno da aptidão ao trabalho, a um modelo capitalista de sociedade e ao melhor exercício político brasileiro; 3) a reivindicação de enredos históricos que enfatizem a herança bandeirante, a italianidade, o embranquecimento a partir da imigração de europeus, a ascensão com o cultivo de Café, o Conflito de 1932, o IV Centenário e o período de urbanização da capital paulista; 4) o preconceito contra o nordestino e o estabelecimento deste como contraponto do paulista; 5) a culpabilização nordestina pelas mazelas do estado de São Paulo; 6) a ideia de que o Brasil seria sustentado pelo estado paulista.

Posto isto, é possível perceber que a paulistanidade engendrada pelo Manifesto segue na tentativa de alçar-se enquanto civilizada demais para o Brasil. Interessa, todavia, pensar nas reconfigurações deste discurso. Creio que seja possível afirmar que uma das descontinuidades mais salientes da paulistanidade analisada nestes documentos estaria relacionada à questão da raça. Apesar de a desigualdade racial ser gritante na sociedade brasileira, percebe-se a aversão ao termo racismo. Longe de pautar-se como racialmente superior de maneira explícita, o discurso enunciado busca afastar-se de suas conexões com tal discriminação e preconceito. Acredito, neste sentido, que se opta por falar em termos culturais, ao invés de explicitamente raciais, apesar de geralmente proferir-se o mesmo conteúdo que em uma estigmatização racial. É possível perceber o motivo desta reconfiguração, uma vez que este é um período em que máximas discriminatórias e/ou preconceituosas não somente são questionadas com vigor pelos movimentos negros, como também podem ser criminalizadas - tendo em vista o ocorrido com Mayara Petruso ou os jovens envolvidos nas ameaças à Escola Acadêmicos do Tucuruvi. Da mesma maneira, vêse que o argumento econômico se sobrepõe ao argumento puramente racial.

Apesar de apresentar uma narrativa temporal vazia e homogênea, o documento situa-se historicamente com precisão: dialoga com seu tempo e com os argumentos conservadores do mesmo. Escritas há oito e seis anos, as versões apresentadas permitem analisar narrativas também presentes nos argumentos que basearam o Golpe da presidência 
ocorrido em 2016. Para além disso, foca em uma série de debates efervescentes do momento brasileiro atual - e tão recrudescidos no universo virtual - como o da educação ideológica, de uma ideia restrita de liberdade de expressão e da alegada manipulação das acusações por discriminação racial.

É interessante, contudo, perceber que - pela linguagem apresentada tanto no documento quanto nos comentários de seus signatários - o Manifesto não parece ter sido feito e reproduzido por membros da elite intelectualizada. Da mesma maneira, a insistência nas falas sobre roubo de empregos e casas em programas populares indicam certa preocupação com um tema que interessa pouco às classes dominantes. É possível pensar, neste sentido, se não estaria imersa nesta lógica o que Gramsci (1987) afirmou acerca da estigmatização sofrida pelos sulistas da Itália por seus conterrâneos também pobres do norte: ignora-se a ideia de que o desenvolvimento capitalista do norte é ocasionado pelo atraso do sul e imputa-se a este sulista culpa pelas contradições sociais e problemas deste sistema econômico. Um processo que sem dúvidas serve às classes dominantes.

Paralelo a isto, encontra-se o fato de que a categoria paulista permite a populações marginalizadas de São Paulo certa superioridade em relação ao Outro Regional. Encontrase nesta questão uma identidade multifacetada a ser levada em consideração: populações não podem ser pensadas desconsiderando-se marcadores sociais da diferença variados. Posto isto, é possível pensar que ao mesmo tempo que, a título de exemplo, se pode ser pobre e paulista - e estigmatizado por isto - pode haver certo sentimento de superioridade em relação a um nordestino, que além de ser estigmatizado por sua classe representativa, também o é em questão de origem. As questões raciais, de gênero e sexualidade também estão conectadas a estas maneiras com que o poder se dispõe.

Em relação à imposição cultural alegada de que o documento tanto fala, se pode mobilizar o que Truzzi (2001) denominou de ideologia antipluralista por excelência, uma vez que São Paulo e a sociedade paulista aparecem como "integradoras ou diluidoras das características de afirmação étnica dos grupos que receberam" (TRUZZI, 2001:143). Exigir que grupos migrantes se portem com discrição, como apresentado no Manifesto, indica a necessidade diluidora das características nordestinas. Operando neste sentido também estão as exigências acerca do fechamento dos Centros de Tradições Nordestinas, Casas do Norte e bailes de forró em São Paulo. É nítido o incômodo - até mesmo repulsa em relação à formação regional distinta, sobretudo quanto esta é racializada. 
Como apontam Gemignani e Hernandez-Albujar (2015) a fronteira entre insiders e outsiders transcende a definição geográfica, uma vez que diz respeito à criação de identidades dicotômicas. Desta maneira, a narrativa sobre o outro - o outsider - é, ao mesmo tempo, uma narrativa sobre si, sobre o nós (GEMIGNANI, HERNANDEZALBUJAR, 2015:2756). Sob a perspectiva foucaultiana, os autores apontam que grupos estadunidenses contrários à migração buscam para si o ideal de heroísmo, de defensores do país. Como no caso do Manifesto sobre o qual se debruça este estudo de caso, estes grupos buscariam apresentar narrativas sobre poder, sacrifício e heroísmo para basear sua autoridade. É neste mesmo sentido, de pautar-se a si como bom e ao outro como ruim, que o nordestino é visto como ser anômico - criminoso nato - e os imigrantes em território americano são considerados terroristas. Estes mecanismos de desumanização aparecem, segundo os autores, a partir da intenção de encontrar uma justificativa racional para seus atos (GEMIGNANI, HERNANDEZ-ALBUJAR, 2015:2760). ${ }^{264}$ Como aponta Hall (1996) imputar características ao outro é uma forma de criar a identidade grupal por contraste.

Posto isto, é possível pensar em como aquilo que Foucault (1983) denominou de games of truth se adequa a este estudo de caso. Vê-se no Manifesto São Paulo Para Paulistas, bem como no estudo de Gemignani e Hernandez-Albujar, um jogo da verdade em que o problema da migração é identificado e descrito para em seguida dotar o grupo enunciador da habilidade de resolvê-lo e com isto desenvolver posições de poder específicas (GEMIGNANI, HERNANDEZ-ALBUJAR, 2015:2765).

Este paralelo com a realidade estadunidense permite pensar em como certas narrativas encontram coro para além do território brasileiro. Uma discussão em torno do suposto vitimismo do migrante e a manipulação do termo racismo também foi uma narrativa apontada por Gemignani e Hernandez-Albujar nos grupos de ódio que pesquisaram. Como estes autores, acredito que a força dos discursos de grupos de ódio extremistas - e de certa forma falidos - se encontra na tensão exercida sobre o discurso geral. Se estas margens são capazes de determinar o centro (GEMIGNANI, HERNANDEZ-ALBUJAR, 2015) é possível entender em parte a campanha vitoriosa de um presidente com discurso fortemente racista como Donald Trump. Como já dito, acredito que o Golpe brasileiro de 2016 - em seus aspectos regionalistas - possui relação com o recrudescimento de um discurso que historicamente tachou o nordestino como ser

264 "The subaltern is silenced (Spivak 1985) and constructed as evil, in contrast to the similarly stereotypical oversimplification of the protector as 'good saviour'" (GEMIGNANI, HERNANDEZ-ALBUJAR, 2015:27610. 
ligado à inaptidão política. Creio que o Manifesto sobre o qual se debruçou este estudo de caso seria exemplo de como um discurso preconceituoso e recorrente, apesar de minoritário em termos de militância, possui implicações sociais relevantes. 


\section{CAPÍtULO VI \\ Livre-Mercado e Paulistanidade O Conservadorismo do Movimento São Paulo Livre}

\section{1 - São Paulo Livre (SPL)}

Para o SPL, paulista é aquele que mora no estado de São Paulo, acredita na força do trabalho e do esforço individual, na honestidade e na livre iniciativa. (SPL, 2014).

O Movimento São Paulo Livre é uma organização política separatista e, em teoria, apartidária que surgiu no mês eleitoral de outubro de 2014, após a segunda vitória da presidenta deposta Dilma Rousseff. Com repercussão na imprensa, o SPL se destaca ao reconfigurar o discurso de uma paulistanidade historicamente agressiva através da apresentação de pautas aparentemente inclusivas.

Neste estudo de caso me debruçarei nas atividades e dizeres deste grupo que venho acompanhando desde sua fundação. Acredito que a relevância desta análise se encontra na possibilidade de mapear um período político em que os temas regionalistas efervesceram e foram remodelados. Do mesmo modo, torna-se viável analisar as continuidades e descontinuidades da paulistanidade separatista que aparece, nesta segunda década do século XXI, como reivindicadora da primazia de uma política conservadora.

O SPL foi homologado formalmente como Organização Sem Fins Lucrativos em fevereiro de 2016, tendo dezenas de núcleos no interior e litoral paulista e possuindo sua sede na capital do estado. O Movimento apresenta-se com certa visibilidade na demanda para que São Paulo se torne um país independente do Brasil. Para tal, possui um estatuto extenso e burocrático e foco em um conceito restrito de liberdade. Realizando palestras, plebiscitos, reuniões e passeatas, o grupo se destaca pelo apelo empresarial e engajamento nas redes sociais. Analisarei neste estudo de caso o discurso apresentado no website ${ }^{265}$ do movimento em questão, bem como em suas redes sociais virtuais, em especial sua página no Facebook. Para isto, analisarei uma série de imagens produzidas pelo grupo, uma vez que estas seriam parte importante de sua propaganda.

\footnotetext{
${ }^{265}$ Disponível em <http://www.saopaulolivre.org/> Data do último acesso: 19/03/2018.
} 
De início vale dizer que o SPL se caracteriza por aparentar formalidade em suas propostas e enunciações. Possuindo cinquenta e quatro artigos em seu estatuto, o grupo assume a defesa jurídica de seus membros quando necessário. Da mesma forma, apresenta uma forma de filiação burocrática e a exigência de que os membros paguem a anuidade de $\mathrm{R} \$ 90,00$ para serem aceitos ou seguirem sendo parte do movimento.

O SPL divide seus militantes em Núcleos de Ação e Aconselhamento. São estes: o Núcleo de Comunicação (NuC), o Núcleo de Apostilas e Cursos (NAC), o Núcleo de Organização de Eventos (NOE), o Núcleo de Marketing e Produtos (NuMP), o Núcleo de Estudos Socioeconômicos (NESE), o Núcleo de Resgate Histórico (NuRH), o Núcleo de Vídeo, Imagem e Som (NuVIS) e o Núcleo de Tecnologia de Informação (NTI). A partir do exercício destes núcleos, o grupo ministra cursos, reuniões e palestras em iniciativas do resgate e proteção do passado paulista, da inclusão da diversidade em suas pautas e na aproximação com o empresariado de São Paulo.

O Sampadeus seria uma das iniciativas do movimento de maior repercussão midiática. Este trata da realização de um plebiscito que indique o desejo de separação paulista. Tendo sido realizado informalmente em 09/10/2016 e atingido - supostamente 48.912 votos, o pleito $^{266}$ é reivindicado pelo SPL como vitorioso, uma vez que teria conseguido 81,5\% de favoráveis à proposta separatista. Em 2018 o SPL realizaria outro plebiscito. Este, todavia, foi adiado para 2020. A justificativa para o atraso foi de que a extensão do prazo permitiria maior alcance da consulta. Em suas propagandas, o movimento se compara com às lutas independentes da Catalunha e da Grã-Bretanha.

Apesar de possuir princípios excludentes, o São Paulo Livre revela engajamento em afastar, de maneira formal, sua imagem de qualquer forma de racismo ou preconceito. Para tal, mobiliza narrativas em prol da diversidade racial e sexual brasileiras. Em consonância com isto, seus quatro princípios são: 1) Se você mora em São Paulo, é um paulista; 2) Não temos nada contra o Brasil ou os brasileiros; 3) A independência virá por meios pacíficos; 4) Ser separatista não é ilegal. No que concerne à questão da ilegalidade, apresenta preocupação em expor que o grupo não fere a lei 7.710, referente aos crimes contra a segurança nacional. Vale dizer que tal lei foi sancionada durante o período ditatorial militar e que o SPL, em seu website, a justifica devido ao temor da época frente ao terrorismo

\footnotetext{
266 “A fim de garantir a lisura da votação, o SPL requereu identificação (Título de Eleitor, RG ou Carteira do Motorista) dos votantes, o que nos permitiu anular votos duplos, seja gente que votou em dois ou mais postos de votação diferentes, seja quem tenha votado online." (SPL)
} 
político. ${ }^{267}$ Tal afirmação é eficaz em demonstrar o lado do espectro político em que o grupo se situa.

O desejo de separatismo defendido pelo movimento possui como argumento principal a questão econômica. Novamente para uma paulistanidade inflamada, São Paulo apareceria como estado saqueado pela Federação Brasileira. Além disso, reivindica-se a questão cultural: para o SPL, São Paulo teria uma história única, diferente, o que justificaria suas demandas distintas.

Tais reivindicações são acompanhadas da defesa da primazia paulista em relação à política conservadora. Afirma-se com certa constância e de maneira valorativa que o governo Dilma teria sido deposto graças a São Paulo e que este estado seria o centro do conservadorismo brasileiro. Do mesmo modo, remonta-se, com base em enredos imaginários, uma historicidade que aponta o paulista enquanto inquestionavelmente superior. Alegando que o mérito, a livre iniciativa e o trabalho seriam o cerne de São Paulo enquanto país, se apresenta um caráter liberal e meritocrático como mote do movimento

Nos dizeres do grupo, a separação virá em três momentos. O primeiro seria a grande divulgação da causa separatista. O segundo, ocasionado em teoria por esta divulgação, seria a mobilização popular pela independência. O terceiro, que consagraria a proposta secessionista, seria a formalização da mesma através de um plebiscito e da transitoriedade estatal pacífica.

Esta separação almejada teria como justificativa a melhoria da vida em São Paulo, o crescimento econômico, a estabilidade política, maior justiça social, bem como a expansão da educação de qualidade e de recursos diversos. Com estas promessas, o SPL conclama diversos paulistas a se juntarem ao movimento, em especial no que se refere ao empresariado. Para além da classe empresarial, é interessante notar que se solicita a participação de professores de história, que pesquisem acerca de um passado paulista imaginado, e de economistas, que avaliem as condições da separação, bem como de profissionais do marketing que ajudem a dar visibilidade ao movimento.

\footnotetext{
267 “A lei 7.170, de 14 de Dezembro de 1983, foi criada ainda no tempo da Ditadura Militar, quando havia o temor de terrorismo político. As penas e proibições contidas na lei dizem respeito a tentativas violentas de separar territórios da federação. Como o SPL é um movimento pacífico, que prega o diálogo e a conscientização popular das vantagens que a liberdade trará para Sâo (sic) Paulo e seu povo, tal lei não se aplica ao movimento nem a nossas ações." (SPL)
} 
O aliciamento por parte do grupo independentista conta com o fato de que os afiliados, para além de participarem das decisões e iniciativas do movimento, podem criar e dirigir diretórios em suas cidades. Deste modo, viu-se nos últimos três anos e meio expansão do SPL no interior paulista. O grupo, que afirma não ter qualquer patrocínio específico, possui uma direção nacional composta por um presidente, Flávio Rebello, um vice-presidente, um secretário-geral e um tesoureiro. Para além da direção nacional, possui quinze direções regionais e outros grupos dirigentes relacionados a esferas menores: municípios e bairros.

Uma das questões mais interessantes do movimento seria a mercantilização da causa separatista. O SPL possui uma loja em que vende bandeiras de São Paulo, panfletos, broches e livretos sobre sua causa. É possível perceber que o grupo dispõe de fundo econômico considerável, uma vez que as eleições para os plebiscitos necessitam de pessoal, urnas, cabines, tendas e grande quantidade de papel impresso.

O fato de que o SPL tenha aparecido em jornais e veículos de imprensa do país e do exterior, é mobilizado pelo grupo para enfatizar e supervalorizar sua notoriedade. Com composição incerta e sem disponibilizar os dados que mostrem a idoneidade de seu plebiscito, é difícil saber seguramente a validade de suas informações. Apesar disto, é interessante notar que a página do grupo no facebook possua 25 mil seguidores. ${ }^{268}$ Acredito que o alcance, ainda que limitado, que este movimento possui deve ser analisado não em seu caráter marginal, mas pela tentativa de legitimar-se socialmente, de ser aceito.

Para além disso, creio que seja possível afirmar que a iniciativa do São Paulo Livre tem conexões com a recente crise política brasileira, permitindo, desta forma, a análise da efervescência de uma paulistanidade que tende a recrudescer em momentos conturbados e emergir de formas diferentes em grupos variados. Da mesma maneira, é possível perceber como um novo separatismo tenta afastar-se de sua histórica conexão ao higienismo e hierarquização social. O SPL afirma, em seu website, que busca manter-se moderno: antenado, plural. A compilação de imagens que será apresentada neste capítulo é exemplo do esforço do grupo pró-independência neste sentido.

\footnotetext{
${ }^{268}$ Termo utilizado pela rede social em questão para indicar quem se filia a uma determinada página online de modo a acompanhar o conteúdo que esta disponha.
} 


\section{O SPL ESTAVA GERTO!}

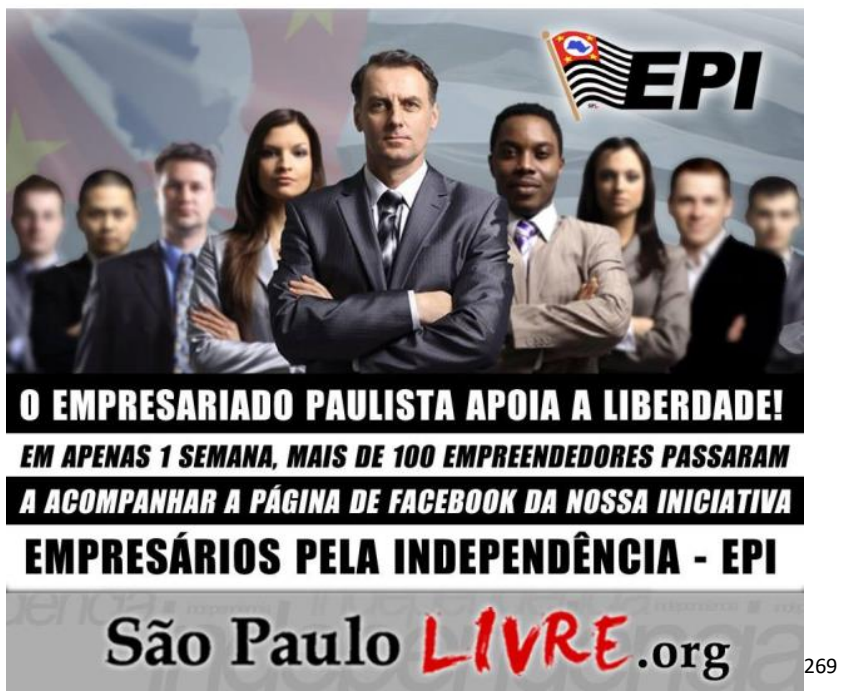

\section{Imagem 37}

Nota-se na imagem o apelo ao empresariado paulista e a figuras sociais que aparentem empreendedorismo e sucesso econômico. Vale ressaltar a composição majoritariamente branca dos que aparecem nas imagens e o fato de que figuras femininas e negras aparecem em segundo plano em relação ao homem branco.

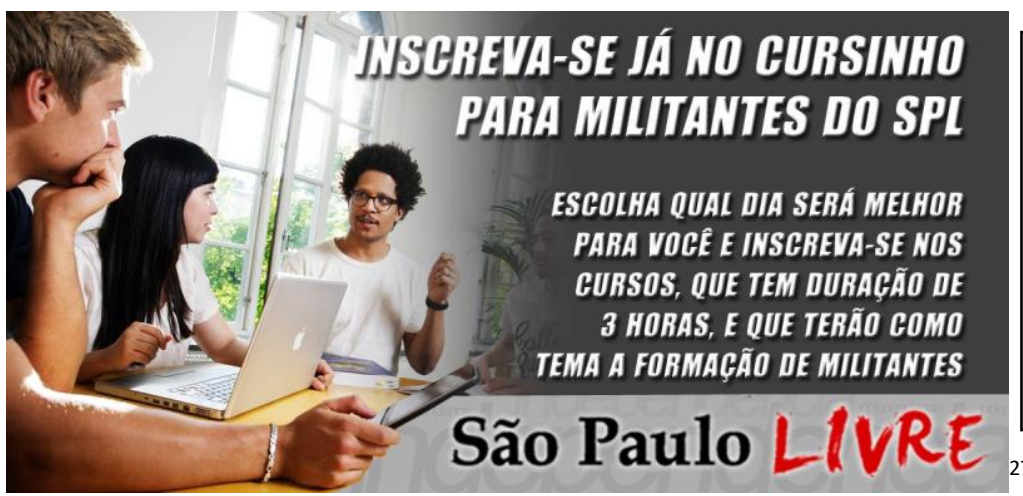

\section{Imagem 38}

Além do empenho na formação de militantes, notase a tentativa de aparentar seriedade, profissionalismo e modernidade.

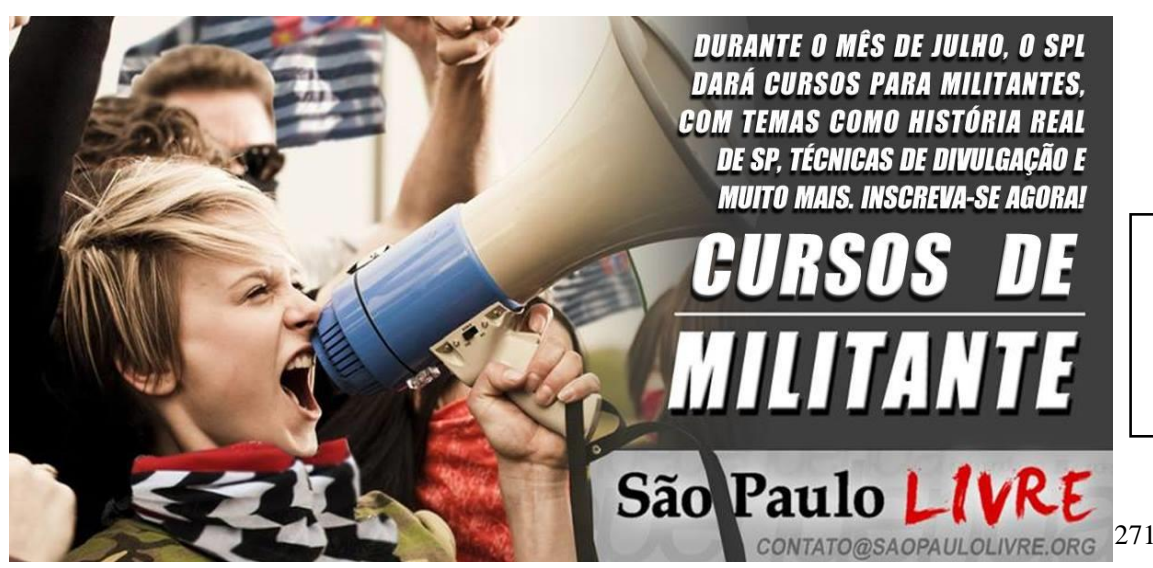

Imagem 39

Visível apelo à juventude.

269 Imagem retirada em: SÃO PAULO LIVRE. Facebook. 24/11/2017. Disponível em: < https://www.facebook.com/movimentoSPL/photos/a.1732684196957716.1073741827.1732658630293606 /2490158327876962/?type=3\&theater > Acesso em: 29/04/2018.

270 Imagem retirada em: SÃO PAULO LIVRE. Facebook. 03/07/2015. Disponível em: <https://www.facebook.com/movimentoSPL/photos/a.1732684196957716.1073741827.173265863029360 6/1887289788163822/?type=3\&theater> Acesso em: 20/04/2018. 


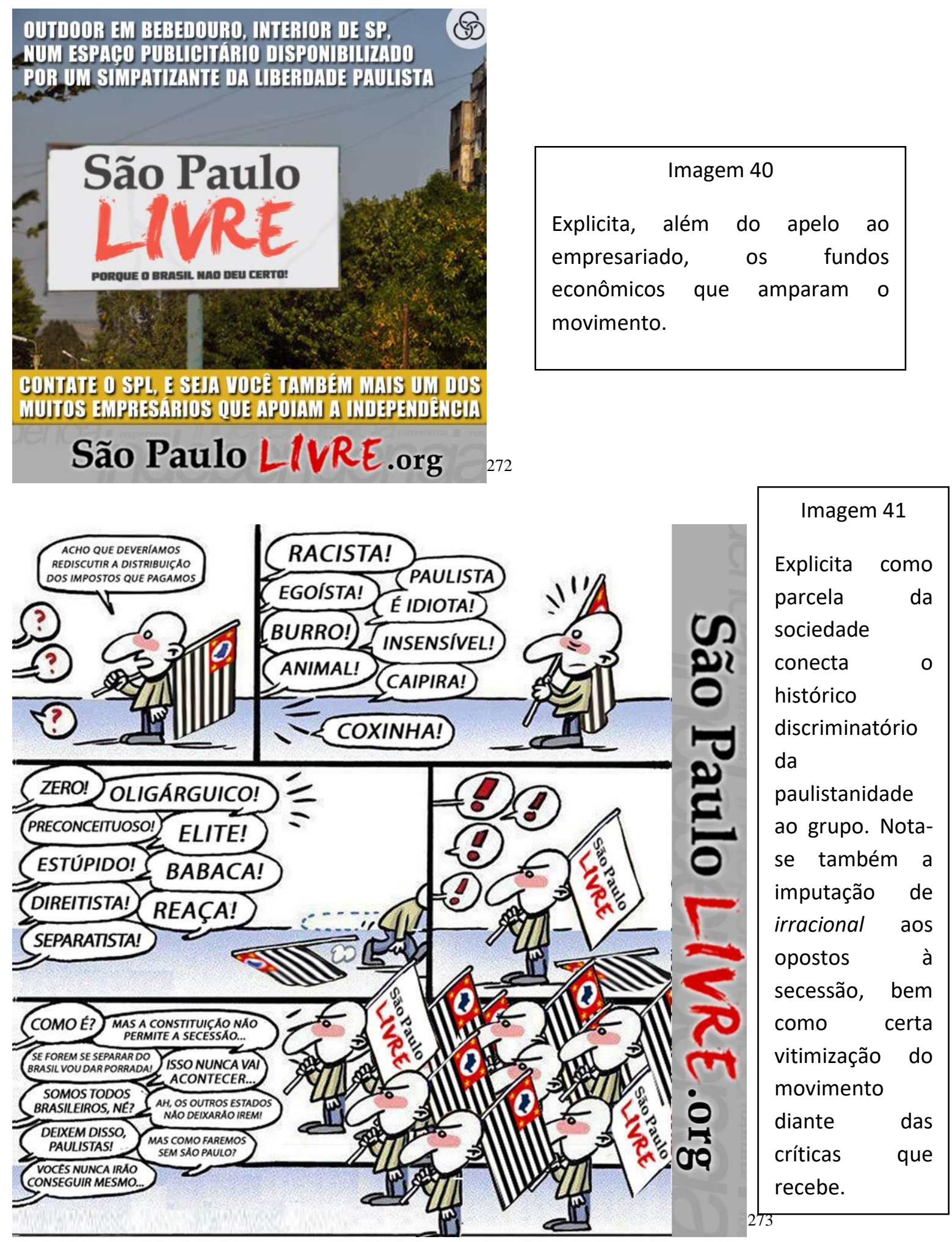

271 Imagem retirada em: SÃO PAULO LIVRE. Facebook. 21/06/2015. Disponível em: <https://www.facebook.com/movimentoSPL/photos/a.1732684196957716.1073741827.173265863029360 6/1881225888770212/?type=3\&theater $>$ Acesso em: 20/04/2018.

272 Imagem retirada em: SÃO PAULO LIVRE. Facebook. Disponível em: <https://www.facebook.com/pg/movimentoSPL/photos/?ref=page_internal> Acesso em: 30/04/2018. 


\section{2 - A Paulistude do Movimento São Paulo Livre}

Temos uma história colonial própria, bem diferente do restante do Brasil. Hoje, nosso estado lidera o movimento de direita do país e também lideramos as passeatas contra o governo Dilma. O paulista é como o nova-iorquino se sente em relação ao americano médio. (REBELLO, F. in O GLOBO, 2016).

O Movimento São Paulo Livre apresenta um novo conceito para expressar sua paulistanidade: paulistude. As acepções clássicas de um paulistanismo que tende a afirmar sua pretensa superioridade se condensam neste termo. Da mesma forma, está a imputação de atraso e insustentabilidade ao restante do território nacional. Interessante neste sentido é a formação regional engajada em torno de um futuro proposto como unicamente paulista. Para este novo país o SPL já teria criado moeda, hino e princípios básicos.

Como exposto nesta dissertação, nacionalismos e regionalismos tendem a basear-se na montagem de sua história. Neste sentido, o movimento em questão permite uma análise frutífera. O SPL possui apego ao Conflito de 1932 e ao bandeirantismo. Da mesma forma, defende que o território paulista chegou a ser a maioria do país no século XVIII. Desta defesa depreende-se a afirmação de que a história do estado não é ensinada para que a população não possa acessar o orgulho que deveria ter diante de sua grandiosidade regional.

Do contrário do que indica a bibliografia especializada - como já citado pela análise do estudo de Cerri (1998) - nesta lógica, ao invés de a paulistanidade ser perpetuada por um ensino de história conservador, o estado seria vítima de uma educação que busca apagar sua cultura. Neste sentido, o movimento toma máximas conservadoras para reivindicar sua paulistude: bandeirantes aparecem como heróis; não havia interesse das classes dominantes no Conflito de 1932; São Paulo seria responsável pela extensão do território nacional; o paulista, trabalhador nato, teria sido saqueado por uma população nacional irresponsável.

A partir da compilação das fotos a seguir, retiradas da página de facebook do movimento em questão, procuro expor aquilo que Anderson (2008) e Hobsbawm (2004) afirmaram acerca da invenção e imaginação das comunidades e de como estas se baseiam em uma história montada em determinados enredos para legitimar-se enquanto antigas, até

\footnotetext{
${ }^{273}$ Imagem retirada em: SÃO PAULO LIVRE. Facebook. 07/10/2017. Disponível em: < https://www.facebook.com/movimentoSPL/photos/a.1732684196957716.1073741827.1732658630293606 /2439610226265106/?type=3\&theater $>$ Acesso em: 29/04/2018.
} 
mesmo predestinadas. Vale pontuar também o conservadorismo que acompanha a análise histórica do SPL.

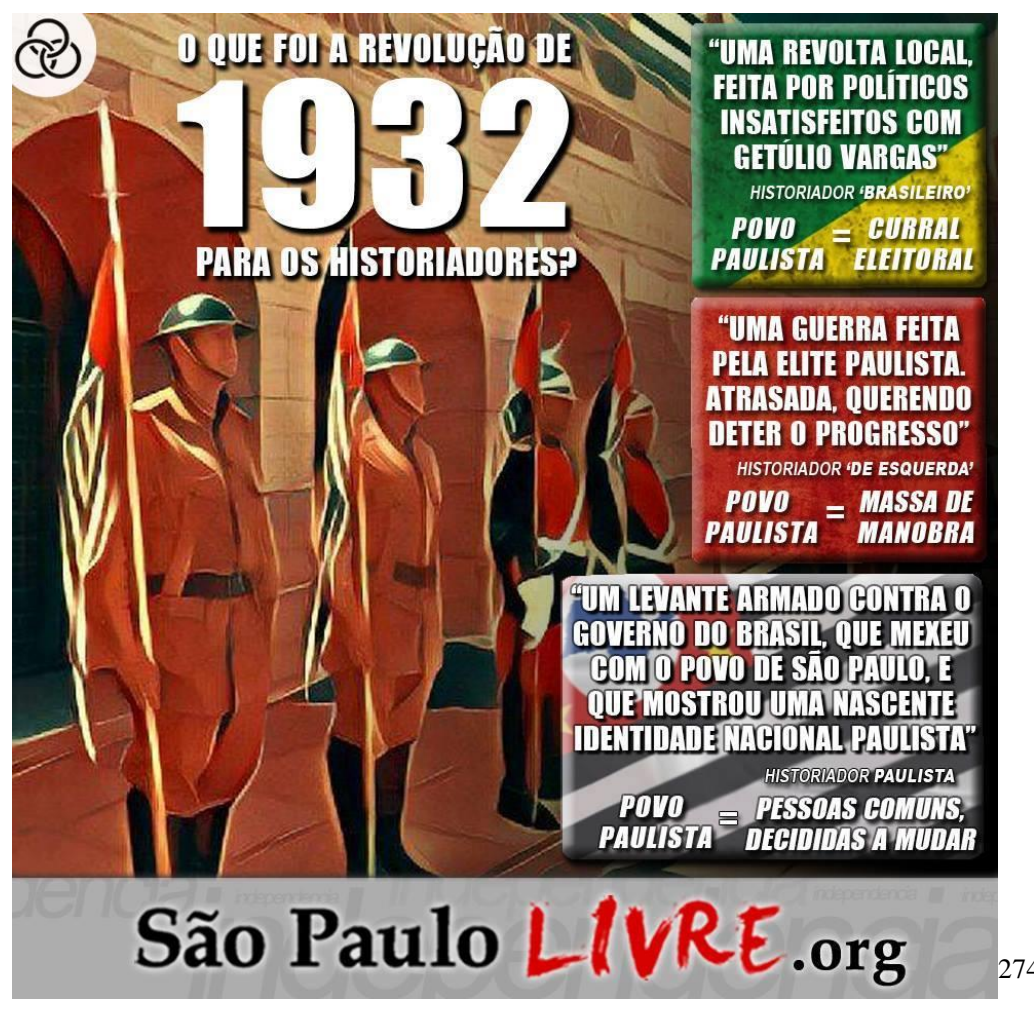

\begin{tabular}{|lrr|}
\hline \multicolumn{3}{|c|}{ Imagem 42} \\
Nota-se a & reivindicação \\
regionalista & na análise do \\
período & e & o \\
escamoteamento & dos \\
interesses de classe que o \\
marcaram.
\end{tabular}

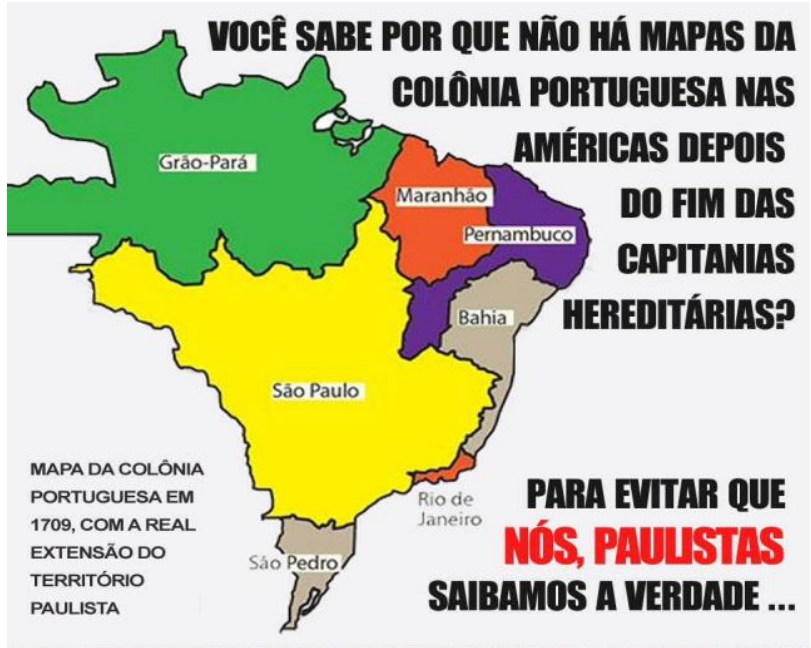

\begin{tabular}{|l|l|}
\hline \multicolumn{4}{|c|}{ Imagem 43} \\
Explicita a reivindicação \\
territorial paulista, baseada \\
no bandeirantismo e na \\
apresentação de um \\
propósito colonizador em \\
referência ao território \\
nacional.
\end{tabular}

\section{São Paulo LIVRE.org}

274 Imagem retirada em: SÃO PAULO LIVRE. Facebook. 24/11/2018. Disponível em: < https://www.facebook.com/movimentoSPL/photos/a.1732684196957716.1073741827.1732658630293606 /2470755929817202/?type=3\&theater> Acesso em: 29/04/2018.

275 Imagem retirada em: SÃO PAULO LIVRE. Facebook. 02/03/2017. Disponível em: < https://www.facebook.com/movimentoSPL/photos/a.1732684196957716.1073741827.1732658630293606 /2276386505920813/?type=3\&theater> Acesso em: 29/04/2018. 


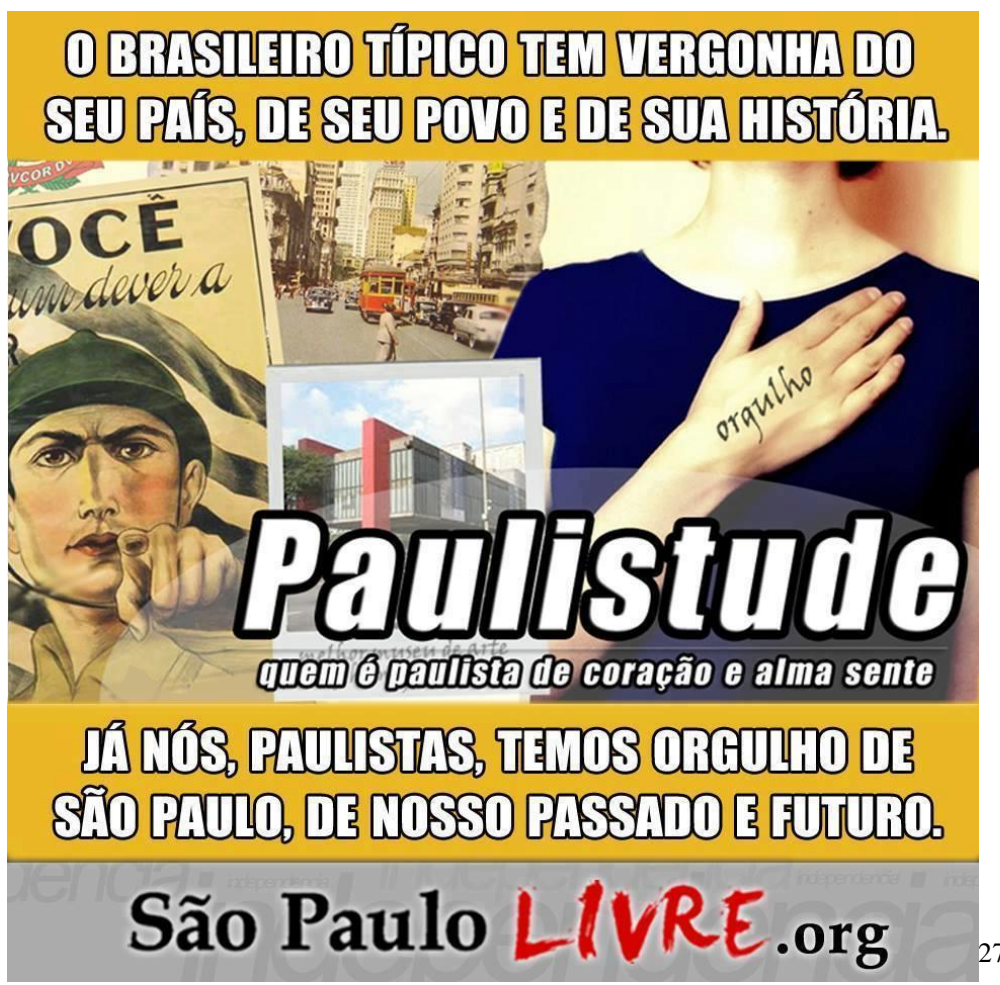

\begin{tabular}{|c|}
\hline Imagem 44 \\
\hline $\begin{array}{l}\text { Mobiliza atributos do } \\
\text { orgulho paulista (Guerra de } \\
1932 \text { e urbanização) para } \\
\text { contrapor a população do } \\
\text { estado a um brasileiro } \\
\text { estigmatizado. Nota-se, } \\
\text { uma vez mais, a } \\
\text { mobilização de pessoas } \\
\text { brancas nas imagens } \\
\text { apresentadas pelo grupo. }\end{array}$ \\
\hline
\end{tabular}

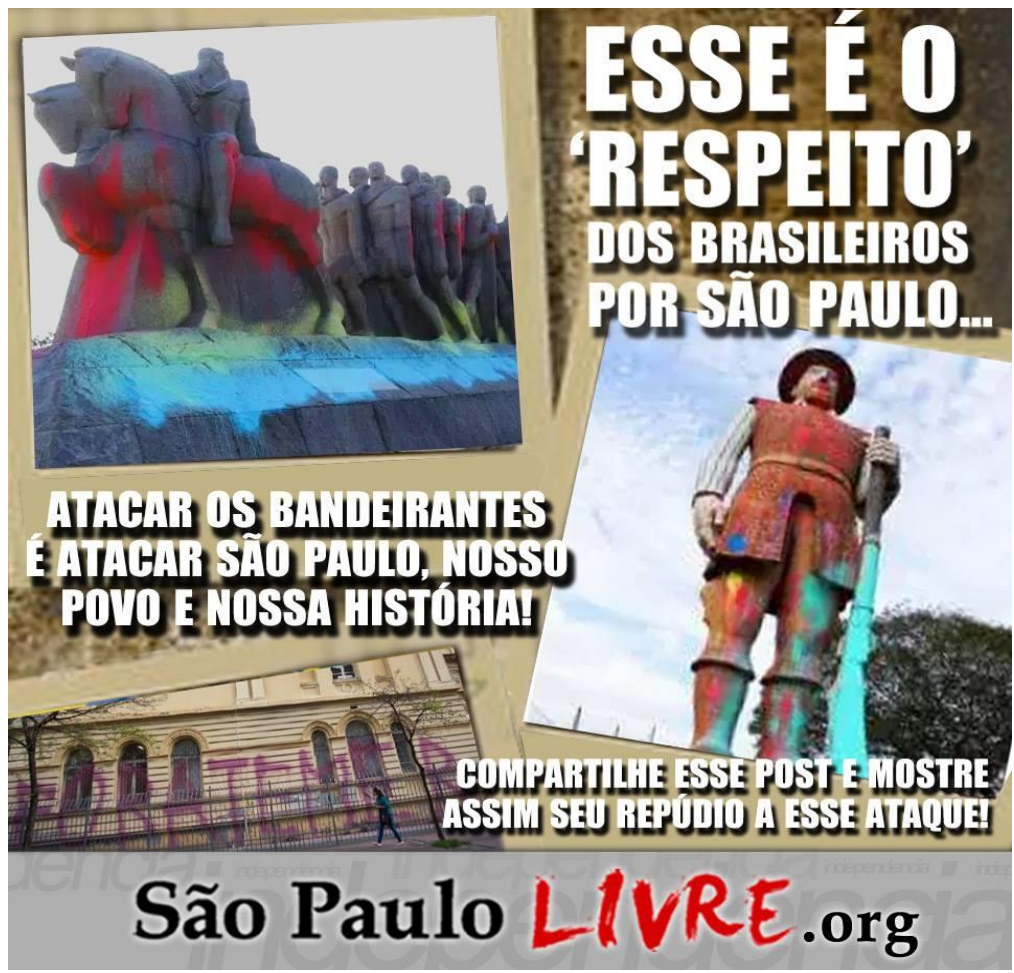

Imagem 45

Explicita $\quad 0 \quad$ caráter bandeirologista do SPL, bem como o apego ao período colonial com consequente sublimação do genocídio indígena e escravocrata que o compuseram. Brasileiro aparece como categoria moral avessa à simbologia paulista. Apesar da grande possibilidade dos que fizeram a intervenção serem do estado, são afirmados enquanto exógenos. $\mathrm{O}$ Brasileiro aparece, pois, como categoria rival.

276 Imagem retirada em: SÃO PAULO LIVRE. Facebook. 01/01/2017. Disponível em: < https://www.facebook.com/movimentoSPL/photos/a.1732684196957716.1073741827.1732658630293606 /2230380250521439/?type=3\&theater> Acesso em: 29/04/2018.

277 Imagem retirada em: SÃO PAULO LIVRE. Facebook. 30/09/2016. Disponível em: < https://www.facebook.com/movimentoSPL/photos/a.1732684196957716.1073741827.1732658630293606 /2155385704687561/?type=3\&theater> Acesso em: 29/04/2018. 


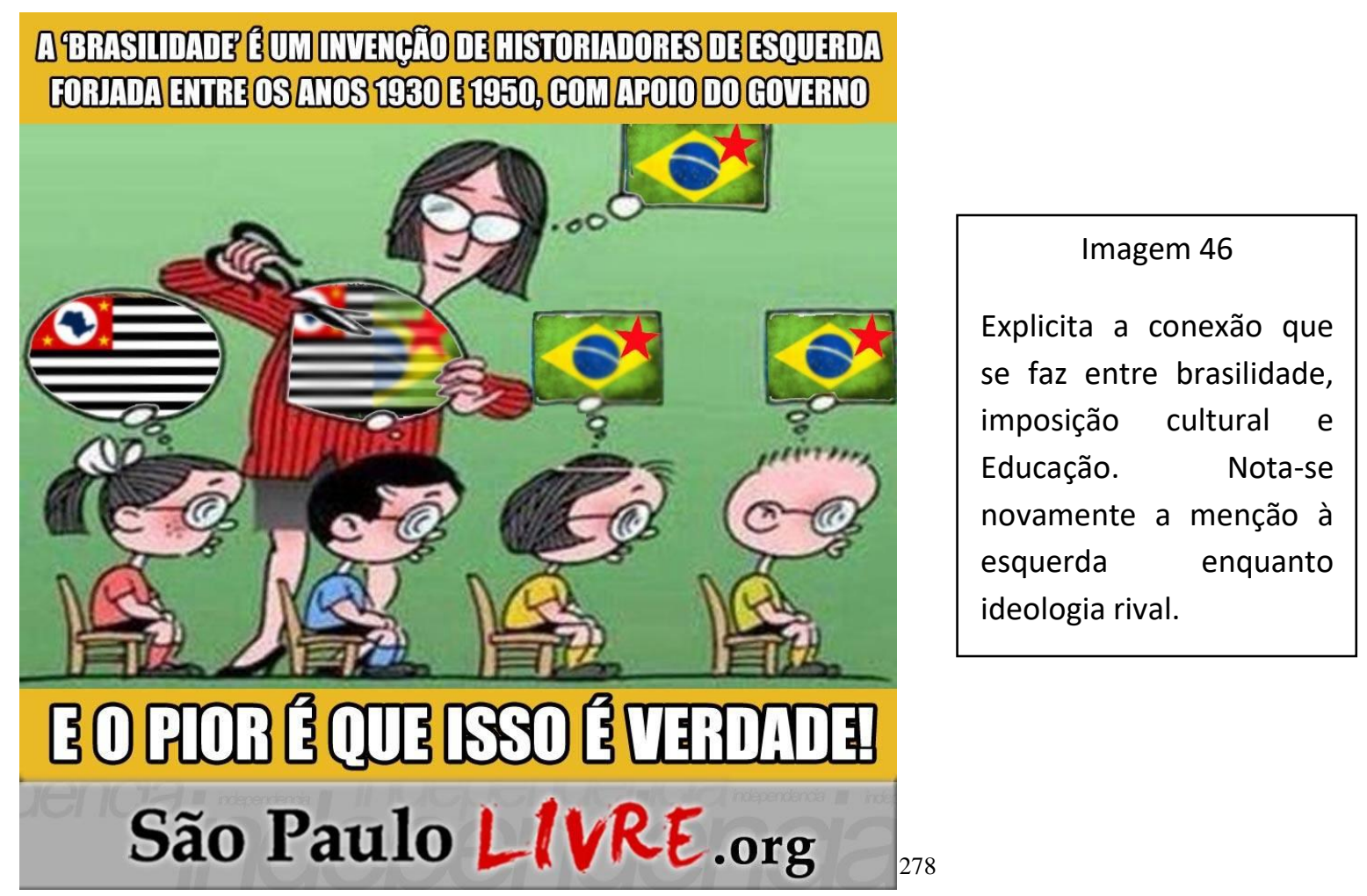

Este resumo da análise histórica feita pelo São Paulo Livre denota a um dado relevante: é interessante que o movimento apresente-se como dotado de uma ideologia contrahegemônica, apesar de reivindicar a hegemonia paulista. Vê-se, neste sentido, que de fato o ideal de separação tem participação popular diminuta. Apesar disto, percebe-se que o cerne da questão pautada pelo SPL - a da superioridade paulista - apresenta-se diversas vezes como hegemônica e não como vítima de uma brasilidade avessa ao estado. As próprias imagens publicadas pelo grupo seriam elucidativas neste sentido: afirmar uma situação com antibandeirantismo sublima o fato de que os bandeirantes seriam tão exaltados na história do estado que até mesmo possuiriam monumentos arquitetônicos e figurariam em nomes de ruas das cidades paulistas.

Posto isto, vê-se que ao mesmo tempo que mobiliza em prol de sua causa certos eventos históricos, o SPL busca afastar a conexão recorrente entre paulistanidade e hierarquização social. Um caso emblemático disto é o argumento do grupo que nega o racismo que historicamente acompanhou a formação do estado, isto sendo feito através da defesa de que o estado teria assumido, de forma coesa, a primazia na luta contra a

\footnotetext{
${ }^{278}$ Imagem retirada em: SÃO PAULO LIVRE. Facebook. 25/05/2016. Disponível em: < https://www.facebook.com/movimentoSPL/photos/a.1732684196957716.1073741827.1732658630293606 /2066609156898550/?type=3\&theater> Acesso em: 29/04/2018.
} 
escravidão. ${ }^{279}$ Esta narrativa aparece a partir da mobilização do mito da democracia racial: o valoroso e genérico povo paulista - que, não por acaso, aparece sem cor nesta argumentação - teria lutado contra a opressão escravocrata. Anula-se, portanto, o conflito racial que havia dentro da própria sociedade estadual. Como se esta não fosse dividida entre escravos e libertos; como se as classes dominantes de São Paulo não fossem beneficiadas pela escravidão. Vê-se, nesta formação regional reivindicada, a tentativa de coesão grupal: defende-se um paulista genérico que, sem cor ou liberdade relevantes, teria lutado contra a escravidão.

Neste mesmo empenho de apresentação de uma historicidade readequada, o SPL reivindica uma série de intelectuais paulistas que, como já visto nesta dissertação, se autoproclamaram à missão de construir a identidade regional e nacional: "os poetaseducadores" (VELLOSO, 1993). Deste modo, o movimento revela admiração a Mário de Andrade e Monteiro Lobato. Na construção deste novo país paulista, os dois autores estampariam as notas de 20 e 50 ouros, respectivamente.

Ouro $^{280}$ é a moeda imaginada do país que viria a ser São Paulo. A moeda de 1 ouro seria estampada pelo padre jesuíta José de Anchieta, a de 5 pelo bandeirante Domingos Jorge Velho, a de 10 pela professora e soldada em 1932, Stela Rosa Sguassábia, a de 20 por Mário de Andrade, a de 50 por Monteiro Lobato e a de 100 por uma foto da Marcha dos Dois Milhões, ocorrida em 1932. A escolha das pessoas e momentos históricos que ilustrariam o ouro evidenciam momentos caros à paulistanidade, como 1932, o modernismo e uma leitura romantizada do período das bandeiras. A imagem a seguir, retirada da página do grupo no facebook, indica como o SPL vai longe em sua proposta: até cotação e símbolo esta inexistente moeda possui.

\footnotetext{
279 “O separatismo paulista não é coisa de agora. Já em 1887 os paulistas defendiam o fim da escravidão e a independência de São Paulo. Isso não te ensinaram na escola? Não querem que você saiba a verdadeira história paulista" (SPL, 2017).

280 "O nome da moeda da República de São Paulo está ligada à história paulista. Durante o nosso período colonial, apesar da circulação tanto de moedas portuguesas quanto holandesas e espanholas, os paulistas, sempre desejosos de mais liberdade, usavam ouro em pó como forma de pagamento para ter mais liberdade em relação à coroa portuguesa. Portanto o nome a ser adotado pela futura moeda do país novo será o Ouro Paulista (ou simplesmente, 'Ouro'). O Ouro terá real poder de compra, e um câmbio estável, ou seja, não se desvalorizá tanto quanto o real frente a moedas mais fortes e estáveis, como o dólar americano e o euro" (SPL, 2014).
} 


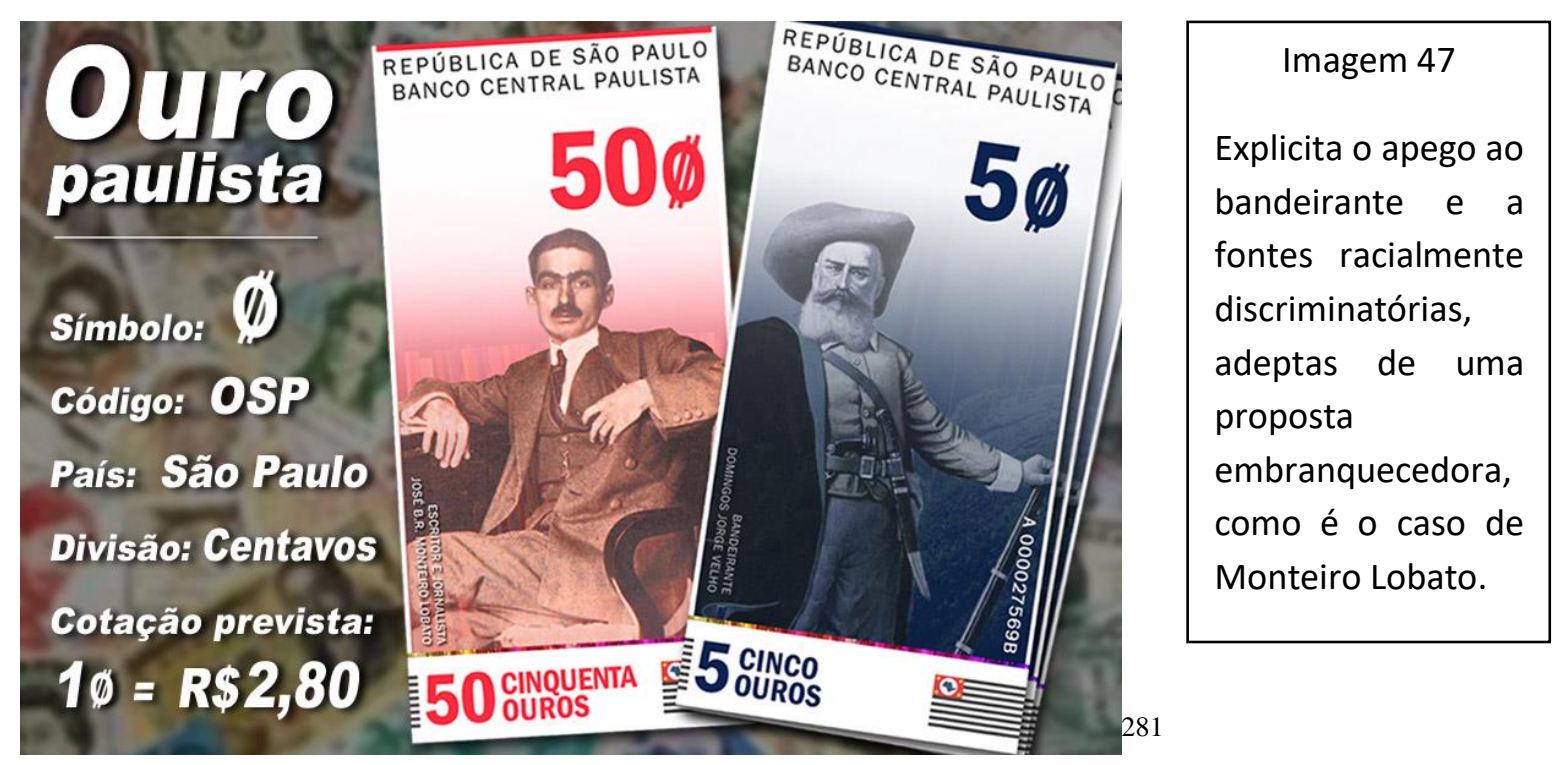

Em suas contradições, o SPL é capaz de reivindicar simultaneamente uma posição anti-racista e Monteiro Lobato, escritor que fez parte da Sociedade Eugênica Brasileira e afirmou: "os negros da África vingaram-se do português da maneira mais terrível amualatando-o e liquefazendo-o" (LOBATO, 1944:133). Vale lembrar que o autor hoje em dia é rechaçado pelos movimentos negros devido ao projeto eugênico de suas obras. Atento a estas questões, o SPL publicou no facebook uma prova de que seria representativo e contrário ao racismo. Esta residiria na escolha de quem estamparia a moeda de 25 centavos na possível República de São Paulo: Luís Gama. Sobre o advogado abolicionista, o website do movimento apresenta:

Num tempo em que não havia negros em faculdades e a escravidão era a regra, Luís Gama usou a força da lei para libertar escravos. Ele é um símbolo das possibilidades que São Paulo dá a todos os paulistas de coração. (SPL, 2014).

É interessante pensar nestas possibilidades teóricas que São Paulo dá, segundo a visão do SPL. Luís Gama, nascido em Salvador, foi a São Paulo após ser vendido enquanto pessoa escravizada, sendo que a crueldade do escravismo de Campinas - cidade para a qual foi levado - era notória. ${ }^{282}$ Deste modo, esteve longe de ser recebido de braços abertos

281 Imagem retirada em: SÃO PAULO LIVRE. Website. 2014. Disponível em: <http://www.saopaulolivre.org/imagensspl.html> Acesso em: 30/04/18.

${ }^{282}$ Vale salientar que tal crueldade era notória em todo território brasileiro. Apesar disto, a Comissão de Igualdade Racial da Ordem dos Advogados do Brasil (OAB) investiga o diferencial da cidade do interior 
por uma possibilidade paulista. São narrativas deste tipo que indicam o empenho do SPL em torno da construção regional romantizada e inventada. Sendo assim, esta história "montada em determinados enredos" (SCHWARCZ, 2008) que o SPL propõe é capaz de imprimir uma sofisticada forma da mítica democracia racial: como se Luís Gama e Monteiro Lobato - de séculos e posições sociais distintas - representassem um único lado, um lado paulista genérico e difuso.

Para além da reivindicação histórica suprema, a paulistanidade expressa pelo Movimento São Paulo Livre segue a acepção de que paulistas e brasileiros seriam distintos em níveis culturais. Com isto vê-se que apesar de o engajamento em apresentar uma linguagem pacífica, o movimento baseia-se na ideia da superioridade paulista. Afirma$\mathrm{se}^{283}$ que a sociedade brasileira seria imatura, baseada em um novo voto de cabresto "bolsa-isso, bolsa-aquilo" - e que tal população ainda não haveria chegado à modernidade. O paulista, ao contrário, aparece como sinônimo de progresso - "o que há de mais vibrante e atual na cultura mundial" - e não poderia viver atado a este desnível. É válido salientar que é patente nesta argumentação um ideal do evolucionismo social: como se populações distintas possuíssem níveis diferentes em uma única concepção de progresso.

Assumindo uma linguagem paternalista, o presidente do SPL chega a afirmar que o Brasil - apesar das dificuldades que teria com a separação de São Paulo - poderia ser um país amigo, "um ótimo mercado consumidor" (REBELLO, F. in O GLOBO, 2016). Esta linguagem, todavia, não é frequentemente assumida. Há engajamento em apresentar as supostas imoralidade e atraso brasileiros. Neste argumento encontra-se a ideia de que com a independência, São Paulo teria acesso pleno a seus recursos e não sofreria com violência, atraso e incivilidade. As imagens a seguir, retiradas da página do facebook do SPL, são elucidativas em relação a este ideal de superioridade paulista e a tentativa de rebaixar o brasileiro à imoralidade .

paulista, uma vez que não só esta teria sido a última a abolir a escravidão como "ser vendido a um Barão de Campinas era considerado castigo." Disponível em: O GLOBO. Ser vendido para Barão de Campinas era castigo para escravos, diz advogado. Disponível em: <http://g1.globo.com/sp/campinasregiao/noticia/2015/11/ser-vendido-barao-de-campinas-era-castigo-para-escravos-diz-advogado.html> Acesso em: 10/05/2018.

283 “Um das principais diferenças entre os paulistas e os brasileiros é o grande desnível cultural que existe entre estes dois povos. Enquanto em São Paulo já temos um povo maduro, pós-moderno, inserido no que há de mais atual e vibrante da cultura mundial, em grande parte do Brasil as populações locais ainda se esforçam para chegar na modernidade. Voto de cabresto, em seu novo formato - bolsa-isso, bolsa-aquilo bem como a falta de educação formal, pouca leitura e tradicionalismo tacanho fazem do povo brasileiro uma sociedade ainda imatura, ainda em vias de tornar-se consciente de si e de suas necessidades"(SPL). 

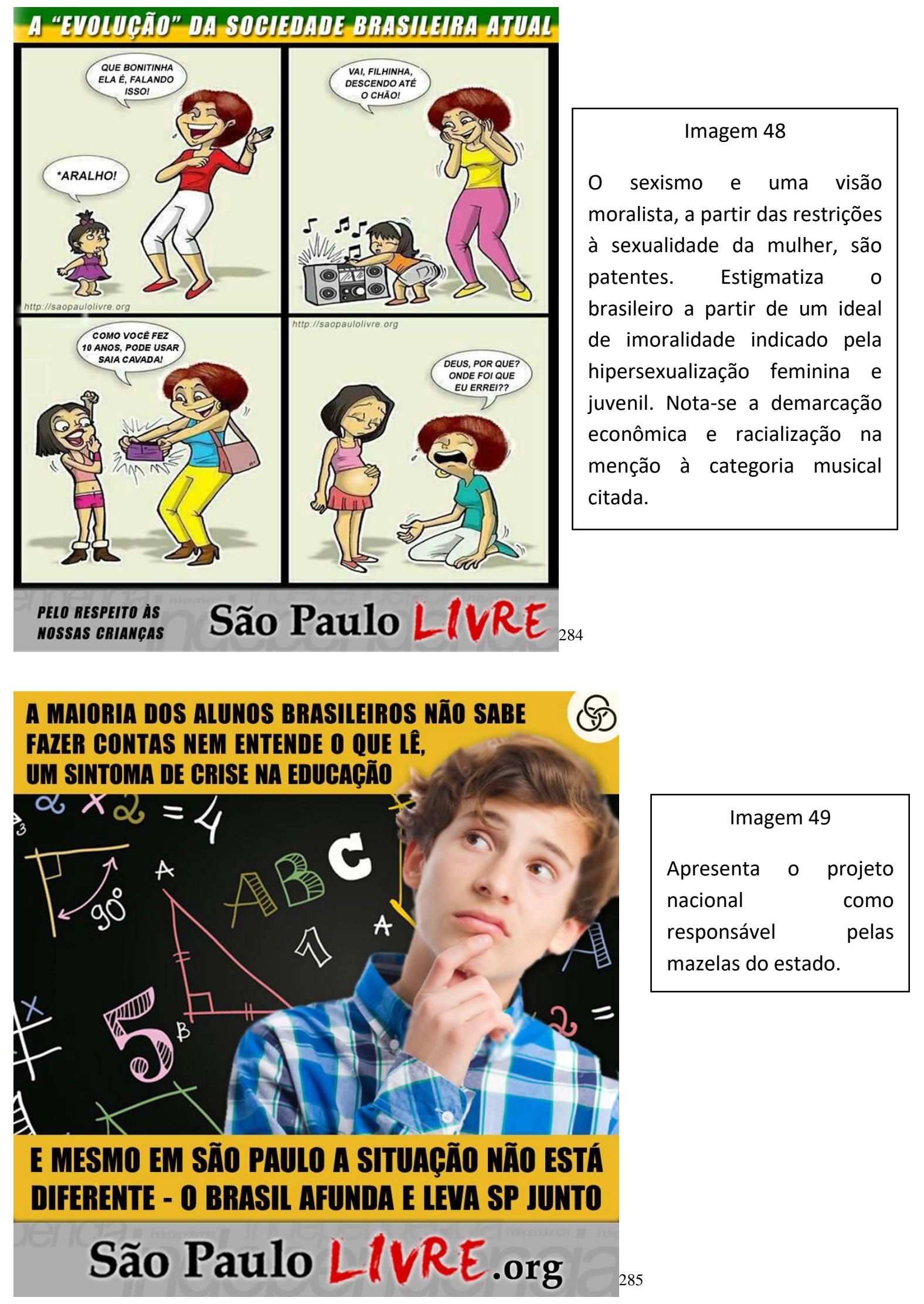

284 Imagem retirada em: SÃO PAULO LIVRE. Facebook. 20/09/2015. Disponível em: <https://www.facebook.com/movimentoSPL/photos/a.1732684196957716.1073741827.173265863029360 6/1896239480602186/?type=3\&theater> Acesso em: 29/04/2018. 


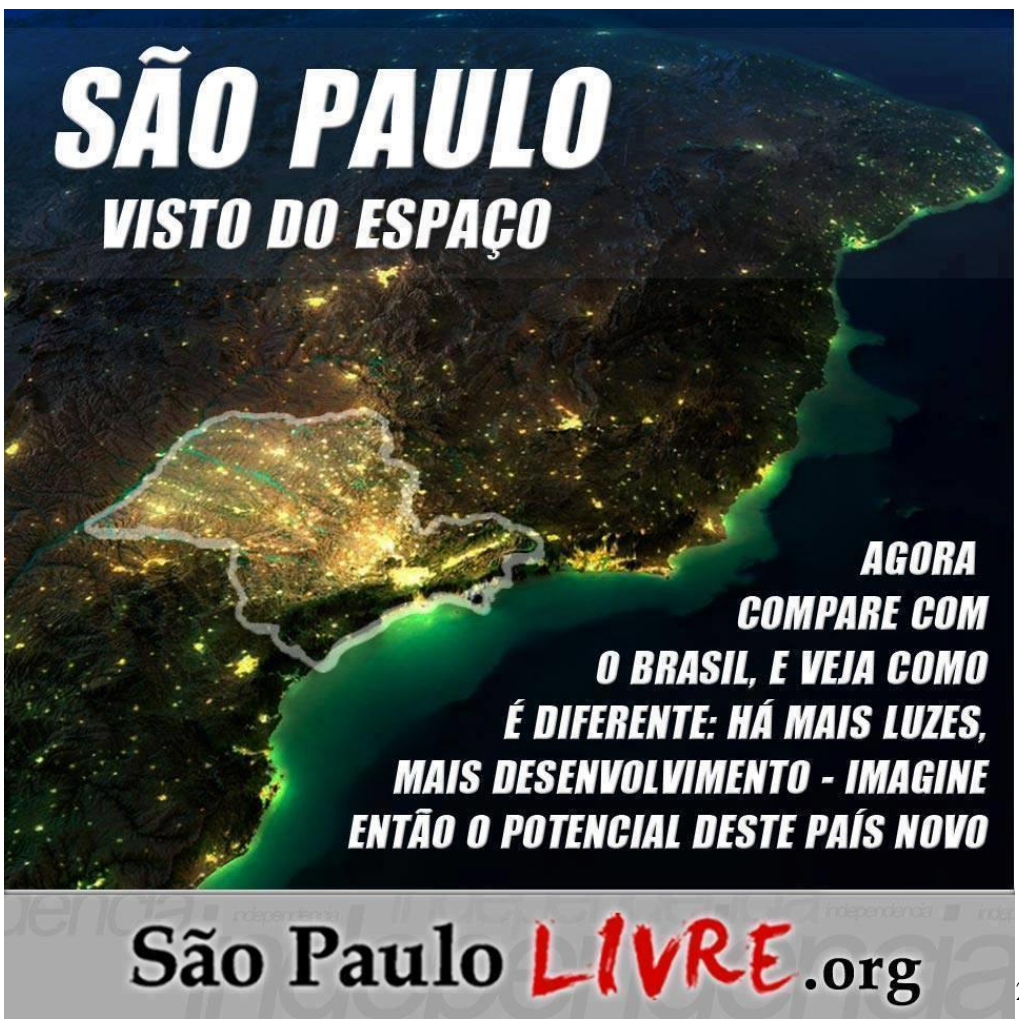

Imagem 50

Explicita o apego à assimétrica distribuição regional brasileira, bem como à meritocracia. São Paulo aparece como local mais desenvolvido sem que sejam relevados os fatores históricos de sua industrialização. Salienta-se um diferencial paulista baseado em noções restritas de progresso. Da mesma maneira, nota-se a ode à urbanidade e crença da ruralidade como aspecto a ser superado.

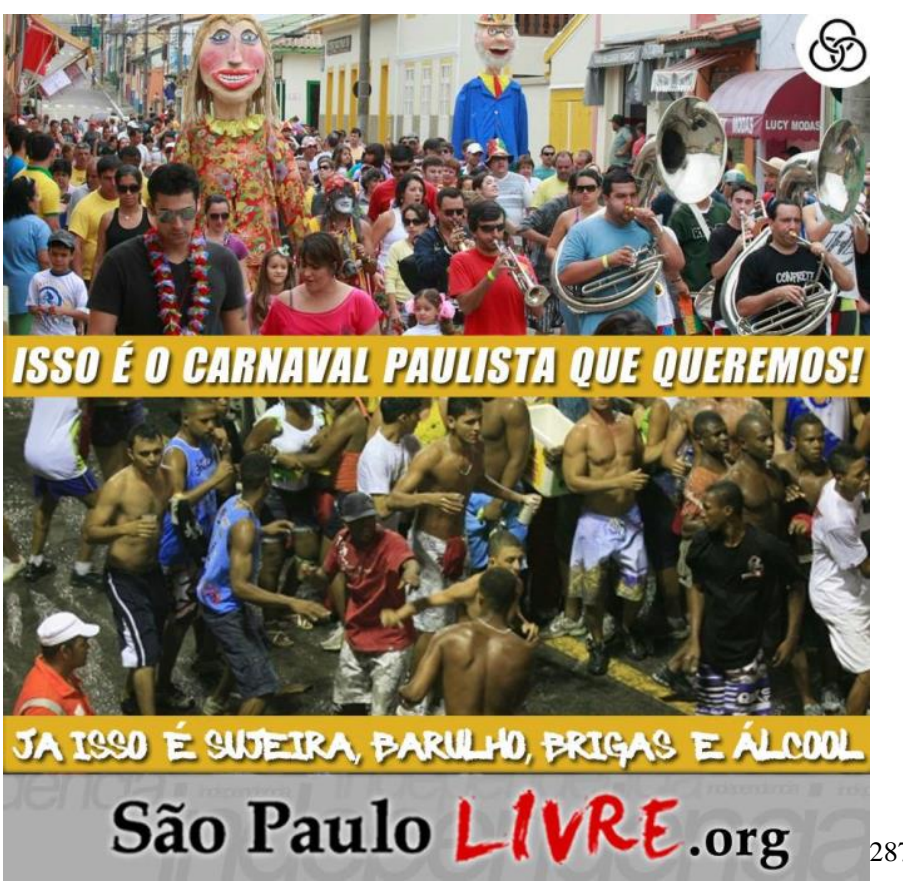

Imagem 51

$\mathrm{Na}$ segunda imagem aparecem pessoas majoritariamente negras, sendo conectadas ao estigma da "sujeira, barulho, brigas e álcool". $\mathrm{Na}$ imagem do carnaval paulista vê-se pessoas majoritariamente brancas, apresentadas enquanto moral e culturalmente superiores. É interessante pontuar que na segunda imagem não há qualquer indicação à sujeira, o que denota o higienismo social do SPL: como se o agrupamento humano fotografado representasse intrinsecamente este atributo.

285 Imagem retirada em: SÃO PAULO LIVRE. Facebook. 06/12/2016. Disponível em: < https://www.facebook.com/movimentoSPL/photos/a.1732684196957716.1073741827.1732658630293606 /2209549685937829/?type=3\&theater $>$ Acesso em: 29/04/2018.

286 Imagem retirada em: SÃO PAULO LIVRE. Facebook. 27/01/2017. Disponível em: < https://www.facebook.com/movimentoSPL/photos/a.1732684196957716.1073741827.1732658630293606 /2250781905147940/?type=3\&theater $>$ Acesso em: 29/04/2018. 


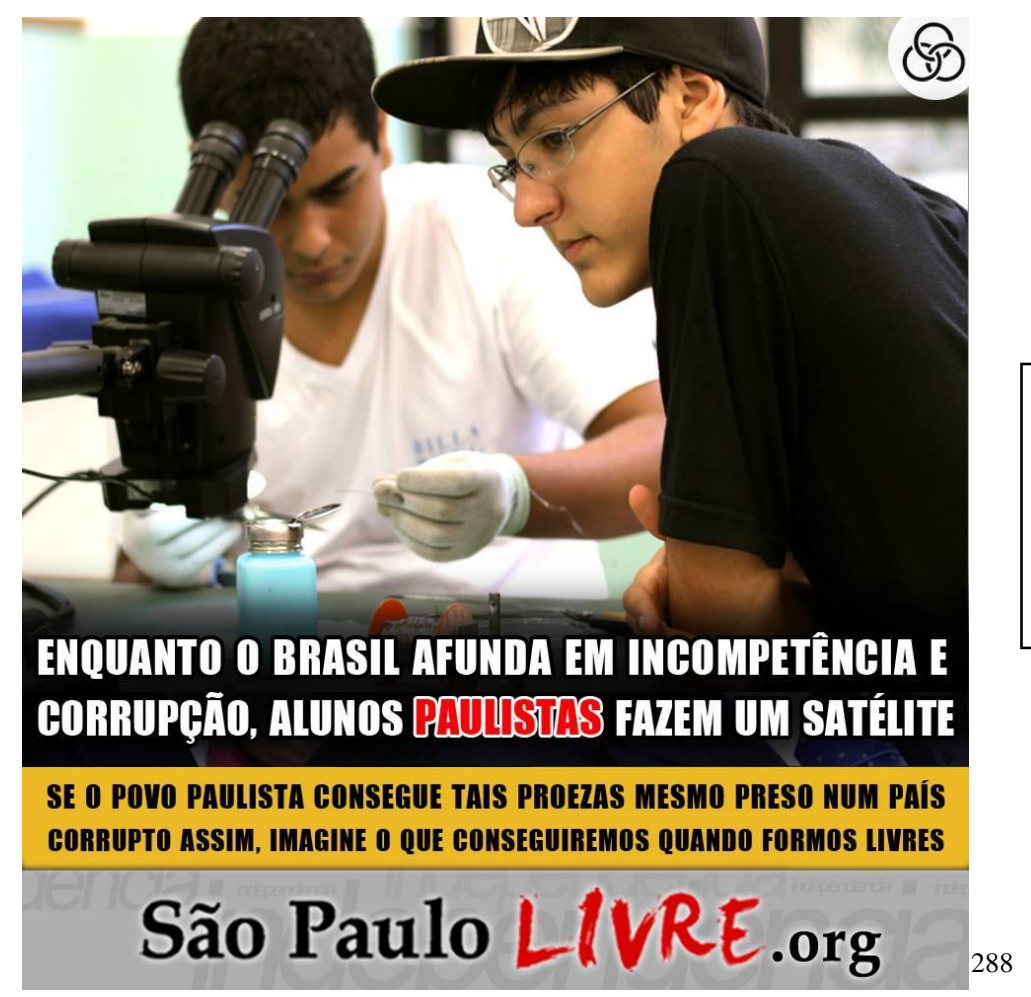

Imagem 52

Salienta um diferencial paulista e estigmatiza a população nacional.

Percebe-se nestas imagens uma argumentação típica: se há algum problema estrutural em São Paulo, como o da educação, este seria causado não pelo sistema socioeconômico, mas sim por um conceito difuso de nacionalidade inferior. Simultaneamente a isto, se São Paulo possui energia elétrica, se algum paulista teve mérito científico, os louros vão para o estado e sua população. Para além de não relevar a desigualdade estrutural brasileira, tão exemplificada pela imagem por satélite utilizada, há uma visão cultural higienista e também o ideal que aponta a urbanização, em contraposição à ruralidade, como melhor. Com carga considerável de racialização e sexismo em parte das imagens expostas, esta cultura brasileira apresentada pelo SPL é colocada enquanto anômica e com menor valor humano. Vê-se com clareza que a contraposição social que se pauta é baseada em uma série de marcadores sociais da diferença historicamente hierarquizantes.

É interessante pensar que o Movimento São Paulo Livre considera, em consonância com a paulistanidade de diversos períodos, sofrer uma imposição cultural. Tem-se uma

287 Imagem retirada em: SÃO PAULO LIVRE. Facebook. 26/02/2017. Disponível em: < https://www.facebook.com/movimentoSPL/photos/a.1732684196957716.1073741827.1732658630293606 /2272411919651605/?type=3\&theater $>$ Acesso em: 29/04/2018.

288 Imagem retirada em: SÃO PAULO LIVRE. Facebook. 10/12/2016. Disponível em: < https://www.facebook.com/movimentoSPL/photos/a.1732684196957716.1073741827.1732658630293606 /2213591255533672/?type=3\&theater > Acesso em: 29/04/2018. 
leitura especial acerca de festas juninas e carnavais e como estas deveriam ser, o que deveriam aparentar. Em relação à festa junina, o grupo fez comunicados lamentando que a música caipira não fosse mais lembrada, sendo substituída muitas vezes por funk e forró. Há, nesta ideia de imposição cultural, vontade de diferenciar os paulistas - que também não se constituem como um grupo homogêneo - de forma coesa frente ao Outro Regional estigmatizado. Vale lembrar, da mesma forma, o debate que há sobre o preconceito em relação ao funk e ao forró no que concerne a suas demarcações raciais e econômicas.

Posto isto, torna-se essencial destrinchar o fato de que o incômodo com uma identidade nacional é factível nos mais diversos grupos humanos. Como exposto nesta dissertação, a construção da identidade brasileira contou com uma série de esforços homogeneizantes que escamotearam diferenças e hierarquias sociais. Curioso no caso de um movimento independentista como o SPL é justamente a busca de escapar de uma identidade arbitrária para formar outra também homogeneamente restrita. Uniformizando a história do estado paulista, bem como a narrativa e os povos que a engendraram, busca-se criar uma categoria nacional una. Apesar de engajado em aparentar ser sensível à diversidade humana, o movimento recorre àquilo que historicamente a paulistanidade significou: a uniformização ideal interna seguida da hierarquização frente a um entendimento restrito de externo. Interessa, neste sentido, observar as descontinuidades desta proposta separatista: há, seguramente, diferenças entre um movimento como o SPL que afirma o ser paulista como uma questão de valor e movimentos que tratam a identidade explicitamente como uma questão de raça, de origem.

\section{3 - Argumentos Econômicos e Políticos do Movimento São Paulo Livre}

Apoiamos a ideia de viver num país menor, com muito menos burocracia e mais incentivos à livre iniciativa e ao progresso individual pelo próprio mérito. (SPL, 2014).

Para justificar a causa independentista, o SPL possui dois argumentos principais. O primeiro seria a acepção econômica da paulistanidade, reivindicando que São Paulo sustentaria o Brasil, daria mais do que receberia. Neste sentido, o movimento defende que com a separação o paulista teria acesso a melhorias na educação, segurança, saúde e qualidade de vida. O segundo argumento mais mobilizado pelo SPL seria em torno da inaptidão política atribuída à população brasileira. Afirma-se que São Paulo não teria 
representatividade eleitoral e não coadunaria com a corrupção estrutural presente no cenário político brasileiro. Vale salientar que tal corrupção é entendida a partir de uma lógica moral e não estrutural.

Para justificar o porquê de São Paulo possuir um P.I.B. grandioso, o movimento mobiliza outro argumento recorrente à paulistanidade: o do apego ao trabalho. Em uma visão meritocrática, São Paulo seria o provedor nacional, sustentaria outros estados e isto não se deveria “apenas ao dinamismo econômico do Estado de São Paulo, mas também ao respeito que nós, paulistas, temos pelo trabalho, pela valorizacão do esforço pessoal e ao apreço que nós, paulistas, temos pela livre iniciativa" (SPL, 2014). A partir deste posicionamento, o movimento não somente determina o paulista enquanto ser de inata aptidão ao trabalho, como também relega o insucesso de outras populações à questão da vontade, não levando em consideração uma série de assimetrias sociais e a premissa liberal em torno da dicotomia entre ricos e pobres.

Desta forma, os naturais de São Paulo aparecem enquanto superprodutivos frente a um cidadão nacional inativo. Afirma-se que 160 milhões de brasileiros realizam o trabalho que é feito por apenas 44 milhões de paulistas; que São Paulo daria mais de $92 \%$ de seu lucro ao Governo Federal e não receberia praticamente nada em troca. Diz-se, do mesmo modo, que os paulistas dariam este dinheiro de seus impostos com satisfação se estes fossem bem investidos, mas isto não ocorreria devido a uma corrupção brasileira naturalizada. A imagem exposta na próxima página é elucidativa na demarcação regional do Brasil considerado explorador.

Vê-se que o movimento mobiliza a, tão sociologicamente investigada, vergonha de ser brasileiro. O Brasil, determinado enquanto de terceiro mundo, comparado a um estado paulista primeiromundista, estaria fadado pelo jeitinho brasileiro e pela moral corrupta de sua população. Se apreende deste discurso que para além de o paulista ser delineado economicamente, se acredita que este seja uma categoria moral avessa a qualquer estigma que atinge a brasilidade. Nesta lógica, a população não-paulista não é afetada pelos problemas estruturais do sistema econômico e político brasileiro, mas é parte ativa do mesmo, culpada por sua ineficácia. 


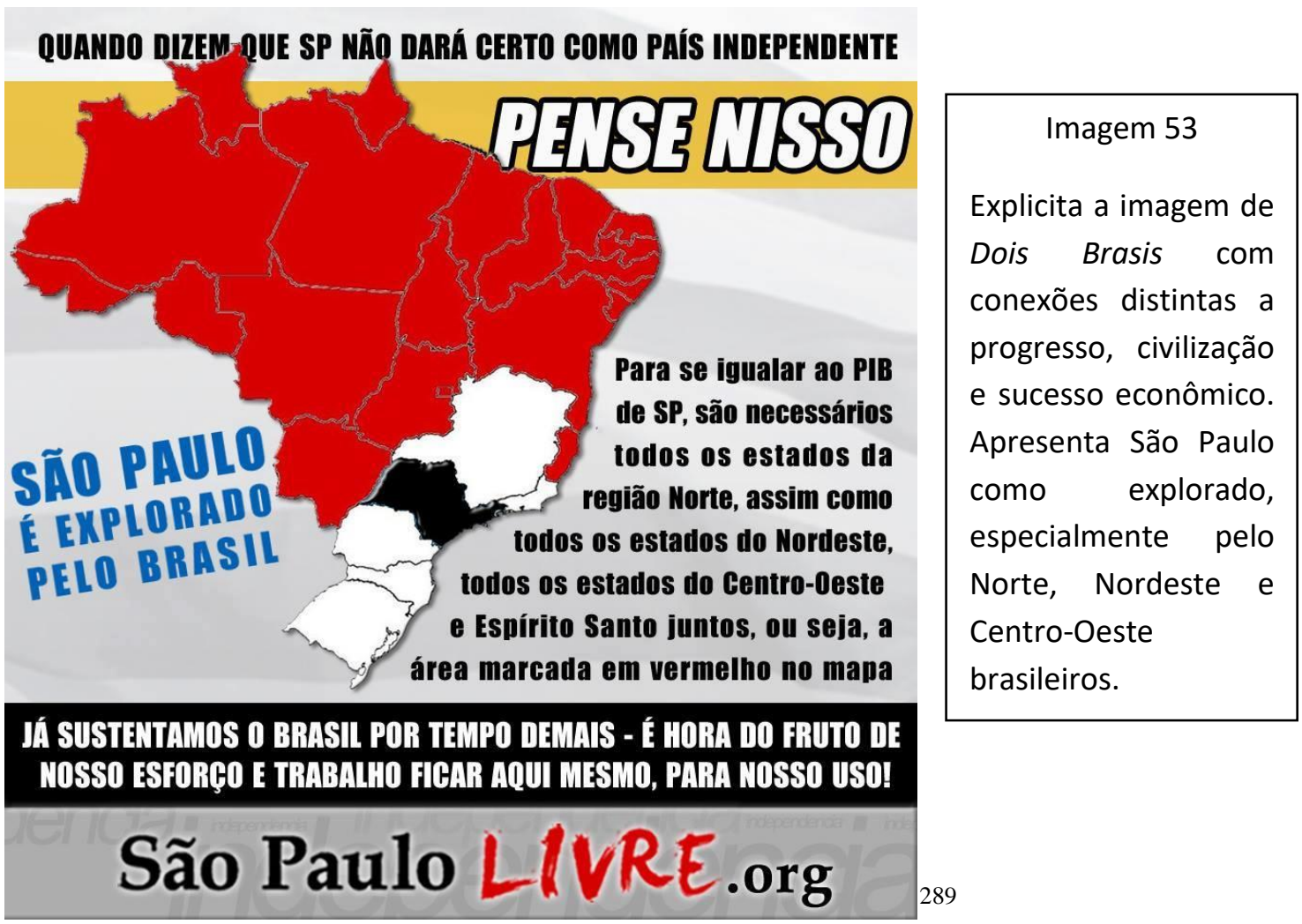

Desta acepção parte-se para outra máxima da paulistanidade: a reclamação em torno da falta de representatividade eleitoral paulista. Neste sentido é interessante pensar que o SPL tenha sido fundando em outubro de 2014, mês marcado pela revolta em relação à vitória da ex-presidenta Dilma Rousseff. Acredito, neste sentido, que - como exposto no quarto capítulo desta dissertação - trata-se de um regionalismo que em diversos períodos mobiliza-se para assumir a primazia em torno de uma política conservadora. Em diversas de suas publicações, o movimento culpabiliza outras regiões brasileiras pela eleição com vitória petista. O SPL, todavia, vai além desta narrativa ao afirmar que a Deposição de Dilma só teria ocorrido devido ao pioneirismo paulista; que São Paulo é o centro do avanço e da direita brasileira. As imagens a seguir, retiradas da página do facebook do Movimento São Paulo Livre, são capazes de expor isto.

289 Imagem retirada em: SÃO PAULO LIVRE. Facebook. 02/10/2017. Disponível em: < https://www.facebook.com/movimentoSPL/photos/a.1732684196957716.1073741827.1732658630293606 /2436589833233812/?type=3\&theater> Acesso em: 29/04/2018. 


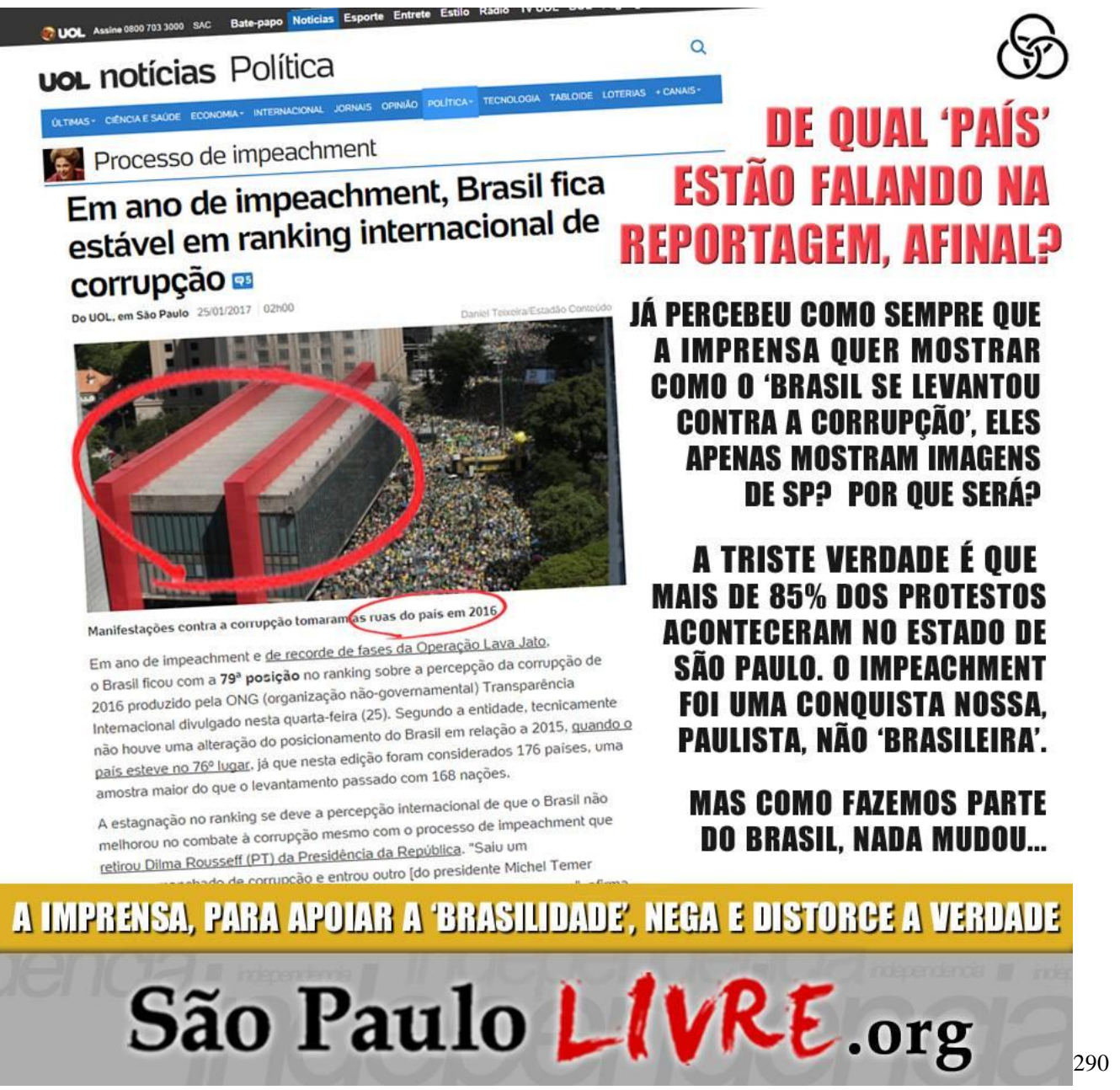

\section{Imagem 54}

Explicita a reivindicação de um diferencial moral paulista enquanto população avessa à corrupção.

290 Imagem retirada em: SÃO PAULO LIVRE. Facebook. 25/01/2017. Disponível em: < https://www.facebook.com/movimentoSPL/photos/a.1732684196957716.1073741827.1732658630293606 /2249132005312930/?type=3\&theater> Acesso em: 29/04/2018. 


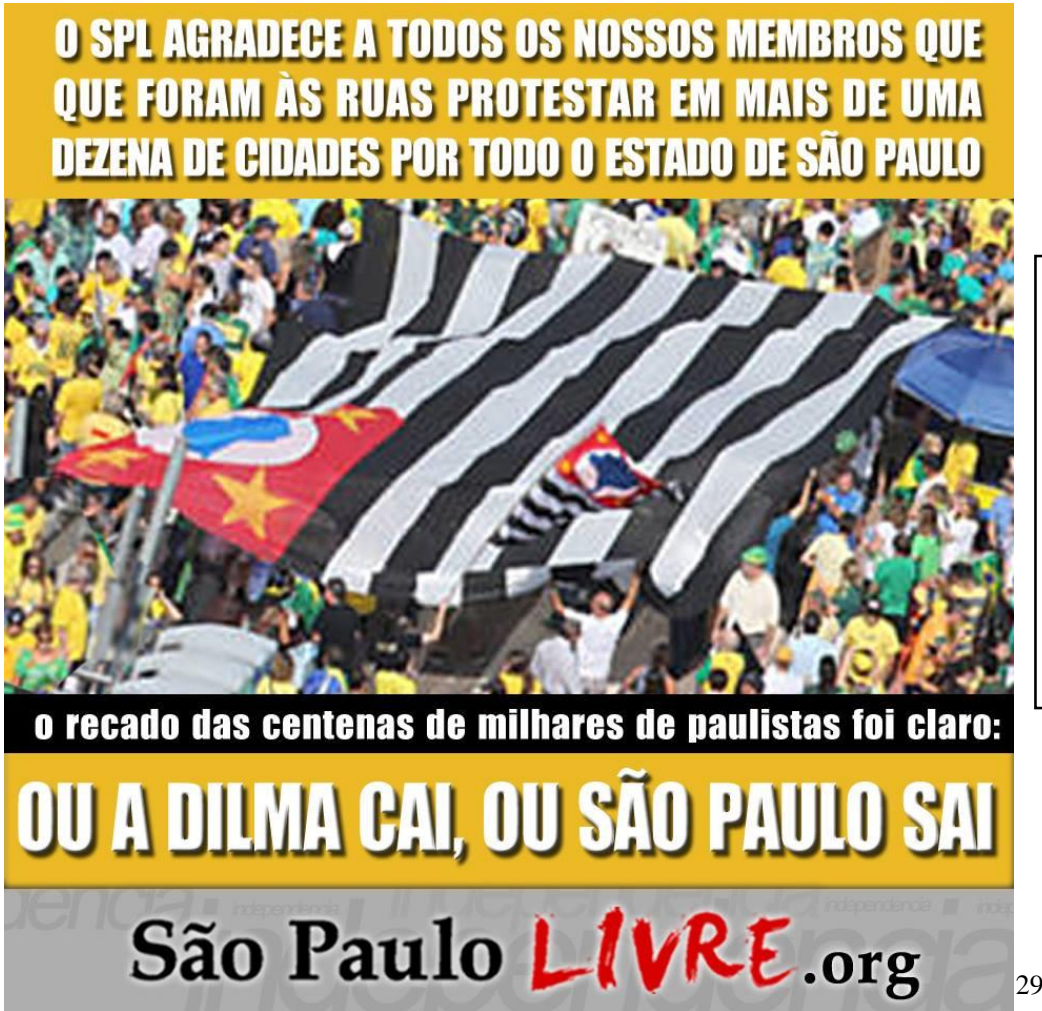

"SÓ JESUS GRISTO GANHA DE MIM NO BRASII" - DISSE
LULA, AO GOMENTAR AS DENÚNGIAS DE GORBUPĞ̃OO

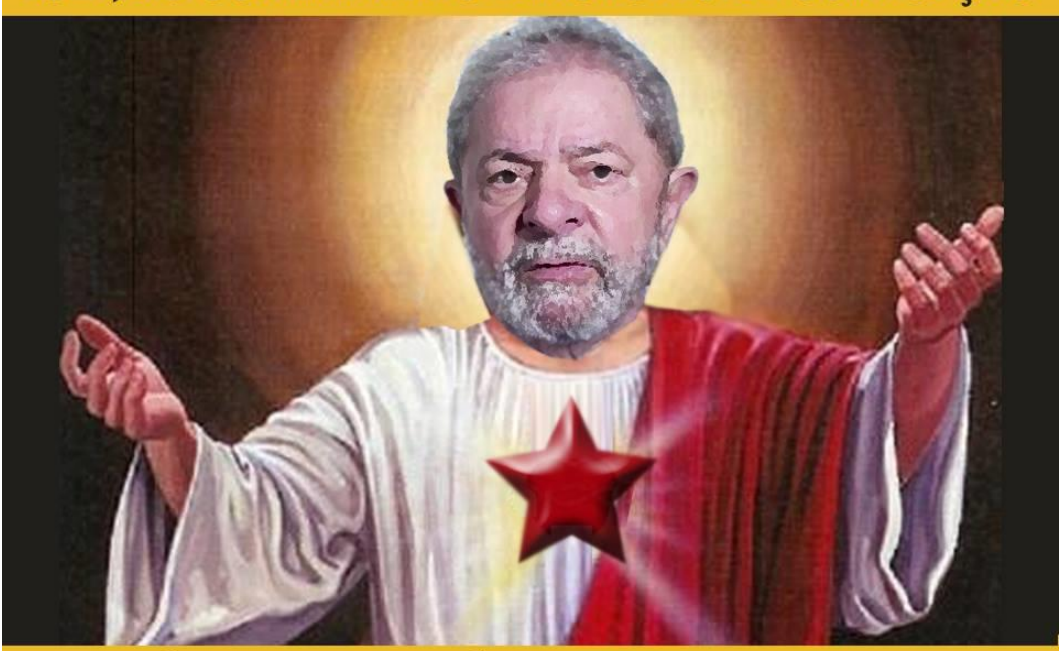

E O PIOR E QUE EM MUITAS REEIOTES DO BRASIL, EIF GONTA GOM MAIS DE 50\% DE APOIO ENTRE OS EIEITORES, MESMO GOM TODAS AS DENÚNCIAS DE GORRIUPEĨO. POR ISSO DITEMOS QUE NÓS, PAUUISTAS, SOMOS OUTRO POVO

\section{São Paulo LIVRE.org}

\section{Imagem 55}

Reivindica primazia no Processo de Golpe em 2016 e pauta uma relação de dependência brasileira com o estado paulista.

\begin{tabular}{|c|}
\hline Imagem 56 \\
\hline $\begin{array}{l}\text { Imputa a outras } \\
\text { populações o estigma } \\
\text { da inaptidão política, ao } \\
\text { mesmo tempo que } \\
\text { pauta um diferencial } \\
\text { moral paulista. Nota-se } \\
\text { que se opta pela } \\
\text { referência indireta às } \\
\text { populações nordestinas } \\
\text { e nortistas (que são } \\
\text { conhecidas, } \\
\text { majoritariamente, por } \\
\text { optarem pelo } \\
\text { candidato). }\end{array}$ \\
\hline
\end{tabular}
292

291 Imagem retirada em: SÃO PAULO LIVRE. Facebook. 13/03/2016. Disponível em: <https://www.facebook.com/movimentoSPL/photos/a.1732684196957716.1073741827.173265863029360 6/2015681085324691/?type=3\&theater> Acesso em: 29/04/2018. 


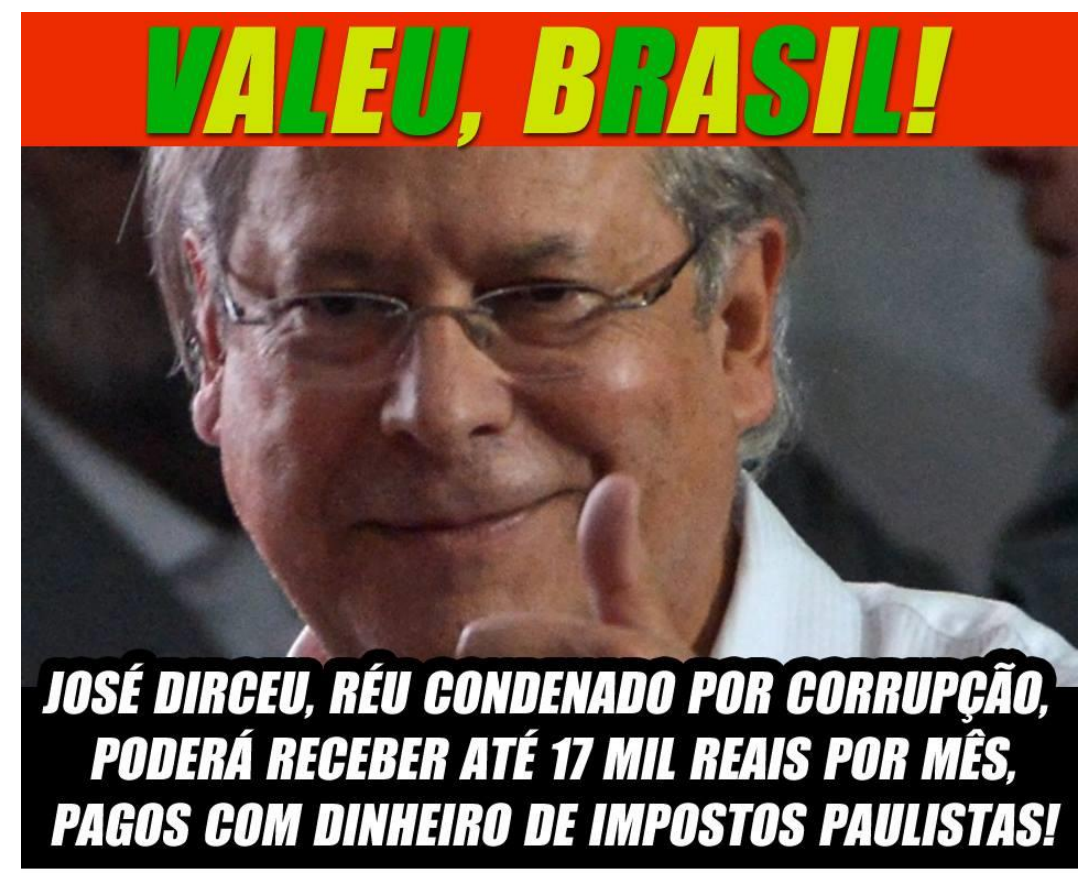

\begin{tabular}{|c|}
\hline Imagem 57 \\
\hline $\begin{array}{l}\text { Estabelece São Paulo } \\
\text { como } \\
\text { econômico e culpabiliza } \\
\text { o Brasil pela corrupção } \\
\text { estrutural. }\end{array}$ \\
\hline
\end{tabular}

\section{E aÍ, VALE MESMO a PENA GONTINUAR a SER PARTE DE UM PAÍS ASSIMP}

\section{São Paulo LIVRE.org}

Como já dito nesta dissertação, uma paulistanidade inflamada reivindicou a primazia no Golpe Militar de 1964. É interessante notar que o SPL tenha empreendido narrativa similar em 2016. Apesar de os processos (1964 e 2016) serem distintos em diversos sentidos, viu-se em ambos o empenho de parcela considerável da classe média que se mobilizou em busca da ordem e segurança mantenedora da hegemonia dominante (CHAUÍ, 2016:19).

É com isto em mente que se pode pensar nos últimos dois pleitos presidenciais brasileiros e como estes teriam ferido a proposta hegemônica paulista. Acerca da revolta frente à vitória petista em 2014, o presidente do SPL, Flávio Rebello, afirma que esta teria destrancado a porta de um sentimento paulistanista que sempre havia existido, mas que estava menos organizado até que o candidato da maioria paulista, Aécio Neves, não fosse eleito (O GLOBO, 2016). É interessante como a tese de Moutinho (1991), de que a

292 Imagem retirada em: SÃO PAULO LIVRE. Facebook. 15/09/2016. Disponível em: < https://www.facebook.com/movimentoSPL/photos/a.1732684196957716.1073741827.1732658630293606 /2144481759111289/?type=3\&theater $>$ Acesso em: 29/04/2018.

293 Imagem retirada em: SÃO PAULO LIVRE. Facebook. 14/11/2017. Disponível em: <https://www.facebook.com/movimentoSPL/photos/a.1732684196957716.1073741827.173265863029360 6/2464361093790019/?type=3\&theater> Acesso em: 29/04/2018. 
paulistanidade recrudesce em momentos de disputa pelo poder central, é reconhecida também por aqueles que a engendram.

As imagens que expus nas páginas anteriores demonstram que na narrativa do SPL, São Paulo estaria no centro do destino político do país. Da mesma forma, é possível identificar com nitidez o rechaço ao PT que recrudesceu o conservadorismo brasileiro dos últimos tempos. Apesar de os mandatos políticos petistas terem ido contra pautas históricas da esquerda e, além disto, terem tido como característica essencial a conciliação de classes, o partido é colocado pelos seus contrários como ameaça. Creio, atenta a esta questão, que o ódio ao PT em muito se relaciona ao estereótipo e também à maioria material de seu eleitorado: nordestino, pobre, não-branco. Cabe a pergunta se não seria um incômodo maior que seu exercício político, a representação de sua imagem e a população a qual esta está ligada. ${ }^{294}$

Deste modo, é possível localizar o SPL como um, dentre tantos movimentos conservadores brasileiros, que ascenderam em momento de disputa e crise política. Interessante neste sentido seria a forma com que o grupo mobilizaria a revolta e descrença popular nas atuais instituições. Diz-se: "nem PT, nem PSDB, o separatismo é a terceira via" (SPL, 2016). Afirma-se que no Brasil nada dê para aproveitar e que por tal motivo seria necessário um país novo. Aparece, portanto, um separatismo que se fortalece diante do reembaralhamento da hegemonia e hierarquia nacional.

Relevante também em relação a este fato seria o diálogo estabelecido pelo SPL com aqueles que se mostram contrários ao ideal do grupo. Ao ser denominado enquanto fascista, racista e retrógrado, o SPL responde com a afirmação de que estas seriam provas de que os paulistas sofreriam opressão pelo resto do Brasil. A imagem a seguir expõe como o grupo se coloca nestas discussões.

\footnotetext{
${ }^{294}$ O trecho a seguir demonstra como parcela de quem é contrário ao Golpe de 2016 está interpretando esta questão: O sentimento de ódio contra o PT fomentado (...) sobretudo pelos meios de comunicação, é um sentimento de ódio contra tudo que o PT representa simbolicamente (...) o antipetismo, como fenômeno sociológico, é síntese de antiesquerda, antigay, antifeminista, antinegro, antimovimento social. (GUIMARÃES, BOULOS, 2016:141).
} 
GHAMAR A GENTE DE NAZISTAS NÃO VAI MUDAR O FATO DE QUE VAMOS GONSEGUIR A LIBERDADE!

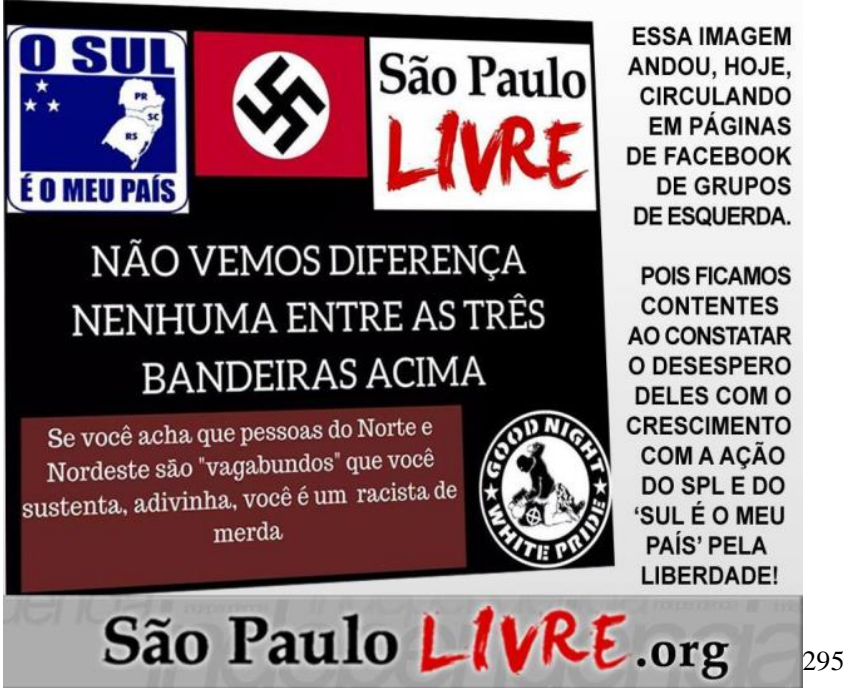

Imagem 58
Explicita como as propostas do
movimento, baseadas no ideal de
superioridade, são recebidas por
parcela da população.

Faz-se necessário destrinchar os motivos dos contrários ao SPL afirmarem o grupo como excludente, apesar de o mesmo buscar aparentar tolerância. Creio que as afirmações políticas do movimento sejam deslocadas ao plano das figuras que o SPL apresenta como admiráveis. Em outras palavras: a filiação política do grupo não seria tão visível em seu discurso próprio, mas sim em sua mobilização de figuras notadamente excludentes em seu discurso social.

Assim, o empenho em angariar apoio do empresariado e a defesa do livre mercado tornam nítido a proposta econômica de cunho liberal do movimento. Com isto em mente, é interessante analisar a reivindicação que o SPL possui em relação ao presidente estadunidense Donald Trump. O político norte-americano é mobilizado para dar força ao movimento paulista: "Lembra quando disseram que o Trump jamais seria presidente dos EUA? Pois está chegando a hora. São Paulo vai se separar do Brasil” (SPL, 2016). Curioso neste sentido, é o fato de que uma figura racista, sexista e anti-imigrante - e reconhecida como tal em grande parte do cenário mundial - é reivindicada por um movimento que busca aparentar tolerância e apreço à diversidade.

295 Imagem retirada em: SÃO PAULO LIVRE. Facebook. 26/02/2017. Disponível em: < https://www.facebook.com/movimentoSPL/photos/a.1732684196957716.1073741827.1732658630293606 /2273543406205123/?type=3\&theater $>$ Acesso em: 29/04/2018. 


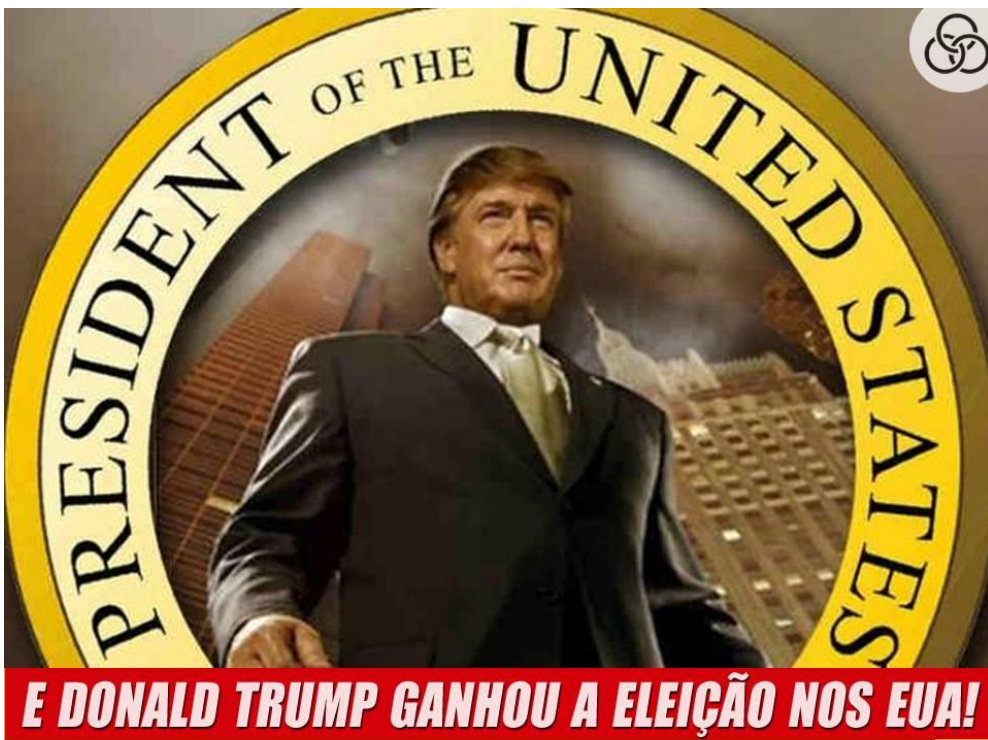

Imagem 59

Explicita a filiação com Donald Trump, político com mandato marcado pela restrição de direitos a migrantes.

FALARAM QUE O BREXIT NÃO ACONTECERIA. E ENTÃO ACONTECEU! FALARAM QUE TRUMP NUNCA SERIA ELEITO. E ENTÃO ACONTECEU! FALAM QUE SÃO PAULO JAMAIS SERÁ UM PAÍS INDEPENDENTE. E ...

\section{São Paulo LIVRE.org} 296

Deste modo, a análise de um movimento como o São Paulo Livre é interessante não somente devido ao alcance que este consiga a partir de sua tolerância restrita, mas, em especial, devido a possibilidade de ver factualmente a inadequação da paulistanidade ao estereótipo nacional. Da mesma maneira, é válido destrinchar como se organiza um grupo que surge e ascende em momento de reelaboração política do país. É neste sentido que é possível entender a fundação da Aliança Nacional, futuro partido político que surge a partir da união de movimentos separatistas. A imagem exposta na próxima página, anunciada na página de facebook do SPL, foi um dos anúncios do partido.

É marcante notar que o SPL, que surgiu em momento de desconfiança popular em torno dos partidos políticos e sempre se declarou apartidário, tenha unido forças com outros quatro movimentos independentistas brasileiros para formar um partido. Nota-se que a reconfiguração política pós-2016 permite uma análise densa sobre os regionalismos do Brasil. Creio que de tudo isto seja possível apreender que diante da descrença generalizada na política tradicional, o SPL, como tantos outros grupos, ascende na tentativa de trazer suas pautas historicamente latentes a um cenário político de maior visibilidade.

296 Imagem retirada em: SÃO PAULO LIVRE. Facebook. 09/11/2018. Disponível em: < https://www.facebook.com/movimentoSPL/photos/a.1732684196957716.1073741827.1732658630293606 /2187431454816319/?type=3\&theater> Acesso em: 29/04/2018. 


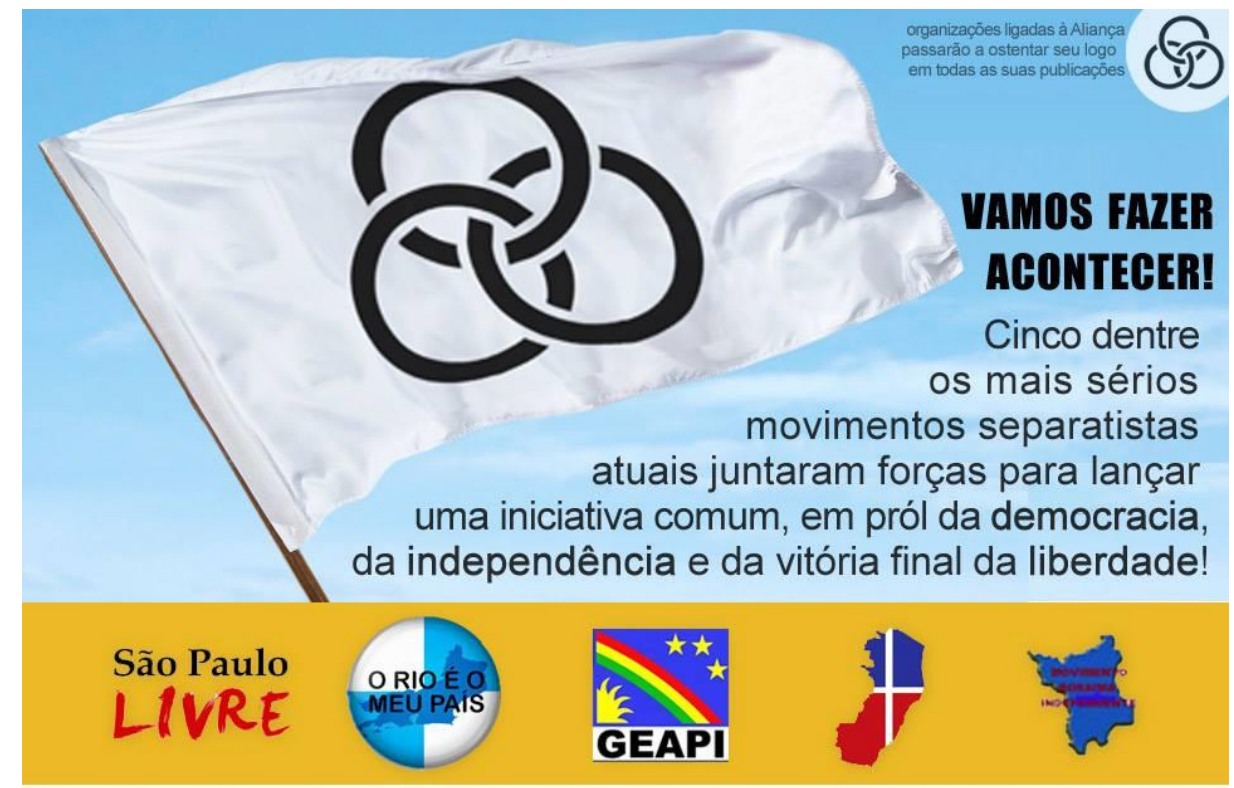

Surge a Aliança Nacional, o embrião de um verdadeiro partido político separatista. Venha fazer parte dessa verdadeira revolução!

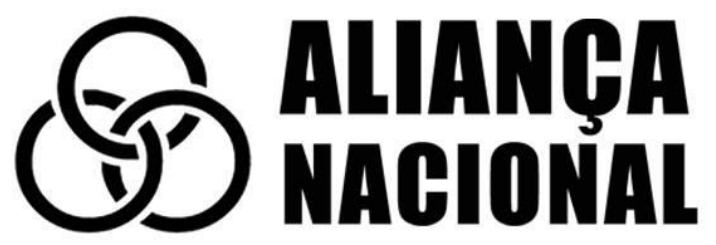

\section{São Paulo LIVRE.org}

Imagem 60

Apresentação do Partido Político Separatista: Aliança Nacional. Com participação de grupos separatistas do Rio de Janeiro, Pernambuco, Rio Grande do Sul, Paraná, Santa Catarina e Roraima.

Para além disso, vale salientar que a proposta do São Paulo Livre trata do estado paulista tomando como referência o Brasil enquanto nação. Não somente indicam isto as suas alianças políticas, baseadas em outros movimentos separatistas brasileiros, mas, em especial, o argumento da superioridade, uma vez que este só faz sentido de forma relacional. É, pois, essencial notar como na proposta do movimento rechaça-se e necessitase, simultaneamente, do brasileiro enquanto categoria externa e contraposta.

297 Imagem retirada em: SÃO PAULO LIVRE. Facebook. 09/11/2016. Disponível em: < https://www.facebook.com/movimentoSPL/photos/a.1732684196957716.1073741827.1732658630293606 /2187362558156542/?type=3\&theater $>$ Acesso em: 29/04/2018. 


\title{
6.4 - A Mobilização das Pautas Contra Preconceito e Discriminação
}

\begin{abstract}
Nós, do SPL, queremos um país novo, menor, melhor e mais justo para todos que vivam nele. O país novo que queremos será tolerante e inclusivo - uma terra de oportunidades para todos, não importando sua origem, a cor de sua pele, sua opção sexual, sua idade ou aparência. O país que vamos fazer será melhor do que o Brasil jamais foi. (SPL, 2014).
\end{abstract}

Busquei apresentar nesta dissertação certo consenso entre a bibliografia especializada de que preconceito no Brasil, em especial no que se refere à negritude, costuma ser velado de formas diferentes. Acredito, neste sentido, que o recrudescimento das pautas de movimentos sociais históricos (como o negro, indigenista, feminista e LGBTQIA+) tenha sido capaz de tensionar o discurso social de modo que os mecanismos para velar certas discriminações e preconceitos se tornaram ainda mais sofisticados. Inserindo-me nesta discussão que apresento o São Paulo Livre e a questão hierarquizante que a paulistanidade pode abarcar.

O SPL apresenta engajamento em afirmar que todos os grupos culturais, raciais e étnicos de São Paulo seriam considerados legítimos paulistas. Mais que isto: paulista, para o grupo, não seria mais afirmado como uma questão de origem - aparece quase como um valor, uma mentalidade. Neste sentido, o grupo busca afastar-se da conexão frequente que há entre o paulistanismo e a discriminação e preconceito contra nordestinos e negros.

O movimento afirma que se São Paulo viesse a ser um país, ninguém seria expulso e que haveria até mesmo a possibilidade de formar-se uma pátria menos discriminatória, sem racismo ou qualquer outra forma de exclusão. As cores da bandeira do estado são, inclusive, mobilizadas para perpetuar a ideia mítica de miscigenação pacífica das três raças: o vermelho representaria "os valentes indígenas paulistas", o branco os europeus "que tanto fizeram por São Paulo" e o preto "a nobre raça negra, forte, linda e capaz" (SPL, 2014).

Do mesmo modo que busca aparentar tolerância, o movimento apresenta o preconceito como maior obstáculo de sua causa. Seu presidente, Flávio Rebello, afirma que ele e seu grupo sofreriam falsas acusações de racismo e que no atual contexto quando se fala em separatismo, já o conectariam à discriminação (EXTRA, 2014). Deste modo, o tema da imigração que toca o grupo é tratado de maneira autovalorativa: São Paulo aparece 
como a terra das possibilidades imigrantes por execelência, sempre de braços abertos, cosmopolita. $^{298}$

Acredito que a maior validade de um trabalho sobre este grupo esteja em analisar não somente a reconfiguração do discurso paulistanista, mas também o panorama em que ele se insere. Como já dito, o SPL surgiu após o resultado eleitoral de 2014, marcado não somente pela divisão ideológica e regional do país (tal qual 2010), mas também pela discussão acirrada em torno de variadas formas de estigmatização. Pensar, portanto, na fundação do grupo neste período é estar atenta aos debates da paulistanidade à época, marcados pelo discurso de contraposição ao estereótipo nordestino.

Em 2010 chegou a se falar publicamente que nordestinos deveriam morrer afogados, o que, apesar de ter sido condensado na fala de uma única pessoa (Mayara Petruso), deve ser tratado como um fenômeno de relevância extrema, já que foi enunciado por número gigantesco de pessoas. Apesar de parte considerável da sociedade brasileira coadunar com tal preconceito e até mesmo enunciá-lo publicamente por meios virtuais, expressões excludentes diversas, em especial a de Mayara Petruso, foram enquadradas e condenadas como racismo. E o tão grandioso número de pessoas que endossavam estes dizeres não se depararam com uma sociedade una e passiva frente a esta estigmatização.

De tal maneira, defendo que este caso tenha sido crucial para que se abalasse um discurso ancorado no mascaramento das discriminações e preconceitos raciais em que, para fins similares, ao invés de raça utilizava-se a origem como ofensa. Tratado pública e judicialmente como racismo, a ofensa de milhares, condensada na figura de Mayara Petruso, não teve o mesmo nível de aceitação que já possuiu em outros contextos e momentos históricos. Fato marcante para grupos engajados na paulistanidade.

Acredito que seja justamente por este grau de aceitação social, que varia de acordo com o contexto político, que um grupo como o SPL mobilize argumentos distintos para defender a superioridade do estado. Creio, neste sentido, que o grupo tenha optado pelo autoenaltecimento em concomitância à generalização difusa deste Outro que historicamente teve origem, raça e classe tão bem demarcados. As imagens a seguir são

\footnotetext{
298 “Quanto a questão da imigração, ora, São Paulo é a terra dos imigrantes por excelência. Recebemos ao longo de nossa história portugueses, italianos, espanhóis, japoneses, libaneses, nordestinos, sulistas, mineiros, gente de todo lugar do Brasil e do mundo, sempre com os braços abertos. Se você quiser trabalhar com afinco, se acredita no valor do esforço pessoal, se quiser uma vida melhor para si e para seus filhos, não vejo por que não vir para São Paulo" (SPL, 2014).
} 
capazes de expressar o empenho do SPL em pautar-se enquanto avesso a discriminações e preconceitos costumeiramente associados à paulistanidade.
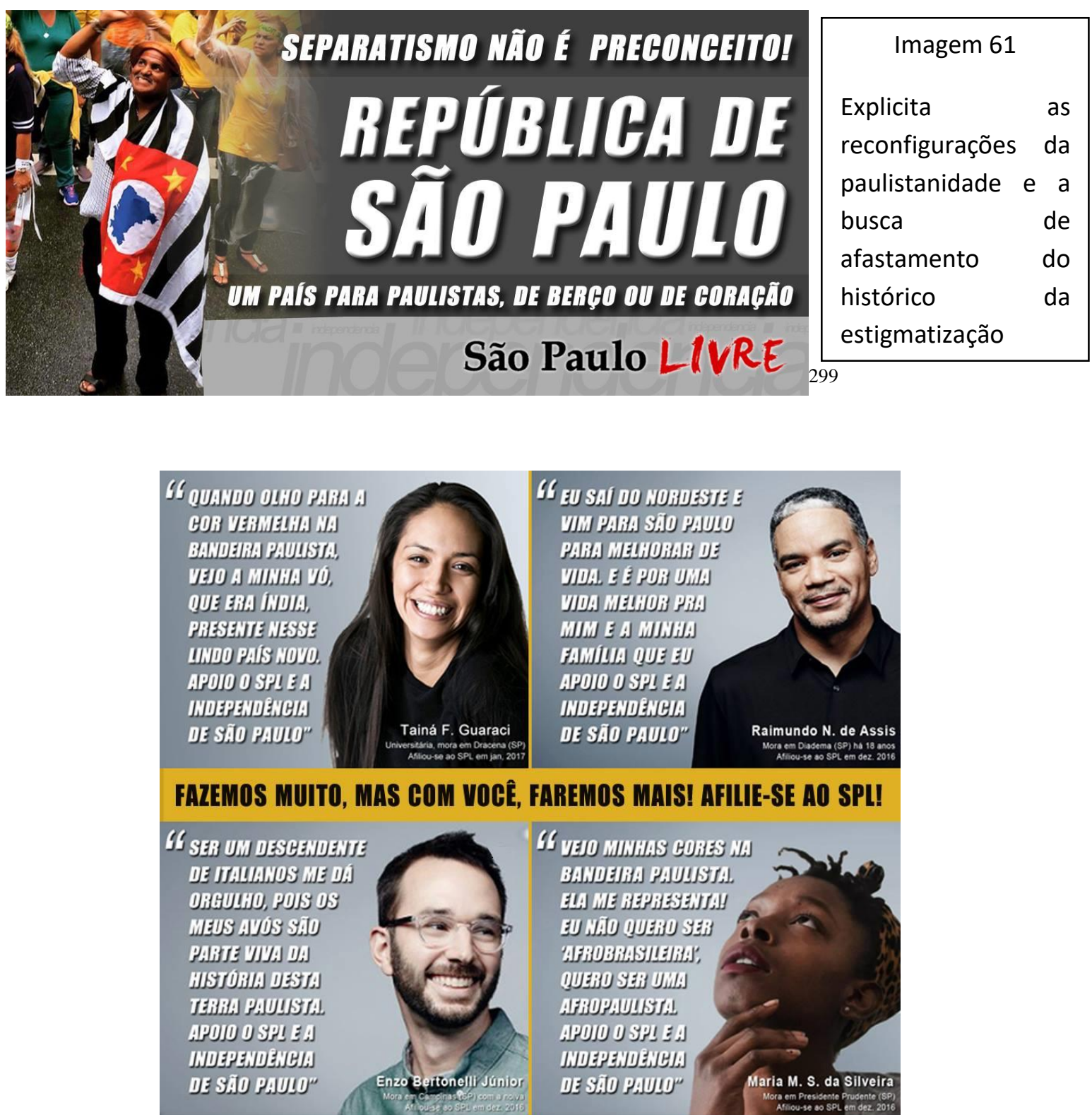

\section{São Paulo LIVRE.org}

Imagem 62

Traz à pauta do SPL a questão da representatividade.

299 Imagem retirada em: SÃO PAULO LIVRE. Facebook. 22/03/2015. Disponível em: <https://www.facebook.com/movimentoSPL/photos/a.1732684196957716.1073741827.173265863029360 6/1826940514198750/?type=3\&theater> Acesso em: 29/04/2018.

300 Imagem retirada em: SÃO PAULO LIVRE. Facebook. 21/02/2017. Disponível em: < https://www.facebook.com/movimentoSPL/photos/a.1732684196957716.1073741827.1732658630293606 /2270404949852302/?type=3\&theater> Acesso em: 29/04/2018. 
É inegável que o discurso presente nestas imagens, retiradas na página de facebook do SPL, apresentam uma paulistanidade reconfigurada em sentidos diversos. Caracterizando-se pela anulação das composições índigenas, negras e pobres do estado, o ideal de supremacia paulista foi historicamente marcado por ideais racistas e elitistas. Causa espanto, portanto, que o SPL reivindique que as cores vermelha e negra da bandeira estadual representem grupos sociais que parte marcante da ideologia da paulistanidade buscou invisibilizar.

Diante desta reconfiguração, torna-se essencial analisar como uma nova paulistanidade concebe o tema da exclusão, não somente em nível discursivo, mas em suas propostas e filiações ideológicas. É por tal motivo que saliento novamente que o SPL se baseia na narrativa de apaziguação em torno do tema racial. Se vê isto não somente na exaltação bandeirante e na negação da hierarquia racial da sociedade paulista, mas a partir da acepção de uma lógica meritocrática baseada na categoria frágil de esforço individual. Como exposto pelas fotos mobilizadas neste capítulo, todavia, a imagem mais utilizada valorativamente pelo movimento segue em consonância com o ideal da paulistanidade: branca e rica.

Apesar de seguir com preceitos de superioridade, é interessante que o movimento, guiada pelo e para o empresariado paulista, apegue-se à ideia de tolerância. É, inclusive, sintomático um contexto social em que se recorre com tanta frequência a este termo: como se certos grupos humanos tivessem que ser tolerados. Abdias do Nascimento (2017) apresenta, em referência a Freyre, que tolerância enquanto conceito moral seria um condescendente ideal de superioridade. À luz disso, creio que seja possível afirmar que os discursos de mulheres, negros e LGBTs ascenderam a ponto de não ser mais abertamente aceito o escancaramento de opressões variadas e que estas passariam a aparecer, em diversos momentos, a partir do discurso da tolerância.

Imersa nesta questão e nas práticas do SPL está o amplo, e tão efervescente no contexto atual, debate sobre representatividade. Vê-se artistas mundialmente conhecidos adotando lutas contra a violência policial e assumindo o lema black lives matter. Vê-se Hollywood, historicamente tão adepta a objetificar mulheres, debatendo o tema sobre a violência contra a mulher. Vê-se a Rede Globo realizando telenovelas com artistas trans e debatendo transfobia. Vê-se, de modo geral, a expansão, e em muitos casos, capitalização, 
de pautas invisibilizadas historicamente. Nota-se, portanto, uma Indústria Cultural ${ }^{301}$ que passou a se apresentar enquanto tolerante.

$\mathrm{O}$ incômodo com aquilo que o discurso conservador chamou de fascismo politicamente correto está conectado a esta ascensão das discussões em torno de lugar de fala, silenciamento e invisibilização. O fato de grupos como o SPL e o Manifesto São Paulo Para Paulistas mobilizarem opressões históricas e afirmarem sofrer preconceito e discriminação possui relação com o ascenso de diversas pautas que antes se restringiam a meios engajados, mas que estão em voga no debate cultural atual, inclusive nos meios midiáticos. Vê-se, em muitos destes casos, uma disputa conceitual: grupos conservadores que afirmam que discriminação seria a apresentação das expressões de desigualdades sociais ou até mesmo indivíduos que afirmam, irrelevando o histórico das opressões, as inatingíveis analiticamente categorias de racismo inverso, misandria e ditadura gay. Cabe a pergunta se não estaria o SPL se inserindo nesta prática ao afirmar como discriminador quem contraria seu ideal de superioridade.

De todos os modos, apesar da lógica contraditória em que pode estar a questão da representatividade, como se poucos indivíduos, normalmente ricos, fossem capazes de representar a opressão de todo um grupo humano, vê-se a generalização do discurso que pauta a diversidade e condena expressões de escancaramento discriminatório ou preconceituoso. Defendo, neste sentido, que o SPL foi capaz de inserir-se em seu período: buscou, frente a um debate social efervescente, readequar pautas da paulistanidade que não possuem mais o mesmo espaço que antes. Isto do mesmo modo que se vê a grande mídia buscando, através de indivíduos modelos, expiar-se de seu histórico de invisibilização de grupos humanos diversos.

Vale lembrar que no caso do SPL, isto possui relação com seu futuro enquanto grupo político, uma vez que o movimento acaba de formar um partido e em um jogo eleitoral as opressões históricas a que sua ideologia se filiou poderiam causar perda de apoio. O que não impede o grupo, todavia, de ser preconceituoso com uma nova linguagem. A imagem a seguir, retirada da página de facebook do SPL, consegue transmitir com eficácia preconceitos raciais, culturais e econômicos caros à paulistanidade. Tudo isto, todavia, sem fazer menção direta a qualquer uma destas opressões em seus termos clássicos. Neste sentido, vale lembrar que a "reprodução ampliada das desigualdades

${ }^{301}$ Em referência ao conceito de Adorno e Horkeimer. 
raciais no Brasil coexiste com a suavização crescente das atitudes e dos comportamentos racistas" (GUIMARÃES, 2004).

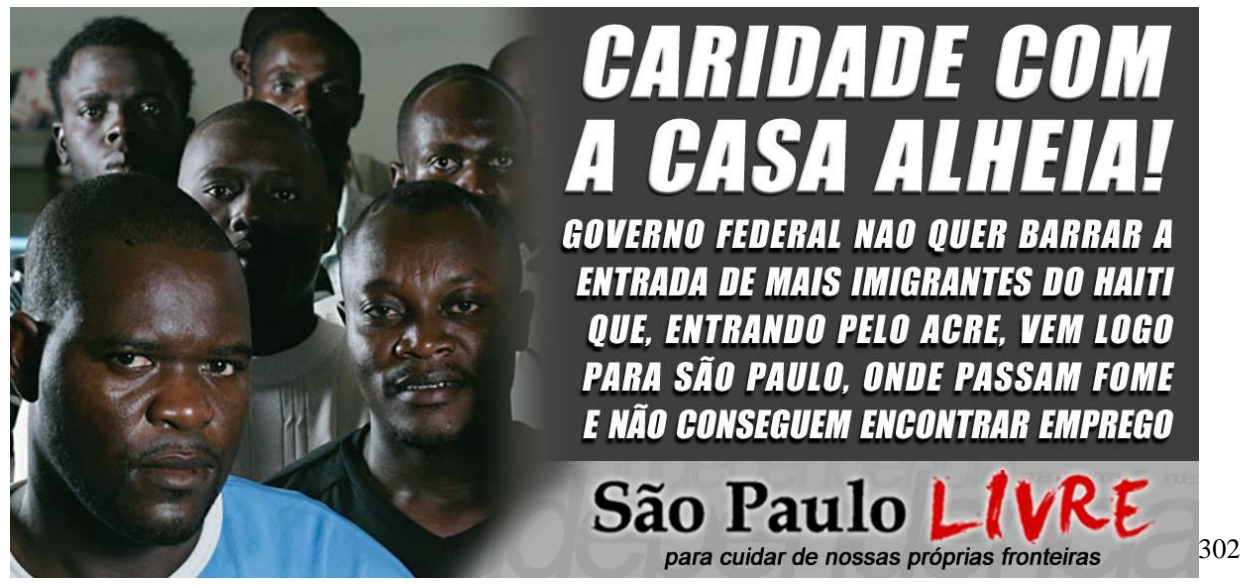

Imagem 64

Explicita o preconceito contra os haitianos e a restrição de São Paulo a estes. Evidencia um processo de racialização, uma vez que haitianos negros são narrados como indesejados e passíveis de caridade. Vale lembrar que nas imagens de propaganda do SPL costumam aparecer, majoritariamente, pessoas brancas com aparência enriquecida, a partir de narrativas de empreendedorismo e sucesso. Vê-se, neste caso, o argumento da não adequação haitiana ao plano paulista.

Quais seriam os motivos do SPL pautar a inadequação haitiana ao plano paulista? Supor que estes não iriam trabalhar? Por que sua vinda para São Paulo seria considerada um ato de caridade? Quando perguntado sobre a questão da migração, o presidente do SPL, Flávio Rebello, afirmou:

Se você quiser trabalhar com afinco, se acredita no valor do esforço pessoal, se quiser uma vida melhor para si e para seus filhos, não vejo por que não vir para São Paulo. (EXTRA, 2014).

Sabe-se que a premissa do esforço individual é eficaz tanto em naturalizar desigualdades sociais diversas, quanto em manter grupos humanos em situação de desigualdade. Flávio Rebello afirma que São Paulo, se fosse um país, vigiaria suas fronteiras para combater o crime e a mendicância. ${ }^{303}$ Não é necessário mobilizar o apego

302 Imagem retirada em: SÃO PAULO LIVRE. Facebook. 02/06/2015. Disponível em: <https://www.facebook.com/movimentoSPL/photos/a.1732684196957716.1073741827.173265863029360 6/1873860512840083/?type=3\&theater> Acesso em: 29/04/2018.

303 "Mas como em todo país independente, haverá vigilância nas fronteiras paulistas para evitar o crime, a mendicância, as drogas ou tráfico de pessoas em nosso território" (REBELLO, F. EXTRA, 2014). 
aos bandeirantes e ao Conflito de 1932 para perceber que se trata de um movimento que perpetua um ideal excludente. São populações específicas, exemplificada nesta imagem pelos haitianos, as indesejadas. Afasta-se o estigma da mendicância, do crime, da raça, da classe e daqueles que não indicam a viabilidade do esforço pessoal, uma vez que são prejudicados justamente pela ineficácia da meritocracia. São os mesmos indesejados que estruturalmente a sociedade marginaliza com o recorte de classe, raça, gênero e sexualidade. De fato o SPL não é abertamente discriminatório. Isto não anula, todavia, a eficácia do grupo na demonstração de preconceitos a partir de métodos que são mais facilmente aceitos e difundidos.

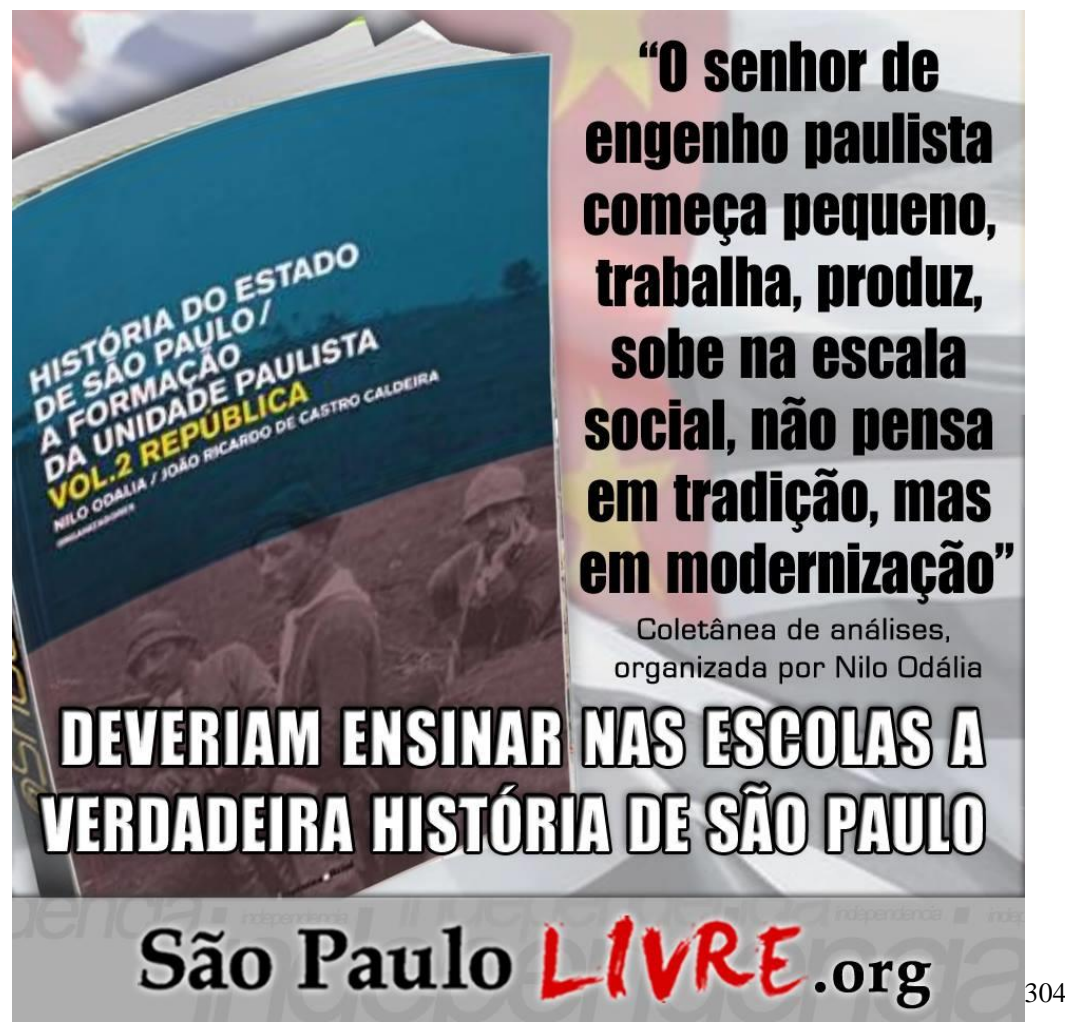

Imagem 63

Evidencia a sublimação que se faz do período escravocrata: "Quando você ouve a palavra 'senhor de engenho', provavelmente vem à sua cabeça aquela imagem de um coronel branco, vivendo numa Casa Grande, com centenas de escravos negros, mal-tratados e amontoados em uma senzala miserável. Só que essa imagem, tão propagada nos livros de história, refere-se apenas aos engenhos do Nordeste de então. Em São Paulo, a situação foi bem diversa. Sempre houve um natural empreendorismo junto ao povo paulista." (SPL,

304 Imagem retirada em: SÃO PAULO LIVRE. Facebook. 16/10/2015. Disponível em: <https://www.facebook.com/movimentoSPL/photos/a.1732684196957716.1073741827.173265863029360 6/1944966679062799/?type=3\&theater> Acesso em: 29/04/2018. 
Como já dito, um destes métodos consistiria na realocação de questões sociais referentes à desigualdade: se há alguma discriminação, isto se deve a um brasileiro difuso, não ao paulista coeso e tido como unitário. A afirmação do grupo de que "São Paulo é diversidade, a verdadeira sociedade multicultural, e não aquela que o Brasil falsamente diz que é, mas que na verdade pertence a São Paulo" torna nítido não apenas a perpetuação do mito da democracia racial, mas, em especial, a restrição deste ao estado paulista. Neste sentido, vê-se uma mobilização já antiga à brasilidade: o Brasil enquanto projeto nacional esforçou-se em indicar uma superioridade em relação aos outros países do mundo a partir da narrativa de que seria a sociedade mais democrática em termos raciais. Como se sabe, tal argumento teve força no encobrimento da desigualdade racial brasileira. É, pois, com este esforço apaziguador em mente que se deve notar a estratégia do SPL diante de um recorte estadual tão marcado pela hierarquização em função de raça: nega-se a sua existência.

Reside justamente nesta adequação paulista ao projeto racial brasileiro, empenhado no mascaramento de opressões, o diferencial que o SPL traz à narrativa da paulistanidade, uma vez que esta, ao longo da história, possuiu relações com uma proposta mais explícita em termos discriminatórios e preconceituosos. Um novo regionalismo que se afirma pósracialista e que busca aproximar-se em termos relativos ao politicamente correto apresenta não somente originalidade, mas, em especial, uma nova adequação de São Paulo à mítica democracia racial.

É curioso, portanto, que o SPL afirme, como visto na imagem 63, que São Paulo não tenha possuído um sistema escravocrata desumano, mas sim empreendedor. Neste sentido sublima-se até o fato de que foi uma cidade do estado (Campinas) a última a abolir a escravidão. Deste modo, vê-se uma tentativa que pode ser relacionada à de Gilberto Freyre na primeira metade do século passado. Apesar das diferenças marcantes entre ambas, há uma similaridade: tenta-se imputar uma suavidade inexistente a um período que mancharia a história regional. A defesa do senhor de engenho paulista, portanto, seria uma readequação do SPL a uma paulistanidade que sempre foi conectada com a narrativa da branquidade, mas que agora mobiliza outros termos para defender os grupos brancos do estado.

No que concerne à questão de classe, a coesão paulista defendida é visível na fala do grupo, exposta na próxima imagem, em resposta à alcunha de elitista que vem recebido. Vê-se que se trata de um discurso que delimita em termos econômicos quem seriam os 
paulistas. A promessa de que todos os paulistas serão elite não só aloca e legitima uma desigualdade enquanto externa a esta categoria estadual, como imprime ao movimento uma forma atualizada de expressar-se, não tratando diretamente dos grupos pobres que foram afastados historicamente por este regionalismo. "Somos a elite", "seremos todos elite" se apresenta, portanto, como uma ferramenta distinta às narrativas históricas que negaram ou afastaram ativamente os pobres do estado. Engendra a continuidade de um preconceito de classe que se estabelece e se forma por outros meios: a narrativa aparente é de que paulista seria elite se dependesse somente de si, que todo paulista poderia alcançar este status porque naturalmente está apto para isto enquanto populações outras não estão e não permitiriam esta ascensão de São Paulo. É, pois, o argumento da locomotiva paulista que é prejudicada por uma inapta economicamente população nacional.

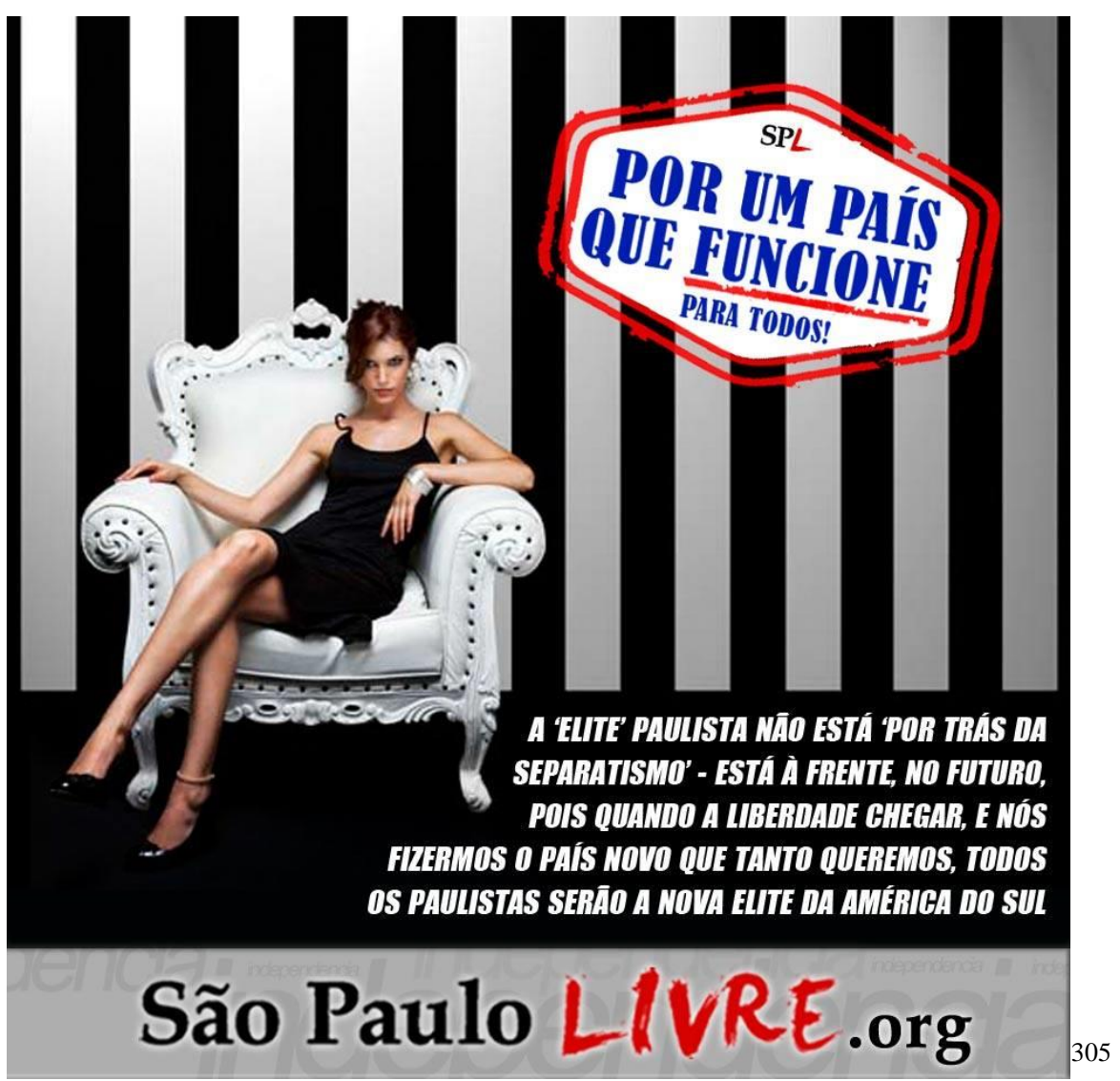

\begin{tabular}{|l|}
\hline \multicolumn{2}{|c|}{ Imagem 65} \\
Explicitarara a \\
demarcação \\
econômica do \\
paulista \\
enquanto elite \\
através do ideal \\
de uma mulher \\
jovem e branca \\
com aparência \\
enriquecida. \\
\hline
\end{tabular}

305 Imagem retirada em: SÃO PAULO LIVRE. Facebook. 30/04/2016. Disponível em: <https://www.facebook.com/movimentoSPL/photos/a.1732684196957716.1073741827.173265863029360 6/2051325215093611/?type=3\&theater> Acesso em: 29/04/2018. 
A ascensão do conservadorismo de um movimento como o São Paulo Livre pode ser pensada em consonância à análise do Movimento Brasil Livre (MBL) que foi gerado e patrocinado por uma rede de fundações de direita localizadas nos Estados Unidos (AMARAL, 2016). Não só ambos os grupos fazem menção a uma liberdade liberal, como também se caracterizam por reivindicar a primazia no golpe de 2016. Do mesmo modo, o MBL é marcado, enquanto grupo, por apropriar-se de pautas dos movimentos sociais sob as figuras de Fernando Holiday, que defende o fim das políticas raciais afirmativas, e Kim Kataguiri, que se mobiliza contrariamente ao que chama de teor ideológico da educação brasileira.

Pierucci (2000) dissertou sobre como a apropriação das pautas de movimentos sociais pela direita poderia se transformar em Ciladas da Diferença, uma vez que o discurso da diferença humana seria usado com eficácia maior por grupos que não prezam pela igualdade. $\mathrm{O}$ autor não pontua, todavia, como se pode travar estas lutas que recebem a alcunha de identitárias e, na realidade, buscam expandir o conceito de humanidade, pontuando a diferença para evidenciar a desigualdade e, assim, suprimi-la. De todos os modos, pode-se perceber estas ciladas apontadas por Pierucci na expansão de movimentos como o Brasil Livre e São Paulo Livre, que se valem da presença de indivíduos de grupos estigmatizados para mobilizar discursos e práticas políticas excludentes. Interessante, neste sentido, é que - ao contrário do previsto pelo autor - vê-se a diversidade não como argumento da diferença: é a narrativa da igualdade que aparece para legitimar os propósitos destes grupos.

Atenta a isto, Djamila Ribeiro (2017) apresenta o fato de que frequentemente pessoas pertencentes a grupos oprimidos encontram maior exigência social para agirem politicamente de determinada maneira. Deste modo, estes indivíduos não seriam só marginalizados em um discurso explicitamente conservador, mas na naturalização da ideia de que sua militância deveria ser coerente. ${ }^{306}$ A importância da análise da filósofa encontra-se na indicação de que é necessário atentar-se a quais são os grupos sociais mais beneficiados nas propostas políticas de movimentos conservadores. Ribeiro aponta que o cerne da questão cara à análise da hierarquia social não estaria na participação de indivíduos pertencentes a grupos estigmatizados em movimentos que recrudesçam a exclusão. Do contrário: se encontraria no fato de que estes movimentos servem com

\footnotetext{
306 "Pessoas de grupos oprimidos são pessoas frutos dessa sociedade, como todas as outras" (RIBEIRO, 2017:69).
} 
eficácia maior a grupos dotados de poder histórico em termos raciais, sociais, políticos e de gênero.

É com atenção a isto que penso no apelo do SPL às composições nordestinas, negras e pobres que vivem em São Paulo e na possibilidade de participação das mesmas neste movimento pró-independência. Foi neste sentido que se debateu o cenário eleitoral recente em parte da Europa Ocidental. Nos últimos anos mulheres e LGBTQIA+s votaram, majoritariamente, em partidos da extrema direita na Alemanha, França e Holanda. Um preconceito anti-islâmico, inclusive, foi apontado como justificativa para que muitas pessoas destes grupos preferissem votar no Alternativa para a Alemanha (AfD) apesar de o mesmo ser contrário ao casamento gay e à igualdade feminina. Vê-se, deste modo, uma estratégia política de mulheres e LGBTs que não se baseia na possibilidade de diminuição de sua desigualdade sexual ou de gênero, mas sim na perpetuação da assimetria de poder nacional, de seu diferencial frente ao externalizado estrangeiro. O que, desta maneira, recrudesce um poder significativo a grupos beneficiados pelas desigualdades de gênero e pela estigmatização de sexualidades dissidentes.

Pontuo, deste modo, que nas questões que remetem a marcadores sociais da diferença variados nem sempre o posicionamento tomado por uma pessoa vai ao encontro da realidade de uma opressão sofrida, uma vez que um indivíduo não é dotado apenas da carga histórica de seu gênero, sexualidade, raça ou classe. A importância da análise interseccional concentra-se justamente na mescla destes fatores. Para além disso, há a questão de que aparecem com mais vigor as ideologias das classes dominantes, notadamente mais disseminadas. Saliento novamente, portanto, que é atentanto-se a estes fatores que se pode pensar na participação de indivíduos que não são da classe dominante tanto em um movimento como o São Paulo Livre quanto em um conflito como o de 1932.

Apesar de serem movimentos mobilizados majoritariamente em prol dos grupos dominantes, membros diversos da população podem se sentir impelidos, por questões também inseridas em uma lógica de poder, a defenderem o orgulho paulista. Pensando em uma identidade multifacetada como a que aponta Hall (2005) e Castells (1999) pode-se conceber o porquê de indivíduos ampararem-se em uma estratégia que vai além da narrativa única da classe ou da raça ou do gênero ou da origem: não se é apenas classe estigmatizada quando se pode ser paulista. Da mesma forma que não se é apenas pobre, quando se é um pobre estadunidense anti-imigração tido como melhor que os estrangeiros. 
Interessa, neste sentido, mobilizar a análise de Ribeiro: é visível a diferença de eficácia destas narrativas e práticas para grupos humanos distintos. Indivíduos estigmatizados em função de classe, não deixam de ser discriminados por perpetuarem uma lógica política que frequentemente esboça-se como elitista. Por outro lado, indivíduos abastados encontram nestes movimentos, para além do engendramento de suas pautas políticas, a possibilidade de manterem-se privilegiados no que concerne à hieraquização de classe. São, desta maneira, beneficiados em frentes mais amplas.

Como já dito, a relação que o SPL estabelece com este fenômeno concentra-se no fato de que sua narrativa adequa-se em níveis diferentes para grupos societários distintos. A filiação do grupo a uma historicidade que romantiza o bandeirante e o período colonial, a título de exemplo, apresenta relações com proximidade a um ideal que mascara a discriminação racial a partir da sublimação do período escravocrata e do genocídio indígena. Já foi exposto que isto também se apresenta no apego a Monteiro Lobato, Alfredo Ellis Jr. e até mesmo Donald Trump. Do mesmo modo, a reivindicação econômica do paulista como elite endossa um ideal com maior coro às camadas abastadas da sociedade. Vê-se, portanto, o engendramento de uma narrativa que, apesar de não pontuar a discriminação e o preconceito como mote, filia-se ao repertório dos grupos dominantes brancos em prol de sua hegemonia.

Atentando-se a isto e pensando uma vez mais no gradiente da paulistanidade, notase o SPL como um movimento que busca a expansão de sua proposta: quanto mais indivíduos o apoiem, melhor ao seu propósito político. Não se trata, portanto, de um movimento que restrinja às suas fileiras membros de determinada classe, raça ou origem. Neste sentido, o grupo perpetua uma proposta preconceituosa que não possui a aversão e o ódio que marcam outros tipos de movimento. Acredito, atentando-me a isto, que o SPL se aproxime de uma prática etnocêntrica que se vale de fontes históricas marcadas por discriminações outras, em especial raciais e econômicas. Seu discurso aparenta um teor antidiscriminatório balanceado recorrentemente pela mobilização de suas fontes.

Deste modo, vê-se no Movimento São Paulo Livre um discurso exclusivista que busca mobilizar uma superioridade que é, acima de tudo, moral: como se quem residisse em São Paulo fosse tocado por determinados valores. Sua finalidade e originalidade discursiva encontra-se na redefinição do que é paulista e na busca de que grupos humanos variados - com a inclusão de mulheres, negros, indígenas e pobres - se filiem a sua ideologia. 
Os desafios encontrados pelo movimento concentram-se no seu ancoramento em bases historiográficas adeptas à discriminação, uma vez que seu discurso se afirma contrário a isto, bem como no fato de que se recrudesce o ideal de tolerância e diversidade humana, em simultaneidade a apresentação de imagens e ideais conectados aos processo de racialização e assimetria econômica no Brasil. Rechaça-se o forró, o funk, a situação de rua, o estigma do atraso; elogia-se Donald Trump, Monteiro Lobato, o bandeirantismo e o mérito: notadamente atributos que acompanham um processo racializador e de demarcação econômica.

A partir disto nota-se um projeto regionalista que desloca o debate racial de sua pauta ao mesmo tempo que recrudesce atribuições do que considera cultura legítima, sendo esta conectada ao ideal branco e rico. O que restaria do viés racial neste regionalismo seria justamente a aproximação com suas fontes históricas racistas e um conceito higientista, frequentemente branco, do que é considerado cultura superior.

Neste sentido, o projeto do grupo é ineficaz em desvencilhar-se do histórico restritivo da paulistanidade, mas apresenta eficácia em apresentar um novo regionalismo que traz os valores como principal diferencial humano. Não se fala em raça paulista, em paulista nascido em São Paulo - fala-se em paulistas de grupos humanos diferentes que convergem à coesão por determinada mentalidade e proposição política. Interessa, ao analisar este regionalismo que se coloca enquanto pós-racial e pós-sexista, o destrinchamento das hierarquizações que comportam esta mentalidade. Como exposto neste capítulo, estaria imersa nesta a defesa do livre mercado, da assimetria de poder regional e do prosseguimento de um projeto racial que nega a discriminação presente no estado.

Deste modo, este paulista apresentado enquanto mentalidade e valor é conectado à contraposição do que se entende enquanto pobre, não-branco e nordestino. Por mais que nordestinos não sejam citados diretamente pelo grupo, percebe-se que as diferenças culturais a que o movimento se refere em muito se relacionam ao estigma do Nordeste. Do mesmo modo, se mobiliza a generalização de um Outro Regional, sabendo-se que é ampla a conexão com o que está sendo dito às populações nordestinas. $\mathrm{O}$ que, a título de exemplo, já foi exposto na imagem 56: "e o pior é que em muitas regiões do Brasil, ele (Lula) conta com mais de 50\% de apoio entre os eleitores, mesmo com todas as denúncias de corrupção. Por isso dizemos que nós, paulistas, somos outro povo.” 
É por tais motivos que o SPL costuma ser atacado por seus opositores como um movimento antinordestinos. Seu discurso trata, mesmo que indiretamente, dos mesmos, já que suas máximas são conectadas historicamente ao Nordeste. Trata-se, portanto, de um processo de estigmatização suavizado, uma vez que aparece a partir de um preconceito que não se cola às expressões discriminatórias ou de ódio que marcaram os últimos anos.

As acusações de racista que o movimento recebe também se baseiam nas incongruências discursivas do grupo: os elementos culturais, a história e a imagem propagandeada compõem, em sua maioria, elementos caros à branquidade. Sendo assim, o SPL não necessita citar nordestinos ou negros de forma direta para ser entendido enquanto excludente para estas composições humanas. Já é suficiente a mobilização em torno dos estereótipos que sempre circundaram estas populações e a autoproclamação enquanto contraponto do que as estigmatiza. A imagem a seguir é elucidativa neste sentido.

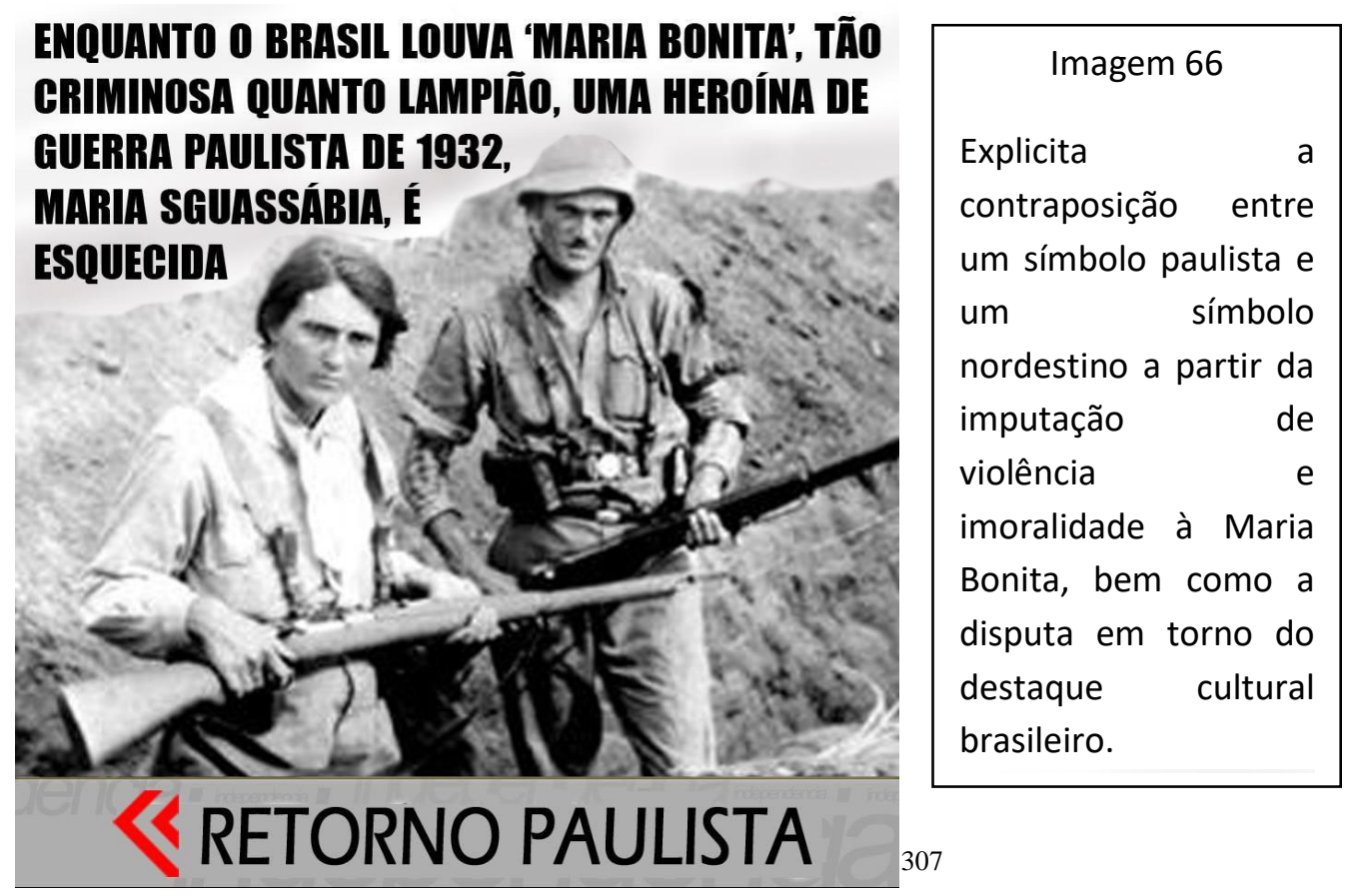

A menção ao estereótipo de Maria Bonita é eficaz ao mobilizar o estigma da anomia e violência nordestinas como contrárias ao valor moral paulista: é a narrativa clássica de classe média branca x jagunçada. Da mesma maneira que a imagem contrapondo um carnaval paulista, com pessoas majoritariamente brancas, e um carnaval

307 Imagem retirada em: SÃO PAULO LIVRE. Facebook. 07/02/2018. Disponível em: < https://www.facebook.com/movimentoSPL/photos/a.1732684196957716.1073741827.1732658630293606 /2521608974731897/?type=3\&theater $>$ Acesso em: 29/04/18. 
de "sujeira, brigas, barulho e álcool", com pessoas majoritariamente negras, já indicaria um processo de racialização que não é abertamente colocado em pauta. O SPL prossegue, deste modo, uma construção regional que contrapõe grupos humanos a partir do que considera desnível cultural e desnível de valor humano. Aparece, portanto, como movimento recrudescedor da hierarquização social brasileira.

Posto isto, vê-se que o ideal de tolerância que o grupo tenta aparentar é negado recorrentemente pela exacerbação de superioridade regionalista que engendra a racialização e o preconceito de classe. Uma das provas disto estaria na defesa do grupo em relação à canção Pobre Paulista. Em seu portal de imprensa afirma-se que esta não traria teor preconceituoso ${ }^{308}$ e que seria mal compreendida, o que o trecho a seguir consegue contrariar facilmente.

Dentro de mim sai um monstro. Não é o bem nem o mal. É apenas indiferença, é apenas ódio mortal. Não quero ver mais essa gente feia, nem quero ver mais os ignorantes. Eu quero ver gente da minha terra, eu quero ver gente do meu sangue. Pobre São Paulo! Oh oh. Pobre Paulista! Oh oh. (Pobre Paulista, Ira!).

Afirmar "ódio mortal" e não querer ver "gente feia e ignorante" em um estado marcado pela restrição a certos grupos humanos, possui relação com a reprodução da discriminação regional que é racializada frequentemente em território paulista. Por anos o grupo musical que popularizou a canção negou seu teor preconceituoso, até que em 2009 o vocalista do Ira! confessou o caráter excludente da letra. Tal fato evidencia o, tão recorrente no Brasil, fenômeno da negação discriminatória e preconceituosa.

Velar preconceitos é capaz de recrudescer narrativas que não necessitam aproximar-se da sofisticação argumentativa para negarem a hierarquização que propagam ativamente. É por tal motivo que "eu quero ver gente da minha terra, eu quero ver gente do meu sangue" pode ser afirmado pelo SPL simplesmente como gosto musical sem teor político. Prossegue-se, simultaneamente, com a negação e o recrudescimento da desigualdade. Apesar da tentativa do SPL de afastar-se da brasilidade, sua aproximação com uma narrativa velada não deixa dúvidas das origens de seu substrato ideológico: seria um mecanismo da mítica democracia racial e da meritocracia enquanto máximas constantes da nação brasileira.

308 PÁTRIA PAULISTA. Pobre Paulista, um clássico mal compreendido. 2018. Disponível em: $<$ https://patriapaulista.com/pobre-paulista-um-classico-mal-compreendido/> Acesso em: 29/04/2018. 


\subsection{Conclusões Sobre o Movimento São Paulo Livre}

Apesar de a paulistanidade basear-se em características específicas, seria um erro supor que o ideal de superioridade paulista apareça no mundo social de maneira unívoca. Ao contrário: enquanto discurso ou prática, a paulistanidade pode se expressar em grupos diferentes com propósitos distintos. A bibliografia especializada, todavia, é eficaz ao demonstrar certas recorrências do orgulho paulista enquanto ideologia: a reivindicação de destaque econômico, o incômodo com a distribuição nacional de recursos, as narrativas em torno do embranquecimento, da primazia política e do diferencial histórico do estado aparecem com frequência. Isto ocorre simultaneamente ao rebaixamento de um Outro regional racializado e associado ao nordestino.

Estudar o Movimento São Paulo Livre permite a análise de uma expressão de paulistanidade dentre tantas possíveis. Tendo isto em vista, percebe-se que em maior ou menor grau, vê-se as características históricas do orgulho paulista no discurso empreendido por este grupo. Como estas são mobilizadas, todavia, seria a questão crucial em torno do movimento independentista.

Afirmei neste capítulo que o SPL apresenta uma proposição reconfigurada em torno de sua representatividade racial. É necessário destrinchar, no entanto, até que ponto é nova esta fuga da paulistanidade de seu histórico excludente. Em 1932, a título de exemplo, fez parte do Conflito Constitucionalista justamente o discurso da união de segmentos sociais diversos em torno da causa paulista, apesar de esta ser à época (e também hoje) uma sociedade estadual hierarquizada em termos raciais. Não faria parte, como exposto por Anderson (2008), destas comunidades imaginadas a tentativa de coesão grupal, apesar do recrudescimento de suas disparidades sociais? Não seria essencial à paulistanidade, como expõe Weinstein (2015), transpor o problema da desigualdade para o externo enquanto mobiliza os de seu estado com a promessa de superioridade, apesar de hierarquiza-los internamente?

Neste sentido, creio que seja possível dizer que o argumento do SPL, adequado à mítica ideia de democracia racial, reconfigura-se ao buscar apresentar representatividade e tolerância de acordo com um momento histórico específico. Há momentos da História em que discursos preconceituosos e práticas discriminatórias se dão de maneira mais escancarada. Também há a narrativa de movimentos sociais que pressionam o imaginário conservador. Creio, como já disse, que movimentos com princípios excludentes como o 
SPL se baseiam, de acordo com seu período, no grau de aceitação social da superioridade que propõem.

Estaria imerso nos objetivos destes grupos a necessidade de angariar apoio: seja por se tornarem um partido político, por lutarem pela Independência ou por se engajarem na deposição de um governo. O SPL possui lojas, portal de imprensa, sede, endereço, rostos conhecidos. Seu discurso busca, justamente, atuar no centro da sociedade, trazer seu ideal político à realidade social, e não manter-se nas fronteiras do aceito. Curioso é o fato de que outros grupos orgulhosos de seu paulistanismo se mantém à margem do permitido: skinheads regionalistas seriam exemplo disto. Nota-se, deste modo, os diferentes propósitos, modos de expressão e, em especial, recepção que a paulistanidade pode abarcar.

Posto isto, se um grupo como o SPL afirma sofrer preconceito e falsas acusações de racismo é porque sob um olhar atento vê-se que, historicamente, a ideologia a que o movimento se filia se baseou no ideal de superioridade racial e econômica. Isto não reduz as diferenças múltiplas que movimentos empenhados no orgulho paulista possuam entre si, mas ajuda a expor o fato de que o ideal de superioridade paulista é, para quem tem acesso ao seu histórico, associado ao projeto de desigualdade econômica e racial. É com este histórico em mente que setores da população acusam o SPL de racismo e elitismo.

Uma série de estudos mobilizados na bibliografia utilizada nesta dissertação aponta o fato de que o racismo figurou-se ao longo do tempo na questão cultural e econômica. Em outras palavras: afirma-se uma suposta diferença cultural ou econômica, para basear um discurso que é também preconceituoso racialmente. Ora, o que se vê em movimentos como o São Paulo Livre e o São Paulo Para Paulistas é exatamente isto. Sabe-se que raça e classe são categorias com relações estreitas no contexto brasileiro. Devido ao histórico escravocrata e à desigualdade racial, os grupos negros do país são mantidos, majoritariamente, em situações de vulnerabilidade econômica. Do mesmo modo, culturas da negritude são estigmatizadas constantemente.

O Movimento São Paulo Livre ao defender a riqueza enquanto questão de mérito e a pobreza enquanto questão de vontade, coaduna com o ideal que relega os pobres brasileiros, muitos deles negros, a uma condição naturalizada de inaptidão ao sucesso econômico. Se apresenta como parte desta racialização e demarcação econômica a desvalorização perpetrada pelo SPL em torno de expressões culturais como o funk e o forró, uma vez que é sabido que não se relaciona estes gêneros musicais à branquidade e às 
elites. Não seriam estas expressões de rechaço ao que é considerado avesso ao paulista uma racialização que flui a partir da estigmatização cultural e econômica?

Deste modo, a tão recorrente defesa do grupo em torno do mérito, do esforço individual e do livre mercado expõe a perpetuação de um projeto liberal que não leva em consideração a estrutura desigual de oportunidades que baseia a sociedade. Como já dito, reside justamente nestas supostas possibilidades paulistas que o movimento tanto afirma existir, a crença de que os indivíduos possuem êxito ou fracasso econômico de acordo com seu esforço. Isto, por conseguinte, leva à argumentação de que é por mérito próprio que São Paulo é o principal polo econômico do país. Deste modo, o movimento afirma-se não preconceituoso, mas sua premissa básica é de que São Paulo merece independência porque sua riqueza não deve ser distribuída igualmente, de que a história paulista é única, distinta, melhor.

Reside na incongruência do discurso do SPL a necessidade de investigação das reformulações que envolvem a paulistanidade através dos tempos. Está nestas mobilizações em torno das ideias de preconceito, discriminação, elitismo e racismo o cerne de um embate social em torno de narrativas históricas rivais. É necessário um esforço argumentativo muito grande para afirmar que São Paulo é discriminada por possuir uma terra (por mérito rica) fadada a dividir sua riqueza com externos. Vê-se neste fenômeno, portanto, a disputa em torno de conceitos que evidenciam velhos embates sociais.

Posto isto, é possível concluir que o SPL é um movimento que, atento a seu tempo, segue em uma máxima da superioridade paulista a partir da contraposição clássica, sutilmente racializada e abertamente economicista, de um Outro Regional. Outro este que aparece de forma muito mais generalizada do que já apareceu nos discursos paulistanistas de outros períodos, mas que segue sendo, no estereótipo do atraso, conectado ao nordestino. A atenção que o grupo confere ao empresariado - bem como à noção de que se São Paulo fosse um país, todo paulista seria elite - perpetua uma paulistanidade que se demarca econômica e culturalmente enquanto civilizada, bem sucedida e em posse do progresso. $\mathrm{O}$ fato de o grupo possuir uma série de iniciativas culturais e até mesmo uma loja e um portal de imprensa, evidencia que a mercantilização e disseminação da identidade paulista ancora-se em delimitações sociais reconfiguradas e adequadas a seu momento histórico. 


\section{Considerações Finais}

É possível que a maior validade de uma análise focada nas diferenças entre o regionalismo paulista e a formação regional nordestina, bem como nas representações estereotipadas destas populações, se concentre no destaque com que aparece o racismo e o preconceito de classe existentes na sociedade brasileira. Ao longo desta pesquisa foi possível notar que apesar de determinados regionalismos (do qual o paulista é um exemplo) focarem na branquidade e na rejeição ao pobre, estes são fenômenos patentes em toda sociedade nacional, aparecendo com frequência a partir de outras formas que não a narrativa regionalista. Como já dito anteriormente, o desafio analítico diante deste dado seria destrinchar os motivos de a paulistanidade mobilizar tais fatores através do viés estadual. Como busquei mostrar nesta pesquisa, possivelmente isto se relacione à concentração econômica que envolve o estado, dotando sua população, em especial suas elites, de maior materialidade em suas narrativas regionais.

Deste modo, não é de se estranhar que a questão da identidade regional, tão marcante ao fim do século XIX e início do século XX, ainda possua coro inflamado em determinados estados brasileiros, com grupos separatistas em especial no Sul do país e no estado de São Paulo. Creio que seja possível afirmar que locais com elites que possuíram maior aproximação aos propósitos embranquecedores e da possibilidade de ascensão econômica, carreguem consigo um incômodo diante da imagem nacional.

Isto, todavia, não pode levar à conclusão de que o propósito de hierarquização social, em especial no que diz respeito à raça e à classe, não possua saliência em outras proposições regionalistas. Acredito que a demarcação do Nordeste enquanto pobre e nãobranco tenha servido às elites de todo o país, inclusive da região em questão, no que concerne ao domínio social. Exemplo disto seria o fato de que o estigma da preguiça baiana foi gerado pela própria elite estadual da Bahia, de modo a acirrar suas fronteiras no convívio com a população negra e trabalhadora.

Percebe-se, neste sentido, que o afastamento da negritude, da indianidade e da pobreza podem aparecer de formas diferentes de acordo com o contexto social, sendo, porém, visíveis em todos os espaços estaduais. Uma das evidências mais emblemáticas disto seria a frequência de repetição da frase "mas nem todo nordestino." Sendo estes 
dizeres, complementados constantemente com adaptações como "recebe Bolsa Família", "é ignorante", "não sabe votar", "é pobre", "convive com a seca". Vê-se grupos sociais do Nordeste, região marcada por assimetrias e heterogenias, afastando e reproduzindo os atributos que racializam e estigmatizam a região. $\mathrm{O}$ que não somente perpetua um ideal preconceituoso, como também engendra hierarquizações internas ao recorte espacial: nesta lógica, o problema é a seca e a pobreza, e não a estigmatização destes fatores, já que esta seria essencial à estratificação local.

Deste modo, o fator caro aos estudos regionalistas se concentra na possibilidade de analisar a disputa entre as regiões, bem como a eficácia discursiva de regionalismos distintos. Imersas nesta questão estariam as assimetrias de poder que marcam o Brasil: notadamente locais marcados pela ruralidade e por possuir grande concentração indígena e negra são estigmatizados como atrasados, enquanto locais urbanos e com maiores compostos brancos são afirmados arautos do progresso.

É evidente, portanto, que a desigualdade racial e econômica serve com eficácia maior a determinadas regiões: quanto mais ao Sul do Brasil se vai, melhores exemplos se vê disto. Há que atentar-se, todavia, ao processo invisibilizador destas propostas, uma vez que populações negras, indígenas e pobres são ativas e expressivas em todo território brasileiro.

Deste modo, viu-se que o maior desafio encontrado pelas narrativas da paulistanidade seria o fato de que afirmar a população paulista enquanto branca e enriquecida não mudaria a realidade social do estado. As oligarquias de São Paulo percorreram um caminho imaginativo que não possui consonância, material e discursiva, com a realidade estadual. Isto porque as populações excluídas nesta narrativa não apenas existem no local, como são fundamentais ao que é produzido no estado. Para além disso, setores destas populações resistem contra os processos das discriminações e preconceitos que sofrem: a cidade de São Paulo pode ser tanto a riqueza de Higienópolis e uma cantina italiana no Bixiga quanto Heliópolis e um samba no bairro, também nordestino, do Bexiga. Inclusive, tratar o bairro com "e" já evidenciaria que nem tudo é italiano. ${ }^{309}$

Deste modo, vê-se uma configuração regional brasileira que indica como a regionalização possui relações com a racialização e desigualdade econômica. Um país há tempos empenhado em mostrar-se apto a um padrão capitalista e que passou dos propósitos do racismo científico à descolada da realidade narrativa da democracia racial, possuiu em

${ }^{309}$ Em referência a obra Nem tudo era italiano, de Carlos José Santos. 
mãos um marcador social da diferença vigoroso: a região. Defendo, atenta a esta questão, que a ascensão da formação regional que envolveu o Brasil após sua independência, comporte uma série de aspectos caros à estratificação social. Não é a toa que seja tão recorrente a imagem de um Brasil rural, pobre e não-branco e outro urbano, rico e branco: a região, especialmente do modo que foi concebida pelas elites, engendrou e comportou uma série de assimetrias sociais.

Por tal motivo, demonstrei que a viabilidade de uma narrativa paulistanista em torno da branquidade, do poder econômico e de uma noção restrita de civilização diz respeito à desigualdade. Creio que São Paulo tenha possuído grupos oligárquicos empenhados em acirrar fronteiras sociais a partir de uma narrativa que, ao colocar enquanto exógenos os pobres e não-brancos, recrudesceu a restrição interna ao estado. É por isto que, como já tão afirmado nesta dissertação, a imagem do paulista é frequentemente imaginada como a de um homem branco de classe média. Tal narrativa regional não seria apenas eficaz em imputar ao Outro Regional estigmas, mas especialmente, em afastar grupos estigmatizados de $s i$.

Como exposto, este discurso traria a possibilidade de manutenção do domínio de raça e classe no Brasil, uma vez que a ideia da racionalidade econômica e política paulista permeia todo o imaginário nacional, dotando as elites do estado de um diferencial diante de um país que frequentemente afirma a vergonha de ser brasileiro. Vergonha esta capaz de engendrar os estigmas raciais e econômicos que hierarquizam a nação. O desconserto se direcionar justamente à existência de um Brasil considerado arcaico, com salientes parcelas pobres e não-brancas, não apenas dota os discursos regionais ancorados na branquidade e na industrialização de um trunfo nacionalmente redentor, como também perpetua a desigualdade brasileira.

Desigualdade esta que não pode ser analisada sem a perspectiva global do que representam os nacionalismos e regionalismos. Como já dito, estados-nações outros - em especial da Europa Ocidental - nem ao menos necessitam trabalhar de forma demasiada sua identidade para estabelecer uma superioridade. As assimetrias de poder nacionais já seriam eficazes para pontuar isto. Deste modo, a vergonha de ser brasileiro não somente se baseia nesta fonte considerada superior, como busca para seu projeto nacional a aproximação de um poder que se põe enquanto global, no qual a ruralidade, a pobreza, a negritude e a indianidade não têm vez. 
Desta maneira, o anseio de aproximação à europidade que teria marcado alguns regionalismos brasileiros - e grupos de elite de todo o país - ajuda a situar melhor o surgimento da paulistanidade. Esta seria capaz de reservar ideologicamente parcela significativa do conservadorismo nacional, uma vez que seu poder econômico a legitimaria enquanto apta a empreender os caminhos de uma hierarquização brasileira empenhada no domínio de classes.

Apreende-se, portanto, que as expressões de regionalismo destrinchadas nesta dissertação não somente sejam frutos de grupos dotados de poder econômico e da narrativa da branquidade, como também sirvam a estes para a perpetuação de seu poder. A paulistanidade aparece como sustentáculo de poderio regional diante de um país com notável assimetria de poder entre regiões e como subsidiadora dos privilégios de ricos e brancos. Não é de se estranhar, portanto, que uma ideologia que tanto se aproxime da ode ao trabalho consiga, simultaneamente, negar a contribuição da classe que foi escravizada e da atual classe trabalhadora pobre: o elogio é ao outro polo do trabalho - o patrão, o empresariado.

Analisar o que gera e o que mantém este discurso majoritário da paulistanidade, todavia, não pode levar ao reducionismo. Longe de manter-se restrito aos meios de elite, o ideal de superioridade paulista é eficaz em sua difusão, bem como os preconceitos e discriminações que este possa abarcar. Neste sentido, torna-se essencial perceber que a identidade estadual enquanto sinal diacrítico seja capaz de ser mobilizada também pelas classes populares e por grupos estigmatizados, uma vez que os dota de poder quando da relação com seus semelhantes de outras regiões.

Deste modo, a insistência na superioridade paulista pode ser entendida através da eficácia da difusão de seu ideal, uma vez que São Paulo conferiria um orgulho estadual que pode ser argumentado pela cena cultural do estado, pela amplitude de oportunidades, por seu caráter urbano ou até mesmo por sua concentração de riqueza. Sua capital consegue ser musicalmente descrita tanto como "túmulo do samba, mas possível novo Quilombo de Zumbi" 310 quanto como cansada de ver "os feios e ignorantes" ansiando por "ver gente da sua terra e gente do seu sangue." 311

Como exposto, acredito que esta convivência de narrativas díspares possa ser explicada não somente pelas vivências e projetos políticos diferentes dos grupos sociais

\footnotetext{
${ }^{310}$ Menção à música Sampa de Caetano Veloso.

${ }^{311}$ Menção a canção Pobre Paulista do Grupo Ira.
} 
paulistas, como também pela readequação brasileira em torno de um projeto racial: antes esmerado no embranquecimento e posteriormente em aparentar uma irreal convivência harmônica. Deste modo, um regionalismo como o paulista - que se valeu tão fortemente, no início do século passado, da aposta no embranquecimento - encontrou dificuldades e benefícios para adequar-se à narrativa nacional do mito da democracia racial. Dificuldades porque não aparentava tanta brasilidade e tradição quanto outros recortes estaduais e benefícios devido ao fato de que a narrativa de elogio à mestiçagem, não anula que no Brasil quanto mais branco, mais privilegiado.

Neste sentido, certa parcela da paulistanidade continuou a tentar se diferenciar como um contraste branco diante de um país majoritariamente negro e indígena. Os neonazistas regionalistas de São Paulo seriam grupos que ainda trazem à cena regionalista paulista este projeto. De modo geral, no entanto, um ideal sofisticado de superioridade paulista conseguiu encaixar-se tanto na perpetuação do preconceito racial com sua emparedada branquidade, quanto na afirmativa de não ser racista. É por tal motivo que o nordestino enquanto contraponto paulista foi uma ferramenta poderosa: baiano poderia ser tanto o não-branco de fato vindo do Nordeste quanto o não-branco paulista - era uma categoria racializada do que se queria que fosse externo, mas não podia ser abertamente dito enquanto negro.

Creio que este estigma nordestino, visivelmente racializado e demarcado economicamente, seja uma narrativa eficaz para escamotear o conflito de classes e raças. Tentativa esta que serviria tanto a este Sul difuso quanto a um Norte igualmente difuso. Isto porque estabelecer uma região enquanto pobre e não-branca a partir do estabelecimento de outra como enriquecida e branca favorece a invisibilização das discriminações e preconceitos raciais e econômicos destes locais. Colocar enquanto pobre - enquanto símbolo de trabalhador explorado - o nordestino, serve, portanto, ao deslocamento de uma realidade social que é também paulista: a da hierarquização entre classes sociais. Do mesmo modo, um regionalismo nordestino que se narrou enquanto harmônico - o freyreano sendo exemplo disto - buscava colocar o conflito e uma desigualdade grande o suficiente para gerar desarmonia como categorias externas a este local, como patente somente nos centros industriais - do qual o paulista seria o maior exemplo.

Vê-se, assim, que regionalismos, assim como nacionalismos, seriam construções históricas com possibilidades de homogeneizar narrativas e práticas humanas díspares, até 
mesmo contrapostas. Desta maneira, falar de um estado paulista branco e enriquecido não apenas negaria a maior parte da população estadual, como também formaria uma imagem representacional que não permite espaços à heterogenia e conflitos. Do mesmo modo que um novo regionalismo, que traz uma questão de mentalidade, valores e posicionamentos políticos como diferencial regional, reduz uma série de embates que existem dentro do estado.

Concebo, deste modo, as narrativas regionalistas como constructos históricos dotados de materialidade política, podendo abarcar extremos das proposições sociais. Afirmar que a região é inventada, não seria conceber todos os grupos humanos de partes distintas e distantes como homogêneos, mas justamente atentar à falta de homogenia interna em qualquer que seja a região, estado ou objeto de defesa de uma narrativa. Tratase, justamente, de entender como desigualdades internas são trabalhadas quando se constrói e se apresenta a identidade regional diante da nacional e global.

Assim, busquei apresentar os níveis de adequação que as regiões e manifestações regionalistas brasileiras podem ter em relação a noções caras a um país marcado pelo complexo do subdesenvolvimento: civilização e progresso. Notei que estes termos possuem referência com um processo de racialização e demarcação econômica e política das camadas da população brasileira. Deste modo, civilizados e em posse do progresso aparecem como brancos e enriquecidos. Tal manifestação de desigualdade pode, como exposto, ser expressa politicamente a partir das afirmações de que certos exercícios políticos possuiriam menor valor e racionalidade.

Deste modo, a crise política brasileira da década de 2010 aparece como processo fomentado por setores apegados a noções civilizatórias restritas. Como já dito, acredito que a imputação de ilegitimidade ao último governo presidencial - fator marcante para a ocorrência do Golpe de 2016 - tenha raízes na ideia de Dois Brasis, sendo estes habitados por populações consideradas moral e racionalmente distintas. A revolta com os resultados eleitorais de 2010 e 2014, imputados como responsabilidade nordestina, foi capaz de escancarar como a população desta região é considerada inapta politicamente. A racialização e demarcação econômica nas ofensas que foram proferidas - "povo de empregadas e porteiros que não sabe votar"312, "pretos dinheiristas dependentes de

${ }^{312}$ Twitter. 03/10/2010. 
bolsas"313 - expõe um ideal perverso que considera racional e moralmente superiores aqueles que são brancos e ricos.

Deste modo, não só foi possível ver a ascensão de movimentos separatistas que queriam evidenciar - e supervalorizar - um poder de mando e hegemonia paulistas, como também se viu um incômodo difundido com o exercício político de nacionais despossuídos. Afirmar o voto destas pessoas como de menor valor, nesta narrativa, não se concentrou na ineficácia da representatividade eleitoral dos modelos políticos atuais, mas na perpetuação de um ideal que continuamente estigmatiza a maior parcela da população nacional. Prossegue-se, assim, um ideal de civilização restrito: a Ordem sendo direcionada àqueles estigmatizados e o Progresso sendo conceito formulado e dirigido pelos que concentram privilégios.

${ }^{313}$ Twitter. 03/10/2010. 


\section{Referências Bibliográficas}

ABUD, Kátia Maria. O sangue intimorado e as nobilíssimas tradições: a construção de um símbolo paulista: o bandeirante. Tese de Doutorado, Departamento de História/FFLCH-USP, São Paulo, 1986.

ALBUQUERQUE JR., Durval. A Invenção do Nordeste e Outras Artes. Editora Cortez, São Paulo, 2011.

ALENCAR, Eunice M. L. Atribuição de estereótipos a grupos regionais por parte de alunos do primeiro grau. Psicologia, Teoria e Pesquisa, 1985.

ALVES, Benno Warken. Construindo o Homem Paranaense - O monumento do centenário do Paraná e as tensões regionais e raciais do Brasil do pós-guerra. Texto apresentado no Simpósio "A Cidade e a Sujeição Racial", Faculdade de Arquitetura e Urbanismo da Universidade de São Paulo, 2017.

AMARAL, Marina. Jabuti Não Sobe em Árvore: Como o MBL se tornou líder nas manifestações pelo impeachment in Por que Gritamos Golpe? JINKINGS, I; DORIA, K; CLETO, M. (Orgs.). Editora Boitempo, São Paulo, 2016.

ANDERSON, Benedict. Comunidades Imaginadas: reflexões sobre a origem e a difusão do nacionalismo; tradução Denise Bottman. Editora Companhia das Letras, São Paulo, 2008.

ARENDT, Hannah. Eichmann em Jerusalém. Editora Companhia das Letras, São Paulo, 2000 .

ARRUDA, Maria Arminda do Nascimento. Metrópole e Cultura: o novo modernismo paulista em meados do século. Tempo Social - Revista de Sociologia da USP, 9, São Paulo, 1997.

Brasiliense, 1990.

A Mitologia da Mineiridade. Editora

AZEVEDO, Thales de. As elites de cor numa cidade brasileira: um estudo de ascensão social \& classes sociais e grupos de prestígio. Edufba/Egba, Salvador, 1996.

BATISTA, José. Os estereótipos e o efeito do contato virtual no preconceito contra negros e nordestinos. Tese de Doutorado, Universidade Federal da Paraíba, 2014.

BERLIN, Isaiah. El retorno del bastón, sobre la ascención del nacionalismo. In: DELANOI, Gil \& TAGUUIEFF, Pierre-André (comp.). Teorias del nacionalismo. Barcelona: Paidós, 1993. 
BOULOS, Guilherme; GUIMARÃES, Vitor. Resistir ao Golpe: Reinventar os Caminhos da Esquerda in Por que Gritamos Golpe? JINKINGS, I; DORIA, K; CLETO, M. (Orgs.). Editora Boitempo, São Paulo, 2016.

BOURDIEU, Pierre. A identidade e a representação: elementos para uma reflexão crítica sobre a ideia de região. O poder simbólico. Trad. Fernando Tomaz. Difel, Lisboa, 1989.

BORGES, Vavy Pacheco. Memória Paulista. Edusp. São Paulo, 1997.

BRACHT, Alessandro. O Nacionalismo dos Skinheads Brasileiros. Saeculum - Revista de História, João Pessoa, 2005.

BRAGA, Ruy. A Política do Precariado. São Paulo: Editora Boitempo, 2012.

O fim do Lulismo in Por que Gritamos Golpe? JINKINGS, I; DORIA, K;

$\begin{array}{llllll}\text { CLETO, M. (Orgs.). } & \text { Editora Boitempo, }\end{array}$

CALDEIRA, T. Cidade de muros. Edusp, São Paulo, 2000.

CARDOSO, Irene. A Universidade da Comunhão Paulista. Editora Cortez, 1982.

CAROLA, Carlos. Jeca Tatu e o Processo Civilizador da Família Rural Brasileira. Simpósio Processo Civilizador, História e Educação, 2004.

CASTELLS, Manuel. O poder da identidade. São Paulo: Paz e Terra 1999.

CASTRO, Josué De. Geografia da Fome. Rio de Janeiro: Civilização Brasileira, 2001.

CERRI, Luis. Non Ducor Duco: A Ideologia da Paulistanidade e a Escola. Revista Brasileira de História, São Paulo, v. 18, n. 36, 1998. Disponível em: <http://www.scielo.br/scielo.php?script=sci_arttext\&pid=S010201881998000200007> Acesso em: 12/06/2015.

CHAUÍ, Marilena. Ideologia e Educação. Educação e Pesquisa. São Paulo, 2016.

A Nova Classe Trabalhadora Brasileira e a Ascensão do Conservadorismo in Por que Gritamos Golpe? JINKINGS, I; DORIA, K; CLETO, M. (Orgs.). Editora Boitempo, São Paulo, 2016.

CORDOVA, Maria Julieta Weber. A formação social e cultural no sul do Brasil: a "mancha loira" como um contraponto ao Brasil "mestiço e mulato". História Revista, 2012.

CUNHA, Euclides. Os sertões. São Paulo: Editora Três, 1984.

DAMERGIAN, Sueli. Migração e referenciais identificatórios: linguagem e preconceito. Psicologia USP[online], 2009. Disponível em: $<$ http://pepsic.bvsalud.org/scielo.php?script=sci_arttext\&pid=S167851772009000200007 \&lng=pt\&nrm=iso $>$ ISSN 1678-5177. 
DANTAS, Lucas. Oxente Meu Rei: Uma análise dos preconceitos reproduzidos pela propaganda turística do governo da Bahia. Revista Pangea, 2013.

DEBES, Célio. Júlio Prestes e a primeira república. Imprensa Oficial, São Paulo, 1982.

DINIZ, Péricles J. Questões de Raça na Identidade Baiana. Anais do Quinto Encontro de Estudos Multidisciplinares em Cultura, 2009.

DUARTE, Paulo. Memórias. Inteligência da Fome. Hucitec, São Paulo,1975.

DUNDES, Alan. Nationalistic Inferiority Complexes and the Fabrication of Fakelore. Journal of Folklore Research. 1985.

ELIAS, Norbert. SCOTSON, John. Os estabelecidos e os outsiders: sociologia das relações de poder a partir de uma comunidade; tradução Vera Ribeiro; tradução do posfácio à edição alemã, Pedro Süssekin. Zahar, Rio de Janeiro, 2000.

O processo civilizador. Rio de Janeiro, Jorge Zahar, 1990.

ELLIS JR, Alfredo. Confederação ou Separação. Editora Piratininga, São Paulo, 1933.

A Nossa Guerra. Editora Piratininga, São Paulo, 1933.

Raça de Gigantes. São Paulo, 1926.

ENGELS, Friedrich The Housing Question. New York, 1935.

FACÓ, Rui. Cangaceiros e Fanáticos. Civilização Brasileira, Rio de Janeiro, 1976.

FELDMAN-BIANCO, Bela. Reinventando a localidade: globalização heterogênea, escala da cidade e a incorporação desigual de migrantes transnacionais. Horiz. Antropol., Porto Alegre, June 2009.

FERNANDES, Florestan e BASTIDE, Roger. Brancos e Negros em São Paulo. Editora Global, São Paulo, 2008.

FERREIRA, Antonio Celso. Epopéia bandeirante, letrados, instituições, invenção histórica (1870-1940). UNESP, São Paulo, 2002.

FIGUEIREDO, Antonio Cândido de. Novo Dicionário da Língua Portuguesa.1913.

FISKE, S. T., CUDDY, A. J., GLICK, P., \& XU, J. A model of (often mixed) stereotype content: Competence and warmth respectively follow from perceived status and competition. Journal of Personality and Social Psychology. 2002.

FOUCAULT, M. 'On the Genealogy of Ethics.' In Ethics, Subjectivity and Truth:Essential Works of Foucault, 1954-1984, Vol. 1, edited by P. Rabinow, 253-280, New York: 1983. 
FRANKENBERG, Ruth. Introduction: Local Whiteness, Localizing Whiteness" in Ruth Frankenberg (org.), Displacing Whiteness: Essays in Social and Cultural Criticism. 1999.

FREIRE, Laudelino de Oliveira. Grande e Novíssimo Dicionário da Língua Portuguesa. Editora José Olympio, 1957.

FREYRE, Gilberto. Nordeste: Aspectos da Influência da Cana sobre a Vida e a Paisagem do Nordeste do Brasil, 7ª Edição, Editora Global, São Paulo, 2010.

Manifesto regionalista. 7.ed. Ed. Massangana, Recife, 1996.

Casa Grande \& Senzala. Editora Global, São Paulo, 2005.

FRY, Peter. Para inglês ver. Identidade e política na cultura brasileira. Zahar, Rio de Janeiro 1982.

GALETTI, Lylia S. G. Nos confins da civilização: sertão, fronteira e identidade nas representações sobre Mato Grosso. Tese (Doutorado em História Social) - FFLCH/USP, São Paulo, 2000.

GASPAR DA MADRE DE DEUS, Freire. Memórias Para a História da Capitania de São Vicente. Editora Itatiaia, 1975.

GERVAISEAU, Henri. Tem que ser Baiano? Alô Vídeo, 1993.

GEMIGNANI, Marco \& HERNANDEZ-ALBUJAR, Yolanda. Hate groups targeting unauthorized immigrants in the US: discourses, narratives and subjectivation practices on their websites. Ethnic and Racial Studies. 2015.

GILROY, Paul. O Atlântico Negro. Editora 34, São Paulo, 2012.

GODOY, João. Identidade e Regionalismo Paulista: Trajetórias e Mutações. Anais do XXVI Simpósio Nacional de História - ANPUH, São Paulo, 2011.

GOMES, Alexandre; OLIVEIRA, Ana. A construção social da memória e o processo de ressignificação dos objetos no espaço museológico. Revista Museologia e Patrimônio, 2010.

GOMES, Fernando; SILVA, Edilson. "O Canto das Águas": Fafá de Belém e a política cultural da SECULT/PA. Revista Estudos Amazônicos, 2013.

GRAMSCI, Antonio. A Questão Meridional. Rio de Janeiro: Editora Paz e Terra, 1987. GUIMARÃES, Antonio Sérgio. Classes, raças e democracia. Editora 34, São Paulo, 2002.

Pesquisa, São Paulo, 2003. Como trabalhar com raça em sociologia. Educação e 
Preconceito e Discriminação. Editora 34 Ltda, São

Paulo, 2004.

Antropologia, 2004.

Preconceito de cor e racismo no Brasil. Revista de

São Paulo, 2016.

Formações Nacionais de Classe e Raça. Tempo Social,

GUPTA, Akhil. e FERGUSON, James. Beyond "Culture": Space, Identity, and the Politics of Difference. Cultural Anthropology, 1992.

HALL, Stuart. Identidades Culturais na Pós-modernidade. DP\&A, Rio de Janeiro, 1997.

HARVEY, David. "O direito à cidade." Lutas Sociais. ISSN, 2012.

HERMANN, Jacqueline. Canudos Destruído em Nome da República: Uma Reflexão Sobre as Causas Políticas do Massacre de 1987. Tempo. Rio de Janeiro, 1996.

HOBSBAWM, Eric. Não basta a história de identidade. Sobre História: Ensaios. Trad. Cid Knipel Moreira. Companhia das Letras, São Paulo, 2004.

HOLLANDA FERREIRA, Aurélio Buarque. Pequeno Dicionário Brasileiro da Língua Portuguesa. Editora Civilização Brasileira, 1969.

HOLANDA, Sérgio Buarque de. Raízes do Brasil. 1' edição, 1936. José Olympio, Rio de Janeiro, 1979.

KAISER, Jakzam. Ordem e Progresso: O Brasil dos Gaúchos. Dissertação apresentada ao Programa de Pós-graduação em Antropologia Social da Universidade de Santa Catarina, 1998.

LEITMAN, S. L. Raízes sócio econômicas da Guerra dos Farrapos: um capítulo da História do Brasil no século XIX. Rio de Janeiro: Graal, 1979.

LESSER, Jeffrey. A invenção da brasilidade. Editora Unesp, São Paulo, 2014.

LIMA, Márcia. Desigualdades Raciais e Políticas Públicas: Ações Afirmativas no Governo Lula. Novos Estudos, 2010.

LOBO, Alan. Os estereótipos nas piadas sobre baiano. Anais do SETA-ISSN, 2012.

LOPES, Raimundo. "Cada brasileiro receba a parcella do insulto que lhe cabe": regionalismo, separatismo e bairrismo no processo de mobilização cearense durante a Guerra de 1932. Revista Espacialidades, 2009. 
LOVE, Joseph. Autonomia e interdependência: São Paulo e a Federação Brasileira. In: FAUSTO, Bóris (org.) História Geral da Civilização Brasileira, Tomo III, Volume I, São Paulo: DIFEL, 1977.

LOWY, Michael. Da Tragédia à Farsa: O Golpe de 2016 no Brasil in Por que Gritamos Golpe? JINKINGS, I; DORIA, K; CLETO, M. (Orgs.). Editora Boitempo, São Paulo, 2016.

LUVIZOTTO, Carolina Kraus. Cultura gaúcha e separatismo no Rio Grande do Sul. Editora Unesp, 2009.

MACHADO, Felipe. "Morram" os cariocas! O regionalismo paulista nas páginas esportivas (1901-1938). Tese de Doutoramento apresentada ao Programa de PósGraduação em História da Pontifícia Universidade Católica de São Paulo, 2016.

MAESTRI, Mário. O gaúcho era gay? 2006.

MARQUES, Fabrício. O mito da preguiça baiana, trabalho e racismo. Revista FAPESP, 2004.

MARTINS, José de Souza. Do PT das lutas sociais ao PT do poder. Editora Contexto, São Paulo, 2016.

MARTINS, Romário. Paranística. A divulgação, 1948.

MATTOS, Cláudia de Valladão. Da Palavra à Imagem: sobre o programa decorativo de Affonso Taunay para o Museu Paulista. Anais do Museu Paulista, v. 6/7, São Paulo, 2003.

MENDES, Pedro. História e Permanência de uma Negação da Negritude na Pátria Ceará. Academia.Edu. São Paulo, 2017.

MONSMA, Karl. Racialização, racismo e mudança: um ensaio teórico, com exemplos do pós-abolição paulista. Anais do XXVII Simpósio Nacional de História - ANPUH, Natal, 2013.

MORAES, Pedro. O Jeca e a Cozinheira: Raça e Racismo em Monteiro Lobato. Revista de Sociologia e Política, 1997.

MORAES SILVA, Antonio de. Diccionario de Lingua Portugueza. Lisboa, 1789.

MOUTINHO, Jessita. A Paulistanidade Revista: Algumas Reflexões Sobre Um Discurso Político. Tempo Social, São Paulo, 1991.

MUNANGA, Kabengele. Negritude - Usos e Sentidos. Editora Autêntica, 2009.

NASCIMENTO, Abdias. O Genocídio do Negro Brasileiro. Editora Perspectiva, Rio de Janeiro, 2017. 
NÓBREGA, Ricardo. "Baianos" e "paraíbas": notas sobre a discriminação. Anais do XIII Congresso Brasileiro de Sociologia, Recife, 2007.

NOGUEIRA, Ricardo José Batista. Amazônia e questão regional. Um regionalismo sufocado. GEOUSP: Espaço e Tempo (Online), São Paulo, 1999.

NOVA, Luiz e MIGUEZ, Paulo. O Mito Baiano: Viço, Vigor e Vícios. Anais do Quarto Encontro de Estudos Multidisciplinares em Cultura, Recife, 2008.

OESP. Os paulistas e a nação em perigo. Editorial, 23/03/1964.

São Paulo repete 32. Editorial, 01/04/1964.

OLIVEN, Ruben. A Parte e o Todo: a diversidade cultural no Brasil-Nação. Vozes, Petrópolis, 1992.

OLIVEIRA AMARAL, Luciano. "Mate um nordestino afogado" - Análise crítica de um artigo da revista Época. Linguagem em (Dis)curso, 2011.

OLIVEIRA, Almir Leal de. O Instituto Histórico, Geográfico e Antropológico do Ceará - memória, representações e pensamento social $(1887$ - 1914). Tese de Doutoramento. Pontíficia Universidade Católica de São Paulo - USP. São Paulo, 2001.

OLIVEIRA, Pedro C. O Ódio aos Nordestinos e as Identidades Neofascistas Brasileiras no White Rock. Boletim Historiar, Aracaju, 2014.

OLIVEIRA, Ricardo Costa de. O silêncio dos vencedores: genealogia, classe dominante e estado no Paraná. Moinho do Verbo, Curitiba, 2001.

OLIVEIRA VIANA, Francisco José de. Populações Meridionais do Brasil. Senado Federal, Conselho Editorial, Brasília, 2005.

PARK, Margareth. De Jeca Tatu a Zé Brasil: a possível cura da raça brasileira. Estudos Sociedade e Agricultura, 1999.

PIENIZ, Monica. Novas configurações metodológicas e espaciais: etnografia do concreto à etnografia do virtual. Revista Elementa. Comunicação e Cultura. Sorocaba, 2009.

PIERUCCI, Antônio. F. Janistas e malufistas: a direita mora do outro lado da cidade. In: XII ENCONTRO ANUAL DA ANPOCS / GT PARTIDOS E ELEIÇÕES, Águas de São Pedro: 1988.. Disponível em:

<http://www.anpocs.org.br/portal/publicacoes/rbcs_00_10/rbcs10_03.htm> Acesso em: 05/08/2015.

Linguagens Autoritárias, Voto popular. In: Dagnino, Evelina (org.) Anos 90: Política e sociedade no Brasil. Brasiliense. São Paulo, 1994.

Ciladas da Diferença. Editora 34, São Paulo, 1999. 
PINHO, Osmundo de Araújo. Bahia no fundamental: notas para uma interpretação do discurso ideológico da baianidade. In: Revista Brasileira de Ciências Sociais. v. 13, n.36, fev. 1998.

PIZA, Edith."Branco no Brasil? Ninguém sabe, ninguém viu" In Antonio Sergio Alfredo Guimarães; Lynn Huntley (orgs.), Tirando a máscara. Ensaios sobre o racismo no Brasil. Editora Paz e Terra. São Paulo, 2000,

QUEIROZ, Maria Isaura Pereira de. Ufanismo Paulista: Vicissitudes de um Imaginário. Revista USP, São Paulo, v. 13, p. 78-87, 1992.

QUEIROZ, Paulo Roberto Cimó. Mato Grosso/Mato Grosso do Sul: divisionismo e identidades (um breve ensaio). Diálogos - Revista do Departamento de História e do Programa de Pós-Graduação em História.

RAO, Ursula. Making the global city: Urban citizenship at the margins of Delhi. Ethnos, vol. 75, no 4, pp. 402-424, 2010.

REZENDE, C. B. Os limites da sociabilidade: "cariocas" e "nordestinos" na Feira de São Cristóvão. In: Estudos históricos, n. 28. Rio de Janeiro: 2001.

RICARDO, Cassiano. Martim Cererê. 13ª Ed. Rio de Janeiro: José Olympio, 1974.

Marcha Para o Oeste. Rio de Janeiro: José Olympio, 1970.

O Estado Novo e Seu Sentido Bandeirante. Cultura Política, Rio

de Janeiro, 1941.

RIBEIRO, Djamila. O que é lugar de fala? Letramento, Belo Horizonte, 2017.

RIGAMONTE, Rosani. Sertanejos contemporâneos: entre a metrópole e o sertão. Humanitas, São Paulo, 2001.

RISÉRIO, Antônio. Caymmi: uma utopia de lugar. São Paulo: Perspectiva,1993.

ROCHA NetTO, Bento Munhoz da. Presença do Brasil. Rio de Janeiro: José Olympio, 1960.

ROCHA, Simone Maria. Identidade regional, produção e recepção: A "mineiridade" na televisão. In: Congresso Nacional de Pós-graduação em Comunicação, 2001.

ROMERO, Mariza. Nordestinos em São Paulo nos anos 1950: Imprensa Popular, Ciência e Exclusão Social. Santos: Anais do Encontro Anual de História da ANPUH-SP, 2014.

SAHLINS, Marshall. Ilhas de história. Rio de Janeiro, Jorge Zahar, 1990.

SAID, Edward. Orientalismo: o Oriente como invenção do Ocidente. São Paulo, Companhia das Letras, 2007. 
SALLES, Alberto. Pátria Paulista. Brasília, Universidade de Brasília, 1983.

SALTURI, Luis Afonso. Paranismo, movimento artístico do sul do Brasil no início do século XX. Perifèria: revista de recerca i formació en Antropologia. Espanha, v. 11, p. $1-22,2009$

SANTOS, Carlos José. Nem Tudo Era Italiano: São Paulo e Pobreza (1890-1915). Editora Annablume, São Paulo, 2017.

SANTOS, José. As possibilidades das metodologias informacionais nas práticas metodológicas: por um novo padrão de trabalho para os sociólogos do século XXI. Sociologias, Porto Alegre, Ano 3, n. 5, p. 116-148, 2001.

SANTOS, Marco; MOTA, André. São Paulo 1932: Memória, Mito e Identidade. Editora Alameda, São Paulo, 2010.

SASSEN, Saskia. The global city: New York, London, Tokyo. Princeton, NJ: Princeton University Press, 2001.

SCHWARCZ, Lilia Moritz. Nem preto nem branco, muito pelo contrário: cor e raça na sociabilidade brasileira. Editora Companhia das Letras, 2013.

Complexo de Zé Carioca- Notas sobre uma identidade mestiça e malandra. Revista Brasileira de Ciências Sociais, São Paulo, Anpocs, p. 49-63, 1995.

O Espetáculo das Raças. Companhia das Letras, 1993.

Prefácio. In: ANDERSON, Benedict. Comunidades imaginadas: reflexões sobre a origem e a difusão do nacionalismo; tradução Denise Bottman. Editora Companhia das Letras, 2008.

SCHILlER, N.G. and CAGLAR, A. Locating Migration: Rescaling Cities and Migrants. New York: Cornell University Press, 2010.

SILVA, Francisco Carlos Teixeira da. Fascismo e neofascismo: a questão da ressurgência nos anos 80/ 90. In: GUTFREIND, Ieda \& REICHEL, Heloísa Jochims (coords.). América Platina e historiografia. São Leopoldo: PPGH-UNISINOS, 1996.

SOUSA, Antônio Vilamarque Carnaúba de. Da negrada à negada: a negritude fragmentada - o movimento negro e os discursos identitários sobre o negro no Ceará (1982-1995). Dissertação (Mestrado em História) - Universidade Federal do Ceará, Departamento de História, Programa de Pós-Graduação em História Social, Fortaleza-CE, 2006.

SOUZA, Ricardo. História regional e identidade: o caso de São Paulo. História e Perspectivas, Uberlândia (36-37): 389-411, 2007. 
SUASSUNA, Ariano. O Auto da Compadecida. Recife, 1955.

TAQUES, Pedro. Nobiliarquia Paulistana, Genealogia das Principais Famílias de São Paulo. Disponível em <https://archive.org/details/NobiliarchiaPaulistanaGenealogiaDasPrincipaesFamiliasDeS.Paulo> Data da última visita: 11/04/2017.

TAUNAY, Afonso. Subsídios para a História do tráfico africano no Brasil. Rio de Janeiro, Imprensa Nacional.

TELLES, Vera e HIRATA, Daniel. "Cidade e práticas urbanas: nas fronteiras incertas entre o ilegal, o informal e o ilícito". Revista Estudos Avançados: 21(61), 2007.

TESCHAUER, Carlos. Novo Dicionário Nacional. Editora Globo, 1928.

TRUZZI, Oswaldo. Etnias em Convívio: O Bairro do Bom Retiro em São Paulo in Estudos Históricos, Rio de Janeiro, 2001.

VAZ, Florencio. Ribeirinhos da Amazônia : Identidade e Magia na floresta. Revista de Cultura Vozes. ${ }^{\circ} 2,1996$.

VELLOSO, Mônica. A brasilidade verde-amarela: nacionalismo e regionalismo paulista. Revista Estudos Históricos, América do Norte, 1993.

WEINSTEIN, Barbara. Racializando as diferenças regionais: São Paulo x Brasil, 1932. Esboços-Revista do Programa de Pós-Graduação em História da UFSC, v. 13, n. 16, p. 281-303, 2007.

The color of modernity: São Paulo and the making of race and nation in Brazil, Duke University Press Books, 2015.

WIMMER, Andreas. Ethnic Boundary Making: Institutions, Power, Networks, New York: Oxford University Press, 2013.

WU, Timothy et al. Does Google content degrade Google Search? Experimental Evidence. Disponível em < https://pt.slideshare.net/lutherlowe/wu-l> 2015.

ZANLORENZI, Elisete. O mito da preguiça baiana. $267 \mathrm{f}$. tese (Doutorado em Antropologia Social) - Faculdade de Filosofia, Letras e Ciências Humanas da Universidade de São Paulo, São Paulo, 1998.

ZORZATO, Osvaldo. Conciliação e identidade: considerações sobre a historiografia de Mato Grosso (1904-1983). Tese (Doutorado em História Social) - FFLCH/USP, São Paulo, 1998.

Alicerces da identidade mato-grossense. Revista do Instituto Histórico e Geográfico Brasileiro, Rio de Janeiro, ano 161, p. 419-436, jul./set. 2000. 